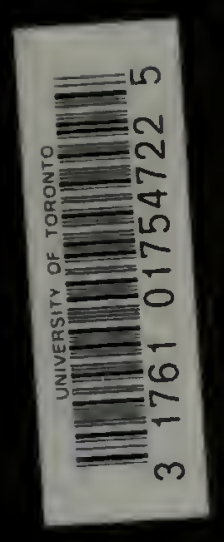

Univ ar TOROKTO LIBRARY 




\section{Digitized by the Internet Archive in 2008 with funding from Microsoft Corporation}




\title{
THE SALTON SEA
}

A STUDY OF THE GEOGRAPHY, THE GEOLOGY, THE FLORISTICS, AND THE ECOLOGY OF A DESERT BASIN

\author{
D. T. T. MACDOUGAL \\ and Collaborators
}
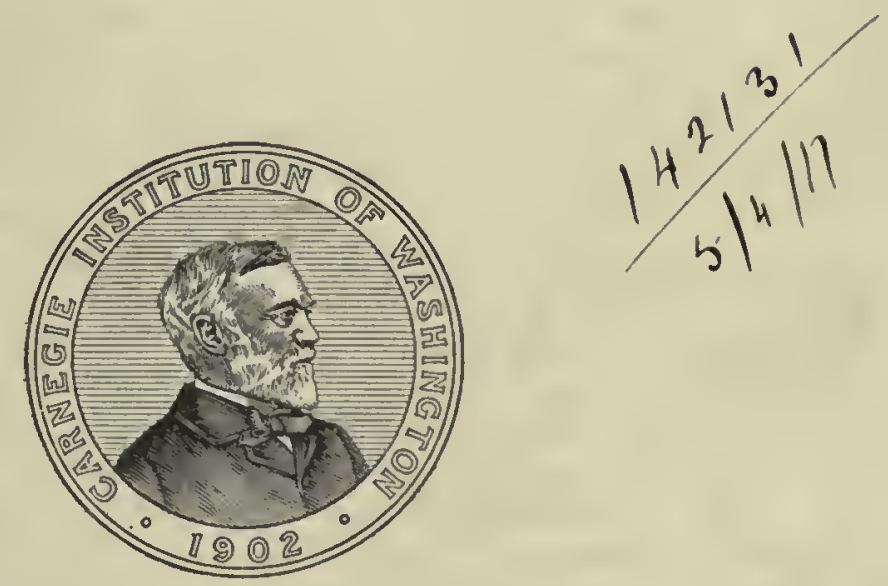

WASHINGTON, D. C.

PUBLISHED BY THE CARNEGIE INSTITUTION OF WASHINGTON 1914 


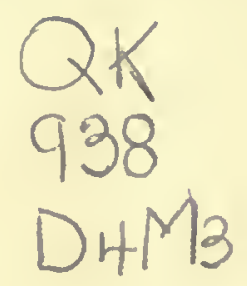

CARNEGIE INSTITUTION OF WASHINGTON

Publication No. 193

\author{
Crpies of this 8ook \\ were first issuod \\ JUiv 301914
}

IRRES OF J. B. LIPINCOTT COMPANY

PHILADELPHIA 


\section{PREFACE.}

Bx D. T. MacDodoal.

The geological and biological processes of the surface layers of the earth's crust are profoundly different under subaerial exposures to those which prevail under subaqueous conditions. Any region, therefore, which may be subjected to submergence and to weathering, alternately, will offer a changing complex of environic conditions, with accompanying disturbances in the balance and distributional movements of the organisms of the region.

The solid ground, in one case, is subject to the crosion of precipitation-water and stream-flow, coupled with a leaching action of the water, while surface material will be variously transported and deposited. Wind effects will vary widely with aridity and other climatic features, while precipitation, evaporation, and temperature will act as determinants as to the character of the living forms supported.

The submersion of any area may be expected to be followed by the complete or nearly complete destruction of the land flora and fauna. The temperature of the substratum is equalized, variations in moisture disappear, wind comes in only as an agency for transporting propagative bodies and as a cause of wave-action, sorting, wearing, and depositing material along shore lines. The deposition of sedimentary material in submerged areas under lakes takes place in such manner as to be easily distinguishable from the effects of stream-action.

The superposition of the two groups of effects in any region such as the lowermost part of a desert basin, especially when submergence and desiccation alternate at intervals of sufficient length to give full force to the two extremes, might be expected to offer highly unusual physical conditions of the surface layers and of the soil, to which organisms would be expected to display reactions of interest and importance useful in the interpretation of phytogeographical phenomena in general.

The great Cahuilla Basin, which lies to the westward of the lower or southern part of the main delta of the Colorado River, has been the scene of alternations of the kind in question. The lower part of this basin has been submerged and desiccated many times in the last few hundred years, as attested by the numerous beach or strand formations and layers of travertine on the shores. The making of the lake in 1904, 1905, and 1906, at the time of the organization of the work of the Desert Laboratory, offered opportunities for some studies the results of which are presented in the present paper. The facts to be taken into account were so diverse in character, and the necessary methods of calibration and estimation so unlike, that the cooperation of a number of workers in various branches of science was enlisted.

First of all the senior contributor was so fortunate as to secure a general sketch of the geology and topography of the basin by the late Professor William Phipps Blake, whose barometric measurements as a member of the Williamson expedition in 1853 first established the fact that the region was an inclosed basin, the lowermost part of which was below sea-level. The history of earlier travel and the general geography of the basin is described by Mr. G. Sykes, geographer of the Desert Laboratory. The analyses of water samples have been carried out under the direction of Professor R. H. Forbes, at the Agricultural Experiment Station of Arizona, by the aid of Dr. W. H. Ross and Professor A. E. Vinson. The surface geology, with especial reference to the soil formations, has been the subject of much painstaking examination by Mr. E. E. Free, formerly of the United States Bureau of Soils. Professor G. J. Peirce, of Stanford University, has contributed the results of studies of organisms living in brackish and saline waters, which are of especial concern 
with the subject, especially in the stages of the desiccation of the lake yet to come. Professor M. A. Brannon, of the University of North Dakota, has carried out a series of cultures by which the specific action of the micro-organisms upon the sulphates, iron, and calcium compounds has been determined and some important facts bearing upon the changes in woody tissue probably initial to the formation of coal have been obtained. Professor J. C. Jones, of the University of Nevada, has made brief studies of the travertine coatings found on the solid granite near the level of the highest beach line, establishing the participation of biological agencies in their formation. Mr. S. B. Parish, of San Bernardino, has written a description of the plants which form the vegetative setting of the drama of the appearance and disappearance of the lake; the senior contributor has devoted attention chiefly to the revegetation of the areas laid bare by the desiccation of the lake. The field parties have been accompanied by scientific visitors at various times, from whom valuable suggestions as to interpretation have been received. 


\section{TABLE OF CONTENTS.}

Pretack . ....

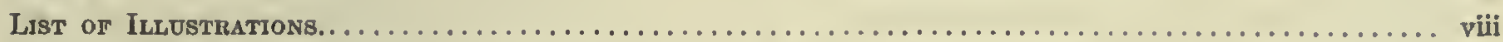

The Camulla Basin and Desert of the Colorado. By William Pintpg Blake ............... 1-12

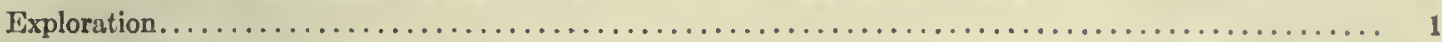

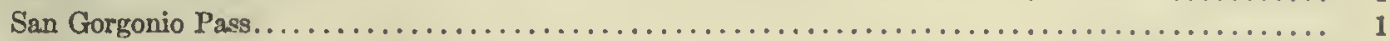

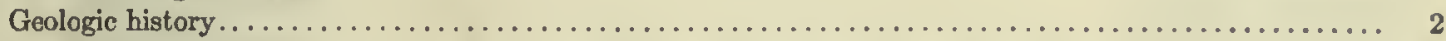

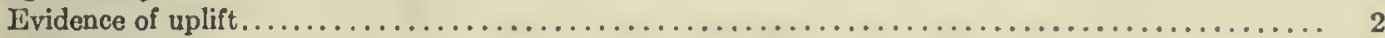

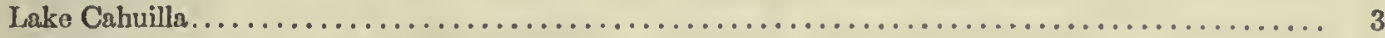

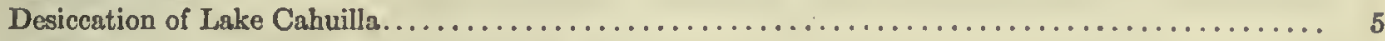

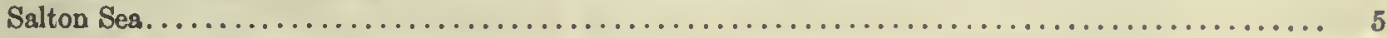

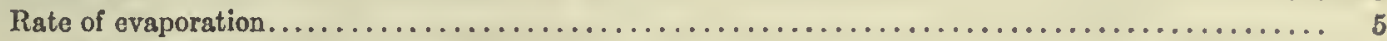

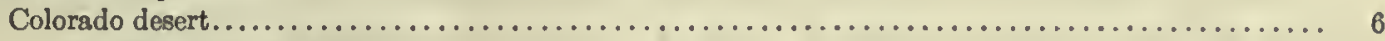

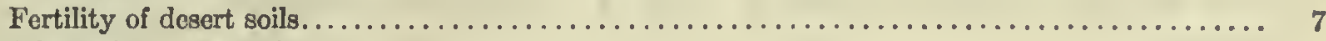

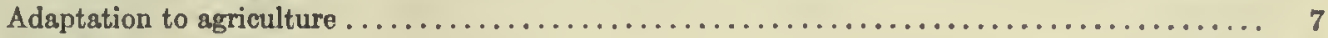

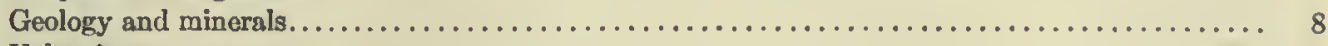

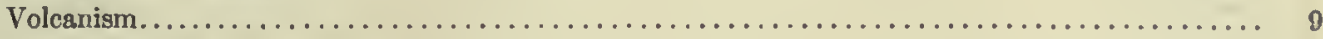

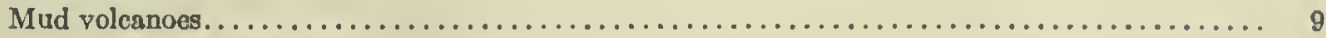

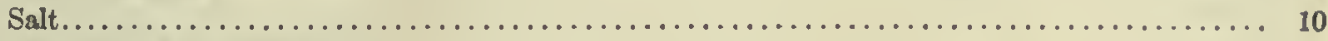

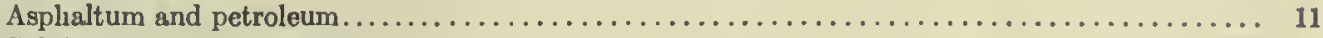

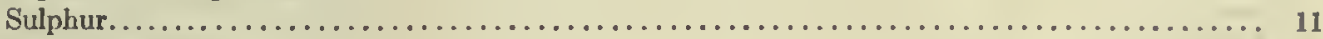

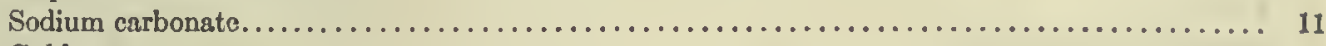

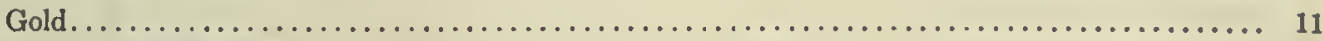

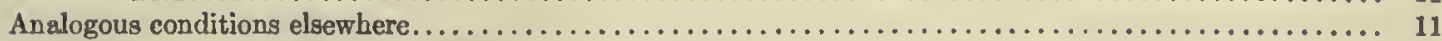

Geocraphical Features of the Cahumla Basin. By Gonfrey Stkes ................... 13-20

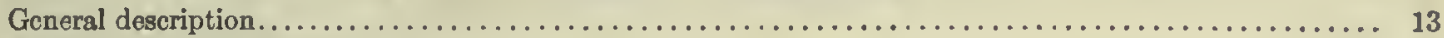

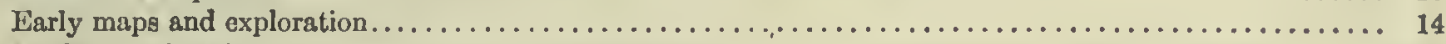

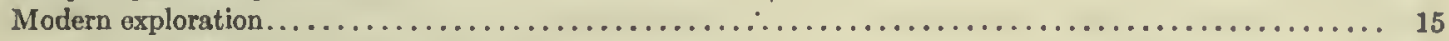

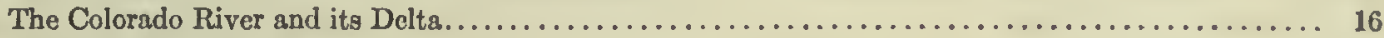

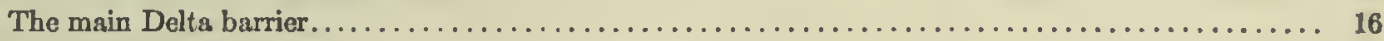

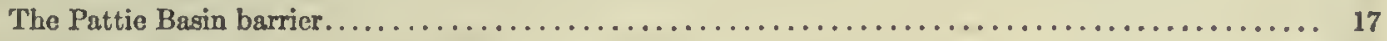

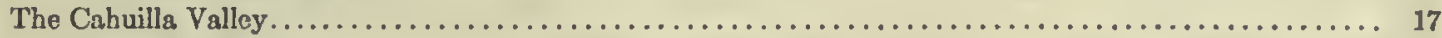

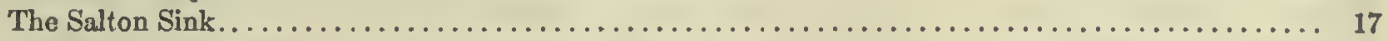

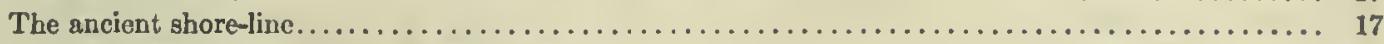

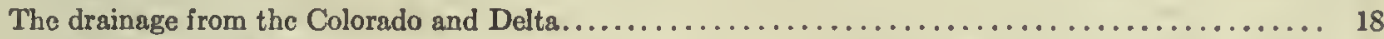

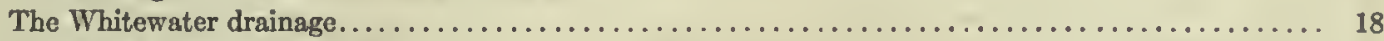

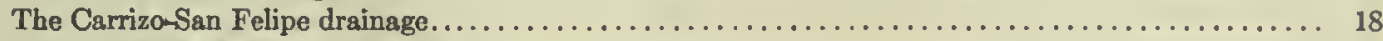

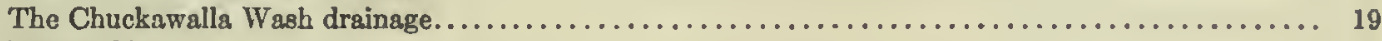

Recent history.................................................. 19

Sketch of the Geolooy and Solls of the Cahullua Basin. By E. E. Free.............. 21-33

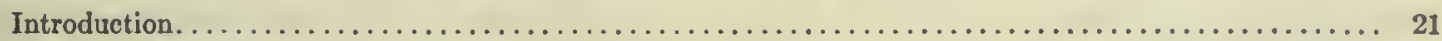

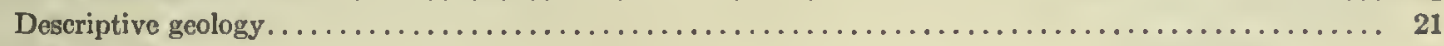

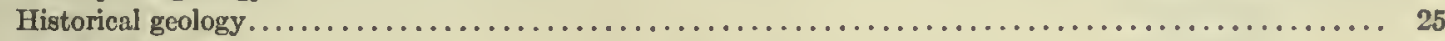

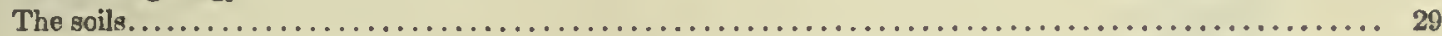

Chemical Composition of the Water of Salton Sea and Itg Annual Variation in Concentration

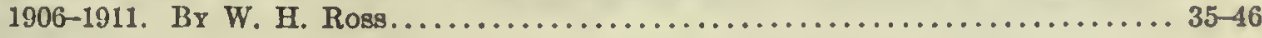

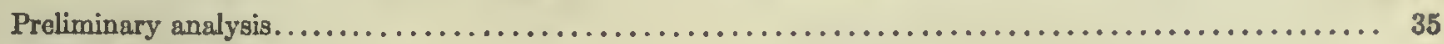

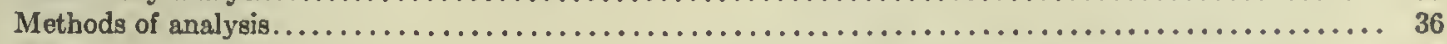

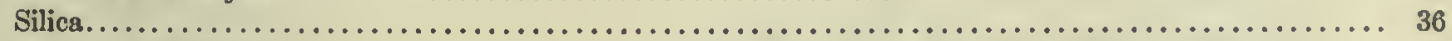

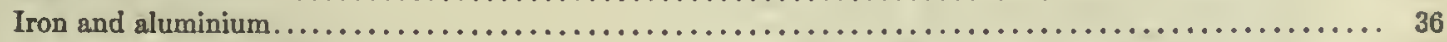

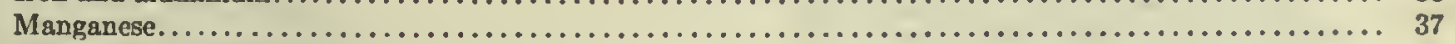

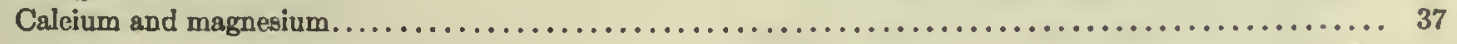


Cuevical Composition of tue Salton Sea, etc.-Continued. Page

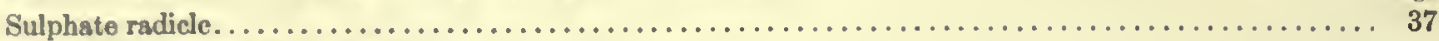

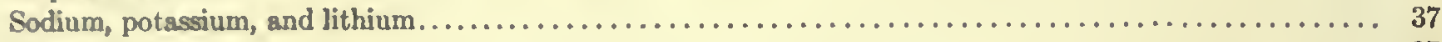

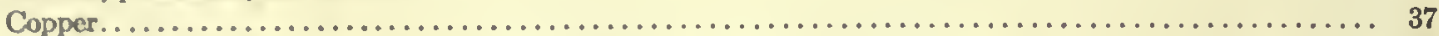

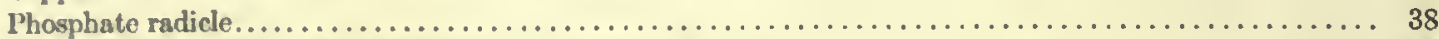

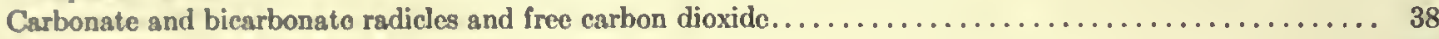

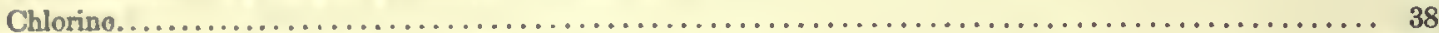

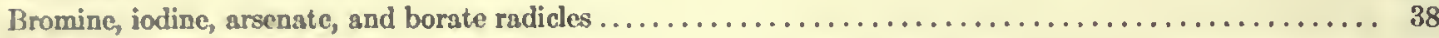

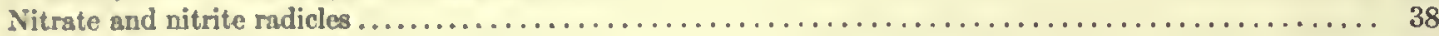

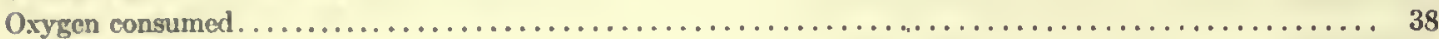

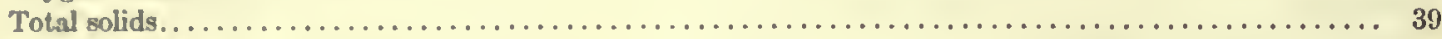

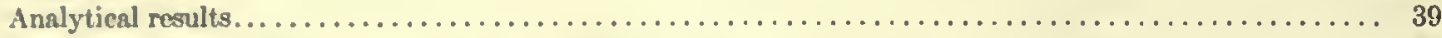

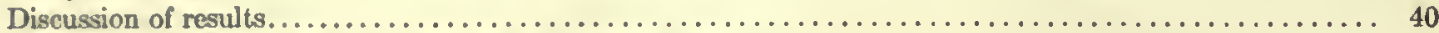

Variation in concentration of the lake at different points in $1911 \ldots \ldots \ldots \ldots \ldots \ldots \ldots \ldots \ldots \ldots \ldots \ldots \ldots$

Composition of the salts leached out from the bottom of the Salton Sea........................ 43

Vaniations in Composition and Concentration of Water of Salton Sea 1912 and 1913. By A. E. Venson.......................................... $47-48$

Bemavior of Certain Micro-oronnisms in Brine. By George James Peirce.............. $49-70$

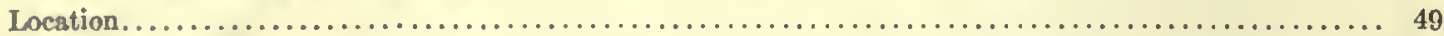

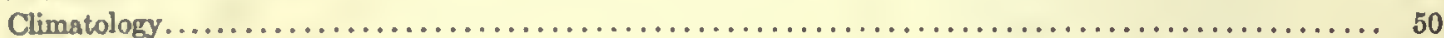

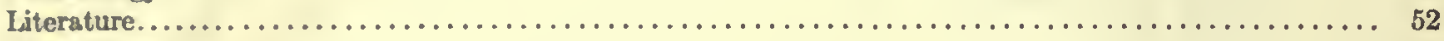

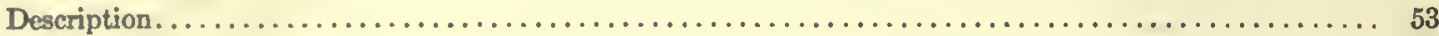

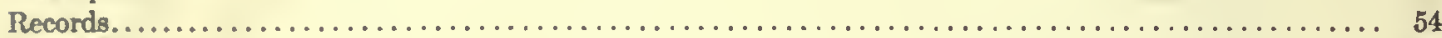

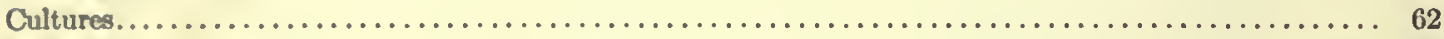

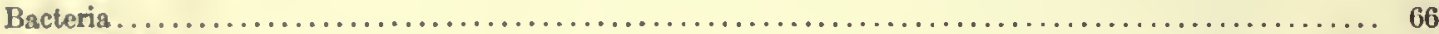

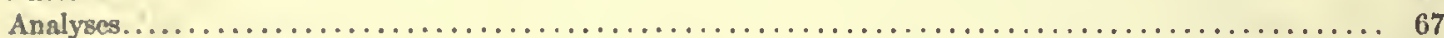

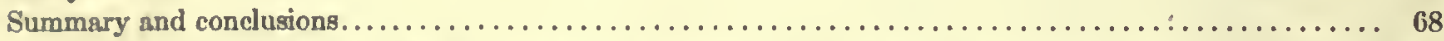

Tile Action of Salton Sea Water on Vegftable Tisgues. By Melvin A. Brannon..........71-78

Anatomical studies of the specimens submerged one to five years. . . . . . . . . . . . . . . . . 73

Decorticating processes in specimens of fresh wood jmmersed in Salton Sea water..............

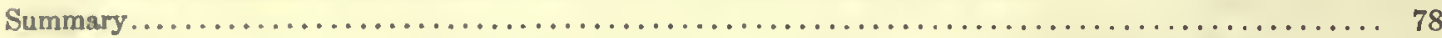

The Tuya Deposits of tue Salton Sink. By J. Chaude Jones.......................... $79-84$

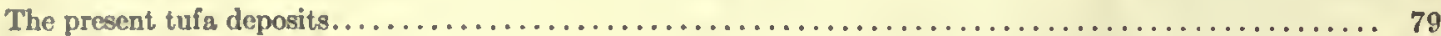

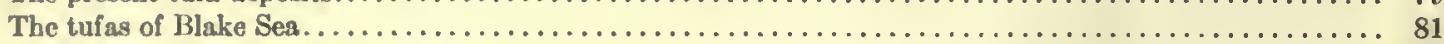

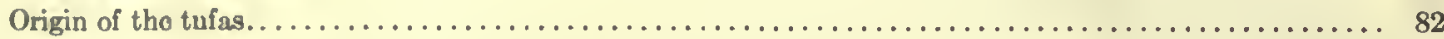

Plant ficology and Floristics of Salton Sink. By S. B. Parish.................... $85-114$

Territorial limitations. . . . . . . . . . . . . . . . . . . . . . . . . . . . . . . . . . 85

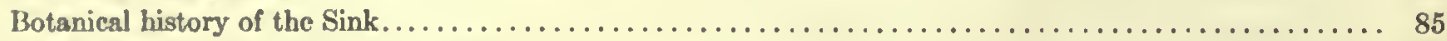

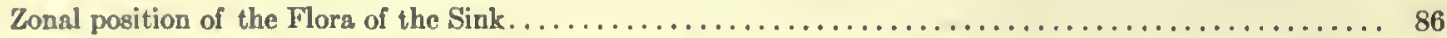

Factors determining the distribution of the Sink Flora . . . . . . . . . . . . . . . . . . . . . . . 87

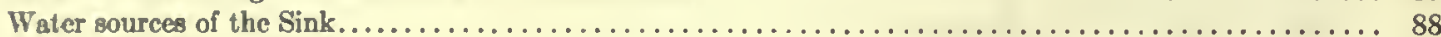

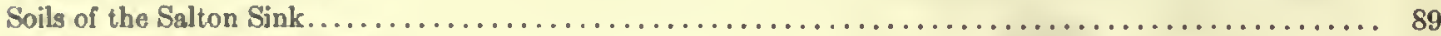

Derivation of the Sink Flora. . . . . . . . . . . . . . . . . . . . . . . . . . . . . . . 89

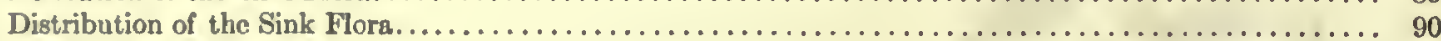

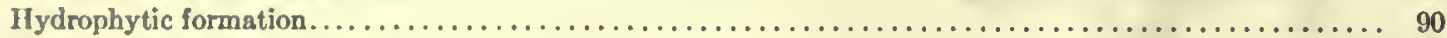

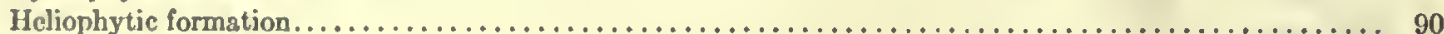

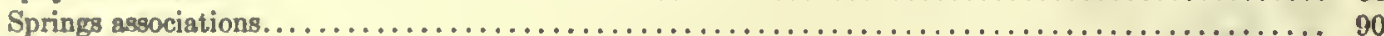

Mortmere.............................................. 90

Dos Palmas.................................................. 91

Agua Dulce and Fig-tree John Springs................................ 91

Scirpus-Typha association of Alamo and New Rivers........................... 91

Halophytic formation. ............................................... 92

Mecca-Indio Chenopodaceous associations.................................. 92

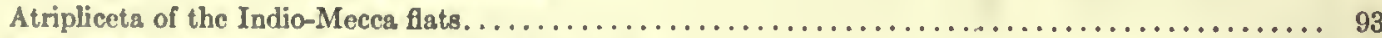

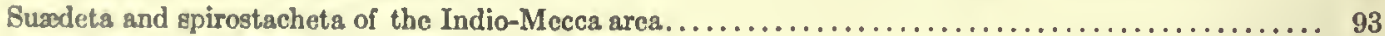

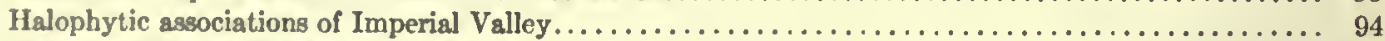

Seruvium-Spirostachys associations..................................... 94

Halophytic associations of the river bottoms................................. 95

Sesuvium-Phragmites association of Salt Slough............................... 95 
Plant Ecology and Floristics of Salton Sink-Continued.

Mesophytic formation

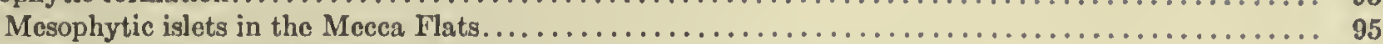

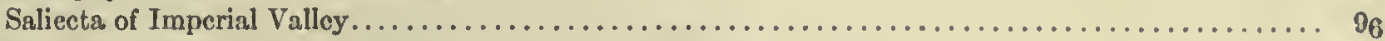

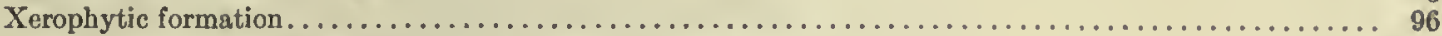

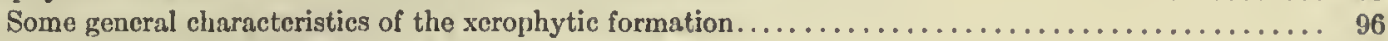

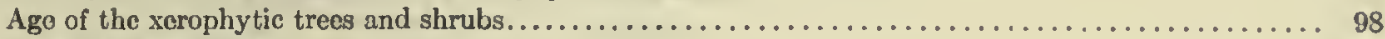

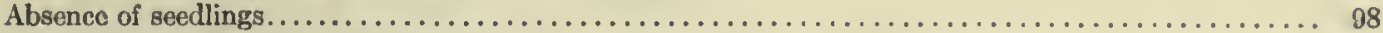

Associations of the xerophytic formation. . . . . . . . . . . . . . . . . . . . . . . . . . 99

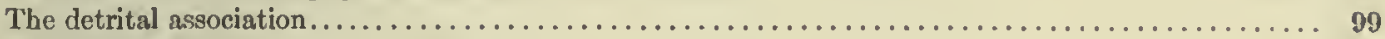

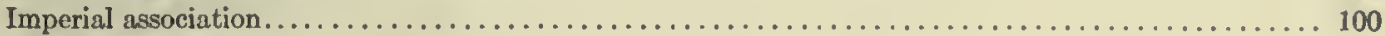

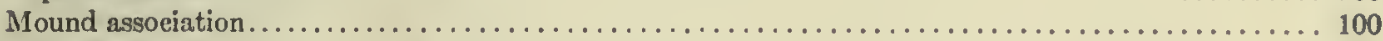

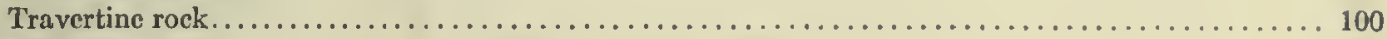

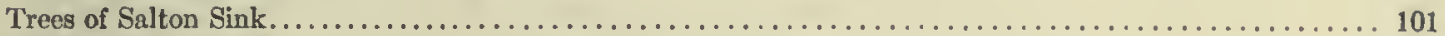

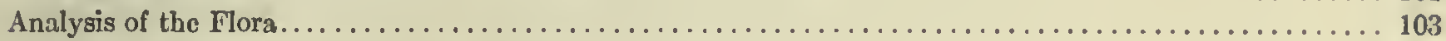

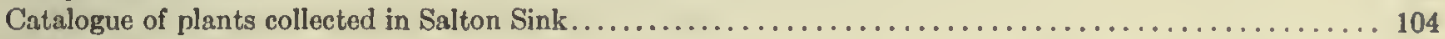

Movements of Veoetation Due to Submersion and Debiccation of Land Areas in thue Saltow Sink.

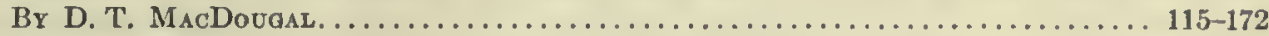

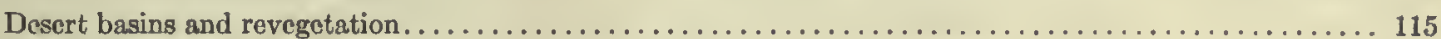

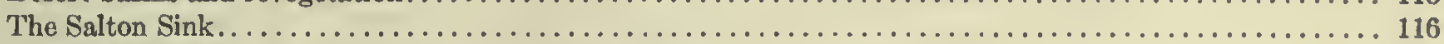

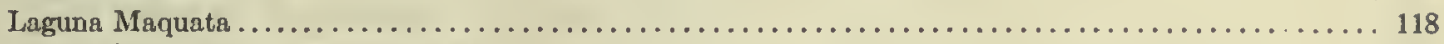

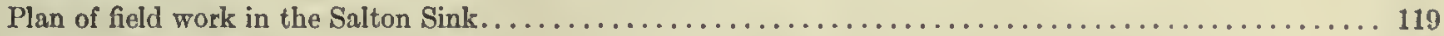

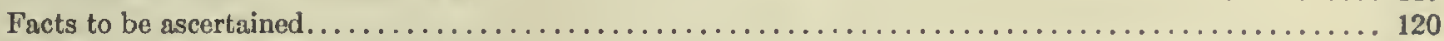

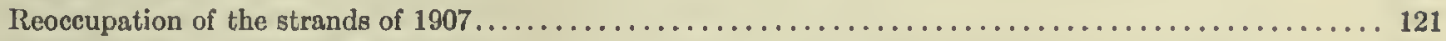

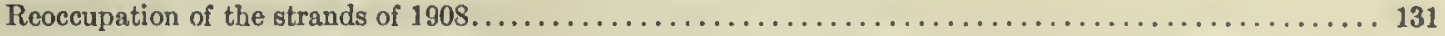

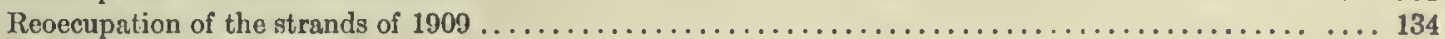

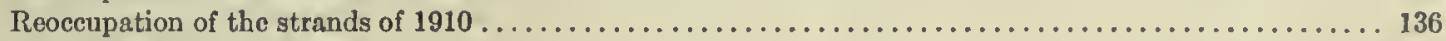

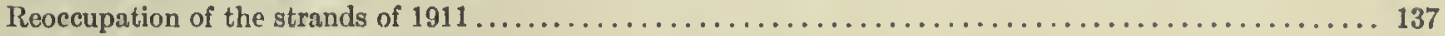

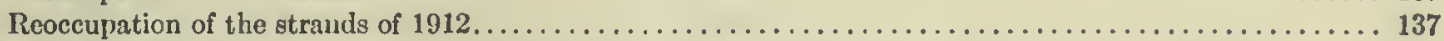

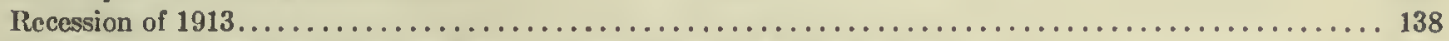

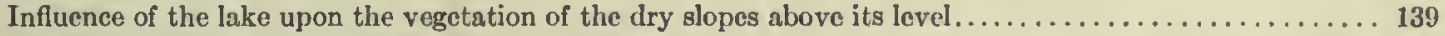

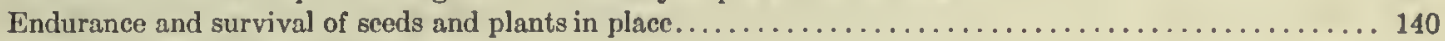

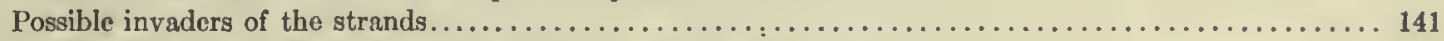

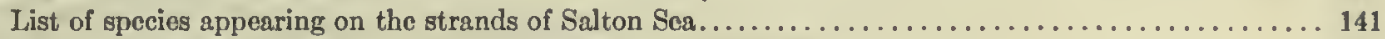

Biological and physical conditions of dissemination and reoccupation.........................

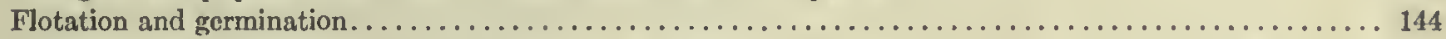

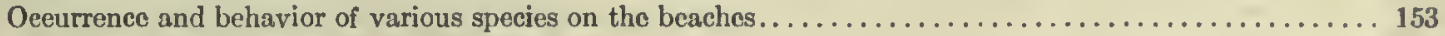

The movements of plants into sterilized areas. . . . . . . . . . . . . . . . . . . . . . . . . . . .

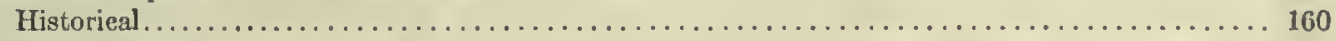

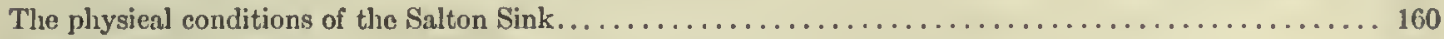

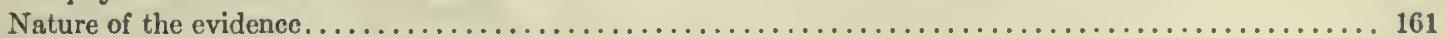

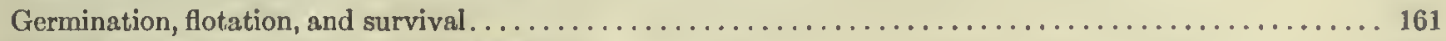

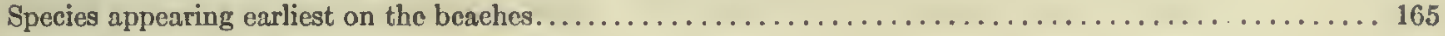

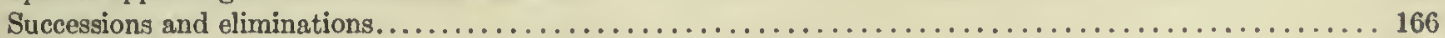

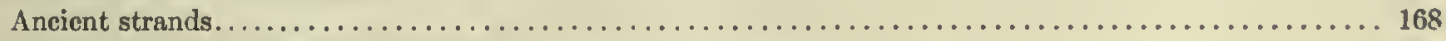

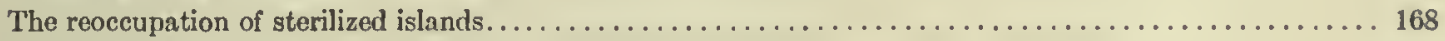

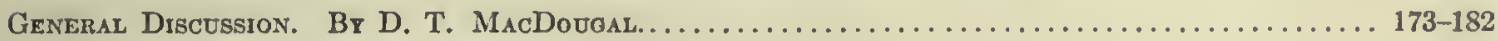





\section{LIST OF ILLUSTRATIONS.}

\section{PLATES.}

1. San Gorgonio Pass. Tago

1. San Gorgonio Pass. The late Professor W. 1. Blake. Saline plain of Salton Siık.............. P'acing 2

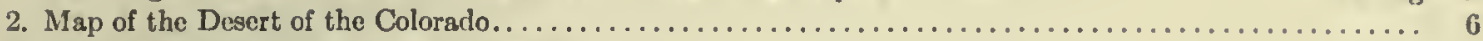

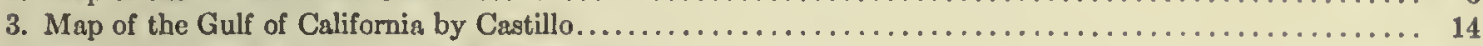

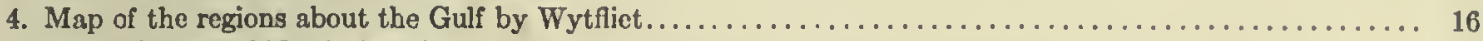

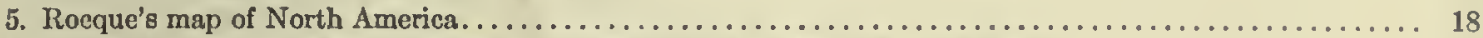

6. Accretion dune. Creseentic dunes. Old Beach line of Blake Sea. Big Island................ 22

7. San Jacinto Mountains. Foothills of Santa Rosa Range.............................. 26

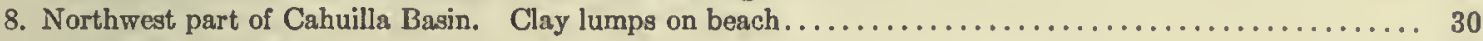

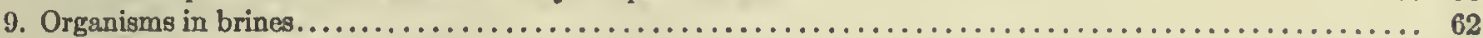

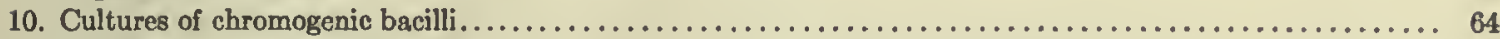

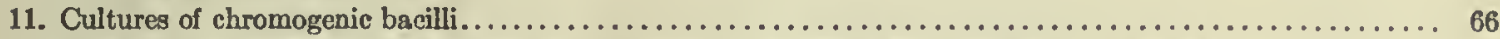

12. Prosopis glandulosa. Dune surrounded by water. Tongues of sea extending up wasbes........... 72

13. Prosopis glandulosa and P. pubescens in various stages of decortication. . . . . . . . . . . . . . . . 74

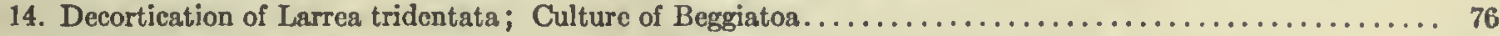

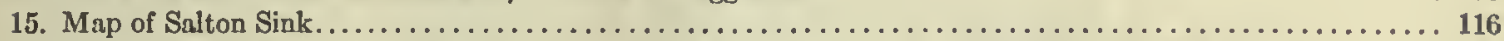

16. Emersion of 1907, Imperial Junction Beach. Big Island and Rock Island, from Obsidian Island......... 120

17. Travertine Wash, February 1907. Travertine Wash, February $1909 . \ldots \ldots \ldots \ldots \ldots \ldots \ldots$

18. Upper limit of Travertino Terraces, February 1908. Strand of 1907, Travertine Terrace, November $1908 . . .126$

19. Travertine Wash, November 1909 . Channels of desert washes after submergence ................ 130

20. Emersion of 1907, Imperial Junetion Beach, Oetober 1911. Emersion of 1907, Travertine Terraces,

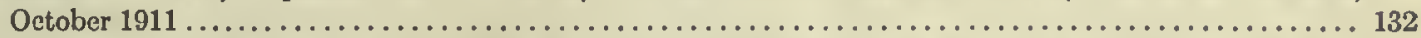

21. Southeast point of Obsidian Island, October 1912. Strand of East Bay, Obsidian Island, October 1912.... 134

22. Strand of 1909, Travertine Terraces, Oetober 1912. Ranch on emersion of 1910, Mecea, October 1912.... 136

23. Emersion of 1910, Mecea, Ootober 1912. Emersion of 1911, Mecea, October $1912 \ldots . . . \ldots \ldots \ldots . \ldots 138$

24. Uppermost portion of strand of 1911, Travertine Terraces, October 1912. Strand of 1911, Imperial

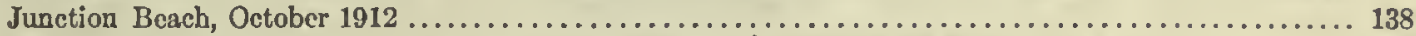

25. Travertine Wash, Oetober 1912. Cut bank of mid-winter $1911-12$, Travertine Terraces............ 140

26. Cut bank at upper limit of strand of 1913 . Cut bank of 1913 , three months later .............. 142

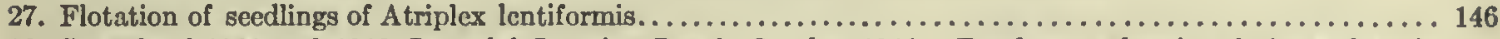

28. Strands of 1909 and 1910, Imperial Junetion Beach, Oetober 1911. Dead stems bearing fruits and seeds on submerged areas. Rank of Suæda on strand near Salton station.................. 152

29. Prosopis and Cucurbita on strand of 1907, Obsidian Island. Rank of vegetation on ancient strands; high

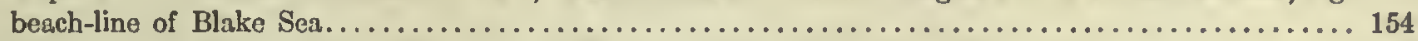

30. Ranks of ancient vegetation of Blake Sea. Heliotropium as pioneer on emersed island............ 168

31. Pluchea and Spirostachys as pioneers on islands. Baceharis as pioneer on Cormorant Island.......... 170

32. Islands and bars, southwest shore of Salton Sea. Spirostachys near cormorant's nest on new island...... 170

\section{FIGURES IN TEXT.}

1. Detail of Rocque's map showing body of water separated from head of Gulf of California............ 15

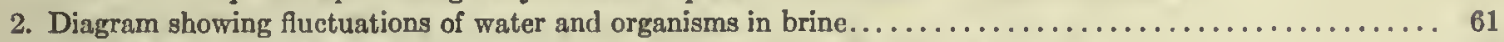

3. Curves showing alterations in level of Salton Sea, 1905-12, with estimated inflow................ 138

4. Diagram showing recession of sea at Travertine Terraces, $1907-12 \ldots \ldots \ldots \ldots \ldots \ldots \ldots$ 



\section{THE SALTON SEA}

A STUDY OF THE GEOGRAPHY, THE GEOLOGY, THE FLORISTICS, AND THE ECOLOGY OF A DESERT BASIN

By

D. T. MACDOUGAL and Collaborators 



\title{
THE CAHUILLA BASIN AND DESERT OF THE COLORADO.
}

\author{
By Wilitiam Phippg Blake.?
}

\section{EXPLORATION.}

The year 1853 was notable in the history of explorations of United States territory west of the Mississippi River. In that year, under the administration of President Pierce, with Jefferson Davis as Secretary of War, four fully equipped expeditions, authorized by Congress, were sent out to explore the almost unknown country lying between the Mississippi River and the Pacific Ocean, to look for and determine a practicable route for a railway.

Our knowledge of the country at that date may be summarized as follows: Aside from the early exploration in the northwest, Fremont, in his daring overland explorations, had made us acquainted with the obstacles and perils of a route across the Sierra Nevada; Stansbury had told us of the great Salt Iake; Sitgreaves had crossed Arizona south of the Grand Canyon, entering what is now California near the mouth of Bill Williams Fork. Emory had made a rapid military reconnaissance of the route from Fort Leavenwortl, Missouri, to San Diego, in California.

To one of the expeditions of 1853 was assigned the duty of following the Sierra Nevada of California southward, to scek for any suitable pass through which a railway might be built. This survey was placed in charge of Lieut. R. S. Williamson, of the United States Topographical Engineers, with Licut. J. G. Parke second in command, and the writer as geologist. Walker's Pass, much vaunted at the time as the best and only practicable pass in the Sierra Nevada, was the first objective point. It was most favored by Senator Gwin of California, who had personally taken the field and journeyed as far south as the Tejon, from whose summit he could see a favorable ronte across the Great Basin eastward. The Williamson expedition made surveys of Walker's Pass, the Taheechapah (the orthography of which has been corrupted to Tehachipi), Tejon, Cañada de Las Uvas, the passes north of Los Angeles, and the Cajon from the Mojave to San Bernardino, without finding any pass that offered an especially favorable and easy route or inviting grades.

\section{SAN GORGONIO PASS.}

Imagine, then, the enthusiasm with which the unknown great break in the mountain range between San Bernardino and San Jacinto was approached by the members of the party as we made our way eastward from the region, then practically unoceupied but now including the towns of Colton and Redlands, and found an easy grade and open country for our train of wagons to the summit, only 2,580 feet above the sea. Here, at last, was discovered the greatest break through the western Cordillera, leading from the slopes of Los Angeles and the Pacific into the interiol wilderness. It had no place upon the maps and had not been traversed by surveying parties or wagons. From the summit, we could look castward and southward into a deep and apparcntly interminable valley stretehing off in the direction of the Gulf of California. This pass was evidently the true gateway from the interior to the Pacific Ocean. (Plate 1 A.)

1 This paper was prepared by P'rofessor Blake two years prior to his death in 1910 with a view to its publieation in conjunction with a series of other essays upon the control of the Colorado liver by the Ameriean Society of Civil Engineers. 'The manuseript, however, was found to be more suitable to the present volume and was seeured for publieation here through the kind offiees of Mr. I. T. Cory. But few alterations have been made, and these consist chiefly in omissions of sections bearing upon the vegetation and other topies which are more fully treated elsewhere. The paper possesses a peeuliar interest, sinee it is based upon observations begun by the author with his diseovery of the basin-like character of the region in 1853 and extended to his last visit in May 1906. 
The discovery of this practicable and easy railway route determined the construction of a southern railroad and made it necessary to acquire from Mexico the strip of country in southerı Arizona since known as the "Gadsden Purchase."

We descended with eagerness into this great unknown valley, carefully reading the barometer at regular distances to ascertain the grade. Proceeding without obstacles, but with no trace of a road, and following the dry bed of a stream, now known as the Whitewater, we reached the bed of a former lake and found it to be below the level of the sea. (Plate 1 c.)

The value of this pass, as a great natural gateway through the mountains from the ocean to the interior, is emphasized by the magnificence of the mountain masses rising like sentinels, on the north and on the south. These are San Bernardino, over 11,000 feet and snow-capped for the greater part of the year; and San Jacinto, the sharp peak on the south with rugged sides, and similar elevation, which forms the northern end of the Peninsula Range.

This San Gorgonio Pass is the only great break directly through the mountains from Cape St. Lueas to the Golden Gate; and like the Golden Gate, it is a great draft channel for the inrush of ocean winds to supply the uprising heated air of the interior deserts. Topographically this valley into which we descended is the northwestern extension, prolongation, or head of the Gulf of California.

\section{GEOLOGIC HISTORY.}

That this valley was formerly occupied by sea-water is shown by the reefs of fossil oysters and other marine shells. As these fossils are now above tide-level, it is evident that there has been a considerable uplift of the whole region, and a change from marine to fresll-water conditions. Further north on the west coast of the United States we have another great longitudinal valley separating the Coast Range of California from the Sierra Nevadas. The two great valleys are similar in many respects; they both receive the drainage of the larger rivers of the interior and protect the deltas of their rivers from the direct destructive or modifying action of the sea. In the Gulf of California we find the Delta of the Colorado, and in the California valleys the deltas of the San Joaquin and of the Sacramento Rivers. The California Valley is nearly at the sea-level. The sea has been displaced by alluvium. A depression of the western coast of less than 1,000 feet would flood the valley with sea-water through the Golden Gate from the 'Tejon to Shasta. A similar or even less depression of the Lower California region would carry the waters of the Gulf far north of Yuma and flood the valleys for 200 miles northwest of the present head of the Gulf. A depression of 2,580 feet would connect the water of the Pacific and the Gulf at the pass of San Gorgonio, where the trains of the Southern Pacific Railway cross the divide, and would make an island of the peninsula of Lower California.

EVIDENCE OF UPLIFT.

Such, no doubt, were the conditions in Middle Tertiary times. The waves of the Gulf then washed the slope of the San Jacinto and San Bernardino, where we now find arid mountains and desert plains.

The silt of the Colorado was distributed far and wide in the interior sea, only partially cut off from the broad Pacifie by a chain of islands which now form the crest of the Peninsula Mountains from San Jacinto to Cape St. Lucas. As the land gradually rose from the waves, the beds of oyster-shells and of other forms of marine life came into view and may be seen to-day, 1,000 feet above the valley on the sides of the San Jacinto Mountains. Such evidences of the former marine occupation of the valley are particularly strong and convineing along the castern base of the Peninsula Mountains, where marine fossils of the Tertiary period are numerous, especially in the stratified formation along Carrizo Creek. 
A

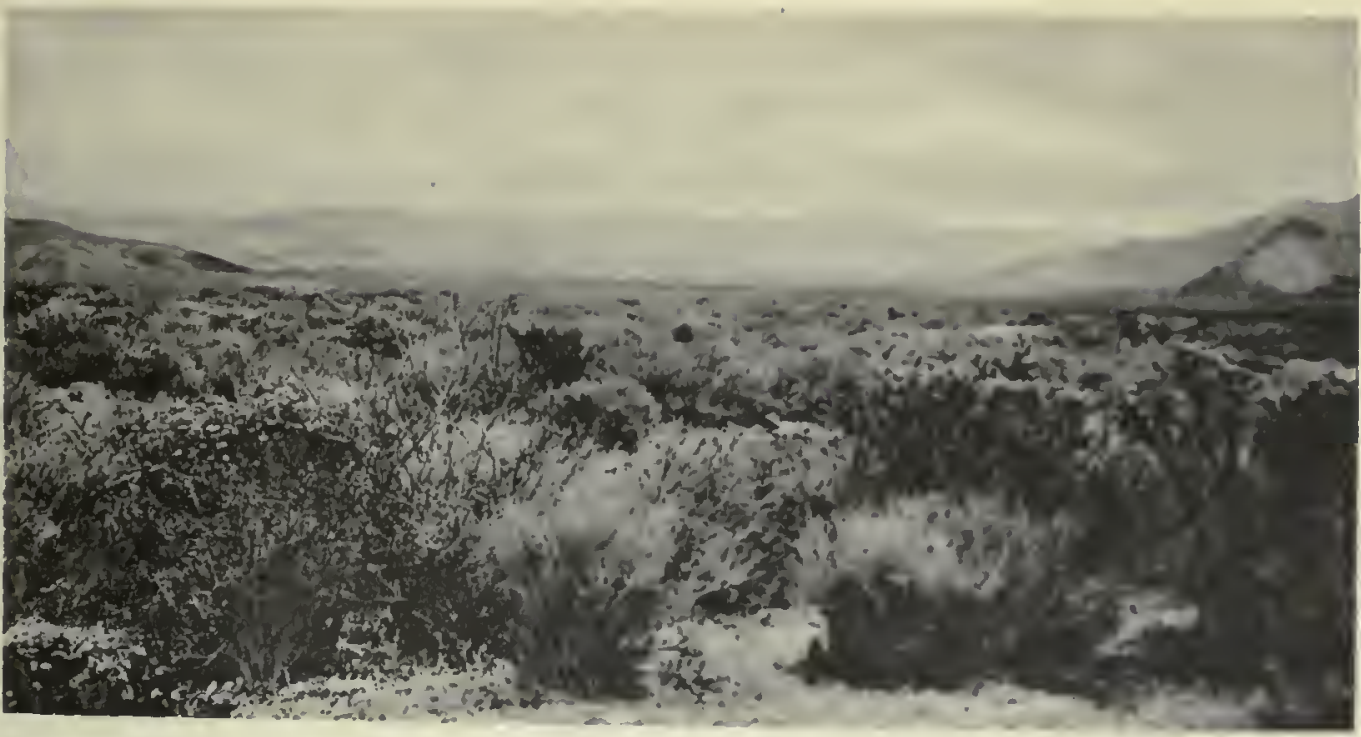

B

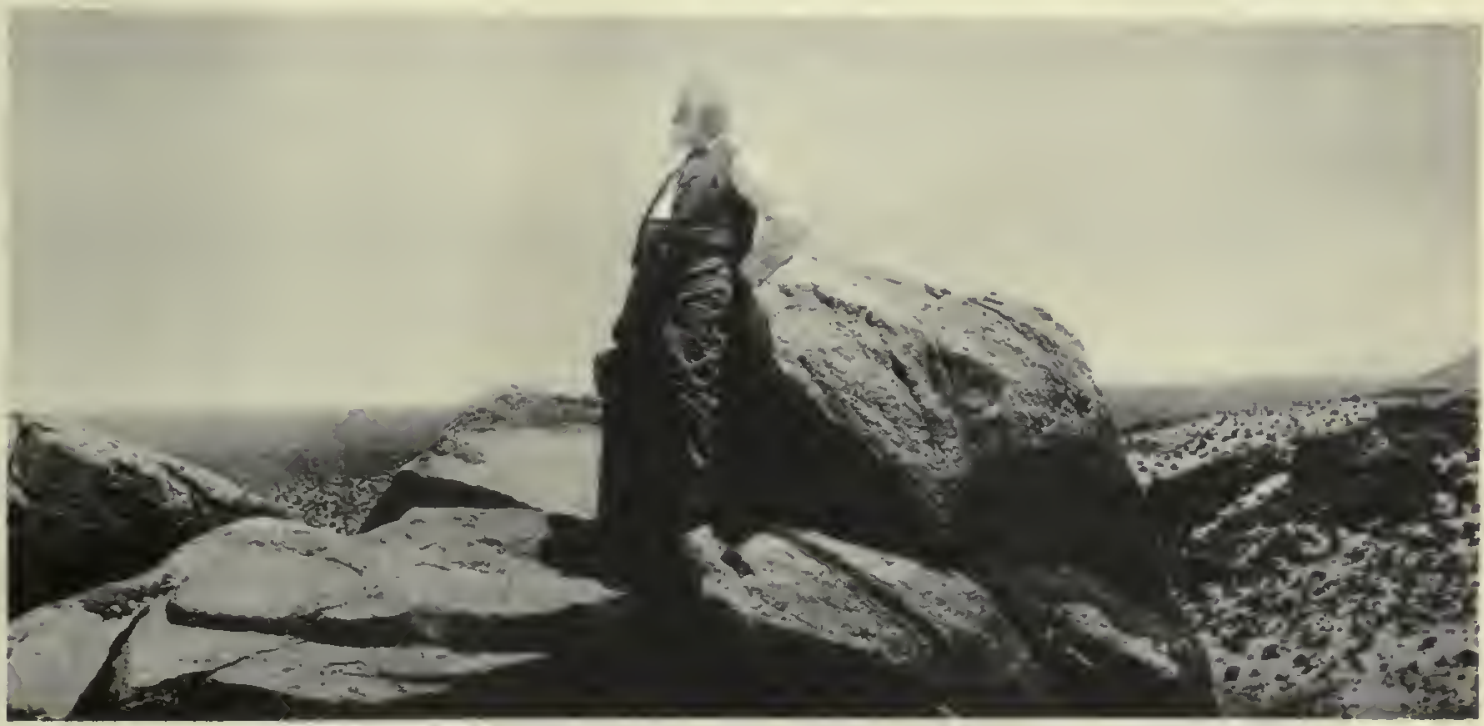

C

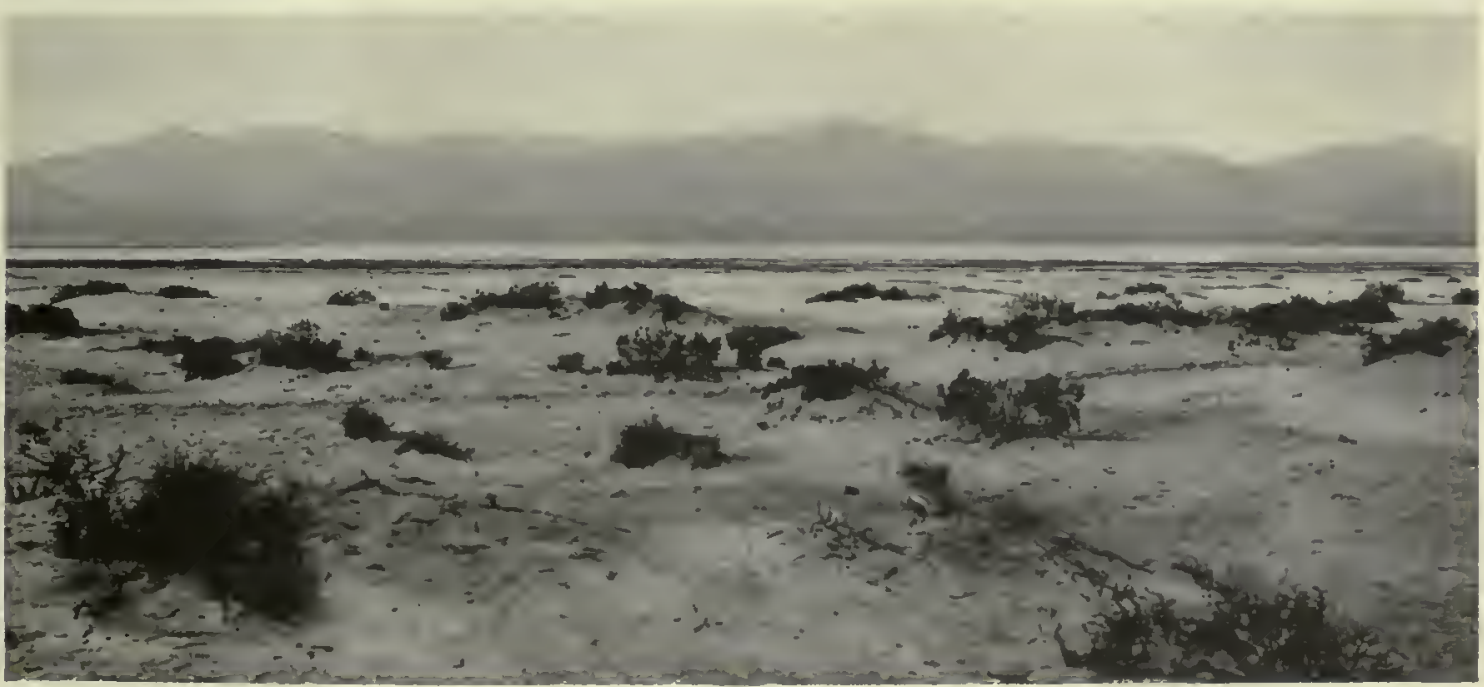

A. View in San Gorgonio Pass eastward into the Cahuilla Basin.

B. The late Prof. William Phipps Blake standing on Summit of Travertine Rock, May 1906, fifty-three years after his original discovery of this formation.

C. View of Saline Plain or Saltern at bottom of Salion Sink, taken from near the railroad station of Salion, February 1903. 
Many of these fossil shells were observed in 1853, but have since been deseribed more in detail by other explorers, notably by Dr. E. E. Stearns of California.

Dr. Stephen Bowers, who describes many of the localities, writes of the region generally as follows:

"The water of the old Tertiary Sea, which once prevailed here, must have been extremely favorable to the propagation and growth of mollusks, especially oysters. After the vast erosion that has taken place, there are many square miles of fossil beds, especially of oyster-shells, which, in places, are 200 feet thick and may extend downivard to a much greater depth. The oysters existed not only in vast numbers but in many varieties, from the small shell which is in evidenee over so much of the territory, to varieties nearly a foot long and to others weighing several pounds each. One variety is nearly as round and as large as a dinner plate."

Fossil oyster-shells are perhaps most abundant in the Coyote Wells Distriet, about 7 miles north of the international boundary line and about 375 feet above the level of the sea. Other deposits of marine shells, including shark's teeth, pectens, and univalves, are reported from one of the branches of Carrizo Creck. But the oceupation of the valley by sea-water, while comparatively recent geologically, has extreme antiquity and long antedates human history, dating back to the Middle Tertiary.

The continental elevation which followed culminated in the Pleistocene, or Glacial period, when the precipitations of rain and snow are believed to have attained their maximum. At that time, the Colorado of the West had its greatest volume and transporting power. Its silt was distributed far and wide in the interiol sea, then only partially cut off from the broad Pacific by a chain of islands which now form the crest of the Peninsula Mountains from San Jacinto to Cape St. Lucas. Entering the Gulf just below where the mouth of the Gila River now is, it began dropping its load of débris and silt, forming the raised delta which gradually extended westward and southerly across the upper end of the Gulf toward the Cocopah Mountains and finally to the ligher ridges beyond the Pattic Basin, even to the eastern base of the Peninsula Mountains.

Aided by the gradual elevation of the land and by the tides of the Gulf, the building up of the delta proceeded rapidly. It assumed the nature of a great dam or levee stretching across the Gulf and diverting the river-water through shifting chamnels to one side or the other, first to the lower part leading to the Gulf and then to the upper end of the depressed area shut off from the tides. At certain seasons the tides rise to a great height at the head of the Gulf and are accompanied by dangerous bores. Such tides rushing up the mouth of the Colorado have ever been important factors in the formation of the delta. Ordinary tides are said to rise 15 fect, and in extraordinary cases to 37 feet. Aceording to the United States Geological Survey the tidal range is from 14 to 32 feet. (See p. 17.)

\section{LAKE CAHUILLA.}

The head of the Gulf, being cut off by the Delta from the free aceess of the sea, became an inland lake of salt water, or at least of brackish water, with the great Colorado River at certain scasons and stages of flood flowing into it. This stream then, as now, was laden with the rich alluvial earths of its upper course, torn from the ravines and eañons of the Rocky Mountains and the Grand Cañon of Arizona. This influx of river-water, though variable in duration and quantity, must have exceeded the loss by evaporation. Consequently the level of the lake was raised until the excess overflowed to the Gulf by a lower outlet.

That such conditions continued for centuries appears certain, for the enormous accumulation of sediment within the old beach-lines tells the story of long-continued lacustrine conditions, of the displacement of the sea-water, and of the final oceupation of the valley by fresh water. This is shown to us by the fresh-water shells, not only on the surface but in the blue-clay sediments, in the banks of ravines and arroyos, and in the deep borings for water, showing that the shells dropped to the bottom and were thus entombed. 'These 
fresh-water shells are so abundant in the lacustrine clay of the desert, especially at the northern end, that they accumulate in windrows before the wind. The thin pearly shells of anodonta are common in the clay about Indio. Four or five species of univalves, new to science, were collected in 1853.

The long-continued existence of such a lake is shown, not only by the fossil shells, but by the ancient shore-lines and beaches, as fresh as if recently left by retiring waters, and especially vivid and convincing north of the Delta, where they are visible for miles.

At an outlying mass of rocks at the base of the main ridges of the Peninsula or San Jacinto Mountains, a deposit of travertine marks the former height of the water by a thick incrustation, covering the granite boulders from view. The foundation rock must have been a small islet of granite projecting above the waves of Lake Cahuilla. It is now known as Travertine Point, and its base was nearly reached by the rising waters of the Salton Sea in 1907. (Plate 1 B.)

By the courtcous invitation of Dr. MacDougal, I had the pleasure of revisiting this place in the month of May 1906. Crossing the valley from Mecca on the Southern Pacific Railway, we visited the then rising Salton Sea, skirting it to Travertine Point, which I again ascended half a century after its discovery and description in 1853 . The old waterlines and beaches were comparatively unchanged in appearance. Concentric lines of sparse vegetation marked where the waters had stood centuries before. Looking out from the summit across the Salton Sea, it was difficult to realize that the old-traveled trail across the desert lay 15 fathoms deep under water, where before not a drop could be found.

The former lake, the shores of which are recorded on the rocks and slopes of the Cahuilla Valley north of the Delta, had an area of about 2,100 square miles. It was 100 miles long and about 35 at its widest. It was first identified and described by me in 1853 , in a communication to the San Francisco Commercial Advertiser, edited by J. D. Whelpley, in the winter of 1853-54, and later in the reports of Exploration and Surveys for a Railroad Route from the Mississippi River to the Pacific Ocean, volume v. Its boundaries were then approximately shown and its origin explained. I have named it "Lake Cahuilla," from the name of the valley and of the Indian tribe. (See pp. 24 and 25.) The name "Salton Sea" is appropriatcly applied to the recent inflow and partial inundation of the valley covering the salt-beds at Salton, but the ancient lake in its entirety recuires a distinctive name. If any precedent is needed for naming an ancient lake which has disappeared, it is found in the naming of the old lake in Utah by Clarence King, as Lake Bonıeville. Lahontan is another example. The Great Salt Lake of Utah is the residual lake of Lake Bonneville much as the Salton Sea is the residual lake of Lake Cahuilla.

Lake Cahuilla occupied the northwestern end of the basin of the California Gulfthat portion eut off from the sea by the delta deposits. The northwestern part of the valley is also known as the Cabezon or Caliuilla Valley, so named from the Cahuilla Indians, who have inhabited the oases and tillable fringes of the Desert from time immemorial. There is a difference of opinion regarding the proper orthography of this name. It is ably discussed by Dr. David l'rescott Barrows in the Iithno-Botany of the Cahuilla Indians of Southern California. He writes:

"A word should be said as to the pronunciation and spelling of the tribal name, Coahuilla. The word is Indian, and the tribesmen's own designation for themselves, and means 'master' or 'ruling people.' 'There is some slight variation in its pronuneiation, but the most usual is probably kow-wee-yah, accent on the second syllable. 'The spelling has been varions. That used by the early writers and correct, according to the value aecorded to $l l$ in Spanish-Ameriean, is that adopted here-Coa-hui-lla."

The writer, in the year 1853, when passing through the "Ka-wee-yah" or Four Creck Country in California, with Licutenant Williamson, in the endeavor to conform phonetic- 
ally to the Indian name, wrote it "Cohuilla," and sometimes "Cuhuilla." This last form seems to have been more generally accepted and is preferred to Cohuilla, Coalunilla, or any other.

\section{DESICCATION OF LAKE CAHUILLA.}

With our present knowledge of the delta deposits of the Colorido, the varying phases of the stream, the lightness and depth of its deposits of silt, its quicksands, its shifting channels, and uncontrollable ways, it is easy to realize that the inflow to Iake Cahuilla must have been extremely variable and uncertain. We can realize that under favorable conditions the whole volume of the Colorado may have been diverted alternately to the Lake and to the Gulf, and that long intervals of drought accompanied by drying up were often experienced.

Writing upon the subject in 1853 , attention was directed by the writer to the traditions of the Cahuilla Indians, as follows:

"The explanation of the formation of the lake and its disappearance by evaporation which has been presented, agrees with the traditions of the Indians. Their statement that the waters retired poco-a-poco (little by little) is conneeted with the gradual subsidence due to evaporation, and the sudden floods of which they speak undoubtedly took place. It is probable that the lake was long subject to great floods produced either by overflows of the river at seasons of freshets, or by a change in its channel, or by a great freshet combined with a very high tide, so that the river beeame, as it were, dammed up and raised to an unusual height. The present overflows, though comparatively slight, are probably similar; and yet it is possible that the interior of the Desert might be deluged at the present day, provided no elevation of the land has taken place, and the river should remain at a great height for a long time-long enough to cause the excavation of a decp channel for New River."'

\section{SALTON SEA.}

This is precisely what has recently happened by the cutting of irrigating canals and by the uncontrolled flow of the Colorado water: deep and destructive channels were cut, a partial flooding of the desert followed, and the "Salton Sea" was formed. The body of water which so recently threatened the restoration of the former lake conditions, by the month of February 1907 had attained a length of 45 miles, a maximum breadth of 17 miles, and a total area of 410 square miles, with a maximum depth of 83 feet. It extended from Imperial Junction nearly to Mecca Station. It submerged railway stations and necessitated the removal of the track of the Southern Pacific for 67 miles to a higher and more northern bed. By the great and masterful exertions of the engineers in charge, seconded and supported by the Southern Pacific Railroad, the destroying deluge was stopped in the month of February 1907 and the gradual disappearance of the Salton Sea by evaporation commenced and is now in progress. In this we have immediately before us a practical exhibition of what must have happened many times before.

Evidently in the case of the ancient Lake Cahuilla, with the loss of the supply of water from the Colorado the lake disappeared by evaporation. The conditions for this were extremely favorable. Of the rate of evaporation and the time required for the complete desiccation of the valley, we have no direct evidence, but there is every reason to accept the statement of the Indians that the water retired little by little, or very slowly, and no doubt years passed before the lake dried up.

\section{RATE OF EVAPORATION.}

Experiments by me upon the rate of evaporation in the Tulare Valley, California, in 1853, indicated 0.25 inch per day, or between 7 and 8 feet yearly. ${ }^{2}$ Dr. Buist found

1 Report Geological Reconnoissance in California, p. 238.

Report Geological Reconnoissance in California, p. 195, and Trans. Geog. Socicty, vol. Ix, p. 39, $1840-50$. See also, Trans. National Institute, Washington. 
that the anount of evaporation from the surface of the water at Aden, on the Indian Ocean, was about 8 feet per anium. At the rate of 8 feet yearly, the $\$ 3$ feet of water now covering the Desert, and known as the Salton Sea, will require ten and a half years for its complete evaporation.

Mr. H. T. Cory, the engineer who had charge of rediverting the Colorado River to the Gulf of California in 1906, states that if there is no further inflow of the Colorado River to the Salton Basin, the sea will practically dry up by evaporation in about eighteen years, and that the actual evaporation from the Salton. Sea from February 1907 to July 1912 has been almost exactly at the rate of 5 feet per annum.

From measurements of the evaporation from a tank at Calexico by Mr. Peck, of the California Development Company, the annual evaporation was shown to be about 6.73 feet, as will be seen by the following tabular report:

TABLE 1.-Evaporation from a water surface at Calexico.

\begin{tabular}{|c|c|c|c|c|c|c|c|}
\hline Month. & 1904. & 1905. & 1906. & Month. & 1904. & 1905. & 1906. \\
\hline $\begin{array}{l}\text { January... . . . } \\
\text { February... . . } \\
\text { March.... . . . } \\
\text { April. . . . . . } \\
\text { M1ay....... . }\end{array}$ & $\begin{array}{r}\text { Inches. } \\
4.39 \\
6.32 \\
8.86 \\
9.55 \\
10.91\end{array}$ & $\begin{array}{r}\text { Inches. } \\
2.72 \\
1.47 \\
4.41 \\
4.74 \\
5.38\end{array}$ & $\begin{array}{c}\text { Inches. } \\
2.57 \\
2.43 \\
5.06 \\
5.99 \\
6.84\end{array}$ & $\begin{array}{l}\text { August....... } \\
\text { September... } \\
\text { Oetober..... } \\
\text { November... } \\
\text { December... }\end{array}$ & $\begin{array}{r}\text { Inches. } \\
10.98 \\
8.61 \\
5.78 \\
5.40 \\
3.48\end{array}$ & $\begin{array}{r}\text { Inches. } \\
8.52 \\
7.83 \\
6.77 \\
3.23 \\
3.43\end{array}$ & $\begin{array}{r}\text { Inches. } \\
5.47 \\
6.73 \\
5.45 \\
3.61 \\
2.40\end{array}$ \\
\hline July. . . . . . . & 12.47 & 10.43 & 6.76 & Total..... & 103.64 & 75.00 & 63.60 \\
\hline
\end{tabular}

\section{COLORADO DESERT.}

The drying up of Lake Cahuilla left a broad region at the head of the Gulf; a depressed area below the sea-level, a trackless waste of nearly level land extending, including the Delta, for some 200 miles northwesterly beyond the present limits of tide-water in latitude $31^{\circ} 30^{\prime} \mathrm{N}$., approximately 80 miles south of the mouth of the Gila River at Yuma on the Colorado. The limits of this desiccated area are approximately marked indelibly on the ground by the shore-lines and beaches of I ake Cahuilla, extending on both sides of the valley from near Yuma to Indio and beyond.

The name "Colorado Desert" was given to this region by the writer in 1853. This was before the State of Colorado received its name. It was deemed most appropriate to connect the name of the Colorado River with the region, inasmuch as the desert owes its origin to the river by the deposition of alluvions and the displacement of the sea-water.

A tendency is shown by some writers to extend the area known as the Colorado Desert so as to include the arid regions north of it, especially the mountainous region along the Colorado and the Mohave, partly known to-day as the "Mohave Desert." This was not the intention or wish of the author of the name. It was intended to apply it strictly to the typical desert area of the lacustrine clays and alluvial deposits of the Colorado where extreme characteristic desert conditions prevail, such as arid, trecless plains, old lake-beds, and sand-hills--such conditions as are found in the Sahara of Africa and in the delta regions of the Nile. The appellation may properly be confined to the regions reached by the deposition of the silt of the Colorado, whether in the form of deltas or at the bottom of ancient lakes. I should also include the bordering detrital slopes from the contiguous mountains. So restricted, the area is practically coterminous with the ancient beachlines and terraces of the lakes which occupied the valley.

Its area is estimated at not less than 2,100 square miles; its breadth east and west opposite Carrizo Creek about 33 miles. Its height above tide ranges from 135 fect above 
sea-level at Yuma to an average of 42 feet following the old shore-line of Cahuilla Iake to -287 feet, now partly submerged.

\section{FERTILITY OF THE DESERT SOILS.}

The Colorado River, like the Nile, is a great fertilizer of the land which it overflows. Its alluvions are easy of tillage and are wonderfully productive. The Yuma Indians, after the subsidence of a flood, find the land ready for the seed. Walking over the newly deposited silt, a hole is made in it by the great toe, into which the seed-corn is dropped and then covered with the ball of the foot. The corn sprouts and grows with great rapidity.

The annual deposition of silt is constantly raising the level of the banks and increasing the tillable area. This process has been going on since the elevation of the land above the sea and the foundations of the Delta were laid. It is diffieult to compute satisfactorily the quantity of silt brought down by the river and added to its Delta every year.

The Arizona Experiment Station made observations in 1904 indieating that the lower Colorado earries approximately 70,000 acre-fect of silt on an average annually. In the year 1904 the amount of silt in the river water varied from 84 to 3,263 parts in 100,000 parts by weight, and an acre-foot of water contained an average of 9.62 tons of silt. If it is assumed that one-half of the silt in the river water used for irrigation is held in suspension until the irrigated lands are reached, a field to which 3 acre-feet of water is applied would receive 14.43 tons of silt, which has an average value as a fertilizer of approximately $\$ 1.11$ per acre-foot of water. Mr. H. T. Cory ${ }^{1}$ gives the mean annual discharge of the Colorado River as 17,070 cubic feet per second, and the mean total discharge as $12,388,000$ aere-fect.

The fertilizing sediments from the annual overflow of the Nile, which stream has much in common with the Colorado, are estimated at 6 inches of depth in a century. It is thought that the bed of the river rises 4 feet in 1,000 years. It is said that 7 feet in depth of mud have accumulated around the pedestal of the statue of Colossus, the date of which is about $1430 \mathrm{~B}$.C.

The French estimated the deposit of Nile mud, from Essonan to Cairo, at 5 inches per century. The column of Rameses II is surrounded by a sediment 9.3 feet deep, fairly estimated. This monument was erected 3,215 years before, which gives a rate of 3.5 inches per century. But there are similar deposits below the depth of 30 feet, which, at the same rate of deposition, would require 13,500 years to A. D. $1854 .^{2}$

\section{ADAPTATION TO AGRICULTURE.}

Attention was early directed to the adaptation of the desert soil to agriculture, as shown in the official report to the War Department in $1855 .^{3}$

"The upper or gravelly plains of the Desert, especially those in the vicinity of the mouth of the Gila, are too arid and wanting in soil to be ever used for agriculturc. But this is not so with a large part of the Desert-the part formed by alluvial and lacustrine clay. The whole of this elay surface may be considered as capable of supporting a luxuriant growth of vegetation provided it is supplied with water by irrigation.

"The Cahuilla Indians in the northwestern part of the Desert raise abundant crops of corn, barley, and vegetables in the vicinity of the springs at their villages. We also observed a dam at the Caluuilla villages on the northern margin of the Desert, where we stopped over night. The ground was principally clay, which by drying in the sun had become very hard, but on being cut and pulverized by the passing of the train, became dry and dusty, like dry ashes. On cutting down into it for about 12 inches it was found to be more sandy and micaccous. It appeared to be a rich soil, for wherever water reaclied the surface the vegetation was abundant; and a large area near the mountains was covered with a dense growth of weeds, the ground being moist.

1 Procecdings of American Socicty of Civil Enginecrs, November 1912.

${ }^{2}$ Compiled from Drapcr's Intellectual Development of Europe, p. 87

${ }^{3}$ Report Gcological Reconnoissance California, Blake, and vol. v, Pacific Railway Reports, pp. 248-249. 
"The vegetation around the springs was luxuriant; and wherever the soil was moistened it supported either a growth of grass or of rank weeds. 'The Indians had their houses in the thickly growing mesquite trees around the springs. A growth of weeds was noted over a wide area near the mountains, but not far from the eultivated field."

Samples of the soil, taken for analysis, showed the presence of all the elements necessary to fertility. It is added:

"From the preceding facts it becomes evident that the alluvial soil of the Desert is capable of sustaining a vigorous vegetation. The only apparent reason for its sterility is the absence of water; for wherever it is kept moist, vegetation springs up.

"If a supply of water could be obtained for irrigation, it is probable that the greater part of the Desert eould be made to yield erops of almost any kind. During the seasons of high water, or of the overflow of the Colorado, there would be little difficulty in irrigating large areas in the vicinity of New River and the Lagoons.

"By deepening the ehannel of New River, or eutting a eanal so low that the water of the Colorado would enter at all seasons of the year, a constant supply could be furnished to the interior portion of the Desert. It is incleed a serious question whether a eanal would not cause the overflow of a vast surface and refill, to a certain extent, the dry valley of the ancient lake. This is possible and would result, provided no change of level has taken place sinee the water dried up." (Pages 249-250.)

\section{GEOLOGY AND MINERALS.}

The mountain ranges, which figuratively frame the valleys, rise wall-like on both sides of the Cahuilla Valley and the Desert. Those on the west are the most abrupt and rugged, and form a complete separation between the Delta region and the Pacific Ocean. These are the San Jacinto ranges of the Peniusula Mountains. San Jacinto, the highest peak, stands at the south end and on the south side of the San Gorgonio Pass, which separates it from the massive ridges of San Bernardino. Both of these mountains rise to an altitude of over 11,500 feet above the sca. The white snow-covered summit of San Bernardino is a conspicuous object for a large part of the year from the decks of vessels sailing along the coast. San Jacinto does not attract so much precipitation, but is a very sharp and picturesque peak. (Plate 7.)

Geologically, these mountains are essentially crystalline and granitic. The Peninsula ranges north of the boundary line consist chiefly of granite and syenitic rocks, in which there is an unusual amount of the mineral known as schorl, or black tourmaline. Gneiss and inicaceous schists are largely developed and are sharply upraised and plicated, forming extremely rough and jagged croppings, especially on the side bounding the Desert, where there is but little soil. Owing to the desiccation of the wind from the sea, the scanty precipitation is insuffieient for mountain streams of much volume. The few brooks or rivulets of the higher ridges in their descent to the valley in the rainy season are quickly absorbed or dissipated by evaporation on reaching the lower slopes.

On the seaward side of the mountain range the conditions are very different and many small and fertile valleys are found.

Amongst these, Warner's, so named for the pioncer settler, Don Juan Warner ("Juan Largo"), a tall New Englander from Lyme, Connecticut, was a great haven of rest in the early days for those who had survived the terrors of the desert in the 90 miles journey from Yuma to Carrizo Creek, without water.

These granite ridges from San Jacinto, southward, through San Diego County, have become noted for the superb gems taken from many places, more particularly for red, green, and pink colored tourmaline, obtained by patient mining. The rock generally may be said to be characterized by the abundance of the ordinary black tourmaline or schorl. Amongst the other gem-stones, the rare form of spodumene, a lithia mineral known as kunzite, is 
obtained liere in beautiful purple or violet-colored erystals. Garnets and beryls are also obtained in these mountains. The beryls are sometimes colorless and almost as brilliant as diamonds, and are often tinted a pale rose-pink, greatly enhancing their beauty.

The mountains on the north of the great Cahuilla Valley are also granitic and form a series of sharp ridges in constant sequence, separated by gravelly slopes ancl valleys for a great distance up the valley of the Colorado. Some outcrops have been worked for gold in the mountain ridges a few miles north of Indio, and also at Carga Muchacha, near Yuma.

The geology south of the international boundary is but little known. At the Sierra Giganta, between Muleje and Loreto, there are precipitous cliffs of red sandstone.

VOLCANISM.

The evidences of voleanism are many and impressive in the lower Delta region of the Colorado and on the Sonora side of the head of the Gulf, where numerous craters exist and are clominated by the extinct volcano known as Pinacate. This mountain rises in a volcanic center of great extent, only about 25 miles from the shores of the Gulf. It had been recently visited by Dr. MacDougal, of the Carnegie Institution of Washington, in company with Engineer Sykes; Messrs. Hornaday, of the Zoological Park, New York; and Mr. Phillips of Pittsburgh, Pennsylvania. 'They found extensive pit-craters with precipitous sides and a broad region covered with lava.

Northward from this Pinacate region, volcanic outflows continue as far as Molnawk, on the railroad in Arizona, on the north side of the international boundary-line.

In close proximity to the deposits of the Colorado Delta we find the eraters and outflows of the Cerro Prieto, or Black Butte, on the flanks of the Cocopal Mountains. The chicf crater is in the mountain, 750 feet high, and is flanked by smaller eraters, all now extinet but giving evidenee of comparatively recent activity. Mud voleanoes, or salses, occur there, from which hot water and steam are escaping.

At the time of the great earthquake in San Francisco, April 18, 1906, there was an earthquake in the Imperial region of the Delta, which suggests the probable continuation of a fault-plane passing along the great interior valley of California and southward through the valley of the Gulf.

\section{MUD VOLCANOES.}

In the year 1852, Major Heintzelman, U. S. A., then commanding at Yuma, was surprised to see clouds of steam arising from the southwest portion of the desert. Visiting the place he found a great cruption of hot water and mud, with jets of steam, issuing from conical hillocks of mud. Masses of dark-colored mud were thrown to a height of 40 feet. These salses were later visited and described by Dr. John L. LeConte, ${ }^{1}$ and by Dr. Veateh. ${ }^{2}$

An excellent graphic description was given by Dr. David P. Barrows in $1900 .^{3} \mathrm{He}$ correctly observes:

"The volcanoes are doulutless immediately due to the infiltration of water from the Colorado overflow down to the heated beds of rock not far beneath. Converted into steam, these waters burst violently upward through the deposits of silt, and around their orifices throw up encircling walls of mud."

Similar outbursts have been seen not far from the line of the railroad opposite the Salton Sea deposit, but are now covered by water.

Dr. MacDougal described the volcanic phenomena as follows:

"Hot springs and other manifestations of volcanic energy are to be found all along the geological axis on the castern side of the Peninsula of Baja California, but the most pronounced feature

1 American Journal of Science and Arts, (II) xux, May 1855.

${ }^{2}$ Ibid., (II) XxvI, 1858.

National Geographic Magazine, Sept. 1900, vol. xı, No. 9, p. 337. 
of this character is to be found well out in the Delta, near Volcano Lake; here, on a saline plain, a few miles in extent, innumerable small mud cones, solfataras, and boiling pools of nud and water enit stcam, smoke, and sulphurous gases, accompanied by a dull rumbling sound.

"According to the traditions of the Cocopah Indians, a momber of the tribe accused of sorcery, or other serious erime, was sent back to his evil master by the simple process of dropping him into a pool of boiling mud-an obvious entrance to his abode below."1

SALT.

The accumulation of salt in the lowest part of the Desert was well known to the Cahuilla Indians, who resorted to it for salt for an unknown period. Being a little off the trail or road then traveled from Yuma to the settlements in California, it was not often visited or seen by the early explorers, who, after the long journey of 90 miles without water, pressed forward without delay to the shades and springs of potable water on the seaward slope of the mountains at Warner's Ranch.

Emory, 1S48, mentions the salt lake as three-quarters of a mile long and a half a mile wide, and that the water had receded to a foot in depth. The salt-bed was not conspicuous in 1853, at the time of Williamson's survey. Its precise position was not ascertained. It was said that it was sometimes flooded with water, which was supposed to have reached it from the overflow of the Colorado, through the channel of New River. ${ }^{2}$ Evidently this occasional submergence and desiccation must have caused a great difference of appearance at different times, the depression when dry being sheeted with salt, and when flooded appearing as a shallow lake of briny water. (Plate 1 c.)

This bed of salt, when not flooded, was extensively exploited by the New Liverpool Salt Company. Shipments were made from the Salton Station on the railway for many years, until the last overflow, which for a time has destroyed the industry.

In 1892 the lake was described as a salt marsh connected by a branch railway with the main track of the Southern Pacific road. At the end of this track, some 15,000 feet west of the railway, a well was bored by the Company to a depth of 300 feet. The top material largely consisted of black mud resting on a crust of salt, a mixture of the clloride of sodium and chloride of magnesium, 7 inches thick. On passing through this erust the drill dropped through 22 feet of a black ooze containing water over 50 per cent, sodium and magnesium salts, fine sand, iron oxide, and clay. It rested on hard clay, through which the drill passed for the remaining distance, 277 feet, varied only by two or three streaks of cement. ${ }^{3}$

The inflow of water from the Colorado River in 1891 is described as follows:

"In the month of June 1891, a steady flow of water entered the depression (of the salt lake) from the southeast and continued to the northwest uninterruptedly until an area 30 miles long and averaging 10 miles in width was covered to a depth of 6 feet, measured at the end of the Salton Salt Works' branch track. When first examined the water showed a density of $70^{\circ}$ Beaume, which gradually increased to $25^{\circ}$ Beaumc."

This influx of salt water gave rise to the idea that the water of the Gulf had penetrated through some underground channel, but no such channel could be found. It was fancied that the soft, briny ooze might extend under the crust beyond the marsh even to the Gulf, and so obtain the supply of salt water enriched by passing into and through the ooze. The water, however, entered the basin through the New and the Alamo River channels which led from the lower Delta region overflowed by the unusually severe Colorado River flood, exactly as occurred again in 1905 and 1906.

\footnotetext{
1 The Delta of the Rio Colorado, Bull. Amer. Geog. Soc., p. 10, 1907.

2 Report Gcol. Rec. California, p. 245.

Report State Mineralogist of California, X1, p. 388.
} 
ASPHALTUM AND PETIROLEUM.

In the year 1907, according to the report by Dr. Stephen Bowers to the State Mineralogist of California, the recorder's office at San Dicgo showed that more than 450,000 acres of land liad been located for petroleum in the Colorado Desert Mining District, in San Diego County. Expectations were great and many borings were made, but it does not since appear that any petroleum has been developed there.

Asphaltum was reported in 1891 by Dr. Bowers, from the Fish Creek District, southwest from the Mesquite Company's wells. Asphaltum occurs there and at Superstition Mountain. Dr. Bowers also reports nearly pure asphaltum from section 7, Township 11 south, Range 10 east, and at several points in the same township.?

\section{SULPIIUR.}

Deposits of sulphur in the Cocopah Mountains have been worked in a desultory, intermittent way for many years. Common report assigns a considerable quantity to the locality on the west side of Volcano Lake, but no reliable descriptions are at hand. It is about 20 miles south of the boundary.

\section{SODIUM CAIRONATE.}

Carbonate of soda occurs in quantity on the shore of the Gulf at Adair Bay, but has not been developed. The quality, as shown by samples submitted at the University of Arizona, is excellent and the crude material could no doubt be advantageously shipped to United States ports were it not for the import duties.

GOLD.

Gold-bearing quartz veins are found in the nountains north of the Desert. One was worked at Carga Muchacha, and the ore was milled at Pilot Knob for several years.

\section{ANALOGOUS CONDITIONS ELSEWHERE.}

We find in the Old World conditions analogous to those of the Gulf of California. The Red Sea, for example, also occupies a great trough or valley about 1,200 miles long, extending northwesterly and southeasterly over nearly 20 degrees of latitude, from approximately $12^{\circ}$ to $32^{\circ}$, from the Indian Ocean nearly to the Mediterraneall. It appears to have been eut off from a former connection with the Mediterranean by the deposits which form the Isthmus of Suez.

The Gulf of Sucz, at the north end of the Red Sea, extends nortll-northwest for 170 miles, with an average width of 30 miles. Its shores may be regarded as a portion of the Isthmus reclaimed from the sea; the former limits of the occan waters can be traced for several miles inland.

In cach of these great continental longitudinal valleys, great geographic changes have resulted from deposits of silt-laden rivers. The Red Sea has been shortened by the deposits from the Nile, and the Red Sea of California by the deposits of the Colorado.

The phenomena of the Colorado Delta, especially changes of channels, find a close counterpart in those of the Indus Delta. This river, rising in Central Asia, in the mountains of northern India at the northeastern extension of the Himalayas, flows south and westerly and empties into the Arabian Sea about $25^{\circ}$ nortl latitude. It there forms a delta 10,000 square miles in area, with a coast line of 125 miles. It exhibits a network of abandoned channels and "lost rivers," calamitous in their drying up, reducing thousands of square miles of a once fertile and inliabited country to waste and solitude. Channels once filled with flowing water are often forsaken. The flow often shifts suddenly and

${ }^{1}$ Reconnaissance of the Colorado Descrt Mining Distriet, by Stephen Bowors, Ph. D., Sacramento, 1901, p. 17. 
many dry channels are left. Great changes in the course of the river took place in the last century. The length of the main channel abandoned was not less than 100 miles. There is evidence that shiftings of the river-bed have been going on through all ages.

An inland sea once covered the Rann of Kachh and the region is sometimes flooded during the season of the southwest monsoons.

The rate of advance of the shore-line of the Delta is rapid. It is stated that in ten years the advance of the banks at the river mouth is 3.33 geographical miles, or one-third of a mile yearly. It is estimated that the river brings down 217,000,000 cubic yards anuually.

Changes very similar to the displacement of the waters of the Gulf of California by the Colorado Delta have been in progress in other parts of the world, notably at the head of the Persian Gulf, which, within a comparatively recent period, extended 250 miles farther to the northwest than the mouth of the combined stream of the Tigris and Euphrates.

In the interior valley of the upper California, which is topographically an extension of the great trough of the Gulf, there are also analogous conditions of delta and lacustrine deposits. In the valley of the Tulares there are broad regions of level lacustrine clays where evidently there were formed broad lakes of fresh water, represented to-day by the chains of shallow residual lakes from the Buena Vista to the Kern and the Tulare. These lakes, ever varying in their extent according to the water supply, owe their origin as separate sheets of water to the diversion of the San Joaquin River by its own detrital deposits from a southern and land-locked to a more northern outlet leading to the sea. The Delta deposits of this river, by extending into and across this interior valley, divided it into two parts near its center, so that the floods of the San Joaquin, which once swelled the volume of the Tulares, were finally withdrawn into the sea at the Golden Gate. All such river and lake deposits, both of the Old World and the New, are remarkable for their fertility and capacity of sustaining large populations. From this point of view the value of the Delta of the Colorado can scarcely be estimated. It fully justifies the great cost of its reelamation and control of the water supply for the benefit of this and future generations. 


\title{
GEOGRAPHICAL FEATURES OF THE CAHUILLA BASIN.
}

\author{
Bt Godfrey Stres.
}

\section{GENERAL DESCRIPTION.}

Although the extensive arid area of southeastern California is strikingly homogencous in its general physical features, it has nevertheless been nominally divided, for purposes of local convenience and geographical distinction, into certain definite districts or deserts, and the Cahuilla Basin, with its associated drainage, lies almost entirely within the confines of the most southeasterly of these subdivisions-the Colorado Descrt. This name was first applied to the region by the late Professor Blake, as narrated elsewhere in this volume, and it has since come into very general use.

As now defined, the Colorado Desert may be considered to include the area between the Coast Range on the west and southwest; the Colorado River on the east; the San Bernardino and Chuckawalla Mountains on the north; and to merge, without any very definite limits, into the castern bajadas of the Peninsula Mountains to the south - some 8,000 square miles in all. (Plate 2.) It lies mainly within the United States, but its southern portion extends across the international boundary-line into the Mexican State of Baja California. It is traversed near to its northern limit, in a southeast to northwest direction, by the main line of the Southern Pacific Railroad, and within the last decade or so several subsidiary lines have been built to serve the growing needs of the prosperous communities which have sprung up upon the irrigable lands of the Imperial Valley.

Topographically the Colorado Desert is divided into two main and parallel basin areas which merge at their southeastern extremities in the alluvial plains of the Delta of the Colorado and are separated elsewhere by the Cocopal Range of mountains.

The Pattic Basin, which is the smaller and most southerly of the two, lies almost wholly within the Republic of Mexico. It has not as yet been fully examined or deseribed, but we know that its central and lowest portion is oceupied by a fluctuating lake or lagoon, fed by overflow from the lower Colorado, and it is probable that the bottom of this depression is many fect below sea-level.

The basin to the north and northeast of the Cocopahs, which constitutes the main portion of the Colorado Desert, and to which the name Cahuilla Valley was given by Professor Blake, has the general form of an acute-angled sealene triangle--the west bank of the Colorado River forming its base; the Cocopah, Superstition, and Santa Rosa mountains its southern side; and the gradually converging line of the Chocolate, Chuckawalla, and San Bernardino Mountains its northern side. The apex of the triangle lies at the summit of the San Gorgonio Pass, between the San Bernardino and San Jacinto Mountains. (Plate 7.) The extreme length of this triangle is about 185 miles and its width at the base about 75 miles.

The floor of the basin is roughly spoon-shaped, gradually dropping from its soutlcastern end for a distance of about 140 miles until it has attained a depth of 265 feet below sea-level, and then rising with increasing rapidity until at the summit of the San Gorgonio Pass it has risen to an elevation of some 2,500 feet above. An area of sand-hills and gravel mesas toward the northeast and a piedmont district which lies between the Supcrstition Mountains and the main escarpment of the Peninsula Range, complete the area under consideration. 


\section{EARLY MAPS AND EXPLORATION.}

Our real knowledge of the Colorado Desert extends back but few years and is still, in many important respects, far from eomplete; but we know the Spaniards approached the region, if they did not actually penetrate it, within a few years after the discovery of the New World.

The first expedition to explore the head of the Gulf of California and examine the cireumjacent region was the one sent out in 1540 by Don Antonio de Mendoza, the Viceroy of Mexico, under the leadership of Francisco Vasquez Coronado.

Pedro de Alarȩon journeyed up to the mouth of theColorado River by sea, and examined some parts of the Delta, and later in the year Coronado sent Melelior Diaz, with a small party, overland from Corazones, to eoöperate with him. Diaz reached the river, but failing to meet Alarçon, he crossed it on rafts, and was afterwards aecidentally killed while on the west side. He has, however, left an account, as recorded by Castenada, ${ }^{1}$ of reaching a land of "hot ashes and volcanic rumblings," which no doubt refers to the mud volcanoes near Voleano Lake.

Castillo, the pilot of Alarçon's squadron, made a ehart of the head of the Gulf, which appears to have been first published by Lorenzana in Mexieo in $1770^{2}$ (Plate 3), and is doubtless the earliest authentic map we have of the region. Castillo's interest, however, was ehiefly that of the mariner, and he made little attempt to portray inland features.

The knowledge gained by this expedition was evidently the inspiration for the eharts of all the early eartographers such as Joannes Cimerlinus, ${ }^{3}$ Plancius, ${ }^{4}$ Mereator, ${ }^{5}$ Wytfliet ${ }^{6}$ and others.

Wytfliet's map is by far the best and most interesting of these early charts, and whoever his authorities may have been, they elearly had some first-hand knowledge of the country. (Plate 4.)

The western river, which figures so prominently in nearly all of these early maps, although it appears merely as an estuary or entrance to a lagoon in Castillo's own chart, is elearly meant for the Hardy, and it is not at all improbable that in the days of these early navigators and eartographers the Hardy, the Colorado, and the eomparatively insignifieant ehannel which is now known as the Santa Clara Slough, may all have entered the Gulf by separate estuaries, and each earried a running stream, and, indeed, there is some reason for surmising that this latter ehannel may at that time have constituted the main mouth of the river.

Spanish interest in these distant and inhospitable lands began to wane after this early attempt at their exploration, and it was not until the memorable journey of Father Kino, in 1702 , that any real addition was made to our knowledge of the region. His map, which is carefully drawn and fairly aecurate, was published in various forms some years later," and shows two mouths to the Colorado, but as his detail to the west of the river is obviously less complete than it is elsewhere, this omission of the estuary shown by Castillo may be regarded as inconelusive.

Father Fernando Consag was nearly contemporary with Father Kino, and a very interesting manuseript map showing the results of his work in the Gulf exists in the British Museum. ${ }^{8}$

${ }^{1}$ The Journey of Coronado, by Geo. Iarker Winship, New York, 1904, p. 59.

${ }^{2}$ Lorenzana y Buitron, Ilistoria de Nueva Espana, 1770. British Museum, 145, d. 14.

Hritish Museum, Maps 70, d. 1, 1566.

- British Muscuin, Maps 920 [279], 1590.

'A copy of Mercator's unap of 1569 is to be found in the library of the American Geograplical Society in New York. It is included in Jomard's Atlas, and shows the influence of Castillo's work very plainly.

- British Museum, Maps 71, 0.7, 1598. Another excellently preserved eopy of this map exists in the library of the Ameriean Geographieal Soeiety, New York.

${ }^{7} A$ new map of North Ancrica, by Eusebius Franeis Kino, London, 1786; British Muscum 699, 15 (31).

Add. MSS. $17660 \mathrm{C}$. 


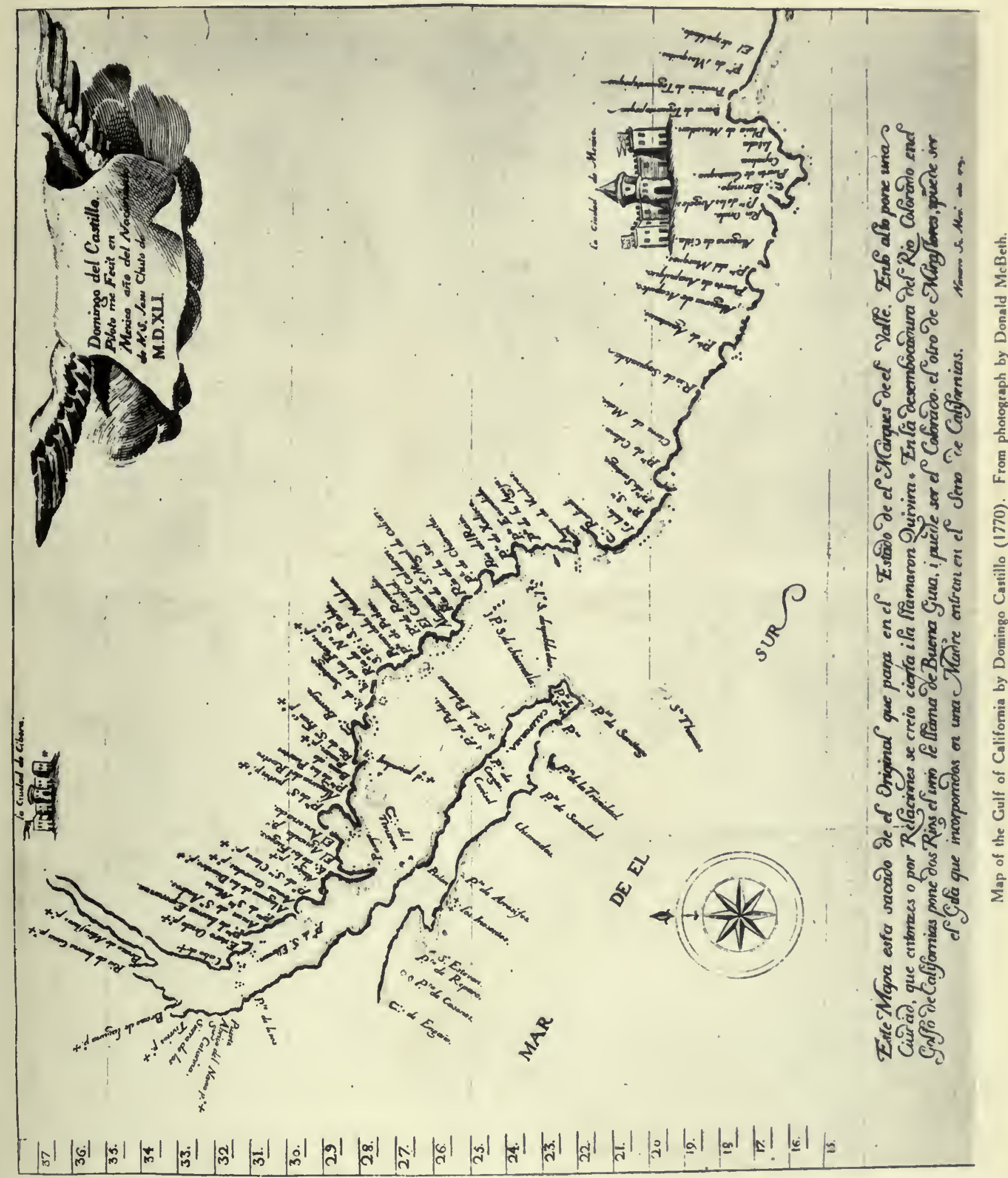


His exploration was earried on by boat and extended some distanee up the Colorado. Peneilled range marks upon the original map indieate that his ehief observational station was upon the south end of Angel Island, and his survey was mainly a marine and coastal one.

At some time subsequent to the journeys of Fathers Kino and Consag, some other explorer or explorers must have penetrated the region, and the result of this work is to be seen embodied in the remarkable map of John Roeque. ${ }^{1}$ (Plate 5.) This map is unique in several respects: The unusual aeeuraey of its detail over most of North $A$ meriea; the evidenee that the eartographer must have had at his disposal very complete sourees of information in regard to the Southwest; but ehiefly, as far as the seope of this paper is eoncerned, from the fact that it clearly shows the combined streams of the Colorado and the Gila flowing into a lake, and having no connection with the Gulf. (Fig. 1.)

The nomenelature throughout the region shows knowledge of the work of Kino, but this very radieal feature in the topography is elearly due to the work of some explorer of whose work we as yet know nothing more.

A fairly comprehensive search for and examination of the early maps of the Southwest have been made in the hope of finding some conclusive evidence of former fillings of the Salton Basin within historic times, and this map at least seems to indieate that such a diversion of the river water towards the west has been known to travelers at some time between 1706 and 1760 . With this elue it is probable that further seareh may result in giving us positive information upon the subject. A common tradition amongst the Indians of the region points to the fact that sueh a filling of the Basin has taken place within comparatively reeent times, in whieh the water extended "from mountain to mountain."

Father Pedro Font traveled in and explored the region in 1776, and doubtless erossed the Colorado Desert at least twice, and also reaehed the shore of the Gulf on the west side of the river. His map shows a large irregular opening still farther to the west than his own approaeh to the Gulf, and here again we may have the western opening of the early

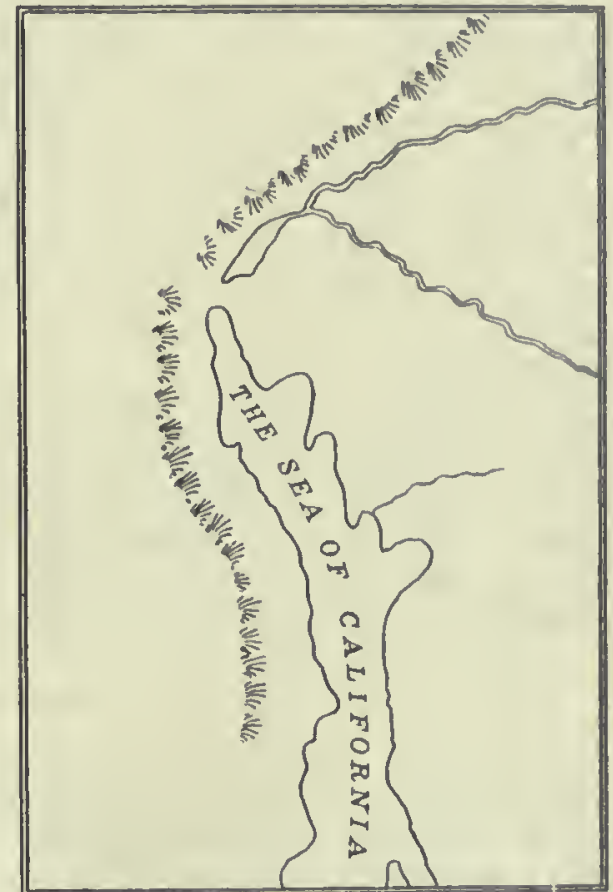

FIG. 1.- Outline map of the hear of the Gulf of California explorers, or another interpretation of the lake of Rocque. ${ }^{2}$ Father Font was the last of the Spanish explorers to add anything to our knowledge of the delta or desert, and his work was followed by a virtual blank of over fifty years.

\section{MODERN EXPLORATION.}

James O. Pattie was the first of more reeent explorers to reach the head of the Gulf. $\mathrm{He}$, with his party of trappers, journeyed down the lower Colorado to tidewater in January 1828 , and during February of the same year they erossed the westem part of the Delta, the Cocopah Mountains, and the basin beyond, on their way to the Spanish settlement at San Diego. ${ }^{3}$

${ }^{1}$ British Museum, K. 118.32. $\Lambda$ divided eopy of this same map also exists in the library of the Ameriean

Geographieal Soeiety, New York.
${ }^{2}$ An excellent reproduction of Font's map is to be found in The Diary and Itinerary of Franeisco Garees, by Elliott Coues. New York, 1900.

The personal narrative of James O. Pattic, of Kentucky. Edited by Timothy Filint, Cineinnati, 1833. 
Lieutenant Emory marched across the basin in the latter part of 1848 and seems to have reached the shore of the Salton Lake. ${ }^{1}$

Major Heintzleman, commandant at Yuma, visited the mud volcanoes near Volcano Lake in 1852, and these were afterwards visited by John LeConte ${ }^{2}$ and others.

The Williamson expedition of 1853, in which the late Professor Blake took part, is dealt with exhaustively elsewhere in this volume, and since that time our knowledge of the Colorado Desert has been gradually added to from many sources.

\section{THE COLORADO RIVER AND ITS DELTA.}

The Colorado River, carrying its heavy burden of silt toward the sea, has been the dominant factor during recent geological times in upbuilding and molding the region under consideration.

Emerging from a succession of small cañons and inclosed basins, a short distance below its junction with the Gila, it has spread its load over a vast area and in course of time has built a broad barrier across the Gulf, and so isolated the two basins which now constitute the major portion of the Colorado Desert from the sea.

The seasonal change of volume in the flow of the river is in itself favorable to the rapid upbuilding of this barrier, for the mud-laden and comparatively late spring run-off from the mountains of Wyoming and northern Colorado reaches the flat lands of the Delta at a time when the growth of annuals is well advanced, and as a consequence the overflowing water is retarded, its erosive power checked, and its load of silt evenly and quietly laid down.

So rapidly is this building going on that there is good evidence that the mouth of the river has been brought several miles farther south within the last 40 years. ${ }^{3}$

Such rapidity of upbuilding and the very character of the stream itself and the enormous burden of solid material which it carries yearly to the sea almost warrant us in assuming that the Colorado has been by far the most potent factor in working topographical changes in the region during recent geological times.

\section{THE MAIN DELTA BARRIER.}

From the point of the Algodones Sand Hills at the head of the Delta to the small outlier of the Cocopah Mountains known as the Cerro Prieto the distance is about 35 miles, and a line drawn between these two points represents roughly the crest of the Delta dam which separates the Salton Basin from the Gulf. This crest-line falls from about 110 feet above sea-level at the Algodones to 30 feet at the foot of the Cerro Prieto, and the present course of the Colorado River lies a little to the southeast of it.

The bed of Volcano Lake, at an elevation of about 28 feet above sea-level, no doubt represents part of the last spillway over this dam and may be taken as indicating the water-level of the Salton Lake at its last complete filling.

Gradients are so low and the growth of vegetation on the Delta so rapid that drainage channels are not very strongly marked or permanent, quickly becoming obliterated when unused, or surviving only as detached ponds or sloughs. It is fairly evident, however, that the New River and the Hardy, which together form a continuous channel across the barrier, falling in both directions from a meeting-point near the foot of the Cerro Prieto, have also formed such a spillway; and the bed of this channel at its highest point lies at practically the same level as the bed of Volcano Lake.

' Notes of a military reconnoisance from Fort Leavenworth in Missouri to San Diego in California, by W. H. Emory, Washington, 1848.

2 Ameriean Journal of Scicnce and Arts, vol. xIx, May 1855.

'11. 'I'. Cory, Irrigation and River Control in the Colorado River Delta, Transactions of American Society of Civil Engineers, vol. Lxxvi, pp. 1204 to 1571. 1912. 


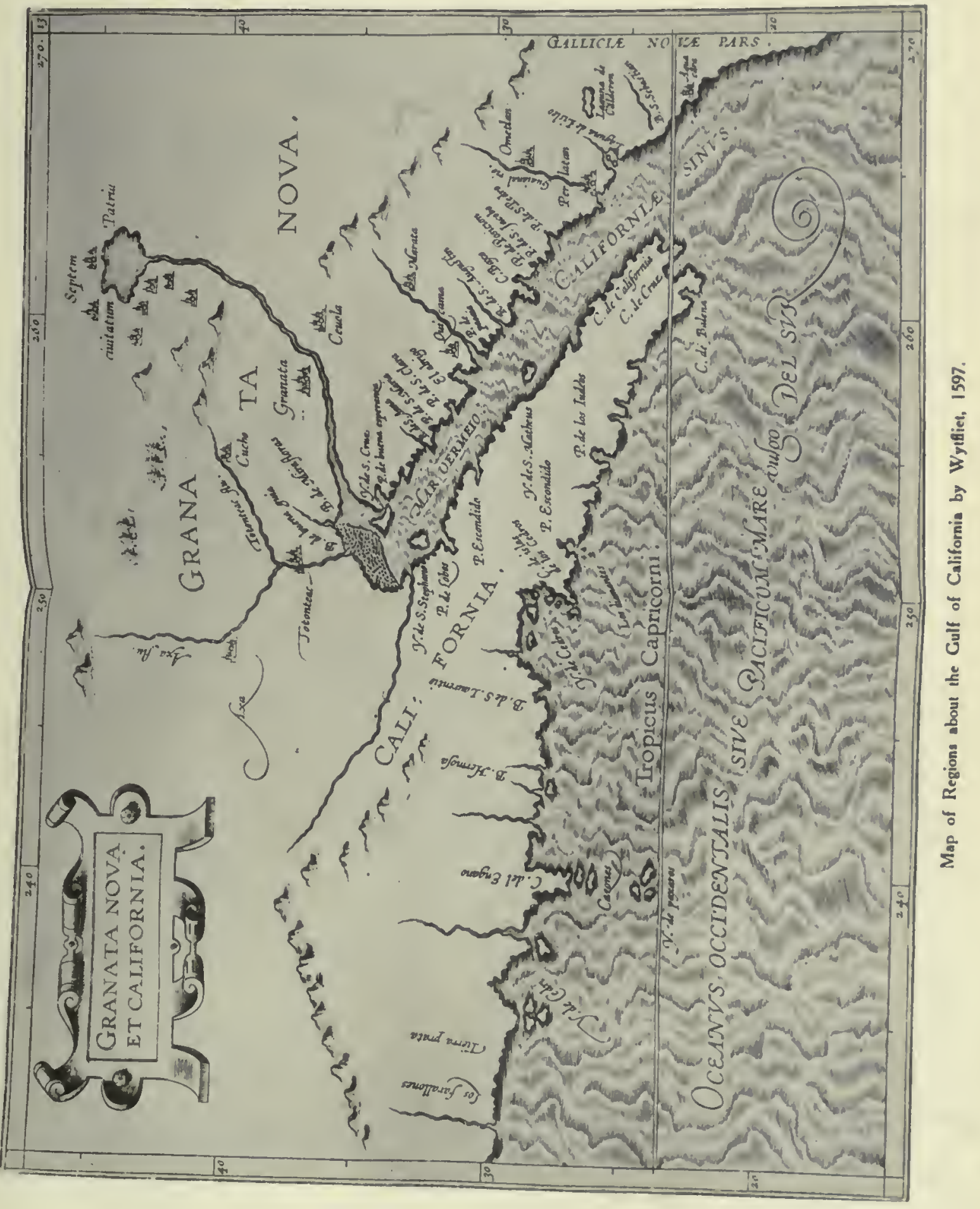



THE PATTIE BASIN BARRIER.

The extensive alluvial region which forms the barrier between the Gulf and the Pattie Basin is in reality a continuation, past the partial obstruction offered by the Cocopah Mountains and sundry small isolated hills, of the main Delta slope until it has met and become ineorporated with the shore of the peninsula. In general character the country is low and flat, cut into by numerous tidal ehannels from the Gulf side, and subject to much tidal and river overflow. It is probably but few feet above sea-level at any point, but as no detailed surveys or observations have as yet been made in this region, our knowledge of it is far from complete.

\section{THE CAHUILLA VALLEY.}

THE SALTON SINK.

The total area of the Cahuilla Valley is about 8,000 square miles, and out of this total an area of approximately 2,200 square miles lies below sea-level and doubtless still represents with fair accuracy the former limits of the upper extremity of the Gulf. This depressed portion of the valley floor is nearly surrounded, at a slightly higher level, by a conspicuous aneient shore-line; and as thus inclosed and defined is generally known as the Salton Sink. Its total length is about 100 miles, its greatest width 35 miles. It is roughly elliptical in form, with its major axis extending from $32^{\circ} 35^{\prime} \mathrm{N}$. and $115^{\circ} 20^{\prime} \mathrm{TV}$, to $33^{\circ} 45^{\prime} \mathrm{N}$. and $116^{\circ} 15^{\prime} \mathrm{W}$. There is a break in the inclosing shore or beach-line of about 14 miles at the southeast end of the ellipse, and this space has been the entrant point for an immense prism of sedimentary material, which has almost eovered the floor of the ancient gulf. A rough computation, based upon the assumption that this ancient gulf-floor was approximately level, gives the contents of this prism at about 17 cubic miles, this volume representing the amount of solid matter deposited by the Colorado within the area since its isolation from the sea, and therefore further indicating the quantity of river water which must have flowed into and been evaporated from the inclosed basin since such isolation was accomplished. (See p. 6.)

\section{THE ANCIENT SHORE-LINE.}

The tides in the head of the Gulf of California rise to a great lieight and are at times very violent, ${ }^{1}$ and this energetic tidal action has been mainly instrumental in building up along the surrounding shore-line strongly marked beach-ridges, raised in exposed situations to heights of 20 or 30 feet above mean sea-level.

The extent and character of the beach-terraces surrounding the Salton Sink at once suggest their common origin with the above- the same great tidal action. With the exception of the opening mentioned above the beach-line around the Sink is nearly complete, generally conspicuous and discernible from a great distance, and about 235 miles in total length.

It should be borne in mind, however, that all this beach material must lave been subjected to much washing and rearrangement by lacustrine wave-action since the cutting off of the basin from the sea, and it has probably been literally rolled and pushed up the shore slope in the exposed situations in which this action has been most vigorous and as the progressive building up of the Delta dam has raised the spillway toward its present height above sea-level. The marine shore-line in its original location has thus been obliterated. The prevailing winds in the Cahuilla Valley are from the west, and we may there-

1 The tide tables of the United States Const and Geodetic Survey give the ratio of range between the entrance to the Colorado River and the port of referenee, San Diego, as 5.65. The extreme tidal range in San Diego is about 8.50 feet, so that under exceptional conditions a tidal range of over 50 feet may easily be exceeded at the mouth of the river. This tallies with the writer's own observation, a range of over 45 feet having been measured upon more than one oceasion. (See p. 3.) 
fore find that a great deal of the observed difference of level in the shore-line has been due to this same wave-action, inasmuch as there is a general discrepancy of about 15 fect between the two sides of the Sink, the northeastern, the more exposed one, being higher than the southwestern one, which has been sheltered under the lee of the mountains. The shore-line has been regular and unbroken along the northeast side of the former lake, but upon the southwestern one it has come against the mountain walls in several places, and has in general been much more irregular and diversified, the Superstition and other mountain masses having thrust forward as bold promontories. One small group of islets has existed about midway along the northeastern side of the lake, and about 6 miles offshore when the water was at its highest level. This is the small hill-ridge to the northeast of Durmid Station on the main line of the Southern Pacific Railroad. It still bears unmistakable signs of having been subjected to the heavy assaults of surf for some considerable period.

\section{THE DRAINAGE FROM THE COLORADO AND DELTA.}

The main natural drainage lines from the Colorado to the Salton Basin, before the changes brought about by recent engineering operations, have been the Alamo and New River channels. The Alamo was the most direct, but its eonnection with the Colorado was in general rather obscure and liable to obstruction and obliteration by vegetation and the deposition of silt. The flow of water was intermittent and irregular and only occurred in seasons of extremely high water. The New River flow did not come directly from the Colorado, but partly from the Alamo by way of the Garza and other sloughs, and partly as overflow from the shallow eatehment basin of Volcano Lake. This lake was itself filled, in seasons of normal high watcr, through the channels of the Paredones, the Pescadero, and other less clearly defined waterways. Normally the whole efflux from the lake went directly into the Hardy, and so into tidewater, but in seasons of exceptionally high water it would be forced also to right and left-into New River on the one hand and into the lower Peseadero on the other, and so into the lower Hardy and the Gulf. The influence of the tides is noticeable in the Hardy as far as the point of the Cocopah Mountains and has at times been instrumental in foreing a part of this Hardy and Paredones floodwater into the Pattie Basin.

The Hardy, with its associated sloughs, backwaters, and lagoons, has always occupied the position of relief channel for the flooded and surcharged Delta in times of ligh water, filling thus a somewhat analogous position to that of the Bahr el Zaraf in the economy of the Upper Nile. ${ }^{1}$

Since 1901 the flow of water in the Delta has been greatly changed, as will be detailed later, owing to the various engineering operations earried out by or on behalf of the irrigation companies and settlers in the Imperial Valley.

\section{THE WHITEWATER DRAINAGE.}

The Whitewater receives its water through various small tributaries from the south and east slopes of the San Bernardino Mountains. It is an intermittent surface stream, but undoubtedly has a large underflow, as is evideneed by the copious flow from the artesian bores in the Coachella Valley. (Plate 15.) The total length of this stream is not much over 60 miles, but its mean gradient is very steep and its oceasional floods very violent. (Plate 8A.)

THE CARRIZO-SAN FELIPE DRAINAGE.

The combined drainage area of Carrizo and San Felipe Creeks is about 900 square miles, situated in the piedmont district before alluded to, to the west of the Salton Sink. San Felipe Creek rises almost immediately under the escarpment of the main, or coastal, 


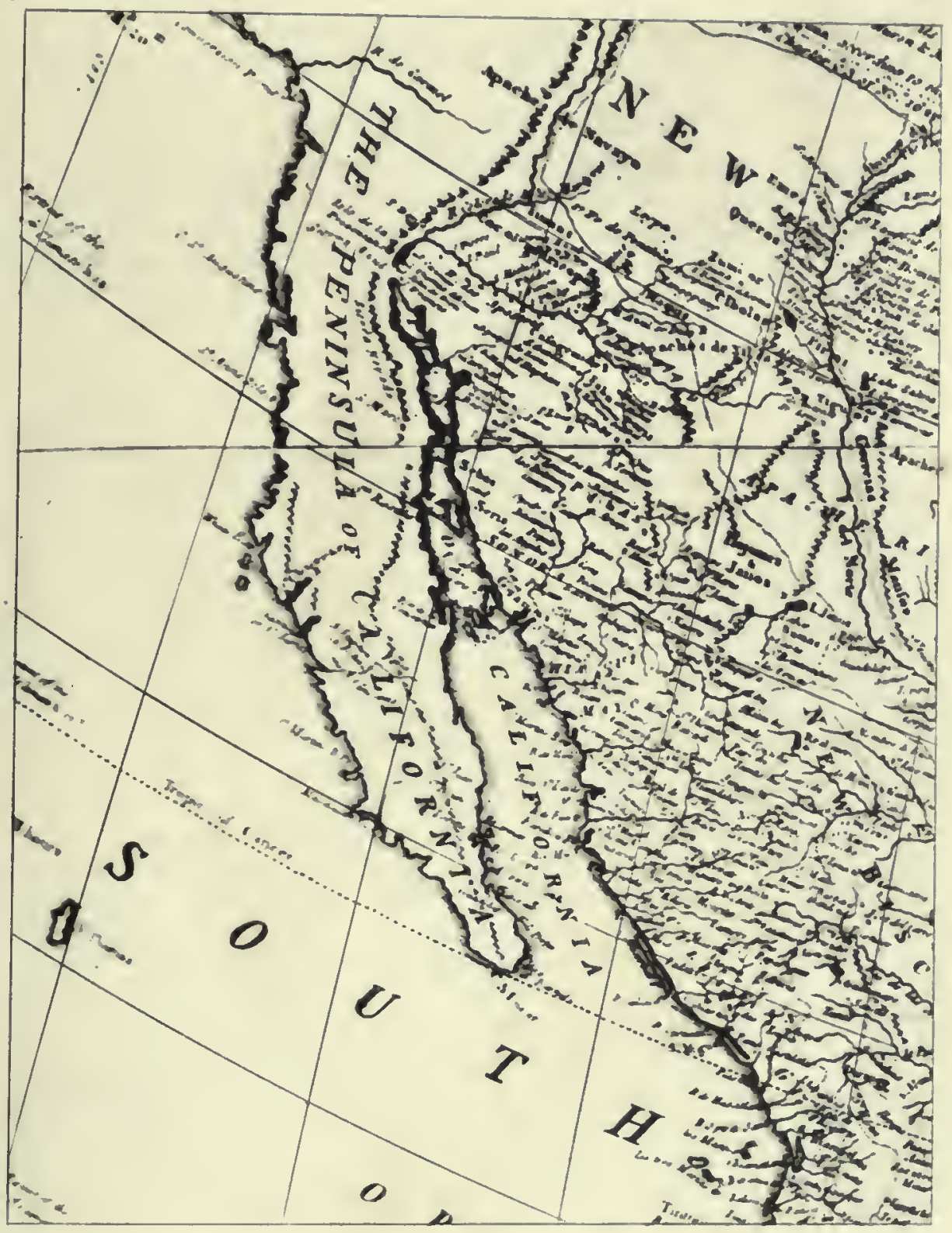

Portion of Rocque's map, of North America, showing Colorado River flowing into a lake to northward of head of Gulf of California, 1762 (?). Photograph by Donald MeBeth. 
range, some 7 miles north of Julian. It drains the country to the south and west of the Santa Rosa Mountains and forms a junction with Carrizo Creek in about $33^{\circ} 6^{\prime} \mathrm{N}$. and $115^{\circ} 57^{\prime} \mathrm{W}$. Carrizo Creck itself has two forks, one coming from near the international boundary-line, and the other from the south side of the Fish Creek Mountains. The combined ereek thus formed runs north to its junction with San Felipe Creek, as above mentioned, and earries on its own name down into the Salton Sink. Here, too, the waterflow is very irregular, long periods of total dryness alternating with oceasional heavy floods.

\section{THE CHUCKAWALLA WASH DRAINAGE}

The only drainage system of any importance which reaches the Salton Sink from the northeast is that known as the Chuckawalla Wash. This is a large but generally dry desert wash, which drains an area of some 250 square miles, beginning with the slopes of the Chuckawalla and Eagle Mountains. It spreads out and is virtually lost in the extensive playas which lie northeast of Durmid, but at times, during some of the heavy and violent rains to which this region is occasionally subjected, a portion of its water may pass on clown into the lowest part of the Sink by way of the Salt Slough.

\section{RECENT HISTORY.}

During the summer of 1890 the water from the Colorado River filled many of the small channels and lagoons toward the southwest, and in 1891 flowed through into the Salton Sink and formed a lake several miles in length. The intervening region was conparatively little known and its drainage system hardly comprehended at that time, and the appearance of such a large body of water in elose proximity to the Southern Pacific Railroad attracted much attention and gave rise to some of the wildest of rumors and hypotheses as to its origin. William Convers, followed by one or two others, succeeded in making the journey by boat from the Colorado to the lake, and so the mystery was solved.

Mr. H. T. Cory, who has a comprehensive knowledge of the conditions in the Delta of the Colorado, concludes that some flood water has found its way down the channel of New River toward the Salton every year since the inundation of 1891, and cites opinions of old settlers who allege that water eame into the Salton in $1840,1842,1852,1859,1862$, and 1867. The mail stage service between Yuma and San Diego was interrupted by the flood of 1862 and a flatboat was used for crossing New River for several wceks in the summer of that ycar. (Transactions Amer. Soc. Civil Engineers, vol. Ixxvi, pp. 1204, 1571.)

In 1900, a company having been formed for the purpose, work was begun upon the task of connecting and clearing the various channels which formed the natural waterway between the river and the basin; and by the middle of 1901 water was flowing upon the irrigable lands of what has since become known as the Imperial Valley. It had been deemed advisable by the promoters of the scheme to take the water from the river in United States territory, and so the upper section of the canal was cut almost parallel to the river for several miles and with a very low gradient. This cireumstance, together with the general unsuitability of the site selected for the head works, caused considerable trouble for two or three years, as more and more water was required to fulfil the demands of the growing communities in the desert; and so various openings were made between the river and the canal in order to furnish a more adequate supply.

Then in the winter of 1904-05, one of the infrequent winter floods in the Colorado, coincident with a tremendous rush of storm waters from the Gila, found before itself the unprotected head and comparatively steep downward grade of the canal, and at once began to cut and enlarge the channel. The ordinary summer flood of 1905 also poured its water through the opening, and it was soon realized that the outpour had got beyond control.

Practically the whole of the Colorado was now flowing into the Salton Basin and another flood in the following November (1905) made the task of closing the breach seem 
almost hopeless, although the most strenuous efforts were being made by the engineers; and it was not until February 1907 that the Colorado was finally returned into its former channel. Here again, however, the vigorous vegetation of the Delta had played its part, for the river bed had in the meantime become so choked by plant growth and the deposition of silt that the water since made repeated attempts to escape, first towards the southeast through the Santa Clara Slough, directly towards the head of the Gulf, and since-in spite of some rather hastily planned and inadequate efforts to control it in that direction-into the head of Bee River and the Pescadero and so by various ways into the Hardy, which is now, in its lower reaches, carrying virtually the whole volume of the Colorado. This surcharging of the Hardy Channel had the further effect of allowing a large quantity of water to flow over its western bank and towards the Pattie Basin, and a large lake now fills the lower part of this Sink.

During the summer of 1906 , and at the time when the maximum inpour was reaching the Salton Sink, the channels of the Alamo and the New River began to cut backward from the lower end, and the soluble, loess-like soil along their courses was carried bodily into the lake, leaving the deep, precipitous-sided valleys through which the present streams flow. Much apprehension was felt at the time by the engineers lest their cutting action should reach the Colorado and so preclude all possibility of repairing the breach, but the closure was effected in time and the danger averted.

Recent observations at the eastern end of the Salton Lake (October 1912), now that the water is receding, show that there has been an enormous deposition of this or other sedimentary material subaqueously; and with further recession it will doubtless be found that this deposition has taken place far out into the lake.

Some idea of the magnitude of this displacement and redistribution of material may be obtained from a statement made by Mr. Cory, ${ }^{1}$ that the total yardage thus moved is over 450,000,000 cubic yards, or almost twice that of the Panama Canal.

$\Lambda$ good deal of water still passes through both the Alamo and the New River, but this is merely the overflow from the irrigation canals, and it is quite improbable that with the interests now at stake in the Imperial Valley and the close watch kept upon the river by the engineers, any further uncontrolled incursion of water will be allowed to take place.

In the region of the lower Delta, however, conditions are very different; here we have a large, wayward, and silt-laden river, thrown out of balance by a temporary diversion, and always hampered at its mouth by great and violent tides, wandering at present virtually unchecked over a large area of friable alluvium with downward grades in several directions.

All these conditions tend, as may be readily imagined, toward a condition of instability and possible geographical change; in fact, it is probable that even if the Colorado and the general drainage conditions through the Alamo and its associated channels had not been interfered with in any way by the operations of the irrigation engineers, another diversion of the river water towards the west was about due from the natural causes outlined above, and would in any case have ensued within a few years.

It is furthermore evident that as so much of the flow of the river during the growing season of the early spring is now diverted and utilized for agricultural purposes, and as the bed of the river in its lower reaches is left practically dry during the period of most rapid growth of the Delta vegetation, its obstruction and elevation will be more rapid and the stability of the irrigation and protective works menaced more and more unless adequate measures are taken for controlling and storing the flood-waters of the early summer upon the upper Colorado.

1 Transactions of American Society of Civil Enginecrs, vol. Lxxvr, pp. 1204, 1571. 


\title{
SKETCH OF THE GEOLOGY AND SOILS OF THE CAHUILLA BASIN.
}

\author{
BY E. E. lHeE.
}

\section{INTRODUCTION.}

The first geological examination of the region covered by this volune was made by the late Professor Blake as a part of his work for the Pacific Railway Survey and is described in the reports of that survey, ${ }^{1}$ and more fully in the present volume. Following Professor Blake's examination, the region received only incidental notice ${ }^{2}$ until 1909 , when Mendenhall ${ }^{3}$ published a geologic sketch of the desert in connection with a discussion of water resources. More recently Harder ${ }^{4}$ has published some observations incidental to a study of the region just to the north.

The conclusions of the present paper are based mainly upon personal study of the region, though much use has been made of the data of Blake and Mendenhall. On various trips to the region the writer has had the advantage of accompanying the late Dr. W. J. McGee, Dr. J. M. Bell, and Professor J. C. Jones, as well as others associated with preparation of this volume, though not concerned with the geology or soils. Acknowledgments are due to all of these gentlemen for many valuable suggestions. The soil studies were made while the writer was connected with the Bureau of Soils of the United States Department of Agriculture, and were carried out with the permission and advice of Professor Milton Whitney and Dr. F. K. Cameron, of that Bureau. The writer is indebted to these gentlemen both for facilitating the course of the work and for permitting the present use of the data obtained. During these soil studies the writer was accompanied by Mr. L. D. Elliott, to whom thanks are due for most efficient assistance.

\section{DESCRIPTIVE GEOLOGY.}

The general topography of the Cahuilla Basin and its bordering mountain ranges is outlined in Mr. Sykes's paper in this volume and need not be reviewed. In its major features it differs little from the topography characteristic of nearly all desert basins of North America-rugged bordering mountains half-buried in long smooth-sloped aprons of mountain waste, which merge finally in a central salt flat, in this casc covered by the Salton Sea. The main exception in the Caluilla Basin is the openness of the southern end toward the Gulf of California. Here the mountain rim is lacking and the basin is separated from the Gulf only by the alluvial ridge of the Colorado Delta described by Mr. Sykes. Perhaps the depression as a whole is better described as a "trough" than a "basin."

The geological structure of this trough is not well known. The bordering mountain ranges have not been studied in detail and little is known of their strueture, execpt that it is not simple. The tilted block strueture, so frequent in the "basin ranges" to the north, is not discernible here. There is some reason to believe that the axis of the trough is the locus of a major fault-line continuous with the great Cajon fault to the west, and running substantially nortliwest by southeast. Whether or not this be the ease, there has undoubtedly been much faulting in all the bordering mountains and the trough in general is certainly structural, whatever may have been its origin in detail.

${ }^{1}$ Pacific Railway Reports, Sen. Ex. Doc. No. 78, 33d Congress, 2d Session, vol. 5, part 2, 1856.

2 See especially, Bailey, Saline Deposits of California, Cal. State Mining Burcau, Bulletin 24, 1902.

U. S. Geologieal Survey, Water Supply Paper 225, 1909.

- U. S. Geological Survey, Bulletin 503, 1912. 
Petrologically, the available information is similarly meager of detail. On the north and northeast the Chocolate, Cottonwood, San Bernardino, and San Gabriel Mountains form one range, nearly continuous from the Colorado River, until they merge with the Sierra in the highlands of Tehachapi. Where this range has been examined it is composed almost entirely of granites, gneisses, and ancient schists. From his studies in this range and to the north, Harder distinguishes two general divisions of the granitic rocks; the furst is probably l're-Cambrian and associated with gneisses and schists; the second is a later intrusive, probably Mesozoic. Overlying the early granities, but antedating the intrusives, are fragments of slates, quartzites, and limestones of unknown age, and usually much metamorphosed and disturbed. The studies of Mendenhall ${ }^{1}$ indicate a similar character for the Santa Rosa Mountains, Fish Creek Mountain, and other outliers of the Peninsula Range which border the basin on the southwest.

Along the basin-ward foot of the San Bernardino Range, throughout nearly its whole extent, are irregular and much eroded hills of poorly consolidated conglomerates, sandstones, and shales. In most cases these strata have been greatly disturbed and their original relations are not clearly decipherable. It seems probable, however, that they consist of three fairly well-defined members: (1) a basal conglomerate resting normally upon an eroded surface of schists and granites, such as make up the core of the range; (2) lying conformably upon this, a thick member of coarse, arkose sandstone, usually reddish in color and of quite uniform texture; (3) an upper member of very variable sandstones and elays, mostly thinly bedded and showing many probable minor unconformities. Aside from the vertical variation as thus noted it seems also that the fineness of the material in each of the main divisions increases as one recedes horizontally from the mountains. Thus the lower conglomerate decreases in thickness and its constituent pebbles become smaller, the middle arkose member shades off into a sandstone of much finer and more uniform grain, and the top member, while almost entirely of sandstones at the foot of the mountains, becomes almost entirely of clays as one approaches the basin floor. In many places these clays contain thin erusts of gypsum and in one place, about 5 miles north of the railway station of Pope, they contain an interbedded stratum of mirabilite or hydrous sodium sulphate, several feet in thickness. This series of strata will be designated the Mud Hill Series, from the Mecca Mud Hills, where it is perhaps best developed. At that locality the section corresponds to perhaps 3,000 vertical feet, ${ }^{2}$ but it is impossible to be sure of this or to draw a general section because of the very broken character of the strata as exposed and the impossibility of determining whether observed differences in the visible fragments of the strata indicate strata of different vertical position in the section or simply variations in the same stratum at different distances from the mountains.

Beyond the southeastern end of the Santa Rosa Mountains similar sandstone and clay strata surround the granite core of Superstition Mountain and form several series of low hills which flank the outliers of the Peninsula Range much as the San Bernardino Range is flanked by the strata just described. It is scarcely possible definitely to conrelate these strata with the similar series on the northeastern side of the basin, but the lithologic similarity is apparently eomplete and it seems very probable that both exposures belong to the same series and to the same genetic eondition, whether or not they be exactly synchronous. Provisionally, all will be regarded as belonging to the Mud Hill Series.

No fossils have been found in the Mud Hill Series at the type locality at Mecca or, indeed, anywhere on the nor theast side of the basin. In the valley of Carrizo Creek, however, Blake discovered strata of partially consolidated clay and sand eontaining oysters, pectens, and other marine shells of Miocene age. According to Mendenhall these fossiliferous beds are here the basal member of the sedimentary series. This, in eonnection with its general

\footnotetext{
Loc. cil., pp. 10-14. ${ }^{2}$ Mendenhall estimates 4,000 to 5,200 feet, loc. cit., p. 12.
} 

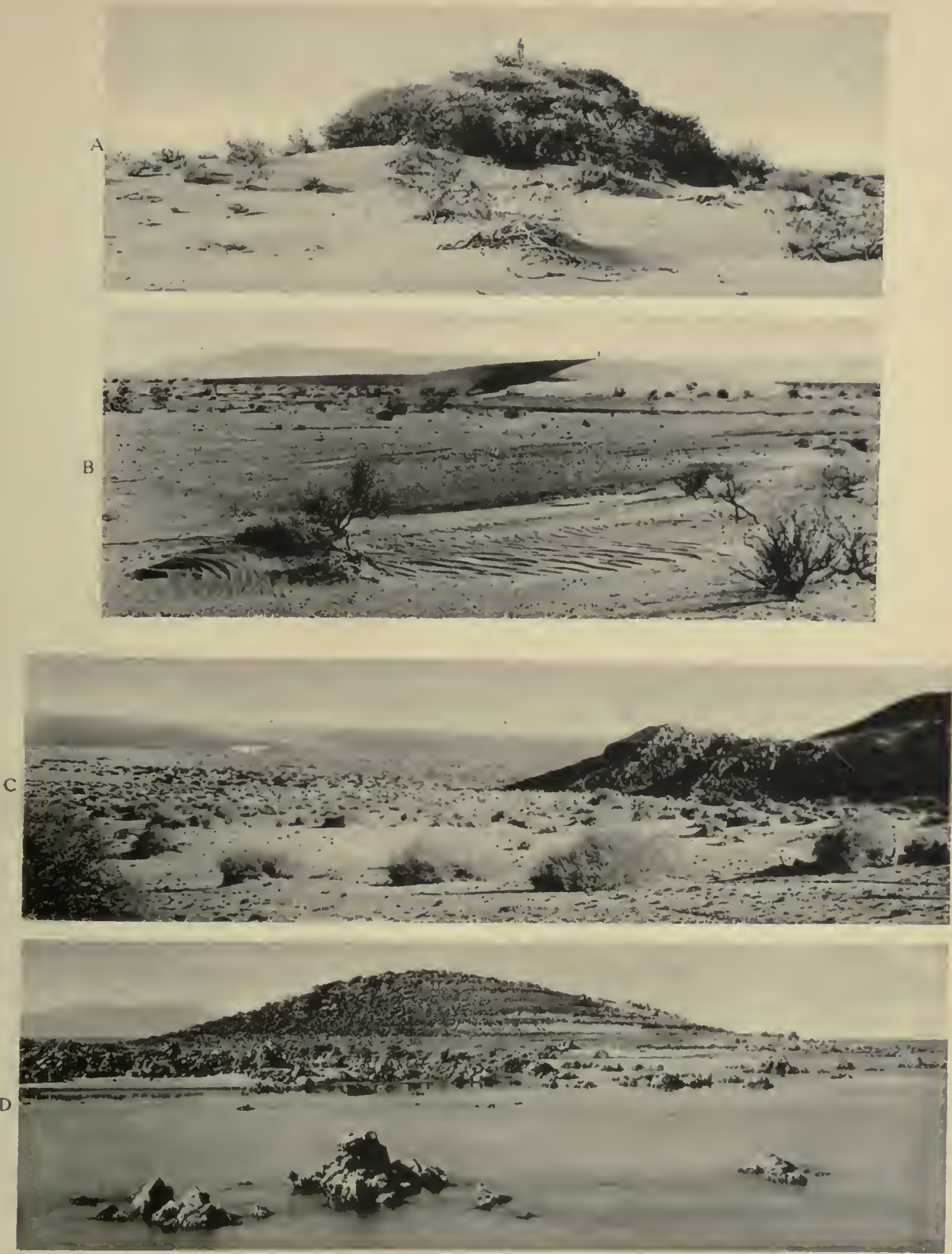

A. Accretion Dune in Carrizo Region with Prosopis Shrubs.

B. Barchan or Crescentic Duses in Carrizo Region with wiod ripples in the foregrouad.

C. Line of Erosion at high level of Blake Sea on rocks at night. Salion Lake at level of 1912 on left. Lighter fringing zone on shore is strip bared by recession, 1907-1912.

D. Big Island showing numbers of old strands on its eastern slopes. Photographed in 1909. 

character, indicates that the Mud Hill Series is essentially late Tertiary. Very probably it includes beds of all ages from the Carrizo Creek Miocene into the early Pleistocene.

The origin of the series as a whole seems unmistakable. Its strata liave every characteristic of continental beds laid down on the bordering débris slopes of desert mountains and composed of materials earried down and assorted by rain wash. Precisely similar beds are now being deposited on the flanks of hundreds of the desert niountains of North America. The prevalence of elay beds in the basin-ward part of the series suggests that these portions were deposited in a marine estuary or in the central lake of an inclosed basin which the mountains bordered, but no conclusive evidence of marine or lacustrine deposition has been discovered in this part of the series. The presence of gypsum and mirabilite, as above noted, indicates that there were at least local areas of inclosed drainage and salt accumulation. There is also the implication, strongly confirmed by the general nature of the series, that the climate under which it was deposited was arid and not essentially dissimilar from that of the present. As a whole, the series nust be regarded as continental and alluvial. The marine strata of Carrizo Creck probably represent an incursion of the sea into the southern portion of the trough only.

Below the hills of the Mud Hills Series the floor of the valley is of typical alluvial outwash, similar in every respect to that of other desert basins. Nearer the mountains this is gravelly and sandy; toward the center clays and silts predominate. Always the slopes are natural and gentle, the only cuttings being the shallow channels of the "washes," always dry except for the sudden floods which follow occasional storms. This alluvial outwash covers the whole central portion of the valley and has filled it to an unknown depth. As usual, it is of interbedded sands and clays, the clay strata forming a seal for the waters of the sandy strata and producing artesian potentialities recently much developed in what is known as the Coachella Valley between Indio and Mecea. (Sec Plate 15.) Numerous shallow wells have been bored in this region, and several have been sunk to 1,000 feet or more. None of the wells penetrated anything but the usual alluvial succession of clays, sands, and gravels.

At present the deepest depression of the basin is occupied by the Salton Sea, the origin and character of which are fully discussed elsewhere in this volume. Before the incursion of the waters the deepest depression contained a body of crystallino salt, located south of the station of Salton, and which was utilized commercially (See Plate Ic.) It consisted of a crust of fairly pure sodium chloride under which was black mud with disseminated crystals and crystalline masses of sodium cliloride and other salts, and known to extend to a deptl of 25 fect below the surface. According to Bailey this was underlaid by hard elay to 300 feet. Both mud and salt were saturated with a brine, the main constituent of which was sodium chloride, but the exact composition of which is unknown.

In summary, the basin before the formation of the Salton Sea consisted of a presumably structural trough lying between mountain ranges essentially of Mesozoic or earlier granites, gneisses, and schists, and decply filled with the erosional debris of these ranges. Bordering the ranges proper were foot-lills of Tertiary strata, apparently the broken and tilted remnants of a former alluvial apron. Below these hills the surface was entirely of recent and present alluvial fill, a typical bajada merging into a central sink of comparatively small extent and which carried a small salt body of usual type.

The extension of the Colorado Delta into this trough has already been described by Mr. Sykes, and very little need be added from the geologic point of view. The superficial layers of the Delta material, where exposed in the cuttings of the New and Alamo Rivers, consist of the usual alternating beds of fine sand and silt. No decper sections are available and the depth of the Delta material, its relations to underlying rock or alluvium, etc., remain quite unknown. At its edges the cone of Delta material merges so imperceptibly 
into the rain-washed alluvium of the basin slopes that the boundary is indeterminate and the mutual relations undecipherable.

Superposed on the major features of the basin, as thus described, are several minor features which require brief notice. First is the line of "mud volcanoes," evidently decayed fumaroles, which approximately parallels the axis of the trough. These are well developed near Volcano Lake, and are now represented by several hot springs, boiling pools, etc. A former more intense activity is indicated by groups of inactive mud cones, extensive deposits of sulphur and alum, and similar evidences of fumarole action. Another group of hot springs and mud geysers was located just north of the buttes which are now islands in the Salton Sea. These were described by several early explorers and especially by Le Conte. 'They were considerably more active than the Volcano Lake group, but not so extensive. They are now under water and their present condition is not determinable. Some 6 miles north of these, near the railway station of Lano, is another group, somewhat smaller and much more nearly extinet. Activity here is limited to a very small flow of muddy water and the escape of an occasional bubble of gas.

The buttes above mentioned as being present islands in the Salton Sea are exclusively of volcanic rocks, including pumice, glassy obsidian, and a variable volcanic tuff containing many fragments of the pumice and obsidian. No erater or other vent is visible, and the buttes are probably simply the summits of a larger mass of eruptives, probably of Tertiary age and disturbed and buried by the post-Tertiary movement and alluviation. Other small bodies of effusives and tuffs are reported by Mendenhall as interstratified with the lower members of the Mud Hill Series in the Carrizo Creek Valley. An olivine basalt, apparently effusive, was found by J. C. Jones and the writer on the summit of the Peninsula Range near Jaeumba. So far as known, these are the only representatives within the Cahuilla Basin of the Tertiary voleanism so marked farther north.

Among the more recent deposits mention should be made of two areas of sand dunes, both of which are still in course of formation and change. The larger of these is the complex of "Los Algodones," in the northeastern part of the basin, as noted on Mr. Sykes's map. It is a single great dune area of usual character and offers little of interest. The second dune area is in the embayment between the Santa Rosa Mountains and Superstition Mountain and lies just south of the end of the former range. It is remarkable chiefly because the dunes are few enough and far enough apart to permit the development of the crescentic form characteristic of a freely moving dune. One of the crescentic forms is shown in Plate $6 \mathrm{~A}$ and $\mathrm{B}$. Many others are scattered over the surrounding slope, making the only good example of these forms known in the United States and probably one of the best in the world.

Of the minor features of the basin the only additional one which needs notice is the ancient beach-line which surrounds the basin about 40 feet above sea-level and which is described by Mr.Sykes. This is well marked in almost all quarters of the basin. On the alluvial slopes it appears as a deep wave-cut terrace, as illustrated in Plate $6 \mathrm{c}$ and $\mathrm{D}$. On rock walls and spurs it is evideneed mainly by the crusts of travertine, described elsewhere in this volume by Professor Jones. Below this lighest beach-line, wherever the topography has permitted their preservation, there appear numerous minor strands, each a few feet or inches below the next, and the series extending downward to the terrace corresponding to the high-water level of the Salton Sea. This series of ancient strands is well illustrated by Plate $29 \mathrm{~B}$, where the influence of the gravel accumulations along the terrace lines has so controlled the vegetation as to mark the strands very clearly. It is difficult to regard this series of strands as anything but the record of a lake which once occupied the basin and which disappeared by evaporation as the present Salton Sea is disappearing. This was the interpretation made by the late Professor Blake, and the ancient lake has been named

\footnotetext{
' LeConte, Amer. Jour. Scicnce, 1855.
} 
"Blake Sea" in his honor. (See p. 4.) The present Salton Sea has left precisely similar records. Its high-water terrace corresponds in everything but depth of cutting to the ancient high beach-line, and the present sea in its recession has left a series of semi-annual strands, illustrated in Plates $16,21,25$, and 26 , which are precisely similar in every respect to the strands of the ancient lake. Plate $6 \mathrm{v}$ shows the strand system on one of the islands in the present sea. The upper two-thirds of this system belong to the strand series of the ancient lake; the lower one-third consists of the strands of the present Salton Sea. Without actual leveling it is impossible to distinguish one system from the other or to tell where the latter begins to be superposed on the former. It scems not improbable that the strands of the ancient series are semi-annual, as are their analogues in the records of the present sea.

\section{HISTORICAL GEOLOGY.}

'The deciplierable history of the Caliuilla Basin begins with the uplift of the San Bernardino and Santa Rosa Mountains. There is no means of dating this directly, but it seems probable on general grounds that it was associated with the uplift of the Sierra Nevada at the close of the Jurassic. It seems useless to speculate concerning the condition of the country prior to this uplift, as also concerning the cause, duration, and character of the uplift and its rolation to the granitic intrusives of apparently about the same age.

Following or during the genesis of the mountains there must have been a period of considerable erosion. The earlicr portions of this period are represented by no known deposits, and the material removed from the mountains either was carried entirely outside the area or is buried in the lower and unexposed portions of the alluvial fill of the trough. A little later the discharge of the products of erosion was not so free, and there were laid down on the mountain slopes the conglomerates, grits, and sandstones forming the Mud Hills Series. At the beginning of this period the sca must have occupied the southern portion of the trough, at least as far north as the locus of the Carrizo Creek Miocene. Evidently it did not fill the whole trougl, sinee the basal member of the Mud Hills Series is well exposed at Mecca and is a true basal conglomerate of strong continental facies. It is quite possible that this period was marked by the gradual retreat of tlie sea from the trough, with the formation behind it of the alluvial strata charaeteristic of the Mud Hill Series.

The deposition of these alluvial strata was interrupted, probably in the very late Tertiary or the early Pleistocene, by the violent and general movenent which broke and bent the Mud Hills strata into their present fragmentary and distorted form. While the eausal displacement was perhaps relatively simple, the resultant movement of the Mud Hills Sories was exeeedingly complex and has not yet been unraveled in detail. This second uplift seems also to have been followed by a period of considerable erosion. The newly exposed blocks of soft elays and sands were earved into a very rugged topography. The products of this erosion doubtless went to fill the trough still further, and with time this sea of mountain waste has gradually risen until it has partially submerged the hills from which it came. At the present time each hill of the Tertiary series has its apron of alluvium, the canyons which cut it are filled with tongues of débris, and many half-buried spurs which front the major ridges indicate that we sec only the top of a rugged bad-land, the larger portion of which lies submerged in its own waste. This gradual submergence of the foot-hills brings us to the present time, and the process is still at work.

'Two phases of this listory have not been discussed: the relations of the trough to the ocean and the Colorado, and the history of Blake Sea. The hypothesis regarding these

Two other names have been suggested for this lake: Lake LeConte by Bailey (Bull. Cal. State Mining Bureau, 24 : 12 (1902), and Lake Cahuilla by Blake (Nat. Geog. Mag., 18:830 (Dec., 1907). Neither has taken root in the literature. The name Blake Sea is due to Mendenhall, who, however, abandoned it before pullication in favor of Lake Cahuilla, as used by Blake (Mendenhall, loc. cit., p. 20, footnote). In the present volume Cahuilla has been reserved for the whole basin for reasons stated elsewhere, and 13lake Sea is adopted as being obviously more suitable, in the light of the history of discovery in the basin, than is the alternative name, Lake LeConte. 
matters, which was advanced by Blake and is still current among geologists who have examined the basin, is that the trough was originally open to and partly filled by the ocean and was gradually cut off therefrom by the building of the Delta of the Colorado. The growth of the Delta being complete, the Colorado might flow direetly into the Gulf as now, or might flow into the Cahuilla depression, fill it, and overflow into the Gulf, as it would probably have done had the engineers failed to control it after the inbreak of 1905 . On topographic grounds alone Blake Sea might be regarded either as the final cut-off remuant of the arm of the sea which onee oecupied the trough, or as a lake produced by the incursion of the Colorado as noted. The present writer, while not venturing a vigorous dissent from this hypothesis of the exelusion of the sea by delta-building, regards it as quite unproven. The known facts of the matter are two: the strata of the Mud Hills Series are of continental origin, and Blake Sea was fresh. The former fact has already been discussed, and it has been pointed out not only that the strata in general resemble in every cletail those characteristic of mountain aprons in a desert valley, but that the occurrence of gypsum and mirabilite in the series proves the existence of at least local areas from which the drainage had no seaward egress. It can not be held certain that the basin as a whole was undrained. The observed facts can be explained as well on the hypothesis of local undrained areas cut off from the main drainage line of the valley by low structural or alluvial divides. Examples of this are numerous in the present desert valleys of North Ameriea. It should be noted, however, that while the evidence does not necessarily indicate an entirely inclosed basin during the late Tertiary, it does indicate arid conditions and the absence of the sea from at least that part of the Sink which is now the lowest.

The second fact, the freshness of Blake Sea, follows from three other facts. First, shells characteristic of fresh or slightly brackish waters are seattered by millions over the desert once oecupied by the ancient lake and must have been plentiful in its waters. Second, the coating of travertine deposited by the lake at its water-line, and as it underwent subsidence, is such as would be deposited from a fresh or at least a continental water. These coatings are discussed elsewhere in this volume by Professor Jones. Third, the amount of salt present in the salt-body now covered by the Salton Sea was only a small fraction of the salt which would have been deposited had Blake Sea been of ocean water. There is no possibility of the escape of any salt, and burial by alluvium seems seareely likely when the strand-lines and terraces of Blake Sea are so excellently preserved.

We know, therefore, that the ocean did not occupy the trough just previous to the post-Tertiary uplift, and that it did not occupy the trough during the later history of Blake Sea. This leaves a long intermediate period of which we know nothing at all. During this period there may liave been a marine occupation, the Delta may have been built, and the sea shut out, as generally assumed. This is quite possible, but there is no cvidence directly indicating it, and it is pure speculation. It is quite as possible that the trough remained above sea-level until after the Delta dam was built, and that the depression behind the dam has never been occupied by the sea. During this doubtful period there occurred unquestionably two events: (1) the general depression of the trough relative to sea-level; and (2) the formation of the Delta dam. The varying hypotheses concerning the period vary only in the relative order in which they view these events. The current hypothesis regards the depression as prior to the building of the dam; the hypothesis suggested by the writer regards the formation of the dam as prior to the depression. Our outline of the history of Blake Sea will vary greatly according to which of these hypotheses we aecept. If the former, Blake Sea will be regarded as the cut-off portion of an arm of the ocean; if the latter, it appears as a lake ereated by the accidental flow of the Colorado into a previously existing depression behind an alluvial divide. In either case it is certain that the formation of Blake Sea could not have been prior to the depression of the valley relative to sea-level (the Delta dam would not withstand a steeply graded overflow), 
A

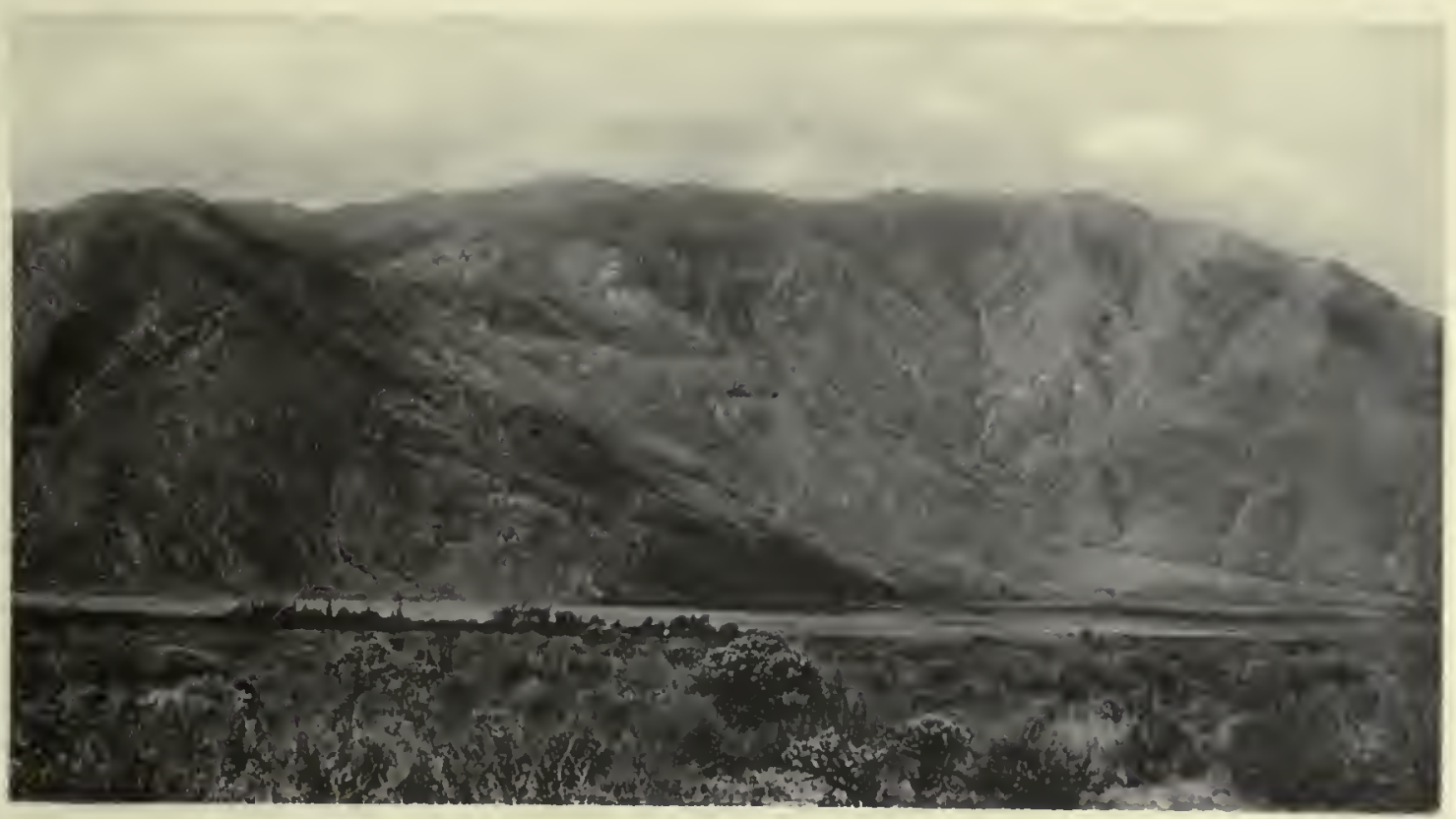

B

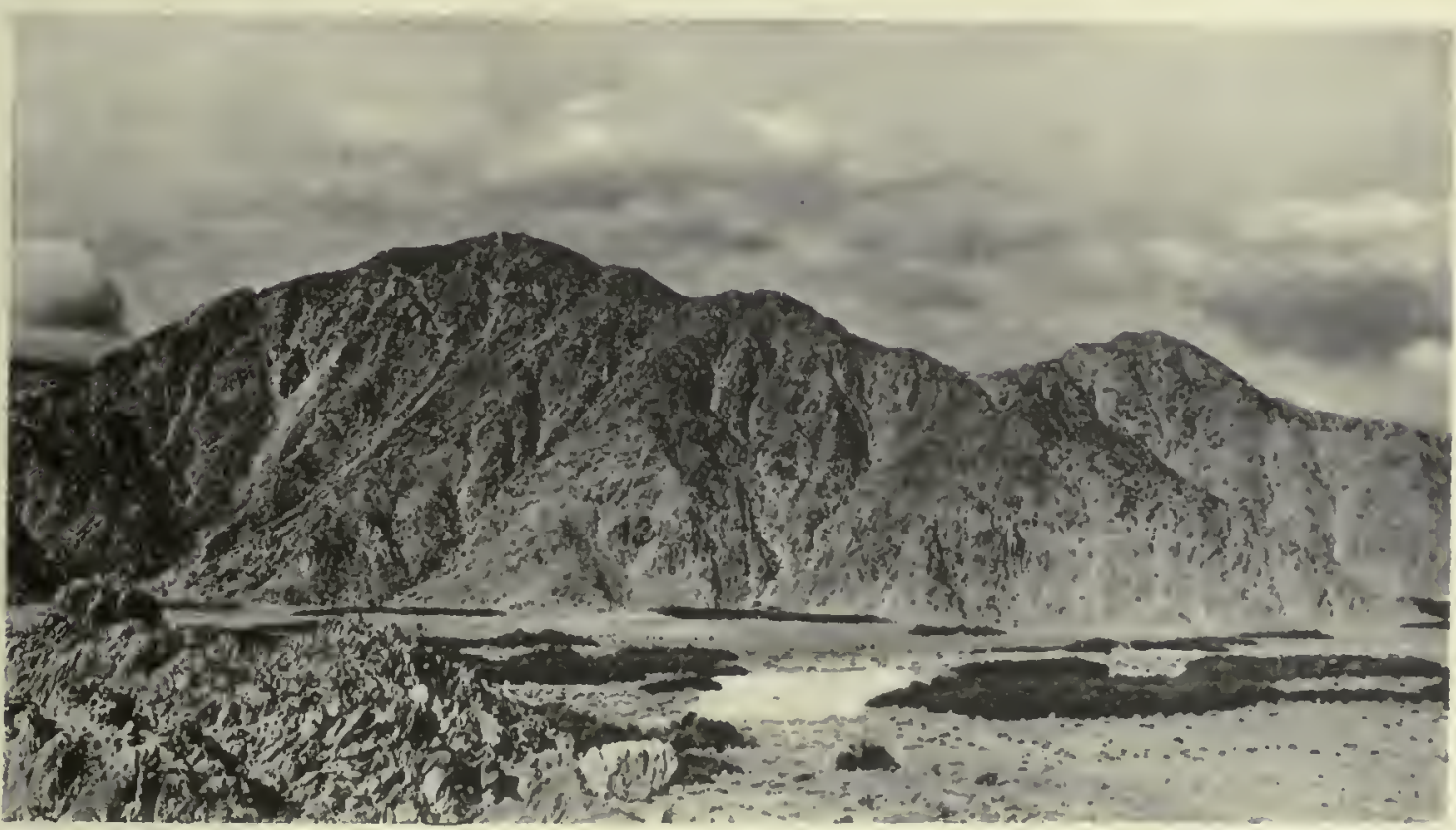

A. San Jacinto Peak with outwash and line of Snow Creek. Seen from San Gorgonio Pass. B. Foothills of Santa Rosa Range with Sandy Alluvium and Dense Mesquite Formation. 

and it is certain that the Colorado flowed into Blake Sea and overflowed out of it, whether or not the river stood to the Sea in a genetic relationship. If Blake Sea was originally a marine water-body, it was soon and effectually freshened by the inflow of the Colorado.

As stated, clecision is now impossible between the two variant hypotheses noted. The topography of the Delta and the Delta dam strongly suggests that it was built in a water-body and at water-level, hence, that the current hypothesis is the correct one. However, an opposite implication of even greater strength is furnished by the high-level beach of Blake Sea. If Blake Sea were marine and were eut off from the ocean by the building of the Delta, this process must have required a considerable time. But the high beachline does not indieate long-eontinued wave-erosion. Where the beach erosses gravels or uneonsolidated strata it is deeply eut, but where it crosses rock walls there is alnost no cutting, even on exposed points which would be attacked strongly by the waves. On such rock faces the ancient water-line is marked only by coatings of travertine or accumulations of loose stones. Persistent shore-lines are usually cut markedly even into the lardest rocks, and even the comparatively transient shore-lines of the Quaternary lakes of Nevada and Utah are frequently deeply graved. Absolutely nothing of the sort oceurs on the high strand of Blake Sea. Any eutting which the writer las observed along it could have been done in a few score years. Indeed, some of the lower strands of the Blake Sca series, or the high-level strand of the present Salton, are sometimes eut almost as deeply as the high beach of the ancient Sea. It is diffieult to reconcile this shallow cutting of its ancient beach with the long duration of Blake Sea required on the hypothesis that it was originally marine. Collateral suggestion is carried by the absence of known marine fossils from the deposits of Blake Sea, but this is far from eonelusive, since such beds would belong to the earlier portion of the Sea's history and would be buried by later deposits. (See p. 46.)

In the writer's opinion, the most probable harmonization of these variant hypotheses concerning the origin of the present depression lies in a slight modification of the second hypothesis above suggested. That is, that the rise of sea-level relative to the basin has been slow and gradual and that the growth of the Delta has proceeded and kept pace with it. On this assumption the post-Tertiary Colorado is supposed flowing into the side of, and through the lower part of, a trough freely open to the sea. The sea is supposed to have advanced very slowly up this trough, the river meanwhile aceommodating itself to the changing conditions by a change of grade and the resultant cleposition of alluvium. It is conceivable that before the advaneing sea-line reached the point where the river entered the side of the trough, the river would have built across the trough a clam suffieient to prevent further advance of the sea, especially if the displacement of sea-level were becoming less rapid-as was no doubt the truth. Further vertical displacement might produce no horizontal displacement, the deposition of alluvium by the river being rapid enough to keep the Delta dam always above the rising sea. In this way there might be formed behind the dam a dry depression such as actually exists. On this hypothesis the formation of Blake Sea would be regarded as a recent and unimportant incident due to the accidental diversion of the Colorado into the depression behind the dam. The writer regards this hypothesis as being rather more in accord with known facts than is the theory currently held. However, he has no wish to urge its aceeptance. With the facts at present available, that particular period in the basin's history must be regarded as quite unknown.

With the existence of Blake Sea we leave speculation behind and return to listory for which there is better evidence. Whatever its origin, Blake Sea was ultimately fresh and its disappearance was almost certainly due to evaporation following the eutting off of water supply from the Colorado. Probably this stoppage was due to a natural return of the river to its gulfward channel, though this may have been complicated by slight orographic movement or by climatic or other changes affecting the reginen of the Colorado. The fall of Blake Sea must have been by annual or semi-annual stages, much as the Salton 
is falling at present and as is deseribed elsewhere in this volume by Dr. MacDougal. It has already been noted that the series of strand-lines formed by Blake Sea and by the Salton can not be distinguished from each other. Blake Sea must be included among very recent phenomena. Its strand lines and terraces are of such character as to fall a ready prey to the elements, even under desert conditions; yet they appear so fresh and undisturbed that any great antiquity is not to be thought of. It is probable that the final disappearance of Blake Sea was less than five hundred years ago, and the entire existence of the water-body can scarcely have been longer. The Indians of the region have a tradition of the previous existence and gradual disappearance of a water-body in the basin, and in spite of the notorious untrustworthiness of Indian legends it seems probable that this one has a basis of truth. Probably some direct evidence, at least of the time required for the disappearance of Blake Sea, could be obtained by a thorough study of its strand-lines, including the accurate determination of their relative elevations.

If the rise and fall of Blake Sea were due to the accidental entry of the Colorado into a previously existing basin and the later accidental diversion of the river toward the Gulf, there is no reason why this might not have happened many times nor why the basin should not have been often the home of transient lakes, such as Blake Sea seems to have been. Indeed, on a priori grounds such occasional repetitions of the incident would seem very probable. There is, however, absolutely no evidenee that any other incursion of the river ever took place. The series of strand-lines of Blake Sea contains no member deeply enough cut to be regarded as marking more than a very transient position of the lake. Nowhere is there any evidence of rise and fall. Nowhere except below the highest level of the present Salton Sea are there any signs of a later series of strands superposed on an earlier. The strand-lines seem to record a continuous and fairly rapid fall of the water-level, and that only. It is possible, of course, that strand-lines, terraces, and similar topographic records of a lake considerably more ancient than Blake Sea might have been entirely destroyed by rain wash during an intervening period, and that earlier lakes might thus have failed to leave any record. It is difficult, however, to see how this could have happened to travertine left by these earlier lakes. If these lakes were similar to Blake Sea and to the present Salton Sea they must have deposited travertine on exposed rocks. It is not likely that such travertine coatings would be removed entirely, even by a fairly long subsequent period of erosion. The travertine of Blake Sea would have been deposited on top of these earlier travertines and the present travertine would show a superposition of different travertines, what might be called an unconformity in the travertine layer. Phenomena precisely similar to this are found in the continental lake basins of Nevada and Utah, and are especially well exhibited in the travertines or tufas of Lake Lahontan. Nothing of this sort has been observed in the Cahuilla Basin. Wherever examined the travertines are uniform in character, from the surface of the original rock to the outer layer of the coating; they show no signs of any interruption during their deposition. It is scarcely possible to be dogmatic as to the non-existence of any lakes prior to Blake Sea, but there is certainly no evidence indicating their existence. It would seem that any previous incursions of the Colorado must have been so soon checked by natural causes that the lakes produced were small and transient. A lake no larger than the present Salton Sea might fail to leave any record now legible. Indeed the occasional occurrence of such very partial fillings seems probable from the historical records cited by Mr. Sykes on page 15 of this volume. It is a little difficult to understand why the river always returned to its channel after these temporary incursions instead of continuing to fill the basins, as it seems to have done in the case of Blake Sea, and seemed about to do in the case of the present Salton Sea.

It is perhaps worth while to note the dissimilarity between the history of the Cahuilla Basin and the histories of the superficially similar undrained basins of Nevada, Utah, and eastern California. These latter also have been the home of large lakes now disap- 
peared, and contain terraces, strand-lines, travertine deposits, and other records similar to those of Blake Sea. However, the records of these northern lakes are much more complex, and indicate a long and complicated history of rises and falls, with long periods of nearly stationary level and probably long periods of complete desiccation. These lakes were fucluating lakes. Blake Sea was simply a falling lake. There are no records in the Cahuilla Basin of anything comparable to the fluctuations which are so marked a feature of the histories of Lake Lahontan, Lake Bonneville, and their smaller analogues. Tlıe reason is apparent. The fluctuations of the northern lakes were almost certainly elimatic in origin, and due to changes of rainfall, or evaporation, or both. These ehanges were recorded in the fluctuations of the lakes because the basins were inelosed and varying balance of rainfall and evaporation found expression in expansions or contractions of the final evaporating surface, the lake. In the Cahuilla Basin these conditions did not exist. Whether we believe the trough to have been oceupied by the sea, or whether we believe it a high and essentially a drained valley subsequently depressed, it is apparent that the rainfall would have free or nearly free egress to the sea and that variations of climate would not find so ready a record as in the permanently inclosed and high-walled basins to the north. Even if there were a period of true basin eonditions following a separation from the ocean and preceding the origin of Blake Sea, it is scarcely likely that climatic fluctuations would leave a record now readable. The rainfall area tributary to the Salton Sink is not very large, and a very considerable increase of rainfall would be necessary to maintain a permanent lake in it. Records of shallow transient lakes, formed by rainfall only, may exist in the elay and salt beds of the sink bottom, but these can not now be examined, and it is doubtful if any such lake would rise high enough to leave records coinparable with those of Blake Sea.

For these reasons the history of the basin offers little cither for or against the theories of fluctuating climate recently advanced by Huntington and others. The evidence of climatic variations furnished so richly by the ancient lake basins to the north is altogether lacking. It is possible that the gravel-sand-clay alternations exhibited by Tertiary and Quaternary alluvium alike may be connected with climatic change, but it is just as possible that they are due to shifting of stream channels, gradual changes of grade, and the like. The decipherable events in the history of the basin scem to be connected with orographie or other changes with which climatic clsange had little or nothing to do. It is possible, of course, that the changes in the course of the Colorado, noted as accidental, are really related to climatic changes in the drainage basin of that river with their resulting changes in degree of overloading and in seasonal regimen, but these remain undeciphered.

\section{THE SOILS. ${ }^{1}$}

In origin and general character there are two types of soil represented in the basin: the desert soils of the bajada, and the river alluvium soils of the Colorado Delta. The former are mainly sandy and gravelly, though occasionally strean-action or local depressions have produced soils of silty or elayey type. The minerals composing the soil are mostly angular fragments, fresh and unweathered, and indicating in their eharacter the shortness of the journey which they have undergone. Being derived originally from the granitic and similar rocks of the mountains, the soils are mineralogically very lieterogeneous and are amply supplied with the useful soil-forming minerals. 'That they are very fertile when supplied with water is indicated by their very successful agricultural use in the Coachella Valley. (Sec Plate 15.) The alluvial soils of the Delta, being derived from the whole drainage area of the Colorado, are similarly diverse and fertile, but differ in that their mineral

1 Considerable use has been made in this section of the reports of soil surveys in the area made by T. II. Means, J. Garnett Holmes, and others for the Bureau of Soils, U. S. Department of Agriculture, and published in the "Field Operations" of that Bureau for I901 and 1903. 
particles are somewhat weathered and are much more uniform in size. Practieally all the soils of the Delta are silts or very fine sands. They are agriculturally excellent and form the very productive fields of the Imperial Valley. Aside from "alkali" (which will be discussed in a moment) their chief fault is too great heaviness and difficulty of working, due to their fine texture. True clays, however, are practically unknown.

The soils of the beaches of the Salton Sea all come within the two classes mentioned. About the northwestern two-thirds of the Sea's periphery the soils are of the desert, mountainwash type. Nearly everywhere they are sandy and gravelly, but there are two localities where important areas of silt are found. The first, and by far the larger, is at the extreme northwestern end of the Sea and has been formed by the flood-waters of Whitewater Creek. For perhaps 5 miles along the edge of the Sea, westward from a point southeast of Mecca, the shore-line is silty and muldy. Beyond this to the west and south one encounters the sandy outwash of the Santa Rosa Mountains. The other silty area is much smaller and oceurs in the valley of Carrizo Creek between the southern end of the Santa Rosa Mountains and the Superstition Mountain uplift. The soils are similar to those of the Mecca region, but are somewhat more sandy.

Over the southeastern third of the Sea's periphery the soils are of the Delta type and are very heavy and muddy. Everywhere the slopes of the beaches are very slight and the mud is usually so soft that landing from a boat is very difficult if not impossible. Toward the north, soils of this type extend along the beaches as far as the railway station of Lano, where they merge with the sandier soils derived from the outwash of the Mud Hills to the north. Indeed this merging of Delta and outwash material extends considerably to the southeast, and is noticeable perhaps as far as half-way from Lano to the mouth of the Alamo River, though the Delta material predominates through nearly all of this distance. On the southern side the Delta soils extend a lesser distance, being separated from the Carrizo Creek silty area above mentioned by about 10 miles of somewhat sandy soils produced by the outwash from Superstition Mountain. During the present submergence the area of the Delta soils has been somewhat extended along the beaches by the silt poured into the Salton Sea and distributed by it. It is probable also that the submerged soils near the mouths of the New and Alamo Rivers have received considerable vertical increments of river alluvium. (Plate 8 B.)

So far as their physical and mineral nature is concerned the soils of all the beaches are likely to be of very high fertility. Their only fault is the frequent presence of "alkali," this being the aceumulation in the surface layers of excessive amounts of soluble salts, mainly ehloride and sulphate of sodium. The natural accumulation of these salts is exclusively a desert phenomenon and is due to the natural movement of water, through the soil being too slight to remove the salts freed by chemical decay of the soil minerals. The water of the infrequent showers penetrates a few inches into the soil, dissolves the salts it finds there, and, when the shower is over, returns to the surface by capillary action and evaporates, leaving the salts it has brought up from below. Desert soils that are fine enough in texture to permit capillary rise of water through them are nearly always more or less "alkaline." In sandy soils, the forces of eapillarity are so weak that rain-water can not reaseend to the soil surface and must continue its downward journey to stream cliannel or underflow, taking its dissolved salts along. Sandy soils are never alkaline unless the natural drainage is for some reason insufficient. In general, on all the Salton beaches, the silty soils are more or less alkaline; the sandy soils are never so, except for some local reason, such, for instance, as the rise of underflow to the surface.

The submergence of the soils by the waters of the Salton secms to have had surprisingly little effect upon their alkali eontent. On the Salton beach just southwest of Imperial Junction is one of the "observation stations" described elsewhere in this volume by Dr. MacDougal, and the soils of the area have been studied by the writer since their 

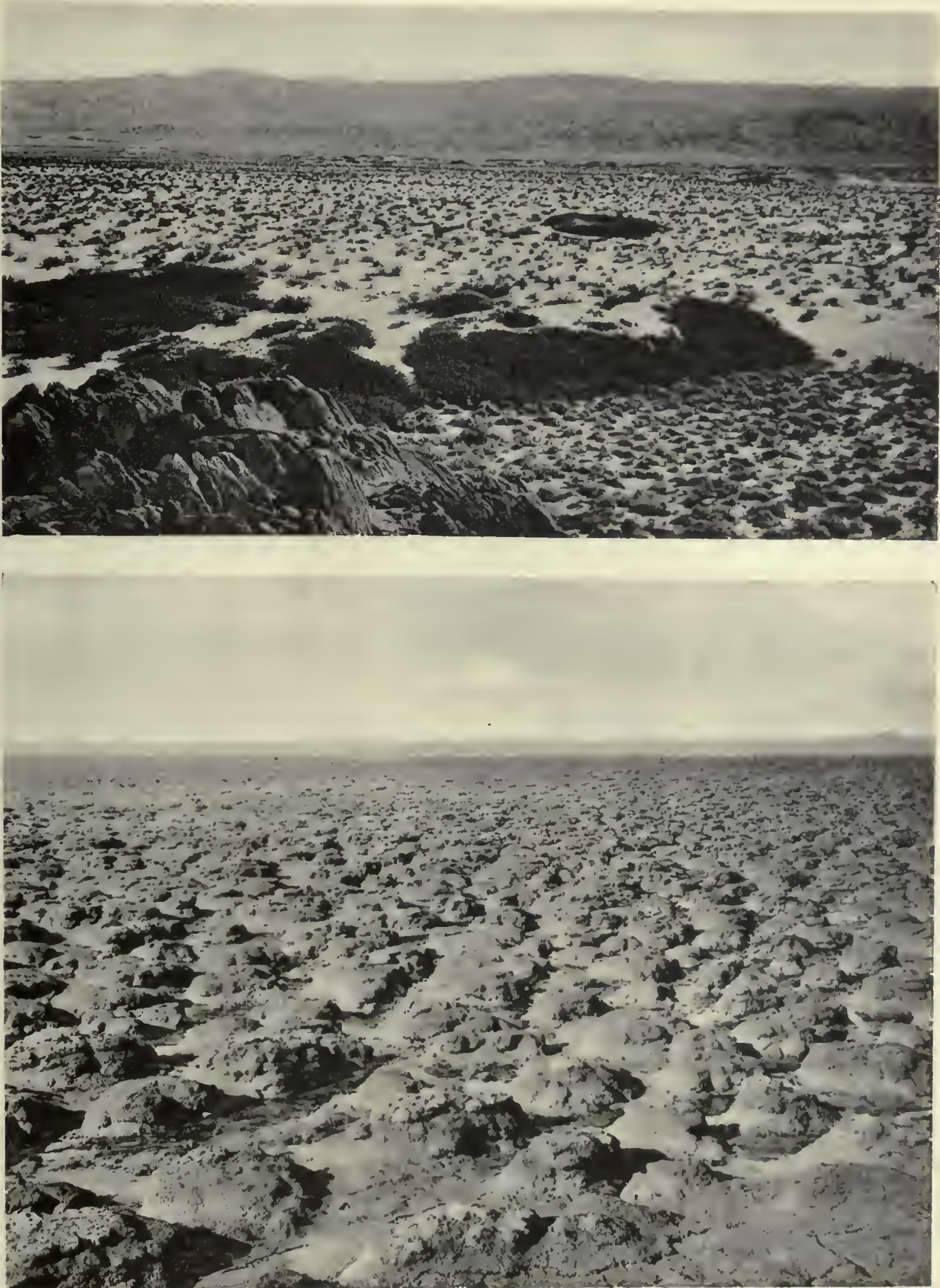

A. View across northwest part of the Cahuilla. showing Area of Intense Wind Action; Accretion Dunes and Clumps of Vegetation.

B. Clayey lumps formed on shores of Imperial Junction Beach. 

emergence from the waters of the Sea. The soils are silts composed mainly of Delta material with perhaps a slight admixture of mountain wash from hills several miles north. Table 2 gives the avernge alkali content of soils submerged for different lengths of time, as well as several which were not submerged at all.

It is apparent that whatever alkali was leached out by the waters of the Sea is almost immediately restored on its retreat. 'This is probably because of two circumstances. First, diffusion of salts through wet, silty soil is very slow, and it is probable that the submergence really produced very little leaching beyond cleaning the actual surface. Second, when the waters retreat they do so slowly and the underground watertable lags (horizontally) considerably behind the actual

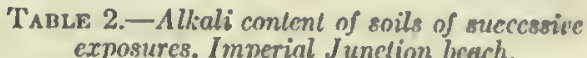
exposures, Imperial Junelion beach.

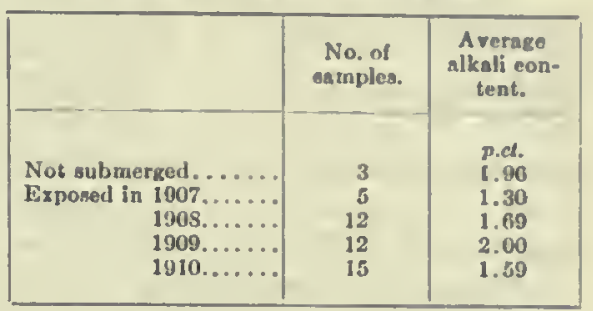
water-line. It follows that for some time after its emergence the soil is wet and has Salton water continually supplied to it by outward diffusion from the Sea and subsequent capillary rise. Evaporation is intense and the Salton water is brackish. These are ideal conditions for the rapid accumulation of alkali, and it is to be expected that what alkali was leached out by the Sea will be restored, or more than restored, on its retreat. Indeed, as the retreating waters become more and more saline they will leave

TARLE 3.-Mechanical analyses of soils from planlless and plant-covered zones, Imperial Junction beach.'

\begin{tabular}{|c|c|c|c|c|c|c|c|}
\hline \multicolumn{8}{|c|}{ Plantless areas. } \\
\hline $\begin{array}{l}\text { Sample } \\
\text { No. }\end{array}$ & $\begin{array}{l}\text { Fide gravel, } \\
2 \text { to } 1 \mathrm{~mm} \text {. }\end{array}$ & $\begin{array}{l}\text { Coarse snod, } \\
1 \text { to } 0.5 \mathrm{~mm} \text {. }\end{array}$ & $\begin{array}{l}\text { Medium } \\
\text { sand, } 0.5 \text { to } \\
0.25 \mathrm{~mm} \text {. }\end{array}$ & $\begin{array}{l}\text { Fioe eand, } \\
0.25 \text { to } 0.1 \\
\text { mm. }\end{array}$ & $\begin{array}{l}\text { Very tino } \\
\text { and, } \\
0.1 \text { to } 0.05 \\
\text { mm. }\end{array}$ & $\begin{array}{c}\text { Silt, } \\
0.05 \text { to } 0.005 \\
\text { m m. }\end{array}$ & $\begin{array}{l}\text { Clay, below } \\
0.005 \mathrm{~mm} \text {. }\end{array}$ \\
\hline $\begin{array}{r}52 \\
53 \\
55 \\
56 \\
57 \\
58 \\
59 \\
60 \\
63 \\
65 \\
66 \\
109 \\
123 \\
126\end{array}$ & $\begin{array}{r}p . c t . \\
0 \\
0 \\
0 \\
0 \\
0.2 \\
0 \\
0 \\
0 \\
0 \\
0 \\
0 \\
.3 \\
0 \\
0\end{array}$ & $\begin{array}{c}p . c t . \\
0 \\
0 \\
0.3 \\
0 \\
.2 \\
.1 \\
.2 \\
0 \\
0 \\
.3 \\
0 \\
.3 \\
0 \\
0\end{array}$ & $\begin{array}{r}p . c t . \\
0.1 \\
0 \\
.2 \\
.2 \\
.2 \\
.7 \\
1.3 \\
.2 \\
.2 \\
.2 \\
.3 \\
.3 \\
1.1 \\
.1\end{array}$ & $\begin{array}{r}p . c t . \\
0.2 \\
.6 \\
3.3 \\
2.0 \\
4.0 \\
1.6 \\
2.4 \\
.4 \\
.3 \\
.4 \\
.3 \\
.6 \\
1.1 \\
4.8\end{array}$ & $\begin{array}{r}\text { p.et. } \\
1.9 \\
5.1 \\
29.3 \\
34.3 \\
40.8 \\
6.3 \\
9.0 \\
8.3 \\
2.2 \\
5.4 \\
.7 \\
1.4 \\
4.2 \\
77.4\end{array}$ & $\begin{array}{l}\text { p.ct. } \\
66.2 \\
65.8 \\
44.3 \\
35.2 \\
30.7 \\
48.5 \\
47.9 \\
50.9 \\
73.3 \\
64.8 \\
57.8 \\
45.1 \\
60.3 \\
9.5\end{array}$ & $\begin{array}{l}\text { p.ct. } \\
31.5 \\
28.6 \\
22.5 \\
27.5 \\
24.0 \\
42.7 \\
38.7 \\
30.9 \\
23.7 \\
28.8 \\
41.1 \\
52.2 \\
33.3 \\
8.2\end{array}$ \\
\hline \multicolumn{8}{|c|}{ Plant-covered areas. } \\
\hline $\begin{array}{r}73 \\
74 \\
79 \\
80 \\
81 \\
91 \\
113 \\
114 \\
115 \\
116 \\
117 \\
113\end{array}$ & $\begin{array}{l}0 \\
0 \\
0 \\
0 \\
0 \\
0 \\
0 \\
0 \\
0 \\
0 \\
0 \\
0\end{array}$ & $\begin{array}{r}0 \\
0 \\
0 \\
0.1 \\
.1 \\
.2 \\
.2 \\
0 \\
.1 \\
0 \\
0 \\
0\end{array}$ & $\begin{array}{r}0.1 \\
.1 \\
.1 \\
0 \\
.1 \\
0 \\
0 \\
0 \\
.2 \\
7.7 \\
0 \\
.2\end{array}$ & $\begin{array}{r}0.3 \\
8.0 \\
.9 \\
.3 \\
3.6 \\
1.0 \\
.9 \\
0 \\
9.4 \\
69.5 \\
.5 \\
.7\end{array}$ & $\begin{array}{r}5.2 \\
72.8 \\
13.1 \\
2.9 \\
51.5 \\
13.7 \\
10.5 \\
11.0 \\
55.2 \\
68.4 \\
11.4 \\
8.0\end{array}$ & $\begin{array}{r}68.1 \\
10.4 \\
40.1 \\
53.3 \\
25.1 \\
50.0 \\
52.3 \\
60.2 \\
23.0 \\
7.0 \\
50.0 \\
55.9\end{array}$ & $\begin{array}{r}20.2 \\
11.4 \\
39.0 \\
43.3 \\
19.5 \\
34.8 \\
35.9 \\
29.0 \\
12.1 \\
7.2 \\
30.9 \\
34.0\end{array}$ \\
\hline
\end{tabular}

behind them larger and larger proportions of soil alkali, probably far exceeding the alkali present in the soil before submergence. The beginnings of this process ean already be detected in the fact that thin salt crusts are beginning to be visible on the soils last exposed. The soils of beaches to be exposed in future will probably have had alkali added rather

${ }^{1}$ Analyses are by Dr. C. C. Fleteher and others, of the Bureau of Soils, U. S. Dept. of Agriculture. 
than abstracted by their submergence. In time it is to be expected that rain will restore these over-alkaline soils to substantially their eondition before submergence, but the rains of the Cahuilla Basin are not only infrequent but are commonly torrential and run off so quickly that they have little action on alkali other than the washing of the soil surface. Their leaching aetion will be very slow.

It must be realized, of course, that all this applies only to silty soils or other soils the texture of which is fine enough to permit significant capillary rise of the soil-water. In sandy soils there is no opportunity for the shoreward seepage, capillary rise, and evaporation of the lake water, and there is therefore no tendency for the accumulation of soil alkali shoreward from the retreating water-line. Furthermore, sandy soils are so much more easily penetrated and leached by rain-water that even a very slight or very rapid rain is sufficient to remove their exeess alkali.

From the viewpoint of this volume, the most important matter relating to the soils is their influence upon the distribution of the vegetation. This seems surprisingly slight. The detailed soil study of the Imperial Junction beach was undertaken especially from this point of view and led to the conclusion that no influence of the soil upon the local distribution of the vegetation was discernible. On this beach the vegetation offers two distinetive features: a repeated banding parallel to the water-line, and a thickening in and near the ehannels of small dry washes eoming from the hills. Both of these matters are fully described in Dr. MacDougal's eontribution. It was quite impossible to correlate either of these distribution features with any variation of soil or soil alkali. As a whole the soil was quite uniform both in its physical properties and its alkali-eontent, but sueh variations as did exist had absolutely no relation to the presence or absence of vegetal cover. This is shown by the data of tables 3 and 4. Table 3 gives the mechanical analyses, according to the method of the Bureau of Soils, ${ }^{1}$ U.S. Dept. of Agriculture, of soils taken from the plantbearing and plantless portions of the beach, respectively. It will be noted that the variations between different samples in the plantless area are greater than the difference between the soils of the two areas. Table 4 gives similar data for alkali content and leads to similar conclusions. The actual eauses of the distribution of vegetation as noted relate to water supply and to the position of the shore-line, and are elsewhere fully discussed by Dr. MaeDougal.

TABLE 4.-Alkali content of soils from plantless and plant-covered
Imperial Junction beach. ${ }^{2}$

1. U. S. Dept. of Agr., Bureau of Soils, Bulletin 84, 1912.

"The analyses on which tables 2 to 4 were based were made by L. D. Elliott and by the Bureau of Soils. 
General observations at many other points about the beaches fully confirm the results of the more intensive study of the Imperial Junction beach. The distribution of the beach vegetation seems to be quite independent of the soil. The only important influence is an indirect one, the influence of soil texture on water movement and water retention. These influences may be summarized as follows: ${ }^{1}$

1. Capillary power is stronger in the soils of finer texture. Water will rise higher and spread farther horizontally in such soils.

2. Rain penetrates more rapidly into the coarser soils. From a silt or clay, most of the rain will run off instead of being absorbed.

3. Drainage is more rapid and complete from the coarser soils. A fine soil will hold more interstitial (or "capillary") water than a coarse.

4. When exposed to intense evaporation a coarse soil moistened witl capillary water dries out at and near the surface more rapidly than the fecble capillary powers of the soil can supply more moisture from below. $\Lambda$ dry surface layer is thus produced, in which layer the thin water films responsible for capillary movement do not exist. This dry layer breaks the continuity of the path by which capillary water is ascending, acts as a "dry mulch" or insulator to the water below, and prevents the rise and loss of this water. On the other hand, the capillary powers of a fine soil are so much better that water is usually supplied from below as fast as removed by evaporation, with the result that all the water of the soil is lost down to the depth from which capillary rise can act. Because of this different behavior toward intense evaporation, it frequently happens that desert soils of sandy texture will retain moisture and nourish plants, when surrounding finer soils are entirely desiccated and their vegetation killed.

All four of these gencral principles find application to minor features of plant distribution both on the Salton beaches and on the higher slopes of the basin which the Salton waters did not reach. Many specific examples are noted in Dr. MacDougal's contribution. In all cases, however, these influences of soil texture are far subordinate to the influence of major and minor topography as directly controlling water supply. The distribution of the small dry washes which form channels for the occasional rains is far more important than the variation in soil.

It is true, of course, that the prevailing soil-alkali content of some regions, the prevailing gravelly nature of others, and similar wider soil and topographic differences between different parts of the Basin, have had considerable influence upon the content of the general flora of these "provinces." Certain species have been barred out because of their unsuitability to the general conditions of the province. In these larger ways, soil character has perhaps had an important influence on the vegetation of the basin, fully discussed elsewhere in this volume.

'For details the reader must consult the text-books of soil physics, e.g., Mitscherlich-Bodenkunde. 



\title{
CHEMICAL COMPOSITION OF THE WATER OF SALTON SEA AND ITS ANNUAL VARIATION IN CONCENTRATION, 1906-1911.
}

\author{
Br W. H. Ross.
}

PRELIMINARY ANALYSES. ${ }^{2}$

Before undertaking a complete analysis of the water of the Salton Sea a preliminary examination was first made of samples taken at intervals from different points in the lake. These samples not only showed to what extent the lake varied in concentration in different parts as it approached its maximum volume, but they also served as a guide to the rate at which the concentration of the lake became uniform when the inflow of water from the Colorado River was finally stopped on February 10, 1907. In this way information was gained on the shortest time following this date which must elapse in order that a sample collected for complete analysis would be representative of the whole lake.

TABle 5.-Preliminary partial analyses.

\begin{tabular}{|c|c|c|c|c|}
\hline \multirow[t]{2}{*}{$\begin{array}{l}\text { No. of } \\
\text { asmple. }\end{array}$} & \multirow[t]{2}{*}{ Ioestlon. } & \multirow[t]{2}{*}{ Depth. } & Totsl solids. & $\begin{array}{l}\text { Chlorine, } \\
\text { tated as } \\
\mathrm{NaCl}\end{array}$ \\
\hline & & & \multicolumn{2}{|c|}{ Parts in 100,000} \\
\hline $\left.\begin{array}{r}1 \\
2 \\
3 \\
4 \\
8 \\
6 \\
7 \\
8 \\
9 \\
10 \\
11 \\
12 \\
13 \\
14 \\
15\end{array}\right\}$ & 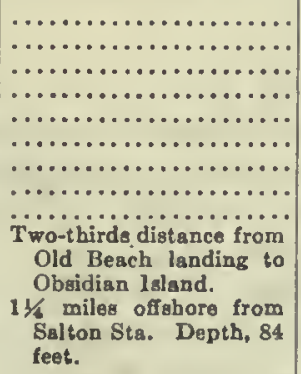 & 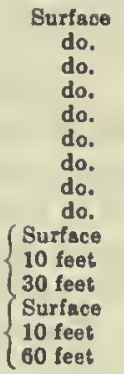 & $\begin{array}{l}330.0 \\
331.2 \\
336.0 \\
321.8 \\
330.4 \\
327.0 \\
330.6 \\
338.4 \\
258.8 \\
338.2 \\
338.6 \\
340.0 \\
341.8 \\
338.6 \\
352.0\end{array}$ & $\begin{array}{l}243.0 \\
242.5 \\
249.0 \\
238.0 \\
242.0 \\
240.0 \\
246.0 \\
249.0 \\
188.0 \\
250.0 \\
250.0 \\
250.0 \\
250.5 \\
250.0 \\
259.0\end{array}$ \\
\hline
\end{tabular}

As might be expected, those samples were found most salty which were taken from shallow regions overlying saline flats, while samples taken from the surface in deep parts of the lake contained less amount of salts. Thus, on June 10, 1906, when the greatest depth of the lake was about 60 feet, a sample taken $11 / 2$ miles from shore near Mecca was found to contain 401.6 parts of total solids in 100,000; a second sample, taken at the same time from a point 100 feet from shore, contained 697.4 parts of solids; and a third sample, collected a sliort time before within a few feet of the shore near Travertine Point, showed a salt content of $1,152.8$ parts. The water at this point was very shallow and covered a saline deposit.

Within the next few months a marked increase in uniformity took place, as shown by the analysis of two samples collected on October 11. One of these taken from shallow water near the shore contained 363.2 parts of solids in 100,000 , while a half-mile from shore a sample yielded 359.6 parts.

All samples collected before June 3, 1907, were analyzed by Dr. A. E. Vinson and Mr. E. E. Free, Arizons Agricultural Experiment Station. 
During the first ten days in February 1907, when the lake had reached its maximum volume, a set of samples collected from different points on the lake and at different depths were analyzed for their total solids and chlorine content; and, as the samples were collected from points extending over the entire range of the lake, the results obtained represent the variation in concentration existing in the lake at the time of its greatest volume.

These results show that with one exception no very great variation was found in any of the samples analyzed. Sample No. 9, which was less salty than the others, was taken within a few miles of the mouths of the New and Alamo Rivers, through which only a short time before flowed the fresh water of the Colorado River. (Table 5.)

The greatest concentration was found near the bottom of the lake at a depth of 60 feet. This would indicate that leaching of salts from the bed of the lake was still taking place. On account of this result, and from the fact that the concentration found for the lake in general was not as uniform as it was expected to become ultimately, no further samples were collected until June 3 of the same year. On this date a sample was collected for complete analysis at a point 4 miles from shore in a southwestern direction from Mecca Landing. Each year following samples were collected in the same way and in approximately the same location.

\section{METHODS OF ANALYSIS.}

The methods of analysis were selected according to what seemed best suited for the concentrations of the constituents to be determined, but only those methods were used which have been slown by extensive use to give accurate results. All determinations were carried out in quadruple and blank determinations were made of the reagents used in order to be able to judge accurately as to the increase in concentration which was taking place from year to year. With certain constituents this was easy to determine accurately, but with others which occurred in smaller proportions the experimental error, even with the greatest care, must necessarily be considerable.

\section{SILICA.}

For the determination of silica and of the following constituents which were made in the same sample, 2 liters of the water were evaporated to dryness with hydrochloric acid in a platinum dish and then dried for 2 hours at $120^{\circ} \mathrm{C}$. As the concentration of the water inereased a correspondingly smaller volume was taken. The residue was taken up in hydrochloric-acid solution, filtered, and washed. 'The filtrate was evaporated as before, and the process repeated three times. The insoluble portions were combined, dried, and ignited in a platinum crucible. The residue was then treated with a few drops of dilute sulphuric-acid solution and ignited to constant weight. The silica was driven off with hydrofluoric acid, a few drops of sulphuric acid again added, and the ignition to constant weight repeated. From the loss in weight noted the silica present was determined. Any residue remaining after the final ignition was brought into solution and combined with the filtrate from which the silica had been separated.

IRON AND ALUMINIUM.

The filtrate from the silica determination was heated almost to boiling and hydrogen sulphide passed in for an hour. The slight precipitate which formed was found to consist principally of platinum taken up from the platinum dish in which the water had been evaporated. It was consequently rejected and tests for the heavy metals made in a solution prepared by evaporating water in a porcelain dish as described under "copper."

The filtrate from which the precipitate was rejected was heated to drive off hydrogen sulphide and then oxidized with bromine water. To the hot solution was added a slight excess of ammonia, and on filtering and igniting the combined oxides of iron, aluminium, and phosphorus were obtained. The phosphate radicle was determined in a separate sample. 
For the direct estimation of the iron the mixed oxides were digested in dilute sulphuric acid until all were completely dissolverl. The solution was transferred to a small Erlenmeyer flask and oxidized by boiling with a little bromine water. The excess of bromine was expelled by boiling, and the solution then poured into a Nessler tube.

In other tubes were placed known amounts of a standard iron solution made by dissolving a weighed amount of iron in sulphuric acid and oxidizing with bromine water, after which the solution was made up to a known volume. To cach of the tubes containing the standard solution was added an amount of sulphuric acid equal to that in the tube containing the unknown amount of iron; 5 c.c. of a 5 per cent solution of potassium sulphocyanide were then added to each tube. The tubes were finally filled to the mark with water and mixed. By thus making up standard tubes until one was obtained which agreed in color with the one containing the unknown amount of iron, the amount of iron originally present in the water was determined. The aluminium was calculated by difference.

\section{MANGANESE.}

The filtrate from which the mixed oxides of iron, aluminium, and phosphorus were precipitated was concentrated somewhat and acidified with a slight excess of hydrochloric acid. Bromine water was added until the solution was colored dark brown, after which it was treated with a considerable excess of ammonia and the solution was heated to boiling. The negative result obtained in this way for manganese was confirmed by making a qualitative test with lead oxide and nitric acid on the residue from a separate portion of water.

\section{CALCIUM AND MAGNESIUM.}

The solution in which the manganese was found to be absent was used to determine calcium and magnesium according to the usual methods.

\section{SULPHATE RADICLE.}

For the determination of sulphates a separate portion of 500 c.c. of the water was taken in 1907, but as the water became more concentrated a correspondingly less amount was used. This was evaporated to convenient volume and the sulphates determined by the usual gravimetric method.

\section{SODIUM, POTASSIUM, AND LITHIUM.}

The usual methods were likewise cmployed in determining sodium and potassium in the filtrate from the sulphate determination.

For the estimation of lithium a separate preparation of the mixed alkali chlorides was prepared. Part of the sodium was removed by dissolving in a small amount of water and adding alcohol. The filtrate from the sodium precipitate was washed with $\$ 0$ per cent alcohol, evaporated to dryness, and the lithium line $(6708.2 \mu)$ given by the residue in the spectroscope was compared with the lines given by mixtures of sodium and lithium ehlorides. Knowing the ratio of sodium and lithium in the mixture which gave the same intensity of line as the residue containing the unknown amount of lithium, the extent to which this constituent occurs in the Salton Sea water could be calculated.

\section{COPPER.}

Two liters of water were evaporated to dryness in a poreelain dish and the silica removed, as already described. The filtrate was then heated almost to boiling and hydrogen sulphide passed in for an hour. The slight precipitate formed, mostly sulphur, was filtered off, washed with hydrogen-sulphide water, and dissolved by digesting with concentrated nitric acid. The excess of acid was expelled, and the residue taken up in a solution containing 0.5 c.c. each of nitric and sulphuric acids in 25 c.c. of water. The solution was 
finally electrolyzed by depositing the copper first on a platinum dish and then on a platinum spiral weighing about 0.3 gram. A current of about 5 milliamperes was used for the final deposition.

\section{PHOSPHATE RADICLE.}

Six liters of water were evaporated to a small volume and part of the sodium chloride and calcium sulphate separated by crystallization.

The mother-liquor was treated with concentrated nitric acid and evaporated nearly to dryness in a porcelain dish to drive off hydrochloric acid. The residue was taken up with water and made alkaline with ammonia. Some ammonia nitrate was added, and then enough nitric acid to restore acidity, after which the phosphates were precipitated in the usual way, first with molybdate solution and then with magnesia mixture.

\section{CARBONATE AND BICARBONATE RADICLES AND FREE CARBON DIOXIDE.}

Determinations of the carbonate and bicarbonate radicles were made in the same 100 c.c. sample of water. As no color developed on adding phenolphthalein, the former was shown to be absent. A few drops of methyl orange were then added, and the solution titrated with $\mathrm{N} / 20$ potassium acid sulphate solution. The number of cubic centimeters required, multiplied by the factor 0.00305 , gave the value of the bicarbonate radicle $\left(\mathrm{HCO}_{3}\right)$ in grams.

The total free and combined carbon dioxide was determined in the ordinary direct way in a separate sample of water specially collected from the lake. For the decomposition of the carbonates dilute sulphuric acid was used, and to prevent the escape of any hydrochloric acid through the action of the sulphuric acid on the salt in solution a tube containing silver sulphate was interposed between the flask containing the water and the Geissler potash bulb used for the absorption of the evolved carbon dioxide. By subtracting from the total carbon dioxide the value corresponding to that combined as bicarbonates, the free carbon dioxide was obtained.

A third sample of 2 liters of water was evaporated to dryness on the water bath in a platinum dish. The residue was transferred to a flask and the carbon dioxide, which thus remained combined when the water was evaporated to dryness, was determined in the same way as the total carbon dioxide.

\section{CHLORINE.}

Since the water was shown to contain no normal carbonates the chlorine was determined in the usual way by titrating 50 c.c. with standard silver nitrate solution.

\section{BROMINE, IODINE, ARSENATE, AND BORATE RADICLES.}

As these constituents do not occur in sufficient quantity to make accurate quantitative determinations they were only tested for qualitatively. One liter of water was taken for each test.

\section{NITRATE AND NITRITE RADICLES.}

For the determination of nitrates and nitrites the well-known colorimetric methods were used. To counterbalance the effect of the sodium chloride in the water when determining nitrates the same quantity of salt was added to each of the standard potassium nitrate preparations as was present in the 50 c.c. of water taken for this determination.

\section{OXYGEN CONSUMED.}

Of the water to be examined 200 c.c. were measured into a wide-mouthed, glassstoppered bottle; 10 c.c. of phosphoric-acid solution $(1: 4)$ were then added, followed by 10 c.c. of a standard potassium-permanganate solution, approximately $\mathrm{N} / 50$. The bottle and its contents were placed in a water bath and kept at a temperature of $30^{\circ} \mathrm{C}$. for 4 
hours. The amount of potassium permanganate left undecomposed at the end of this time was determined by adding a few drops of a 10 per cent potassium-iodide solution and titrating with standard sodium thiosulphate, using starch paste as indicator. From the amount of permanganate which was decomposed by the water its oxygen-consuming power could be calculated, knowing that 1 c.c. of $N / 50$ potassium-permanganate solution contains $\frac{8}{50 \times 1000}$ gram of available oxygen.

\section{TOTAL SOLIDS.}

The residue, obtained by evaporating 50 c.c. of the water in a platinum dish on the water bath and then drying to constant weight at $110^{\circ} \mathrm{C}$., contained, besides the dissolved constituents, water occluded by crystals of salt and hydration water contained in the basic magnesium compounds. The amount of water thus contained in the residue was determined by evaporating a separate sample of 500 c.c. in the same way as before, and noting the difference obtained between the weight of the residue dried at $110^{\circ} \mathrm{C}$. and when ignited gently below redness. The same result was found for the concentration of the total solids when 500 c.c. were evaporated as when a smaller sample was taken.

\section{ANALYTICAL RESULTS.}

The dates on which the samples were collected and the results of the five yearly analyses are given in table 6 . Instead of aiming to give a statement of the constituents which occur in solution, the analysis of each sample was made to represent rather the com-

TABLE 6.-Five complete analyses of the Salton Sea water.

\begin{tabular}{|c|c|c|c|c|c|}
\hline & \multicolumn{5}{|c|}{ Parts per 100,000 . } \\
\hline & $\begin{array}{l}\text { June 3, } \\
1907 \text {. }\end{array}$ & $\begin{array}{c}\text { May 25, } \\
\text { 1908. }\end{array}$ & $\begin{array}{l}\text { June 8, } \\
1909 .\end{array}$ & $\begin{array}{c}\text { Mey } 22 \\
1010 .\end{array}$ & $\begin{array}{l}\text { June } 3 \\
1911 .\end{array}$ \\
\hline \multicolumn{6}{|l|}{ Total aolida (dried at $110^{\circ} \mathrm{C}$.) plus } \\
\hline water of occlusion and bydratioa.. & 364.8 & 437.20 & 519.40 & 603.80 & 718.00 \\
\hline Water of occlusion and bydration... & & & 17.50 & 22.50 & 20.84 \\
\hline 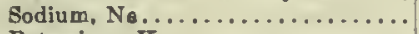 & 111.05 & 134.26 & 160.33 & 139.28 & 227.81 \\
\hline Potaasium, K................ & 2.30 & 2.78 & 3.24 & 3.53 & 3.81 \\
\hline Lithium, Li. . . . . . . . . . . . . . & trace & 0.013 & 0.017 & 0.021 & 0.025 \\
\hline Calcium, Ca.................. & 9.95 & 11.87 & 12.70 & 13.67 & 15.62 \\
\hline Magneaium, Mg............... & 6.43 & 7.63 & 8.98 & 9.84 & 11.68 \\
\hline Alumina, $\mathrm{Al}_{2} \mathrm{O}_{2} \ldots \ldots \ldots \ldots \ldots$ & 0.056 & 0.065 & 0.117 & 0.075 & 0.168 \\
\hline Ferrio oxide, $\mathrm{FerO}_{2} . . . \ldots \ldots \ldots . . .$. & 0.007 & 0.009 & 0.014 & 0.011 & 0.051 \\
\hline Silica, $\mathrm{SiO}_{2} \ldots \ldots \ldots \ldots \ldots \ldots \ldots$ & 0.92 & 0.93 & 1.01 & 1.01 & 1.19 \\
\hline 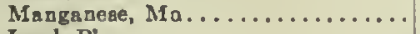 & nons & none & nono & none & none \\
\hline 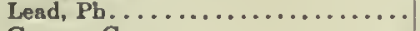 & none & none & noos & Dona & Done \\
\hline Copper, Cu. . . . . . . . . . . . . & 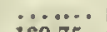 & $\ddot{n} \ddot{\sim}$ & $\operatorname{trace}$ & traca & trace \\
\hline Chlorine, Cl.................. & 169.75 & 204.05 & 240.30 & $2 S 0.93$ & 339.42 \\
\hline Bromine, Br.............. & ...... & $\ldots \ldots$ & ....... & ....... & trece \\
\hline Iodine, $1 . \ldots \ldots \ldots \ldots \ldots \ldots \ldots$ & $\because \cdots \cdots$ & & ........ & m.... & noos \\
\hline Sulphate redicle, SO $\mathrm{SO} \ldots \ldots \ldots \ldots$. & 47.60 & 56.74 & 65.87 & 76.36 & 91.67 \\
\hline Carbonate radicle, $\mathrm{CO}_{2} \ldots \ldots \ldots \ldots$ & 6.58 & 7.60 & 7.34 & 6.38 & 5.78 \\
\hline A raenato radicle, AeO $\ldots . . . \ldots \ldots$ & & $\cdots \cdots \cdot$ & & & noos \\
\hline Phosphate radicle, PO......... . & 0.009 & 0.011 & 0.01 & 0.013 & trece \\
\hline Nitrets radicle, $\mathrm{NO}_{2} \ldots \ldots \ldots \ldots \ldots \ldots$ & 0.18 & 0.20 & 0000 & none & aone \\
\hline Nitrite radicle, $\mathrm{NO}_{2} \ldots \ldots \ldots \ldots \ldots$ & none & trace & 0.0006 & none & Done \\
\hline Oxygen consumed.............. & 0.093 & 0.059 & 0.068 & 0.045 & 0.063 \\
\hline Borate radicle, $\mathrm{BO}_{2} \ldots \ldots \ldots \ldots \ldots$ & $\ldots \ldots$ & trace & trace & trace & trace \\
\hline Total conatituent & 354.93 & 426.27 & 500.61 & 581.17 & 697.28 \\
\hline
\end{tabular}

position of the anhydrous inorganic matter which is left when the water is evaporated to dryness. Those elements like silicon, iron, and aluminium, which occur in the residue in the form of their oxides, are represented as such, but all other constituents which occur in combination as salts are expressed in the ionic form. In this way the necessity for making assumptions regarding the way in which the constituents are combined is avoided. On evaporating the water the alkaline-earth bicarbonates in solution are decomposed, yielding 
the normal carbonate of calcium and the hydrated carbonate of magnesium. Consequently the carbonate, and not the bicarbonate radicle, is given in the table of results. All constituents are stated in parts per 100,000.

\section{DISCUSSION OF RESULTS.}

In order that a comparison may be made of the increase in coucentration which has taken place in the total constituents from year to year, correction must be made for the fact that the samples were not collected on the same date each year. When applying this correction to the total constituents, in order to give them the values which they would have if the samples were collected on June 3 of each year, it was assumed that the daily evaporation from the lake during the last week in May is 1.5 times as great as the average daily evaporation for the whole year.

With the exception of the first year period, the yearly percentages of increase of the constituents are seen to increase progressively. This result is to be expected, for as the volume of the lake becomes smaller an equal loss of water by evaporation will produce a greater increase in concentration of the constituents.

The high result found for the increase of the constituents during the first year period may be explained on the assumption that the water had not yet reached a state of equilibrium with respect to the salts in the bottom of the lake.

TABLE 7.-Pcrentage yearly incrcase of total constituents.

\begin{tabular}{|c|c|c|c|c|}
\hline \multicolumn{4}{|c|}{ Total constituents, parts per 100,000 . } & \multirow{2}{*}{$\begin{array}{l}\text { Yearly } \\
\text { increase } \\
\text { of con- } \\
\text { atituents. }\end{array}$} \\
\hline $\begin{array}{l}\text { Date of } \\
\text { estopliog. }\end{array}$ & $\begin{array}{l}\text { Determined } \\
\text { in collocted } \\
\text { samples. }\end{array}$ & $\begin{array}{c}\text { Correc- } \\
\text { tion. }\end{array}$ & $\begin{array}{l}\text { Calculated } \\
\text { for Juge } 3 \text { of } \\
\text { each year. }\end{array}$ & \\
\hline June 3, 1907. . & 354.93 & \pm 0.00 & 354.03 & p. ct. \\
\hline Møy 25, 1908....... & 426.27 & +2.70 & 428.97 & 20.9 \\
\hline June 8, $1900 . \ldots \ldots$. . & 500.67 & -1.47 & 499.14 & 16.2 \\
\hline May $22,1910 \ldots \ldots \ldots$ & 581.17 & +4.20 & 586.37 & 17.4 \\
\hline June $3,1911 \ldots \ldots \ldots$ & 697.28 & \pm 0.00 & 697.28 & 18.9 \\
\hline
\end{tabular}

TABLE 8.-Annual fall of surface of the lake.

\begin{tabular}{|c|c|c|}
\hline $\begin{array}{c}\text { Altitude of eurface } \\
\text { of lake. } \\
\text { Fect below sea-level. }\end{array}$ & $\begin{array}{c}\text { Date of obscr- } \\
\text { vatiou }\end{array}$ & $\begin{array}{c}\text { Fall of } \\
\text { surface, } \\
\text { in fcet. }\end{array}$ \\
\hline 198.8 & July 1,1907 & $\ldots .7$ \\
203.5 & July 1,1908 & 4.7 \\
207.9 & July 1,1909 & 4.4 \\
$\cdots \cdots$ & July 1,1910 & 4.6 \\
\hline$\cdots$ & July 1,1911 & $\ldots .$. \\
\hline
\end{tabular}

The rate at which the surface of the lake is lowering, as a result of evaporation, is shown in table 8. The surface altitudes of the lake as observed from year to year were taken from the gage readings at Salt Creek trestle, maintained for a time jointly by the Southern Pacific Railway and the United States Weather Bureau.

Since the fall of the surface of the lake was greater during the first year period than for any equal period since then, it might at first sight appear that the high result found for the increase of the constituents during the first year period was due to a greater evaporation during that time, or to a smaller volume of inflowing water, or to both. The difference, however, in the fall of the surface of the lake between the first and second year periods is not great enough to correspond to the difference found between the total constituents for the same periods, and it may therefore be concluded that the high value found for the first year increase of the constituents was largely caused by leaching of salts from the bottom of the lake, as already stated.

When the composition of the residue is expressed in percentages of the total anhydrous inorganic solids, as is done in table 9, it will be seen that the concentrations of the principal constituents with respect to the water must have increased each year in almost the same proportion as the total constituents, since the percentage which each forms of the latter has remained fairly constant.

Although the composition of the salts in solution has remained fairly constant when considered as a whole, yet some slight variations have taken place. Thus, the calcium and carbonate ions have decreased, as will be discussed later, while both the sodium and chlorine ions have increased slightly. The magnesium and sulphate ions, however, have 
remained practically constant. Some of the other constituents which occur in small quantities have varied somewhat irregularly. This may be due in part to experimental error in analysis, but principally to the method of collecting the samples, as it was found very difficult to collect samples perfectly free from silt.

The samples for the first analyses were collected and transferred to the laboratory in a large carboy. 'The water, as needed for analysis, was siphoned off without disturbing the container, which gave any sediment in the water an opportunity to sink to the bottom.

\begin{tabular}{|c|c|c|c|c|c|}
\hline & 1907. & 1008. & 1009. & 1010. & 1911. \\
\hline Sodium, Na.................. & 31.280 & 31.406 & 32.027 & 32.560 & 32.671 \\
\hline 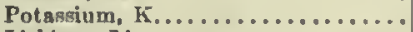 & 0.648 & 0.652 & 0.647 & 0.607 & $0.5+6$ \\
\hline Lithium, Li. . . . . . . . . . . . & trace & 0.003 & 0.003 & 0.004 & 0.003 \\
\hline Calcium, $\mathrm{Ca} \ldots \ldots \ldots \ldots \ldots \ldots$ & 2.803 & 2.785 & 2.537 & 2.352 & 2.240 \\
\hline Magnesium, $\mathbf{M g} \ldots \ldots \ldots \ldots \ldots \ldots$ & 1.812 & 1.791 & 1.700 & 1.003 & 1.675 \\
\hline Alumina, $\mathrm{Al}_{3} \mathrm{O}_{3}, \ldots \ldots \ldots \ldots \ldots$ & 0.016 & 0.015 & 0.023 & 0.013 & 0.024 \\
\hline Ferrio oxide, FetOa.............. & 0.002 & 0.002 & 0.003 & 0.002 & 0.007 \\
\hline 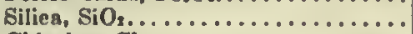 & 0.250 & 0.218 & 0.218 & 0.174 & 0.171 \\
\hline Chlorine, Cl................. & 47.826 & 47.868 & 48.122 & 48.330 & 48.678 \\
\hline Sulphato radicle. SO............. & 13.411 & 13.310 & 13.158 & 13.139 & 13.147 \\
\hline Carbenate radicle, $\mathrm{CO}_{3} \ldots \ldots \ldots \ldots$ & 1.854 & 1.706 & 1.460 & 1.088 & 0.829 \\
\hline Phosphate radicle, $\mathrm{PO}, \ldots . . . \ldots$. & 0.003 & 0.003 & 0.002 & 0.002 & trace \\
\hline & $\begin{array}{l}0.051 \\
0.026\end{array}$ & $\begin{array}{l}0.047 \\
0.014\end{array}$ & $\because 0.01$ & $\ddot{0} 00 \mathrm{~s}$ & $\ddot{0} 00 \mathrm{~s}$ \\
\hline \multirow{2}{*}{ Oxygen consumed................. } & & nan & & In & \\
\hline & 100.000 & 100.000 & 100.000 & 100.000 & 100.000 \\
\hline
\end{tabular}

In 1909 it was thought that this method of sampling, which would certainly give low results for iron and aluminium, on account of their partial precipitation through loss of carbon dioxide by the water on standing, might also give rise to some loss of calcium and magnesium in the same way. 'The residue which had settled out in the bottom of the demijohn from the samples collected in the year referred to was accordingly filtered off and analyzed. The constituents are expressed in table 10 in parts per 100,000 of the water in the demijohn.

These figures confirm the view already expressed that iron and aluminium separate out from the Salton Sea water on standing, which explains the somewhat irregular results obtained for these constituents from year to year. 'The amounts of calcium and magnesium carbonates lost in this manner, however, are insignificant. Instead of being formed by precipitation from the water, the greater part of the residue analyzed is

TABLE 10.-Analysis of sill depositcd by the collected sumple.

\begin{tabular}{|c|c|}
\hline Constituents. & $\begin{array}{l}\text { Parts per } \\
100,000 .\end{array}$ \\
\hline Total resid & 0.01 \\
\hline Silica. $\mathrm{SiO}_{2}$. & 0.33 \\
\hline Calcium, Ca. & 0.04 \\
\hline Magnesium, Mlg & 0.02 \\
\hline Alumina, $\mathrm{Al}_{3} \mathrm{O}_{3}$. & 0.13 \\
\hline Forric oxide, $\mathrm{FeO}_{3}$. & 0.10 \\
\hline Carbonate radicle, $\mathrm{CO}_{3}$. & 0.07 \\
\hline
\end{tabular}
due to silt which settled out from suspension.

The sample for 1911 was collected and filtered on the spot into graduated flasks. The total contents of a flask were then taken for a determination. In this way it was thought that inaccuracies would be avoided through loss of any of the constituents by precipitation. It was found, however, that the water of the lake was quite noticeably turbid and could not be obtained perfectly elear by filtration through filter paper. The duplicate results obtained for silica, iron, and aluminium did not for this reason agree very closely, and all are no doubt slightly high.

In order that the analyses might represent the composition of the anhydrous inorganic matter remaining when the water was evaporated to dryness, a gravimetric determination was malle each year of the combined carbon dioxide in the residue. As shown in the table, this amounted in 1911 to 5.78 parts as $\mathrm{CO}_{3}$ in 100,000 , equal to 4.24 parts of $\mathrm{CO}_{2}$. The bicarbonates in solution were also determined by titrating with potassium acid sulphate, using methyl orange as indicator. The value found amounted to 17.14 parts as $\mathrm{HCO}_{3}$ 
in 100,000 , equal to 12.36 parts expressed as $\mathrm{CO}_{2}$; or to 8.43 parts of $\mathrm{CO}_{3}$ when the carbonates in solution are expressed as the normal carbonates, which is considerably greater than the value found for the $\mathrm{CO}_{3}$ radicle in the evaporated residue.

If the normal carbonates are formed on evaporating the water, then the combined carbon dioxide in solution should be double that found in the evaporated residue. The ratio found, however, is considerably greater than this, amounting to $\frac{12.36}{4.24}=2.9$. It was shown by Davis ${ }^{1}$ that, when magnesium carbonate is boiled with water, part of the carbonate is hydrolyzed, forming a basic magnesium carbonate and magnesium hydroxide. The same result undoubtedly takes place when water containing magnesium bicarbonate is evaporated to dryness, which would explain the high ratio found between the carbon dioxide in the water and in the evaporated residue. When the evaporations were carried out in the same way, as was done each year by evaporating on a water bath in a platinum dish, duplicate determinations of carbon dioxide in the residue agreed closely. It follows from this that the same proportion of the magnesium carbonate must have been hydrolyzed in each determination.

In the year 1909 it was noticed that, although the constituents as a whole increased about 18 per cent since the previous analysis, the carbonate radicle as determined in the evaporated residue, on the contrary, decreased. The quantity of calcium present increased only 7 per cent over the preceding year instead of 18 per cent, as might have been expected. The difference between these two values is more than equivalent to the deficiency found for carbonates. This would, therefore, indicate that a precipitation of calcium carbonate must have taken place during the years 1908 and 1909.

A similar result has been found each year since then, so that the precipitation of calcium carbonate would appear to be continuous. Table 11 gives the amounts by which calcium and magnesium and the carbonate radicle fall below the average increase in concentration for each year over the year preceding, and the last column shows the exact values which the carbonate radicle in the preceding column should have in order to be exactly equivalent to the sum of the corresponding values for $\mathrm{Ca}$ and $\mathrm{Mg}$. This shows that the amounts by which calcium and magnesium each year fall below the average in-

TABLE 11.-Showing amounts by which calcium and magnesium, and the carbonate radicle fall below the average annual increase of the total constituents.

\begin{tabular}{|c|c|c|c|c|}
\hline \multirow{2}{*}{ Ysar. } & \multicolumn{4}{|c|}{ Parts per $100,000}$. \\
\cline { 2 - 5 } & $\mathrm{Ca}$. & $\mathrm{Mg}$. & $\mathrm{CO}_{3 .}$ & $\mathrm{CO}_{3}=\mathrm{Ca}+\mathrm{Mg}_{\mathrm{g}}$ \\
\hline $1909 \ldots .$. & 1.23 & 0.00 & 1.65 & 1.84 \\
$1910 \ldots .$. & 1.06 & 0.55 & 2.23 & 2.83 \\
$1911 \ldots . .78$ & 0.78 & 0.13 & 1.87 & 1.48 \\
\hline
\end{tabular}
crease in concentration of the constituents is approximately equivalent to the amount by which the carbonate radicle falls below the same increase.

In addition to determining the carbonate radicle an analysis was also made in 1911 of the free $\mathrm{CO}_{3}$ in samples of water taken from the surface and the bottom of the lake. The amounts found in the water from the two sources agreed within the limit of experimental error, and gave as an average 0.72 part of $\mathrm{CO}_{2}$ in 100,000 parts of water.

On account of the small amount of phosphates in the water it would be very difficult to make an analysis sufficiently accurate to show with certainty that they are undergoing any change from year to year. It was for this reason that only a trace of phosphates is reported in the analysis for 1911.

Tests were also made for hydrogen sulphide by treating the water in a Nessler tube with alkaline lead acetate, but a negative result was always obtained.

It was not thought necessary to make a determination for barium, since its presence would be precluded by the comparatively large amount of sulphates in solution. 


\section{VARIATION IN CONCENTRATION OF THE LAKE AT DIFFERENT POINTS IN 1911.}

From observations on the rate at which the volume of the lake is decreasing, and from calculations on the amount of salt in the lake at the end of each year period, Mr. Free has shown (pp. 30-33) that the increase in salt-content of the lake is greater than can be ascribed to evaporation alone, and that the total amount of salt in solution is increasing instead of remaining constant or decreasing, as might be expected from the deposition of salt on the shores as the water recedes. This inerease results, partly at least, from inflowing waters. In order to determine whether or not leaching of salt from the bottom of the lake likewise serves as a factor in this connection a number of samples were collected in 1911 from the surface and from the bottom of the lake at different points, and on the same day as the regular sample was taken.

The source of the samples, the total solids (dried at $110^{\circ} \mathrm{C}$.), and the ehlorine which they contained are given in table 12.

TABLE 12.-Showing variation in concentration of the lake at different points in 1911.

\begin{tabular}{|c|c|c|c|}
\hline \multirow{2}{*}{$\begin{array}{l}\text { No. of } \\
\text { aample. }\end{array}$} & \multirow[b]{2}{*}{ Sourec. } & \multicolumn{2}{|c|}{ Parts per 100,000 . } \\
\hline & & $\begin{array}{l}\text { Total } \\
\text { solids. }\end{array}$ & Chlorioe. \\
\hline $\begin{array}{l}1 \\
2\end{array}$ & $\begin{array}{l}\text { Extreme northwest end of lake at point neareat Mecca................... } \\
\text { Bottom of lake, depth } 40 \text { feet, in locality from which regular asmple was }\end{array}$ & 734.8 & 347.3 \\
\hline 3 & 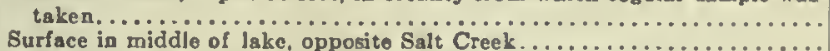 & 715.8 & 335.5 \\
\hline 1 & Bottom of lake at depth of 50 feet; in eame locality as No. $3 \ldots \ldots$ & $\begin{array}{l}718.8 \\
718.6\end{array}$ & $\begin{array}{l}339.2 \\
339.2\end{array}$ \\
\hline 5 & Surface in middle of lake, about 10 miles from Pelican Ialand......... & 717.2 & 338.5 \\
\hline 6 & Bottom of lake at depth of 56 feet; in same locality as No. $5 \ldots \ldots \ldots$. . . . & 717.8 & 339.1 \\
\hline 7 & 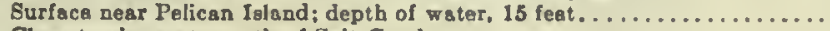 & 721.4 & 340.8 \\
\hline 8 & 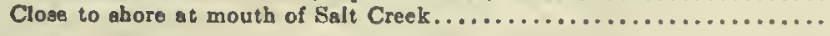 & 716.4 & 338.8 \\
\hline
\end{tabular}

From this table it is seen that the lake is remarkably uniform in composition. Sample No. 1, which has a higher salt-content than any of the others, was collected in a very shallow place near the shore. The sand on the shore at this point is covered with an incrustation of salt for a considerable distance back. Some of this salt must be washed back into the lake again by occasional rains, which would account for the high result found for the salt-content of the water at this place.

The shore at the mouth of Salt Creek is very rocky and steep, and no deposit of salt could be seen at this point. Sample No. 8, colleeted near the shore at this place, shows the same concentration as the main body of the lake. Sample No. 4 was taken from the bottom of the lake at a point as near to the old salt beds as could be determined. The agreement between the salt-content of this sample and the other samples from the main body of the lake makes it improbable that any appreciable leaching is now taking place; consequently, any increase in the total salt-content which may be taking place must now be due prineipally to inflowing waters.

\section{COMPOSITION OF THE SALTS LEACHED OUT FROM THE BOTTOM OF SALTON SEA.}

In 1900 R. H. Forbes and W. W. Skinner made, at intervals of two months, seven analyses $^{1}$ of composites of samples collected almost daily from the Colorado River at Yuma, between January 10,1900, and January 24,1901. The mean of these analyses represents the average composition of the Colorado River for an entire year, but not the average composition of the total water discharged by the river, since its volume varies greatly at different seasons. 
The diagram on page 197 of the bulletin referred to shows representative variations in the flow of the river at different times of the year; although it is to be remembered that, at the time Salton Sea was formed, the flow of the Colorado was very irregular. From the data there given an estimate was made of the average flow of water in the river for each of the periods during which samples were collected for analysis. The results thus obtained for each of the periods are given in table 13 in parts of a total of 100,000 taken as the yearly discharge of the river.

By means of these relative values showing the variation in the flow of the river the mean composition of the water discharged by the river in a year may be readily calculated from the analyses of Forbes and Skinner by multiplying the values given for each constituent for the different periods by the number representing the flow of water for that period, and dividing by 100,000 . The sum of the results for each constituent will represent its concentration in parts per 100,000 of the total water discharged by the river in a year.

TABLE 13.-Scasonal variation in the flow of the Colorado River.

\begin{tabular}{|c|c|}
\hline $\begin{array}{l}\text { Parlods during which samplos wore } \\
\text { collected for analyain. }\end{array}$ & $\begin{array}{l}\text { Estimated } \\
\text { avorage flow } \\
\text { of water } \\
\text { expressed in } \\
\text { relative } \\
\text { terms. }\end{array}$ \\
\hline 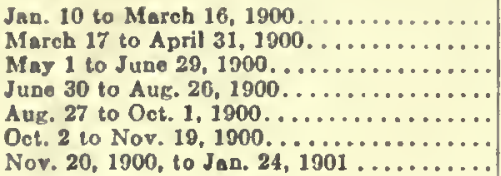 & $\begin{array}{r}8,000 \\
14,000 \\
38,000 \\
21,000 \\
8,000 \\
8,000 \\
6,000\end{array}$ \\
\hline 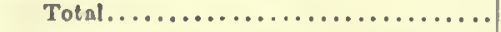 & 100,000 \\
\hline
\end{tabular}

TABLE 14.-Composition of the salts leached aut from the bollom of the Salion Sea as calculated from the excess of the constituents of the lake water in 1907 over that of the waler from which the lake was formed.

\begin{tabular}{|c|c|c|c|}
\hline \multirow[b]{2}{*}{ Conatituenta. } & \multicolumn{3}{|c|}{ Parts per 100,000 . } \\
\hline & $\begin{array}{l}\text { Composi- } \\
\text { tion of } \\
\text { Salton Sca } \\
\text { in } 1907 .\end{array}$ & $\begin{array}{l}\text { Calculated } \\
\text { mesn conjposi- } \\
\text { tion of water } \\
\text { annuslly } \\
\text { diachnrged by } \\
\text { Colorado } \\
\text { River. }\end{array}$ & $\begin{array}{l}\text { Salt taken } \\
\text { up from } \\
\text { bottom of } \\
\text { Salton Sea. }\end{array}$ \\
\hline Ns..... & 111.05 & 10.36 & 100.69 \\
\hline K............ & 2.30 & 1.38 & 0.92 \\
\hline $\mathrm{Ca} \ldots \ldots \ldots \ldots \ldots$ & 9.05 & 5.78 & 4.17 \\
\hline & 6.43 & 1.70 & 4.73 \\
\hline SiO. & 0.03 & 1.97 & \\
\hline Cl..... & 169.75 & 9.85 & 159.90 \\
\hline Br..... & trace & & trace \\
\hline $\mathrm{SO}_{4} .$. & 47.60 & 14.18 & 33.42 \\
\hline $\mathrm{CO}$.. & 6.58 & 8.31 & \\
\hline
\end{tabular}

Since the present water in the Salton Sea came from the Colorado River, then the excess of its constituents when expressed in parts per 100,000 over that calculated for the water discharged in a year by the Colorado River must represent the composition of the salts leached out from the bottom of the lake. In table 14 is given the composition of the salts thus ealculated to be leached out from the bottom of the lake previous to June 3, 1907. That the greater part of the salts in the bottom of the lake were taken up before this date is indieated by the yearly analyses made sinee then, and by the partial analyses of 1911.

The concentration of the carbonates in the Salton Sea would appear from these analyses to be less than in the Colorado River. The difference, however, is largely due to different methods of analysis. In 1907 the carbonates in the Salton Sea were determined only in the cvaporated residue, while the carbonates given for the water of the Colorado River represent the total carbonates in solution expressed as the normal earbonates. As was shown by the analysis of 1911, the carbonates in the residue from the Salton Sea water amounted to only about two-thirds of the carbonates in solution expressed as the normal carbonates. It would appear, therefore, that the concentration of the carbonates in the Salton Sea in 1907 differed little from what would be expected to come from the Colorado River, and as the carbonates have not increased since then it follows that little or no leaching of carbonates from the bottom of the Salton Sea has taken place.

If it be assumed that all the salts deposited by the evaporation of the original lake were again taken up by the present lake, then the constituents given in the last column of table 14 must represent the composition of the original lake. 
It is seen that the waters listed in table 15 may be conveniently divided into four groups, as follows:

(1) Chloride waters in which sodium chloride is the principal constituent as illustrated in ocean water, the water of Great Salt Lake, and the original Salton Sea.

(2) Chloride-sulphate waters in which both chlorides and sulphates predominate. The water of the Caspian Sea is the only representative of this group given in the table.

(3) Chloride-sulplate-carbonate waters which contain notable amounts of carbonates as well as sulphates and chlorides. To this group belong the waters of the Salton Sea and the southwestern rivers of which analyses are given in the table. All are of the same general type, in that each contains considerable quantities of sodium, calcium, and magnesium, as well as the three acid radicles.

TABLE 15.-Comparing the composition of the water of the Salton Sea with other natural waters.

\begin{tabular}{|c|c|c|c|c|c|c|c|c|c|c|}
\hline & $\boldsymbol{\Lambda}$ & B & C & D & E & $\mathbf{F}$ & G & $\mathbf{H}$ & 1 & J \\
\hline 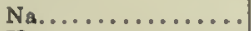 & 31.29 & 33.14 & 19.75 & 25.64 & 26.67 & 14.43 & 30.59 & 33.39 & 24.70 & 13.39 \\
\hline K................ & 0.05 & 0.30 & 2.17 & 1.87 & 1.20 & 1.95 & 1.11 & 1.08 & 0.50 & 2.37 \\
\hline $\mathrm{Ca} \ldots \ldots \ldots \ldots \ldots$ & 2.80 & 1.37 & 10.35 & 7.30 & 6.43 & 14.78 & 1.20 & 0.42 & 2.29 & 4.70 \\
\hline $\mathrm{Mg} \ldots \ldots \ldots \ldots \ldots$ & 1.81 & 1.55 & 3.14 & 2.50 & 2.61 & 2.05 & 3.72 & 2.60 & 5.97 & 11.85 \\
\hline $\mathrm{Al}_{2} \mathrm{O}_{3}+\mathrm{Fe}_{2} \mathrm{O}_{2} \ldots \ldots \ldots$ & 0.02 & $\ldots \ldots$ & $\cdots \cdots$ & ..... & $\ldots \ldots$ & 4.63 & ... & ..... & 0.03 & trace \\
\hline $\mathrm{SiO}_{2} \ldots \ldots \ldots \ldots \ldots$ & 0.26 & $\ldots \ldots$ & 3.04 & 4.60 & 2.93 & 4.63 & $\therefore \cdots$ & $\ldots \ldots$ & \} 0.03 & \\
\hline $\mathrm{Cl} \ldots \ldots \ldots \ldots \ldots$ & 47.83 & 52.62 & 19.92 & 32.68 & 40.71 & 13.55 & 55.29 & 50.54 & 42.01 & 05.22 \\
\hline Br........... & trace & trace & $\ldots \ldots$ & ...... & $\ldots \ldots$ & & 0.19 & $\ldots \ldots$ & 0.05 & 2.08 \\
\hline 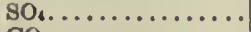 & 13.41 & 11.00 & 28.61 & 15.24 & 7.59 & 31.33 & 7.69 & 5.97 & 23.99 & 0.20 \\
\hline $\mathrm{CO}_{3} \ldots \ldots \ldots \ldots \ldots$ & 1.85 & $\ldots \ldots$ & 13.02 & 10.11 & 11.80 & 17.28 & 0.21 & $\ldots \ldots$ & 0.37 & 0.01 \\
\hline \multirow[t]{2}{*}{ Otlice constitucnta... } & 0.08 & $\cdots \cdots$ & $\ldots \ldots$ & ..... & ..... & ..... & ..... & $\ldots \ldots$ & $\ldots \ldots$ & $\ldots \ldots$ \\
\hline & 100.00 & 100.00 & 100.00 & 100.00 & 100.00 & 100.00 & 100.00 & 100.00 & 100.00 & 100.00 \\
\hline Salinity $\{100,000 \ldots$ & 351.93 & & 69.59 & 92.32 & 101.45 & 39.92 & 3519.0 & 19558.0 & 1294.0 & 22283.4 \\
\hline ( Рет cent.... & 0.355 & $\ldots \ldots$ & 0.070 & 0.092 & 0.101 & 0.040 & 3.519 & 19.558 & 1.291 & 22.283 \\
\hline
\end{tabular}

A. Salton Sea. According to analyais of 1907 .

B. Original Salton Sca. Suppased composition as calculated Irom exceas of constituenta of present lake in 1907 aver that found for Colorado River.

C. Colorado River at Yuma. Mean ol acyen annlyges, made at intervals of about two mostbs, of composites al eamples callected almost daily between Jan. 10, 1900, and Jna. 21, 1901. Analyacr by 12. H. Forbes and W. W. Skinner, Bull. Aris. Agri. Expt. Sta., Na. 44 (1902).

D. Gila River at head of Florence Canal, Aris. Mean of four analyaes of composites repreacatiag anmples collected daily tor aeven, Give, four, and five wecke, reapectively, at intervalg between Nov. 28, 1899, and Nov. 5, 1000. Analyses by R. 11 . Forber and W. W. Skinner, loc. cil.

E. Salt River nt Meaa, Arix. Mean ol aix analyscs of compositea repreaenting anmplcs collected daily for faur, one, four, ten, thirtecn, and eight weeka, reapectively, between Aug. 1, 1899, and Aug. 4, 1900. Analyses by $R$. 1I. Forbes and W. W. Skinner, loc. cil.

F. Rio Grande at Las Crucas, N. M. Maan of twelve consccutive monthly analyses of composiles of eamples collected daily tram Juno 1, 1893, to June 1, 1894. Analyeca by Arthur Goss, Bull. N. M. Agri. Expt. Sta., No. 34 (1900).

C. Ocesn water. Mean of 77 analysea by W. Dittmar, 1I. M. S. Challenger, Pliysica and Chemistry, vol. 1, p. $203,1884$.

11. Grant Salt Lake. Analyaes by J. E. Talmage, Science, 14, 445 (1889).

1. Caspian Sea. Mean of five nualyses by C. Schimdt, Bull. Acnd. St. Peteraburg, 24, 177 (1878).

J. Dead Sea. Analyais by F. A. Genth, Ann., 110, 240 (1859).

(4) Natural bitterns, of which the water of the Dead Sea is the only representative given in the table. In waters of this type prolonged evaporation has brought about a concentration of the bromides and the soluble potassium and magnesium salts, while the more insoluble compounds, as sodium chloride and the carbonates and sulphates of calcium, have for the most part crystallized out.

If the assumption is correct that the salts leached out from the bottom of the Salton Sea represent approximately the composition of the original lake, then this must have resembled in a striking way the composition of the water of Great Salt Lake.

The salts taken up by the Salton Sea likewise resemble in a general way the composition of the salts in the occan. The higher sodium, the lower potassium and bromine, and the probable absence, or low proportion, of carbonates in the former are the principal points of difference. The concentration, however, of the former lake which deposited the salts taken up by the present lake no doubt differed much from that of the ocean, for at its maximum volume the total salinity of the present lake was only about one-ninth that of sea-water; consequently if it be assumed that the salts taken up by the Salton Sea originally 
came from the evaporation of sea-water without loss from being covered up with silt, then the volume of water which could have evaporated must have been much smaller than the present lake. (See pp. 25-27.)

There is strong geological evidence, on the other hand, that a former lake existed in Salton Basin much larger than the present lake. It might be assumed that this original lake was once in contact with the ocean, and that the greater part, but not all, of the salts were buried beyond reach of the present water in the lake. If this were the case, then it would be expected that the composition of salts taken up by the water would be similar to that of salts found in bittern waters, or at least would be decidedly different from the ocean type of salts originally deposited. Since no such difference is noted, it seems safe to conclude that the salts which have been taken up by the Salton Sea are not of ocean origin, but have a similar source with the salts in Great Salt Lake; and that if the Salton Basin were at some former time filled with sea-water all salts contained therein and deposited when the water evaporated must have been completely buried beyond the action of the present water of the lake. 


\title{
VARIATIONS IN COMPOSITION AND CONCENTRATION OF WATER OF SALTON SEA, 1912 AND 1913.
}

\author{
Br A. E. Vinson.
}

The matter of the analysis of the annual sample of Salton Lake water was taken over from Dr. Ross upon his departure from the Agricultural Experiment Station of Arizona in 1911. The methods by which the results of 1912 and succeeding years were obtained are identical with those used by Dr. Ross, and hence all results are strictly comparable. (Table 16.)

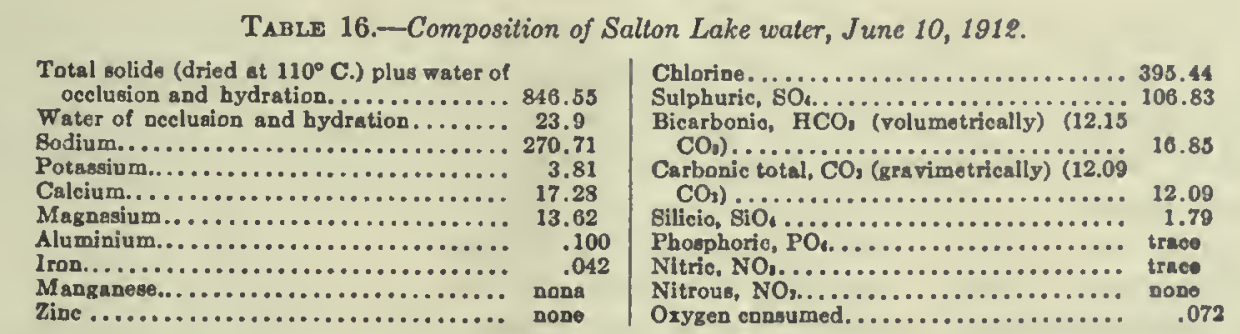

The total soluble solids, including water by occlusion and hydration, for the period of 373 days ending June 10, 1912, have increased 17.9 per cent; or about 17.5 per cent for the even year ending June 3,1912. This is somewhat less than the corresponding increase of 19 per cent reported for last year.

Calcium has increased 10.6 per cent, and magnesium 16.6 per cent. These lower rates of increase, especially that of calcium, point to a considerable deposition of carbonate of lime, especially about the edges of the lake, as already noted during the last two or three years. Further evidence of the deposition of calcium carbonate is found in the relation between the decrease in calcium and the decrease in the bicarbonate radicle. For the past two years $\mathrm{HCO}_{3}$ has been determined volumetrically. In $1911 \mathrm{HCO}_{3}=17.14$ per 100,000 . If $\mathrm{HCO}_{3}$ had increased at the same rate as the total solids in 1912 it would have equaled 20.31 instead of 16.85 , showing a falling off for 1912 of $3.46 \mathrm{HCO}_{3}$ per 100,000 . In 1911 $\mathrm{Ca}=15.62$ per 100,000 , and in 1912 at the normal rate of increase should have equaled 18.42 instead of 17.28 , a falling off of 1.14 per 100,000 . The $\mathrm{HCO}_{3}$ corresponding to this decrease of $1.14 \mathrm{Ca}$ would equal 3.47 parts per 100,000 , whereas 3.46 parts were found by analysis. The additional $\mathrm{HCO}_{3}$ required for the slight decrease in $\mathrm{Mg}$ would not exceed the analytical error, although the ratio $\mathrm{Mg}:\left(\mathrm{HCO}_{3}\right)_{2}$ is very high.

An analysis, made by Mr. Catlin, of the incrustation formed on woody stems and stones in the shallow waters and along the margins of the lake, gave the results shown in table 17.

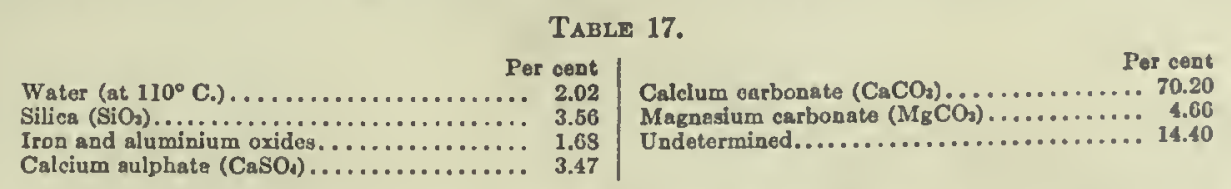

The undetermined substances consist largely of the organic matter which it was impossible to separate entirely from the deposit, and some alkali salts.

Chlorine has increased 16.5 per cent and the sulphuric radicle 16.5 per cent over the content of these constituents last year. 
Sodium has increased 18.9 per cent, but potassium remains stationary. This latter fact is interesting, and confirmatory of an observation not heretofore reported, namely, that since 1908 the ratio of potassium to total solids in the waters of Salton Lake has steadily decreased.

The sample for the annual complete analysis was taken on June 13, 1913, and the results are given in table 18.

TABLE 18.

\begin{tabular}{|c|c|}
\hline $\begin{array}{l}\text { otal aolids (dried at } 110^{\circ} \text { C.) plus water of } \\
\text { ocelusion and hydration.............. }\end{array}$ & $1,002.56$ \\
\hline Water of occlugion and hydration......... & 32.6 \\
\hline 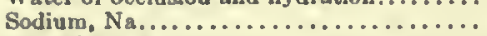 & 323.08 \\
\hline Potassium, $\mathbf{K} \ldots \ldots \ldots \ldots \ldots \ldots \ldots$ & 3.45 \\
\hline 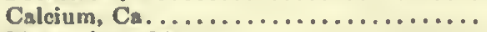 & 19.75 \\
\hline Magnesium, $\mathbf{M}_{\mathbf{k}} \ldots \ldots \ldots \ldots \ldots \ldots \ldots \ldots \ldots$ & 16.22 \\
\hline 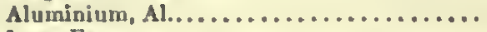 & .125 \\
\hline Iron, Fo...................... & .038 \\
\hline 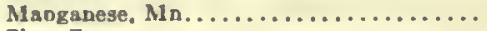 & nono \\
\hline Zinc, Za....................... & none \\
\hline ead, $\mathbf{P b}$. & nons \\
\hline
\end{tabular}

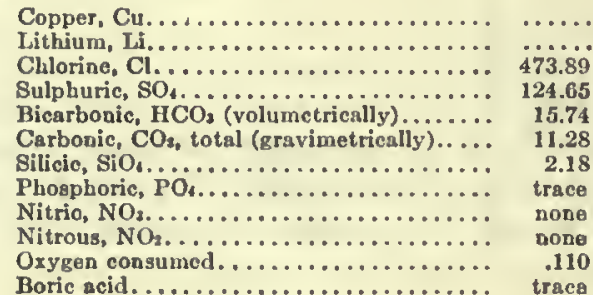

During 373 days from June 10,1912, to June 18, 1913, the total solids in Salton Sea water have increased from 846.55 parts to $1,002.56$ parts per 100,000 , an increase of 18.4 per cent for the period. When calculated for the year ending June 3, 1913, by the method suggested in the 'Twenty-second Anmual Report, Arizona Agricultural Experiment Station, the aumual increase becomes 17.7 per cent ( 17.5 for the year ending June 3,1912$)$. The Salton water may now be considered as 1 per cent brine.

Calcium, again, showed a marked decrease, having concentrated only 14.5 per cent, and some additional calcium undoubtedly was brought into the sink by drainage. The total carbon dioxide, as also the bicarbonic radicle, show a less concentration than in 1912. The decrease in carbon dioxide is slightly greater than required by the decrease in ealcium, as shown by analysis. This is due, probably, to drainage water carrying calcium salts other than bicarbonate.

'The most interesting feature brought out by this year's analysis is the rapidly increasing rate at which potassium is disappearing. It became apparent in 1912 that the ratio of potassium to sodium and to total solids was decreasing rapidly, the number of parts per 100,000 in 1912 having remained the same as in 1911. The analysis this year shows less potassium than in 1913 , although sodium has increased 19.3 per cent. The ratio of potassium to sodium and to total solids during the seven years that the Salton water has been analyzed is traced in table 19 .

TABLF. 19.-Annual ratios of potassium to sodium and to total solids in Salton Sea water.

\begin{tabular}{|c|c|c|c|}
\hline Yeara. & Potrssium. & Sodium. & Total sulids. \\
\hline 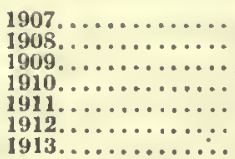 & $\begin{array}{l}1 \\
1 \\
1 \\
1 \\
1 \\
1\end{array}$ & $\begin{array}{l}48.3 \\
48.3 \\
49.5 \\
53.0 \\
59.8 \\
71.1 \\
94.0\end{array}$ & $\begin{array}{l}158 \\
157 \\
100 \\
171 \\
188 \\
222 \\
288\end{array}$ \\
\hline
\end{tabular}




\title{
THE BEHAVIOR OF CERTAIN MICRO-ORGANISMS IN BRINE.
}

\author{
By Grorge James Perree.
}

The number of organisms, plants and animals known to live under what are commonly supposed to be fatal conditions is a surprisingly long and increasing one. Illustrations more or less generally known include the molds of various sorts which seem to thrive vegetatively, if not reproducing themselves otherwise, on solutions of strychnine, formaline, and earbolic acid; the insects in the scepages of oil wells and asphaltum; the organisms in hot and cold waters. In all of these, however, conditions are fairly stable, and the organisins, once able to adjust themselves to the unusual factor or factors of the environment, can continue to survive by maintaining this adjustment. It is still harder to understand how organisms can continue to readjust themselves to conditions which change greatly from those ordinarily called favorable to those fatal, and vice versa. Mild examples of this sort are afforded by those craft regularly plying between salt and fresh water, on the bottom of which algæe and other organisms seem to thrive despite the range of the moving environment. Osterhout, ${ }^{1}$ for example, describes the red, brown, green, and blue-green algre thriving on the bottoms of the steamers which daily make the trip between San Francisco (with sea-water of approximately 3 per cent salt-content) and Stockton (with fresh water). In these instances, however, the range of environment is comparatively short, but it is also run through in a very short time.

Annual ranges of temperature between the favorable and the fatal are general and we take more or less for granted the means of adjustment to them possessed by plants and animals. In certain parts of the world annual ranges of moisture of similar extent are well known and more or less understood, but annual changes of an extreme sort in other factors of the environment are less common. Where salt is made from sea-water extreme changes in the salt-content of water regularly occur. In the salt works on the shores of the Bay of San Francisco the changes are annual. In spite of the extreme anmual range from rain-diluted sea-water to brine from which common salt erystallizes, there are many organisms which live in the salterns. Some of these organisms will be considered in the following pages, but we should first ascertain the conditions under which they exist.

\section{LOCATION.}

Lying between two ranges of mountains which run parallel with the coast-line of middle California is the Bay of San Francisco. It possesses an area of nearly 500 square miles. Nearly midway of its north and south extent this great sheet of water communicates with the Pacific Ocean through the Golden Gate, a narrow passage between two mountains of the outer coast range. From the east it receives the drainage waters of the great central plain of California in the San Joaquin and Sacranento River systems, while small streams running down the slopes which bound the valley flow into the bay at various points cluring perhaps half the year. The shores of the bay are mainly flat. There are extensive areas of undrained marsh where plants of various sorts are contributing to land formation. Other areas are fairly dry throughout the dry season and covered with a mat of low herbs, the roots of which bind the clayey soil into a firm turf. In this, as in other "adobe" soils, cracks open on the surface during the dry season. These long and irregular

1 Osterhout, W. J. V.: The resistance of certain marine algæe to change in osinotic pressure and temperature. Univ. Calif. Publ., Botany, II, 227-8, 1906. 
cracks show how firmly bound the soil is by the roots of the turf-forming flora which it supports. When wet, the turf and soil may be cut into blocks of suitable size, and such are used for building dikes. These dikes run in some cases as dams along the tidal channels"sloughs" - of the lower parts of the marsh. In others they form the borders of artificial ponds, often of extensive area. The undisturbed and carpeted soil of the marsh forms the bottoms of these ponds. Into the ponds the water of the bay is pumped. Formerly the pumps used were Archimedes screws driven by low sails. These used to give a curiously foreign and antiquated appearance to the parts of the shore used for salt-making, but electric pumps have now displaced the slower wind-driven ones and rough poles and wires disfigure the marsh.

\section{CLIMATOLOGY.}

As is well known, the climate of middle California is extraordinary. Because of the decided differences in rainfall, temperature, clearness, humidity, and wind within short distances, on account of topographical and other differences, general statements are difficult. The lack, therefore, of official rainfall and other climatological data for a given spot makes accurate description of that spot the more difficult. As shown by McAdie, ${ }^{1}$ the mean annual rainfall increases from San Jose, near the southern end of San Francisco Bay, to San Francisco about 50 per cent, being 14.88 inches at the former station and 23 inches at the latter. The organisms described below inhabited the salterns near Redwood City, about midway between these two points. There are no official rainfall data for this locality, but computation from the figures in MeAdie's important book and from the Annual Reports of the Chief of the Weather Bureau, supplementing my own records, will throw inuch light upon the behavior of the organisms in question and be entirely safe. Much greater differences in rainfall may be found within shorter distances in this same region, ${ }^{2}$ but they do not concern us. The difference in rainfall in a nortli-south direction is due principally to the trend of the mountain chains. On them the rainfall is much greater than on the valley floor. San Jose is at some distance from both chains of mountains walling in the Santa Clara Valley; Redwood City is nearer the Montara Range on the west, and San Francisco is upon its slopes. The annual rainfall on the Redwood marsh should average about 18 inehes.

Quite as significant as the smallness of the annual rainfall is the limited time of its occurrence. Although this varies from year to year, with accompanying differences in the behavior of all living organisms, it is generally true that no rain falls from May until September. There may be no rain until November, and the season's rains may come to an end early in April. Generally, the heaviest rains occur in January or even in December. The annual distribution of rain may be seen in table 20, taken from McAdie's Climatology of California.

TABLe 20.-Average rainfall, in inches, at San Francisco and San Jose, by months, far certain periods.

\begin{tabular}{|c|c|c|c|c|c|c|c|c|c|c|c|c|c|}
\hline & Jan. & Feb. & Mar. & Apr. & May & June & Juiy & Aug. & Sept. & Oet. & Nov. & Dec. & $\begin{array}{l}\text { Annual } \\
\text { incbes. }\end{array}$ \\
\hline $\begin{array}{l}\text { Ban Francisco, } 63 \text { yeara, } \\
1849-1902 . . \ldots \ldots \ldots \ldots \\
\text { Ban Jose, } 26 \text { yeara, } 1874-\end{array}$ & 4.85 & 3.54 & 3.14 & 1.82 & 0.73 & 0.14 & 0.02 & 0.02 & 0.23 & 1.05 & 2.75 & 4.80 & 22.76 \\
\hline $1899 . \ldots \ldots \ldots \ldots$ & 2.77 & 2.22 & 2.63 & 1.35 & 0.50 & 0.14 & $\mathbf{T}$ & 0.03 & 0.20 & 0.89 & 1.39 & 2.70 & 14.83 \\
\hline
\end{tabular}

The mean between these would give us approximately the rainfall at Redwood City, but this calculation is unnecessary. It is evident from the table that rain falls in late autumn, throughout the winter, and in early spring; that in summer and in late spring and carly autumn there is little or no rain.

${ }^{1}$ McAdie, A. G.: Climatology of California. Bull. L, Weather Bureau, U. S. Dept. Agric., Washington, 1903.

' 'eirce, G. J.: The botanical aspects of Stanford University. Plant World, vol. XII, p. 245, 1909. 
The next point to establish is the average temperatures. The mean annual temperature is not far from $58^{\circ} \mathrm{F}$., with the lowest monthly mean in January and the highest in July. The daily range is regularly greater than the seasonal range, the difference between the average daily maximum and average daily minimum being greater than the difference between the mean temperatures of the coldest and the warmest months of the year. The season of greatest warmth is that of least rainfall, and vice versa. The average of the maximum temperatures in July for 23 years at Menlo Park, 4 miles from the Redwood salt ponds and on the valley floor, is $92.7^{\circ} \mathrm{F}$. The average of the minimum temperatures in December, for the same 23 years, is $30.4^{\circ}$.

In the evaporation of any solution there are eoncerned the degree of concentration and the composition of the solution, its temperature and that of the surrounding medium, the proportions of the cvaporating solvent in the surrounding medium, the frequency, quantities, and eompositions of the materials which may be added to it. Rain-water is usually added to whatever may be in the brine ponds at Redwood City only during the cool months of the year, or when evaporation is slow because of the prevailing low temperatures. The air-temperatures will necessarily influenee the temperature of the brines. We see that the air is warmest when the days are longest. The reeords given below (table 22 , pp. 56-60) suggest also the degree to which the temperature of the air influenees the temperature of the brine. But the rate at which a brine will eoncentrate will depend also upon the humidity of the air. This is given in the Annual Reports of the Chief of the Weather Bureau, for the cities of San Franciseo and San Jose, but not for Redwood. The San Franciseo figures are of little value, sinee it lies in the path of the summer fogs which eonstitute sueh a marked and benefieial feature of the coast elimate of middle California; and the San Jose figures are incomplete, being reported only for $8 \mathrm{p.m.}{ }^{1}$ The time of lowest humidity and of most rapid evaporation would generally be that of highest temperatures. This is patent to anyone so far as daily conditions go, but people accustomed to the humid summers of the eastern and central States and of middle and western Europe do not realize that on the Pacific Coast conditions are opposite to those to the eastward. Thus our season of greatest humidity, outside of the coast "fog belt," is the winter rainy season with its moderately low temperatures, whereas the rainless summer, with moderately high mid-day temperatures, has low humidity. The condition may be illustrated by comparing the data for Cincinnati and St. Louis with those for San Jose, comparing a moist fertile region with one semi-arid. Thus the mean temperatures and humidity at 8 p.m. in June, July, August, and September, 1910, in Cineinnati, Ohio, were $76.95^{\circ} \mathrm{F}$. and 58.5 per cent; in St. Louis, Missouri, $77.45^{\circ} \mathrm{F}$. and 62.7 per cent; in San Jose $72.50^{\circ} \mathrm{F}$. and 54 per cent.

Turning from this to the cloudiness and elearness as indicating the conditions which affect evaporation and the rate of concentration of the brines, we find reports of the following fractions by the Chief of the Weather Bureau for 1910 (table 21):

TABLE 21.

\begin{tabular}{|c|c|c|c|c|}
\hline Montho. & San Jose. & Cincinnati. & St. Louis. & San Franciscn. \\
\hline 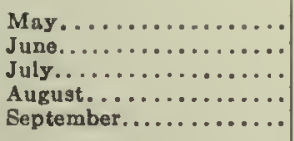 & $\begin{array}{l}1.6 \\
1.2 \\
0.8 \\
0.0 \\
0.7\end{array}$ & $\begin{array}{l}6.3 \\
6.0 \\
6.7 \\
4.9 \\
5.1\end{array}$ & $\begin{array}{l}5.1 \\
5.1 \\
4.6 \\
4.1 \\
4.2\end{array}$ & $\begin{array}{l}2.9 \\
1.9 \\
2.9 \\
1.7 \\
2.7\end{array}$ \\
\hline Mean... & 0.8 & 5.8 & 4.6 & 2.24 \\
\hline
\end{tabular}

These figures again have less value than I sliould like, for the records on which they are based are made at the end and not in the middle of the day. The percentage of cloudi- 
ness in San Jose (and also over the salt ponds near Redwood City) at mid-day in May, June, July, August, and September is very small indeed, even less than at 8 p.m. Into this clear air, therefore, with an average humidity of 54 per cent and an average temperature of $72.5^{\circ}$ at 8 p.m., water will evaporate more and more rapidly as the temperature rises; for, owing to the dryness of the ground, the humidity will fall very rapidly from morning to mid-day, to rise again, but more slowly, from mid-day to night.

In the climatic conditions, then, on the shores of San Franciseo Bay the conditions for rapid and great concentration of brines by natural means are very favorable. This is plainly proved by the extensive seale on which salt is made from Bay water on these shores, and it is precisely the elimatic conditions which promote the manufacture of salt from sea (Bay) water on a large commercial seale which influence the peculiar organisms inhabiting concentrated brines.

\section{LITERATURE.}

Kellogg, ${ }^{1}$ in a brief note deseribing a new species of peculiar erustaceans inhabiting concentrating salt solutions, refers to various other papers on the animals of this peculiar habitat. The plants of coneentrated salt solutions have received comparatively little attention. Hamburger ${ }^{2}$ gives a bibliography to which need be added only a second paper on the same subject by Teodoresco. ${ }^{3}$ Oltmanns ${ }^{4}$ makes scanty reference to the brine algx and points out the incompleteness of our information about them and their environment.

What seems most eommonly to have drawn attention to pools of brine, whether natural or artificial, is the peculiar color of the water, red, of a shade between that of fresh iron-rust and of blood. Miss Hamburger gives a historical sketch of the studies and explanations of the color. These explanations were some of them chemieal, some biological, so contradictory in the early part of the last century that the Académie des Sciences Naturelles, Paris, appointed first a commissioner and later a commission to determine the faets. Apparently the first biologieal explanation was that the color was due to the small animals (Artemia) found swimming in the water. Then the color was attributed to unicellular algæ variously called Protococcus salinus (Dunal), Chlamydomonas dunalii (Cohn), Dunaliella salina (Teodoreseo), etc. And I wish to offer still another, namely, the red chromogenic bacteria which grow in these concentrated brines and even in and upon heaps of crude salt.

The various explanations given from time to time by seientific men I have heard advanced or reported by those connected with the salt works on the shores of San Franeisco Bay. The simplest conjecture is that the color is due to iron. There may be iron in the brine of some localities, but there is no eonsiderable proportion in the brines which I have studied most, as the analyses given later (p. 67) show, and since the color of brine and salt is found to disappear permanently on heating, it is obvious that the color has another eause. Sereening out the Artemias does not remove the color, and one may find colorless Artemias, for that matter, in colorless brines. So, too, one may find the abovenamed algm in great numbers in uncolored brines, or, on the other hand, fail to remove the color of a red brine by filtering it. It must be admitted that filtration of concentrated brines is very slow and imperfeet, the filters clogging with suspended salt and organic matter. But proof of the cause of the red color is furnished by inoculating a colorless and sterile natural brine from a pure culture of the red chromogenic bacteria. 'The brine, and

' Kellogg, V. L. A new Artemia and its life conditions. Seience, N. S., xxıv, 1906.

2 Hamburger, Clara. Zur Kenntniss der Dunaliella salina und einer Ämöbe aus Salinenwasser von Cagliari. Archiv für Protisten-Kunde, vi, 1905.

'Teodoresco, L. C. Observations morphologiques et biologiques sur le genre Dunaliella. Revue générale de Botanique, xvuI, 1906.

‘ Oltmanns, F. Morphologie und Biologie der Algen. 2 Bãnde, 1904, 1905. 
the salt as it erystallizes out, gradually become rose pink. Larger volumes of brine, with more or less clay and other matters in suspension, exhibit a deeper color, but a color no deeper than that of the pure colonies on an agar-agar plate or a streaked tube. To this I shall return later.

\section{DESCRIPTION.}

In addition to the animals described by others as inhabiting concentrated brines (Artemia, Amoebæ, etc.) there must obviously be a sufficient number of plants to furnish them food. It was to answer my own question as to what these animals feed upon that I first examined the waters at the salt works on the shore of the Bay of San Francisco. The food is principally two species of unicellular green alga. According to Oltmanns's classification of the green algx, Chlorophycex, this order is divided into five sub-orders, viz, Volvocales, Protococcales, Ulotrichales, Siphonocladiales, and Siphonales, of which the lowest is the Volvocales. The Volvocales in turn are divided into families, of which the lowest is the Polyblepharidacex. To the genera, Polyblepharis and Pyramimonas, recognized by Oltmanns as belonging to this family, Teodoresco and Fräulein Hamburger would add Dunaliella, a new genus cut off from Chlamydomonas. Believing that I had the organisms described by Teodoresco and Fräulein Hamburger, I sent a bottle of brine witl the plants in it to Teodoresco at Bucharest, and received in reply a letter stating that he recognized in my material the two species described by him, namely, Dunaliella salina and $D$. viridis (see figures $1 a$ and $1 c$, Plate 9). Unfortunately, only a part of the organisms survived the long journey in sufficiently good condition to be determined, for the records show that other unicellular green algæ occur at certain seasons. I have no doubt that study of these salterns continued throughout the year by a taxonomical algologist would yield a harvest of new species really inspiring to him; but beyond believing that at certain scasons a species of Carteria appeared, to represent the Chlamydomonadacese, and at others a curiously flanged form, presumably a species of Pyramimonas (sec figure 1b, Plate 9) another of the Polyblepharidacen according to Dill, ${ }^{1} \mathrm{I}$ did not feel able to attempt to go; and I was more interested in the relation between the appearance and the behavior (modes of reproduction, etc.) of these organisins and the varying concentrations of the solutions in which they lived.

In addition to these algæ there are a great number of bacteria, which also aroused my interest; but I made no attempt to isolate them, with the single exception of the red chromogenic form already referred to in this paper, and also in previous annual reports. ${ }^{2}$ Decay follows death in these brines, although they are concentrated enough to serve as preservatives for organic substances originating in relation to fresh water or to ordinary sea-water. It follows, therefore, that the usual putrefactive bacteria are not the ones concerned, and that the breaking down of the bodies of dead Artemias and of the waste of the algal vegetation of the salterns is brought about by a set of saprophytic bacteria entirely different from those to which we are accustomed. The action of these bacteria is putrefactive, if by putrefaction is meant decay accompanied by offensive odors, for there are often distinetly unpleasant odors in the salterns; the brine itself may smell badly, the salt produced may have a disagreeable odor, and in such materials as codfish strongly impregnated with the crude, or even refined but unsterilized, salt from these works, the odors of decay are more or less marked according to circumstances. By circumstances I mean mainly the weather-the temperature and the humidity of the air. Fish "preserved" with such salt and kept dry will be comparatively odorless; it will be the more nearly odorless the drier and colder it is; but if in damp air it becomes moist, by the salt

' Dill, O. Die Gattung Chlamydomonas und ihre năchsten Verwandten. Jahrb. f. wiss. Bot., vol. xxvır, 1895.

- Year Book, Carnegie Institution of Washington, Annual Report of the Director of the Department of Botanieal Researeh, vol. 11, p. 53, 1912; vol. 10, p. 51, 1911; vol. 9, p. 56, 1910. 
taking up water, the evidence of incomplete preservation will beeome the more pronounced the more moderate the temperature. Of these baeteria one is chromogenie, and is the organism which eauses salt fish to turn red, a result which makes it unsalable. Presumably, the putrefaction accomplished by this red chromogenic organism is no more undesirable in what is used as human food than those putrefactions unaccompanied by pigment formation; but in this instance a handsome color seems to be more offensive than an unmistakable odor of deeay. The same peculiar psyehologieal phenomenon is to be noted in the public taste regarding milk: red milk is unsalable, while the various forms of spoiled milk have a pronounced market value. This ehromogenic organism living in coneentrated brines and upon damp salt is the cause of the color of the salterns on the shores of the Bay of San Franciseo. It is also of eeonomie importance, since it sometimes makes a certain article of food unsalable. The cultural and other characteristies of this organism will be deseribed later.

Perhaps still more surprising than the oceurrenee of alga and bacteria in brines so concentrated that salt is erystallizing out, is the growth of the two species of Dunaliella and of the red and other bacteria on the great heaps in which the salt is piled near the salterns for shipment elsewhere. The salt, erystallizing out both on the bottom of the brine ponds (or salterns) and on the upper surface of the brine, aceumulates on the bottom, often in very regular layers. The salt may form crusts on the surface. These, breaking under wind and wave action, founder as flakes of greater or less size whieh lie more or less regularly piled on the bottom. Between these flakes all sorts of floating objects may be eaught, animate as well as inert, there to remain until the salt is completely disintegrated onee more by solution. From the bottom of the salterns the salt is removed in barrows and piled in great heaps, say 20 feet wide, 40 feet long, and 12 to 15 feet high, with sloping sides and ends. From these heaps the mother-liquor drains off, leaving animals and plants alike stranded in the mass of salt. Ordinarily the heap glazes over as a result of the first rain and subsequent fair weather, and the salt is visible for a long distance on the flat shore as a white and sometimes shining pyramid. Examination of the salt, however, will generally diselose the presence of green or brown or red material on and in the mass of white or soiled erystals. The green and brown material commonly oceurs in layers, and wherever there is sufficient moisture and light there is evidenee that the cells are active. The colorless bacteria are everywhere throughout the mass, but when the chromogenie ones oecur at all abundantly, as they do when there is ample moisture and no excess of light, it is as pink patehes of soft and gelatinous consisteney, on the surface or throughout the mass of salt. These plants, alga and bacteria, respectively, were so abundant during the winter of 1910-11, which was distinguished by unusually heavy scasonal rainfall, as to give the salt a greenish or pink tinge wherever they oceurred. They were correspondingly ineonspicuous in the winter of 1911-12, during which there was only a seanty seasonal rainfall. The connection between these organisms and the changes in their environment will beeome plainer, however, from the records (see pp. 56-60).

\section{RECORDS.}

My first observations were made in the autumn of 1906, at the end, therefore, of the long dry season. Thus, on Oetober $25 \mathrm{I}$ found the water in the salterns red in color, of a shade between that of blood and of iron-rust, with salt crystallizing out on the surface and edges of some of the ponds, the crystals drifting as floating flakes before the wind and accumulating in the eorners to leeward like an "ice-pack." The density of the water, determined by hydrometer indicating specific gravities from 1.000 to 1.500 , ranged in different salterns from 1.050 to 1.225. This densest brine was almost sirupy in consistency and all of them filtered very slowly, the papers rapidly elogging with salt erystals and other solid matter. Examined in the laboratory on the following day, the brines were found 
to contain, besides the Artemias, the two species of Dunaliella above referred to. The movements of these uniccllular, more or less pear-shaped algæ by sweeps of their long paired flagella, through the sirupy brine, were curiously slow and, apparently, deliberate. There was none of the familiar swift jerky movement which one sees ordinary zoöspores executing under a microscope.

The next cxamination was on November 7, 1906, after the first rain of the season. The maximum specific gravity on this date liad fallen to 1.190. This was both because of the rain and also because brine had been pumped in from the so-called "pickle-pond." In the "pickle-pond" the preliminary concentration occurs, in the course of which the volume of liquid is greatly reduced and much calcium is thrown down. In this brine of lowered specific gravity I saw fewer Artemias than nearly two weeks before, and the brine had a slightly greenish tinge on the surface. This latter fact was accounted for by the superintendent of the works as due to the rain.

At this time, also, I collected the "mother-liquor" from the saltern from which salt was being liarvested. This "mother-liquor" had a specific gravity of 1.225. Its composition, though still a solution saturated with common salt $(\mathrm{NaCl})$, had changed greatly in its proportions. The ratio between the magnesium salts in the solution and the sodium salts had changed to the extent of the salt precipitation. What the ratios of these magnesium salts are to the calcium, sodium, potassium and other salts in the brines will be shown later (p. 67); but I wish here to call attention not only to the concentration, but also to the extraordinary composition of the solutions in these salt ponds. Despite this remarkable concentration and composition, the two species of Dunaliella were present even in the "mother-liquor," though in considerably smaller numbers than before. As we shall sce, these brines offer very striking exceptions to the rule implied by the idea of "balanced solutions;" but as the brine organisms are living in concentrations ordinarily regarded as fatal, they may be supposed to have adjusted themselves to the extraordinary composition also. This whole matter, however, we shall understand better if, before considering the composition of the solution, we first study the behavior of the organisms during the progress of the scasons and in relation to the changing concentrations of the solutions.

Regular collections and examinations of the brines at Redwood City were begun in January 1908. From the middle of January until the end of April collections were made weekly, the specific gravities ranging during this time from Bay water at 1.023 to 1.165 in one of the salterns. The collections were all made at about $10 \mathrm{a.m.}$, and were uniformly less productive of plants than those made at the afternoon hour adhered to from January 1910 until June 1912. The relation of light to the position and distribution of ciliate motile unicellular algæ is well known, and the behavior of these markedly phototactic brine alga is entirely similar. Thus my records show that during the winter and spring of 1908 algæe were found only in small numbers in the bottles of brine brought by me to the laboratory from the various salterns. The reason for this, I believe, was that they became fairly uniformly distributed throughout the brine during the hours of darkness after collecting nearer and nearer the surface during the hours of daylight. Their maximum concentration at the surface was generally in mid-afternoon, and the time of the collections from January 1910 on was about 4 p.m. As these later records show, the alga were abundant, other things being equal, in the latter part of the day, when light had bcen falling for hours upon the brine. Phototaxis, exhibited by these brine alga in bottle and test-tube in the laboratory, is displayed, therefore, on a huge scale out of doors in these brine ponds.

Table 22 records the living contents of samples of brine taken from six salterns. This table contains the obscrvations made in the field (of temperature, cloudiness, condition of the salterns as to color, etc.) and the results of microscopic examination in the 
laboratory. I give this table only, rather than the tabulated record of all the observations since the beginning, for the following reasons: (1) increasing skill in collecting and observing makes these later records the most complete; (2) they show the same fluctuations in population, color, etc., coincident with the changing densities of the brines, as appear in all the records; (3) they show the range of concentrations during the year, from that at which the salt crystallizes, down to the minimum, and up again to the formation of salt once more.

TABLE 22.-Record of living conlents of samples of brine taken from six salterns.

TANK No. 1.

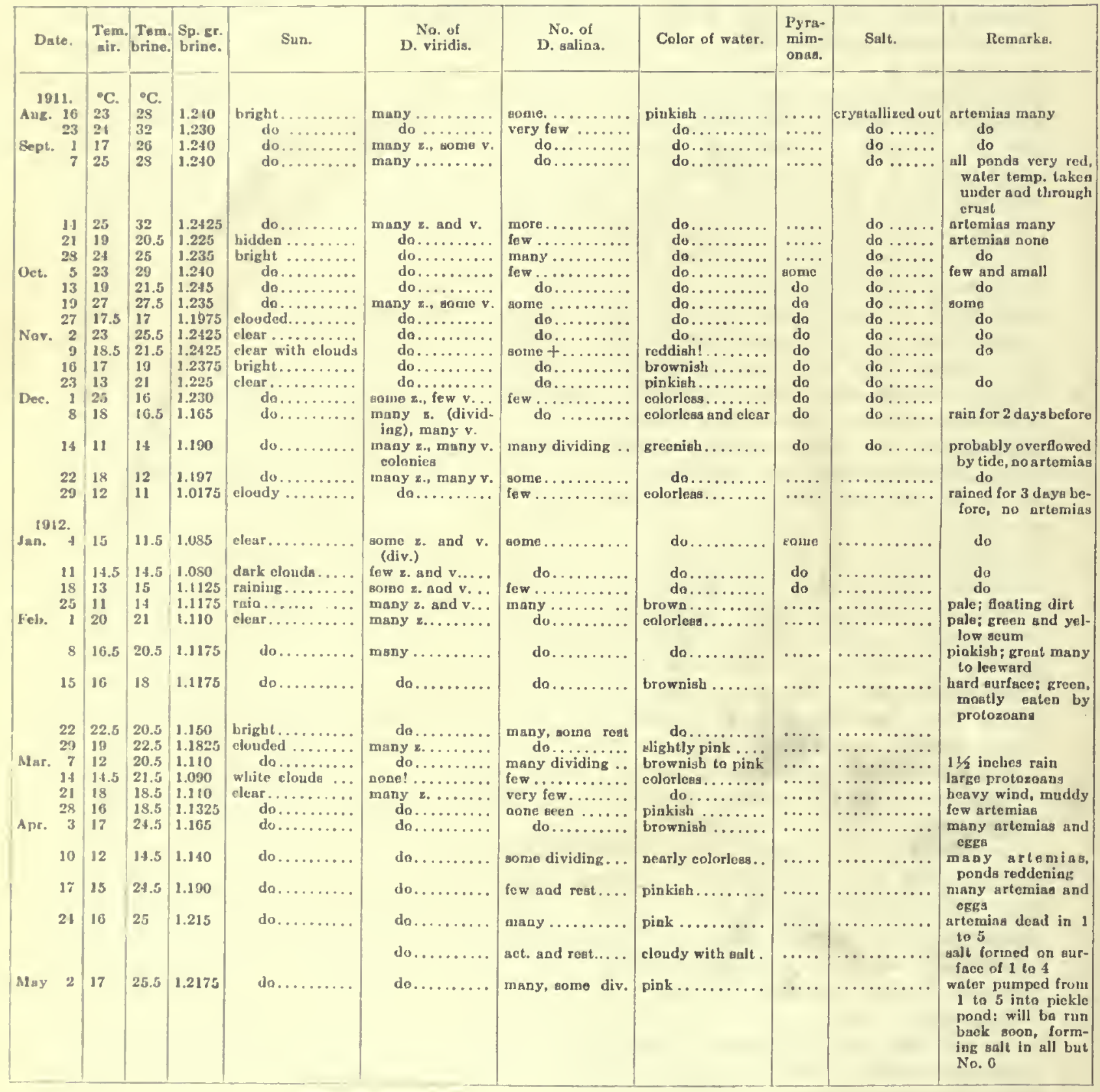


TARLE 22.-Record of living contcnts of samples of brine taken from six salterns-Continued.

TANK No. 2.

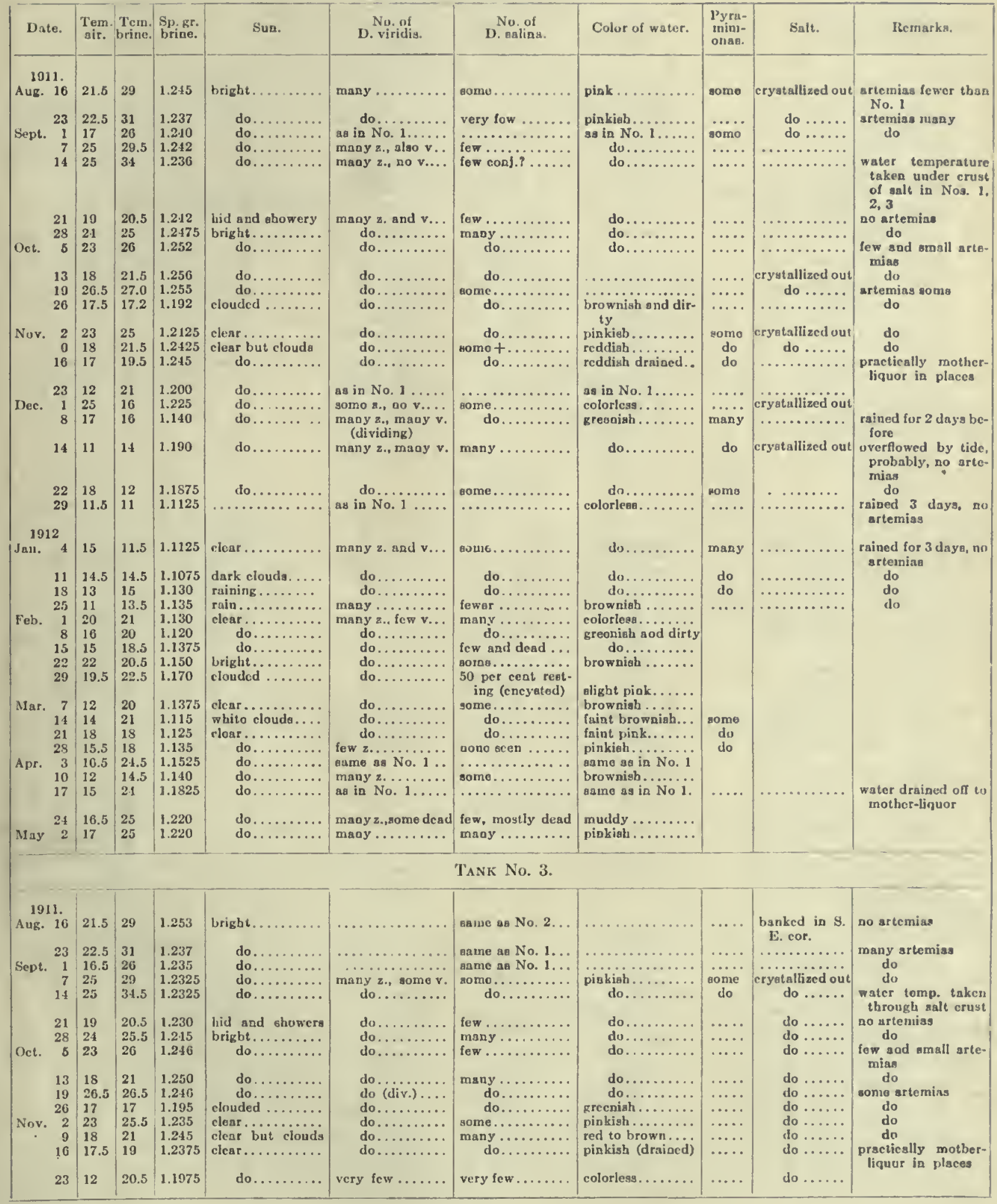


TABLE 22.-Record of living conlents of samples of brine taken from six sallerns-Continued.

TANK No. 3-Continued.

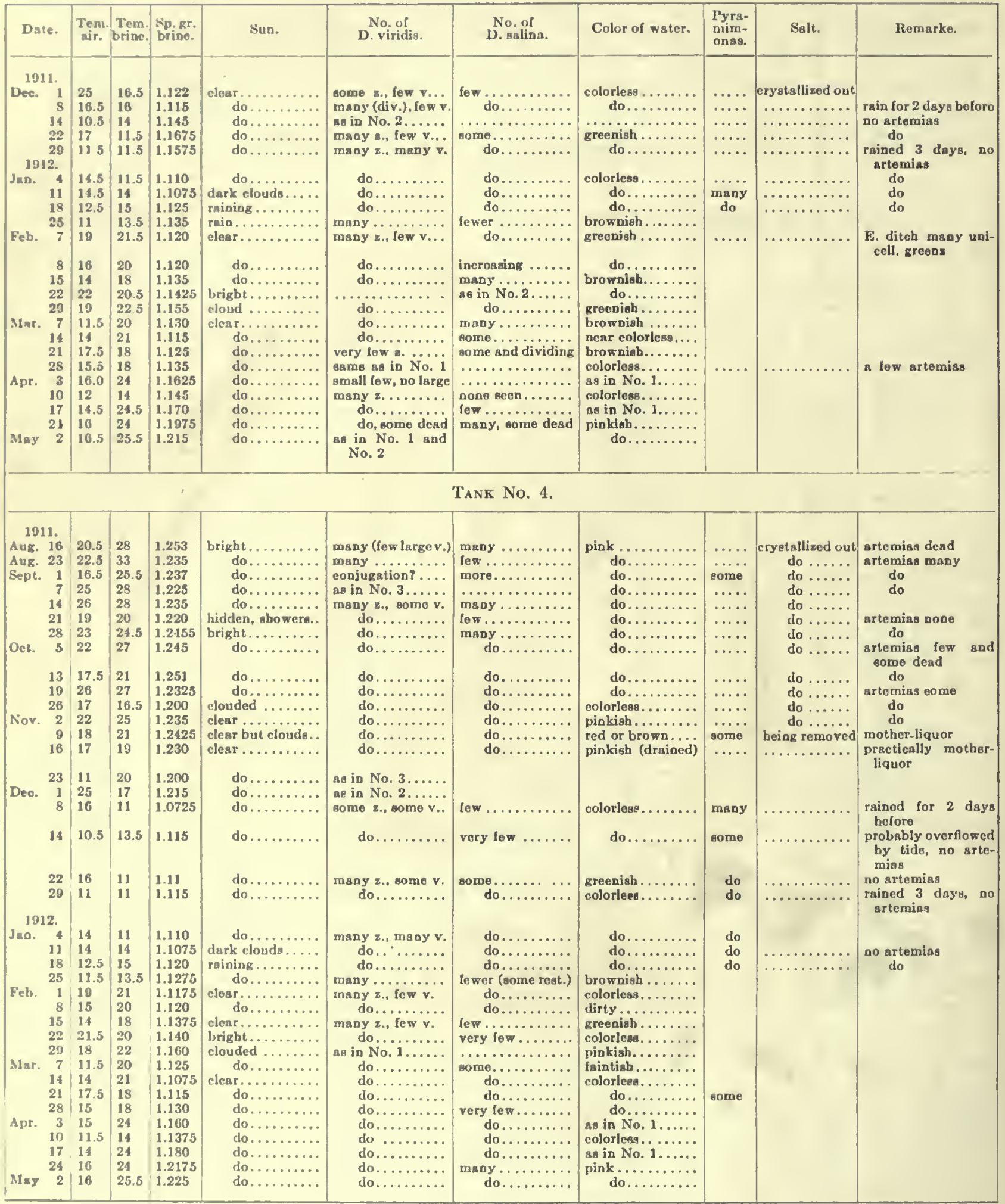


TABLE 22.-Record of living contents of samples of brine taken from six sallerns-Continued.

Tank No. 5.

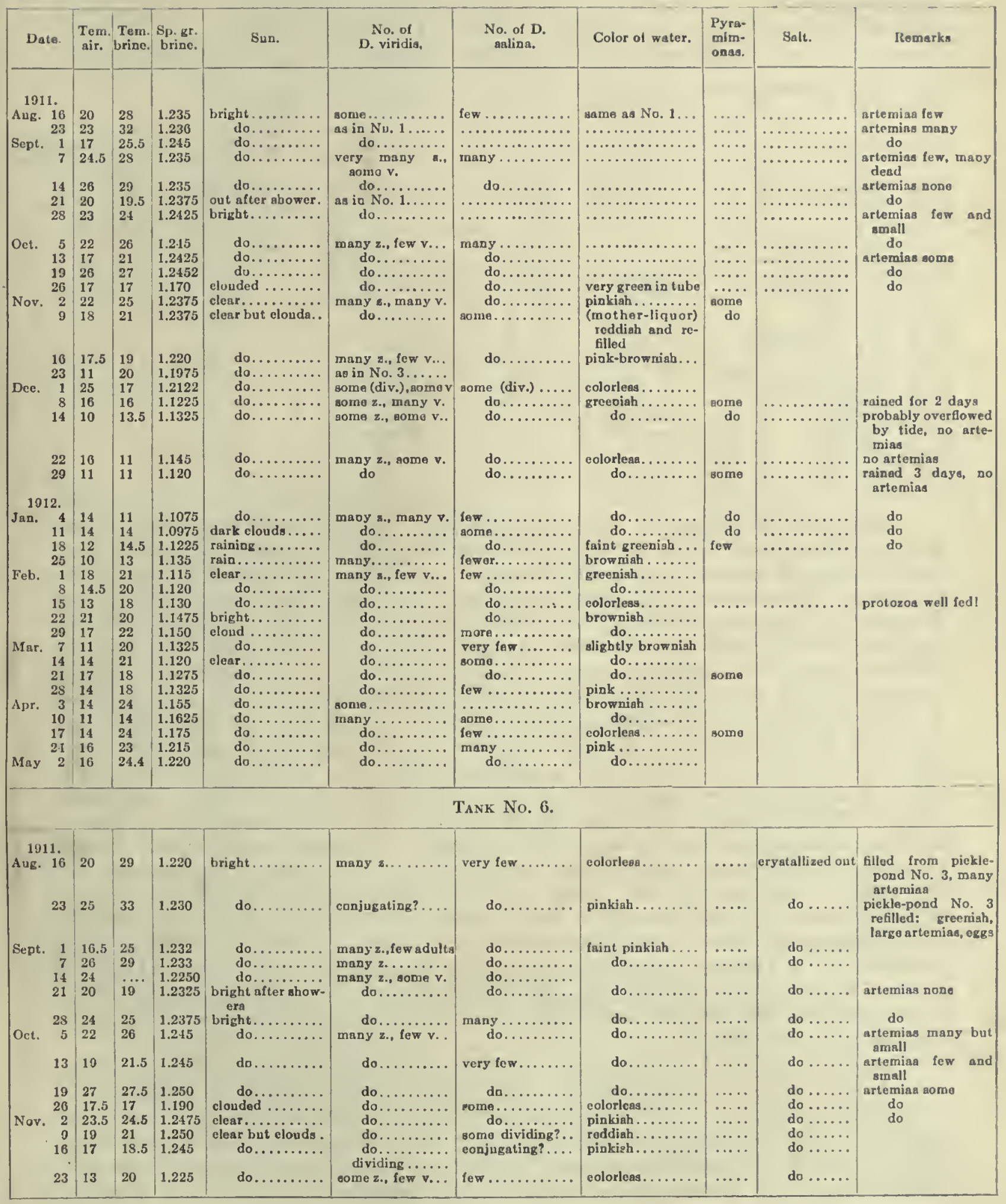


TABLE 22.-Record of living contents of samples of brine taken from six salterns-Continued.

TANK No. 6-Continued.

\begin{tabular}{|c|c|c|c|c|c|c|c|c|c|c|}
\hline Dste. & $\begin{array}{l}\text { Tem. } \\
\text { air. }\end{array}$ & $\begin{array}{l}\text { Tem. } \\
\text { brioo. }\end{array}$ & $\begin{array}{l}\text { Sp.gr. } \\
\text { brine. }\end{array}$ & Sun. & $\begin{array}{l}\text { No. of } \\
\mathrm{D} . \text { viridis. }\end{array}$ & $\begin{array}{l}\text { No. of } \\
\text { D. ssliaa. }\end{array}$ & Color of wator. & $\begin{array}{l}\text { Pyra- } \\
\text { mim- } \\
\text { onss. }\end{array}$ & Salt. & Iemarks. \\
\hline $\begin{array}{rr} & 22 \\
& 29 \\
1912 . \\
\text { Jad. } 1 \\
11 \\
15 \\
\\
25 \\
\text { Feb. } 1 \\
\\
8 \\
15 \\
22 \\
29 \\
\text { Mar. } \\
7 \\
14 \\
21 \\
25 \\
\text { Apr. } \\
3 \\
10 \\
17 \\
24 \\
\text { May } \\
2\end{array}$ & \begin{tabular}{|l|}
18 \\
12 \\
15 \\
15 \\
13.5 \\
11 \\
20 \\
16.5 \\
16 \\
23 \\
20 \\
12.5 \\
15 \\
18 \\
16 \\
17.5 \\
12 \\
15 \\
17 \\
17.5
\end{tabular} & $\begin{array}{l}11.5 \\
11.5 \\
11.5 \\
14 \\
15 \\
13 \\
21 \\
20 \\
18 \\
20 \\
22.5 \\
20.5 \\
21.5 \\
18.5 \\
18.5 \\
24.5 \\
14.5 \\
22.5 \\
23 \\
25\end{array}$ & $\begin{array}{l}1.2475 \\
1.185 \\
1.205 \\
\\
1.240 \\
1.0575 \\
1.1175 \\
1.1275 \\
1.120 \\
1.135 \\
1.1125 \\
1.1375 \\
1.130 \\
1.1625 \\
1.170 \\
1.1475 \\
1.1325 \\
1.145 \\
1.1475 \\
1.1675 \\
1.1275 \\
1.175 \\
1.2025 \\
1.210\end{array}$ & 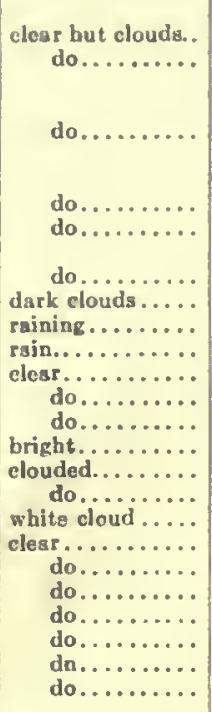 & 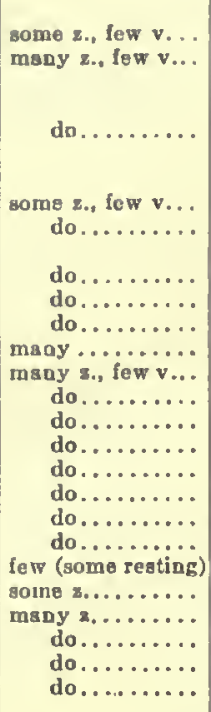 & 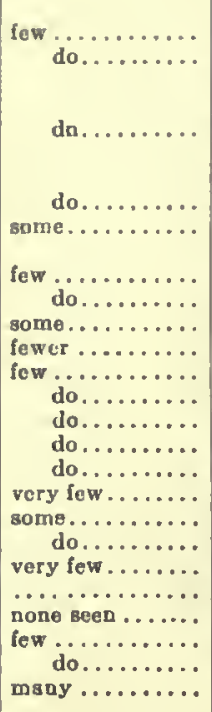 & 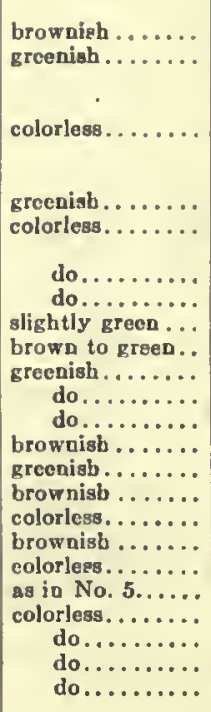 & 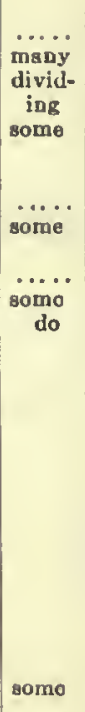 & $\begin{array}{l}\ldots \ldots \ldots \ldots \ldots \\
\ldots \ldots \ldots \ldots \\
\ldots \ldots \ldots \ldots \ldots \\
\cdots \ldots \ldots \ldots\end{array}$ & $\begin{array}{l}\text { probably ovcrflowed } \\
\text { by tide, no arto- } \\
\text { mias } \\
\text { do } \\
\text { rained } 3 \text { dsya, no } \\
\text { artemias } \\
\text { do } \\
\text { do }\end{array}$ \\
\hline
\end{tabular}

Certain features of these records merit comment. The table shows the temperature of the air (column headed Tem. air) in degrees centigrade, of the brine (column headed Tem. brine), the specific gravity (Sp.gr.) of the brine, the clearness or cloudiness (Sun) at the time of collecting, the numbers of Dunaliella viridis (No. of D. viridis) as determined by counting the number of organisms in the field of the same mieroscopic objective and eye-piece when the material was brought into the laboratory; and similarly of $D$. salina (No. of D. salina). Pains were taken to make the conditions of these counts as nearly as possible the same week after week; and as the counts were repeated for different fields in the same drop of brine and in other drops of brine, the record of some, few, many, and very many, is fair and reliable. Dunaliella viridis occurs in two forms: a small, slender, and very actively motile one, like a slender pear, designated in the tables as $z$., though Teodoresco calls them gametes; and a larger, plumper, and less rapidly moving one, designated in the tables as $v$., but called zoospores by Teodoresco. Both forms divide under the conditions recorded in the tables, and this is also shown to be the case in the cultures to be described subsequently. Dunaliella salina also has these two forms (and others), but does not exhibit them so constantly. The record in the column headed "water" is of the color of the brine as seen in a test tube in the laboratory. A color recorded in this column as pinkish would indicate that the brine in the salterns was red. Under Pyramimonas is recorded the presence of this peculiar organism, but as I did not succeed in getting this in pure culture on agar-agar, as I did the others, I can say little more about it. The column headed "Salt" shows whether or not salt was forming. Under "Remarks" the rainfall and other items are recorded which bear a relation to our organisms.

Inspection of these tables shows that, between the density of the brines and the numbers of individuals of these three species of unicellular algx, there exists an intimate relation. How intimate this is is indicated by reducing these tabular records to graphs, and also by cultures. In figure 2 we have the records of Saltern No. 1 in graphical form. The lower continuous line represents specific gravities of the brines as they were determined week by week from August 16, 1911 (viII, 16, '11), to May 2, 1912 (v, 2, '12), a specific 
gravity of 1.245 on Oetober 11, 1911, being the highest encountered, and of 1.0175 on December 29,1911 , the lowest during this period. Immediately above this line indieating the specifie gravities is a broken line showing the numbers of brown unicellular alga belonging to the speeies Dunaliella salina. Comparison of the eourse of these two lines will show that, in the main, there is a remarkable similarity; with the inerease in water in the brine

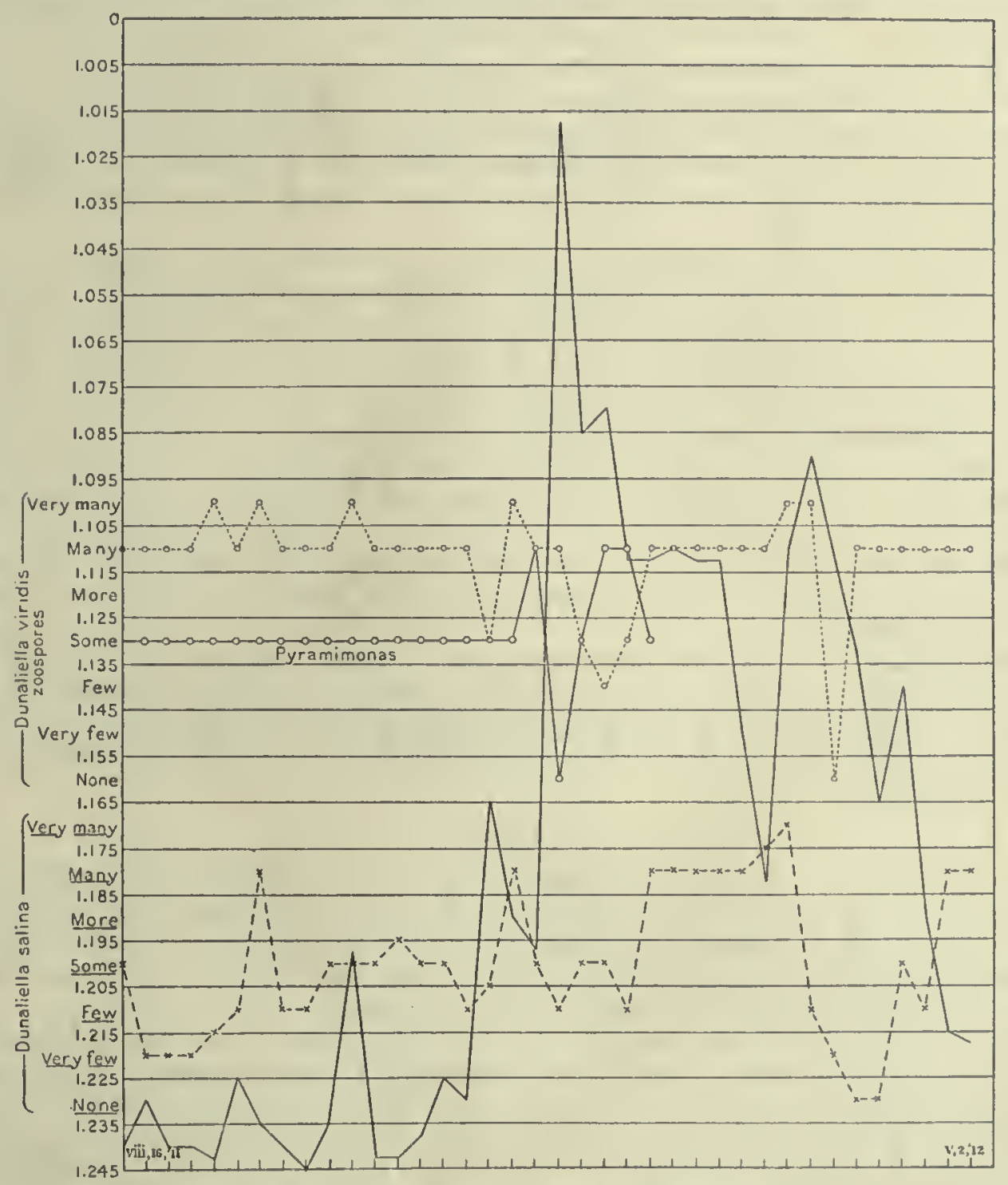

F10. 2.-Dingram ahowiog fluctustions of water and of orga vism in brine.

Continuous line: varying epecific gravity of brine under tho influeace of showerg and of contioued rain.

Broken line (......) indicates numbers of Dunaliella salina varying with the dilution of the brine (note the increase in numbers with every increase in water).

Continuous lino connecting circles: indicates numbers of Pyramimonas sp.? varying only with the principal fluctuations in water-content of the brine.

Broken line connecting circles indicates numbers of Dunaliella viridis varying with the dilution of the brine (note the mortality when water auddenly jocreased).

Observations made at weekly intervals, as indicated by horizontal line at the hottom.

there is an increase in the number of individuals of this characteristically brine alga. Thus on September 28, following a decided decrease in the concentration of the brine (from sp. gr. 1.2425 to 1.225 ), owing to the addition of brine from a "piekle-pond," there 
were many browns. The number decreases as the brine concentrates again. On October 27 the brine had a specific gravity of 1.1975 , two weeks after having had its maximum specific gravity. Following this, with the lag to be expected, the number of browns increases. This decrease in specific gravity was due to rain ${ }^{1}$ and was followed by condensation and a decrease in the numbers of $D$. salina. The next decided fall in concentration was recorded on December 8, after two days of rain. This was followed by an increase in the numbers of $D$. salina and a decrease corresponding with the subsequent concentration of the brine. On December 29 a specific gravity of 1.0175 was recorded, after three days of rain. This sudden large increase in the amount of water was fatal to an enormous number of all the algæ, as the other two curves also show (continuous line between circles for Pyramimonas, and a broken line between circles for $D$. viridis). The subsequent fluctuations in specific gravity are followed by corresponding fluctuations in the numbers of this brown Dunaliella.

The green species of Dunaliella (D. viridis) shows a very similar record, its numbers increasing and decreasing after each increase and decrease in the proportion of water in the brines, except where the increase in water is very sudden and very great. Presumably the effect on the individuals in the ponds is similar to that under the microscope when there is a sudden addition of water. I have never been able to cause the cells to burst, even by suddenly adding a large amount of distilled water to the edge of a cover-glass under which was a drop of concentrated brine containing many Dunaliellas of both species: but the cells become very plump, passing from pear to ball shape, and disorganization soon sets in.

The occurrence of Pyramimonas also corresponds with the proportion of water, so far as our observations go, but less is known of this alga, peculiar in form and in behavior, than of the others.

For the sake of some degree of completeness, I should add that in April 1907 there occurred a species of Carteria, often in great abundance. These one-celled green alga have four cilia and appear, so far as my observation goes, in water ranging in specific gravity from 1.025 to 1.040. But for some reason I have not seen them since 1907, although I have always looked for them.

\section{CULTURES.}

In table 22 such records of the behavior of the algx as dividing, encysted, colonies, etc., appear. It will be noticed that when the record shows conditions to be fairly uniform, the behavior of the organisms is also fairly uniform. In order to learn more about the connection between circumstance and action, as indicated by these one-celled plants, I attempted to cultivate them in liquid and on solid media.

In some respects the manipulation of these organisms is extremely simple. One need have no fear, for instance, of a culture becoming infected or contaminated from the air or from contact with unsterilized instruments; for when concentrated brines are employed in the culture media, they present conditions fatal to the existence of all organisms adjusted to fresh or nearly fresh water. On the other hand, none of the usual fixing agents which I have tried fixes the organisms in culture or freshly brought in from the salterns. Also it is obviously impossible to sterilize eoncentrated brines by steam without lowering the eoncentration of the brines. Boiling heavy brines is disagreeable enough, but boiling a heavy brine to which agar-agar has been added is still worse.

Although I thought I should be obliged to use silicic aeid jelly to solidify the concentrated brines of the Redwood salterns late in the dry season, when salt is crystallizing out, I tried the gelatine and agar-agar commonly used in bacteriological laboratories.

${ }^{1}$ Mr. J. A. Squire, U. S. volunteer weather observer, kindly shares with me his record that 0.36 inch of rain fell in Palo Aito on Uctober 26. There was certainly no less at Redwood and there may have been more. On December 4 and 6 a total of 0.89 inch of rain fell, and on December $27,28,29$, a total of 0.64 , with continuous cloudiness. 
$62^{a}$

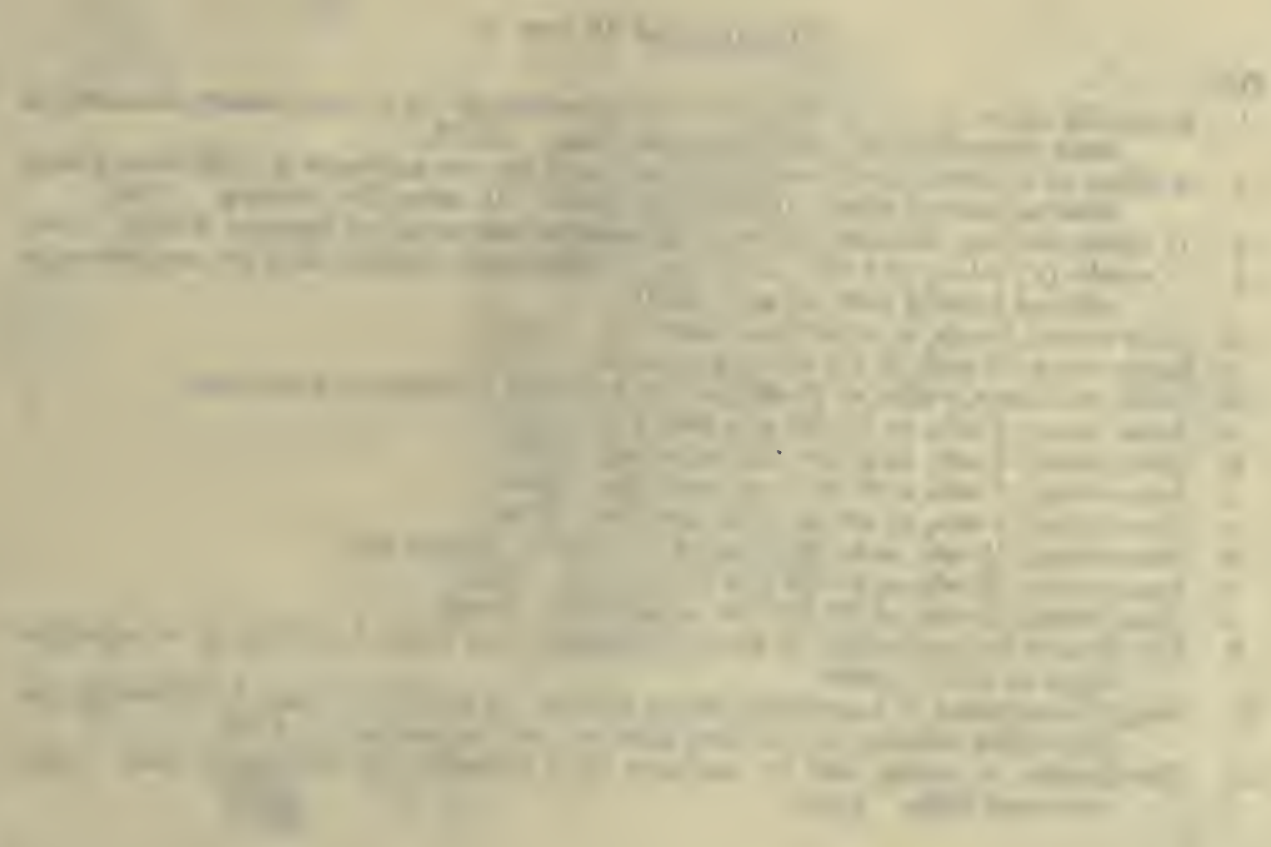



Gelatine would not go into solution in hot brine of high specific gravity in quantities sufficient to solidify it on cooling, but agar-agar was perfectly satisfactory and is much more easily usable than silicic acid jelly. The objection to agar-agar commonly made is that it filters very slowly and is not clear. Both of these objections ean be readily overcome by the method described by Kanthack and Drysdale, ${ }^{1}$ which consists essentially in allowing the agar-agar fiber, cut into short pieces, to soak and swell for 15 minutes in a considerable volume of 1 per cent acetic acid, washing in rumning water until every trace of acid is gone, and dissolving in the hot brine. A proportion of 0.5 per cent agar-agar is scarcely sufficient to keep the brine quite solid under the microseope at ordinary room temperatures, while 1 per cent is a little more than is needed. A certain amount of water will escape from the brine as steam while the agar-agar is being dissolved. In order to clear and at the same time to restore the density of the brine, beat the white of an egg to a froth in a volume of cool distilled water about equal to the quantity of water given off in heating the brine; mix this thoroughly with the brine and allow it to settle and solidify in a clean hot-water funnel, keeping the solution warm but quiet for a half hour and then allowing it to cool. In this way the greater part of the cloudy material of the brine as well as of the agar-agar will be carried down by the egg and may be cut off and thrown away. The clearer, if not quite clear, upper part of the conical block of agar-agar may now be melted again in a double boiler and poured into the test-tubes, flasks, and petri dishes to be used for the cultures. No further sterilization is needed, for the brinc organisms have already been killed and have settled out with the frothy egg-albumen, and no other organisms can live in these concentrated brines.

In figure 1, Plate 9, are represented the three species of unicellular algæ occurring in concentrated brines at Redwood. These are Dunaliella salina ( $a$ in the figure), Pyramimonas sp. ? ( $b$ in the figure), and the remainder represent the two forms of $D$. viridis. The rectangular bodies of large size are crystals of salt $(\mathrm{NaCl})$. A brine of 1.190 specific gravity, which I had filtered, sterilized by heating, solidificd with 1 per cent agar-agar, and cooled in a petri dish, was inoculated at five points on its surface with five drops of brine of the same concentration but containing only the two species of Dunaliella. Their numbers were very dissimilar, as figure 1 suggests. This, and the other dishes inoculated at the same time, were set on a plate-glass shelf in a window, and pains were taken to keep the culture dishes always in the same position relative to the direction of illumination. When inoculated, all the organisms were actively moving and plainly ciliated. Figure 2, Plate 9, shows $(g r)$ a group or colony of $D$. viridis, formed by division of one or a few cells which had come to rest. Their cilia have become invisible. One of the cells is in process of division. The numerous granules in these cells are starch and testify to ample food manufacture under the conditions of culture. The same figure (br) also shows an individual $D$. salina, also in process of division after having come to rest, and its cilia having disappcared. In botl $D$. viridis and $D$. salina on the surface of the agar-agar the cells have become slightly flattened and broader and considerably less elongated than the pear-shaped cells which, impelled by the motion of their paired cilia, were being pulled through the sirupy brine in which I first saw them. Although these organisms are actively phototactic, I was not able to see that the direction of their divisions could be connected definitely with the dircetion from which the light fell most strongly upon them, namely from the window. Figure 3, Plate 9, indicates this for D. salina and figures 4-8 show the same for $D$. viridis in another culture, for here the division walls run at various angles to the incident rays of light. There results from this, in the formation of the one-layered colonies on the surface of agar-agar, no regular relation of the cells to the direction of illumination, their clear ends, eye-spots, etc., lying generally toward the periphery of the colony but not always, as three cells in figure $4 a$, Plate 9 , show.

\footnotetext{
' Kanthack, A. A., and Drysdalo, J. H. A course of elementary practical bacteriology, p. 90. London, 1895.
} 
The division of the cells of both species of Dunaliella, brown and green, as they come to rest on agar-agar impregnated with brine, is the most striking first change which takes place, a change which, however, is directly proportioned to the change in density of the brine. Thus figures 2 and 3 show the divisions in the two species of Dunaliella at the end of one week when agar-agar impregnated with brine of slightly less than 1.190 specific gravity is inoculated from a brine of exactly this specific gravity. Figure 4 indicates the rate of division in a similar agar-agar plate of 1.050 specific gravity inoculated a week earlier from a brine of 1.200 specific gravity. The same result is shown by the growths in test-tubes containing brines of different concentrations inoculated from the same source, thus: December 4, test-tubes containing brines of 1.195, 1.105, 1.050, 1.025, and 1.0125 specific gravity were sterilized, cooled, and inoculated by a "loopfull" of brine from a stock bottle containing brine of 1.200 specific gravity. These tubes were placed in a test-tube rack on a shelf in a window. Direct access of sunlight to the cultures was prevented by a white holland shade constantly drawn over the window, but the illumination was ample, as the success of the cultures proved. On February 12, almost ten wecks later, I examined the tubes and found very little growth in those containing brine of 1.195 specific gravity, some in the tubes of 1.105 , very abundant in the 1.050 tubes, fair in 1.025 brine, very slight in 1.0125 . From these plate and tube cultures, therefore, it is evident that an increase in water (a decrease in concentration) in a brine is advantageous, provided it is not excessive. 'This corresponds exactly with the observations in the salterns themselves, as previously recorded (see table $22, \mathrm{pp} .56-60$ ).

Some idea of the rate of division is indicated by the series of drawings in figures 4-8. Thus figure 4 represents a colony $a$ of eight cells on a 1 per cent agar-agar plate of brine of 1.050 specific gravity. This plate was inoculated on January 15 . The figure was drawn, under camera lucida, at 11 a.m. on January 22. Presumably this colony of eight cells started from a single cell, as evidently all the others in the figure did; for, with the single exception noted in table 22, tank No. 1, column 6, for December 14, I do not recall colonies being formed out of doors or in the stock bottles. The same colony is shown in figure $5 a$ at $4^{\mathrm{h}} 20^{\mathrm{m}}$ p.m., January 22 , with 9 cells; in figure $5 b$ at $11^{\mathrm{h}} 45^{\mathrm{m}}$ a.m., January 23 , with 15 cells; in figure $8 a$ at $3^{\mathrm{h}} 50^{\mathrm{m}}$ p.m., on January 23 with 15 cells; in figure $8 b$ at $3^{\mathrm{h}} 50^{\mathrm{m}}$ p.m., January 24, with 16 cells; in figure $8 c$ at $10^{\mathrm{h}} 55^{\mathrm{m}}$ a.m., January 25 , with 16 cells. But this plate had been continuously in the dark, except for the short times required to make the camera drawings, since the first drawing was made on January 22 till January 25 at the same hour. On the other hand, figure $6 b^{\prime}$ shows a week-old colony of 4 cells at $4^{\text {h }} 40^{\mathrm{m}}$ p.m., on January 22, on another similar plate inoculated at the same time and from the same source. The same colony, now 5-celled, is shown in figure $6 b, "$ which was drawn at $11^{\mathrm{h}} 30^{\mathrm{m}}$ a.m., on the day following, namely, January 23 ; again in figure $7 a$ at $3^{\mathrm{h}} 45^{\mathrm{m}}$ p.m. of the same day, which had been dull; in figure $7 b$ at $3^{\text {h }} 40^{\mathrm{m}} \mathrm{p} . \mathrm{m}$. of the following day (January 24), which had been showery and dark; and in figure $7 c$ at $10^{\mathrm{h}} 40^{\mathrm{m}}$ a.m. on January 25, on a day dark and showery, but still light enough to bring about an increase in the starch-content of the cells. Comparing these two colonies, the one in the dark, the other in all the light there was, we see, in addition to the differences in starch-contents disclosed by the figures, that a colony of 8 cells formed 8 new cells in three days in the dark (a 100 per cent gain), while a colony of 4 cells formed 3 new cells in the same time in the light of showery or rainy days alternating with complete darkness during the long January nights (a 75 per cent gain). These are average figures for other colonies on these two plates. Later in the year, on brighter days, the difference is greater.

Thus we see that the effect (on a small scale and under conditions deliberately controlled, in cultures) of slight increase in the water-content of a brine is the same as on a large scale out of doors, namely, an increase in the number of individuals by vegetative means, by division, and that division is favored by darkness, other things being equal. 


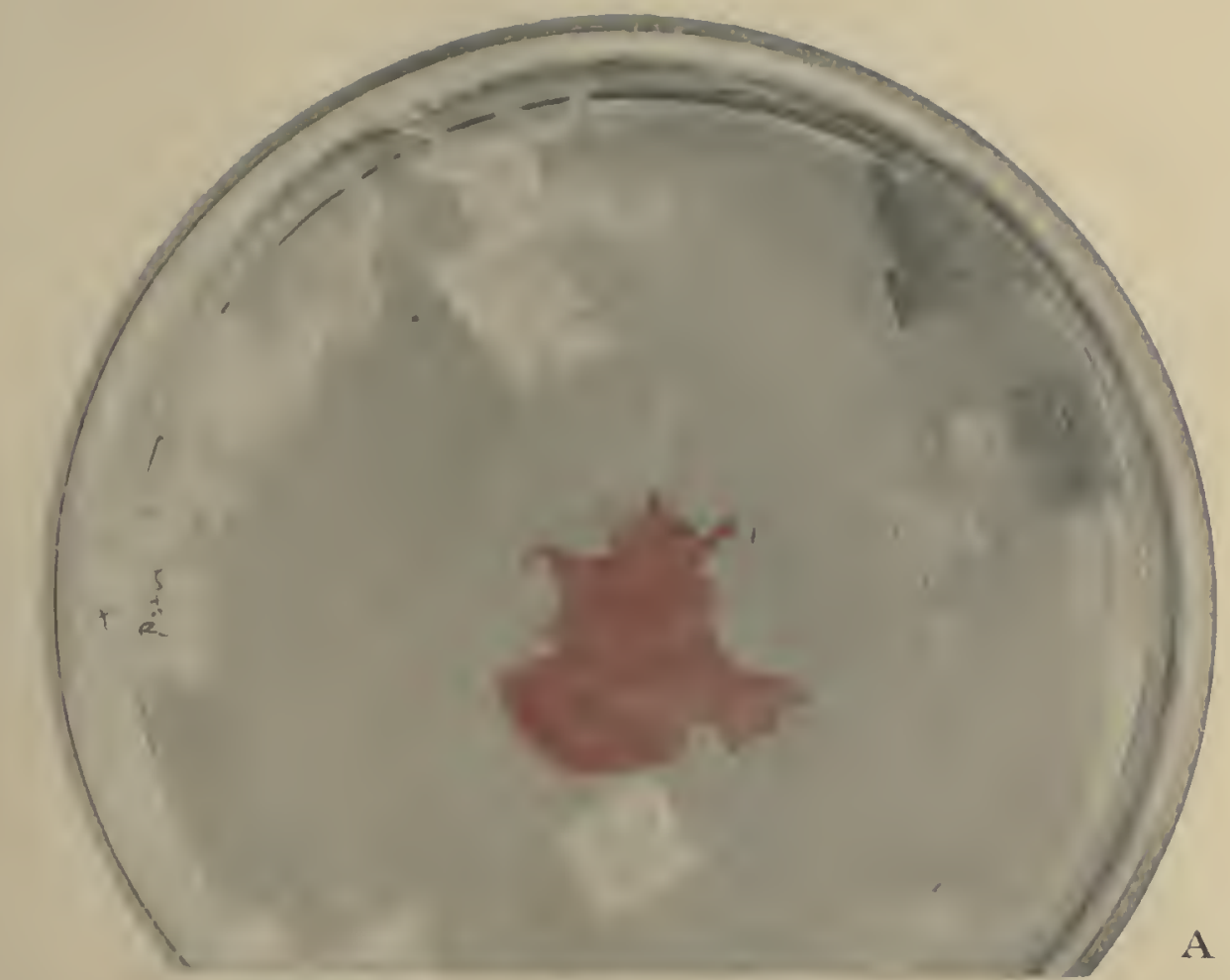

PLATE 10.

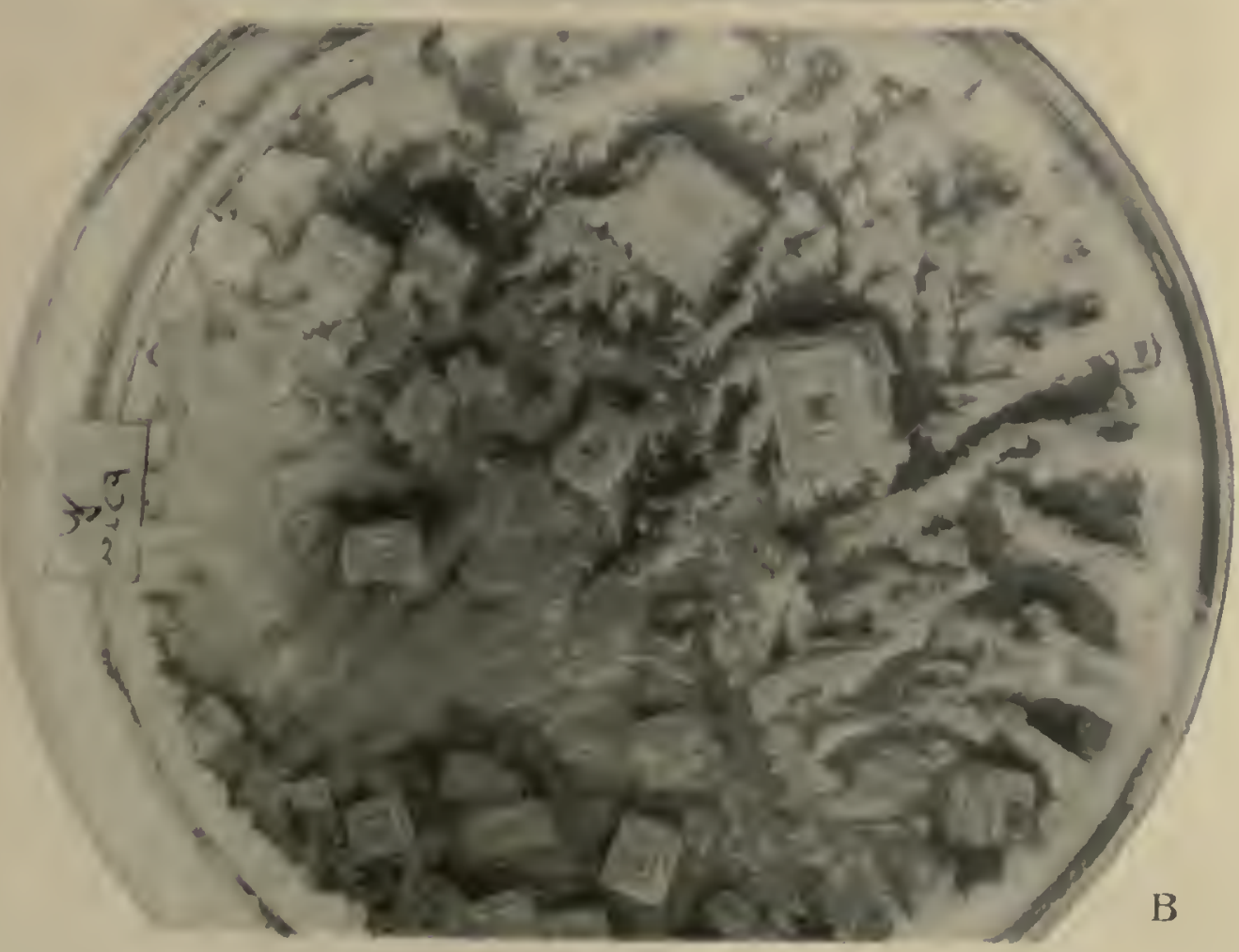

CULTURES OF CHROMCGENIC BACILLI.

A. Photograph of a 1 per cent agar-agar brine plate showing colony of red chromogenic bacillus. $X$.

B. Photograph of a I per cent agar-agar brine plate showing diffuse growth of red chromogenic bacillus. X 4 . 

A result of even a slight change in density is shown by figure 9 , which represents the condition at 11 o'clock in the forenoon of November 21, on the surface of a 1 per cent agar-agar plate of brine of 1.190 specific gravity inoculated at $11^{\mathrm{h}} 50^{\mathrm{m}} \mathrm{a.m}$., on November 17 from brine of 1.200 specific gravity. Even this slight difference in density is accompanied or followed by cell division.

One result of gradual loss of water, concentration of the brine, is presented in figure 10. On January 10 a sterile drop of brine of 1.050 specific gravity was inoculated from a culture of $D$. viridis on a plate of 1.105 specific gravity. On January 17 there had been a large increase in the number of alga in the drop and they were thriving. This culture had been kept on a glass shelf in a window and it remained there, exposed therefore to alternating daylight and darkness and to gradual drying (concentration). Four weeks and a half later, February 1 at $11^{\mathrm{h}} 17^{\mathrm{m}}$ a.m., I drew under the camera the cell shown as $a$. By $11^{\mathrm{h}} 40^{\mathrm{m}}$ a.m. this had changed as shown in $b$. At the same hour on the following day it looked as in $c$. Two days later it $(d)$ had a clearly marked wall, and on the 6 th at 4 p.m. it was a completed resting cell, walled and well filled with food. Salt was beginning to crystallize out at the edge of the drop of brine, thus proving the increased concentration. 'The change thus witnessed and figured seems very slow, and it may be slower than a similar change would have been out of doors; but in a saltern it would have taken place at the bottom, the cell having lost its cilia or drawn them in and with them losing its power of locomotion, and there the change might go on quite as slowly as in a culture, for the concentration of the brine would at least be no more rapid in a saltern than in a hanging drop culture. In this resting, or cncysted, condition the cells appear to be able to withstand very great concentration of the brine and the remarkable composition of "mother-liquor."

The germination of similar resting cells is seen in figure 11, in which they are represented as forming a considerable number of much smaller cells. This is a germination which, I believe, was experimentally produced, for on a 1 per cent agar-agar plate of brine, originally of 1.025 specific gravity, many cells had gone over into the encysted condition in the course of nearly four months, during which the brine had so concentrated that salt had begun to crystallize out in various parts of the plate. At one side of the plate I put a few drops of sterile distilled water, allowing it to diffuse unaided. In the course of a day or two the resting cells divided, and (as indicated in the figure) some of the daughter cells escaped through the broken or digested wall of the parent cells. I did not see any cilia on these daughter cells, but I attach no other signifieance to this than that cilia are very hard to see over agar-agar. Presumably these were ciliated motile cells, which, under usual conditions, would have scattered by swimming, but which were prevented by the agar-agar. These may be zoospores or they may be gametes.

I come now to the matter of gametes and of conjugation. Unfortunately I can throw only less light upon it than did 'Teodoresco, ${ }^{1}$ who reports having seen, in addition to a considerable number of abnormal conjugations, hundreds of others. Conjugation, according to this author, occupies about 10 minutes to the stage in which the two gametes have become completely merged, although the zygote has four cilia. Later changes he was not able to follow, for "le zygote, qui possède des mouvements très vifs, disparait du champ du microscope, et il erre, sous cette forme, pendant un temps qui je n'ai pu déterminer." Nor was he able to determine the circumstance or circumstances leading to conjugation. I have seen a few double cells or double individuals which looked like gametes conjugating, by their opposite ends, so that each end of the small mass had a pair of eilia, but I have never seen complete fusion nor anything like germination of the zygotes. I have no reason to doubt that these alga form zygotes, but I have not been fortunate enough to see them under conditions enabling me to recognize them positively as such. 


\section{BACTERIA.}

Something remains to be said about the bacteria in these brines. As already pointed out, decay goes on in them as in other waters; but the bodies of the peculiar organisms inhabiting these concentrated and heavy solutions are decomposed, after death, by organisms quite other than those carrying on similar decompositions in ordinary waters and in the organisms adjusted to them. This is proved by the escape of plate and other cultures, even when uncovered, from the usual infections from air and contact. But I have made no attempt to isolate the species and determine the characteristic activities of the different bacteria in these brines, except to ascertain, as previously stated (pp. 52-53), that the red color of these brines is the product of a very short and small bacillus ( 3.2 to $3.3 \mu$ wide by 3.4 to 3.6 $\mu$ long). Like the unicellular alga inhabiting these brines, this organism can be cultivated on agar-agar impregnated with brines of suitably high concentration. On agar-agar plates it forms raised colonies ranging in shade from pink through clear red to crimson, according to the size of the colony. The colonies first appear as small red spots, as indicated by figure $\mathrm{B}$, Plate 10. This is a photograph of an agar-agar plate, originally 1.190 specific gravity, inoculated with a loopful from a very concentrated pink brine in a stock bottle. The inoculation was accomplished by drawing this platinum loopful lightly and rapidly across the smooth surface of the plate in the shape of a $Y$; for I hoped, by so doing, to accomplish the same end attained in bacteriological laboratories by "pouring a plate," namely, the separation and distribution of the individuals over the surface of the plate. I could not "pour a plate" in working with these organisms, for the temperature at which these brine plates melt is fatal to the brine organisms, as experience had proved. Colonies of the Dunaliellas formed along the line of inoculation, but I did not see this red colony until salt began to crystallize out. It continued to grow for some time, but was finally lost in the snowy mass of crystals which covered the plate as evaporation continued.

A much larger and more diffuse growth is shown in figure $\Lambda$, Plate 10, in which another plate is represented. This plate was thicker (deeper) and did not dry out so rapidly. It was inoculated in a manner similar to $\mathrm{B}$, but in two lines crossing each other, as in $\mathrm{x}$. From these plates other plates and a certain number of test-tubes of agar-agar brine were inoculated. The two types of growth, colonial and diffuse, are shown in the figures of Plate 11. In all of them the pigment diffuses more or less through the agar-agar, imparting to it a fine and delicate shade of pink, which, with the glistening snowy crystals of common salt, give a very striking appearance to the cultures.

Suspecting that this small bacillus might be the cause of the red color which sometimes develops in salt codfish, I determined to try two experiments: (1) to inoculate sterilized salt codfish from one of my pure cultures of this pink organism; (2) to inoculate a sterilized agar-agar brine plate from a piece of salt codfish which had turned red. I was fortunate enough to find a box of "Georges Codfish" in which the fish was spotted with red. By means of a sterile platinum needle I inoculated various sterile agar-agar brine plates from the red spots. Presently colonies appeared on the agar-agar plates of the more concentrated brines, none forming on the more dilute brines. Growth on the agar-agar plates was never very rapid, for laboratory air is rarely at the optimum humidity for this organism, and the usual incubating temperatures are too high.

The reverse of this experiment, inoculating sterilized salt codfish from my pure cultures on agar-agar brine, was equally but not uniformly successful. It is obvious that if, in contravention of the regulations of the pure food and drugs act, an antiseptic or other deterrent of growth be contained in the salt fish, attempts at inoculation would probably fail. I have regularly failed with certain lots of fish at local groceries, and as regularly succeeded with other lots bought at the same shops. One such culture on a piece of steam-sterilized codfish inoculated from one of my pure cultures is shown in figure E, Plate 11. This culture is several months old and shows the condition which salt codfish may and sometimes does reach in the grocery or in the larder when kept where the air is moist and cool. 


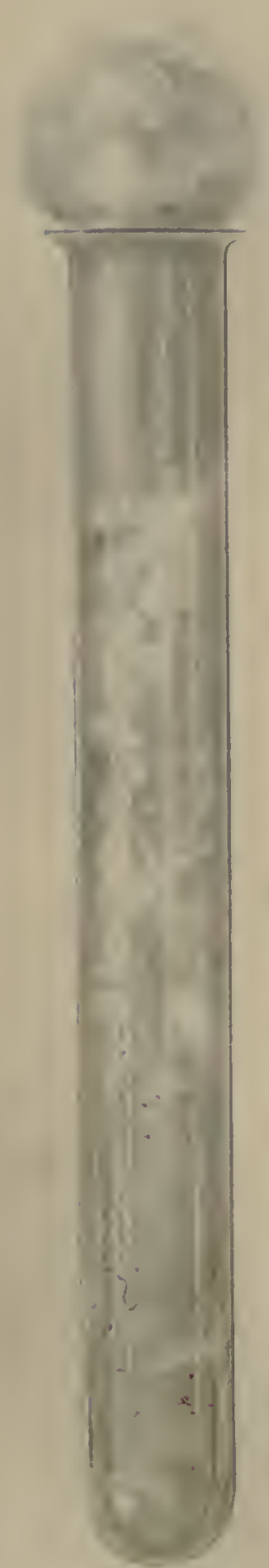

$\Lambda$

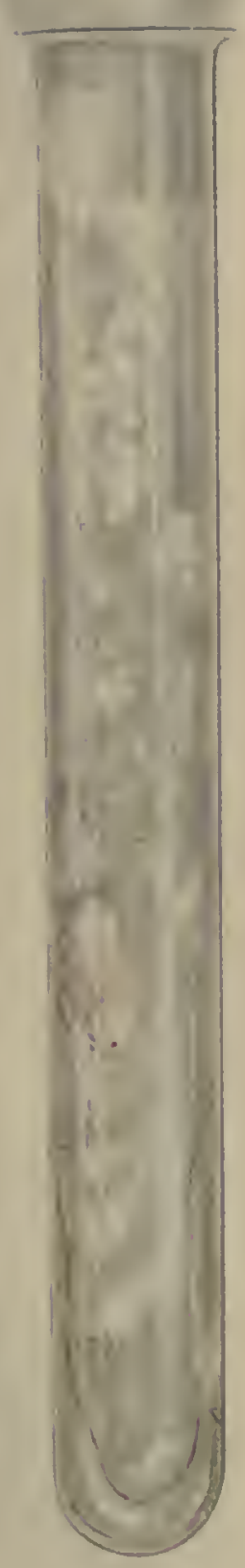

B
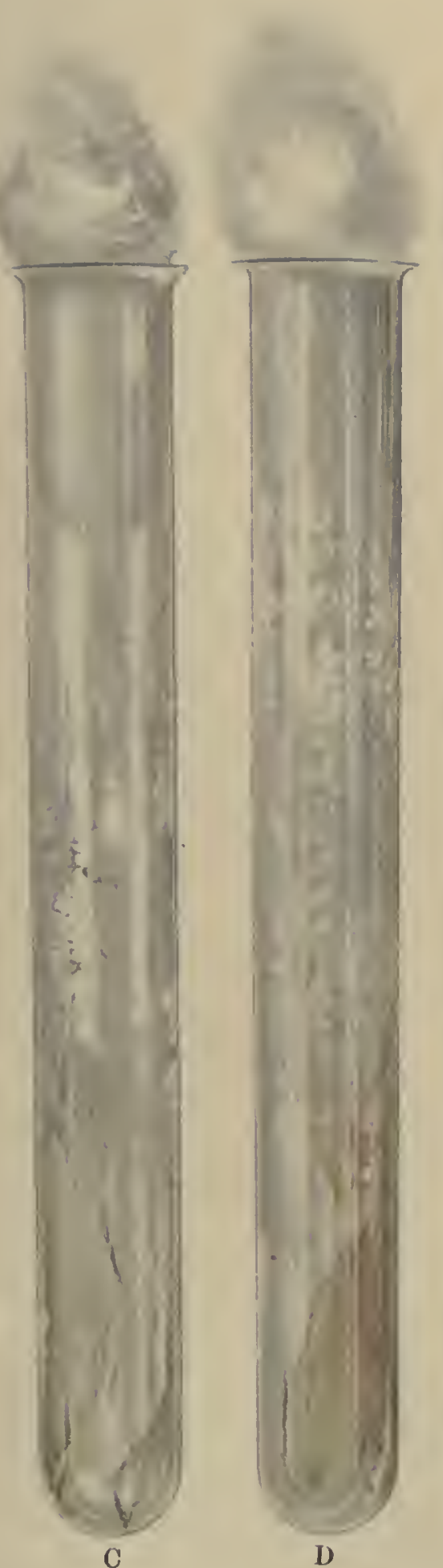
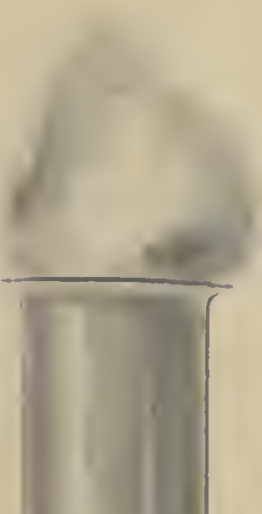

14

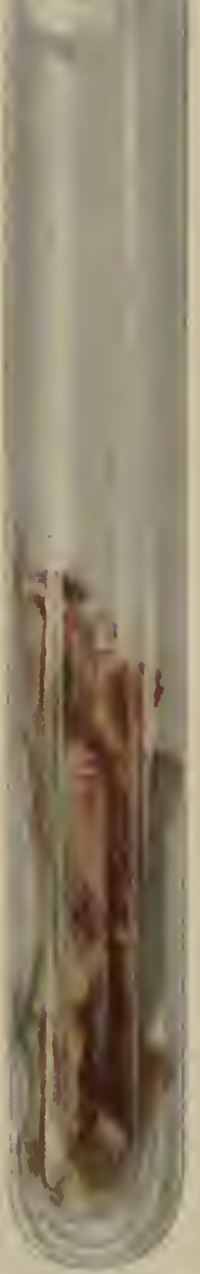

$\mathbf{E}$

CULTURES OF CHROMOGENIC BACILLI.

A, B, C. D. I per cent agar-agar brine tube cultures showing colonial and diffuse growith of red chromogenic bacillus. $X 2$. E. Sterilized salt cod-fish inoculated from a pure plate culture of the red bacillus. $\times 2$. 

It is elear, then, that the small bacillus which gives to the eoneentrated brine in the salterns on the shores of the Bay of San Franciseo their striking red eolor, may go over into the salt as it is harvested and stored, and be carried with it into eontaet with organic matter, forming a suitable medium for its growth. Its growth may be eheeked or prevented by the addition of preservatives or by keeping the material dry and in dry air. But it certainly does not occur alone in erude salt (or even in salt of a certain degree of refinement) from salterns the brines of which it colors; it is simply the most conspieuous form. Other putrefactive bacteria, presumably more serious in the decompositions which they aceomplish, accompany it and are carried with it into salted cod-fish unless such salt be sterilized. As these bacteria, like the brine algx, are killed by temperatures not fatal to most other organisms, the salt ean be sterilized on a commercial seale by low heat and at a eost which would not seem to be prohibitive. In fact, sterilized salts are now advertised in San Franeiseo by one of the producers, thus proving the realization, on the part of the owners of salt works, that even such a preservative as salt may earry with it its opposite.

\section{ANALYSES.}

The knowledge that these brines are formed by condensing sea-water pumped from the Bay of San Francisco gives us only a very imperfect idea of their composition, either qualitatively or quantitatively. We know that a great number of substanees may be recovered from sea-water by sufficiently refined methods of analysis, but that they all remain in solution, either in the same or in changing proportions, throughout the stages of salt manufacture, is not the case. 'The ratios, then, of the dissolved salts in sea-water to each other is not the same as in the brine at various stages of its eoneentration. Thus the sea-water undergoes by evaporation such eoneentration that most of its load of calcium is thrown down in the "piekle ponds" or before. The brine pumped from the "pickle ponds" into the numbered salterns, the organisms in which have been the theme of the foregoing pages, is rich in sodium, magnesium, and potassium, in chlorides and sulphates, poor in calcium, iron, and nitrates; and the final "mother-liquor," the discarded residue from which salt has been harvested and in which living organisins may still be found, is poor in sodium and ehlorine, rich in magnesium, potasTABLE 23.-Analyses of brines (expressed in milligrams per liter).

\begin{tabular}{|c|c|c|}
\hline & $\begin{array}{l}\text { No. I } \\
\text { Sp. gr. } \\
1.232 \mathrm{I}\end{array}$ & $\begin{array}{l}\text { No. } 2 \\
\text { Sp. gr. } \\
1.1007\end{array}$ \\
\hline Silica $\left(\mathrm{SiO}_{2}\right) .$. & 14.00 & 6.00 \\
\hline Bicarbonate radicle $\left(\mathrm{IICO}_{3}\right)$. & 610.00 & 328.00 \\
\hline Sulphate radicle $\left(\mathrm{SO}_{6}\right) \ldots . .$. & $30,050.00$ & $10,030.00$ \\
\hline Borax radicle $\left(\mathrm{B}_{4} \mathrm{O}_{7}\right) \ldots$ & 160.00 & trace \\
\hline Nitrates......................... & trace & \\
\hline Bromine $(\mathrm{Br}) \ldots \ldots \ldots \ldots \ldots \ldots \ldots$ & $1,000.00$ & 330.00 \\
\hline Chlorino (Cl)...$\ldots \ldots \ldots \ldots \ldots$ & $182,380,00$ & $81,513.30$ \\
\hline Irod (Fe)........... & 4.90 & 2.80 \\
\hline Calcium (Ca)....... & 250.00 & $1,420.60$ \\
\hline Magnesium (Mg).... & $23,330.00$ & $5,624.20$ \\
\hline & $89,910.00$ & $45,091.00$ \\
\hline \multirow{2}{*}{ Potsssium (K)................... } & $6,210.00$ & $1,610.00$ \\
\hline & $334,818.90$ & 146.774 .90 \\
\hline
\end{tabular}
sium, and sulphur. The aecompanying quantitative analyses of brines ${ }^{1}$ (table 23), one of high and the other of low specifie gravity, make these facts clear. A brine containing upwards of 30 grams of solid matter in every 100 e.e. of water is very eoncentrated. 'The specific gravity indicates this, but analysis shows it even more strikingly.

In addition to a load of dissolved matter equaling one-third of its own weight which the water of these densest brines earry, there is a very considerable anount of suspended matter, mueh of it organic. This organic matter is of most plyysiological importance, but I have not been able to have its amount accurately determined, still less its constituents, the diffieulties of inorganic analyses being suffieiently great.

${ }^{1}$ Made for me by Mr. W. H. Sloan, Instruetor in Chemistry in Leland Stanford Junior University, to whora I wish here also to express iny thanks. 
Inspection of this table shows the extraordinary composition, as to both quality and quantity, of the medium in which these brine organisms live. How any sort of balance, osmotic, adsorptive, and chemical, is maintained against such odds, is difficult to understand.

\section{SUMMARY AND CONCLUSIONS.}

The favorable climatic conditions and the flat clayey parts of the shore of the Bay of San Francisco are taken advantage of to manufacture salt from sea-water on a commercial scale. Water is pumped from the Bay into shallow diked ponds. Containing about 3 per cent common salt at this stage, it is concentrated by the sun's heat, the water evaporating rapidly into the dry air of the rainless summer. In the course of this concentration, much of the calcium comes down, crystallizing out in the so-called "pickle ponds." From these ponds the brine is again pumped into the salterns, where it undergoes still further concentration by evaporation hastened by the sun's action. At the time salt crystallizes out the percentage of common salt has reached nearly 30 per cent. Bcsides being a saturated solution of sodium chloride, such a brine is also a concentrated solution of magnesium salts and contains a considerable proportion of potassium. Between the proportion of calcium and magnesium in concentrated brines and in the mother-liquor there can be no "balance"; but sinee, in other respects than lack of "balance," these solutions are fatal but inhabited, they throw no real light on the value of the idea of "balanced solutions" and only continue, if they do not justify, natural skepticism regarding it.

The color of these brines, and often of the salt obtained from them, is clue to a small red chromogenic bacillus, but the brines are inhabited by a considerable number of organisms, animals as well as plants. In the concentrated brines and in the mother-liquor from which salt has been taken by crystallization the living plants are unicellular, members of the Polyblepharidaceæ, motile green or brown organisms belonging to the genera Dunaliella and Pyramimonas, and bacteria, which are often present in great numbers. These bacteria bring about the destruction of animal waste and of plant remains which would otherwise encumber the salterns, thus serving the same purposes that the putrefactive and other destructive bacteria of the land and of the sea accomplish. The bacteria of decay adapted to waters of the usual concentrations are killed by concentrated brines. The decay which must and does go on in high brines is accomplished, therefore, by entirely different bacteria. At least one of these is chromogenic and sometimes appears as the agent which turns salt cod-fish red.

The behavior of the brine organisms is closely related to the changes which take place in the brines in the course of the days, the scasons, and the process of salt manufacture. The brine algæ are markedly phototactic and their distribution in the brine is determined in great part by light and the direction from which it comes. Light does not seem to determine the direction in which they shall divide, but division secms to occur oftener and to take place more rapidly in darkness than in the light. (See Peirce, pp.49-71.)

The main changes, apart from the daily cycle of darkness and light, taking place in these brines are in the temperatures and concentrations of the solutions. The changes in temperature exercise no very evident influence on the behavior of the brine organisms, but the changes in the proportion of water are reflected in the behavior of the brine algæ. Inspection of the tables, and of the graphs constructed from them, shows that the numbers of the brine algæ are directly proportioned to the amount of water in the solution, and that increase in the amount of water is followed by increase of the alga by division. The numbers of alga in the brines, as shown by collections and examinations extending over five years, though reported in these tables only from mid-August 1911 to mid-May 1912 , rise and fall with the proportion of water as this fluctuates in consequence of rain, dilution of concentrated brine by additions from the "pickle ponds," evaporation, and harvesting of salt. 
The fluctuations shown by determinations of specific gravity and by census of the organisms in brines collected at the salt works are confirmed by the behavior of the brine alga in cultures in sterilized brines and on such brines solidified by the addition of 1 per cent or less of agar-agar. In liquids, indoors and out, the alga do not generally form colonies, but on agar-agar brine they commonly do so, especially when cell-division is stimulated by dilution of the brine or by transferring the alga from a ligher to a lower concentration. Even slight decrease in density results in decided increase in the rate of cell-division, whether upon a solid medium or in a liquid.

Concentration of the brine, on the other hand, carried far enough, induces the opposite effect, permanence of the cells instead of their division. When salt is crystallizing out the alga begin to encyst. Although I have never seen all the cells go over into the resting condition, the number so doing increases with the concentration. This change takes place only slowly, so far as my observation goes.

The germination of encysted cells takes place when the brine in which they lie is diluted. The germination of a resting cell consists in its division into many small cells, gametes or zoospores. These presently escape through the broken or digested wall of the mother-cell. The addition of water, then, favors both vegetative cell-division and this reproductive cell-division, both of which, since these alga are unicellular, result in increasing the number of individuals.

Whether the cells thus formed in the germination of a resting spore are gametes or zoospores I can not say; for I have never seen conjugation take place. Cells in certain stages in division might so closely resemble cells in certain stages of conjugation that they would be indistinguishable, unless the processes were seen at their beginnings.

The color of the concentrated brines in the salterns of the Bay of San Francisco is due to a small chromogenic bacillus, 3.2 to $3.3 \mu$ wide by 3.4 to $3.6 \mu$ long, which not only lives in saturated brines but also upon and in the heaps of salt as it is piled for drainage and shipment. Small volumes of brine and small masses of salt, as they may be kept in glass vessels in the laboratory, owe their pink hue to this organism. Color will develop in sterilized colorless brine of suitable concentration if inoculated from a pure culture or other source of this organism. On agar-agar it grows either as distinct colonies of deep-red hue or more diffusely over a moister surface. In either case, the pigment diffuses beyond the outlines of the colonies into the brine or agar-agar.

Experiment proves that this organism, inoculated with unsterilized salt into salt cod-fish, will cause the cod-fish to turn red, thus making it unsalable; and that the cases of cod-fish reddening in the grocery or in the larder are due to the growth of this bacillus on the fish when the fish is kept in an unduly moist and cool place. Since all the brine organisms are killed by moderately low heat, stcrilization of the salt is simple. Thus, sterilized salt is a remarkable preservative; but unsterilized salt often carries organisms the putrefactive or other destructive activities of which it can not check.

Quantitative analyses show that, in the course of salt manufacture, the qualitative changes in the brine are as great as the quantitative, that the proportions of ealcium and magnesium change greatly with relation to each other, that calcium becomes very much reduced by precipitation in the "pickle ponds" and elsewhere, while the solution becomes richer and richer in magnesium and potassium as it concentrates. The osmotic, adsorptive, and other relations of the brine organisms to their environment are so extraordinary that they may well be studied for the light they may throw on the more usual adjustments with which we are more familiar, but of which, in fact, we are almost equally ignorant.

In thesc extraordinary organisms, low thougl they are according to schemes of classification, simple though they are in form, we have a remarkable illustration of the adaptability, the plasticity, of living things. In the living organism, a creature of substance and of circumstance, we see behavior molded by circumstance, substance changing to meet conditions. 



\title{
THE ACTION OF SALTON SEA WATER ON VEGETABLE TISSUES.
}

\author{
By Melvin A. Breannon.
}

'The recession of the water's of the Salton Sea began in February 1907, and as the level fell from 42 to 54 inches annually, each year laid bare wide strips of beach which had been occupied by a halophytic and xerophytic vegetation previous to the formation of the lake. It is probable that many representatives of the species listed by $\mathrm{Mr}$. Parish in a separate section of this volume were covered by the water during the years 1904 to 1907.

But examination of the emersed zones uncovered by the recession of the lake failed to diselose the remains of any annuals or herbaceous plants, and their disappearance may be attributed to facts revealed by the investigations reported in this paper. Remains of the woody plants were fairly abundant, however, and in the autumn of $1911 \mathrm{Dr}$. D. T. MacDougal forwarded portions of stems and branches of Prosopis glandulosa and Larrea tridentata to the Botanical Labolatory of the University of Chicago, where a study of the changes which this material had undergone was made. The material included specimens which had been submerged in 1906 and had emerged in 1907, 1908, 1909, 1910, and 1911. It was all thoroughly desiceated by the time it came to hand. The specimens were very liard, except those which had been submerged but a year, and all were destitute of cortex. (12 s., 13, and 14.) Material which had been submerged for more than a year had undergone the full extent of the alterations described below.

Efforts were made to secure literature relating to the subject under investigation, but extensive inquiries in America and Europe were fruitless. While a very large number of examinations have been made of the action of saline and brackish water on living plants, reported in hundreds of papers, and while many tests of the preservative effects of various salts on different woods have been made, yet the action of saline waters or fresh waters on the tissues of plants killed by flooding and remaining immersed in situ for long intervals of time has been little investigated. This omission seems strange when we consider the intimate relations of the physical chemistry of such problems and the large economic questions involved in the disposal of sewage, decomposition of manure and humus, and the carbonization processes associated with the coal formations.

The appreciation of the problem reported in this paper will be increased by knowledge of the geography and topography of the Salton Sea region. Detailed reports respecting the formation of the Colorado district and the low-lying basin known as the Salton Sea may be had by consulting references $(1)^{1}$ and (2), ${ }^{2}$ and the sections of this volume on the geography and surface geology of the Salton Sink and the Cahuilla Basin.

A consideration of the physical and biological factors operating in the Salton Sea waters during the years that these woods were immersed, are illuminating in connection with experiments which were earried forward in the Botanical Laboratories of the University of Chicago while endeavoring to discover the processes which caused the changes in the woody tissues.

The chemical analyses of the Salton Sea waters during the years 1907-11 are instructive. The reports set forth in table 24 were secured by the chemists, Dr. W. H. Ross and Prof. R. H. Forbes.

\footnotetext{
${ }^{1}$ D. T. MacDougal: 'The Desert Basins of the Colorado Delta, Bull. Am. Geog. Soc., Dec. 1907.

${ }^{3}$ Newell: Smithsonian Report, pp. 331-345, 1907.
} 
TABLE 24.

\begin{tabular}{|c|c|c|c|c|c|}
\hline Total solids (dried at $110^{\circ} \mathrm{C}$.) & $\begin{array}{c}\text { June } 3 \\
1907\end{array}$ & $\begin{array}{c}\text { May 25 } \\
1008\end{array}$ & $\begin{array}{c}\text { June } 8 \text {, } \\
1909\end{array}$ & $\begin{array}{c}\text { June } 3, \\
1910\end{array}$ & $\begin{array}{c}\text { June } 3, \\
1911\end{array}$ \\
\hline Plus $\mathrm{H}_{2} \mathrm{O}$ of Dcelusion and hydration & 364.80 & 437.20 & 519.40 & 60380 & 718.0 \\
\hline 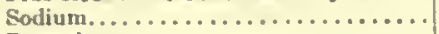 & 111.05 & 134.26 & 160.33 & 189.28 & 227.81 \\
\hline 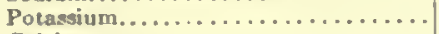 & 2.29 & 2.78 & 3.24 & 3.53 & 3.81 \\
\hline 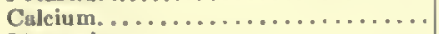 & 9.05 & 11.87 & 13.70 & 13.67 & 15.62 \\
\hline 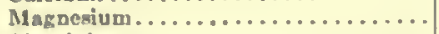 & 6.43 & 7.63 & 8.96 & 9.81 & 11.68 \\
\hline 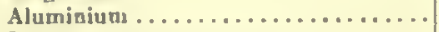 & 0.030 & 0.35 & 0.62 & 0.040 & 0.059 \\
\hline 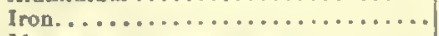 & 0.005 & 0.006 & 0.010 & .008 & 0.036 \\
\hline Mangancse, nonc any year............ & ...... & $\ldots \ldots$ & $\ldots \ldots \ldots$ & $\ldots \ldots \ldots$ & $\ldots \ldots \ldots$ \\
\hline 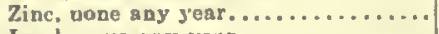 & $\cdots \ldots \ldots$ & $\ldots \ldots$ & $\cdots \cdots \cdots$ & $\ldots \ldots$ & $\ldots \ldots \ldots$ \\
\hline Lead, vone any year................ & …… & $\cdots \ldots \ldots$ & $\because \ldots \ldots$ & $\because \ldots \ldots$ & $\because \ldots \ldots$ \\
\hline & $\because \ldots \cdots$ & ……ㄱ & trace & trace & trace \\
\hline Lithium........................... & trace & 0.013 & 0.017 & .021 & 0.025 \\
\hline Chlorine $(\mathrm{Cl}) \ldots \ldots \ldots \ldots \ldots \ldots \ldots$ & 169.75 & 204.05 & 240.00 & 280.93 & 330.42 \\
\hline Sulphuric acid $\left(\mathrm{SO}_{6}\right) \ldots \ldots \ldots \ldots \ldots$ & 47.60 & 56.74 & 65.87 & 76.36 & 01.67 \\
\hline Carbonic acid $\left(\mathrm{CO}_{2}\right) \ldots \ldots \ldots \ldots \ldots \ldots$ & 6.58 & 7.66 & 7.34 & 6.38 & 5.78 \\
\hline Silicje $\left(\mathrm{SiO}_{2}\right) \ldots \ldots \ldots \ldots \ldots \ldots \ldots \ldots \ldots$ & 1.41 & 1.43 & 1.59 & 1.55 & 1.83 \\
\hline Phosphoric $\left(\mathrm{PO}_{4}\right) \ldots \ldots \ldots \ldots \ldots \ldots$ & 0.009 & 0.011 & 0.01 & .013 & trace \\
\hline Nitric $\left(\mathrm{NO}_{3}\right), \ldots \ldots \ldots \ldots \ldots \ldots \ldots \ldots \ldots \ldots$ & 0.18 & 0.20 & none & none & none \\
\hline Nitrous $\left(\mathrm{NO}_{2}\right) \ldots \ldots \ldots \ldots \ldots \ldots \ldots$ & none & trace & 0.0006 & none & none \\
\hline Oxygen consumed................. & 0.093 & 0.059 & 0.068 & .045 & 0.063 \\
\hline Boric acid..................... & $\ldots \ldots$ & trace & $\ldots \ldots \ldots$ & trace & trace \\
\hline
\end{tabular}

A critical examination of the substances present in the Salton Sea waters does not indicate that they are active in disintegrating the cell walls of woody tissues or necessarily cause even a breaking down of the tissues in herbaceous plants. However, the sulphates present in the water have a very definite relationship to certain bacteriological processes supposed to accomplish decomposition of cortical portions of woody stems.

No analyses were made with reference to the gaseous contents of the Salton Sea water, but it contains manifestly an abundance of oyxgen, inasmuch as large numbers of fish were present during the summer of 1912. The water has a specific gravity of 1.001 . It is clear and quite free from sediment and may show an osmotic pressure of 5.5 atmospheres. The currents of the water are largely confined to those produced by the wind, since there is no outlet to the basin. A review of the physical facts indicates that the decomposition of vegetable tissue immersed in the water, even though some of the woods were covered for five years, could not be attributed to the action of non-biological agents. This conclusion was supported by the laboratory tests conducted with fresh woody tissues of Prosopis glandulosa, Prosopis pubescens, and Larrea tridentata, which remained absolutely intact during the eight months of submergence in sterilized Salton Sea water.

Biologically considered, the submerged condition of all of the herbaceous and woody plants would be, of course, fatal to those organisms within a short time and would remove them, therefore, entirely from the question of resistance to the physico-chemical factors of the Salton Sea. On the other hand, the temperature, the light, the gas-content, and the food supply were extremely favorable for the development of a rich bacterial flora. This was demonstrated by the fact that there were several thousand bacteria per cubic centimeter of water when first collected from the Salton Sea. These organisms were represented by several species, some of which were found to have a definite relation to the change in the chemical composition of the water and to the decomposing processes undergone by dead, submerged organisms. Inasmuch as the plankton did not seem to enter into this study all reference to that biological phase of the Salton Sea was omitted.

The specific investigations of this problem were directed (1) to an anatomical study of the species submerged from one to five years, and (2) to a bacteriological study of considerable quantities of the water itself and of processes undergone by fresh woods submerged in containers filled with Salton Sea water and maintained at room temperature in the Botanical Laboratory. 'The investigations concluded with an anatomical investigation of the fresh woods which had been kept under control in the laboratory during the months that the bacteriological experiments were carried forward. 
A
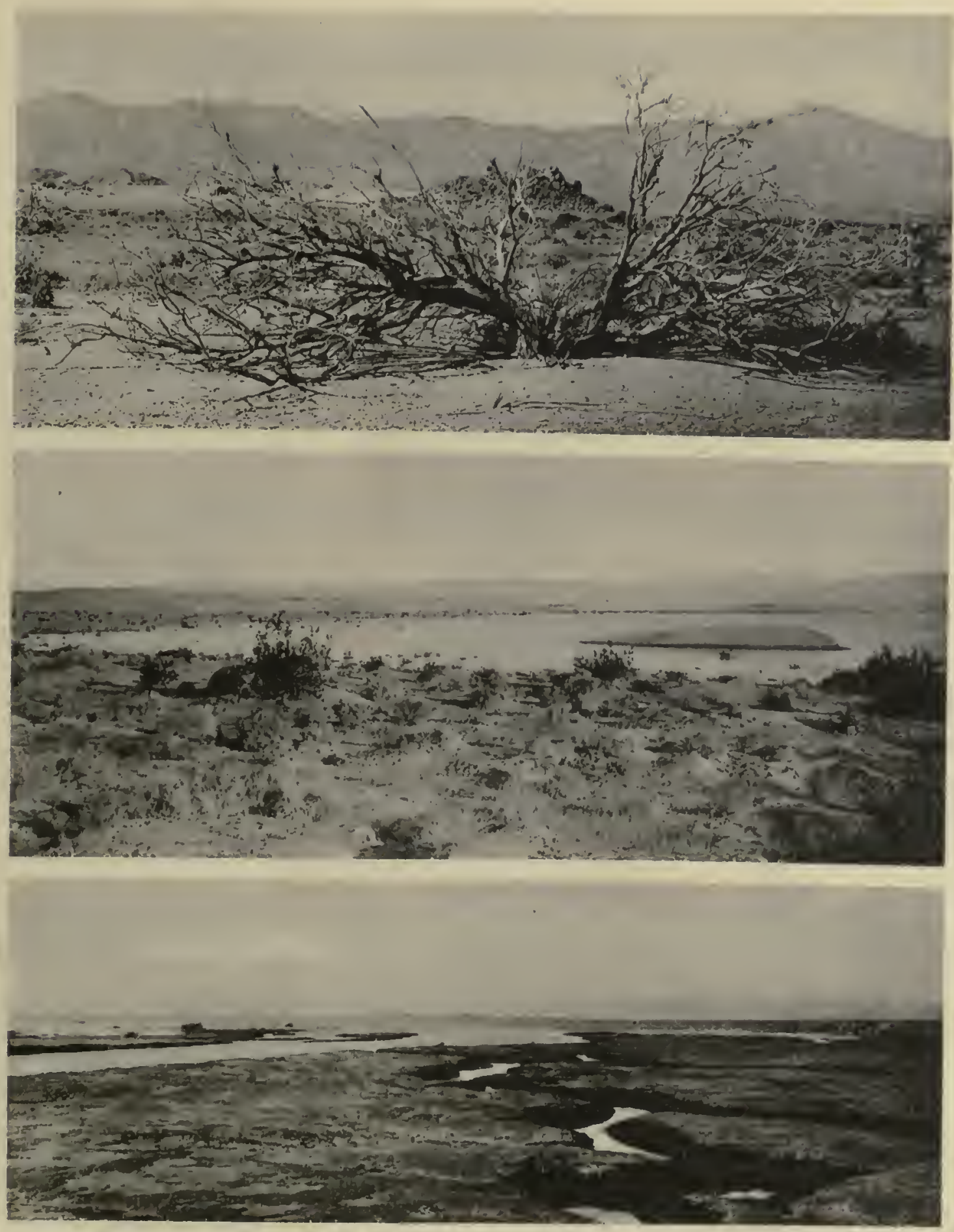
A. Prosopis glandulosa, the base of which was submerged in 1906 and laid bare late in 1907. Pholographed late in 1908
by D. T. MacDougal.

B. Segment of Crescentic Dune surrounded by Rising Waters of Lake in vicinity of Carrizo Creek, February 1907.

C. Tongues of Water from the Rising Sea in the Channels of Desert Washes, Imperial Junction Beach. February 1907. 



\section{ANATOMICAL STUDIES OF THE SPECIMENS SUBMERGED ONE TO FIVE YEARS.}

Obviously it was important to learu definitely what changes, if any, had taken place in the tissues of these woody plants during their term of submergence, as indicated in Plates 13 and 14l. It was found that almost the entire cortex had been lost from all specimens except those which emerged in 1907, after a single year's immersion. A detailed study of the cell walls was necessary in order to answer a question which had arisen relative to the possible procedure of petrifaction. In addition, to give opportunity for study of anatomical structures, a series of sections were made in the transverse, tangential, and radial planes. These were placed in various liquids in order to soften them for sectioning on a special type of swinging microtome. Sterile water, unsterile water, and concentrated hydrofluoric acid were used. It was impossible to secure sections thinner than 25 microns in any of the specimens not freed from mineral contents by hydrofluoric acid. In the specimens that were treated from one to three weeks in concentrated hydrofluoric acid and thoroughly washed it was possible to section 5 to 10 microns. In all cases the sections prepared from the water or hydrofluoric acid softened specimens were stained with a water solution of safranin for 24 to 36 hours and counterstained with aniline blue for a few seconds. These sections showed entire absence of epidermis, cortex, and phlocm. The woody cylinder was unchanged in the xylem, ray, and pith regions. These conditions were the same in both Prosopis and Larrea.

Microscopical measurements of the walls in the cells of the ray regions and pith and the xylem were made in order to determine whether there were variations in the tissues of the woods that had been submerged one, two, three, four, and five years. In no case was there any difference in the same region of the same plant. The walls of the ray cells were 1.9 to 2.5 microns thick; those of the wood fiber cells were 5.7 to 6.6 microns, and those of the trachex were 5.5 to 9.5 microns for Prosopis glandulosa; for the same regions of Larrea they were 1.4 to 2.3 microns, 0.9 to 4.8 microns, and 5.5 to 6.5 microns thick, respectively.

Sections of the woods softened in water preparatory to cutting were carefully examined for evidence of mineral deposition. In no case could crystals other than calcium oxalate be found. These crystals were present in the same relative places in the sections of the fresh woods and in similar quantities as they were in the dried woods that had bcen submerged. In view of this situation, one was forced to conclude that petrifaction had not been initiated in any of the woods submitted for study.

Since the samples of wood that were sent from the Salton Sea represented the final stages of the decomposition processes which had decorticated them it was thought best to secure water from the Salton Sea and reproduce, so far as possible, what had taken place in nature when the samples forwarded underwent decortication. Eight 5-gallon carboys of Salton Sea water were sent to Chicago, four of which were labeled (A), (B), (C), and (D). Pieces of fresh Prosopis glandulosa were placed in (A), of fresh Prosopis pubesccns in (B), and of fresh Larrea tridentata in (C); and fresh specimens of all three woods were placed in (D). These cultures were started on December 9, 1911. The tightly stoppered carboys were maintained at a temperature of $22^{\circ} \mathrm{C}$. After five days, there was a pronounced odor of hydrogen sulphide when the stoppers were removed from the carboys. A milky condition developed in all of the containers supplied with fresh woods. Carboy (C), containing Larrea tridentata, soon showed a remarkable growth of white threads festooned just below the neck of the earboy. These proved to be growths of Beggiatoa, which is semi-anaërobic. The threads were neither on the surface nor at the bottom of the carboy, but in an intermediate position with reference to the oxygen supply (Plate 14M). Later, white films formed on the surface of carboys (A), (B), and (D). A careful examination of these showed that they were composed of filaments of Beggiatoa and free sulphur liberated by the Beggiatoa when they used the hydrogen sulphide for energy releasal in 
place of free oxygen. According to Omelianski, ${ }^{1}$ Beggiatoa is dependent upon the action of Spirillum desulphuricans (which reduces the sulphates of mineral waters and liberates the hydrogen sulphide that serves the Beggiatoa for food supply), and the hydrogen sulphide is acted upon by an organism that oxidizes it and forms sulphuric acid. It was found that this acid acted upon iron and formed ferrous sulphide which dropped to the bottom of all of the carboys in considerable quantities as the foregoing processes proceeded in the carboys of Salton Sea water. Chemical analyses of water from the various carboys were secured through the kindness of Dr. Julius Stieglitz, of the Department of Chemistry of the University of Chicago. (Table 25.) Carboys (A) and (B) contained Salton Sea water, while carboys (C), (D), and (E) contained Salton Sea water into which specimens of Prosopis glandulosa, Prosopis pubescens, and Larrea tridentata respectively had been placed six months previously.

Tabue 25.-Analyses of water of Sallon Sea, in grams per 100,000 c.c.

\begin{tabular}{|c|c|c|c|c|c|c|}
\hline & \multirow{2}{*}{ (A) } & \multirow{2}{*}{ (B) } & \multicolumn{2}{|c|}{ (C) Prosopis glandulosa. } & \multirow{2}{*}{$\begin{array}{l}\text { (D) Prosopis } \\
\text { pubescens. }\end{array}$} & \multirow{2}{*}{$\begin{array}{l}\text { (E) Larrea } \\
\text { tridentata. }\end{array}$} \\
\hline & & & No. 1 & No. 2 & & \\
\hline $\begin{array}{l}\text { Chlorine (Cu) . . . . . . . . } \\
\text { Sulphurie (SOj) } \\
\text { Hydrogen sulphide }\left(\mathrm{II}_{2} \mathrm{~S}\right) \ldots\end{array}$ & $\begin{array}{l}394.735 \\
105.233 \\
\cdots\end{array}$ & $\begin{array}{l}397.512 \\
107.650 \\
\ldots \ldots\end{array}$ & $\begin{array}{c}400.140 \\
75.90 \\
1.9979\end{array}$ & $\begin{array}{l}401.100 \\
75.39 \\
1.0718\end{array}$ & $\begin{array}{r}397.040 \\
101.050 \\
.6088\end{array}$ & $\begin{array}{l}393.760 \\
105.800 \\
.08616\end{array}$ \\
\hline
\end{tabular}

In the waters which contained an appreciable quantity of hydrogen sulphide there was a decided decrease in the amount of sulphate ion, showing that the $\mathrm{SO}_{4}$ had been reduced. From the chemical analyses it is shown that every 100,000 of the parts of the Salton Sea water contain from 105.233 to 107.650 parts of sulphate ion before receiving the different woods. After retaining the wood specimens for six months the amount of sulphuric $\left(\mathrm{SO}_{4}\right)$ varied from 105.800 in Larrea tridentata to 75.39 parts in the culture of Prosopis glandulosa. It was necessary to determine whether or not these changes might have resulted from the direct action of substances in the water.

According to the work of Beijerinck ${ }^{2}$ this reduction of sulphates may have been accomplished by micro-organisms. One of the prominent anaërobic forms is Spirillum desulphuricans. He later' ${ }^{3}$ discovered forms that were less definitely anaërobic, which were able to aid in sulphate reduction. The final products of this bacterial action include sulphureted hydrogen as one of the main constituents. Thus we have an explanation of the large quantities of hydrogen sulphide that appeared in the cultures of Prosopis and Larrea in Salton Sea water. 'There were similar but less pronounced results in the cultures of these same woods in Lake Michigan water, and similarly the same when Robinia pseudacacia was placed in Salton Sea water and Lake Michigan water cultures.

The next modification in the chemical change of the output of these first bacterial forms is caused by Beggiatoa, according to Winogradsky." This organism uses the hydrogen sulphide as a source of energy releasal. The hydrogen sulphide is oxidized to sulphuric acid, and free sulphur is first stored in the cell and then liberated in a free condition. The sulphuric acid acts upon the carbonates or some of the bases, as iron, and forms sulphates and ferrous sulphide. This accounts for the large amounts of free sulphur which collected in the bottom of all of the culture carboys of Salton Sea water. It also explains why considerable ferrous sulphide collected in the bottom of the vessel in which the greatest amount of sulphuric was decomposed, i.c., Prosopis glandulosa, where the 105.233 parts per 100,000 of Salton Sea water were reduced to 75.39 parts after the $\mathrm{H}_{2} \mathrm{~S}$ was largely oxidized.

'Omclianski, W., (1) Centralbl. f. Bakt. 2 Abt., vol. viII, p. 193, 1902; (2) vol. XI, p. 369, 1901; (3) vol. XII, p. 33, 1904 .

'Beijerinck: Centrbl. Bakt., vol. II, 1, p. 1, 1895. a Beijerinek: Centrbl. Bakt., vol. II, p. 193, 1895.

"Winogradeky: Ueber Schwefelbacterien, Bot. Ztg., vol. LIV, p. 493, 1887. 
$14^{a}$
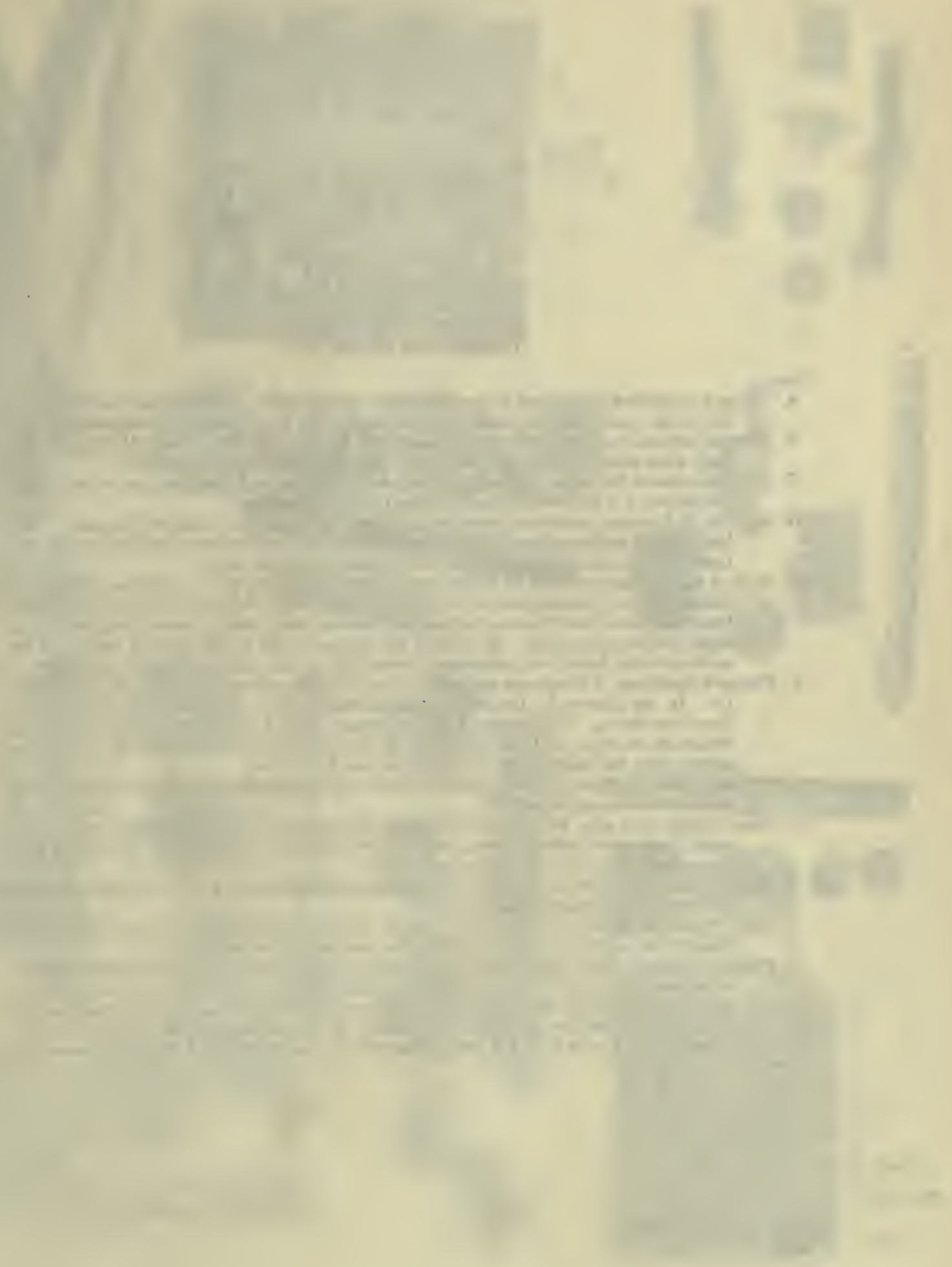


\section{Details of Plate 13.}

Figs.

A. Prosopis glandulosa submerged in the Salton Sea 1906 to 1908. Only the wood cylinder was left in this specimen, the cortex and phloem having been entirely decorticated.

B. Prosopis glandulosa after continuous submergence for two months in Lake Michigan water. Very little decortication had taken place at the completion of this period.

C. Specimens shown in B after two months more of submergence in Lake Michigan water. Slight decortication is shown in the two middle transverse sections.

D. Scctions of Prosopis glandulosa after two months of submergence in Salton Sea water. The longitudinal sections show far more decortication than was indicated in B, the specimens that had been submerged an equal time in Lake Michigan water.

E. Four of the specimens shown in D have now advanced greatly in decortication during four months more of submergence in Salton Sea water. All of the phloem and cortex is raised from the ends of the two long sections and entire decortication has occurred in the two small transverse sections. Hydrolysis has advanced far in the cambial regions of the sections which have been submerged constantly for six months in Salton Sea water.

F. Prosopis glandulosa in transverse section. This shows the cortex $(c)$, phloem $(p)$, and xylem $(x)$. In the phloem $(p)$ the rones of alternating lignified (lig.) and unlignified (unlig.) tissue are shown. Hydrolysis of the unlignified (unlig.) tissue here coincides with the broken-down layers in $\mathrm{D}$ and $\mathrm{E}$ where the lignified (lig.) tissue is lifted in well-defined layers, after the unlignified (unlig.) tissue was hydrolyzed.

G. Prosopis pubescens photographed after two months of submergence in Lake Michigan water. Decortication is slight as in $B$.

H. Same culture as $\mathrm{G}$ aftcr two months of further submergence in Lake Michigan water. The upper transverse section shows considerable decortication after four months of submergence in the Lake Michigan culture.

I. Prosopis pubescens after two months of submergence in Salton Sea water. Some decortication is shown in one transverse section.

J. Same culture as shown in I after two months more of submergence in Salton Sea water. Marked decortication is indicated by the four transverse sections.

K. Prosopis pubescens showing the cortex $(c)$, phloem $(p)$, and xylem $(x)$ in an interesting rclation when compared with F. Here closely associated lignified (lig.) zones are separated by very thin unlignified (unlig.) regions, consequently Prosopis pubescens does not decorticate after the manner of Prosopis glandulosa. A comparison of $\mathrm{K}$ and $\mathrm{F}$, and comparisons of $B$ and $C$ with $G$ and $H$, also a comparison of $D$ and $E$ with $I$ and $J$ are instructive. 

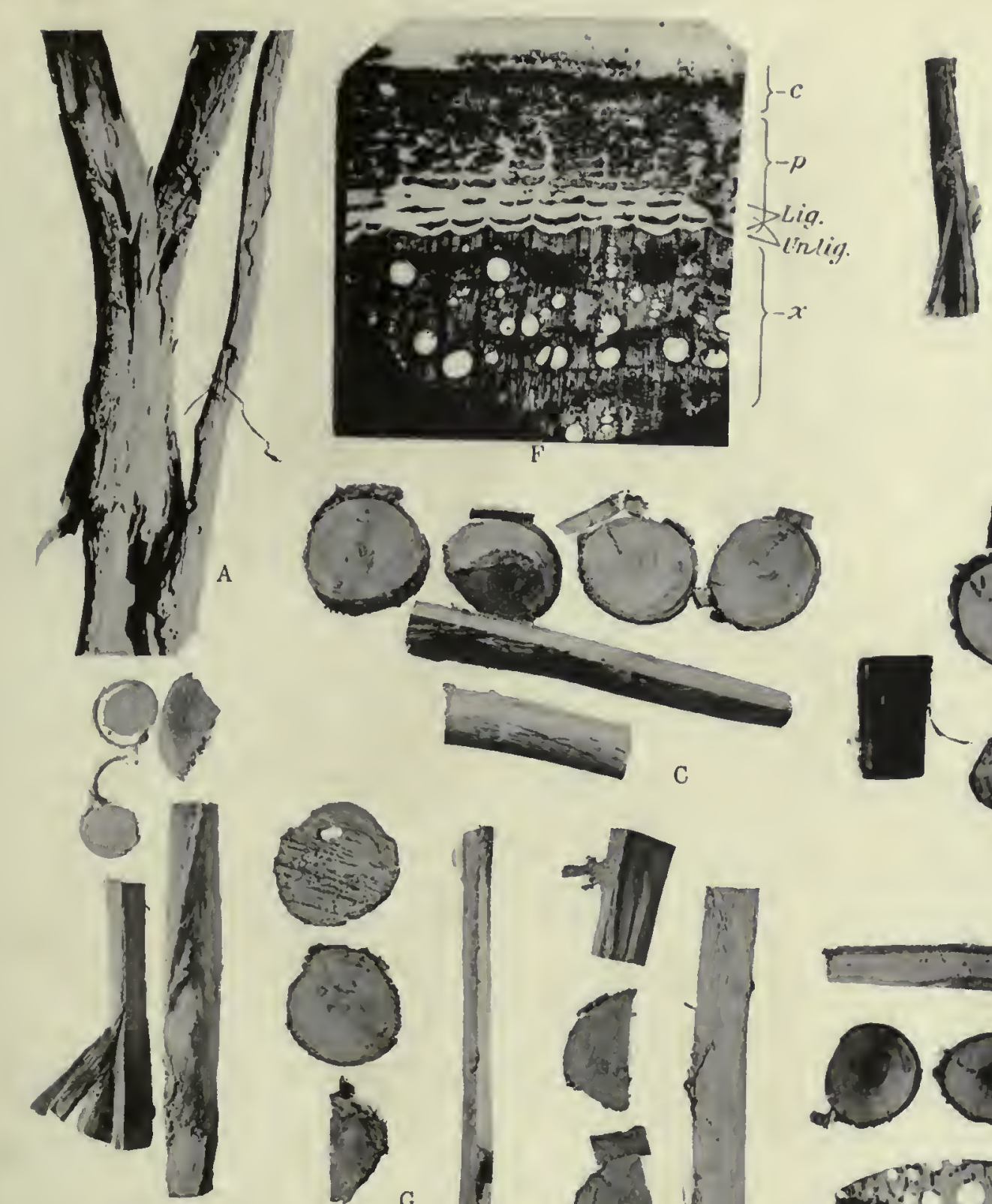

PLATE 13
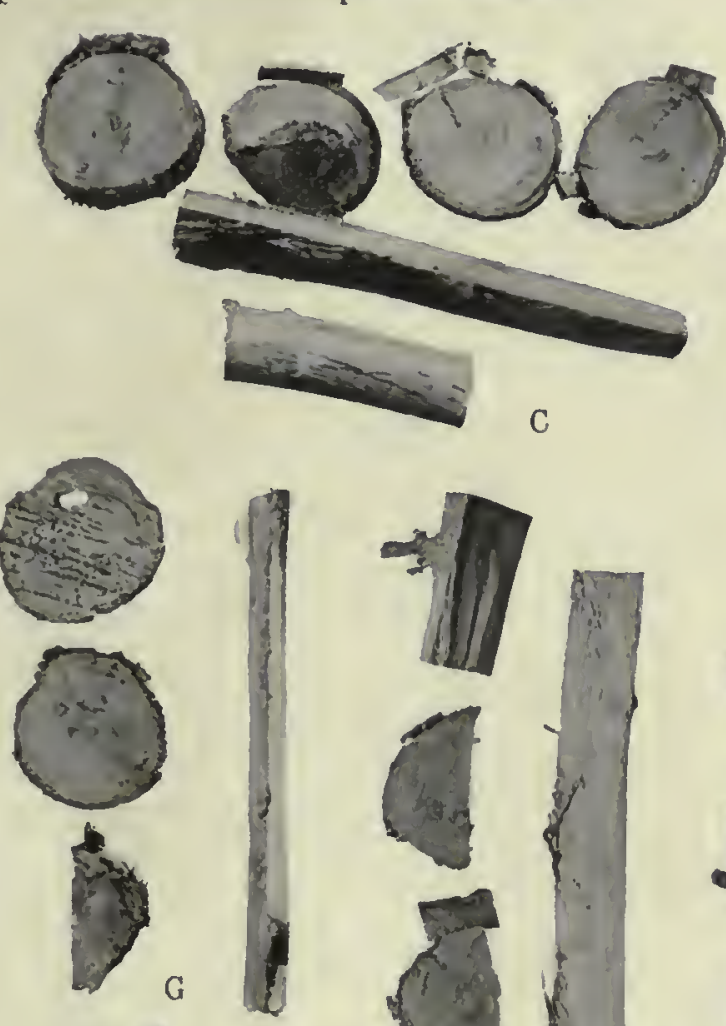

$\mathrm{E}$
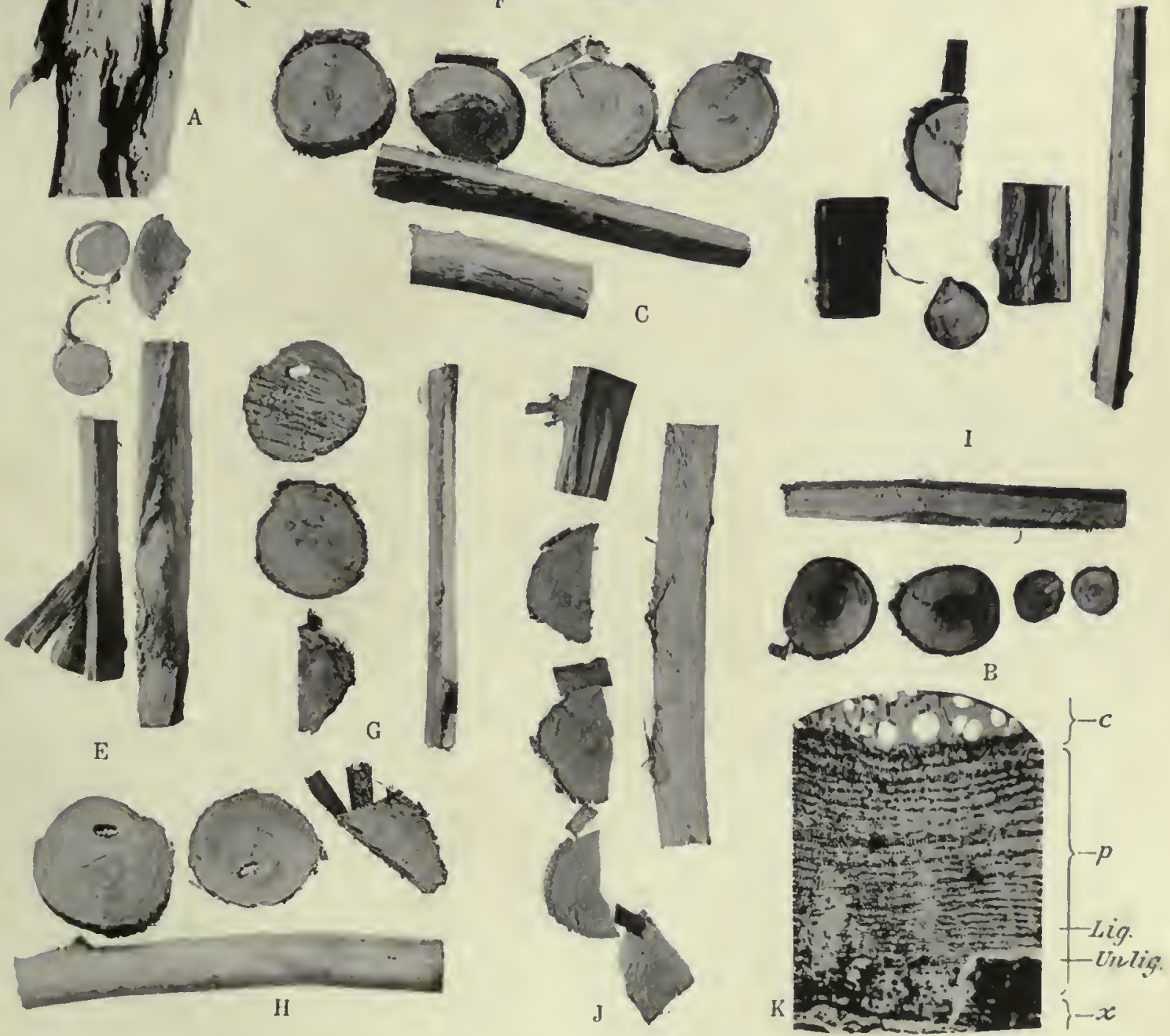

Prosopis glandulosa and Prosopis pubescens in various Stages of Decortication. The Water Cultures in this work were maintained at Room Temperature of $22^{\circ} \mathrm{C}$. 

It is not understood that these analyses represent the ehemical conditions of cultures, in which the various woods were placed, during the entire time of the investigation, inasmuch as the chemical changes were taking place constantly due to the bacterial organisms which were redueing the sulphates and the organisms which oxidized the sulphureted hydrogen. It is quite certain, therefore, that chemical analyses taken at other periods would have slown a different relationship existing in the quantities of sulphates contained in the cultures of these various woods. I'or instance, in the culture of Larrea tridentala the evidence of the evolution of hydrogen sulphide preceded that in the other culture. $\Lambda n$ analysis gotten at the time the supply of hydrogen sulphide was especially abundant in the Larrea culture would certainly have given somewhat different results from those indicated in the above table for Larrea tridentala.

Chemical evidence shows that whenever an appreciable quantity of hydrogen sulphide is present in water whose sulphates have been acted upon by bacterial organisms, the reduction of sulphates has taken place and the decrease in the amount of sulphates is approximately proportional to the increase of the hydrogen sulphide.

Since the Beggiatoa lays hold of the hydrogen sulphide for energy releasal and oxidizes the sulphide, giving rise to acids, the question alises, might not any break-down of woody tissue present in a culture where this process was going forward be due to the presence of newly formed acids? This question was disposed of by the fact that the quantity of acids is very small and is immediately cared for by bases present in the water. Therefore, interesting as are these chemical changes, due to the reduction action of Spirillum desulphuricans and the oxidizing action of Beggiatoa, they can not be held to explain the decorticating changes observed in the wood sections placed in cultures of Salton Sea water.

\section{DECORTICATING PROCESSES IN SPECIMENS OF FRESH WOOD IMMERSED IN SALTON SEA WATER.}

If the substances in the water of the Salton .Sea, either before or subsequent to the processes carried on by the organisms above mentioned, were not active in producing decortication, there is only one possible avenue of investigation open in search for the causal factors of cortex removal.

Certain enzyme-producing bacteria would in all probability have access to the tissues which were decomposed. Investigations with reference to these forms were instituted in two directions; first, a series of controlled cultures were prepared consisting of three sets: A, a series of sections from Larrea tridentala, Prosopis glandulosa, and Prosopis pubescens were sterilized and placed in cultures of unsterilized Salton Sea water; B, sections of the same woods unsterilized were placed in cultures of sterilized water; C, sections of the same woods were sterilized and placed in cultures of sterilized Salton Sea water. These cultures were kept at room temperature and series A and $B$ soon gave evidences of bacterial activity. The changes in $B$ series were considerably greater than those in $A$, while series C remained inactive. 'Throughout the whole test it was noted in the sections from series $A$ and $B$, after three weeks of culture, that the cortex and phloem loosened and slipped from the woody cylinder with ease.

In addition to the controlled cultures, sections of fiesh Prosopis glandulosa were made in transverse, longitudinal, and tangential sections and placed in a 5-gallon carboy. Also specimens of branches 15 to 25 c.c. long were immersed in the same gross culture. Some of these branches were paraffined at the end, so that no bacterial organisms could secure a portal of entry to the cortex except through a superficial break in the epidermis. Other specimens were broken in such a way as to leave a ragged and exposed surface at the ends, giving the most ready access to the cortex, phloem, and cambium. Similarly 5 -gallon carboy cultures were made of Prosopis pubescens and Larrea tridentata. These gross cultures kept under observation for six months gave distinct results with reference to decortication 
wherever a portal of entry to the tissues of cortex, phloem, and cambium had been provided. On the contrary, the specimens whose ends had been protected by paraffine caps possessed a firm, close cortex and phloem which adhered as tightly to the woody cylinder five months after the eultures were made as when the specimens were first immersed.

The various stages of progressing decortication are indicated in Plates 13 and 14. In the latter stages the effects of decortication are pronounced, notably in Larrea tridentata (Plate 14, P, Q, o.) Moreover, it is evident that wherever the branches had sharp and even sections (Plate 13, B, C, G, HI, I, and Plate 14, transverse sections of $\mathrm{N}, \mathrm{O}, \mathrm{P}, \mathrm{Q}$ ), the progress of decortication was far less rapid than in those branches which were broken at an angle producing ragged, jagged fractures, which furnished an admirable portal of entry to any bacterial organisms present in the culture. (Plates 13, D and $\mathrm{E}$, and 14, N, O, P, and Q.)

In order to make microscopical investigations of the changes in the immersed specimens, seetions of the various woods were prepared. Different methods of technique were employed, but the most successful results were secured when specimens of wood were softened for three weeks in hydrofluoric acid, thoroughly washed and imbedded in gelatine, hardened in formaline, and sectioned in a swinging microtome, stained 36 hours with safranine followed by a very brief treatment with aniline blue. Studies of these woods showed that the tissues of the woody cylinder were unchanged, likewise the lignified regions in the phloem were unaltered. (Plate 13, $\mathrm{F}$ and $\mathrm{K}$, and Plate 14, $\mathrm{r}$.) A distinctly different condition was present in unlignified parenchyma zones which alternated with the lignified zone in the phloem; and a notably disintegrated state of affairs was found in the region of the cambium. The walls of the meristem were totally dissolved in places and disintegration following the hydrolysis of these delicate walls had progressed so far that the slightest disturbance caused a breaking away of the whole cambial region from the woody cylinder, marking, of course, a completion of the decorticating process (Plate 13, $\mathrm{D}$ and $\mathrm{E}$, and Plate 14, $\mathrm{P}, \mathrm{Q}$, and $\mathrm{o}$ ). The two factors entering into this lack of uniform decortication are the number of layers of cambial cells intervening between the phloem and xylem and the degree of accessibility afforded to the agents which might act upon the walls of the cambial cells. This, in a measure, would explain why some trees, submerged for five years in the Salton Sea, were found to have patches of cortex remaining after they were exposed by the lowering of the water level.

The breaking down of the walls in the zone of the cambium and in the meristematic regions of the unlignified zones in the phloem (see Plate 13, D and E, and Plate 14, P and Q), call not be accounted for merely by reason of their having more delicate structure than that which characterizes the cells in the woody cylinder and in the lignified zones of the phloem. It is true that it would be possible to rend delicate tissues of this character if considerable physical force were applied to external parts of the uninjured specimens. Such an explanation, however, does not fit this case of decortication. There is a difference not only in the strength of the cell walls in these different regions, but there is a difference in the chemical composition of the walls of the cells of the cambium, the woody cylinder, and the lignified regions of the plloem. This was set forth by Mangin ${ }^{1}$ who held that the cellular meinbrane in young tissues differed from that in adult tissues. He definitely denied that cell walls were composed of pure cellulose. He affirmed that they were always associated with groups of pectins which are essentially distinguishable by color reactions and by certain optical properties, and by great mutability under the action of acids and bases. After conducting extended researches, he concluded that tissues might have their cell walls disassociated by four different processes: (1) prolonged boiling in pure water; (2) prolonged boiling in a 2 to 5 per cent solution of caustic soda or caustic potash; (3) continued action in a cold, weak acid and solvents of pectic acid, alkalines, alkaline salts, ammonia water, and organic acids; and (4) it was possible that certain organisms, which

\footnotetext{
Mangin: Jour. de Bot., vol, vir, p. 336, 1893.
} 


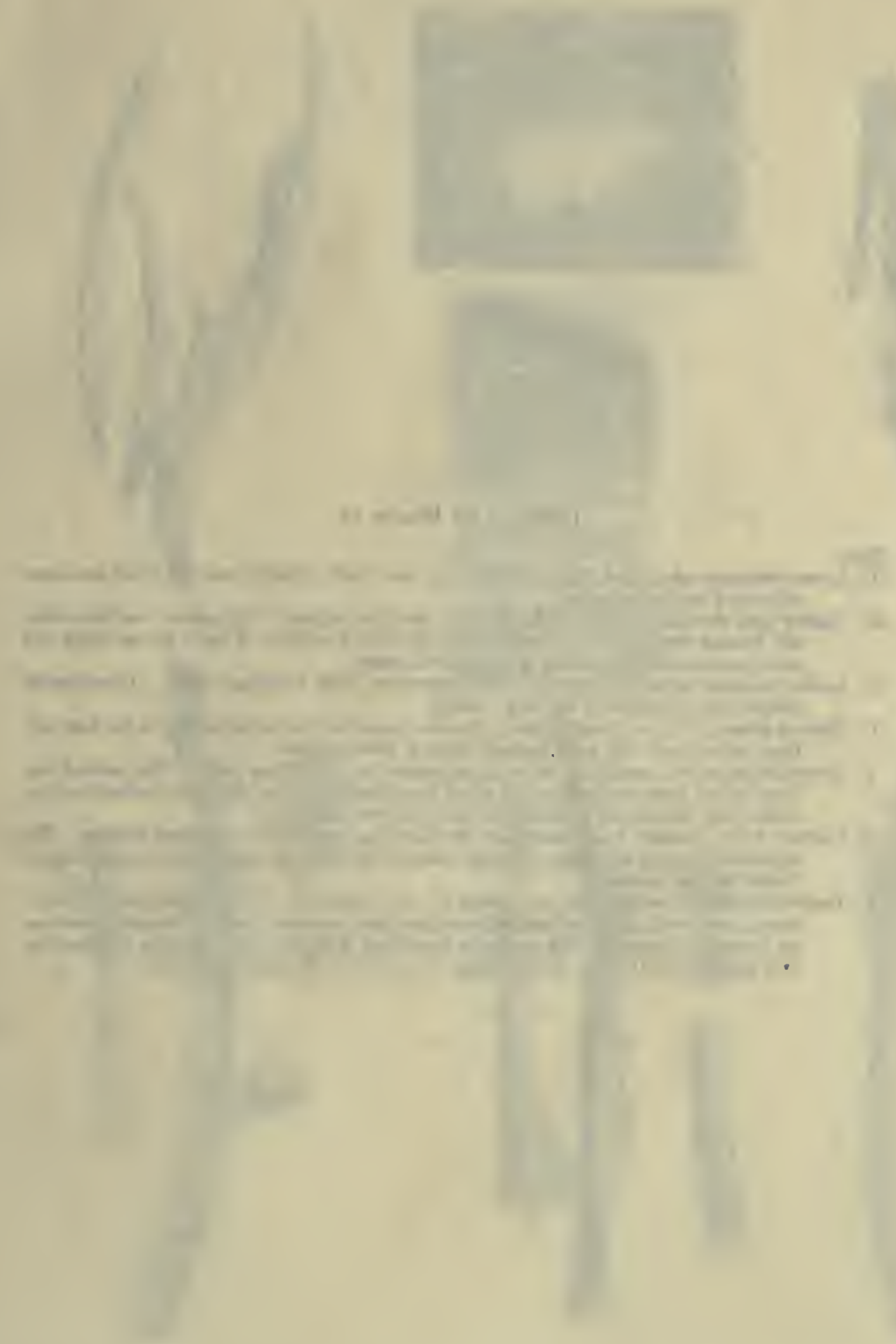




\section{Detalls of Plate 14.}

Figs.

L. Larrea tridentata submerged 1906 to 1908 . Only the woody cylinder was left in the specimen submitted for investigation.

M. Carboy neck showing filaments of Beggiatoa in great abundance. This culture was two weeks old, having developed in the carboy shortly after specimens of fresh Larrea wood had been immersed in the carboy of Salton Sea water.

N. Larrea tridentata after two months' submergence in Lake Michigan watcr. Considerable decortication is shown in the long sections.

O. Culture shown in $\mathbf{N}$ two months later, when decortication has advanced far in the long sections whose ends had been twisted prior to submergence.

P. Larrea tridentata two months after being submerged in Salton Sea water. The twisted portions of the long spccimens show great decortication, while the transverse sections are entire, and there is no breaking away of the cortical zone.

Q. Culture $\mathbf{P}$ two months later, when the decorticating process has advanced further. The transverse section has begun to break away in the cambial region after four months of Salton Sea submergence.

R. Larrea tridentata showing cortex (c), phloem $(p)$, and xylem $(x)$. The unlignified zone (unlig.) here is very wide, and the lignified zones are less numerous than in Prosopis glandulosa or Prosopis pubescens. This is closely associated with the different types of decortication indicated in $\mathrm{D}, \mathrm{E}, \mathrm{I}$, and $\mathrm{J}$ of plate 13 , and $\mathrm{N}, \mathrm{P}, \mathrm{O}$, and $\mathrm{Q}$ of plate 14 . 

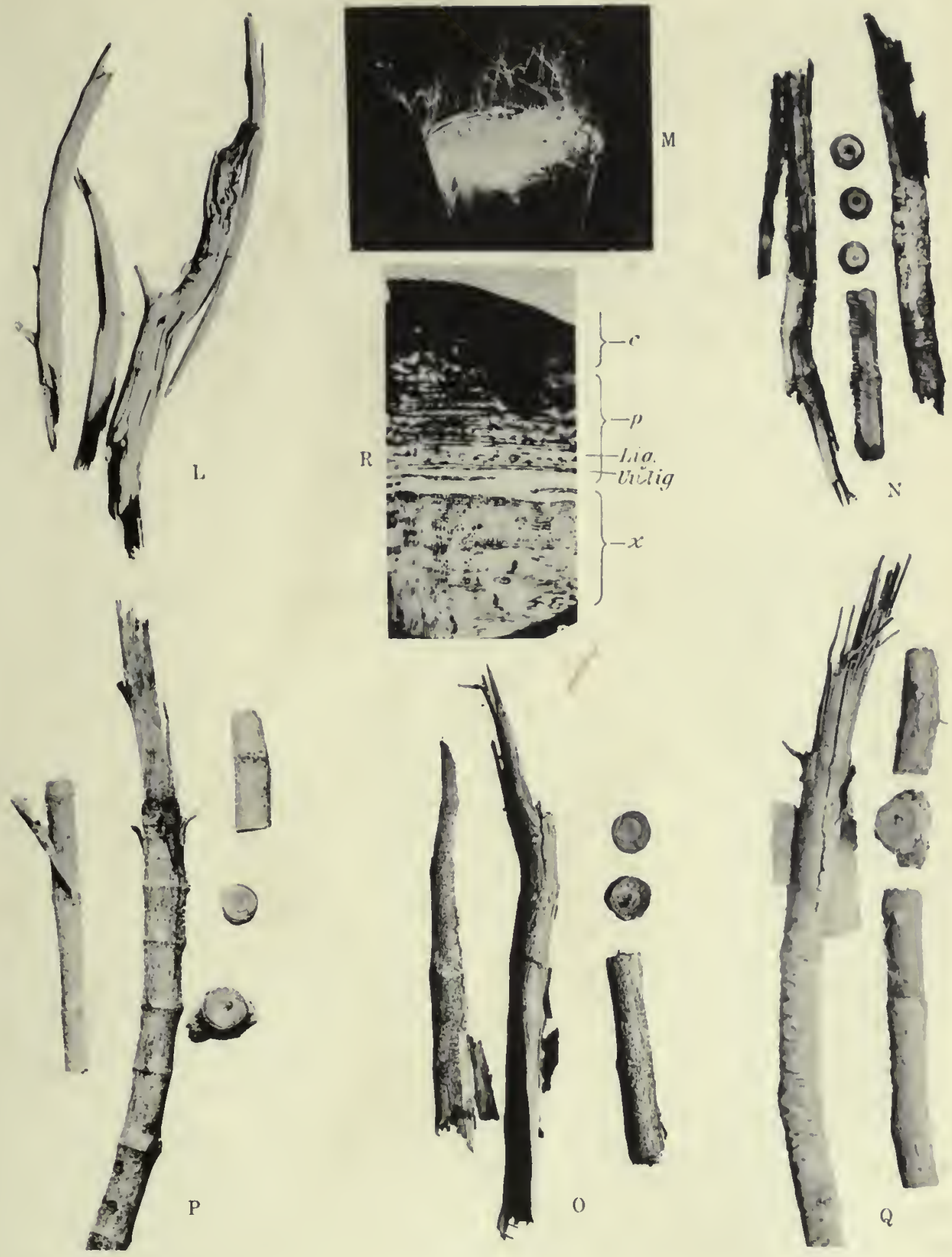

Larrea tridentata in different Stages of Decortication. Transverse Section of Fresh Non-immersed Stem, and also a Culture of Beggiatoa. The Water Cultures were maintained at Room Temperature, $22^{\circ} \mathrm{C}$. 

nourish themselves upon pectic compounds, could effect a disassociation of tissues. In this group of organisms be included a group of bacteria known as the Amylobacter group. Mangin in this last conclusion was supported by previous workers, van Tieghem ${ }^{2}$ and Trecul. ${ }^{2}$ Louis Gaucher ${ }^{3}$ held that the cell membranes were degenerated through the action of bacteria bringing about what he termed an abnormal pathological condition. Speaking of the relation of gums and pectin, ${ }^{4}$ he states that a member of the Leguminosa family, Acacia vereck, breaks down the walls of cells, disengaging all the vascular parts of the plant. In that case the pectin would be hydrolyzed by enzymes produced within the tissues of the growing plants. In other cases he quotes Mangin, who claimed that gum might be made to appear in the cortical parts of plants by injuring their branches with repeated blows upon the bark. In discussing these phenomena, however, these investigators note that the cell walls are composed of a series of complex carbohydrate compounds including pectic acid, pectose, pectin, and cellulose. They note that these substances may be modified in various ways through abnormal and normal processes. But in every case the modification is brought about cither through action of a hydrolyzing agent produced entirely by the cells of the living plant itself, sometimes in a normal and sometimes in an abnormal condition, or else by the presence of invading organisms such as the Amylobacter which had gained access to the tissue whose cell walls had not become wholly lignified but were in the early stages of being laid down.

Subsequent to the completion of the experimental work witl the freslı woods received from the Salton Sea region, it was suggested by Professor Joseph S. Caldwell that the decortication processes were similar to those involved in the retting of flax liemp. This suggestion was supported by an examination of the work of M. S. Winogradsky, ${ }^{6}$ who carried on numerous experiments and investigations with waters concerned with the mass erosion of vegetable tissues. In these researches he came to the conclusion that lie had to deal with a specific bacterial organism which he isolated in his fermentation experiments. This organism was apparently widespread and, according to Winogradsky, might be looked for in any waters where the successful retting of flax was carried forward.

In a later work, Professor Dr. J. Behrens investigated the retting of flax and hemp. ${ }^{6}$ Professor Behrens, by means of extensive laboratory experiments, opposed the view of Hauman, namely, that the retting of flax and other vegetable tissues could be carricd on successfully by many different species of bacteria. In a table containing a report upon a series of controlled cultures, he itemizes the organisms which would be able to produce so-called retting of flax and hemp. His general conclusions were that this work should be referred to definite and specific organisms.

Some of the best work in investigating cellulose fermentation was carried on by W. Omelianski. ${ }^{7}$ His investigations were concerned with several pliases of cellulose fermentation, such as the hydrogen fermentation of cellulose, the methane fermentation of cellulose, and the fermentation of cellulose through the dentrifying bacteria, aërobic bacteria, and mold fungi. Following his suggestions, it was possible to isolate an organism which grew upon sterile filter paper, which was apparently hydrolyzed by its action. In harmony with Omelianski's findings, this organism, which was isolated from Salton Sea water, required a long time for its incubation upon cellulose. The solution employed was composed of phosphate of potassium 1 gram, magnesium sulphate 0.5 gram, sulpliate of ammonia 1 gram; a very small quantity of sodium chloride in a liter of distilled water used as a solvent. Steril-

'van Tieghem, Ph., (1) Comptes rend. de l'Acad., 1879, vol. 88, p. 205. (2) Also vol. Lxxxrx, pp. 25 and $1102,1879$.

(3) Bull. de la Soc. Bot. de France, vol. xxIv, p. 128, 1877; vol. xxvi, p. 25, 1879; also vol. xxvir, p. $243,18 \$ 1$.

2 Trecul, A.1 (1) Comptes rend. de l'Acad., vol. IXI, pp. 156 and 436, 1865; also vol. Lxv, p. 513, 1867.

${ }^{3}$ Gaucher, Louis: Etude générale de la membrane eellulaire, 1904.

4 Gaucher, Louis: Ibid., p. 207, 1904.

Winogradsky, M. S., Sur le rouissage du lin et son agent microbien. Comptes Rendu, vol. cxxi, p. $742,1895$.

- Behrens, J., Úcber die Taurotte von Flachs und Ilanf. Parasitenkunde und Infektion krankheiten, vol. $x, p p$. 524-530, 1903.

' Omelianski, W.: See note 3. 
ized strips of filter paper were then placed in this solution, and flasks containing these preparations were inoculated with 10 to 50 c.c. of water from the different cultures of the Salton Sea woods. These were incubated at room temperature and, of course, accompanied by controls. At the expiration of a week's time, a slight cloudiness was observed in the inoculated cultures. Within a few days small colonies were observed growing on the filter paper. These conformed in essential respects to the group of organisms described by Omelianski as capable of carrying on hydrolysis of cellulose. They were isolated most satisfactorily from the culture of Salton Sea water containing Prosopis glandulosa. There was every evidence that suceessful cultures depended upon using large quantities of the inoculating fluid, though it is probable that small pieces of the infected wood might have been far more effective as an inoculating agent than was the water in which the wood was immersed.

In view of the findings of the authorities quoted there seems to be no question that the disintegration of cambial cell walls and consequent removal of the cortical and phloem portions of woody plants submerged in brackish waters is to be attributed to the action of bacterial organisms belonging to the Amylobacter group. From this it would seem that the present problem and the mass erosion carried on by substances present in the water where flax and hemp are retted are related to such economic problems as the breaking down of cellulose or its related compounds when they pass through the digestive tract of animals, or through the septic tank of sewage-disposal plants, and also to the ultimate breaking down of the mantle of humus overspreading the earth. ${ }^{1}$

\section{SUMMARY.}

1. Woody plants submerged by the flooding of the Salton Sea were found to be decorticated after a period of one year.

2. Microscopical preparations of samples of fresh woods placed in Salton water and kept under control were found breaking down in the zonc of meristematic cells, notably in the region of the cambium and in the zones between lignified regions of the phloem.

3. The chemical composition of Salton water could not account for the decortication of woody plants submerged in the sea for a period of one to five years.

4. Sterilized specimens of fresh woods placed in sterilized Salton water did not decorticate during the ten months they were kept under inspection.

5. Bacteriological cultures made it possible to isolate the bacterial organisms, belonging to the Amylobacter group, which produce an enzyme capable of hydrolyzing pectins which are considered by some chemists to be the principal substances in young cell walls.

6. A microscopical study of woods which emerged annually from the autumn of 1907 to 1911 did not show breaking down of cell walls in any portion of the wood eylinder. Cell walls of the same tissue in the woody specimens of all the species examined were characterized by the same general thiekness.

Consequently, it is believed that the action of the Salton Sea water on tissues of woody plants is wholly related to hydrolyzing agents having a bacterial origin; and, furthermore, evidence is lacking that petrifaction had begun in the tissues of the woody plants submerged for four years in the Salton Sea.

It is a pleasure to make grateful acknowledgment of the helpful suggestions received from Prof. John M. Coulter and Dr. W. J. G. Iand during the time that these investigations werc continued. I am especially indebted to Dr. Land for valuable directions in developing technique suitable for making microscopical preparations of the bone-hard specimens of dead woods which were received from the Salton Sca for study.

${ }^{1}$ While reviewing the above manuseript for publieation, Bulletin 266 from the Bureau of Plant Industry of the U. S. Dept. of Agriculture was received. This bulletin reports results obtained by Physiologist I. G. MeBeth and Assistant Boil Mycologist F. M. Seales, while they were investigating "The Destruetion of Cellulose by I3acteria and Filamentous Fungi." In determining the work of eellulose-dissolving baeteria they made "examinatjons of sewer slime, of manures, and of the soils of the United States." Apparently their studies are allied to, but in no sense identical with. the Salton Sea problems of cellulose hydrolysis. 


\title{
THE TUFA DEPOSITS OF THE SALTON SINK.
}

\author{
Bt J. Claude Jones.
}

One of the most eharacteristic deposits left by the Quaternary lakes of the Great Basin are the masses of calcarcous tufa found in their former basins. Those of ancient Lakes Bonneville and Iahontan especially have been noted by the geologists who examined them and they have been thoroughly studied by Gilbert ${ }^{1}$ and Russell. ${ }^{2}$ In accounting for these deposits it was supposed that they wore due to chemical precipitation resulting from the concentration of the lake waters by evaporation or through the mechanical expulsion of loosely combined carbon dioxide through wave-action.

An examination of specimens of the tufa at present forming in the shrinking Salton Sea disclosed the intimate association of vegetation with the deposit and suggested an alternate hypothesis as to its origin. The present study, made possible through the kindness of Dr. D. T. MacDougal and Mr. E. E. Frec, has indicated that this hypothesis applies to the older tufa deposited in the same basin by the former Blake Sea, and it is not impossible that much of the tufas of the other Quaternary lakes have a similar origin.

\section{THE PRESENT TUFA DEPOSITS.}

During 1906 and 1907 the rising water of the present Salton Sea killed the shrubs and bushes growing on its former shores. As the water receded the dead vegetation remained standing and in 1910 it was noted that a calcareous incrustation or tufa was forming on the submerged twigs and branches. When this tufa is first taken from the water it is soft, gelatinous, and dark greenish-gray in color. On drying it hardens, becomes much lighter in color, and takes on the characteristic appearance of a tufa.

The deposit is a millimeter or so in thickness, with a roughened surface covered with minute warty excresecnees. It is not a simple uniform coating, but is made up of a multitude of protuberant individual deposits. These vary in size from a pin-head up to 0.5 centimeter in diameter and, broadening in their outward growth, coalesee, forming a fairly uniform coating with interspaces scattered here and there where little or no deposit has formed.

A hand-lens disclosed many thread-like green alga originally projecting beyond the mass of the tufa but matted down over its surface with the drying out of the material. By dissolving the tufa with weak acetic acid the alga were isolated. This material was referred to Mr. C. I. Brown, of the University of Nevada, who identified the alga as a species of Calothrix, probably either $C$. thermalis or parietina.

In thin sections of the tufa the carbonates were found to be very fincly crystalline and with a characteristic cloudy appearance. While it was possible to recognize individual crystals under the higher powers of a compound microscope, yet the cloudier material could not be resolved into separate grains. Under an oil immersion objective the cloudy appcarance disappeared almost cntircly and it is possible that it was caused by the reflection of light from the surfaces of submicroscopic crystals.

' G. K. Gilhert, U. S. Geol. Surv. Monographs, vol. I, 1890. ' ${ }^{2}$ I. C. Russell, U. S. Geol. Surv. Monographs, vol. II, 1885. 
The mineral matter was grouped about the algal threads and partially filled the interspaces. As a result, the tufa is very porous and many vacant interspaces remained. Just beyond the main mass of the deposit minute isolated crystals of the carbonates could be noted attached to the free ends of the alga.

An analysis of the tufa, by Mr. C. N. Catlin, of the Arizona Experiment Station, shows it to have the composition shown in table 26.

The undetermined substances were stated to eonsist largely of organic material which it was impossible to separate entirely from the deposit. The analysis shows the tufa to consist essentially of calcium carbonate with minor amounts of calcium sulphate and magnesium carbonate. The organic matter was evidently the included algx.

Omitting the undetermined substances and recalculating the analysis to 100 per cent, it is interesting to compare its eomposition with that of other tufas and a marl deposited in Michigan that has been shown to originate through the activity of alga (table 27).

TABLE 27.

\begin{tabular}{|c|c|c|c|c|c|}
\hline & No. 1. & No. 2. & No. 3 . & No. 4. & Remarks. \\
\hline 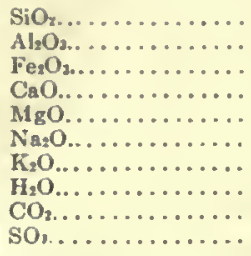 & $\begin{array}{r}4.16 \\
1.96 \\
47.49 \\
2.61 \\
\ldots \ldots \\
2.36 \\
39.0 .1 \\
2.38\end{array}$ & $\begin{array}{l}5.06 \\
1.29 \\
49.14 \\
1.90 \\
\cdots \cdots \\
2.01 \\
40.31 \\
\text { tr }\end{array}$ & $\begin{array}{r}8.22 \\
1.20 \\
4 \mathrm{r} \\
46.50 \\
3.52 \\
0.54 \\
0.22 \\
1.62 \\
38.33 \\
\cdots \cdots\end{array}$ & $\begin{array}{r}2.40 \\
0.89 \\
52.52 \\
1.41 \\
\cdots \cdots \\
\cdots \cdots \\
42.78 \\
\cdots \cdots\end{array}$ & $\begin{array}{l}\text { No. } 1=\text { Salton tufa, omitting organic matter } \\
\text { and recaleulated to } 100 \text { per cent. } \\
\text { No. } 2 \text { = Lahontan dendritic tufa, U.S. G.S. } \\
\text { Monographs, vol. } 11, \text { p. } 203 \text {. } \\
\text { No. } 3=\text { Bonneville tufa, } 40 \text { th Parallel Sur- } \\
\text { vey, vol. 1, p. } 502 \text {. } \\
\text { No. } 4=\text { Mtineral incrustation of "Chara" } \\
\text { forming ehief constituont of marls, C. A. } \\
\text { Davis, Jour. Geol., vol. } S \text {, p. } 492,1000 .\end{array}$ \\
\hline Total......... & 100.00 & 99.80 & 100.14 & 100.00 & \\
\hline
\end{tabular}

The general similarity in composition of the present Salton tufa to the older tufas of the Quaternary lakes is very striking. Especially noteworthy is the constant small amount of magnesia found in all tufas. The signifieance of the presence of sulphates in the recent tufa in eontrast with its absence in the older deposits can not be stated, but it is not impossible that if the former were exposed to the weather for any length of time the more soluble sulphate would be leached to a large extent.

The similarity of analyses No. 1 and No. 4 is still more suggestive. Davis ${ }^{1}$ has demonstrated that the formation of the Michigan marls is in a large measure due to the activities of both Chara and the blue-green alga. His analysis was marle on the material leached by hydrochloric acid from the stems of Chara; and its close similirity to the Salton tufa, both in composition and the close association of the algx with the deposits, implies a like origin.

Aside from the submerged stems and branches of the dead shrubs about the shores of the lake the only other locality where calcareous deposits are forming at the present time is on the submerged volcanic hills at the southern end of the lake. The writer was unable to visit them, but was informed by Mr. Free that a tufa was there forming on the rocks similar to that found on the shrubs. As far as is known at present, there is no general deposition of calcareous material other than the tufa and no eemented sands or oolites have been discovered on the present beaches.

${ }^{1}$ C. A. Davis, Jour. Geol., vol. vil1, pp. 485-497, 1900; vol. ix, pp. 497-506, 1901. 
THE TUFAS OF BLAKE SEA.

The ancient lake, Blake Sea, that formerly filled the Salton Basin, left among the other records of its existence an extensive tufa deposit. As is the case with the present tufa, it is limited in its distribution to the localities where the waters bathed resistant material. The older tufa is found only along the northwestern shore, where the granites of the Santa Rosa Mountains were washed by the sea. The principal deposit is displayed at Travertine Point, although tufa is found on the cliffs and on boulders of granite scattered over the desert sands for several miles to the south. At the time of the Blake Sea, Travertine Point was a low-lying serrate spur or group of granitic hills extending in a semicircle a half mile to the northeast from the mountains. These were submerged by the rising waters until only a few feet remained above the surface of the sea. During the time that the water stood at its highest level, bars of granitic sand were built out from the slore until as the waters began to subside the hills had been comneeted with each other and the shore as typical land-tied islands.

With the retreat of the sca the slopes of the bars were slightly notched by the waves, leaving many distinct recessional terraces. Although these were cut but a short distance in the yielding sand, there has not been sufficient wind erosion since to efface them and they are practically as the sea left them.

At the outermost of these land-tied islands, the original granite hill rose abruptly some 175 fect from the desert sands at its base. Its sheer cliffs were concealed nearly to the top by a steep talus composed of huge boulders up to 10 feet in diameter that had broken and fallen from the cliff. In the cave-like recesses left between the boulders one may penetrate at times 25 or more feet from the surface of the cliff.

The tufa covers the boulders on all surfaces where they are not in contact. It is dendritic in character and at first sight secms to be a vegetative growth fixed through petrifaction on the surfaces of the rocks. 'The illusion is lieightened by the tendency of the projecting columns and spurs to turn upward and outward towards the light.

On the outer surfaces of the boulders the tufa is uniformly about 30 inches thick over a vertical range of 120 feet. In places the growing tufa had evidently been broken from the rocks by the waves and the vacant space healed over by a fresh growth, leaving abrupt local changes in the thickness of the deposit. 'These were entirely local and measured by a few feet, with no relation either to each other or to vertical distribution.

At the base of the cliff the tufa rather abruptly diminished in thickness, probably due to the reccssion of the water. At the top a mere film near the ligh-water mark indicated the first deposition of tufa. Within 4 feet of the high-water mark the tufa was well developed and several inches in thickness.

Around the sides and back into the recesses it diminishes in thickness, until in the darker places it is but a mere film and has lost its dendritic character. Here it is a solid, thinly banded coating similar to the lithoid tufa of the Lahontan Basin. The gradation between the lithoid and dendritic types is gradual, the projecting columns and plates of the dendritic tufa decreasing in size and becoming less prominent with the decrease in the thickness of the deposit until the uniform lithoid coating results.

The dendritic tufa is occasionally banded, duc to a greater coalescence of the individual columns forming the tufa, but there scemed to be no definite relation either in the distance between the bands or in their number at different parts of the deposit. Considerable sand is intermingled with the tufa, in part blown in by the winds since the retreat of the water, and in part included in the tufa and cemented by it. Many snail shells are inclosed by the dendritic tufa, showing that they lived at the time of the formation of the tufa. The lithoid tufa was much purer, containing little if any sand and none of the shells.

On breaking the tufa it is seen to be built up of rudely circular columns or thin plates approximately $3 \mathrm{~mm}$. in thickness. 'The interior of these is composed of a finely crystalline 
and porous aggregate. Coating this are usually several concentric layers somewhat similar to the lithoid type. While the columns and plates retain their individuality for the most part, yet they coalesce and anastomose frequently, thus binding the mass into a firm and resistant whole.

Where the tufa is attached to the sides or beneath the boulders the plates and columns are usually more distinctly separated. The projecting shafts and blades bend outward and upward, as if seeking the stronger light. This tendency is the most striking feature of the deposit and the abundant recesses in the cliff gave an exceptional opportunity for thorough observation of this relation. It was found without exception that the tufa turned towards the entrance of the caves in the direction from which the stronger light was coming. As the caves penetrated the cliff in all directions this relation of the direction of the growth of the tufa towards the stronger light was tested under all conditions. As the thickness of the tufa developed also depends on the amount of illumination received the influence of light is one of the factors that must be considered in accounting for the origin of the deposit.

Thin sections of the tufa show it to be composed of minute crystals of calcium carbonate and masses of cloudy material similar to that composing the recent tufa. The thin banding noted in the lithoid type and around the individual plates and columns of the tufa is due to the alternation of denser material with the more porous. Occasional spots of yellow iron stain are found wherever sand grains are included and are a result of the oxidation of the ferromagnesian minerals of the sand. Frequent thread-like lines of slightly darker color, the same size and form of the algæ, found in the present tufa and radiating at right angles to the banding, suggest algal filaments. Rarely, in favorable locations, the original algæ may be seen preserved in their original position and faint green color.

\section{ORIGIN OF THE TUFAS.}

The source of the calcium carbonate which forms the greater part of the tufas is found in the waters of the lakes. This is self-evident, since the tufa forms wherever a firm point of attachment is offered, regardless of the lime content of its support. The second column of table 25 shows that the waters of the present Salton Sea contained the stated amounts of calcium as shown by the yearly analyses. From the perennial increase in the amount of

TABIE 28.

\begin{tabular}{|c|c|c|c|c|c|c|}
\hline Yesr. & $\begin{array}{l}\text { Parts per } \\
100,000 \\
\text { calcium. }\end{array}$ & $\begin{array}{l}\text { Per cent } \\
\text { calcium in } \\
\text { total solids. }\end{array}$ & $\begin{array}{l}\mathrm{CO}_{2} \text { per } \\
100,000\end{array}$ & $\begin{array}{c}\text { Per cent } \\
\mathrm{CO} \text { in } \\
\text { total solids. }\end{array}$ & $\begin{array}{c}\mathrm{CaCO}_{3} \\
\text { per } \\
100,000\end{array}$ & $\begin{array}{c}\mathrm{Ca}\left(\mathrm{HCO}_{2}\right)_{3} \\
\text { per } \\
100,000\end{array}$ \\
\hline $\begin{array}{l}1007 \ldots \\
1808 \ldots \\
1809 \ldots \\
1910 \ldots \\
1911 \ldots\end{array}$ & $\begin{array}{r}9.95 \\
11.87 \\
12.70 \\
13.67 \\
15.62\end{array}$ & $\begin{array}{l}2.4 \\
2.5 \\
2.4 \\
2.2 \\
2.1\end{array}$ & $\begin{array}{l}6.58 \\
7.66 \\
7.34 \\
6.38 \\
5.78\end{array}$ & $\begin{array}{l}1.8 \\
1.7 \\
1.4 \\
1.05 \\
0.8\end{array}$ & $\begin{array}{r}10.97 \\
12.77 \\
12.23 \\
10.63 \\
9.63\end{array}$ & $\begin{array}{r}8.88 \\
10.35 \\
9.92 \\
8.62 \\
7.81\end{array}$ \\
\hline
\end{tabular}

calcium, it is evident that the lake waters have not yet reached the point of saturation for the lime. In the third column the percentages of the total solids contained in the water are figured and the partial deposit of the lime is shown. In the fourth and fifth columns, the more significant figures of the carbonate radicle show that it has been decreasing since 1908. Assuming for the sake of argument that all of the carbonate radicle was combined with the calcium either as the carbonate or bicarbonate, we find the amounts given in columns 6 and 7 would have been present at the times that the samples were taken.

Of the two compounds the bicarbonate is by far the more soluble and its solubility is largely increased by the presence of carbon dioxide in the water. If either compound 
is present in the water it is probable that it is the bicarbonate. The solubility of the calcium carbonates is shown by table 26 , taken from Seidell. ${ }^{1}$

It is evident that all of the carbonate radicle could not be combined with the lime in the form of the earbonate, for the water would be supersaturated and over 90 per cent of the carbonate would be deposited. It is possible, however, for the bicarbonate to be present, as the water would then contain only a third of the amount possible, even if no carbon dioxide were present. If by any means the bicarbonate should be decomposed to the carbonate a deposit would necessarily result. Owing to the comparative dilute solution of salts in the lake water it is not possible for mass action to cause a deposit and other than simple chemical methods must be in opcration.

Of the various methods by which the decomposition of the bicarbonate may be accomplished, only two (mechanical agitation and vegetation) need be considered. Since the tufa forms beneath the surface of the water it can not be a result from the evaporation of spray.

As was pointed out by Gilbert, in his study of Lake Bonneville, ${ }^{2}$ the thickest deposits of tufa are found

\begin{tabular}{|c|c|}
\hline \multicolumn{2}{|c|}{ Calcium carbonate $20^{\circ} \mathrm{C}$. 1.2 parts per 100,000} \\
\hline \multicolumn{2}{|c|}{ Calcium bicarbonate $15^{\circ} \mathrm{C}$. } \\
\hline e.c. $\mathrm{CO}_{2}$ per 100 c.c. & $\mathrm{Ca}\left(\mathrm{HCO}_{3}\right)_{2}$ per 100,000 \\
\hline 1.72 & 133.1 \\
\hline 0.79 & 124.9 \\
\hline 0.41 & 82.1 \\
\hline 0.25 & 59.5 \\
\hline 0.08 & 40.2 \\
\hline 0.00 & 38.5 \\
\hline
\end{tabular}
where the waves were most active. This is the case with the older tufa of this basin. The deposits are best developed where the waters dashed against the cliffs of Travertine Point and the Santa Rosa Mountains. Nevertheless, the tufa was well developed on the small boulders lying on the gently sloping shores to the south. 'The essential factor in both the present and older tufas seems to be a firm support. Wherever the Blake Sea washed the unconsolidated sands or easily disintegrated Tertiary sediments the tufa apparently did not develop. This is strikingly brought out in the deposits at Travertine Point, where the sands of the bars connecting the heavily coated eliffs show no evidence of cementation or tufa deposits. The present beach sands similarly show no evidence of the deposition of calcium carbonate, although the tufa is forming on the submerged branehes and twigs of the dead shrubs but a few feet away. If the formation of the tufa is due to the agitation of the waves alone it would seem strange that it should be so restricted in distribution. If, on the other hand, the tufa is formed primarily through the activities of the alga its better development where the waves are active would naturally follow, for it is well known that the sedentary aquatic life thrives best where the water is in active circulation.

The alga associated with the tufas are known to produce calcareous deposits elsewhere. ${ }^{3}$ The evident relation of the thickness of the deposit of the older tufa and exposure to light, its growth towards the light, its local development, its uniform thickness over a large vertical range, the abundance of snails implying a food supply, the presence of the algæ, the porous, dendritic eharacter of the deposit-all point to its vegetative origin.

The details of the process by which the algæ decompose the bicarbonates and foree the deposition of the carbonates are not well understood and remain to be worked out. When this is done, we ean say why and under what conditions tufa deposits are formed.

'A. Seidcll, Solubilities of inorganic and organic substances, pp. 86-88.

${ }^{3}$ G. K. Gilbert, op. cit., p. 168.

$3 \mathrm{~W}$. H. Weed, Formation of travertine and siliceous sinter by the vegetation of hot springs. U. S. G. S., 9th Ann. Rept., pp. 619-682, 1889. See also papers eited.

J. Tilden, Minncsotr Algæ, vol. II, pp. 268-271, 1910.

C. A. Davis, Jour. Geol., vol. viII, 11p. 495-497, 1900. 



\title{
PLANT ECOLOGY AND FLORISTICS OF SALTON SINK.
}

\author{
BYY S. B. PARISH.
}

\section{TERRITORIAL LIMITATIONS.}

The area the vegetation of which is here discussed lies betwecn the margin of the prehistoric Lake Cahuilla and that of the present Salton Sea. The boundaries of this ancient body of water are still indicated in many places by easily recognized "old beaches," the gravelly ridges formed by the action of its waves; or, where rocky promontories abutted upon the water, by the heavy coating of travertine deposited upon the subaqueous portions. Everywhere the soil is full of bleached shells of the small nollusks which inhabited this long-vanished lake. Time and again the lake bed has been partially refilled by the irruption of the Colorado River, to again disappear by the slow evaporation of its waters. The most recent replenishment occurred in 1905, through human negligenee, and again this present lake is contracting and dwindling to extinetion.

To the bed of Lake Cahuilla the name Salton Sink has been given. Its upper margin is about 20 feet above present mean tide level, and its lowest point, now beneath the water of the present lake, is 286 feet below. In the eentral depression lies Salton Sea. The whole eatehment area whose drainage is towards the sea is known as the Cahuilla Basin.

The Sink is oblong in shape, its longer axis lying southeast and northwest, a distance of about 80 miles, in an air-line from Indio to Calexico. Its greatest width is measured by a line running slightly south of west through Imperial Junction, and is about 30 miles. On either hand rise aricl and sun-seorched mountains of low altitude. Desolate and barren as these appear, and as they in reality are, their slopes and waterless eanons sustain a scanty but interesting flora, the consideration of which, however inviting, is beyond the present purpose. The southern boundary is formed by the outward slope of the great Delta which has been deposited by the turbid waters of the Colorado River, whose uncertain channel follows the ridge it is continually building.

\section{BOTANICAL HISTORY OF THE SINK.}

Within the last dozen years an irrigation system has brought the water of the Colorado River to a large area of the southeastern end of the Sink, now known as Imperial Valley, and as a result about 275,000 acres of previously arid desert have been brought into cultivation, railways have been built, and busy towns have sprung up. At the northwestern end a considerable but less extensive reclamation has been made by the development of artesian water. These agrieultural operations have entirely changed the character of a large part of the Sink and have complieated the study of its flora. Especially is this the case in Imperial Valley, where the peculiar conditions present problems at once interesting and diffieult. It is to be regretted, therefore, that the referenees in botanical literature to the conditions formerly existing in the Sink are both scanty and unsatisfactory. The papers mentioned below comprise all, so far as I have been able to ascertain, which relate to the subject.

The survey of the boundary between the United States and Mexico, made in 1856, passed across the southwestern border of the Sink, and the first volume of Emory's Report of the Survey contains a botanical paper by Dr. C. C. Parry, the botanist of the party, 
and a longer article, from the same pen, forms the introduction to the fifth volume of the report. In both papers a few paragraphs are devoted to the vegetation about New River.

In 1853 Dr. W. P. Blake made a survey for the proposed Pacific Railroad, which passed through the western border of the Sink. Over much of this route he was the first explorer, but his account, while interesting for the geologist, contains little for the botanist. There are some references to plants of the basin in Torrey's Appendix. Blake's report forms a part of volume 5 of the series of Pacific Railroad Reports.

Dr. E. L. Greene made a pedestrian journey in February 1877 from San Diego to Fort Yuma, along the old stage route, passing through the New River country. He gave an account of his journey in the Amcrican Naturalist, vol. xIv, pp. 787-793, 1880, and vol. $\mathrm{xv}, \mathrm{pp} .24-32$, 1881, under the title "Botanizing in the Colorado Descrt."

A report on the "Lands of the Colorado Desert in the Salton Basin" was published in 1902, as Bulletin 140 of the Agricultural Experiment Station of the University of California. It is devoted to an investigation of the agricultural capabilities of the soil, but contains an annotated list, contributed by J. Burtt Davy, of 22 specics of plants collected in Imperial Valley by F. J. Snow, who had made the examination of the soils.

A brief but valuable account of the botanical aspect of Salton Sink, shortly before its recent inundation, is given by Coville and MacDougal in Carnegie Institution Publication No. 6, pp. 20-22, pl. 23-26, 1903.

The following recent papers by MacDougal contain much information bearing upon present conditions in the Salton Sink and the Colorado Delta:

The Delta of the Rio Colorado. Bull. Amer. Geograph. Society, vol. xxxviri, pp. 1-16; map and figures. 1906. Vegetation of the Salton Basin. Fifth Year Book Carn. Instit. of Wash., pp. 119, 170, pl. 10, 11. 1907. Movements of Vegetation in the Salton Basin. Eighth Year Book Carn. Instit. of Wash., pp. 57, 58. 1908. Surface Greology and Vegetation of Salton Basin. Tenth Year Book Carn. Instit. of Wash., pp. 49, 50.1910. The Desert Basins of the Colorado Delta. Bull. Amer. Geograph. Soe., vol. xxxmx, pp. 1-25, figs. 1-11, map. 1907.

\section{ZONAL POSITION OF THE FLORA OF THE SINK.}

Before entering upon a discussion of the flora of the Sink, it is desirable to indicate the position which it occupies in relation to the general scheme of plant distribution in the Colorado Desert. This will be best understood by a short account of the several floral zones traversed in passing from the northwestern rim of the Colorado Desert at Banning to the dunes which border the sea-level line near Indio, and then considering the zones which intervene between the southeastern margin of the Sink and the Colorado River.

At Banning, altitude 2,300 feet above sea-level, begins a tension zone in which the plants of the desert contend for the possession of the soil with those which have crossed over from the coastal slope of the San Gorgonio Pass. Rapidly the species of the latter contingent are forced to drop out, and are replaced by successive reinforcements from the former. The ground is fully occupied, and while woody and suffruticose plants are most prominent, there are many perennial and annual herbs, including grasses.

This tension zone is a narrow one, and already at Cabezon, only 5 miles from Banning, but 540 feet lower in altitude, it begins to be succeeded by an Opuntia-Yucca zone. The dominant plants are Yucca mohavensis, an inornate tree, 10 to 20 feet high, clothed with dagger-like leaves, and Opuntia echinocarpa, here a robust shrub of upright growth, its numerous branches forming a compact head. Subordinate to these are many low, xerophytic shrubs, in the shelter of which, and in the intervals, herbaceous vegetation finds a place. The soil is less closely occupied than in the tension zone, and only here and there is to be found an intruder from the west. 'The aspect is distinctly desert-like.

First the Opuntia thins out, and then the Yucca, and the creosote bush (Larrea tridentata) becomes increasingly abundant, until at Whitewater, a further descent of 650 feet in a distance of 10 miles, it is the dominant plant of a well-defined Larrea zone. Individuals of this species are to be found seattered over most parts of the desert beyond, 
but are seldom prominent, and then only over limited areas. Here they are both numerous and well grown. There is an increasing amount of bare sand and gravel, but as the mountains are near enough to draw from the elouds a certain amount of annual rainfall, these intervals are often elothed in the spring with bright-flowered annuals.

By another 450 feet of deseent in a distance of 5 miles, Palm Springs railway station is reached, and the Larrea zone has already been left behind. Here is a scene of desolation indeed. A vast, apparently level, plain of gray, wind-swept sand stretehes before the eye. Picked up by the wind from the detrital fan at the pass, the sand is carried along with a force that eats into wood and etches stone. Larrea remains the most abundant shrub, but the individuals are separated by great distances of bare sand, and of many the form has undergone a change. They lie prostrate on the sand, a long, narrow line of green, pointing away from the direction of the wind. By its varying action a hillock of sand may be heaped about them, or much of their roots may be exposed. Here and there a sparse fringe of Panicum urvilleanum serves to partially fix the sand, and where there is a little shelter the surface may be thinly dotted with small tufts of Chamoesyce polycarpa, an inch or two high. This sand desert continues for nearly 20 miles, until it becomes, along the margin of the Sink, a series of dunes, each formed by an overwhelmed mesquite tree, whose projecting ultimate twigs erown it with verdure. ${ }^{1}$

Between the southeastern margin of the desert and the Colorado River the zonalization is less extensive, since the dividing ridge which is here passed over has an altitude of only about 400 feet. The zones are, however, well marked.

The old sea-beach is bordered by mounds heaped about living mesquites, and smaller ones in which are buried larreas, which do not long survive. Beyond is a stretch of drifting hillocks, totally bare of vegetation. These are not "sand hills," as they are usually ealled, but are dunes in form and in every respect, except that they are formed of fine particles transported by the wind from the alluvial soil of Imperial Valley.

Where a little basin has collected the water of a thunderstorm, almost always are to be found mats of Pectis pappose, perhaps Chamasyce setiloba, Lepidium lasiocarpum, Baileya pauciradiata, or a few other annuals.

Beyond these mounds the imperceptible dividing summit is occupied by an Opuntia zone. To this suceeeds a pebble-strewn plain of so slight an inclination as to appear level, scattered over with the tall, slender stems of the ocatilla (Fouquieria splendens), and continuing quite to the verge of the broad bottom-lands of the Colorado River, which are grown up to mesophytic thickets of eottonwoods and willows.

'The general zonal disposition of the flora of the Colorado Desert, on a line drawn from the summit of San Gorgonio Pass through Salton Sea, to the Colorado River, is shown diagramatically below:

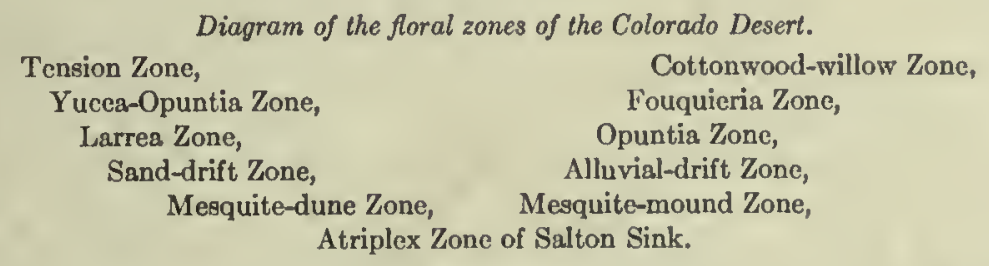

\section{FACTORS DETERMINING THE DISTRIBUTION OF THE SINK FLORA.}

The causes which determine the character and the distribution of vegetation are general in their nature, and apply alike to the parched desert and the humid valley, but the resultant problems which they present are simple or complex in proportion to the modifying influences which are involved.

${ }^{1}$ The distances here given are along the Southern Pacific Railway; by an air-line they would be shorter. 
The Salton Sink is practically a level plane, everywhere exposed to an equal insolation, no irregularitics of surface serving to vary the effects of sun and wind; with a uniform temperature and a uniform deficiency of atmospheric humidity and of rainfall. With these variations of environment eliminated or negligible, the question of distribution is left to depend directly upon the chemical and mechanieal character of the soil and its water-content.

\section{WATER SOURCES OF THE SINK.}

There are four sources from which the Sink derives its supply of water.

(1) 'The preeipitation upon its immediate area; this is scanty and irregular, and its effect is almost negligible.

(2) The run-off from the surrounding mountains; these are subject to torrential downpours, which running at once down their steep and naked acclivities are gathered by the branching cañons and poured out into the so-called "washes." These are shallow channels, broadening as they proceed, and often permitting the water to "flood out" over wide areas of mesa. In a few hours the torrents cease and the washes are again cmpty.

(3) A third water supply is derived from the San Gorgonio and San Jacinto Mountains, some 50 miles northwest of the Sink. These are respectively 11,600 feet and 10,800 feet high, and enjoy a precipitation considerable for the region. Their eastern drainage is carried into the great cone of stones, gravel, and sand which fills the San Gorgonio Pass, into which it promptly sinks. Passing down by percolation, it reaches the northern rim of the Sink, where it is brought so near the surface that, raised by capillary action, it produces the extensive area of alkaline flats between Indio and Mecea. 'The percolating water itself is remarkably pure, as is demonstrated by the artesian wells which have been sunk into it, but in passing upward it becomes heavily impregnated with mineral matter. The same percolation waters are the sources of the springs which oceur along the upper end of the Sink, and they supported the saline marsh which formerly occupied the lowest part of the depression, now drowied beneath the Salton Sen.

(4) The fourth water source of the Sink is supplied by the Alamo ${ }^{1}$ and the New Rivers, two diffluents of the Colorado, forming a part of the intrieate distributory system of channels, sloughs, and lagoons, which, in its Delta, relicves the floods of that stream. By the irruption of the Colorado, in 1906, the character of these diffluents has been greatly changed. They now carry considerable volumes of water throughout the year, and run for most of the way through channels cut 20 to 50 feet deep in the alluvial soil, whose perpendicular banks inclose a strip of moist bottom-lands which becomes wider as the rivers approach their point of discharge in Salton Sea.

Previous to the settlement of Imperial Valley, and the eonsequent changes which have taken place in the character of the diffluents, these appear to have consisted of a series of lagoons, or shallow lakes, connected by much less deeply eroded streams. The names of many of these lakes still appear upon the maps, but they no longer exist; they have been drained and their beds are in eultivation. Annually, or at least in most years, these streams and lakes were refilled by the spring floods of the Colorado River, and when these ceased they contracted as their waters evaporated. Some became dry, but others were permanent. At all events, the New River country was regarded by desert travelers as affording reliable watering-places at all seasons of the year.

About these natural reservoirs, and in the land moistened by them, doubtless grew most of the paludose and halophytic vegetation which now lines the rivers and irrigation canals of Imperial Valley. Parry speaks of camping by one of these lagoons in September, where the party found sufficient grama grass for the mules, and where he noticed an abundant vegetation. 


\section{SOILS OF THE SALTON SINK.}

The soils of the Sink may be classified under three general types. At the upper or northern end the soil is a very fine sandy loam, deposited under water at the time that the Sink was still all arm of the sea, as well as during the lacustrine period. It has a high eapillarity, so that the artesian water is able to secp up towards the surface, carrying with it alkaline salts, which are conecntrated on or near the surface. The water-table is high, and the alkaline content is so great as to confine the vegetation largely to plants of specialized type.

Along the northeastern slope of the Sink, extending from Mecea to Frinks, the surface is covered with wash from the adjacent mountains, consisting of sand, gravel, and stones, assorted in increasing coarseness as the upper contour is approached, where it is eut up by the broad shallow channels through which the flood waters are carried. This soil is readily permeable by water, so that floods and rainfall sink deep, and are thus protected from evaporation. The same porosity renders it easy for the roots of the plants to penetrate and avail themselves of the stored moisture. It is in this wash-soil that the greatest variety and abundance of xerophytic vegetation is found.

The Imperial soils, which oceupy the lower or southern part of the Sink, were deposited by the Colorado River. They are loams of very fine compact grain, varying in the amount of clay which they contain, but with very small percentages of sand. They are permeable by water only to a slight degree. Consequently the water which they may receive readily runs off, and only an inch or two of the surface is wetted, and this is rapidly dried again. The mounds also are composed of similar loam, but of lighter particles which have been selected by the winds and are consequently of a more permeable texture. All the Imperial loams are rich in materials for plant growth, needing only water to be abundantly productive.

\section{DERIVATION OF THE SINK FLORA.}

A student of the flora of the Colorado Desert speedily discovers evidences of a migratory movement from the south and east. Some plants from Arizona reach the Colorado River, but fail to cross it, or, like the saguaro, barely gain a foothold on the California side. Fouquieria splendens abounds on the desolate plains from Fort Yuma to Acolyta on the Southern Pacific Railway, and then falls back to the mountains, along which it is able to persist as far north as to Red Cañon, near Mecea. The palo verde (Cercidium torreyanum) pushes on farther and reaches Palm Springs. A few, like the desert willow (Chilopsis linearis) and the mesquite (Prosopis glandulosa), even straggle over San Gorgonio Pass into the cismontane region of southern California. Instanees of like character might easily be multiplied; indeed the one prominent fact in the distribution of the xerophytic flora of the desert is the successive dropping out of species as one procecds from the southeast to the northwest. The Colorado Desert is the western fringe of the arid flora of Sonora, Arizona, New Mexico, and regions still to the east and south, the so-called Iower Sonoran flora.

Of this general flora of the Colorado Desert the xerophytic vegetation of the Sink is a part, differentiated mainly by the great preponderanec of $\Lambda$ triplices in its composition, so that it may be fittingly denominated the Atriplex zone. As it is only in very recent times, as geological periods are reckoned, that it has ccased to be submerged, it must have directly received its population from the more elevated land bordering it. It has, indeed, again and again been freed of vegetation over areas of greater or less extent, by the repeated partial refilling of the depression, to be again repopulated as the water receded.

The plants which border the diffluent rivers of Imperial Valley were brought in from the delta of the Colorado. Most of them may be found in the river bottoms at Fort Yuma. One most interesting member of this association has descended the Colorado from its distant headwaters in Wyoming and Utah. 
These two sources account for the greater part of the plant population of the Sink. Some individuals belonging to the canion-flora of the bordering mountains are sometimes carried down by the flood waters, mostly as seeds, into the Sink, but they do not increase or probably long endure. Travertine Rock, of which some account will be given farther on, introduces a few montane plants. Two small "Cismontane islands" are formed by small groups of Baccharis viminea at Dos Palmas and of Eriodictyon californicum at Indio.

The endemic flora of the Colorado Desert is not extensive, and but few of its species are found in the Sink. Of these Washingtonia filifera is the most important. ${ }^{1}$

\section{DISTRIBUTION OF THE SINK FLORA.}

The distribution of the flora of the Sink is determined in dependence upon the edaphic conditions outlined on a preceding page, and may be conveniently considered in its relations to them. The term "formation" is applied to the wider groupings, and the term "association" to the minor societies of which the formations are composed.

\section{HYDROPHYTIC FORMATION.}

The hydrophytes are very feebly represented in the flora of the Sink. The water of the rivers and canals is so heavily loaded with silt as to prevent the growth of these plants and the amount of clear water is very limited. The springs, and the pools about them, are nearly free from algæ, such as commonly mantle the surface or float bolow it in similar situations elsewhere. Nor does one find the beds of dried pools coated with the felted filaments of algæ which had grown in the water. The few species which do occur are mostly to be found in artificial pools and streams, such as are formed by the drip or waste of artesian water, and even there they are not abundant. Occasionally a few filaments may be seen on mud banks. No collections were made to determine the presence of desmids or diatoms.

In only a single instance was a submerged spermatophyte observed. This was in Salt Creek, between Seely and Dixieland, in the extreme southern part of the Sink. Salt Creck is a shallow stream, some 50 feet wide, flowing between high and perpendicular bluffs of alluvial soil, from the bases of which the salty water oozes by seepage. Its bed is completely filled with a thick growth of Ruppia maritima.

\section{HELIOPHYTIC FORMATION.}

The heliophytic formation of the Sink is far richer in species and greater in extent than the hydrophytic. It may be considered under two associations, that of the springs at the upper or northern end of the Sink and that of the rivers and canals at the lower or southern end.

\section{SPRINGS ASSOCIATIONS.}

The vegetation growing in the springs, of which there are several on both the eastern and the western sides of the upper end of the Sink, is composed of two species of very extended distribution, Typha latifolia and Scirpus olneyi. In none of them was there apparent evidence of the presence of plankton or of any subsidiary associations. They consist of pools, having little or no run-off, very thickly grown up with the two plants mentioned. Short descriptions of three of these springs, each of a different type, will suffice to give an idea of all.

MORTMERE.

Mortmere is near the northeastern end of the Salton Sea, at an altitude of about 200 feet below mean sca-level. Its position is marked by its clump of green vegetation, which

1 The following species are endemic in the Sink, so far as present knowledge of their distribution indicates, but further exploration of the desert may be expected to extend the range of at least some of them: Astragalus aridus Gray, A. limalus Sheldon, Airiplex saltonensis Parish, Chamosyce sallonensis Millsp., Cryplanthe costata Brandg. Spharalcea orcuttii Vasey \& Rose, Phellorina macrosperma Lloyd. 
eontrasts vividly with the gray and parehed aspect of the gravelly desert plain in which it is situated, and above which it is elevated on a low mound of black earth, formed by the decay of its vegetation and the accumulation of the dust earried by the wind and detained by the moisture of the spring. The water stands in a pool in the summit of this elevation, but there is no run-off. It is strongly impregnated with sulphureted hydrogen and is also slightly saline. The entire pool is filled with a dense growth of robust Scirpus olneyi. Surrounding this, the damp soil of the mound is covered with a sod of Distichlis spicata, and bordering this is a sparse fringe of the shrubs Spirostachys occidentalis and Pluchea sericea.

DOS PALMAS.

This spring is situated also in the northeastern part of the Sink and only 2 feet below its upper contour line. It is at the mouth of a wide wash which drains a large part of the Chuckawalla Mountains, from which source its waters are derived. Below it is a broad playa, flooded oceasionally by the torrential storm waters which eome down the wash. It consists of a swampy pool of eonsiderable area, retained by a slightly elevated border of black earth, which is strongly impregnated with alkali. The water is tepid and very slightly saline, and only suffieient in volume to maintain the pool without needing an outlet. It is filled with robust Scirpus olneyi, for the most part so dense as to exclude other plants, but in places intermixed with Typha latifolia and a little Juncus cooperi. In the middle of the scirpetum grows a fine specimen of Salix nigra and the two lofty Washingtonias which give the spring its name. On its margin Pluchea camphorata is mingled with the sedge, and in the moist saline soil which borders the swampy pool Anemopsis californica forms a narrow intermittent belt, in which grow scattered shrubs of Baccharis viminea. Beyond the immediate border, but still in soil somewhat damp, are considerable areas of Distichlis, with a scattered growth of Pluchea sericea, Prosopis pubescens, and large domes of Atriplex lentiformis.

\section{AGUA DULCE AND FIGTREE JOHN SPRINGS.}

There are several of these springs, alike in character, seattered within a distance of 2 or 3 miles on the southwest side of the Salton Sea, which at the height of its recent replenishment reached most of them. Its shore is now fully half a mile distant. Rising, as these springs do, from an artesian souree, the water, while tepid, is pure and sweet. Their character is similar to that of Dos Palmas-swampy pools grown up with Scirpus olneyi and Typha latifolia. Some afford suffieient water to irrigate small gardens, and there are large tracts of damp soil covered with a sod of Distichlis, in which grow elumps of Juncus cooperi. About them are well-grown trees of black willow, delta cottonwood, and Washington palm, all of which have probably been planted by the Indians, who have made their homes here for generations.

\section{SCIRPUS-TYPHA ASSOCIATION OF ALAMO AND NEW RIVERS.}

The margins of the two diffluents of the Colorado which flow through Imperial Valley are bordered by a close growth of Typha latifolia and Scirpus paludosus, which pushes into the water until its depth exceeds 6 or 8 inches, and creeps up on the mire of the low muddy banks. The width of this zone, therefore, varies in aceordance with the character of the stream. Where, in its meanderings, it crowds elosely to the bluffs there is room for but a narrow belt, but on the opposite side it may extend, in the shallow water and over the mud flats, as mueh as 200 to 300 feet, or even more. The two speeies do not intermingle, but are mutually exclusive, nor is their respective occupancy determined by hydrophytic conditions. Either may occupy the entire border of the strean, or either may have possession of the water front, leaving the landward margin to the other; but always the gregarious colonies are of considerable extent and exclude all other vegetation. 
It is probable that the species which first obtains possession of an unoceupied mud bank so fills it with its rhizomes as to keep out the other.

The character of Typha is too well understood to require any comment, but Scirpus paludosus is a little-known species and until now its presence was not even suspected beyond the marshes of Wyoming (where it was first discovered) and of adjaccnt Utah. It must have descended the Colorado from its distant tributaries, and its colonies will doubtless be discovered along the line of its descent when the flora of these rivers becomes better known. It is plentiful along the Colorado River in the neighborhood of Fort Yuma and, like its companion Typha, has entered the Sink from the delta of that river.

Scirpus paludosus is a vigorous perennial sedge, 1 to $21 / 2$ feet high, and produces an abundance of seed. Each plant throws out one or more rhizomes about $3 \mathrm{~mm}$. in diameter, at the ends of which ovoid tubers are formed which develop new plants. When young these tubers are often an inch in diameter, free from fiber, and edible. As the new plant matures the starch is absorbed and there remains a woody enlargement with a cluster of fibrous roots. 'The young plants soon become independent by the death of the connecting rootstocks and in turn begin to throw out innovating rhizomes of their own.

It will be readily understood how well such a plant is suited to fluviatile transportation. Not only are the abundant seeds discharged upon the water, but as shifting currents disintegrate a bordering marsh they set free a quantity of young plants, cach provided with a store of food-stuffs at its base and ready at once to strike vigorous root as the falling floods deposit it upon some newly formed mud-flat. The same tubers would also serve to carry plants over the seasons of drought to which aquatic vegetation is subject in this region of uncertain water supply.

In the irrigation canals of Imperial Valley Scirpus paludosus is universally present and a source of great annoyance. Its rhizomes fill the mud banks (from which it is practically impossible to remove them), and spread out into the water, checking its current.

Typha also is frequent along these artificial streams. Indeed, throughout the Sink, wherever an artificial pool or reservoir is made, Typha promptly appears and takes possession.

Cyperus crylhrorhizos, an annual sedge, attaining in its best development a height of over 2 feet, and bearing an umbel more than a foot in diameter, but often much reduced in height and inflorescence, is a semi-halophyte, or amphyphyte. It is frequent along the two rivers, but by reason of its reproduction (being entirely by seed), and of its annual duration, its growth is not gregarious. It occupies the banks at the rear of the ScirpusTypha association, in soil not quite wet enough for them, but when opportunity offers it flourishes in water 2 or 3 inches deep. This is not permitted by the vigorous preemptors of the river borders, but it may be seen occasionally along the canals.

\section{HALOPHYTIC FORMATION.}

Some halophytic associations, limited in extent, have already been indicated as bordering the springs described on previous pages. Here are also to be included the salt-grass meadows at the southwestern end of Salton Sea, consisting of a sod of Distichlis spicala, which holds entire possession of the ground by virtue of its stout, matted rhizomes.

\section{MECCA-INDIO CHENOPODACEOUS ASSOCIATIONS.}

Far more important are the associations occupying the extensive alkaline flats, stretching from Indio to the borders of Salton Sea near Mecca, a distance of fully 15 miles. Owing to causes already explained, the soil is strongly charged with soluble salts, consisting of sodium chloride, sodium carbonate, and sodium sulphate in differing proportions, the total saline content varying from 0.5 to over 3 per cent. Over much of the area the water-table is sufficiently high to permit the capillarity of the soil to raise the water to, or nearly to, the surface. 
A careful study of the vegetation of this area, correlated with analyses of the soils in which the different plants grow, would doubtless yield definite and accurate results explanatory of its distribution. In the absence of such studies only a cruder and more general account can be presented.

The dominant plants of this area are all of Chenopodaccous genera. They are Atriplex lcntiformis, A. polycarpa, A. canescens, Suoda torreyana, and Spirostachys occidentalis. A composite, a variety of Isocoma veneta, occupies an important subordinate position. These several species do not grow intermixed, or at most are intermingled only on the borders of the portions respectively occupied by each. Whether the soil shall be monopolized by Atriplex, or by the other two chenopods, appears to depend upon the alkaline content, the latter enduring larger percentages.

\section{ATRIPLICETA OF THE INDIO-MECCA FLATS.}

The three species of Atriplex above named hold possession of the larger part of this area, their distribution being determined by the amount of water in the soil. Those parts in which the water-content is greatest is occupied by Atriplex lentiformis. This is a vigorous species with leaves broader and greener than those of the others. It grows either in thickets close as a hedge, or isolated in great domes, 6 to 8 feet, and exceptionally even 12 or 15 feet in height and base diameter. The same requirement of a very damp soil is manifested elsewhere in its position about springs and on river banks.

Where the soil is somewhat drier Alriplex polycarpa forms a nearly pure stand. Its habit of growth is similar to that of $A$. lentiformis, but mostly in thickets, and less frequently in dense entangled individuals, in neither case much over 3 feet in height. Its leaves are narrowly linear, short, and in color gray.

The third species, Atriplex canescens, has great ecological adaptability, so that while reaching its best development on the drier margins of these flats, it also is frequent in the most arid soils. In such situations it grows in individual isolation, one low shrub more or less distant from its neighbors, but on the flats it is gregarious and forms close thickets, about 3 fect in height. It has the fewest, the smallest, and the grayest leaves of any of the three species, the foliage development of each being in accordanee with the annount of moisture in the soil in which they grow.

In October and November, the season of their fruitage, the Atriplices of the flats are so laden with heavy panicles of fruit that they seem as if thatched with them. These are of a bright green color, which is especially manifest in the broad fruit-wings of $A$. canescens, and the fruit of $A$. polycarpa is frequently tinged with red. By this adaptation the fruit obtains the benefit of a large chlorophyllous surface at the time of ripening, while the sparse foliage of small gray leaves minify the excessive insolation of summer. When thus loaded with fruit these homely shrubs have a checrful and elegant appearance.

\section{SUÆDETA AND SPIROSTACHETA OF THE INDIO-MECCA AREA.}

Those parts of the flats where the alkaline content exceeds the amount tolerated by any of the Atriplices, and perhaps differs in saline composition, are given over to two other chenopodaceous plants, Sucda torreyana and Spirostachys occidentalis.

As it grows in these flats, Suoda is an crect suffrutescent plant, 2 to 4 feet high, with numerous slender, much intertangled branches, which are distantly set with small, terete, sueculent leaves. It is often gregarious in habit, and is notably high and thick-set on soil which has been denuded of its original vegetation. In such places it is the first plant to establish itself.

Spirostachys occidentalis also has terete leaves, which are larger, more numerous, and more succulent than those of Suada, the only other true succulent of the flats. Both appear, where an open interval permits, as subordinates in the Atriplex associations, but 
as dominants they are able to hold possession only of soils too alkaline to permit the growth of the latter. In tracts so heavily charged as to inhibit all the other chenopods of the flats, Spirostachys holds undisputed possession. Here it forms a low, sparse growth, the individuals scparated one from the other by intervals of bare, alkaline-incrusted soil. The stress of the conditions is indicated by the dwarfing of the plants, hardly a foot high, and by the yellowish color of the foliage, in striking contrast to the dark green of the vigorous bushes two or three times their size which flourish under more favorable conditions.

Forms of Isocoma veneta var. acradenia, a many-flowered composite, appear as subordinate members of all of the associations which have been passed in review. Occasionally, in drier and sandier spots, they form a pure growtl, marked, among their somber neighbors, by the bright yellow of their abundant autumnal blossoms. In a variety of unstable ecological forms, some of which have received names as species, Isocoma veneta is the most widely distributed plant of the desert. In other forms it is found in all except the mountainous parts of southern California. Its value as a phyto-geographical index is, therefore, inconsiderable. In the drier parts of these alkaline flats it attains its greatest size and its most abundant inflorescence. It is here several-stemmed, and the clusters of a few heads, borne on pedicles 1 or 2 inches long, are produced in large open panicles.

In all these associations there is a singular dearth of herbaceous plants. A not infrequent Heliotropium curassavicum spreading over the ground and an occasional Conyza coulteri are the only species of any importance.

Not less than five trees grow in this formation, but a consideration of them is reserved for a subscquent page.

\section{HALOPHYTIC ASSOCIATIONS OF IMPERIAL VALLEY.}

The southern extromity of the Sink also las its halophytic associations, whose character varies in accordance with the nature of the soil. The plains of compact Imperial clays reccive but little water from any source, and this little they absorb with difficulty and lose with rapidity. The water-table is far below the limited capillary capacity of the soil. In many places the percentage of alkali is considerable. The factors inimical to vegetable life are at the maximum, and there are wide expanses absolutely devoid of a single plant save in the infrequent furrows and channels which constitute the drainagc system. In these the passage of the water has somewhat leached the soil and rendered it more open and retentive. Hore scattered and stunted suffrutescent plants are able to exist. Mainly they are Suceda, reduced to a low and compact form, with an occasional equally stunted Atriplex canescens. In the minor drain furrows the plants are fewest and smallest, and their number and development, never great, increases in proportion to the size of the channel and the consequent greater leaching effect of the water discharged through it.

A second association, which the railway travelor may observe ncar Estelle, is composed of Spirostachys, growing at intervals of 4 to $10 \mathrm{fcet}$, each the center of a small mound, built up, to all appearance, by wind action. The intervals are flat and perfectly frec from vegetation.

Other parts of these flats are occupied by an open growth of Sucda, usually intermixed with more or less Atriplex canescens. This soil has a less alkaline appearance and probably a less alkaline content, for when reclaimed and irrigated it is considered suitable for agriculture.

\section{SESUVIUM-SPIROSTACHYS ASSOCIATION.}

At points on the southeastern borders of Salton Sca, where the ground is moist and moderately alkaline, the zone nearest the water is covered with Sesuvium sessile, growing in large, prostrate mats, circular in shapc. Behind this is a mixed zone of Sesuvium and Spirostachys, both growing up through mounds which have been heaped about them by 
the wind. These increase in size with the distance from the shore line. It is a condition which soon proves fatal to Sesuvium, so that the outer and drier soil is left to the more resistant Spirostachys. Among these drier mounds Astragalus limatus grows in considerable abundance, and a little Oligomeris glaucescens appears as an interval plant.

\section{HALOPHYTIC ASSOCIATIONS OF. THE RIVER BOTTOMS.}

When the interval between the bluff banks of the rivers is sufficiently wide, it is occupied by low bottoms, little above the water-level of the channel which winds through them, the whole wet or damp in proportion to the distance from the stream. The paludose associations which occupy the immediate margins of the streams have already been described. The remaining vegetation consists of halophytic and mesophytic plants, fairly well segregated in small societies in the wider bottoms, but much confused in the narrower oncs. The mesophytic clement, consisting of willows and cottonwoods, will be considered later. The halophytic societies occupy open intervals which are probably due to soil conditions. Sida hederacea holds possession of some of these. The individuals are small, the declined stems scldom over 6 inches long, and usually the individuals are separated by an inch or two of bare soil. Lippia nodiflora covers small tracts, but covers them compactly, since the stems root at the nodes and continually spread. Atriplex fasciculata, an herbaceous species with prostrate stems, a foot or less in length, is a component of these associations. Other less prominent members are Dicorea canescens, a bushy annual, Sesuvium, and all the chenopods of the Indio-Mecca flats.

\section{SESUVIUM-PHRAGMITES ASSOCIATION OF SALT SLOUCH.}

The so-called Salt Slougl is a dry wash, heading in the playa below Dos Palmas and reaching Salton Sea near the Salton railway station, a mere section house. It is at this point quite deep, with bluff banks of clay, and at the present stage of the sea it forms an inlet of it. From one of the banks a seepage of salty water serves to moisten a strip along its base, so that there is a narrow, more or less muddy bottom, to the maintenance of which the water of the inlet doubtless contributes.

The vegetation is disposed in the following manner: The wettest part of the seepage soil, close to the bluff, is occupied by Scirpus paludosus, but this does not enter the water of the inlet, which is bordered by a shore entirely bare, a feature doubtless due to the rapid recession of the water. The greatcr part of the flat is spread with broad circular mats of Sesuvium, some of thein as much as 6 feet in diameter; with this grows Heliotropium curassavicum, a semi-succulent herb. This, in turn, is bordered by a fringe of Phragmiles communis, which throws out an abundance of stout stolons, 6 or 8 feet long, wandering over the surface of the sand without taking root.

\section{MESOPHYTIC FORMATION.}

As will be rcadily inferred from the climatic conditions, mesophytes are but poorly represented in the flora of the Sink. Even those plants which must be included in this class possess certain xerophytic characteristics. The leaves of the delta cottonwood are but half the size of those of the cottonwood of cismontane California. The leaves of the willows are very narrow and have a cuticularized epidermis. Baccharis glutinosus, also a narrow-leaved species, has the surface of its leaves protected by the varnish which suggested its specific namc. Yet these few are all the plants which, by any construing of the term, can be reckoned as mesophytes.

\section{MESOPHYTIC ISLETS IN THE MECCA FLATS.}

In the lower end of the Indio-Mecca flats, and mostly in the parts occupied by Atriplex lentiformis, there occur small tracts of mire, covered with a surface layer of firmer soil, which yiclds under the foot, and through which animals are likely to break. They are, 
in fact, blind springs, and perhaps a little water may at times appear on the surface. The center is mostly occupied by Typha, with a considerable admixture of Pluchea camphorata. In this, and surrounding it, is an open thicket of slender black willows and delta cottonwoods, with more or less Baccharis glutinosus. Usually there is an outer margin of Distichlis sod. It will be seen at once that this is a society very like that previously described as growing about springs, and it might with some propriety be included with them. It is differentiated, however, by the predominance of the mesophytic trees.

\section{SALICETA OF IMPERIAL VALIEY.}

It has been already mentioned that the flora of the river bottoms of Imperial Valley is, in part, mesophytic. This consists of small elumps of delta cottonwood, but more especially of thickets of Salix. In places the same willow also appears densely bordering the banks of irrigation canals.

\section{XEROPHYTIC FORMATION.}

It is not altogether easy to draw the line between the halophytic associations of alkaline soils and the distinetly xerophytic associations, for the latter often include such typical halophytes as Sucula and Spirostuchys. But these are liere very subordinate members in the associations, most of whose characteristic plants never enter into the composition of true halopliytic societies.

The xerophytic formation occupies an area excecding the combined areas of all the others, comprising, indeed, the greater part of the whole Sink. It can be divided into certain associations which, while including in their composition some plants common to all, yet are in other ways sufficiently differentiated.

\section{SOME GENERAL CHARACTERISTICS OF THE XEROPHYTIC FORMATION.}

The most marked general characteristic of the flora of southern California is the prevalence of shrubs and suffrutescent plants. These are less accompanied by other forms of vegetation in direct proportion to the aridity of the environment. In the Salton Sink the climax is reached. The species of shrubs are few, but they constitute the greater part of the whole plant population, plants of other forms being but an insignificant part of the whole.

Individual shrubs are separated by intervals often great and almost wholly bare. They are dwarfed by lack of moisture; as there is no competition for sunlight, but rather a need of protection from excessive insolation, they are low, compact, and nore or less rounded in outline, this being the shape best adapted to shelter them from the light and the heat of the sun's rays, and from the evaporating effect of the strong, dry winds. This is well exemplified by Larrea, which in some other parts of the desert, where the conditions favor a social growth, attains a height of 6 feet and has a lonse and open form; while in the Sink it seldom exceeds 2 feet in height and is almost as compact as the garden box.

A noticeable feature of the xerophytic vegetation of the Sink is the absence of certain types of plants and certain modifications of others usually present in similar environments and recognized as characteristic of arid regions. Thus, in the mountains about the Sink, and almost to its very margin, in the San Gorgonio Pass down to as low as 400 fect altitude, and on the summit of the broad open plain which divides it from the slope towards the Colorado River, the Cactacea surround the Sink on every side, but do not enter it.' So closely do certain opuntias approach the margin of the Sink, along the flanks of the Chuckawalla Mountains, that there seem to be no differenees of temperature, aridity, or soil

' Ncar Figtrec John Spring a single specimen of Echinocactus cylindraccus was seen in a wash, down which it had evidently been earried from the neighboring mountains, where the species is frequent, and a solitary eylindraceous opuntia was seen near Meea under similar conditions; but neither ean be eonsidered members of the true flora of the Sink. 
to which to attribute the presence or absence of these plants; but in an equilibrium of delicately balanced eonditions a slight cause may have a determining effect. Be the cause what it may, the fact remains that the Sink is below the altitudinal limit of succulent plants.

Induments of various kinds, and aromatic exhalations, are characteristic of xerophytic plants and are often extensively developed; but here, where conditions of aridity are extreme, protections of this nature have not been evolved to a marked degree. Larrea has a highly varnished surface and a strong odor, but it properly belongs to a higher zone. The Atriplices liave a scurfy coating, and other shrubs, such as Franseria dumosa, are moderately pubescent or hirsute. Among herbs, annual and perennial, this charaeter is more pronounced, as exemplified in Psathyrotes ramosissima, Coldenia plicata, and Encelia eriocephala. None of the trees have developed characters of this kind beyond a very slight degree.

Nor are there in the flora of the Sink, with two exceptions, plants which possess any form of storage root, a development so often found in arid regions. The exceptions are Cucurbita palmata, which has moderately large tubers, and Hesperocallis undulata, which has a deep-sented bulb. The first is not uncommon in most parts of the Sink, but is more abundant in the cañons of the adjacent mountains; while the latter, although common in the southeastern borders of the Californian deserts, has as yet been detected in the Sink only at Mecca. The results of the arid eonditions under which the xerophytes of the Sink maintain their existence is doubtless manifested in important anatomical and physiological modifications, but these are not here considered; only the evident exterior adaptations of the plant organs can be noted. 'The agents by which these are produced are the excessive insolation in a region of ever-cloudless skies and the great evaporating effect of a dry and windy atmosphere on plants inadequately supplied with water.

It is to these causes that the distinctive aspect of the desert flora is due, so different from shrubs of more favored regions. The condensed growth of the plants, affording the maximum of shade and protection, has been already adverted to. The same causes have produced the small, narrow leaves, sparse and often early deciduous, so that some are leafless for much of the year, which is so common a feature of the desert flora. Atriplex hymenelytra is an exception in this respect, but its broader leaves are thickened and the epidermis permits so little transpiration that branches broken off are weeks in becoming dry. The prevailing grayness of the desert vegetation is a response of the isolated and exposed plants to the intense sunlight which pours upon them. It affords to the cliloroplasts a needed shade.

Considerations such as these are commonplaces in treating of desert floras. A study less hackneyed, more difficult of prosecution, but promising important results, relates to the character and the extent of the ligneous and fibrous root systems of the desert xerophytes. An example of the method and the value of such investigations is offered by Cannon's "Root Habits of Desert Plants."1

To such a study the flora of the Sink offers an inviting and an untouched field. The soils differ widely in their composition and texture, and consequently in their capacity for admitting and retaining water, in the depth to which it may descend, or from which it may be raised by eapillarity, and in the facility by which they may be penetrated by the roots of plants. While experimental proof is wanting, it is certain that these factors are largely those which determine the distribution of the xerophytic flora. The revelations made by the washing away of bluff banks show that even in compact soils roots penetrate to great depths.

There are certain anomalies to whieh such a study would probably furnish the key. The two species of Prosopis have an abundant, although finely divided, foliage, and they flourish best and attain their greatest size in damp soil, yet they are to be seen in very arid soil, and $P$. glandulosa seems unaffected even when buried to the tips of its branches in 
dunes of drifted sand; but in the very compact soil they are not found. The inference is easy that they largely owe their extended range to the ability of their roots to go deep for water in soils that permit penetration.

A certain endemic peremnial herb, Astragalus limatus, which is scattered all over the Sink, at once impresses one as often out of place in its surroundings. It belongs to a genus well represented in the arid west, where numerous spccies exhibit the reduced foliage, the protective indument, or the limited growing period, which adapts them to their environment. This species has numerous and fairly broad leaflets, which are but slightly thickened; only the growing apex is protected by a sparse pubescence, and while the lower leaves die those above continue green and growing throughout the year. It is, in short, a plant of more mesophytic than xerophytic aspect. Probably an examination of its rootsystem would explain the apparently incongruous conditions under which it often grows.

\section{AGE OF THE XEROPHYTIC TREES AND SHRUBS.}

The student of the arid mesas of the Sink is at once impressed by the apparcnt great age of most of the ligncous vegetation. It is true that this appcarance may be aided by the unsymmetrical forms of many of the trees, by the sparseness or absence of foliage, and by the grayness of the shrubs. No investigations directed to this subject have been made in the Sink, but this aspect of age is characteristic of the sylva of the deserts, only accentuated here in its most arid part. Shreve ${ }^{1}$ has recently made determinations of the age of 146 specimens of Parkinsonia microphylla, a leguminous desert tree growing near Tucson. He found the age of 50 of them to be 200 years and upwards, the oldest exceeding 400 years. Only 10 were of the comparatively youthful age of 75 years. It is probable, therefore, that the aged appearance of the desert trees and shrubs is not altogether deceptive. The proportion of very old trees may be expected to be greater in the Sink than at Tucson, where the aridity is much less. It is greatly to be desired that extended investigations of this nature should be made on the Salton trees.

\section{IABSENCE OF SEEDLINGS.}

The absence of seedlings and of juvenile and adolescent individuals is a topic of interest, in connection with the question of age. During the course of more than a month devoted, at several periods of the year, to a study of the flora of the Sink, the writer did not see a single secdling or the withered remains of one, save of annuals, in any of its arid portions. This deficiency is not due to a lack of seed production; on the contrary the vegetation is exceptionally fertile. Atriplex canescens is literally weighed down with its heavy fruitage. The mesquite produces abundant crops, and the screwbean is littlc less prolific. Beneath Parosela schottii the ripened pods lie thick. In short, all the perennials, from the trees to the radiate Chamæsyces that lie prostrate on the soil, are most prolific in the production of seeds, and the annuals are equally fertile.

Instructive experiments carried on by Dr. MacDougal, to ascertain the readiness of germination and the duration of the viability of the sceds of the desert plants, are detailed in another section of this report. Incidental facts shed some light upon thesc points. Cercidium torreyanum has been extensively planted as a street trec in the town of Brawley, in Impcrial Valley. The trees have now reached the fruiting age, and prove objectionable because of the great number of scedlings which spring up in the lawns and streets. In the same valley, while annuals are far from common, there scems to be an accumulation of their secds in the dry earth, for no sooner is a place well wetted than there springs up an abundance of certain species.

It is altogether probable that the absence of seedlings is due, not to any cause inherent in the seeds themselves, but to the want of proper conditions for their germination. 'These

Shreve, F. Establishment behavior of the palo verde. Plant World, xIv, p. 293, 1911. 
not only need moisture sufficient to induce the seeds to germinate, but that it be continued long enough to enable the young plant to establish itself. Such conditions can occur on the desert but exceptionally, perhaps only at intervals of 100 years or more; or, it may be that an investigation of the ages of the desert trees would afford indications of secular changes in the desert climate.

Only one of the desert trees forms an exception to the absence of adolescent individuals. These may be seen of various ages among the groups of Parosela spinosa, a tree which grows almost exclusively along the dry water-courses of the desert; it is, indeed, as certain an indication of a "dry wash" as is a line of willows of a living stream in a well-watered district. Soaked by the occasional torrents which pour down these washes, their soil affords an exceptional seed bed to the bordering Paroselas.

\section{ASSOCIATIONS OF THE XEROPHYTIC FORMATION.}

While the xerophytic flora has many points in common throughout the whole Sink, it is differentiated into three associations, dependent upon the nature of the several soils. They may be distinguished as the associations of the detrital slopes, of the Imperial clays, and of the drifted mounds.

\section{THE DETRITAL ASSOCIATION.}

The plants of the first of these associations occupy the detrital soils along the northeastern margin of the Sink, extending from the high contour line either to the alkaline flats at the upper end, or, at the lower, as at Durmid, to the present shore of Salton Sea. Eventually, as the Sea evaporates and disappears, the whole lower border will be along the lacustrine flats and marshes of the central depression. A less well-marked area of this association is situated on the opposite side of the Sink, at its upper end. As has been already explained, these areas of washes and detrital fans have soils more permeable to water and to the roots of plants than the other arid soils of the Sink. They are also more subject to torrential floods and have, perhaps, a slightly greater annual precipitation. Consequently the plant population is comparatively denser, although still open, and there is a greater diversity of species. Some of the leading species, as Atriplex canescens, are equally prominent elsewhere, but others, which are here frequent, are seldom or never present in the other associations. This is especially true of those which grow along the upper margin, where a few of the cañon plants come down into the Sink flora.

In passing upwards to this margin there is a certain succession of plants encountered, indicating a zonalization, which depends partially upon soil and, probably, partially upon decp-seated water tables. For, arid as these mountains are, to a certain extent they are reservoirs of water, as is demonstrated by the occasional springs found in the cañons. It is evident that as the drainage slowly percolates through the detrital cones the parts nearest the base of the mountain will contain the greatest and most reliable amount of water, and this can not but have its effect upon the plant covering.

This zonal distribution is readily observable in passing upward from Mecea to the mouth of Red Cañon, in the Chuckawalla Mountains. Leaving the alkaline flats, which have been elsewhere described, a narrow zone of dry lacustrine soil is encountered. It is covered with an open growth of low bushes of Atriplex canescens, the open intervals quite abundantly grown up with dwarfed Plantago fastigiata, Cryptanthe sp., and other annual herbs. Beyond this begins the detrital soil, where the Atriplex is still abundant, but is mixed with much Petalonyx thurberi and Franseria dumosa, and a few Larreas. A little higher leguminous trees appear, Prosopis pubescens, $P$. glandulosa, Cercidium torreyanum, Olneya tesota, and Parosela spinosa, all but the first two being confined to this association. These grow along and near the washes, where the soil is most open and where there is probably more deep-seated water. The principal herbs here are Coldenia plicata, Psathyrotes ramosissima, and Chamosyce parishii. Towards the upper limits of the Sink Parosela 
schottii and $P$. emoryi are very abundant, and there is considerable Croton californicus and Bebbia juncea. Among plants seen only in this association are Chorizanthie rigida, species of Eriogonum, Chamasyce serpens, Helianthus tephrodes, and Encelea farinosa. Atriplex hymenelytra and Cladothrix oblongifolia are abundant here but are seldom seen elsewhere.

\section{IMPERIAL ASSOCIATION.}

The association of the Imperial clays is distinguished by its much sparser plant population, made up of fewer species. Atriplex canescens is by far the most abundant plant, and a low form of Isocoma veneta, with condensed inflorescence, is also common. Sphoralcea orcuttii, a suffrutescent endemic species, 2 or 3 feet high and flowering the most of the year, is confined to this association. 'The only trees, and those mostly in the extreme soutl, are the two species of Prosopis. Where the soil is wetted, under present conditions mostly by leakage from irrigation canals, Bouteloua arenosa and Lepidium lasiocarpum appear in abundance. In some parts there are considerable socicties of Larrea.

\section{MOUND ASSOCIATION.}

The principal plants of the mounds at the southern border of the Sink are Prosopis glandulosa and Larrea tridentala. Both are deeply buried in the loose drifting material of the mounds, the former without apparent detriment to its vitality, but the latter to its ultimate death. Baccharis sarothroides, a compact evergreen shrub, 3 or 4 feet high, is confined to this association. The annuals Pectis papposa, Chamcesyce setiloba, Bailcya panciradiata, and Palafoxia linearis are more frequently seen here than elsewhere. The intervals between the ligneous plants are mostly bare.

\section{TRAVERTINE ROCK.}

Travertine Rock is situated at the northwestern end of the Sink, not far from Figtree John, and a mile or more from the present shore of the Sea. Seen from a distance it appears to be the culmination of a projecting spur of the western mountains, but it is, in reality, separated from them by a broad expanse of sandy wash, which continues past it towards the Sea, bordered by the usual groups of Parosela spinosa. The rock is a precipitous mass of light-colored quartzose, nearly 300 feet high. Its base is heaped about with great angular blocks which have fallen from it. In the far-off time when Lake Cahuilla filled the Sink to its brim, the sharp summit of 'Travertine Rock projected some 25 feet above its waters. All the once submerged part is coated with gray travertine, 1 to 20 inches thick. A distinet horizontal line divides the travertine from the whitish quartzose above and records the former high-water level.

$A$ few small palo verdes are rooted in the sand at the base, and all about grow the gray shrubs of the desert. Travertine Rock itself is almost destitute of any vegetation, but the little there is has the interest of introducing within the Sink limits a few migrant plants common in the neighboring desert mountains. The interstices of the tubereulated surface of the travertine contain, in a few places, a minute black lichen, infertile, and which could not be identified, but resembling one seen in Red Cañon. In sand pockets among the fallen blocks aloout the base grow sparse tufts of Stipa, and in the crevices a few specimens of Nicotiana trigonophylla, Hofmeisteria pluriseta, and Peucephalum schottii, the first two chasmophytes, and all common in the cañons of the adjacent mountains. 


\section{THE TREES OF SALTON SINK.}

In the preceding pages the trees have been referred to only incidentally, the purpose being to reserve further remarks concerning them for a few separate paragraphs. They fall into three elasses: those which grow only in wet soil, those which tolerate both wet and superficially dry soils, and those confined to arid soils.

The first class comprises the palm (Washingtonia filifera), the black willow (Salix nigra), and the delta cottonwood (Populus macdougalii). There are but few indigenous palms in the Sink - the two at Dos Palmas and a group of half a dozen in the alkaline flats near Mecea. There are said to be some others in the flats, but they were not found by the writer. They are abundant along the bases of the mountains northeast of Indio, and in various places in the cañons, but beyond the borders of the Sink.

The desert palm has a columnar trunk 50 feet or more in height and 6 to 8 feet in circumference, surmounted by a crown of large leaves, whose fan-shaped blades are borne on long and stout petioles. Their functional life is about a year, and as they dic they continually add to the mass of deflexed dead leaves hanging beneath the living ones. The palm flowers in May and June, each trec producing five or six large branched panicles of chartaceous blossoms. The fruit, a thin edible flesh surrounding a large bony seed, ripens in early fall.

As it grows in the Sink, Salix nigra has a rough-barked trunk seldom exceeding 6 feet in height. An unusually large specimen measured 82 inches in eireumference at 3 feet from the ground. The black willow fruits in May or June, and so abundantly that often the branches are white with the silky coma of the seeds as it bursts from the opening capsules. Large mature trees are usually found as solitary specimens, or in small groups, but there are often small thickets of pole-saplings along the rivers.

The delta cottonwood has a clear trunk of 15 feet to the branches. One near Mecca was 86 inches in eireunference at 3 feet from the ground, but larger ones were seen. None comparable in size to that attained by the common California cottonwood (Populus fremontii) are to be found in the Sink or have been seen in the bottom lands of the lower Colorado River. Both this and the black willow require abundant and easily reached water, but neither will endure a large excess of alkali.

The two species of Prosopis constitute the second class. Both are tolerant of widely varying edaphic conditions. They reach their best development in the drier and less alkaline parts of the flats about Inclio and Meeca, but are also found in those which have large alkaline and water content. Towards the Mexican boundary, and still more beyond it, they cover large tracts of alluvium in open orchard forest. The occurrence of $P$. glandulosa buried in dunes and mounds, at either margin of the Sink, has been more than once alluded to. $P$. pubescens and more rarely $P$. glandulosa are sometimes seen as solitary specimens in dry detrital soils; but they probably never grow where permanent moisture is beyond the reach of their decply penetrating roots. Indeed, the desert inhabitants hold them to indicate the presence of water at no great depth.

It is seldom that a mesquite $(P$. glandulosa) can be found with a single trunk more than a foot to the point of branching. One at Mecca had a trunk 18 inches to the branches and 42 inches in eireumference; another, at Indio, had a trunk 30 inches high and 78 inches in eircumference. Usually a number of large stems start froin the surface, broadly spreading and becoming much deflexed, so that it is difficult to penetrate the outer cirele of bralichlets. The tree flowers in early spring, and in the fall the clusters of thick pods, 5 to 8 inches in length, ripen and eventually fall to the ground. The crop is usually abundant, but there are occasional failures.

The screwbean is a smaller, less branched, and more erect and slendor tree, rarely excecding 15 fect in height, but usually with a single trunk. Two specimens at Mecea had trunks respectively 38 and 42 inches in height and 20 and 24 inches in eircumference. 
Its fruit is a pod tightly coiled in a eylinder 1 or 2 inches long, borne in close spikes of from 2 to 12 pods. Both species have abundant bipinnate leaves with numerous leaflets, which remain verdant throughout the summer, even in the more arid situations.

Chilopsis linearis should not be included among the trees of the dry soils of the Sink, for although of this class it is represented only by a few migrants which have been brought down a wash from the neighboring eañons, where it properly belongs and where it is abundant. Those of this class which are authentic members of the Sink flora are Olneya tesota, Cercidium torreyanum, and Parosela spinosa. All are here sinall trees, although elsewhere Cercidium attains large dimensions. They grow in the detrital soils at the northern extremity of the Sink, usually along or near washes, where there is likely to be attainable moisture within reach of their roots. As their functional activity is largely suspended during the heated months of summer their demand for water must be limited. None was seen in the compact soils at the lower extremity of the Sink, or in the looser soil of the mounds.

Olneya is a small tree, rarely over 15 feet in height. 'Two specimens near Mecea had trunks respectively 35 and 49 inches to the branches and 62 and 42 inches in circumference. The leaves are pinnate with but few and small leaflets, which had nearly all fallen by the last of June, when the fruit was ripe. The pods are brown and closely pubescent, and one- to three-seeded. I liave not seen the flowers. Only the ultimate grayish twigs appear chlorophyllous.

The palo verde (Cercidium torreyanum) may attain in the Sink a height of 20 feet. A specimen at Figtree John had a trunk 39 inches in the elear and 43 inches in eircumference. Usually there are two to five nearly equal stems from the same root. The leaves are bipinnate and the few small leaflets are early deciduous, so that for the greater part of the year the tree is leafless, but the photosynthetic function is earried on by the bright green bark of the limbs and twigs. The large yellow flowers are produced in Mareh and April, when the leaves have already fallen, and in such profusion that the whole crown is a mass of golden blossoms. The pods are numerous, 2 to 4 inches long, and constricted between the seeds. They were quite ripe late in June and still pendant from the branches, while in October they littered the ground beneath the trees.

No specimen of Parosela spinosa with a single trunk was seen in the Sink, but always there were two or more nearly equal stems springing from the same root, so that it appears more a large shrub than a true tree. Twenty feet would be an extreme height, seldom attained. One near Agua Dulce was divided at the surface of the ground into two branches, respectively 44 and 30 inehes in eircumference. The wood is weak, so that old trees are often split and splintered below by the bending of the stems beneath their heavy load of branches and twigs. The leaves are very few in number and promptly deeiduous, and they have but two or three minute leaflets. The numerous branches divide and subdivide into an intricate tangle of branchlets and twigs, almost gray in color. Some twigs are slender spines on which the violet-blue flowers are produced in great profusion in June, when the tree presents a very handsome appearance. The fruit probably ripens very promptly, as do the fruits of the shrubby species of the genus, which grow in the desert.

Of the eight trees of the Sink, exeluding Chilopsis, five are leguminous, all of the dry-land speeies being of this family. All five, notably the mesquite, are infested, often heavily, with Phoradendron californicum, a leafless, slender-stemmed mistletoe, producing abundant small red fruit. This commensal is an evident drain on the vitality of its hosts and sometimes causes their death. 


\section{ANALYSIS OF THE FLORA.}

Of the plants listed in the following catalogue 23 are sporophytes and 179 are spermatophytes, a total of 202 species. The sporophytes are represented by 15 families and 21 genera. ${ }^{1}$ The spermatophytes are represented by 43 families (21 of them having but one species each) and 121 genera, 89 of which have but a single species each. Of the 179 spermatophytes, 131 are indigenous and 48 are introduced. All the introduced plants except a few found on the beaches of Salton Sea, are eonfined to those parts of the Sink which have been reclaimed through the economic operations of human settlement; in no case have they been able to intrude where natural conditions remain.

The largest families are: the Compositx, with 25 indigenous and 12 introduced species; Graminex, with 12 indigenous and 10 introduced species; the Leguminosæ, with 10 indigenous and 2 introduced species; the Chenopodiacex, with 9 indigenous and 3 introduced species; the Polygonacer, with 6 indigenous and 2 introduced species; and the Euphorbiacce, with 7 species, all indigenous.

Genera having over three species each are: Atriplex 8, Chamasyce 6, Eriogonum 4, Parosela 4, and Spharalcea 4. All the species are indigenous except one Atriplex.

Disregarding 9 species which merely overpass the rim of the Sink, its indigenous flora consists of 8 trees, 23 shrubs, 10 suffrutescent plants, 30 perennial herbs, and 51 annuals. These indigenous spermatophytes may be divided in accordance with their habital character into two classes: (1) those which grow only in water or in moist soils; (2) those which grow in arid soil. The latter constitutes the flora of the absolute desert. Isocoma and the two species of Prosopis are included in the second class, although they grow also in damp soils.

TABLE 30.-Habilal division of the flora.

\begin{tabular}{|c|c|c|c|c|c|c|c|c|c|c|c|c|c|c|c|c|c|c|}
\hline \multirow[b]{2}{*}{ Ecological classes. } & \multicolumn{3}{|c|}{ Trees. } & \multicolumn{3}{|c|}{ Shrubs. } & \multicolumn{3}{|c|}{ Semi-sbrubs. } & \multicolumn{3}{|c|}{ Perennial berbs. } & \multicolumn{3}{|c|}{ Annual herbs. } & \multicolumn{3}{|c|}{ Total. } \\
\hline & 志 & 岕 & 哭 & 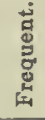 & 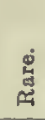 & 욤 & 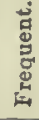 & 离 & 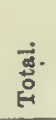 & 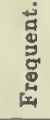 & 节 & 駡 & 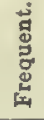 & 怨 & 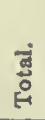 & : & 递 & 离 \\
\hline $\begin{array}{l}\text { Hydropbytes, etc.... } \\
\text { Xerophytes........ }\end{array}$ & $\begin{array}{l}2 \\
5\end{array}$ & $\begin{array}{l}1 \\
0\end{array}$ & $\begin{array}{l}3 \\
5\end{array}$ & $\begin{array}{r}6 \\
13\end{array}$ & $\frac{1}{3}$ & $\begin{array}{r}7 \\
16\end{array}$ & $\frac{2}{2}$ & 6 & $\begin{array}{l}2 \\
8\end{array}$ & $\begin{array}{r}12 \\
4\end{array}$ & $\begin{array}{l}8 \\
6\end{array}$ & $\begin{array}{l}20 \\
10\end{array}$ & 27 & $\begin{array}{r}4 \\
13\end{array}$ & $\begin{array}{l}11 \\
40\end{array}$ & $\begin{array}{l}29 \\
51\end{array}$ & $\begin{array}{l}14 \\
28\end{array}$ & $\begin{array}{l}43 \\
78\end{array}$ \\
\hline Total. & 7 & 1 & 8 & 19 & 4 & 23 & 4 & 6 & 10 & 16 & 14 & 30 & 34 & 17 & 51 & 80 & 42 & 122 \\
\hline
\end{tabular}

A floral census evidently conveys an inadequate and incorrect presentation of the phytogeography of a region if an equal value is given to species widely distributed and abundant and those which are rare-a single specimen of the latter perhaps having rewarded extensive explorations. With this in view an attempt has been made in the above table to separate those species which are fairly frequent (at least in some parts of the Sink) from those which are rarely seen. In making such a division the tabulator must needs be guided largely by what he has himself observed, so that his results are subject to the revision of other and more extended investigations. Especially does this apply to the annual herbs; for under the irregular meteorological conditions of the Sink an unusual season may bring up in abundance annuals which in ordinary years make hardly any appearance. But it is believed that, on the whole, those species which are indicated in the table as "frequent" are those which the botanist will certainly find in more or less abundance in some part of the Sink, though not in every part.

It appears by the table that of the 79 xerophytes, 51 are common in some parts of the Sink. The species which are abundant everywhere in the arid soils of the Sink are but two: Atriplex canescens and Isocoma veneta var. acradenia. These two are also found in the physiologically dry alkaline soils. In number of individuals they probably equal the united total of all the other plants above the rank of herbs.

${ }^{1}$ The undetermined moss and two undetermined lichens are not included in this synopsis. 


\section{CATALOGUE OF PLANTS COLLECTED IN SALTON SINK.}

This catalogue is founded on collections made by Dr. D. T. MacDougal and by the author. A few additional references incorporate the short list of plants published by J. B. Davy in Bulletin 140, Agricultural Experiment Station, University of California, page 9. The numbers inclosed in parentheses are of the Parish collections; those numbered lower than 8200 were made between June 27 and July 4, 1912, those between that number and 8400 between October 8 and 24 of the same year, those from 8400 to 8500 in February 1913, and those above 8600 from September 19 to 21, 1913. Stations without numbers are given from the author's field notes.

The MacDougal specimens are at the Desert Botanical Laboratory at Tucson. A set of the Parisl specimens is in the author's herbarium, and nearly complete sets have been deposited in the herbaria of the Desert Botanical Laboratory of the University of California, and in the Gray Herbarium of Harvard University.

Synonyms are printed in italic, introduced plants in small capitals.

\section{LYCOPERDACEA.}

\section{Podaron farlowii Massce.}

In the alluvial soils of the Sink, in places that have been wet and are drying off. Mounds at the old beach east of IIoltville (8128), Rockwood (8211), Meloland, El Centro, Brawley, Mecca, Coachella (L. A. Greata).

This and the following species were determined by Mr. Lloyd.

Phellorina macrosperma Lloyd.

A single specimen in alluvium which had been recently flooded, on the mesa at Mecca (8212).

An African genus, of which, according to Mr. Lloyd, there have been but three previous collections in the United States.

\section{POLYPORACEA.}

Polyporus corruscans l'rics.

In the fracture of a dead and fallen willow, Figtree John Spring (8605).

Determined by Mr. Lloyd.

\section{ACCIDACEA.}

Negredo scirpi (Cast.) Arth. Uromyces scirpi Burr.

On the leaves and stems of Scirpus paludosus, New River near Rockwood (8217).

Abundant at this station, but not seen elsewhere. It has been collected on Scirpus pacificus at several stations in California. Determined by Dr. Arthur.

\section{CHROOCOCCACEA.}

Chroococcus sp.

On a dripping iron water-pipe, Thermal (8201).

\section{OSCILLATORIACEA.}

Oscillatoria formosa Bory.

On mud, Alamo River at IIoltville (8204).

Phormidium luridum (Kuetz.) Gomont.

With the last species (8204A).

Phormidium tenue (Mengh.) Gomont.

On a dripping iron water-pipe, Thermal (8201A).

Schizothrir lardacea (Ces.) Gomont.

With the last species (8201r).

\section{NOSTOCACE A.}

Nostoc cœruleum Lyngbye.

In the small stream running from the railway waterworks at Mecca (8160).

\section{BACILLARIDACE E.}

Amphora sp.

In the watcr of Salton Sea (MacDougal, 1908).

Gomphronema sp.

With the last species.

\section{VOLVOCACEA.}

\section{Chlamydomonas sp.}

Developed in water taken from Salton Sea at Travertine Terraces, Feb. 8, 1913, by Dr. MacDougal, and used in cultural experiments at Tucson.

\section{CCELASTRACEE.}

Ankistrodesmus falcatus (Corda.) Ralfs.

With the last species.

The four last preceding spccies were determined by Dr. T. E. Hazen.

\section{ULOTHRICACE $E$.}

Conferva utriculesa Kuetz. (?)

In a small stream from an artesian well at Mecca (8402).

\section{CEDOGONIACEA.}

Edogonium sp.

In the water of Salton Sea (MacDougal, 1908). Determined by Dr. Hazen.

\section{CLADOPHORACEE.}

Cladophora crispata (Roth.) Kuetz.

In small streams from artesian wells at Mecca (8402, $8405,8406,8407$ ). Determined by Mr. F. S. Collins.

Rhizoclonium hieroglyphicum Kuetz. var. macromeres Wittrock.

In the water of Salton Sea (MacDougal, 1908). Determined by Dr. Hazen. A variety of the same species was collected in a small pool at Thermal (8202). 


\section{ZYGNEMACEA.}

Spirogyra sp.

Stcrile. In a ditch near Secloy (8203). Sterile Spirogyras were also collected in the small streams running from artesian wells at Mecea $(8403 \mathrm{~A}, 8404)$.

Mougcotia sp.

Sterile. In a ditch near Secley (8203A).

The alove AIga, except as noted, were determined by $\mathrm{Dr} . \mathrm{W} . \Lambda$. Setchell.

\section{CHARACEAE.}

Chara fragilis Desv.

In the pool at Figtree Joliu Spring (S614).

Deterunined by Dr. Ilordsted.

\section{DERMATOCARPACEE.}

Dermatocarpon rufescens (Asch.) A. Zahll.

A vory few plants, in thic sliade of a rock, at base of the mountains southwest of 'Travertine Rock (8472).

Determined by Dr. II. E. Hasse.

A few sterile thalli of a second lichen were growing with the aloove species (8472A), and in the corrugations of Travertine Rock (8410).

\section{MUSCI.}

A small patch of a sterile moss was growing with the Dermatocarpon above mentioned (8411). Another sterile moss, apparently a different spccies, was found on the wet mud banks of the sinall stream flowing from the railway waterworks at Mccea (8482).

\section{NAJADACEE.}

Ruppia maritima Ijin.

Irilling the shallow current of Salt Creek near Secley (8223)

\section{GRAMINEAE}

Holcus halegensis Linu. Sorghum halepense Pers.

A single clump near El Centro.

Introduced 25 years ago into southern California as a valuable forage grass and now become a troublcsonne weed, but only adventive in the Sink.

Pleuraphis rigida 'Thurb.

Rabbit Iay (MacDougal 2I9).

$\Lambda$ common grass at higher al titudes in the desert; here a migrant.

Paspalum disticifom Limn.

Margins of canals, ditches, and reservoirs. Imperial Vallcy, Meloland (8094), Rockwood.

A common weed in cismontanc Califoruia, but probably entering here from the delta.

EchinocuLOA COLONA Link.

A very common weel in irrigated land throughout the Sink. Iloltville (80S5, 8211), Mecez (8101), river bottoin at Rockwell, Imperial, Brawley, El Centro, Thermal.

Very rare in cismontane California, and probably entering here from the delta.

Echinochloa zelayensis Schult.

Very common along the rivers and the irrigation canals and ditches in Imperial Valley. Holtville (8085), New River ncar Rockwood (8240), El Centro, Mcloland, Brawley, Mecca, a single clump along the railway (S618).

The type was collected at Zelaya, in the State of Qucretaro, Mexico. It is the common Echinochloa of Mexico, extending into western Texas and Arizona, and now first reported from California. It occurs in the Colorado River bottoms ncar Fort Yuma, and is here an entrant from the delta. Readily recognized in the ficld by its narrow panicle with erect branchos. Identified by Mrs. Agnes Chase.
GRAMINE EE-Continued.

Crnchrus carounianus IValt.

Depauperate annual, $23 \mathrm{~cm}$. high. Plains northeast of Mecen (8440).

An occasional weed in cismontane southern California.

Setaria glauca Beauy.

Widely introduced, but nowhere abundant, in the cultivated parts of the Sink. Strects of Brawley (8236), Mecca (8244), Thermal.

A widely distributed, but not abundant weed, in cismontane soutliern California.

Aristida bromoides II. B. K.

Occasional in dry soil. Indio (8237), near Dixicland (\$239), base of the range of mountains west of Travertine Terraces (8434).

A widespread but not abundant grass of the Colorado Desert.

Aristida californica 'Thurb. (?)

In sand-pockets, Travertine Rock (8238).

The spikelets had fallen, so that the identification is not positive. In California the species is confined to the eastern borders of the Colorado Desert, thence eastward to Arizona and New Mexico.

Sporobolus strictus Merr.

Near Agua Dulce, at the northwestern end of Salton Sink (8242).

An Arizona specios, now first detected in California.

This and the two preceding species worc determined by Mrs. Agnes Chase.

Sporobolus airoides Torr.

$\Lambda$ fow large tussocks at Indio, and a single one betwecn Calcxico and Signal Mountain.

A species of wide distribution on the Pacific Slope, extending into Mexico.

Avena Fatua Linn.

Brawley, in ficlds (\$613).

Very common and long established in most parts of California, but rare in the Sink.

POLYPOGON MONSPELLIENSIS Desf.

Imperial Junction Beacl (MacDougal 1011). Mecca.

Not scen in Imperial Valley.

$\Lambda$ common weed of cultivation in California.

Cynodon dactylon Pers. Bermuda grass.

Very common in irrigated lands, and about houses throughout the Sink. Indio, Thermal, Mecen, Rockwood, Brawley, Imperial, EI Centro, Calexico.

Common throughout California except in the inountains and deserts.

Cilloris gheqans H. H. K.

Common in cultivated lands and about strects throughout the Sink, always apparently introduced. Thermal (8247), Mccea. A reduced form 2 to $3 \mathrm{~cm}$. high, plains northwest of Mecca (8441). Abundant at the Government Dato Garden, Mecca (8100). Brawlcy, El Centro, IIoltville.

Native of Texas and Mexico and an occasional waif in cismontanc southern California.

Bouteloua arenosa Vasey.

Desert between Brawley and Salton Sca (8234), bluffs of New River near Rockwood (8235), Brawley and El Centro, about strcets, Rabbit Bay (MacDougal 221 ).

A species of northern Mexico, knowu in California only from the castern borders of the Colorado Desert.

Bouteloua barbata Lag. B. polystachya Benth.

In dry soil near Mccea (8102), Town Park, Holtville (8125).

In California known only from eastern part of the Colorado Desert, passing east and south to Mexico. 
GRAMINEAE-Continued.

Leptochloa imbricata Thurb.

Alamo and New River bottoms, and now become an abundant weed in irrigatel lands and about towns throughout the Sink. Indio, Thermal, Mecea (\$119), IIoltville (8243), Brawlcy, Imperial, New River at Calexico, Imperial Junction beach (MacDougal 11s).

Kinown in Imperial Valley as "water grass" becnuse believed to be earried into the fields by irrigating water. Probably an entrant from the delta, as it occurs ulong the lower Colorado River. A few collections have been made in cismontane southern California, probably of waifs.

Eragrostis megastaciys Link.

A depsuperate form 1 to $2 \mathrm{~cm}$. high, plains northwest of Mecca (8442).

Cominon weed througliout the United States and Mexico, but not seen elsewhere in the Sink.

Triodia pulchellus Hitche.

In sand along the base of the travertine range, soutlrrest of Travertine Rock (8434).

A common species of the lower Colorado Desert.

Distichlis spicata Greene. Salt grass.

Common in moderately damp saline soil throughout the western part of the Sink. Thermal, Mecea, Mortmere, Dos Palmas, Agua Dulce.

Conımon throughout United States and Mexico.

Phragmites communis Iinn.

In alkaline soil, Salton slough, near the Southern Pacific Railway station of that name (8068). Abundant at Travertine Terraces.

Frequent about springs in the Colorado Desert, but rare elsewhere in California.

\section{CYPERACEE.}

Eleocharis capitata $\mathrm{R}$. Br.

Dos Palmas (Hall 5984, May 4, 1905).

An infertile Eleocharis was seen at Travertine Terraces.

A common species at low altitudes in southern California.

Cyperus erythrorhizos Muhl.

Wet bottoms of Alamo and New Rivers and along canals and ditches in Imperial Valley. Now River near Rockwood (8234), canal at Holtville (8237), New River at Calexico $(8379,8380)$, ditches at Imperial and El Centro.

$\Lambda$ widely distributed species eastward and collected at several places in central Califoruia, but not otherwise known from the State. It grows along the lower Colorado River and is probably an entrant from the delta.

Crpertos esculentus Linn.

Abundant in the Government Date Garden near Mecca.

A common weed in many places in cismontane southern California.

Cyperus speciosus Vahl.

An immature specimen, only $3 \mathrm{~cm}$. high, which probably belongs here, was collected on Obsidian Island (MacDougal 304). Mecen, in the stream from the railway waterworks (8616).

The species is common in the Colorado River bottoms at Fort Yuma.

Cyperus lavigatus Linn.

On the borders of the pool at Figtree John Spring (8615).

A species of wide distribution in warm latitudes, but in the United States known only in southern California, where it is frequent.
CYPERACEAE-Continued.

Scirpus americanus Pers.

In saline seepage, Travertine Terraces (8127).

Very common in saline marshes in the Colorado Desert, and rare in cismontane soutlern California.

Scirpus olneyi Gray.

Common in springs at northwestern end of the Sink.

Figtree John (8378). Widely distributed in North

Ameriea. Dos Palmas, Mortmere, Travertine Point (MacDougal 409, Parisl 8126).

Scirpus paludosus A. Nelson.

Common in the margins of New and Alamo Rivers and of the irrigation canals and ditches of Imperial Valley. New River at Rockwood (8249), Seeley and Calexico, Alamo River at Holtville, Irrigation ditches at Imperial $(8376,8377)$, Meloland (8093), and El Centro, Mecea, beaches (MacDougal 404).

The type was collected in Wyoming, and the species has been known heretofore only from that State and a few places in Utah. It grows along the Colorado River at Fort Yuma and is here an entrant from the delta. Identified by Dr. Nelson.

\section{TYPHACE E.}

Typha latifolia Linn.

Common in the margins of water and in marshy places throughout the Sink. Indio, Thermal, Meeca, Rockwood, El Centro, Calexico.

A cosmopolitan species common everywhere in California.

\section{JUNCACEAE.}

Juncus cooperi Engelm.

Dos Palmas (8244), Figtree John Spring, Travertine Terraces (8428).

A rare endemic specics of the California deserts.

Juncus balticus Willd.

Ditch along railroad south of Mecea (8455).

A rush of wide distribution, abundant in most parts of California.

Juncus rorrey Coville.

In drain of railway water-tank at Mecca ( 8610).

An occasional species in cismontane southern California, but here evidently introduced.

\section{LIIIACEE.}

Hesperocallis undulatus Wats.

A few plants on plain northeast of Mecen.

Abundant further east in both deserts, extending thence into Arizona. The present station is probably the western limit.

\section{PALMACEÆ.}

Washingtonia filifera Wendl.

A group of a few trees in the alkaline flats near Mecea, two trees in Dos Palmas Spring.

The species is endemic in Cahuilla Basin, and there are extensive groves, not far from the margin of the Sink, north of Indio. The two trees at Dos Palmas have leaves whose petioles are unarmed throughout, the first mature trees thus unarmed which have been seen, except in cultivation. They belong, therefore, to the variety microsperma Beccari. But the varieties of this spccies are founded on insufficient characters and are merely forms.

\section{SAURURACEA.}

\section{Anemopsis californica Hook}

Moist saline soil bordering Dos Palmas Spring.

Frequent in similar soil, notably in southern California and as far north as Sacramento River. 


\section{SALICACEE}

Salix nigra Marsh.

River banks, springs, and damp soil througliout the Sink. Mecea, Dos Palrnas, New IRiver near Rockwood, IIoltville (8079), Rabbit Bay (MacDougal 213).

Possibly the variety vallicola Dudley (S. vallicole IBritton), but our material is insufficient for certain determinatiou. S. gooddingii Ball is apparently the same as Dudley's varicty, but I have seen no authentic specimens. While the reference of these desert trees to the species $S$. nigra is not satisfactory it may suffice for the present.

Salix exigua Nutt. S. longifolia Mulll. in part. (?)

Abundant in river bottoms and along irrigatiou canals in Imperial Valley. New River near Rockwood (83S3) and Calcxieo, Alamo River at IIoltville and east of Calexico, irrigation eanals at Meloland (8092) and Brawley.

Throughout the southern California deserts, and reaching the eismontane borders.

Populus macdougalii Rose.

In the bottom lands of the Alamo and New IRivers, as an entrant from the delta. Also, frequent in cultivation in all parts of the Sink. Mecca (8130, $8385,8471,8607$, and MacDougal 128), Indio (8470)'

According to Indian testimony the delta cottonwood was unknown in the upper end of the Sink before the construction of the Southern Pacific Railroad, when trees were brought from Yuma and planted at several of the stations. From these trees were derived those now growing about the Indian settlements. The only self-planted cottonwoods in this part of the Sink are the young trees which are springing up in abundanee on the moist borders of Salton Sea and along irrigation ditelıes from wind-sown seeds of the cultivated trees. The delta cottonwood occurs along the Colorado River in the neighborhood of Yuma and is especially abundant bordering tho diffluents of the delta. It differs from $P$. fremontii, which is frequent in central and southern California, in its smaller size, the lighter color of the mature trunks, the whitish gray of the bark of the limbs, and its smaller leaves, which are truncate, instead of cordate, at base, and are twice as broad (10 to 12 em.) as high, and short-pointed at the apex.

\section{LORANTHACEAE.}

Phoradendron californicum Nutt.

Common on Prosopis glandulosa, $P$. pubescens, and somewhat less so on Olneya tcsota, Cercidium torreyanum, and Parosela spinosa, throughout the ranges of these trees in the Sink.

Colorado Desert and east into Arizona.

\section{POLYGONACEA.}

Rumex herlandieri Meisncr.

Along rivers and in moist soil in Inperial Valley. Holtville (8078), Meloland, El Centro. Also on Obsidian Island (MaeDougal 30, 109A) and Imperial Junction Beach (MacDougal 32).

Eastward througl Arizona and Ncw Mcxico to Mexico. An cntrant from the delta. Not previously reported from California.

RUMEX crispus Linn.

Along the stream from the railway waterworks, Mecea (8617).

This European dock is abundantly naturalized in California, but only adventive in the Sink.

Polygonum lapathifolium Linn.

In a few places along an irrigation eanal, half way between Calexico and Signal Mountain (8078). Similarly at Meloland.
POLYGONACEAE-Continued.

Polygonum lapatuifolium Linu.-Continued.

Frequent in cultivated grounds in central and southern California.

Eriogonum trichopes Torr.

In dry detrital soil near Meeca (\$2)1).

A common species of the Califorian deserts.

Eriogonum thomasii 'Torr.

Obsidian Island (MacDougal 27, 114).

A common species of thic Colorado Desert.

Eriogonum plumatella Dur. \& Hilg.

Caleb (8290), Durmid (8060), Obsidian Island (MacDougal 205).

A widely distributed species of the Californian deserts.

Eriogonum deserticola Wats.

Big Island (MreDougal 416).

An endenic species of the Colorado Desert.

Chorizanthe rigida T. \& $\mathrm{G}$.

In dry detrital soil at Durmid (S06L).

Common in similar places throughout the Colorado desert.

\section{CHENOPODIACEA.}

Chenopodium morale Linn.

An occasional weed about houses. Mccea, Brawley. Common in many parts of California.

Chenopontum album Linn.

A few plants in fields at Mecea.

This widely distributed weed is abundant in California, but was not scen clsewhere in the Sink.

A triplex semibaccata $\mathrm{R}$. Br.

Abundant along the railway near Imperial (8252), and in the streets at Brawley.

Introduced into eultivation in soutliem California as a.fornge plant, but not proving of value; now a common weed in many places, and especially abundant about San Diego.

Atriplex fasciculata Wats.

Streets of El Centro (8090), Imperial Junction Beach, and Obsidian Island (MacDougal).

The type was collected ncar Duggett in the Mojave Desert.

Atriplex lentiformis Wats.

In wet saline soil throughout the Sink. Indio, Thermal (8266), alkaline flats, Mecea $(8116,8264$, and MacDougal), Dos Palmas (8265), Caleb along ditches, Imperial, bottom lands of Now River at Brawley and Calexico, mouth of Salton Slough. Travertine Wash (MacDougal 9), Obsidian Island MacDougal 411), Imperial Junetion Beach (MacDougal 106)

A species of the California descrts extending into Arizona; also collected in lower San Joaquin Valley.

Atriplex polycarpa Wats.

Common in damp alkaline soil thronghout the Sink. Indio, Thermal, alkaline flats, Meeca (8262), beach at Mccca (MacDougal 405), Travertine Terraces (MacDougal 821, 222A), Obsidian Island (MacDougal 45), Imperial Junction, El Centro, banks of New River at Calexico (8261).

A species of the Californian deserts and adjacent Arizona.

Atriplex linearis Wats.

In dry detrital soil, Durmid (8073), Impcrial Junction beach (MacDougal 108), in alluvial soil, Holtville (8258), between Brawley and Salton Sea (8253).

A Sonoran species, reaching Arizona, and now first reported from California. 
CHENOPODIACEE-Continued.

Atriplex hymenelytra Wats. Desert Holly.

In dry detrital soil in the northeastern part of the Sink, where it is abundant, and occasionally elsewherc. Mecea, Caleb, Salton, Durmid, Bertram, Obsidian Island (MacDougal 33, 48, 414).

A species of the Californian deserts extending into Arizona.

Atriplex canescens James.

One of the most abundant and widespread plants of the Sink, in both moderately damp and arid soils. The wings of the fruit vary greatly in size and in the development of the teeth.

Wings decply toolhed: Bluffs of New River at Calexico (8074), Holtville (S077), between Brawley and Salton Sea (8254), Calcb (\$255, 8256), El Centro, Durmid, Obsidian Island (MacDougal 41, 47, 11S), Imperial Junction Beach (MacDougal 52).

IVings entire, or nearly so: IIoltville (8257), Imperial (S259), Rockwood.

A species of extended range in the arid west, throughout the deserts, and occasionally in other parts of southern California.

Atriplex saltonensis Parish.

Mesa at Meca $(\$ 452,8600)$.

Kinown only from the type station.

Spirostachys occidentalis Wals. Allenrolfa accidenlalis Kuntze.

In alkaline soil througlout the Sink. Alkaline flats at Indio, Thermal and Mecea (8099), mouth of Salton Slough (8071), Caleb, Mortmerc, Figtree John, Travertine Terraces in fruit (8437), Rockwood, borders of Salton Sea near Westmorcland, New River at Calexico.

A species widely distriluuled in the western deserts.

Suæda torreyana Wats. Dondia moquinii A. Nelson.

In alkaline soil throughout the Sink. Alkaline flats at Indio and Thermal, Mecea (MacDougal), Rockwood, Imperial, El Centro.

A species widely distributed in the western deserts and frequent in cismontane southern California.

\section{AMARANTHACEF.}

Amaranthus palmeri Wats.

River bottoms in Imperial Valley and now an abundant weed in irrigated lands. IIoltville (8269), Imperial, Brawley, New River at Rockwood and Calexico, East Bay of Obsidian Island (MacDougal 412).

A species of the southern Colorado Desert extending into Arizona. Here an entrant from the delta.

A. chlorostachys Willd. is reported in Davy's list. There is no specimen from the Basin in tlie herbarium of the University of California, and Davy's record was doubtless founded on an erroneous determination of a specimen of $A$. palmeri.

Amarantuugs grectzans Linn.

A single speciunen in a field at Mecea (8609).

A common weed throughout California, but not seen elsewhere in the Sink.

Amaranthus californicus Wats.

Common in Imperial Valley in cultivated and waste grounds.

Throughout California nortliward to Oregon; ahunrlant in bottom lands of the Colorado River at Fort Yuma, whence prolualsly introduced into Imperial Valley through irrigation canals.

Cladothrix oblongifolia Wats.

I'requent in dry detrital soil at the northeastern end of the Sink, and occasional clsewliere. Durmid (8067), Caleb (8298).

Mountains and mesas of the eastern part of the Colorado Desert and adjacent Arizona.

\section{NYCTAGINACEA.}

Abronia villosa Wats, var, aurita (Abrams) Jepson. In light soil throughout the Sink. Dixieland, Westmoreland, Calexico (8294), Mecca (S474), sands near Travertine Rock.

Frequent in the Colorado Desert.

\section{AIZOACEAE.}

Sesuvium sessile Pers.

Frequent in wet alkaline soil throughout the Sink. Mecca, moutl 1 of Salton Slough, borders of Salton Sea northwest of Brawley, New River bottoms near Rockwood and Calcxico, Imperial Junetion (MacDougal 110), Carrizo Sands (MacDougal).

In California this species lias been collected in San Joaquin Valley and in both the Mojave and the Colorado deserts.

\section{CARYOPHYLLACEAE.}

Agrostema githago Iinn.

A single plant noted along the railway in Imperial Valley.

As yet known in California only as an occasional waif.

\section{PORTULACACEAE.}

Polttulaca oleracea Linn.

A very rare weed about houses. Mecca, Brawley.

This cosmopolitan weed is abundant in tho oldersettled parts of California.

Calandrinia ambigua Howell. Claylonia ambigua Wats. Indio (March 18S1, April 1S84, 1'arish).

An endemic species of the Colorado Desert, seldom collected.

\section{CRUCIFERE.}

Lepidium lasiocarpum Nutt.

In alluvial soil, coming up frecly in places where water has dried off. Abundant on mesa land which had been flooded by leakage from a canal, Rockwood (8296), Imperial Junction Beach (MacDougal 51), in a small basin in the mounds cast of Holtville, near Westmorcland. Alamo River, according to Davy's list.

A species of the westeru deserts.

Dithyræa californica IIarv.

l'lains near Mecca (8451, 8457, 8478), sands near Travertine Terraces

Common northwest to San Gorgonio I'ass.

Streptanthus longirostris Wats. Guillenia longiroslris Greenc.

Mesa nortlicasi of Mecca $(8444,8473)$.

A common species of the Colorado Desert.

Brasaica Nigila Koch.

Sparingly along a roadside near Imperial.

A common weed in the cultivated parts of California.

\section{CAPPARADACEAE.}

Wislizenia refracta Engelm.

Borders of Salton Sea (MacDougal).

From Texas to the desert borders of California, and in the San Joaquin Valley.

\section{RESEDACEA.}

Oligomeris glaucescens Camb.

Borders of Salton Sea (MacDougal 112, 114), Obsidian Island (MacDougal 41), dry desert between Brawley and Salton Sea, near Mecca (8443).

In California in the deserts along the southern borders of the State, and occasionally on the lower coast, without doubt indigenous. 


\section{LEGUMINOSA.}

Prosopis glandulosa Torr. Mesquite.

A tree of wido distribution in the Sink, oceurring wherever its roots are able to reacl moist soil. Abundant in the alkaline flats from Indio to Mecea. river bottoms in Imperial Valley, dunes at Indio, and mounds east of IIoltville and Calexico, Dos Palmas, Westmoreland, Alamo River near the Mexienn boundary (8270), Obsidian Island (MaeDougal 1308), Rabbit Bay (MacDougal 210), Travertine Terraces.

A common species of the Californian deserts and ocessional in eismontane soutliern California.

Prosopis pubescens Benth. Strombocarpus pubescens Gray. Screwbean.

Range of the preceling species, except in the dunes. 'Thermal, Meces, Caleb, Dos P'alnas, Durmid in dry channels of the mesa, Calexico, Rabbit I3ay (M acDougal 210), Obsidian Island (MacDougal 30, 117), ligtree John, Travertine 'Terraces.

A common species of the Californian deserts, thence southward into adjaeent Mexico. A single group grows on the dry banks of the Santa Ana liver between San Bernardino and Redlands in eismontane southern California. Smaller than the preceding species and apparently ablo to endure greater aridity.

Cercidium torreyanum Sarg. Parkinsonia torreyana Wats. Palo verde.

In detrital soil at northern end of Sink, most frequent along washes. Between Meen and Red Cañon, Caleb, 'Travertine Rock.

Colorado Desert and adjacent Arizona and Mexico.

Olneya tesota Gray.

In detrital soil at northeastern end of the Sink, along or near washes; not seen on the western side. Near Mecca (8123), Mortmere, Dos Palınas.

Southern part of the Colorado Desert and adjacent Arizona and Mexico.

Parosela mollis IIeller. Dalea mollis Benth.

Infrequent in arid soil. Mecen $(8312,8450)$, Dixioland (8311).

A common species of the Californin deserts, but apparently inf requent in the Sink.

Parosela emoryi Heller. Dalea emoryi Gray.

Widely distributed in arid soils throughout the Sink and notably abundant in the washes and detrital slopes of its northenstern border. Near Mecea, mounds east of IIoltville (8080), Culeb, Figtrec John, Westmoreland, Obsidian Island (MacDougal 16).

A frequent speeies of the Colorado Desert.

Parosela schottii Holler. Dalea schottii Grny.

Abundant along the washes and on the detrital slopes of the northeastern part of the Sink towards its upper border. Between Meeca and Red Cañon, near Dos Palmas.

Frequent in the Colorarlo Desert and eastward into Arizona.

Parosela spinosa IIeller. Dalea spinosa Grny.

Abundant along washes, in the northeastern and northwestern borders of the Sink, and increasingly so towards its upper margin. Mecea, Caleb, Dos I'almas, Figtree John.

A common species, bordering dry washes and in enñons, in the Colorado Desert, extending into Arizona.

The first leaves of $P$. spinosa seedlings, 5 to 6 in number, are oblong. 2.5 to $2.75 \times 0.5$ to $0.75 \mathrm{~cm}$., glandular-serrate and sparscly guttate-glandular. At the height of alsout $3 \mathrm{~cm}$. they are sueceeded by spines 2 to $2.75 \mathrm{~cm}$. long, sparingly set with
LEGUMINOS $\&$-Continuel.

Parosela spinosa Heller. Dalea spinosa Gray-Continued. pointed glands. The whole plantlet is densely appressed-pubescent.

Segnania macrocarpa Muhl.

Along an irrigation canal near Imperial (8306) and said to oceasionally oceur along other eanals.

At the above station it was spreading into the adjacent irrigated alfalfa fiold. It was here a weed of cultivation, brought in by the eanals from the Colorado River, in whose delta it is abundant and indigenous. Although not seen along the Alamo or New Rivers, it is not inuprobable that it inay also be a natural entrant. It is a weed in the Government Date Garden near Mecea, whero it was sown to test its value as a cover crop, its roots being the host of nitrifying bacteria.

MeLilotus indica All.

Adventive at Imperial.

A cominon weed in eold, damp lands in many parts of California.

Astragalus aridus Gray.

Coachella (L. A. Greata, Herb. Parish), sandhills near Mecea (8467)

An endemic annual of the Sink.

Astragalus limatus Sheldon.

lirequent in arid soil throughout the Sink. Near Meeca, Caleb, Durınid, between Brawley and Salton Sea (8271), El Centro, Meloland, IIoltville (8081), Secley, Westmoreland, Calexico.

It attains a much more luxuriant development when growing in moderately moist soil than in dry. Travertine 'Terraces (MaeDongal 40S, Parish 8429).

An endemie peremial of the Sink.

\section{ZYGOPHYLLACEÆ.}

Larrea tridentata Coville. Covillea tridentata Vail. Creosote busl.

Frequent in arid soil throughout the Sink, but seattered and seldoin dominaut. Caleb, Figtree John, mounds east of Holtville and Calexico, between Calexico and Signal Mountaiı. Near Westmoreland it oceurs in abundance over small isolated traets.

The most eharacteristie shrub of the entire Lower Sonoran life-area.

Trinulus terrestris Linn.

Common along railway tracks throughout their entire length, and extending into the streets of the towns. Indio, Mecea, Durmid, Imperial Junetion, Brawley, Imperial, El Centro, Holtville, Calexieo.

This weed has entered California in recent years along the Soutliern Pacifie Railway, and is now common about most railway stations in southern California and spreading in streets of towns.

\section{GERANACEA.}

Erodium texanum Gray.

Plains nortliwest of Meeca (\$449).

A common species of botly deserts, and eastward to Texas. Also rarc in cismontane southern California.

Eronium cicutanium L'IIer.

In irrigated fields, Mecea (8409).

A common naturalized species throughout California, exeept the deserts and higher inountains.

\section{EUPHORBIACEAE.}

Croton californica Muell.

In detrital soil towards the rim of the Sink near Meeca. Abundant northward in the Basin and in many parts of southern Californis. 
EUPHORBIACEE-Continued.

Chamzsyce cinerascens Small. Euphorbia cinerascens Engelm.

Sand wash near Figtree John Spring (8300).

Not before reported from California.

Founded by Engelmann on plants from northern Mexico (Bot. Mex. Bound. Surv., vol. 2, pt. 1, p. 186), witl a rariety apendiculala from San Felipe, the latter rerluced (Bot. Cal., vol. 2, p. 73) to a form of $E$. polycarpa.

Chamæsyce parishii Millsp. ined. Euphorbia parishii Greenc.

Sand wash between Meeea and Red Cañon (8113).

The type of this little-known speeies was eollected at Daggett, in the Mojave Desert.

Chamzesyce polycarpa var. hirtella Millsp. ined. Euphorbia polycarpa Benth. var. hirlclla Boiss.

Das Palmas (8304), sand wash near Dixicland (8308), Figtree John (8245), shores of Rabbit Bay (MacDougal), sands between 'Travertine Rock and the adjacent mountains, abundant.

Abundant nortliward in the Colorado Desert.

Chamæsyce saltonensis Millsp. ined. n. sp.

Old beach-line near Calexico (8302), streets of Brawley (\$305).

An endeinic species of the Sink, known only from these collections.

Chamesyce setiloba Millsp. ined. Euphorbia setiloba Engelm.

In sandy or loose soil, in which it is often partly buried. Mounds at the old beach-line east of IIoltville (8087), sand wash in the desert southwest of Brawley (8:301).

A species of the southern parts of the Colorado Desert, the type collected at Fort Yuma.

Chamasyce serpens Millsp. ined. Euphorbia serpens H. 13. K.

In hard detrital soil at Durmid (8060).

South to Mexico and east to Kinnsas and Jllinois. Not before reported from California.

The above species of Chamosyce were determined by Dr. Millspaugh.

\section{MALVACEÆ.}

Malvastrum exile Gray.

Plains northwest of Meces (8447).

Common northward in the Colorado Desert and in the Mojave Desert.

Malva parviflora Linn.

Adventive in several of the towns of the Sink, but nowhere aljundant. Meeca, Brawley, El Centro.

An abundant weed in California.

Sida hederacea Torr.

Frequent in extensive societies, in moderately dry subalkaline soil in the river bottoms of Imperial Valley. New Itiver at Rockwood (8316) and Calexico. Also a troublcsome weed in irrigated ficlds. Rockwood, El Centro, Meloland, Seeley, IVestınoreland.

An entrant from the delta, where it is common.

Sphæralcea orcuttii Vasey \& Rose.

Frequent in the arid alluvial soils of the southern and eastern parts of the Sink. Desert between Brawley and Salton Sea (8317), El Centro, Meloland (8097), Holtville, Dixieland, Westmoreland, Calexico, Durmid.

Suffrutescent; flowering at most seasons of the year. An endemic species of the Sink. This and the following Spharalceas were identified by Dr. Robinson.
MALVACE E-Continued.

Sphæralcea emoryi Gray. (?)

Along railway tracks at Indio (8321).

Corollas lilac rather than brick-red, but otherwise agreeing with the ordinary form of this species, which is common in the Californian deserts.

Sphæralcea fendleri Gray.

Streets at Mecea $(8318,8451)$.

A species of western 'Texas, New Mexico, and Arizona. Not heretofore detected in the Colorado Desert, but occasional, in a varietal form, in cismontane southern California.

Sphæralcea angustifolia Spach. var. cuspidata Gray.

A number of plants near Indio (8319).

This also is a plant of the same region as the last; not detected heretofore in California.

TAMARICACEAE.

Tamarix paldasi Desv.

A single shrub on the moist banks of Salton Sea at Travertine Terraces (8512).

Determined by Dr. Niedenzu. In full flower in September, and perhaps not identical with the shrub flowering in early spring, cultivated in southern California as T. gallica, an older name, according to the Kew Index, for that here alopted, but reeognized as a distinct species by Niedenzu in Pflanzenfamilien vol. 2 , tiel 6, p. 294,1895 .

\section{LOASACE A.}

Petalongx thurberi Gray.

Common in detrital soil throughout the Sink. Mecea, (8121), Caleb, Durmid, Figtree John.

A common speeies of the Colorado Desert.

\section{ONOGRACEE.}

Enothera trichocalyx Nutt. Anogra trichocalyx Small.

Desert between Brawley and Salton Sea (8326).

Enothera scapoidea Nutt. var. aurantiaca Wats. Chylisma clavaformis Heller.

Obsidian Island (MacDougal 29), alundant on plains northwest of Mecea (8445), and in sand at Travertine Terraces.

The above Enotheras are common plants of the Colorado Desert.

\section{LYTHRACEE.}

I YTHROM GALIFORNiCUM 'T. \& G.

A single plant, at Figtree Joln Spring (8611).

A common California species, not reaching the deserts, aud here a waif.

\section{CACTACE 2 .}

Echinocactus cylindraceus Engelm.

A single large specimen in a wash near Figtree John, evidently earried down the wash when small, from the adjacent mountains, where the species is frequent. It does not properly belong to the flora of the Sink.

Opuntia echinocarpa Engelm. (?)

A single plant in a wash near Mecca, without fruit or flowcr. Like the previous species it was a migrant from the adjacent mountains.

\section{ASCLEPIADACEAE.}

Asclepias subulata Decsnc.

A few plants in a wash ncar Agua Dulce at the southwestern end of the Sink.

Frequent in the washes of the mountains which border the Sink, here a migrant. 


\section{ASCLEPLADACEAE-Continued.}

Philabertia linearis B. \& $\mathbf{H}$. var. heterophylla Gray. Philabertella hartwegii var. heterophylla Vail.

Oecasional in dry soil throughout theSink. Agua Dulce near Brawlcy (8327), Holtville (8081), mounds near the Alamo River east of Calexico (8327).

A common species of the desert, abundant in the Colorado River bottoms, and passing westward into cismontane southern California.

\section{CUSCUTACEAE.}

Cuscuta caliromica Choisy.

A few plants, parasitic on alfalfa, in the town park at Holtville (8080). Slight infestments on alfalfa, scen elsewhere in Imperial Valley, were probably the same.

A common indigenous specics in many parts of California.

\section{POLEMONIACEA.}

Langloisia schottii Torr. Gilia schollii Gray.

A few plants in sandhills northeast of Niecen (8466). A common species of the Colorado Desert.

\section{HYDROPHYLLACEE.}

Heliotropium curassavicum Linn.

A subordinate member of halopluytic associations througbout the Sink; rarely dominant over limiter. arcas, as on flats near Caleb. Mecea (MacDougal $5,105)$, near Salton (8072), Obsidian Island (MaeDougal 45), Dos Palmas, Rockwood, borders of Salton Sea near Westmoreland, El Centro, New River at Calexico.

Widely distributel in California and in most of the warmer parts of North America.

Phacelia crenulata Torr.

A single plant, in the sandhills northeast of Mecce (8464).

Infrequent in the southeastern Colorado Desert and thence to Arizona and New Mexico.

Eriodictyon californicum Greene.

A single insulated society, occupying an acre or more near Indio.

This common species of cismontane southern California occurs in a few places on the desert slope, as at Whitewater. The present station is its fartliest known eastern and southern limits.

Nama hispidum Benth.

"Alamo river-bed" according to Davy's list. The specimen (Davy 7965) is in the herbarium of the University of Califoruia and the locality noted on the label is Calexico. It has also been collected at Palo Verde on the Colorado River.

\section{BORAGINACEA.}

Cryptanthe angustifolia Grcene.

In a desiccated pool at the old beach cast of Holtville (8124).

Common species of the Colorado Desert, extencling into Arizona.

Cryptanthe barbigera Greene. (?)

Obsidian Island (MacDougal 25, 26).

The specimens are too young for positive determination, but tho species is common in the Colorado Descrt and in Arizona.

Cryptanthe costata Brandegec.

In sands ncar Travertine Terraces (8429). Sandhills near Mecea (8465).

An endemic species of the Colorado Desert. Deter. mined by Mrs. Brandegee.
BORAGINACEE-Continued.

Krynitzkia micrantha Gray. Eremocarya micrantha Greenc.

Sandhills northeast of Meeca (8464).

A common plant of arid soils in southern California, extending eastward to Arizona.

Coldenia plicata Covillc. C. palmeri Gray.

A common xeropliyte of the Sink, especially in detrital soil, but occasional clsewherc. Mecca, Durmid, Imperial Junction, Figtree John, El Centro, Westmoreland.

A common species of the Colorado Desert.

Pectocarya penicillata A. DC.

Mesa at Mecea (8448).

Common in arid soils in southern California.

\section{LABIATE.}

MenTHa citrata Ehrh.

In the stream from the railway waterworks, Mecea $(8462,8608)$.

Naturalized sparingly in cismontanc soutliern California.

\section{VERBENACEAE.}

Lippia nodiflora Michx.

In the moist soil of river bottoms in Imperial Valley. New River at Rockwood (8330) and Calexico (8332), Obsidian Island (MacDougal 38).

A cosmopolitan tropical species; in California known only along the lower Colorado and as above. An entrant from the delta.

\section{SOLANACEE.}

Solanum eleagntfolium Cav.

About railway station yards and tracks. Durmid, Imperial Junction (8104), Imperial, Meloland.

This weed entcred southern California along the Southern Pacific Railway, and is now widely distributed throughout its length in solithern California, but is not abundant.

Physalis wrightii Gray.

Rare in river bottoms, but very common along canals and in irrigated lands, in Imperial Valley. Brawley, Imperial, Ll Centro, Meloland (8091), Rockwood (8338).

An entrant from the delta and apparently owing its presence berc mainly to the irrigation system. It oceurs also in the Colorado River bottoms at Fort Yuma and is now for the first time reported from California. The type was collected in southwestern Texas.

Physalis crassifolia Bcnth.

A single plant at the base of the range southwest of Travertine Rock (8435).

A migrant from the desert mountains, where it is a common chasmophyte in both deserts.

Datura discolor Bernh.

Streets at Mccca (8335), and along a road in the flats a few miles west, along a canal at Dixieland (8336). in somewhat damp soil not far from the borders of Salton Sea at Caleb and Agua Dulce.

This Mexican species grows in the bottom lands of the Colorado River at Fort Yuma, where it appears indigenous. In the Sink it is an entrant from the delta, apparently recent. The stations at Agus Dulee and the Mecea fats are all on land flooded by the recent Salton Sea; that at Caleb is slightly above the late high-water mark. It thus inaintains the ambiguous charaeter assigned it by Gray in the Synoptieal Florn, where it is insufficiently described. 
SOLANACEA-Continued.

Dstura meteloides DC.

Indio, Mecca; rare.

Common in southern California, occasionally reaching the western borders of the clesert, and reappearing in the bottom lands of the Colorado River at Fort Yuma.

Nicotiana trigonophylla Dunal.

A few plants in a wash at Caleb (8333), and three in crevices of Travertine Rock.

A common chasmophyte in the cañons of the desert mountains, and oceasionally in washes from seed carried down by floods. In the Sink only as a rare migrant from higher altitudes.

Nicotiana arades Graham.

A single young plant at Meeca (8622) and two at Calexico.

Common in eismontane southern California, where introlued from Mexico; adventive in the Sink.

\section{BIGNONIACEÆ.}

Chilepsis linearis Sweet. C. saligna Don. Desert willow. A few trees nt Caleb, wherc the seed had evidently been brought down a wash; common in cañons and along the eourses of washes in the detrital soils of the Basin, hut it belongs to ligher altitudes than those of the Sink.

\section{PLANTAGINACEA.}

Plantago lanceolata linn.

Abundant in a few lawns at El Centro.

A common weed in southern California.

Plantago fastigista Morris.

Abundant on the plains northeast of Mecea (8446). Dried remains collected near Dixicland are probably the same.

A common species of the Colorado Desert, extending into Mexico.

\section{CUCURBITACEE.}

Cucurbita palmata Wats. Wild gourd.

Occasional throughout the Sink, notably in washes. Mecer, Caleb, Westmoreland.

A common specics of the Colorado Desert, but most abundant in cañons.

\section{LOBELIACE .}

Nemsclsdus sdenophorus Parish.

On dry messs. Salton (IIall)

An epherneral winter annual of detrital plains, common in both deserts.

\section{COMPOSITE.}

Hofmeisteria pluriseta Gray.

A few plants growing in the ereviees of Travertine llock.

The species is a common chasmophyte of the mountains of the Colorado Desert, whenee here a migrant.

Brickellia californica Gray var. desertorum Parish.

$A$ few plants at the base of the range southwest of Travertine Point.

Frequent in the descrt mountains, from which it is here a migrant.

HETERoTHECA aRANDIFLoRA Nutt.

Along the boundary-line road near Calexico; evidently a recently introduced weed

Indigenous, but more commonly a weed of cultivation, in eismontane southern Californis.

\section{COMPOSIT $\notin$-Continued.}

Isecoma veneta var. acradenia Hall. I. acradenia and $I$. eremophila Greene.

The most widely distributed plant of the Sink, where it is common in both physically and physiologically dry soils. Mecea (8117, and MacDougal 402), Imperial, Westmoreland, Brawley, EI Centro, Travertine Terraces (MacDougal 23), Indio (8353), Thermal (8343) in damp alkaline soil, are tall forms, with large branching infloreseence. Mecea (8350), in like'soil, has few-toothed leaves and represents the I. eremophila form. Desert between Brawley and Salton Sea, in dry alluvinm (8351), has rather broad, entire leaves and agrees with $I$. acradenia. Dixieland (8353) on artifienlly moistened alluvium, is $5 \mathrm{~cm}$. tall, the numerous involucres solitary at the summit of pedicels 2 to $5 \mathrm{~cm}$. long. About Durmid and Imperial Junetion low forms, with the inflorescence almost eapitately condensed, are common.

A plant of such wide distribution as Isocoma veneta, and eaprable of aeeepting such varied edaphic conditions, necessarily responds with a complex of ecological forms. The student who has before him even large suites of herbarium material may be content to define what appear to him valid species, but which field study would convinee him could be sustnined at most only as more or less uncertain forms and varieties. Treated in this light it might be advantageous to give subspecifie names to some of the more marked of these forms, but if too rigidly defined they might be identifialole only with the type specimens.

Aster spinosus lBenth.

Moist soil along the Alamo and New Rivers, and a pestiferons weed in irrigated lands, in Imperial Valley. New River at Roekwood and Calexico, Brawley, Imperial, EI Centro, Meloland, Holtville, Westmoreland. Salton (MaeDougal 120), Obsidian Island (MaeDongal 202, 203).

An entrant from the delta. Inown to farmers of Imperial Valley as " wild asparagus," from a resemblance of its matted roots to those of that vegetable.

Aster exuss Ell, var, Austraus Gray.

A frequent weed about towns and in fields. Thermal, Meeea, Brawley, Imperial, El Centro, Westmoreland, Obsidian Island (MaeDougal 306, 413).

A common weed in California; probably introdueed in Imperial Valley by irrigation, as it is the form most abundant in tho Colorado River bottoms.

Erigeron canadensis Linn.

A frequent weed about towns and in fields. Thermal, Mecca (8358), Rockwood, Brawley, EI Centro.

Common in many parts of California.

Conyza coulteri Gray.

In the alkaline flats at the northwest end of the Sink. Thermal (8357), Meeen (8356).

Ocensional at low altitudes in southern California, in soil more or less alkaline.

Baccharis sarothroides Gray.

Mounds along the old beach at southeastern border of the Sink. Near Alamo River east of Calexico (8349), and east of Iloltville.

In California confined to the southern border, and thence into Arizona and Mexico.

Baccharis sergiloides Gray.

A few shrubs, in subalkaline soil, near Agua Dnlee (8436).

A species of the Colorado and Mojave Deserts, extending into Nevada and Utah. 


\section{COMPOSIT A-Continued.}

\section{Baccharis glutinosa Pers.}

Common along rivers and about springs in most parts of the Sink. New River bottom near Brawley, Rockwood (8354), and Calexico, Alamo River near Calexico, Thermal, Mecca (8127, 8347), Obsidian Island (MacDougal 44, 113, 204, 302).

A species extending south and east to Arizona, Colorado, and Mexico, and extensively distributed at low altitudes in California; but most abundant in the Colorado Desert.

Baecharis viminea $\mathrm{DC}$.

About the moist borders of Dos Palmas Spring (8348).

A common species of eismontane southern California, here quite out of its normal range.

Pluchea camphorata DC.

About springs and in marshy plaees in the northwestern parts of the Sink. Alkaline flats at Mecea, beach at Mecea (MacDougal 403), Imperial Junetion beach (MaeDougal 129), Figtree John Spring, Dos Palmas.

Frequent in like places, at low altitudes, throughout California.

Pluchea sericea Coville. Arrowweed.

Very common in river bottoms, about springs, and in damp soils generally, throughout the Sink. Thermal, Meeca, Mortmere, Dos Palmas, Rockwood, Imperial, El Centro, Calexico, Penguin Island (MacDougal 201).

Cormmon in southern California, most abundant in the desert.

Dicorea canescens T. \& G.

Occasional in moist, subalkaline soil. Indio, as a weed in a young date garden (8366), New River bottom at Calexico (8365).

Colorado Desert and thence into Arizona.

Hymenoclea salsola T. \& G.

Detrital mesas near Mecca, Rabbit Bay (MaeDougal 209).

A common species of the Colorado Desert.

Amarosia psilostachy DC.

Adventive at Imperial.

A common weed in California and in many parts of North America.

Franseria dumosa Gray. Gartneria dumosa Kuntze.

Frequent in detrital soil and oecasional in light alluvium. Mecea, Caleb, Durmid, Westmoreland.

A characteristic speeies of the Californian deserts, extending into Arizona and Mexico.

Xantulua commune Britton.

Frequent throughout Imperial Valley, Calexico, Holtville, Meloland (W. E. Paceard), Brawley. Also at Mecca $(8438,8610)$.

Common in the Colorado bottoms at Fort Yuma; not reported otherwise from California, but it occurs at San Diego.

Echipta alba Linn.

In the river bottoms and very common along canals and in irrigated lands in Imperial Valley, and in waste plnces about the towns of the Sink. Meeea (8362) Roekwood, Brawley, ElCentro (8089), Holtville, Meloland, Calexico, Obsidian Island (MaeDougal 4, 303).

A widely distributed subtropical weed, common along the Colorado River bottoms at Fort Yuma and an entrant into the Sink from the delta. Not before reported from California.

Bebbia juncea var. aspera Greene.

Occasional along washes at the upper margin of the Sink at its northeastern end. Near Red Cañon, Dos Palmas.

A specics of the cañons of the desert mountains, which barely enters the borders of the Sink.

\section{COMPOSITE-Continued.}

Heltanthus annuUs Linn

This eommon California weed is beginning to appear in the fields and towns of Imperial Valley. Brawley, Meloland, El Centro. Also at Mecea, rare.

Encilia farinosa Gray.

Oceasional on detrital soil at the nortlieastern end of the Sink. Salton, Caleb.

A common species of the California deserts, reacling westward into San Bernardino Valley, and eastward into Arizona.

Encelia frutescens Gray.

Rabbit Bay (MacDougal 214).

A widely distributed species in the cañons of the deserts of California, extending to Arizona and Utah. IIere a migrant from the mountains.

Encelia eriocephala Gray.

Common on the plains at Meeea (8345). Obsidian Island (MacDougal 33).

Abundant in sandy soil in the Mojave and Colorado deserts.

BIDENS PILOSA Linn.

A single plant by the railway at Mecea.

Common along ditehes and small streams in eismontane southern California, bere a waif.

Bineng EXPANSA Greene.

A few plants in the stream from the railway waterworks, Meeea (8462).

An abundant indigenous species of eismontane southern California, but here evidently introducel.

Baileya multiradiata Harv, \& Gray var. pleniradiata Coville. A single plant in sandy soil, near Meloland (8095).

Common at lower altitudes in the California descrts, thence east to New Mexico.

Baileya pauciradiata Harv. \& Gray.

Meloland (8095), Dixieland (8368). Abundant in places in the mounds near the Alamo River, cast of Calexico, and in sand at Travertine Terraces (8430).

A species of the eastern parts of the Californian deserts and adjacent Arizona and Mexico.

Palafoxia linearis Lag.

Indio, as a weed in a date garden, Westmoreland. Abundant in places in the mounds near the Alamo River, where it becomes ligneseent at base and more than annual (8361). Sands at Travertine Terraces.

A widely distributed speeies of the Colorado Descrt, less frequent in the Mojave Desert, and extending into adjacent Arizona and Mexico.

Pectis papposa Harv. \& Gray.

Frequent in alluvial soil, notably in the mound region of Imperial Valley. Flats near Mccea (8371), bluffs at Rockwood (8370), mounds of the old beach east of Holtville (8083 epappose, 8084 pappose). mounds of the Alamo River east of Calexico, where plentiful in places, in both pappose and epappose forms (8372), streets of Brawley as a weed.

Southern border of the Colorado Desert, eastward to New Mexico.

ANTIEMIS COTUla Linn.

Adventive at a few places in Imperial Valley. Imperial.

This old-world wced is common in southern California, whenee it has probably been introdueed here.

Peucephalum schottii Gray.

A few individuals grow in the erevices of Travertine Rock and at the base of the range southwest of it (8431).

This is a eharacteristic species of the eanons of the arid mountains of the Colorado Desert, and enters the Sink only under the exceptional cireumstances herc presented. 
COMPOSIT E-Continued.

Psathyrotes ramosissima Gray.

Frequent along washes and on detrital mesas at the northeastern end of the Sink. Between Mecea and Red Cañon (8115), Obsidian Island (MacDougal 116).

Common in similar places in the Colorado Desert, and east and south into Arizona and Lower California.

Stephanomeria runcinata Nutt.

A few plants at Caleb (\$367).

Occasional in the California deserts, and thence into Lower California.
COMPOSIT A-Continued.

SONCHOS Asper Vill.

Occasional in the cultivated parts of Imperial Valley. Brawley, Imperial, Mecca (MacDougal 123), Obsidian Island (MacDougal 31).

Sonchus oleraceus Linn.

Very common in the cultivated parts of Imperial Valley. Brawley, Imperial, El Centro, Mecen Flats (MacDougal 127).

These two sow thistles are abundant weeds of cultivation in California, and owe their presence here to the recent aettlement of the valley.

TABLE 31.-Appropriale altitudes of the locolities, in feet.

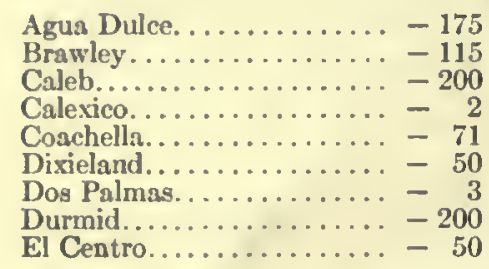

Estelle............... -180

Figtree John............. -195

Holtville............. -15

Indio....................

Imperial. ............

Imperial Junction......... -125

Mecca................. -190

Meloland............. -50

Mortmere............. -175
New River at Calexico..... - 20

New River at Rockwood... - 185

Rockwood.............. $-\mathbf{I 6 0}$

Salton...................

Sceley................ -50

Thermal............. 130

Travertine Rock (base).... -150

Travertine Terraces....... -190 


\section{MOVEMENTS OF VEGETATION DUE TO SUBMERSION AND DESIC- CATION OF LAND AREAS IN THE SALTON SINK.}

By D. T. MacDougal.

\section{DESERT BASINS AND REVEGETATION.}

Extensive basins occur in various parts of North America, Australia, Africa, and Asia, in which the climatic and hydrographic conditions are such that the lowermost parts of the depressions are at times occupied by bodies of water which may disappear or show wide fluctuations of level or volume. Alternations of this kind are followed, of course, by the annihilation of the terrestrial species, as lakes arc formed or as they increase, and by the revegetation of cmersed areas laid bare by receding waters. It is fairly evident that occurrences of this kind have taken place in the great basins of Nevada and Utah, in the Oteri and other depressions in New Mexico and Arizona, in the Pattie Basin in Mexico, and in the Cahuilla Basin in southern California. ${ }^{1}$ In some the alternations date far back in geologic time and many thousands of years must have elapsed since the last change occurred. In others, such as the Pattie and Cahuilla Basins, the transformations follow each other rapidly, and although they may have begun far back in time, yet they continue up to the present.

The evidences of differences in level at which bodies of water have stood in the lowermost parts of inclosed drainage systems during historic times are indisputable, and consideration of the facts obtained from the study of these basins and of the records of longlived trees leads to the conclusion that the variations in the level of some lakes without outlets in North America were connected in a direct way with variations in major climatic factors. Such variations would have great influence upon the movements of plants about the world, but would lie beyond the scope of this discussion. ${ }^{2}$

The chief biological interest of the present paper centers in tlic fate of organisms overwhelmed by floods, in the physical changes which follow emersion, and in the biological mechanism of reoccupation of sterilized areas as they emerge from the water, episodes which must have been duplicated in their main features innumerable times in the history of the surface of the earth. Many of the important features of distribution of plants and animals at the present time may be due to antecedent facts of this character.

Opportunities are not common for studies of this kind and for analysis of the means and manner by which living things move onto a sterilized area or into a sterilized medium. Krakatau, an island in the Indian Ocean, was devastated by a volcanic eruption in 1883 which destroyed practically all of the higher plants growing upon it. The place was visited by botanists in 1886, 1897, and 1906, and brief analytical studies were made of the establishment and constitution of the flora at these widely separated dates. Little attention could be paid, however, to the successions or to the progress of physical conditions upon which the dissemination and establishment of seed-plants depcnded. ${ }^{3}$

- Gilbert, G. K. Lake Bonneville. Misc. Doc. House of Representatives, first session, Fifty-first Congress, $1889-90$.

Russell, I. C., Geological History of Lake Lahontan. Misc. Doc. House of Representatives, first session, Forty-ninth Congress, 1885-86.

Gregory, J. W., The dead heart of Australia, London, 1906.

¿ See Huntington, E., The fluctuating climate of North America. The Geographical Journal, vol. xL, pp. 261-280, $392-411,1912$.

- Ernst, A., The new flora of the volcanic island of Krakatau, translated by A, C. Seward, 1908.

Campbell, D. H., The new flora of Kirakatau. Amer. Naturalist, vol. XLII, August 1909. 
The effects of voleanism have furnished other opportunities for observation upon the invasion of sterilized areas on the surfaces of cooled lava flows. The physical conditions of the substratum are highly specialized under these circumstances, and moreover it has been found difficult to make any definite analysis of the determining factors in the movements of the vegetation appearing in such places, although some extremely interesting records of these phenomena have been made. The most important and most recent work upon this subject was done by C. N. Forbes, in the Hawaiian Islands. ${ }^{1}$ ( See Note below.)

Newly made lands about the mouths of rivers generally furnish a substratum highly favorable to the growth of a number of species of higher plants as soon as the deposition reaches a stage where the surface is brought permanently above the level of the tide, and the conditions are very favorable for observation of the successions. ${ }^{2}$ Such occupations of bare soil by open formations and later by closed ones have also been described by Flahault and Combes. ${ }^{3}$ Newly made alluvial was first occupied by Salicornia macrostachya, followed by Salicornia sarmentosa, Atriplex portulacoides, and Dactylis sarmentosa. As may be seen from the contents of the present paper, the procedure on the emersed lands of the Salton is widely different from that in any of the above cases.

\section{THE SALTON SINK.}

The Cahuilla Basin lies in the most arid part of North America, and although the making of the lake in the Salton Sink or portion of the basin below sea-level may be finally due to climatic factors, yet it is caused directly by overflow from the channel of the Colorado River. The geological record seems to indicate that the Sink has been filled and dried out at intervals over a long period extending up to the present time. Circumstantial evidence points to the conclusion that hardly twenty years have passed without some inflow from the river into the Sink, but the only available actual record of any other inundation besides the one the effects of which are considered is that of the overflow of 1891, when the passage from the river to the small lake formed in the Sink was made by a single man in a boat on the inflowing current for the purpose of ascertaining the source of the water forming the lake. (See p. 19.) (Plate 15.)

The formation of the lake in 1905, 1906, and 1907 occurred under circumstances that gave unexcelled opportunities for a study of the attendant phenomena. A number of naturalists had visited the Sink in the half century following the Williamson expedition through it (1853) and something of the nature of the surface formations as well as of the plants and animals had become known. Furthermore, a short visit to the bottom of the basin near the railway station of Salton had been made by Messrs F. V. Coville and D. T. MacDougal in 1903, and a brief description was published as to the aspect of this part of the Colorado Desert, including an area to the northwestward. Photographs of parts of the Sink which were afterwards submerged were also obtained."

In 1904, an expedition from the New York Botanical Garden, in which Dr. D. T. MacDougal, Mr. G. Sykes, and Prof. R. H. Forbes participated, started from Yuma in February and went down the river through the Delta and to the western shore of the Gulf of California. ${ }^{5}$ One camp was made a short distance to the southward of the boundary between the United States and Mexico, near an intake of an irrigation canal leading to an area in the basin being brought under cultivation, and brush dams were seen extending out into the stream for the purpose of forcing the current into these artificial channels.

1 lorbes, C. N., Plant invasions of lava flows. Occasional Papers, B. P. Bishop Museum, etc, vol. v, p. $244,1912$.

2 Oliver, P. W., The Bouche d'Erquy. New Phytologist, vol. vr, pp. 244-252, 1907.

${ }^{2}$ Sur la flore de Ja Camargue et des alluvions du Rhone, Bull. d. l. Soc. Botan. d. France, vol. xur, 1894.

- See Coville and MacDougal, The Desert Botanical Laboratory of the Carnegie Institution, pp. 20-22. Publication No. 6, Carn. Inst. Wash., November 1903.

- MacDougal, D. T., Botanical explorations in the Southeast. Journal of N. Y. Bot. Garden, vol. v, p. 89, 1904.

NotE.-A copy of a paper by Mr. W. N. Sands giving "An account of the return of vegetation and the revival of agriculture in the area devastated by the Soufriere of St. Vincent in 1902-3" (West Indian Bull., vol. xrI, pp. 2233,1912 ) has been received since this paper was put into type. Some interesting facts as to revegetation of denuded areas are given. 


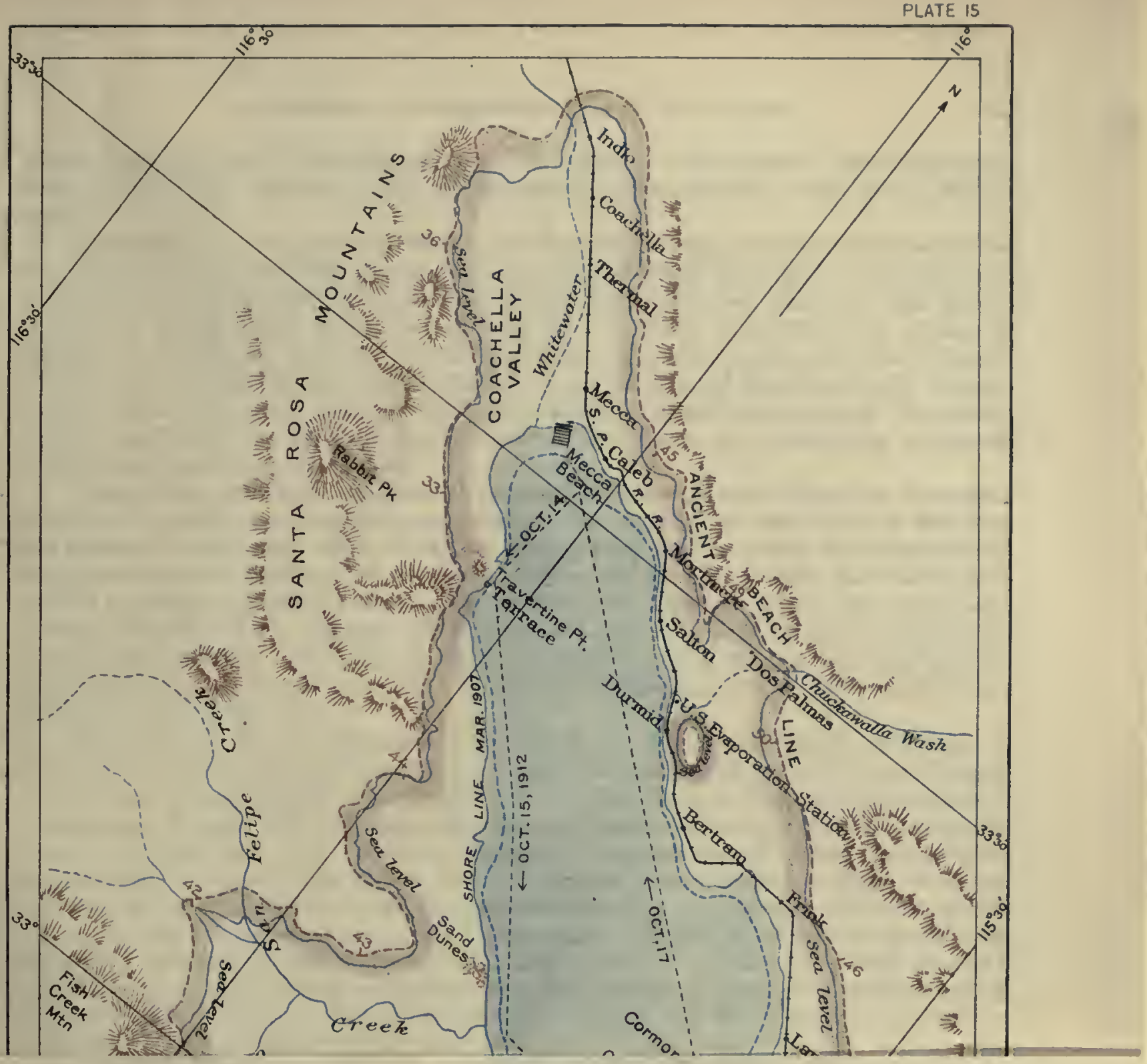



A year later a second expedition, starting 300 miles up the Colorado, was made down througl the Delta, returning to the northward along the western margin of the alluvial lands. ${ }^{1}$

The southernmost of the canal intakes had been eroded deeper and wider by the inflowing current and a stream large cnough to float a steamer flowed through it to the westward, spreading out over the alluvial lands, but finally collecting in two main channels kuown as New River and Alamo River leading down into the Sink. New River was crossed at Calexico in small boats, and it was at this time simply a muddy stream a few feet in depth, but the water was nearly level with the banks. Later, as is noted elsewhere in this volume, a great amount of erosion occurred which excavated a deep and wide channel. Returning to the main line of the Southern Pacific Railway the Alamo was crossed, but no special observations were made on its flow.

A party from the Desert Laboratory proceeded southward from Mecea to Travertine Rock in May 1906, and made an examination of the shore of the lake, which at this time had attained a maximum depth of 34 feet, with a total area of nearly 300 square miles. The party included Professor W. P. Blake, who made the trip to verify his observations of 1853 upon the travertine formations which had been observed by him fifty-three years earlier. (See Plate 1 в.) Samples of the water were taken (see page 35) and the shore phenomena were observed. The scope of the opportunities for research upon several geographical problems was recognized and comprehensive plans for dealing with the entire matter were formulated during the year. ${ }^{2}$

The inflow of the water proceeded, but early in 1907 the engineering operations of the Southern Pacific Railway promised to close the breaks and place the inflow under control, and a small sailboat was eonstrueted at Mecea early in January for purposes of exploration. A party with full field equipment embarked in this boat for a trip around the shores of the lake and to the islands on February 7, and made daily camps ashore during the following ten days. The highest level of the lake with a maximum depth of 84 feet was reached on February 10, at which time the party was camped near the southern end among the great crescentic dunes of the Carrizo sands. During all of this royage landings were made with the greatest difficulty, as the steady rise of the lake had simply pushed a sheet of water out over the loose alkaline soil of the desert and made a soft mud into which one would sink to a depth of 2 or 3 feet in a few seconds, and the saturated soil would be moist and soft for some yards away from the water. Long tongues of water extended far up the channels of the dry washes and no true beaches or strands had yet been formed by the sorting or solidification of the soil material. (See Plate 12 c.) So rapidly had the level risen that several of the great erescentic dunes had been surrounded by water and their long ridges still showed above the water like curved whale-backs. (See Plate 12 B.) Thousands of rounded masses of pumice, from 1 to 6 inches in diameter, floated on the surface, as well as many of the hard-shelled globular fruits of Cucurbita palmata. The water at this time contained about 0.25 per cent of dissolved salts, which is near the limit of potability. This was denoted by the fact that it could be used by some members of the party, but not by others.

Four hills in the southeastern part of the basin stood above the water as islands. The southermmost was known as Big Island and rose in conical form to a height of over 100 feet and showed the terraces of previous lake formations far above the recent level. (Plate $6 \mathrm{D}$. ) Its base was fringed by lower flattish hills on the southward, separated from it by narrow channels, and the recession of the waters rapidly increased the exposed area, while the top of a hill to the northward eame above the water in 1908 . (Plate $6 \mathrm{D}$.) Rock Island was the crest of a

\footnotetext{
'MacDougal, D. T., Botanical explorations in Arizona, Sonora, and Baja California. Journal of N. Y. Bot. Garden, vol. vi, p. 91, 1905 .

${ }^{2}$ Report of Department of Botanieal Research for 1906, Year Book Carn. Inst. Wash., No. 5, 1906.
} 
hill which bore no seed-plants by reason of lack of soil and rose 40 or 50 feet above the water. No landings were made on it. Obsidian island was of dumb-bell shape nearly a mile in its main axis, which lay nearly north and south. The shores of the bays on the eastern and western sides were of sand and alkaline clays and this formation extended southward on the eastern side. These conditions, together with the fact that the island lay in the drift from the Alamo inflow, cooperated to yield some very interesting features. Cormorant Island, 2 miles to the northward, was awash during the period of maximum depth of the lake and was completely sterilized. It is to be noted that the names given to these islands were applied solely for the convenience of the workers of the Desert Laboratory and as they were not formally published have not been generally recognized. Other names for the same formations have probably been used by visitors to the lake, but so far as the author is aware none have been formally presented, and as a matter of course the subsidence of the lake will restore the elevations to their status as hills, which may or may not have received definite appellations (Plate $16 \mathrm{~B}$ ).

The islands bore a sparse vegetation, including four species of Atriplex. Lizards and small rodents were found on Big Island and Obsidian Island. A coyote had survived for a short time on Obsidian Island. The amount of food on Big Island was such that in February 1907, a year or more after this elevation had been surrounded by water, rabbits and a raccoon were still alive, as indicated by their traeks and burrows. The isolation of the tops of these arid hills as islands by the waters of the lake made them attractive to aquatic birds, and Obsidian Island became the site of an extensive nesting-place for pelicans as early as 1907, while some cormorants made nests here and also on the top of the smaller island to the northward, which was barely awash at high water and was named Cormorant Island. Representatives of the fishes of the Colorado River had come into the Sea, but did not seem to multiply, with the exception of the introduced earp, which afforded a food supply of some importance to these birds. Nothing definite may be said about the movements of other flying species, but it is well known that those mentioned above make long flights southward through the Delta to the Gulf of California and along the course of the Colorado. The possibility of seed-introduction by these birds awakened the liveliest interest, although it was probable that the plants which might thus be earried to the islands were likewise the ones which might be most readily borne there by flotation. In any analysis of possible introductions, therefore, the positions of the established plants with regard to the water-level would need careful consideration.

\section{LAGUNA MAQUATA.}

After a brief survey of the lake an excursion two weeks in length was made to another sunken basin to the southward, which lies to the westward of the Cocopah Mountains in Baja California, a province of the Republic of Mexico. The Sink of this basin had been seen to be receiving an inflow from the Colorado River around the southern end of the mountains in April 1905, but nothing was known as to how long this continued. It may be assumed, however, that it ceased with the passing of the summer flood of the Colorado in June of that year, since the water in Mareh 1907 was 12 to 15 feet below the maximum level, which loss or recession could be attributed chiefly to evaporation, which for adjacent regions has been ealculated as over 100 inches per year. The body of water formed here has been variously known as the Laguna Salada and Laguna Maquata. The lake was known to be in existence in 1884, was represented by a chain of saline pools in 1890, was seen in much the same condition in 1892, and filled again in 1893 . Exact records of the eycle of the lake are not available, but it is known to have become entirely dry at various times up to 1905 , when it was seen to be filling as noted above. The rate of evaporation would probably result in the desiccation of the lake in 1909, but early in April 1910 it was again reported to be filling in connection with serious disturbances in the lower course of 
the Colorado River. The main eurrent of the Colorado no longer followed the channel which had earried the main flow for a long period and now made a more southwesterly eourse down the Bee River, which brought its waters directly against the southern end of the Cocopah Mountains. It appears, therefore, that water was poured into this basin in such manner that the lake was maintained continuously from 1910 until late in 1912, at which time this manuscript was prepared.

The maximum-level strand was marked by a heavy band of Prosopis, where it cut across bajadas or detrital slopes, and by a distinct water-line along the rocky mountain wall of the Cocopalis. The high beach of 1905 was marked by a zone of Sesuvium sessile and by the remains of other halophytes, which had perished with the desiceation of the salty soil. This preliminary visit showed the importance of earrying on observations in this basin concomitantly with those to be made in the Salton Sink, but the internal disturbances of Mexico were followed by military operations at Calexico and along the northern margin of the Pattie Basin, which made field work impossible south of the international boundary.

\section{PLAN OF FIELD WORK IN THE SALTON SINK.}

An ideally perfect method of investigation would have been to make frequent examinations of the entire shore-line of the lake, but as this was over 150 miles in length and as parts of it lay below deserts accessible with difficulty and was fringed with mud flats, this was practically impossible. Attention was therefore devoted to areas, a mile or less in width, back from the shore, which extended down the slopes with the recession of the water. One such area was located at the extreme northwestern end of the lake near Mecea. The soil consisted of a clayey alluvium, uneven as to saline content and detail of surface, but in general showing a slope in which the fall was about 1 in 400, giving many effects of a flat surface. The moister places maintained Typha, Populus, Salix, and Phragmites; the saline spots bore such halophytes as Atriplex, Sucda, and Spirostachys, while mats of Distichlis were found scattered over the area.

A second area was sclected on the shore to the southwestward of Imperial Junction, on a clayey slope in which the adobe soil was high in salt content and bore seattering plants of Atriplex, Suceda, and Spirostachys. The slope here was slightly steeper than the one at Mecea, the fall being about 1 in 300 .

The steep detrital slope running down from the mountains to the southward of Travertine Rock on the soutliwestern side of the lake bore a xerophytic vegetation, among which were a few halophytes, such as Atriplex; the remainder were chiefly spinose and selerophyllous forms. Bands or rows of these plants indicated ancient strands, some as high as the maximum level of the ancient lake. (See Plate 18.) The slope here was about 1 in 20. On account of these old terracing effects, which were duplicated by the present lake, this place was designated "The Travertine Terraces."

The shore-line of Obsidian Island, which lies to the westward from the Imperial Junetion beach, about 8 miles from the recent high-water level, was examined over its entire length of sand and gravel strands and rocky shores. The upper parts of the island bore four species of Atriplex, some Spirostachys, and one or two other halophytes. In places the beaches showed a fall of 1 in 7 or 8 .

A few examinations were made at various places on the western shores of the lake, which lay aeross the lower parts of long bajadas or detrital slopes coming down from the distant mountains. Some sand dunes were present on these slopes and the vegetation included a variety of halophytes and sclerophylls.

Sterilized islands, in the form of hill-tops emerging from the receding water, came in for very detailed attention. The surface of Cormorant Island, north of Obsidian Island, was not submerged, but was sterilized by the salty water at the high level. Various smaller 
islands in the vicinity of Big Island in the southern part of the lake were taken into account as they came into view and the character of the surfaces was noted in every case.

During expeditions to these places once or twice yearly, collections of plants were made, and notes and photographs were taken of the formations encountered. A large sample of water was taken annually in June from the surface of the deepest part of the lake in order to follow the changing composition of the dissolved salts, and also from other locations and depths for comparison. A chemical and physical examination of the soils on the bared parts of contiguous areas was made, together with every effort to determine the factors cooperative in influencing the behavior of vegetation as it followed the receding lake.

In addition to the sail-boat built in 1907, a steel-hulled power launch, built in the shop of the Department at Tucson, and a small sectional steel rowboat were used in traversing the lake. Land trips back from the lake and around its southern end were made by camp wagons and field equipment. Some use was made of motors, despite the deep arroyos and great stretches of soft sand encountered. A traverse from the extreme northwestern part of the basin by motor to the northeastern part was made in September 1910, when Messrs. Sykes and MacDougal carried a line of observation on the drainage and surface conditions from the San Gorgonio Pass down to the lake at Mecca, thence by way of Dos Palmas up the Chuckawalla Wash to the Chuckawalla Divide, and down eastwardly to the Colorado River, a distance of 150 miles. Messrs. MacDougal and Sykes came through the San Gorgonio Pass and went down the drainage of the Whitewater to the northwestern end of the lake in June 1912. Here the party was joined by Professor Brannon and a route was followed along the western and southwestern sides of the lake and across the inflowing channel of the New River. From here a line was run to the western margin of the basin and across the range by Mountain Springs to San Diego. Other trips were made from time to time by the collaborators in this volume and the results of their field work were made available for all those engaged in the work.

\section{FACTS TO BE ASCERTAINED.}

The energy of the entire staff of collaborators was concentrated in an effort to obtain facts which might bear upon the more important problems presented by the receding lake, which for convenience may be arranged in the following topical form:

1. Composition and nature of the flora of the basin, with ehief attention to the species inhabiting the Sink.

2. Influence of the lake upon vegetation above the flood-level, either in inereased humidity or hemmed underflow.

3. Endurance and survival of the vegetation in the shallower marginal portions of the flooded area.

4. Geographical relations of the Sink, with especial consideration of the contributing drainage.

5. Physical and chemical analyses of soils of the Sink, with comparisons between those unaffected by the reeent submergence and those taken from the bared strands.

6. Composition of the water of the lake as varying with its coneentration.

7. Algal and bacterial flora of the lake, and influence of these plants upon the composition of the water.

8. Alterations in plant tissues induced by submergenec.

9. Reoccupation of the bared strands left by the receding lake by plants.

10. Alterations or successions in the plant inhabitants of the strands with increasing aridity.

11. Environic response of plants gaining a foothold on the strand and later becoming subjeet to desiccation.

12. Pioneer oceupants of sterilized islands emerging from the water as a result of lowered level.

13. Agencies effective in carrying seeds, spores, and propagula to bared strands and isolated areas on islands.

14. Introductions, or invasions of the Sink by speeics not hitherto native to the region.

It need hardly be said that the evidence obtained on some parts of this comprehensive program was very meager, and that some features, notably those of the animal inhabitants 


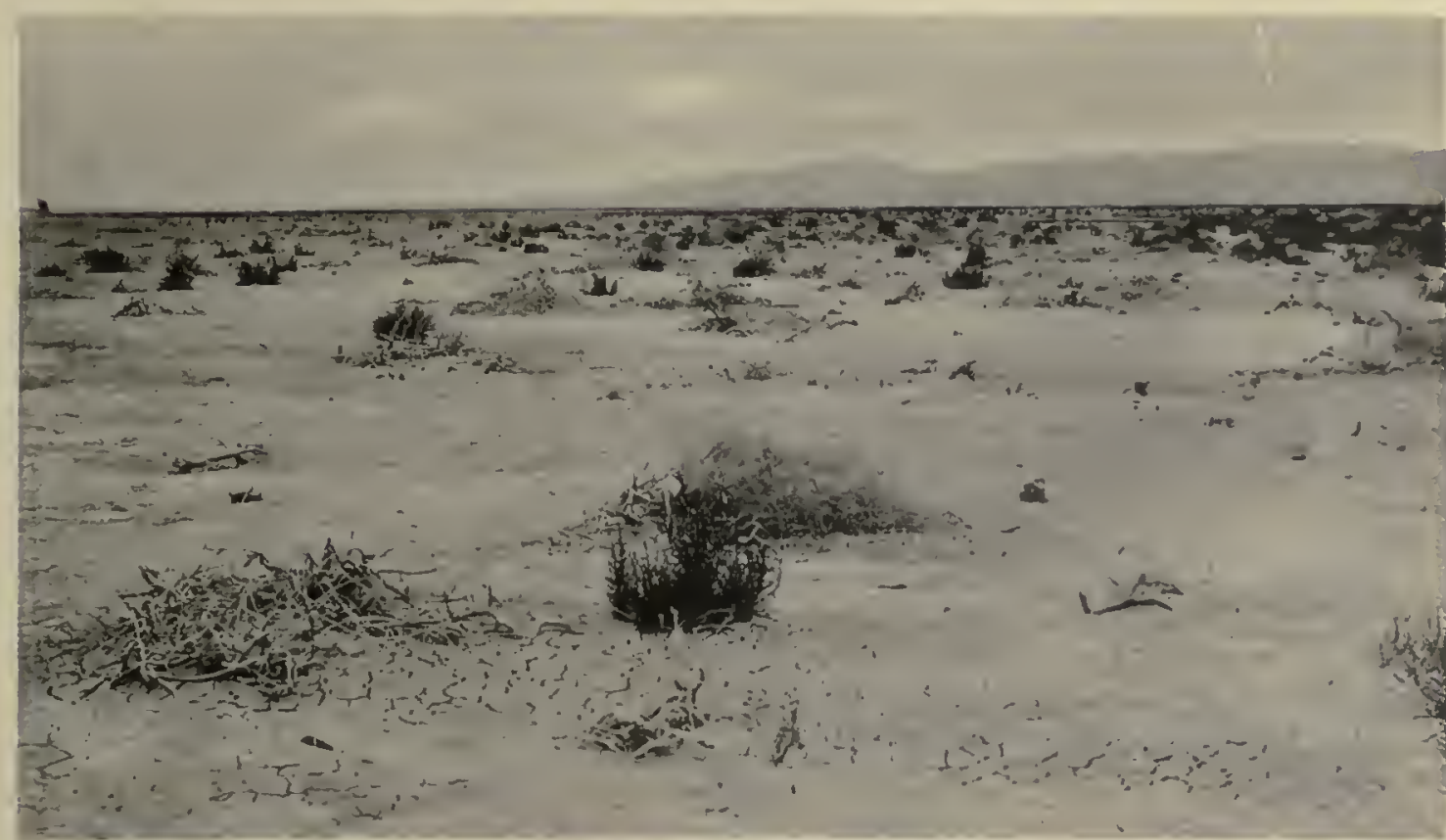

B

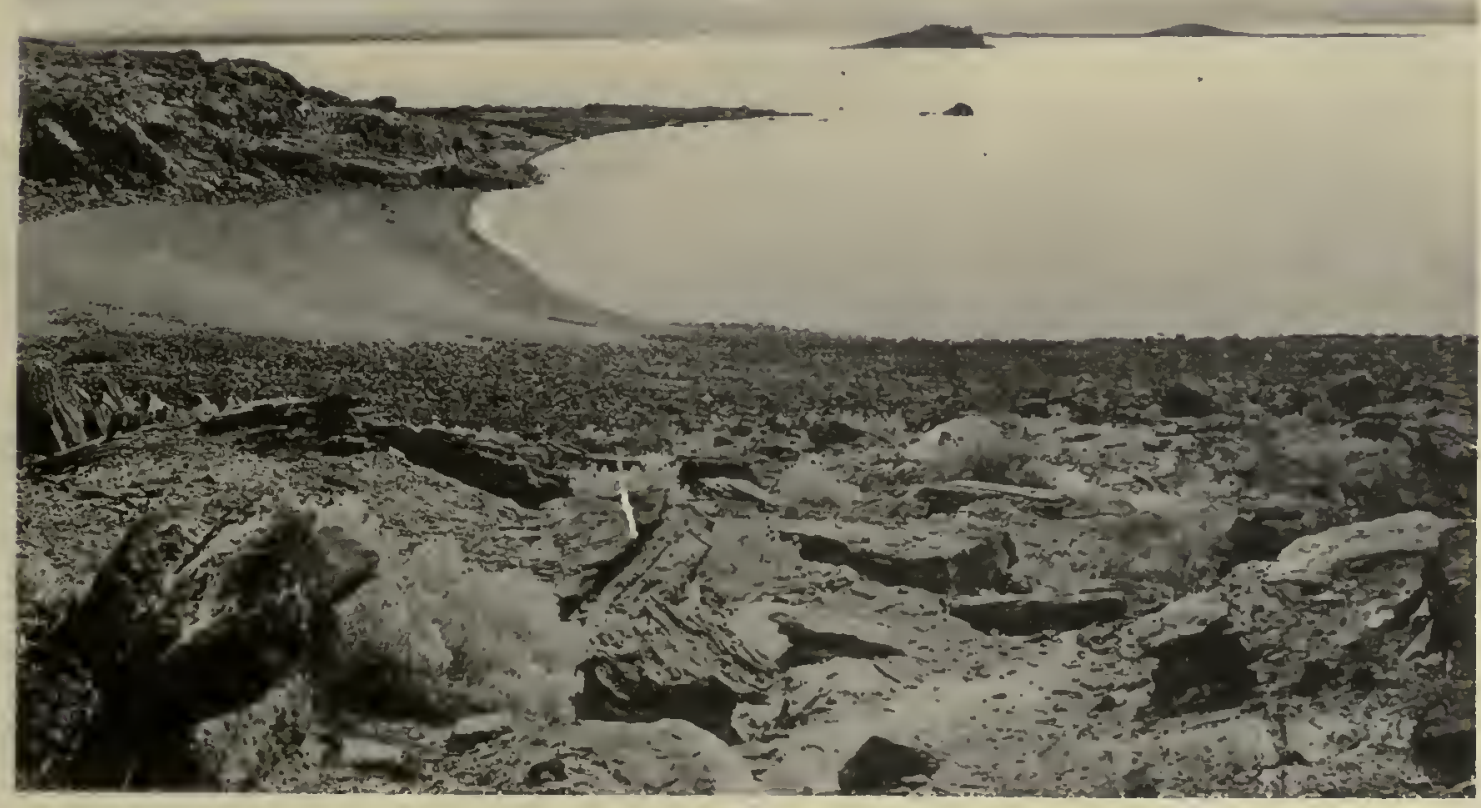

A. View northward parallel to the shore from middle of Emersion of 1907. Imperial Junclion Beacls, taken February 1908. Atriplex, Sureda, and Spiroslachys zone in middle. Denser Vegetation on right is above Flood Level, and Boat is moored near Shore on left.

B. View from Obsidian Island toward the southwest, showing West Bay of that Island: Rock Island in middle distance and Big Island to the right. 

and plankton, were not seriously touched upon, execpt in so far as the work of Dr. Brannon upon the baeteria contributes to the matter.

A number of the above subjects are considered in full in this scction, while others are treated in scparate eliapters, as indicated in the table of contents.

The elief features of the phenomena of revegetation of the beaches may be best presented by a reduction of the ficld notes to a history of the strands or zones emersed during each year of the recession of the lake. Any intelligent consideration of such descriptions must be made in the light of the following conditions affecting the strands:

1. The observational areas selected represent widely different habitats as to soil composition and other environic factors or components.

2. The lake rose quickly to its maximum level and receded rapidly.

3. The infiltration and leaching of the soil varied year by year as affected by the concentration of the water on one hand and the time of submergence on the other.

4. The salt content of the water was least during 1907 and increased about 18 to 20 per cent in each succeeding year.

5. Every emerserl strand would therefore be saturated with a soil-solution resulting from the infiltration of the lake water of the concentration and composition prevalent in the period preceding emergence.

6. The desiccation of the emersed strands would proceed at a ratc determined by the character of the soil and by the composition of the infiltrated water.

7. The rising water of the lake picked up seeds lying on the surface, and their survival constituted a means of revegetation, chiefly of the strand bared in 1907 .

8. The rates of evaporation and of recession of the lake varied with the season, being most rapid in June to August and slowest in Deeember and January. The possible total may be estimated at 116 inches per year.

9. The rainfall data of the Sink, obtained from the records of the U. S. Weather Bureau made at Indio, which is located near the extreme northwestern end of the Sink, only a few feet below sea-level, show an average of $\mathbf{2 . 7 4}$ inches per year.

10. Rapid recession of the water would result in separating stranded seeds quickly from the margin of the water, with consequent rapid desiccation of the surface layer of soil, which would be unfavorable to germination and survival.

11. The shallow water lying on wide mud flats fringing the shores was raised to a much higher temperature $\left(15^{\circ}\right.$ to $20^{\circ} \mathrm{F}$.) than the body of the lake during even the winter season, thereby greatly increasing its toxicity for seeds, plantlets, and propagating bodies. The greater number of the seeds falling into the lake would be subjected to this action. The muddy flats fringing the shores at all stages of the lake must, therefore, be considered as a barrier of some magnitude which would be crossed by a plant carried out into the lake and again when deposited on a beach. (See also p. 140.)

\section{REOCCUPATION OF THE STRANDS OF 1907.}

The level of the lake reached its highest point about February 10, 1907. A record quoted, by the writer (Desert Basins of the Colorado Delta, Bull. Amer. Geog. Soc., December 1907 ) is to the effeet that the rise in the water continued until in March, but the numerous observations on the beaches late in February showed that a fall had taken place beyond doubt and the record for March may be assumed as an instrumental error. The immediate and rapid rate of fall of the water-level consequent upon the diminution of the inflow which was brought about on February 10 may be ascribed to the enormous evaporation and infiltration. This was sufficient to lower the level by a foot at a date early in June 1907 , and in one year from the time of cessation of the rise the fall was between 40 and 42 inches.

The record of the change in level of the lake and the varying area eovered are shown by figure 3, page 138, reproduced from Mr. Cory's records (sec fig. 31, Trans. Amer. Soc. Civil Engineers, vol. xxxvrrr, 1912).

The slope lying above the observational area at Imperial Junction beach showed a surface of adobe containing such an amount of dissolved salts that it bore a distinctly 
halophytic vegetation, inclusive of Spirostachys, Suxda, Atriplex, and Franseria, while Olneya and Larrea were represented by a few individuals back some distance from the shore. A few drainage channels or dry washes cut to a depth of a yard or less ran directly down the slope and offered special conditions when submerged.

The water rose rapidly to the maximum level, and the extreme upper strip covered was submerged for a few days, less than a week, even when wave action is taken into account, and then the recession began as illustrated by the curve in figure 3 . The bared zone had a width of about 1,000 feet in February 1908, and the average rate of horizontal recession was therefore about a yard daily. Much less than this would be laid bare during the winter months, while during the scason of maximum evaporation in the summer as much as 1.5 yards must have been uneovered daily.

The first critical examination of the Imperial Junction area was made in February 1908, or almost exactly a year after the recession began. The extreme high-water level was marked by a ragged band of timbers, drifted wood, and rounded masses of pumice for many miles along this shore, which was exposed to almost direct action of storms coming from the northwestward through the San Gorgonio Pass. The abruptly walled channels of the shallow washes which had been submerged were filled with mud by the action of the waves, and when these deposits were uncovered offered slightly different soil conditions from the contiguous slopes upon which there had been very little sorting of material (see Plate $12 \mathrm{c}$ ). No strand or beach ridges were visible and perhaps the only actual changes were those in the washes just noted and also in the salt and moisture content. The water of the lake when at the ligh level did not contain over 0.3 per cent of dissolved salts, but by January or February 1908 it had inereased to about 0.4 per cent, although no estimation was made until June, at which time the total dissolved salts amounted to 0.46 per cent. This amount was probably much less than that present in the soil of the observational area, in consequence of which a leaching action must have ensued which resulted in freshening the soil to some slight depth. (See Free, pp. 30-33.)

The uppermost portion of the strand, or that part of it which must have been flooded by the advancing water in December 1906 and January 1907, and laid bare before May 1907, was occupied by a dense formation of Sucda torreyana, Amaranthus palmeri, Atriplex fasciculata, A. canescens, A. linearis, and Spirostachys occidentalis. The last-named extended below the limits of the others to a point probably representing the stage of the water in June 1907. Immediately below the Spirostachys was a dense band of Pluchea sericea, the individuals of which were from a few inches to a yard in height.

Seeds of Suceda, Atriplex, and Spirostachys probably were present in the surface layers of the soil at the time of the inundation, and as the zonation was repeated on the corresponding seasonal recession of succeeding years the influence of germination conditions is suggested as the determining factor in all of them. The compositaceous Pluchea did not inhabit this area originally; its crops of seeds are ripened in early summer and are blown about by the wind in enormous numbers. The probabilities are great that some seeds were carried to lodgments on the muddy shore directly by air-currents. Some may have fallen in the water and were then cast ashore by wave-action. Any remaining afloat would be subject to the toxic action of the water, toward which the various species showed specific endurance (see Plate $16 \mathrm{~A}$ ).

A wide zone of hard bare dry soil below the zone of Pluchea was found in February 1908 , which was taken to be the strip laid bare in midsummer, during which time the horizontal recession would be 4 or 5 feet daily. This action, coupled with the high summer temperatures, would result in such rapid desiceation of the surface of the soil that deposited seeds would not be under suitable conditions for germination very many days. The actual rate of evaporation and concomitantly that of recession is suggested by the figures given in tables 32 and 33 , page 134, which have been plotted from the data given in the section 
of this volume by Professor Blake. The relative rates of evaporation by months are: January 10, February 10, March 18, April 20, May 26, June 34, July 30, August 28, September 23, October 21, November 12, December 9 (sec also p. 134 for evaporation of 1909-10).

That the bareness of the soil laid dry in midsummer was due to desiccation and not to dearth of available secds was made evident by the fact that below this arid belt was a second zone of Atriplex which appeared to occupy a strip uncovered during the autumnal months. It is a notable fact, however, that the formation of two definite bands or zones did not occur in any succeeding year, although there were a few late-summer germinations even as late as 1912, at which time the original invasions of 1906 and 1907 were still recognizable. The pelieans and cormorants were frequently observed standing on the shore near the margin of the water, during the middle of the summer especially, and there seems to be greater probability of their agency in bringing seeds to the summer zones than to any other formations examined around the lake. Furthermore, the species represented were those which might most readily have adhered to the legs and feathers of these birds.

The greater number of plants invading the strands were carried there in the form of seeds by the wind, by flotation, or by birds, as will be discussed somewhat fully in a later section of this paper, but the emersion of 1907 was characterized by some reoccupations of a different character. The waters of the lake rose rapidly to the maximum level in February 1907 and then fell quickly. In many places not particularly subjected to violent wave-action shrubs and small herbaceous plants stood erect in place, although the water about their bases was perhaps a foot in depth. If, as in the case of Atriplex and Sucda, the branches bore mature fruits, many of these might be retained until after the soil about the base of the plant had been bared, when their dispersal by the simple mechanics of the plant would result in some patterns of reseeding independent of other agencies.

The rapid recession of the water down the gentler slopes was not accompanied by any sorting of material in lines parallel to the periphery of the lake at Mecca or on the Imperial Junction Beach. The only specialization occurring was that by which suspended silt was dropped in the channels of the washes formed previous to the inundation. The recession of the water left these as moist strips of mud a few feet or a few inches in depth, which furnished conditions for Heliotropium, Lepidium, Typha, Rumex, and Leptochloa in a loose formation extending radially to the lake.

'The salt-grass or Distichlis had formed a few mats on the strand laid early in 1907, but these plants were already showing the strain of desiccation, and Leptochloa had also come in at a level corresponding to the autumnal band of Sucda. A number of hardshelled fruits of Cucurbita palmata had been cast ashore at various places on the slope, but no germinations had been accomplished.

The observational area near Mecca was upon a slope in which the fall was not more than 1 in 400, and as the surface was uneven, the vegetational reactions were not so easily interpreted. In fact, the limit at which the pitch of a slope may be sufficient to produce banding or zonation of the plants upon the given rate of evaporation may be taken to lie between that of the Meeca and that of Imperial Junction beach.

The circumnavigation of the lake in February 1907 was begun at a point on this area, a boat being brought up the shallow channel made by the advanee of the water up a sunken road. The actual margin of the water at this time was an exceedingly crooked line and the high level of the water might not be accurately laid down except at a few points. The second visit to the place in February 1908 showed that in addition to the survival of a fow individuals of Atriplex and Suceda within the inundated area, a few trees of Salix and Populus also endured submergence of their roots for several months. A great number of spreading trees of Prosopis pubescens had been killed and the wood of the trunks and branches had become exceedingly brittle. The total width of the emersed strip here was about 1,400 feet. In addition to the moisture effects from saturation, an uneven underflow 
was present, since this place lies partly on the detritus of the drainage of the Whitewater River coming in from the northwestward. The crop of seeds from plants of Suxda and Atriplex, living and dead, which had maintained an upright position, were sown in irregular patches by the wind (see Plate $28 \mathrm{~B}$ ).

Oligomeris glaucescens, Chenopodium murale, and a few young plants of some unrecognizable species were found on the upper part of the area in the region probably laid bare during the season of February to May. Heliotropium was seattered over the entire area, the older ones, near the high-water line, being in bloom. It was notable that Pluchea sericea and Distichlis, both of which were abundant above the high-water line, had not made their way down the gentle slope, nor had the receding waters deposited any seeds of these plants in such manner as to make possible their successful germination. The results at this place in the following years were vitiated somewhat by operations in locating homesteads and reclamation work, but observations were made from time to time, as noted below.

The extension of the water up the bed of a wide dry wash on the western side of the lake in 1907 offered special conditions and it was hoped that some observations of especial value might be made here. The underflow, however, from the extensive and steep mountain slopes only a few miles away was heavy and the recession of the water down the slope of the bed was accompanied by the breaking out of numerous seeps and springs above the water-level, which gave confused effects not capable of analysis. It is to be noted, however, that 'Typha found lodgment here, and a single Rumex grew from seed, while Heliotropium had become established and was in bloom in February 1908. (Plate 17.)

The banks of the wash rose perpendicularly to a height of 4 to 7 feet and the ground near-by bore a heavy formation of Sucda, Atriplex, Spirostachys, and Pluchea sericca. The damming of the underflow had also resulted in an increase of the available soil-moisture on either side of the wash, with the result that the species named flourished and showed a marked acceleration in development. These might easily have been mistaken for humidity effects (see pp. 139, 140).

Southward from the wash an arehed slope of detrital material ran steeply down below the high-water level and the waves were cutting the erest of the arch at the high level in 1907. A year later this cutting was seen to have resulted in a bank as steep as the nature of the material would allow and about 12 feet at its maximum height. Masses of dirt had already begun to slide down from the crumbling upper margin, carrying whole plants and seeds from the erest in February 1908. Among these were Coldenia, Pluchea sericea, and Atriplex canescens. All of the mature plants perished, as was found on the next visit, but in February 1908 the Atriplex had brought down seeds which had germinated, forming a row of plantlets 6 to 8 inches in height (see Plate 18). The recession of the water had resulted in laying bare a terrace about 60 feet in width. A number of small "tide-pools" had been formed near the base of the slope or cut bank and on the margin of one of these was an active rhizome of Phragmites, which had been floated to the place. A second one was seen, but in an inactive condition. This and the plantlets of Atriplex mentioned above constituted the only invaders of the strand at this place.

The steep slope of the original surface here offered the best opportunities for the analysis of the effects of rapid and slow recession of the water. The low rate of recession in December, January, and February kept the water at nearly the same level, so that the action of the waves resulted in a thorough sorting of the material, and this was heightened by the winter storms. In consequence the midwinter level of the lake was marked by a small beach ridge or by a cut bank which might have a vertical height of over a foot, as illustrated in Plate $25 \mathrm{~B}$. The interval between this and the ridge or cut bank of the following winter was taken as the emersed zone of the intervening year. The bases of these ridges or banks offered favorable conditions for the deposition of floating seeds, and the 


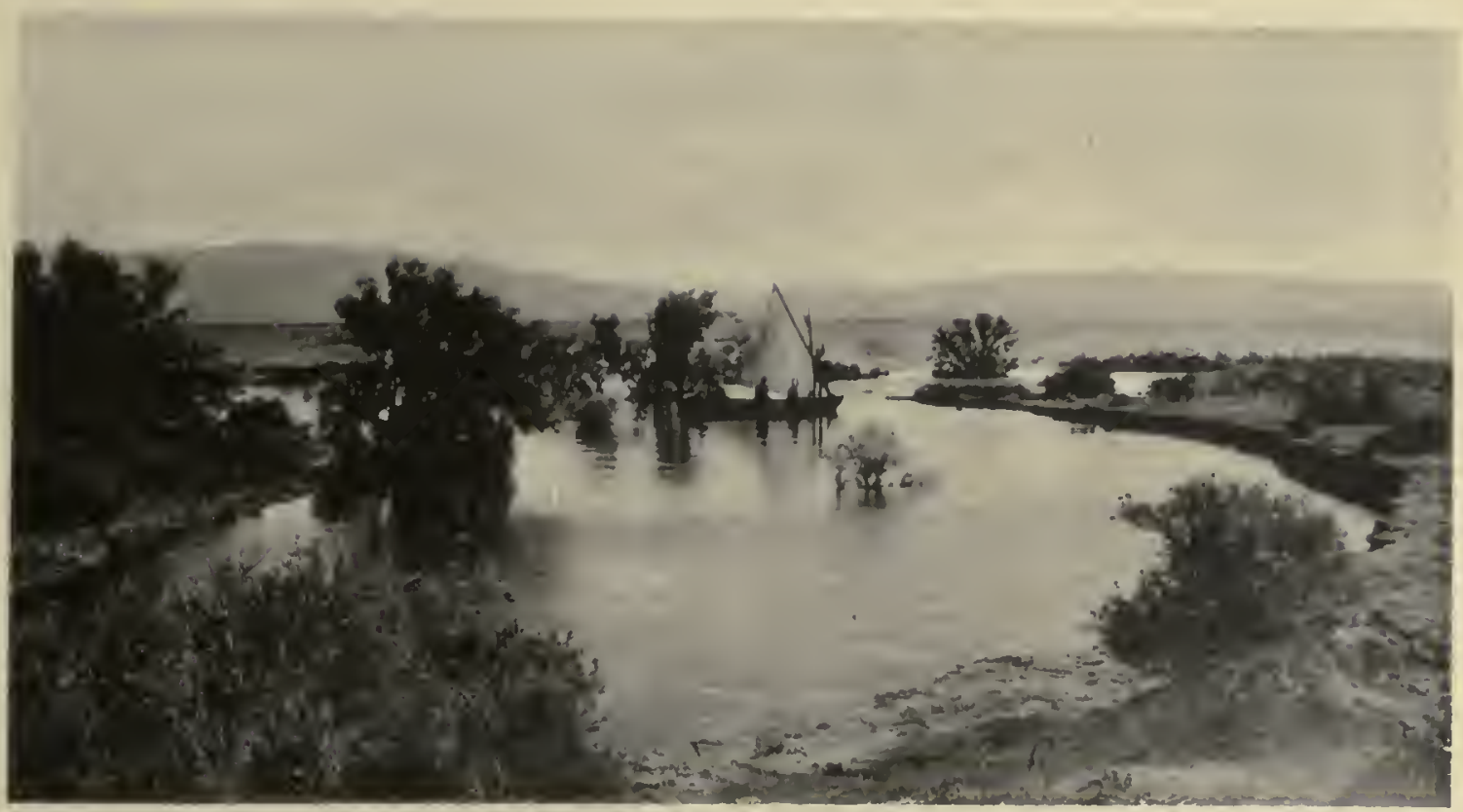

B

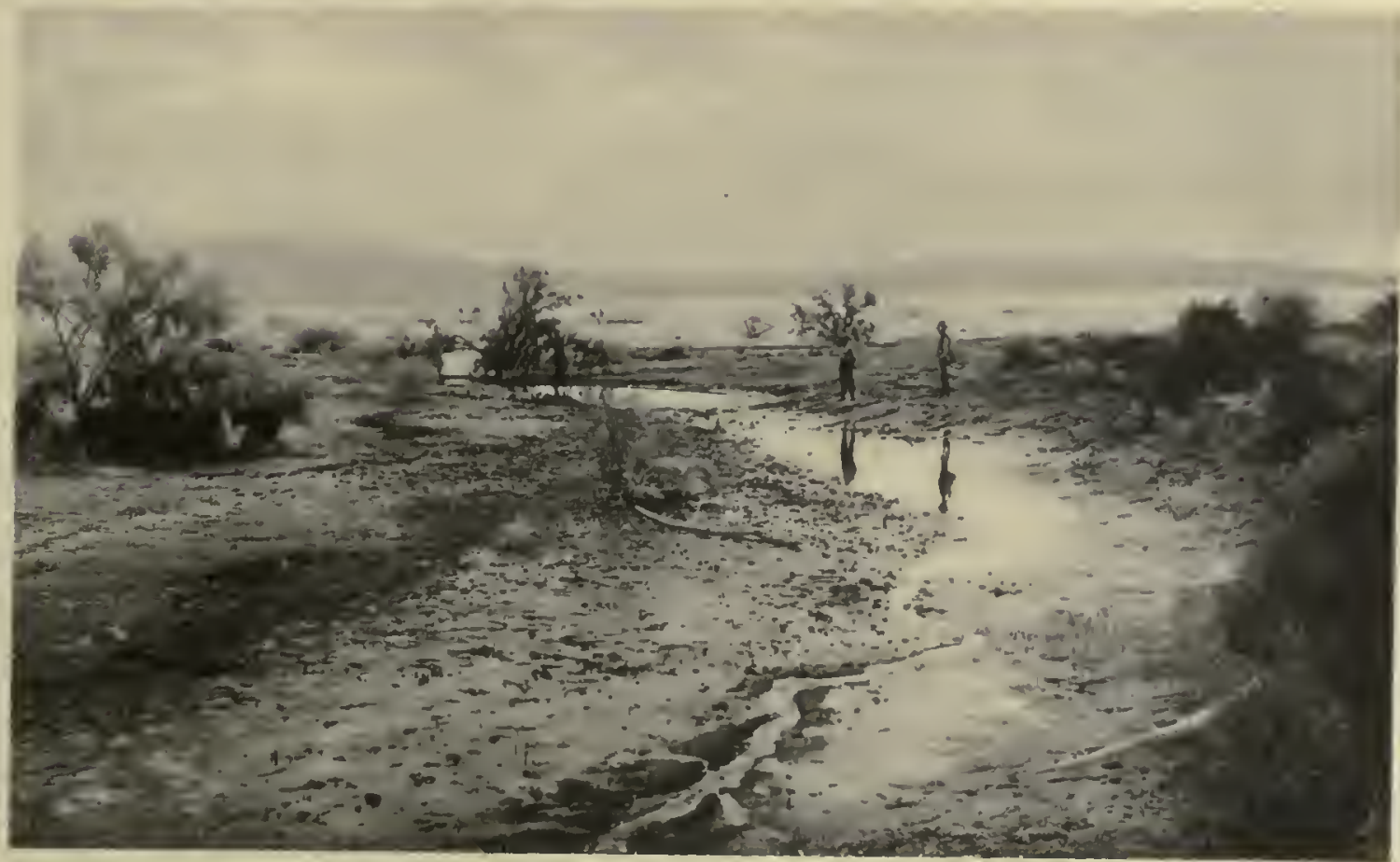

A. Sailboat on flood-water of Lake in Travertine Wash, February 1907. Tree surrounded by water is Parosela spinosa.

B. Same view, taken February 1908, showing Seepage and Dead Trees. 

moisture was sufficient to produce germination, with the result that narrow and welldefined ranks of plants were formed in these angles in the succeeding years of the observations. The ancient beach-lines higher up the slopes were taken to have been produced by prolonged maintenance of the water at about the same general level, as the amount of sorting which had been done would not occur within a single season. (Plates $29 \mathrm{~A}, 30 \mathrm{~B}$.)

The recession of the water during the summer months was checked in some seasons by rains, and the consequent maintenance of level, together with storm action, produced another series of beach ridges and cut banks which varied greatly not only in their height and general character, but also in the composition of the rank of vegetation, as the seeds which were being disseminated at this season were of different species in part from those being carried about by winds and waves during the cooler season.

It is to be noted that the terraces lay across the crest of a detrital ridge or bajada and that it was thus barred from the liability of invasions by run-off streams from the slopes above, the only introductions from landward possible being those which might fall by gravity from the extreme edge of the crumbling bank. It was therefore determined to make an examination of the slope to the southward, which comes down from a greater distance and at a much gentler gradient from the same range of mountains. Here the recession of 1907 had laid bare a gravelly shore nearly 900 feet in width, with a fall of about 1 in 250.

The first glance at this area showed numerous invaders that had come down the runoff streams, which had been strong during the midsummer of 1907 . Plantlets of Franseria dumosa, Encelia eriocephala, and an unrecognizable species were found, as well as mature individuals of Wislizenia refracta and Oenothera scapoidea aurantiaca, while Cryptanthe barbigera and Heliotropium curassavicum were abundant and in bloom. Young shoots of Pluchea sericea were also found and this plant and Heliotropium were the only ones which had not arrived by flotation on the run-off streams of the slopes. The results from this place and the terraces previously examined gave in marked relief the relative importance of flotation from the body of the lake and down the-run-off streams on the slopes. Nowhere else were the conditions so favorable to invasion by the latter method.

Obsidian Island, which lay westward from the Imperial Junction beach about 5 miles, had been selected as offering shore phenomena in good condition for analysis, and this place was reached on the leg of the voyage from the western shore in February 1908. The hill-tops making this island consist of two crests joined by a low neck which was covered, with the exception of a portion about 100 yards in width, by the high water of 1907 . The actual beach line measured 2 miles as paced with a pedometer in February 1908. The shore was rocky and precipitous in places, but about half of the total was sandy, with the admixture of alluvium in East Bay and of coarse gravel at the southern end and in West Bay. (Plate 21.)

A large number of species was found on the beaches at this time and the collections were as follows: Cryptanthe barbigera on upper portions of emersed beach and also above flood-level. Eriogonum thomassii, distributed above and below flood-level, was possibly brought in by the wind or by birds, the soil offering suitable conditions near the water. Psathyrotes ramosissima was found at extreme high-water level, as if the seeds had come in on the waters of the lake. Oenothera scapoidea aurantiaca occurred on the upper level of emersed band; Rumex midway of the beach. Sonchus asper, represented by three individuals in separate places, may have come from seeds floated ashore or may have been earried there directly by the wind. Encelia eriocephala was represented by a single specimen, which probably reached the beach by the flotation of a seed; it was abundant at Imperial Junction, 8 miles distant and 3 miles back from the shore to the northeastward, but may have come from some other source. Atriplex canescens was found in a tide pool; A. polycarpa was represented by a few plantlets on the beaches. A. hymcnelytra and $A$. fasciculata, with the two preceding species, are indigenous to the island and had come down 
on the beaches. Heliotropium curassavicum was abundant in many places on the strand. Spharalcea orcuttii was represented by a single individual, part of which was prescrved. Lippia nudiflora occupied a position immediately below the high flood level. Prosopis pubescens, two individuals, and one $P$. glandulosa arose from a living branch which had been carried to the southeastern point of the island and cast ashore, after which it had been half buried in the sand.

The entire southeastern shorc of the island was exposed to the direct action of the water which was being emptied into the lake by the Alamo and New Rivers. The feeble current of these strcams would be an agency of slight efficiency in carrying plants across the intervening 7 or 8 miles of open water, but once branches or seeds were afloat on the waters of the lake, wave-action might bring many of them ashore on this island. Oligomeris glaucescens was the most abundant of the invaders. Parosela emoryi was represented by a few plantlets on the sorted beach ridge on the shore of West Bay. As will be shown later, this is a species which appears on gravelly shores immediately following the recession of the water and apparently maintains its place in the rank during hundreds of years of aridity. Typha was found at the high flood-level on the eastern shore, evidently arising from a rhizome. Baccharis glutinosa had found lodgment in the mud of West Bay, apparently from floating seeds, and Leplochloa imbricata was established near the high level of the flood on West Bay. The examination of this place in February 1908 completed the initial examination of the observation areas and furnished a census of the pioneer introductions. The fate of the original introductions, together with the accession of additional species, now constituted a subject which aroused keen interest on the part of the workers engaged.

The next visit to Obsidian Island was made on May 8, or only three months later. The multiplication of the fish which had come into the lake with the water from the Colorado River had made a supply of food for aquatic birds, while the elevated arid summits of this and other islands uninhabited by any carnivorous animals had attracted large numbers of pelicans and cormorants which had occupied areas of several acres in extent with nests constructed among the rocks and desert vegetation. Many of the plants were destroyed, while the continuous trampling on the dry soil offered but slight opportunities for any introduced seed to give rise to a plant that might reach maturity.

Nothing had as yet appeared on the part of the beach laid bare by the recession of 1908, but the opportunity was good for observation on the condition of the invaders which had been seen three months earlier. Oligomeris glaucescens, Eriogonum thomassii, Sonchus asper, Cryptanthe barbigera, Psathyrotes ramosissima, Cucurbita palmata, Lippia nudiflora, Rumex berlandieri, Aster spinosus, and Pluchea sericea were maturing sceds and thus furnishing material for reproduction of the pioneers. Distichlis spicata and Leptochloa imbricata were also found. Atriplex canescens and $A$. fasciculata had maintained themselves on the beach, while $A$. linearis and $A$. polycarpa were not to be found. The two young trees of Prosopis pubescens and one of $P$. glandulosa were thriving. Oenothera, Encelia, and Spharalcea had apparently disappeared, while Heliotropium was represented only by dead stems and probably a crop of seeds on the ground. It might therefore be said that the change in the population included one addition, that of Aster spinosus, and three losses.

The shore of the entire northern end of the island was rocky and afforded no lodgment for the higher plants. These were confined to a strip running from East Bay to a point midway of the southern end and to the shore of West Bay. All of these places were subject to heavy storms, so that strands which had been long above the level of the quiet watcr were subject to the wave-action of the water, which had by this time taken on a concentration of 460 parts in 100,000. The shores of sand, clayey material, and heavy gravel were steep and the terracing could not be so definitely assigned to any season with certainty, since storms might entirely obscure the effects of a water-level which had remained stationary for some time earlier in the year. 

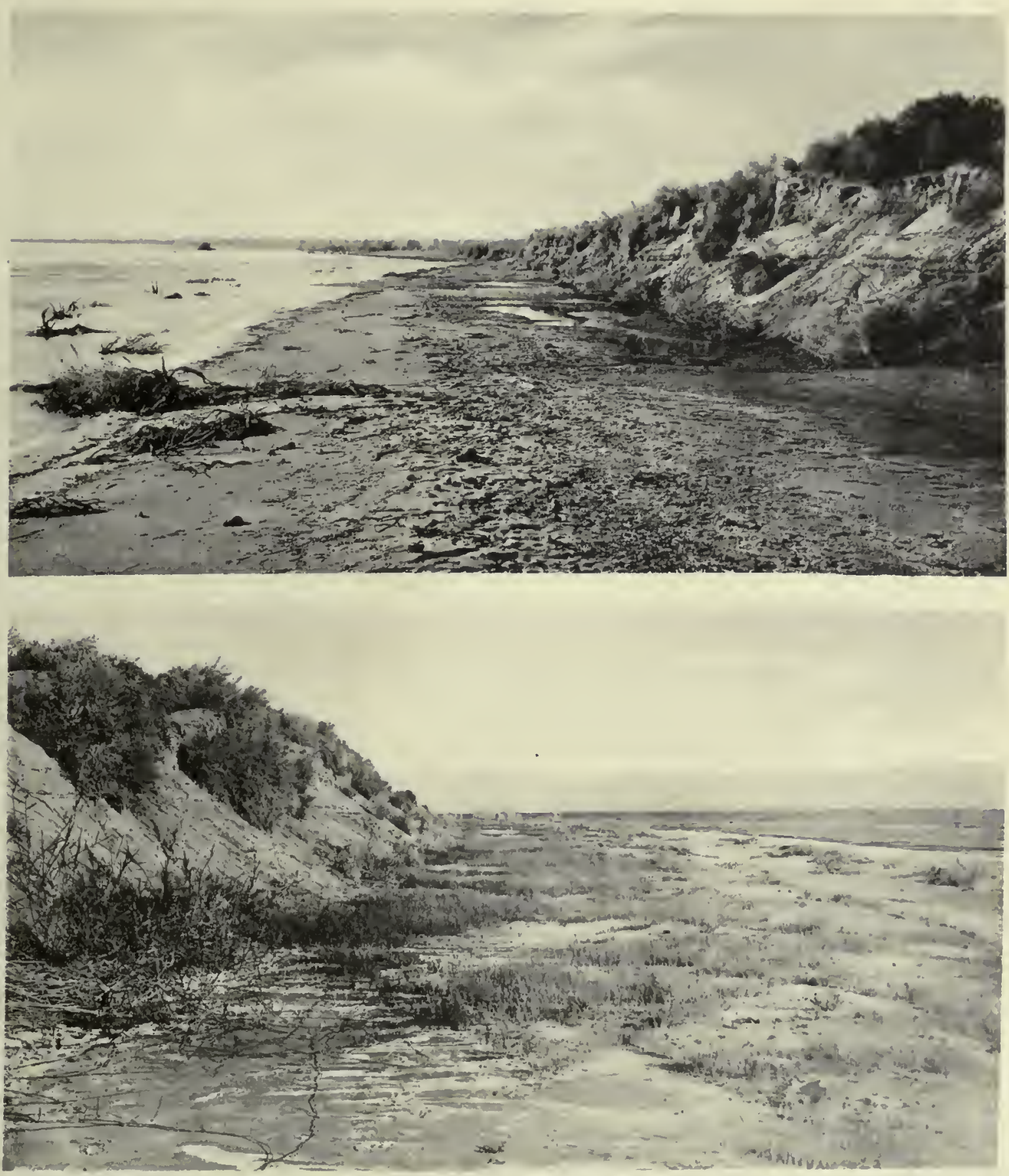

A. Caving Bank marking extreme high-water level at Travertine Terraces as seen February 1908. Tide-pools back of small barrier at margin of Emersion of 1907. One Rhizome of Phragmites present, also row of Seedlings of Atriplex canescens at foot of wall.

B. Strand of 1907 and cut bank at Travertine Terraces as seen November 1908. The Rhizome of Phragmites had elongated and branched, Distichlis was forming mats, while Pluchea, Atriplex, polycarpa and A. canescens, Heliotropium. Sesuvium, Spirostachys, Prosopis pubescens, Astragalus, Juncus cooperi, and Bouteloua were also present. 

The gently sloping alkaline beach of Imperial Junction was examined on the same day as Obsidian Island, and as the two places face each other across a 5-mile stretch of open water the difference in results may be attributed chiefly to slope and soil characters.

The original belt of Sucda, Atriplex fasciculata, and A. canescens had now become very dense, while some Spirostachys was also present. In addition there had come from additional germinations, Distichlis, Heliotropium, and Sesuvium sessile, and the entire formation was showing indications of the increasing desiceation except Atriplex. Two species of this genus were fruiting abundantly, and as they were already represented down the shore by numerous seedlings they might be expected to constitute a strong element in the invasion.

The plants in the zone of Pluchea sericea had made but a scanty growth, but some were maturing and casting seeds which were being carried about by the wind. Sesuvium, Spirostachys, Atriplex of the two species mentioned, and Heliotropium also grew among the Pluchea, while these species were diffused over the area which lay above the Pluchea and between it and the Suoda-Atriplex formation. Rumex berlandieri was also represented in the wash transecting the emersion of 1907, together with Typha, Oligomeris glaucescens, Baccharis glutinosa, and Amaranthus palmeri. A comparison with the census of February shows that Oligomeris, Baccharis, Sesuvium, and Amaranthus represent additions to the population, and their appearance is probably to be ascribed to the germination of seeds with the rising temperature on the advance of the season rather than to new introductions. It is of course possible that the seeds of Baccharis may have been brought in by the wind. Cucurbita seen in February could not be found and might be temporarily reported as a loss.

The difference between these two observational areas being so great, a visit was made at once to the Mecca area on the following day. Pluchea camphorata, which was native above the flood-level, had invaded the emersion of 1907 and was maturing fruits. Pluchea sericea was also maturing seeds in the 1907 emersion. Distichlis was present in abundance. Sonchus oleraceus was likewise casting a crop of seeds and Rumex was maturing seeds. One plant of Conyza coulteri was present. Heliotropium had become very abundant. One young plant of Aster exilis was found. Large numbers of individuals of Oenothera were seen in moister areas, and Atriplex lentiformis and A. polycarpa were represented by large rounded plants, which throve exceedingly in this locality. Suæda and Spirostachys, which had originally occupied the area, were represented by numbers of young individuals. Oligomeris glaucescens, Chenopodium murale, and an unrecognized species had disappeared in the three months since February, while it is to be seen that Pluchea camphorata and $P$. sericea, as well as Distichlis, had advanced down the gentle slope into the sterilized area. Sonchus oleraceus and Rumex had also been added to the population, although it could not be suggested from what source.

A complete round of the observational areas was made in November 1908. The Mecca area appeared to furnish suitable conditions for Suceda, which had made an enormous growth, while the two species of Atriplex mentioned above were still active. Heliotropium and Spirostachys were seen as before. Pluchea sericea was represented by scattering individuals, but $P$. camphorata was not seen, although, as was demonstrated later, it was present in abundance in sced form.

The Imperial Junction beach was examined a day later than Mecca. No marked change from the condition described in May was discernible, except that the stress set up by continued desiccation had limited the growth of some of the species. Typha had apparently succumbed, while Oligomeris, Distichlis, Heliotropium, Sesuvium, Rumex, Baccharis, and Amaranthus could not be found in the hasty examination made in the twilight of a winter day. The results of later examination, however, make it probable that the nonappearance of these plants indicated a real failure to survive the summer temperature and high evaporating power of the air. 
The strand of 1907 on Obsidian Island bore a heavy growth of Pluchea sericea on East Bay in November 1908, with which were growing a few Heliotropium, Sesuvium, Distichlis, and Cucurbita. The exposed gravelly and sandy strip on the southeastern part of the island showed some Lippia nudiflora, Pluchca sericca, one Eclipta alba, Aster spinosus, and a particularly robust form of $A$. exilis. Baccharis glutinosa and Eriogonum thomasii were still present. One Prosopis was seen on East Bay, one on the southeastern point, and one on West Bay as earlier, and all had made a notable growth. Parosela was established on the shore back from West Bay, but Oligomeris, Sonchus, Rumex, Cryptanthe, Psathyrotes, Leptochloa, and Atriplex were not found. Some of these had doubtless fruited and might appear later as a continuation of the original introduction. (Plate 29 A.)

The strand of 1907 at Travertine Terrace bore Sesuvium, Heliotropium, Pluchea camphorata, Atriplex polycarpa, and $A$. canescens, although the rank of seedlings at the foot of the cut bank had perished. Distichlis, Spirostachys, Suada, Prosopis pubescens, Astragalus, Juncus cooperi, Bouteloua arenosa, and Phragmites were also present. All of these except Phragmites and Atriplex canescens had appeared since the examination in February. The increase in the population was of a character widely different from that of the other areas in which the grains had been balanced or overbalanced by the losses. The high cut bank at the upper part of the area had continued to crumble and also showed marked effects of wind erosion. The location was especially favorable to invasion by wind-boine seeds. (Plate $18 \mathbf{B}$.

The course of the voyage for circumnavigating the lake in November 1908 gave favorable opportunities for examination of the strand of 1907 elsewhere, and a landing was made on the sandy shore of the southwestern part of the lake, which was of such slope as to show a recession of about 200 feet. Spirostachys, Coldenia, Pluchea sericea, Parosela spinosa, Heliotropium, and Eriogonum were the principal members of the invading population. The last-named species had undergone a remarkable endurance of untoward conditions in one place. First a group of these plants, with woody stems less than a yard in height, had been overtaken by a sand dune, with the result that the tips of the stems were bent over until they touched the ground. Upright branches arose from the apices, but now the making of the lake submerged these plants for a period of a few months in water containing from 0.25 to 0.33 per cent of saline material. These plants were in bloom at the time of our visit in November 1908.

A second landing on the western shore to the northward of this locality led to the discovery of a plantlet of Salix nigra and representatives of Hilaria rigida, Encelia frutescens, Olneya lesota, and Isocoma veneta var. acradenia, in addition to the commoner species named above on the strand of 1907.

The beaches received but scant attention in 1909. The midsummer season was characterized by precipitation much above the average and a distinct run-off occurred over a large share of the basin. This exerted an influence in two ways. In one the salts were washed from the surface layer, while in another seeds were carried down in drainage lines cutting across the emersed zones.

The first visit to the observational areas in 1909 was made during the closing week of October. The strand of 1907 on the Imperial Junction beach showed only Sucda, Pluchea sericea, Atriplex, and Spirostachys, and the first-named was showing the stress of aridity distinetly, great numbers of dead plants being present. The washes cutting across this zone, as well as those of 1908 and 1909, had received a large supply of rain-water, which had been held with great tenacity by the adobe soil. In such places Suceda, Sesuvium, Spirostachys, Pluchea sericea, Cucurbita, Chenopodium, and Baccharis were growing well. All of the Typha originally noted in this locality had died, but a plant which had been cast ashore this year in the filled wash had survived, making a reintroduction of this plant.

The invasions on the shores of Obsidian Island were now seen to occupy several soil complexes. Thus, one group of plants, comprising Pluchea sericea, Prosopis pubescens, $P$. 
glandulosa, Baccharis glutinosa, and Distichlis had made a luxuriant growth in the clayey deposits on the shore of East Bay, emersion of 1907. The larger Prosopis glandulosa, on the exposed gravelly and sandy shore of the southeastern part of the island, had attained a height of 10 feet and was in bloom. Four smaller P. pubescens were coming up as seedlings, although it could not be determined whether they were the offspring of the larger plant or not. Another $P$. pubescens in bloom was seen on the strand of 1907 West Bay, thus making a total population of six individuals of one species. Cucurbita was present in the same strand. This census indicates no farther introductions into the highest part of the beach, from which (since the previous census of 1908) Heliotropium, Sesuvium, Lippia, Aster spinosus, A. exilis, and Eriogonum thomasii had been lost. Here, as elsewhere, some of the missing constituents might liave been represented by a crop of seeds.

A visit to the Imperial Junction beach only was made in May 1910. The two species of Atriplex, Suada, and Spirostachys were arranged about as previously described, while Pluchea sericea continued to endure the desiccation.

A second inspection of the shore stations was made in September and October 1910. The emersion of 1907 at the Travertine Terraces bore Distichlis, Prosopis, Phragmites, and Astragalus. In the two years since the last visit was made, Heliotropium, Pluchea camphorata, Juncus, Bouteloua, Sesuvium, Spirostachys, Succda, Phragmites, and the two species of Atriplex had been lost from the population.

The return from this locality was made along the shore, so that many miles of the beach were seen. The surviving pioneers on this gentle slope were Distichlis, Spirostachys, Atriplex, Prosopis, and Sucda.

Visits were again made to the shore stations in October 1911. The emersion of 1907 Travertine Terraces bore.Distichlis, Pluchea sericea, Salix nigra, Prosopis, and Phragmites, but Spirostachys had disappeared.

The shores of Obsidian Island were visited by a boat put off with difficulty from the Imperial Junction beach. The only survivors of the population of the strand of 1907 were Prosopis, Heliotropium, Baccharis, and Cucurbita. A registering thermometer, placed on this island two years before, recorded $41^{\circ}$ and $109^{\circ} \mathrm{F}$. The losses recorded in 1909 for this place seem to be permanent and the desiccation of the soil may be taken to have reached a point where it would be difficult for any of the lost species to regain a foothold.

The Imperial Junction beach was much in the same condition in 1911 that was reported in 1910. Two species of Atriplex, Sucda, and Spirostachys comprised the plants that seemed to be holding their own, while the stand of Pluchea was still undergoing great losses from increasing aridity.

It being desirable to bring together the results of the various investigations upon the problems of the Salton, at the close of 1912 arrangements were made for a careful examination of the various beaches at some time during the year. Those at Travertine Terraces and Mecca were visited twice.

In June Atriplex (two species), Prosopis pubescens, and Sucda were seen in the uppermost portion of the emersion of 1907 at Mecca, and the lower limits of this strand could not be made out on the gentle slope.

The emersion of 1907 at Travertine Terraces bore Prosopis pubescens, Distichlis, Astragalus, Salix, and Pluchea sericea, from which it may be seen that there had been no change in the population since 1910.

The final examinations were begun at Mecca on October 14, 1912. 'The gentle slope at this place had operated to prevent any clear delimitation of the limits of the seasonal emersion, but some estimate was made from the known vertical recession of the lake. Sucda, Prosopis, Pluchea sericea, Atriplex canescens, A. lentiformis, with Distichlis probably represented the total population, and a photograph was made with all of these species in view. Reclamation operations had been begun in this region, so that it is probable that 
serious changes may have come from the agricultural operations. The species named, however, are represented abundantly in the area above the water-level and would be the readiest invaders and occupants of any bare surface in their neighborhood.

The expedition proceeded directly from this place to the beach at Travertine Terrace. The strand originally laid bare in 1907 had been open to occupation for six years. Phragmites, one of the first two pioneers, was still present. Prosopis pubescens was present in a vigorous young trec, which was originally noted in 1908. Mats of Distichlis were abundant, and Pluchea sericea was represented by a small number of individuals. Astragalus was in the form of mature shoots with emptied seed pods, while a plant new to the area, Isocoma veneta var. acradenia, was present, being the only innovation noted here for an extended period. The soil and moisture conditions from a superficial examination appear to be similar to those in which these plants ordinarily grow, with the exception of Phragmites, and they may be expected to survive for an indefinite period.

After some water travel for the inspection of islands, the results of which will be described later, a landing was made on Obsidian Island on Oetober 16, 1912. The seven trees of Prosopis (2 species) previously noted were alive and growing rapidly. Heliotropium, Sesuvium, Baccharis, Spirostachys, Atriplex canescens, A. fasciculata, A. hymenelytra, and Parosela emoryi were represented in the flora of the strand of 1907.

It is probable that this last-named species had been overlooked on some visits, as it appeared to have had a place since its original introduction. Cucurbita, however, had dropped out, although, as will be shown later, it came on the beaches of succeeding years. Sesuvium likewise was missed on some visits, though probably continuously present. The conditions in this area are much different from those at the Travertine Terraces. In the last-named locality the ancient beaches offer an example of the final fate of strands, and those recently formed will doubtless progress by slow stages to the same condition (see Plate $29 \mathrm{~B}$ ). The continued flow of the Alamo and New Rivers into the southwestern part of the lake, however, resulted in the deposition of a layer of silt which forms fresh soil with low salt content on the beaches of Obsidian Island and Imperial Junction beach. The return to alkaline desert conditions here would be far slower, and hundreds of years might be necessary for the physical changes which would ultimately bring the lower slopes to the same state as the upper slopes untouched by the last inundation.

A resume of the listory of the strand of 1907 during its first six years of desiccation will lead to a more intelligent consideration of the strands of lower level which will be taken up in the succecding sections.

The pionecrs on the gently sloping Imperial Junction beach were Atriplex canescens, A. linearis, A. polycarpa, A. fasciculata, Sucda torreyana, Spirostachys occidentalis, Pluchea sericea, and Distichlis spicata on the plane slopes, while the filled channels of the washes with a larger moisture content and lower proportion of salts gave lodgment to Heliotropium curassavicum, Typha angustifolia, Rumex berlandieri, Leptochloa imbricata, and Lepidium lasiocarpum. Several hard-shelled fruits of Cucurbita palmata liad been cast ashore, but no activity had been shown by the seeds. To this census, made in February 1908, may be added Oligomeris glaucescens and Baccharis glutinosa, on the plane slopes, while Amaranthus palmeri and Sesuvium sessile were added to the population of the filled washes.

It may be said at once that no secondary invasions occurred on the plane slopes and that no new species were added to the population of this emersion, although Baccharis, Typha, and Amaranthus appeared in new individuals, which apparently were brought in independently, not originating from those already present. All of the invaders had perished in October 1911, except Suceda, Atriplex, and Spirostachys, while some Pluchea still survived in scattered spots.

The slope at Mecca was even gentler than the one just deseribed and the succession of events may not be so succinctly related. The occupants of the strand of 1907 , as examined 
A
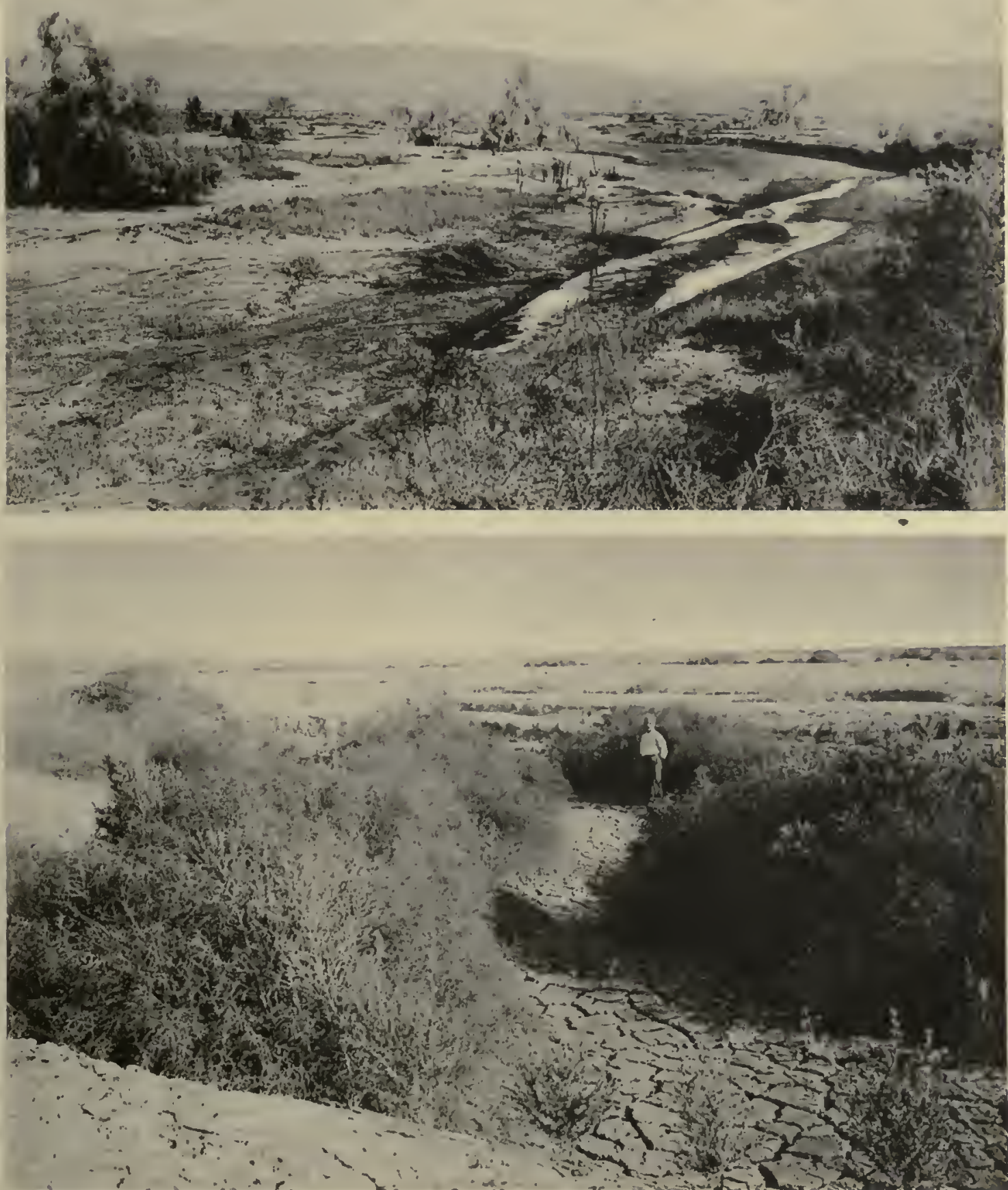

A. View of Travertine Wash in November 1909. Mats of Distichlis and scattered plants of Pluchea camphorata, Atriplex, and Spirostachys. Seepage now confined to defined channel. (See plate 17.)

B. Heavy growth of Baccharis. Pluchea sericea, and Suxda in the channels of the washes into which the water of the lake had risen at Imperial Junction Beach, October 1909. The denser formations in other washes are to be seen in the distance. 

in February 1908, included Oligomeris glaucescens, Chenopodium murale, Atriplex fasciculata, A. lentiformis, IIcliotropium curassavicum, and an unreeognizable species. In May the additional species of Baccharis glutinosa, Oenothera, Sonchus asper, Conyza coulteri, probably Pluchea camphorata, and Distichlis spicata were noted. The survivors in 1912 were the two speeies of Atriplex, Pluchea sericea (which had eome in meanwhile), Distichlis, and Prosopis pubescens, which had probably eome up from stems or seeds left in place.

Phragmites was the sole water-borne introduction to the Travertine Terraces of 1907, seen early in 1908, and Atriplex canescens had fallen down the slope and germinated. In November 1908 the population had increased to inelude 16 species (see page 128), but a census of the area in 1910 showed but 6 species, 5 of which had maintained themselves until June 1912, the soil moisture being influenced to some extent by a hemmed underflow. A single innovation, Isocoma, was of reeent clate.

The emersed zone of 1907 on Obsidian Island was found to bear 25 species when examined in February 1908 and an additional species was added to the population at the next census in November of the same year, whieh meanwhile had suffered a loss of 14 species. A year later the population of the zone had fallen to 7 speeies, and in Oetober 1910 but 6 were present; 10 speeies were found here in 1912, 4 of which had simply come down the slopes from the drier areas, while only a single one of the other 6 had been present from the beginning. (Plate 21.)

The total eensus of the strand of 1907 in the four main observational areas at the close of the season of 1912 was thus seen to include the following:

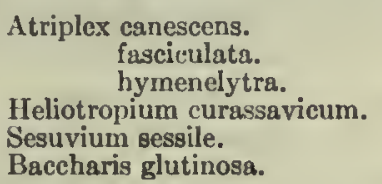

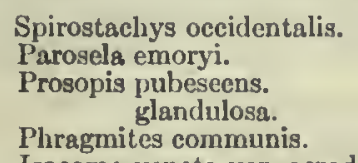

Isocoma veneta var. acradenia.
Pluchea sericea. Astragalus limatus. Distichlis spicata. Suæda torrcyana. Salix nigra.

These plants fall into three groups: xerophytes capable of existence on soil with low moisture-content in an atmosphere of high evaporating power; halophytes which might endure a substratum the moisture of which was highly charged with saline matter; and the single tree Salix, which would grow only with an abundant supply of water with not much dissolved material. All of these plants are native of the Salton Sink in great number and the action of the lake lias simply resulted in their establishment on the beaehes in zones or bands conditioned by the sorting of the soil-material and the proportion of the water supply, and salts.

Not any emersed area at this time had reached a condition equivalent to that in which it had been before the making of the lake. The plant population at Imperial Junction beach, for example, included the species from the slopes above with the addition of Pluchea sericea. The Travertine Terrace had been restored so far as to give a plaee for Isocoma, but its shelves and beach ridges were as yet widely different from those near the ancient beaches near sea-level. Atriplex canescens had come in, and it appears to stay in place on strands during all of the changes of which these beaches are possible. Parosela emoryi was also ineluded among the speeies appearing on the beaches of Obsidian Island in 1908 and it is a constituent of the ranks marking the old strands near the aneient sea-level in which the eonditions tend to extreme xerophytism.

\section{REOCCUPATION OF THE STRANDS OF 1908.}

The level of the Salton Iake was lowered a net total of about 58 or 59 inches in 1908, and the proportion of dissolved salts rose to over 0.5 per cent, from over 0.4 per cent, during the year. The actual width of the bared beaches would therefore be greater than in the year 1907, in which recession went on only during about ten months and amounted to about 42 inches. Calculated from the slope of 1 in 300 , the emersed zone on the Imperial 
Junction strand was about 1,400 feet; about 600 feet of this had been laid bare on May 1908 , when a visit was made to this place and to the beaches of Obsidian Island. This visit was opportune, as it confirmed the observation of the previous year that a series of germinations ensued customarily on this beach on the mud laid bare in April. Scirpus paludosus was in moist depressions near the margin of the water; Leptochloa imbricata was a few yards back from the shore; numbers of plantlets of Atriplex fasciculata were established in the moist soil near the water, a small plant of Typha was found coming up through the mud, probably from a rhizome floated to the place; a few seedlings of Suada and Spirostachys were also present, and some mature plants of Polypogon monspeliensis were shedding seeds.

Numbers of shallow trough-shaped channels, a few inches in width, extended into the soil from the actual margin of the shallow water, and these were filled when the wind was on shore, with the result that loads of débris (including seeds and other parts of plants) were carried up into the land in narrow bands, in which seedlings of an Atriplex polycarpa were found. The steep beach of Obsidian Island, which had been uncovered since the midwinter, was totally bare, and nothing had germinated there when visited again in November 1908.

The strand of 1908 at Imperial Junction beach bore only scattering plantlets of Spirostachys and Sucda with one Sesuvium in the stretch visited. The lowermost portion nearest the water showed an efflorescence of salts. No change was reported in the constitution of the population in November of the same year.

Returning again to the area on the Imperial Junction beach in November, the whole emersion for the year presented the aspect of a stretch of dried and fractured mud, at the upper margin of which could be seen only a few plants of Suada, Spirostachys, and Atriplex.

Typha, Heliotropium, Distichlis, Pluchea sericea, Phragmites, Bouteloua arenosa, Salix nigra, and Populus were present on the Travertine Terrace strand of 1908, the upper margin of this emersion being marked by the beach ridge of midwinter formation.

These introductions being evidently due either to the action of the wind or waves, a long stretch of beach to the southeast was visited for supplementary observations. The total census of several miles of this strand gave the following : Heliotropium, Distichlis, Prosopis, Atriplex, Coldenia, Chamosyce, Polycarpa hirtella, Scirpus paludosus, Parosela emoryi, P. spinosa, and Bouteloua arenosa. The effect of the run-off streams coming down the bajadas from the Santa Rosa Mountains to the westward was plainly evident. These streams might also have an additional effect suggested by some observations on the southwestern part of the lake, where seedlings of Pluchea sericea were seen pushing up through sand which had been deposited over the seeds by such streams in times of precipitation. Without such a protecting layer the moisture would be insufficient for germination.

Only two of the four observational areas were visited in 1909 , and this inspection was made in October. The summer had been characterized by a heavy rainfall over most of the Sink, with the result that numerous channels had been formed and that some salts had been leached from the soil, at least from the surface layers. The total precipitation measured at the U. S. Weather Bureau station near Salton, from July to October, was 3.5 inches, of which 2.887 inches were received in 24 hours and most of this fell within 2 hours.

But little effect had been produced on the Imperial Junction beach. The strand of 1908 at that place bore only four species, Atriplex (two species), Sucda, and Spirostachys.

The steep clayey and gravelly slopes of Obsidian Island had been deeply eroded, and the strand of 1908, on which nothing had been seen previously, now bore Heliotropium, Sesuvium, Spirostachys, Cyperus speciosus, Isocoma venela var. acradenia, Baccharis glutinosa, Aster exilis, Distichlis spicata, Parosela emoryi, Eclipta alba, Sonchus asper, and Cucurbila palmata. This heavy census suggests both delayed germinations and also possible wind dissemination, especially of the winged compositaceous seeds. 

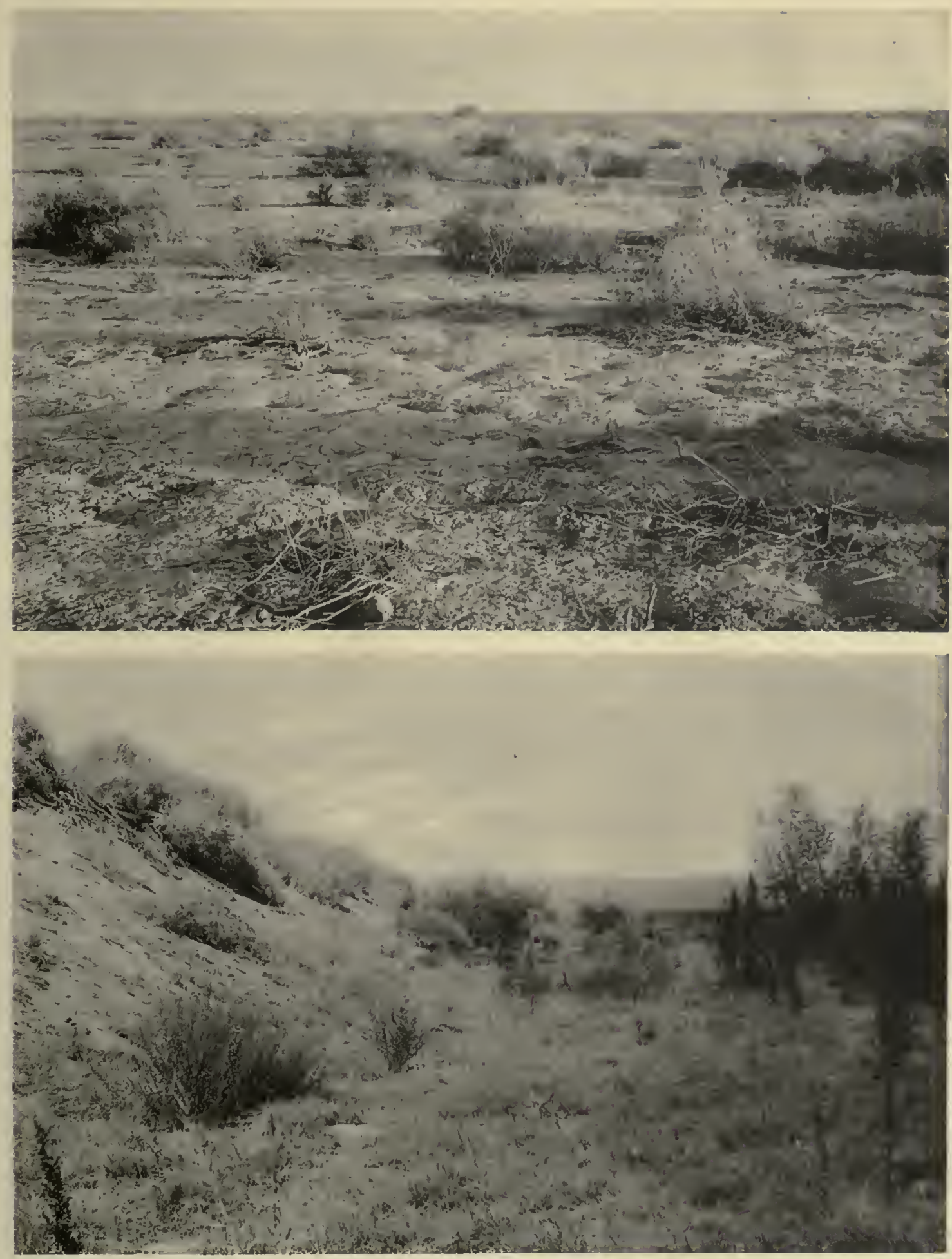

A. Emersion of 1907. Imperial Junction Beach, as it appeared October 1911. Vigorous development of Atriplex. Spirostachys, and Surda in open formation.

B. Emersion of 1907. Travertine Terrace, as it appeared in October 1911. Dense mat of Distichlis, Astragalus, Prosopis pubescens, Pluchea sericea. Isocoma, elc. 

The Imperial Junction beach in May 1910 bore Heliotropium and Sesuvium in addition to the four present in the previous Oetober, the entire number being represented by widely scattered individuals.

The area at Travertine Terraces was examined in September 1910, at which time Pluchea sericea, Distichlis, and Heliotropium were on the strip laid bare before midsummer of 1908, while the beach of the latter half of the year contained, in addition, Juncus cooperi, Pluchea sericea, Astragalus, Prosopis pubescens, P. glandulosa, and Spirostachys. In the two years which had elapsed since the last visit, Bouteloua, Phragmites, Salix, and Populus had dropped out, while Juncus, Pluchea, Astragalus, and Prosopis had come in, probably by delayed germinations of seeds deposited by the water.

'The 1908 emersion at Mecea showed Distichlis, Spirostachys, Atriplex, Prosopis, and Sucda, the invasion by which could not be assigned with certainty to any given factor or ageney in September 1910.

The strand of 1908 at Travertine Terraces bore only Distichlis, Salix, Prosopis pubescens, and P. glandulosa, in October 1911, and the loss of more than half of the initial occupants was indicative of some heavy stresses. Similar unfavorable conditions must have affected Obsidian Island also, for the emersion of 1908, which had appeared so richly populated on the previous visit, bore only Cucurbita, Spirostachys, Heliotropium, and possibly an Atriplex. The vegetation of this strand on Imperial Junction beach included only Sucda, Spirostachys, and the two species of Atriplex previously noted.

Preliminary to the final visit made to all of the observational areas in 1912, the Travertine Terraces were visited in June 1912. Distichlis, Cyperus, Pluchea sericea, Prosopis pubescens, $P$. glandulosa, and Astragalus were present. Here, as in the strand of 1907, a single innovation was included at the last-Cyperus, which had not appeared at this place before, and for the presence of which no reasonable suggestion may be made.

The inclusive closing observations made on all of the beaches in October 1912 were somewhat disturbed at Mecca by the fact that reclamation operations and agricultural utilization of the land below the water level of 1907 had begun and the exact limits of the area laid bare by the recession of the waters could not be made out after the removal of the landmarks.

Conditions in the other localities were much more favorable to a general examination of the behavior of the plants on the strands. The emersion of 1908 at Travertine Terraces bore abundant mats of Distichlis spicata, Juncus cooperi, Pluchea sericca, Prosopis pubescens, P. glandulosa, and Astragalus. The moist condition of the soil which had persisted in small spots indicated (see pp. 124, 139, and 140) a hemmed underflow. A brief visit to the place was made in February 1913, at which time Isocoma, Phragmites, Heliotropium, and Paroscla emoryi were found, in addition to the above-named species.

No plants could be definitely assigned to this strand on Obsidian Island; it will be recalled that the vegetation was very sparse on the last visit, but Atriplex lentiformis, A. hymenelytra, Spirostachys, and Suceda were probably within the limits uncovered by the recession of this year.

The strand of 1908 at Imperial Junction beach appeared to be almost bare when visited in October 1912, but in two traverses three individuals of Pluchea sericea were scen, the only other vegetation being a few scattered examples of Suceda.

The surviving invaders in the strand of 1908 are thus seen to number far less both as to species and individuals than the emersion of the year before, one having had six years of desiccation and the other five.

A satisfactory analysis of the movements of vegetation on the emersion of 1908 is not easily to be made. The gently sloping alkaline surfaces of Imperial Junction beach showed nothing during 1908, 1909, 1910, and 1911 but Atriplex (two species), Sucda, Spirostachys, with an intrusion of Heliotropium in 1910 (which was not found in the following year) and of Pluchea sericea in 1912. 
The $190 \mathrm{~S}$ zone on the shores of Obsidian Island remained bare during that year, but had been occupied by 12 species in 1909, all of which but 3 liad disappeared by 1911. Probably a fourth is to be added to the number in 1912. The Travertine Terraces were oceupied or invaded at once by 8 species not identical with those found on the other strands of the same year. A year later 7 species were found, 2 of the original ones having disappeared and 2 new invasions having oceurred. In June 1912 the plant population was represented by 6 species, which were identical with those noted in October except Juncus and Cyperus; but circumstances justify the assumption that both species were continuously present, so that the final census here may be taken to include 6 species.

'Three species canne into the 1908 zone at Mecca soon after its emersion, being followed by three others, which were seen two years later. Subsequent history of this beach was complicated by economic operations, but it was evident that the number of species would remain small here, as at the other gently sloping beach, although the individuals would be more numerous.

\section{REOCCUPATION OF STRANDS OF 1909.}

The year 1909 was characterized by a net recession of 48 inches in the lake. In July and August there was heavy precipitation, amounting to 3.5 inches (July to October) at the Salton trestle station. Nearly 3 inches of this fell in one day at this place. The runoff and underflow were so great that the results of evaporation were met and the lake stood nearly at constant level for a period of about six weeks, a condition very favorable for sorting material in beach ridges and depositing seeds; also, the precipitation would result in some leaching of salts from the surfaces of all of the exposed beaches, while unusual value would be given to the washes as disseminating or invading agencies in bringing plants down the slopes in lines radial to the lake.

The conditions of evaporation and the changes in the level of the lake from midsummer of 1909 to midsummer of 1910 are illustrated by the following data furnished by the U. S. Weather Bureau from observations made on the northeastern part of the lake near the Station at the Salt Slough. Table 32 shows evaporation from pai 500 feet from shore and 2 feet above the surface of the water.

TABLE 32.

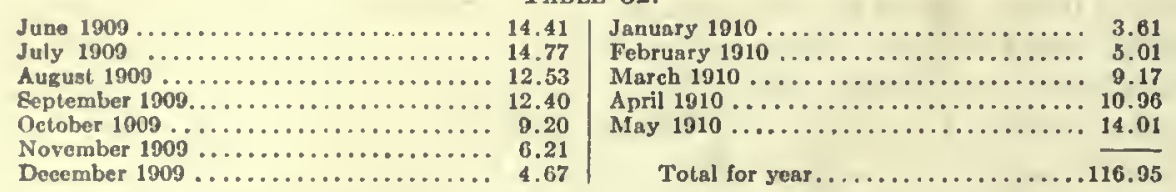

The total evaporation from another pan, 7,500 feet from the shore, was 114.97 inches, and hence for convenience the yearly evaporation from the surface of the lake will be taken as about 116 inches. The level of the lake during this period, however, showed fluctuations of a character more widely divergent from the eurve of evaporation than at any other time during which observations were earried on by the members of the Institution, as denoted by the monthly recession measured by the Weather Bureau showing the alterations in level of Salton Lake June 1909-May 1910 (table 33).

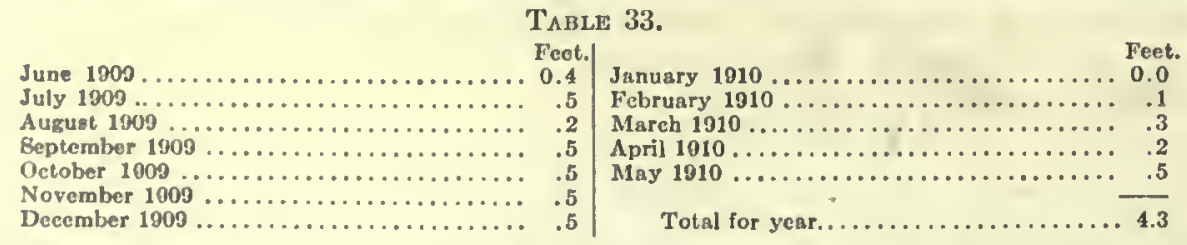

The total net recession of the level during twelve months was therefore less than half the possible evaporation. 

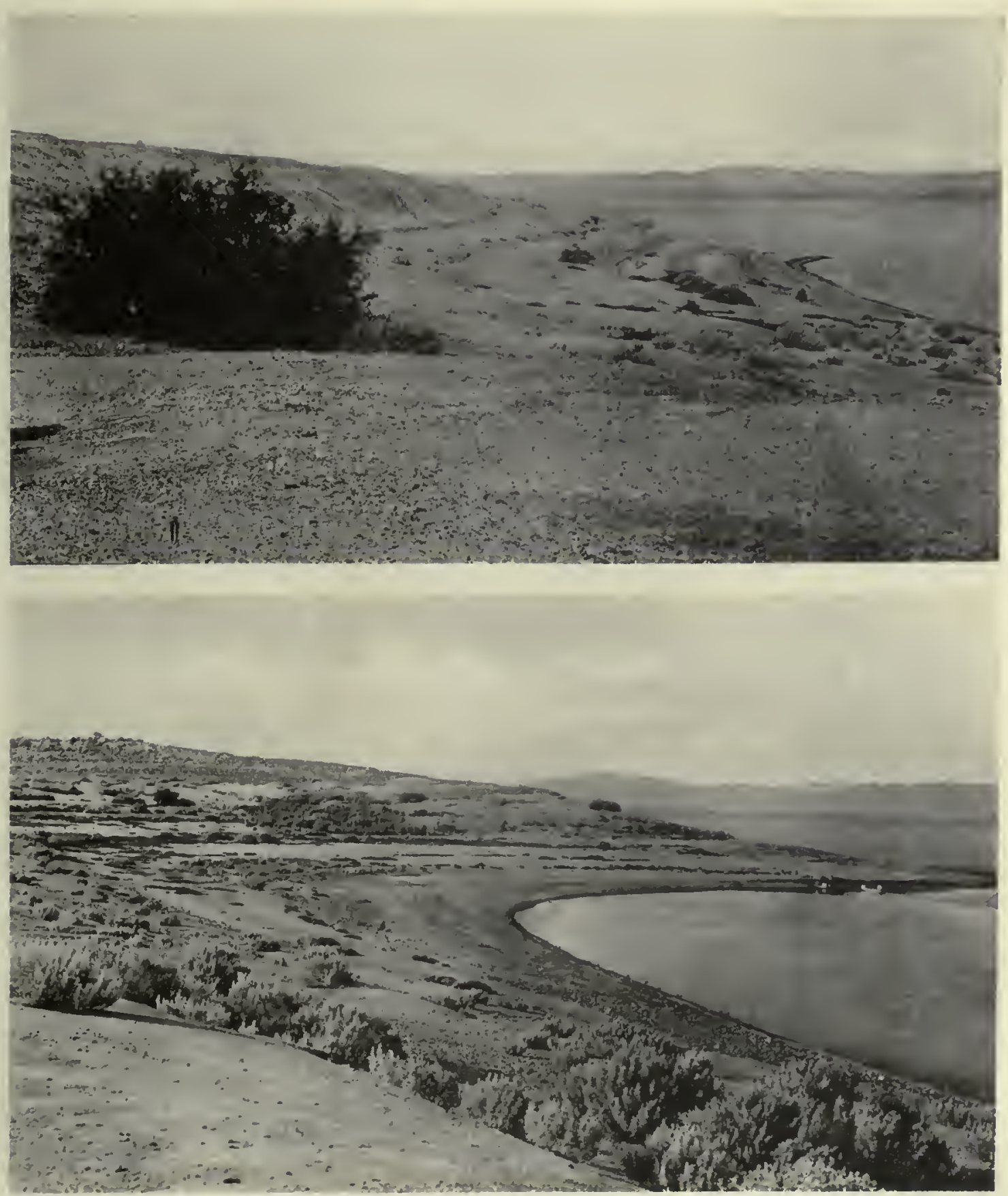

A. View of Shore of southeast point of Obsidian Island, October 1912. A large shrub of Prosopis pubescens on the strand of 1907 at left. Scaltered clumps of Sesuvium, Spirostachys, and Atriplex in distance.

B. View of strands of East Bay, Obsidian Island, October 1912. Dense formation of Baccharis and Pluchea sericea on Emersion of 1907 in distance. Clumps of Sesuvium, Spirostachys, and Atriples in foreground. 

The dissolved salts in the water had reached a proportion of over 0.5 per cent, or 520 parts in 100,000, in June of this year, and some lowering of the rate of increase in the ealcium was also noticeable. The conjoint effect, lowever, of all of the conditions enumerated was a greater number of successful invasions of the emersed strip.

The occupation of the newly bared beach at Imperial Junction was eharacterized by a zone of plants of indefinite width coming to within 300 feet of the margin of the water late in Oetober 1909. This position was one indicative of midsummer germinations in inud moistened by the summer rainfall. Leptochloa imbricata, Scirpus paludosus, Typha angustifolia, Heliotropium curassavicum, Pluchea sericea, Scsuvium sessile, Sucda torrcyanum, and Spirostachys occidentalis were present, the last two being the most abundant and evidently coming from seeds, while the single plant of Typha was growing from a rhizome washed ashore. The two species of Atriplex on this shore were present in the midwinter zone with Suada and Spirostachys. The eollection of precipitation water had furnished a supply of moisture for the plants growing in the filled channels of the washes above the 1909 zone.

A visit a few days later to the beaches of Obsidian Island resulted in the detection of vegetation on the emersion of 1909 , which was the only time in which plants were seen to appear here during the first year of the emersion. The sowings were composed of Heliotropium, Amaranthus palmeri, Sesuvium, Spirostachys, and two species of Atriplex. The other observational areas were not inspected during this year.

In May 1910 the strand of 1909 on Imperial Junction beach included Heliolropium, Sucda, Atriplex (2 species), Spirostachys, Sesuvium, and Cucurbita, the last-named being an innovation, while Leptochloa, Scirpus, Typha, and Pluchea sericca had perished. (Plate 28 A.)

The strand of 1909 at Travertine Terraces bore only Distichlis, Heliotropium, and Pluchea camphorala in September 1910. A year later the entire emersed zone at this place was heavily carpeted with Distichlis, which was also noted in abundance on the soil laid bare during 1909; scattering clumps of Juncus, Salix nigra, Prosopis pubescens, and Astragalus were also found. The entire population was thus seen to be different from that of Imperial Junetion beach.

The 1909 strand on Obsidian Island showed only Spirostachys and two species of Alriplex in October 1911.

The heavy carpet of Distichlis persisted at the Travertine Terruces and was exanined in June and October 1912. Cyperus, Astragalus, Pluchea camphorata, P. sericca, Prosopis pubescens, and a single Salix were seen in June. Cyperus was not found in Oetober 1912, but Isocoma and Heliotropium had come in. A supplementary visit was made in February 1913, at which time Atriplex lentiformis, A. canescens, and Juncus cooperi were added to the above list. (Plate $22 \mathrm{~A}$.)

The limits of the emersion of 1909 at Mecca were not to be accurately deterinined, but a photograph was made of a large Atriplex lentiformis and some Spirostachys, both of which were under very favorable conditions, in October 1912.

The only plants which could be identified at this time as positively on the emersed strip of 1909 on Obsidian Island were Parosela emoryi, Cucurbita palmata, and Spirostachys; Atriplex of two species and perhaps also Heliotropium might be safely included.

In 1912 only Spirostachys and Suæda appeared to be surviving of the large number of invaders which had found a foothold on the moist strand at Imperial Junction beach in 1909. The first of these was inaking a maximum shoot development.

An analysis of the movements of plants on the strands laid bare in 1909 similar to that made for the two years previous brings out the following: The invaders of the bared strip at Imperial Junction beach included 10 species at first, which was reduced to 7 in May 1910, by four fatalities and one additional intruder, while the close of the observations was made with only the two halophytes, Spirostachys and Sucda, persisting. 
The 1909 strand at the Travertine Terraces bore only 3 species late in 1910; a year later the number lad been increased to 8 , while the closing part of the ycar 1912 was marked by the advent of 2 more; 3 additional species were seen in February 1913 . The steep beaches of Obsidian Island were populated in the strand of 1909 by 6 species during the first year, which two years later was reduced to $3 ; 5$ or possibly 6 species may be assigned here at the close of 1912.

The strand of 1909 on the gently sloping beaches near Meeca appeared to be populated only by Atriplex and Spirostachys. It was obvious that the ranks of the invaders were being depleted on the gentler alkaline slopes and accessions were being made on the steeper gravelly slopes of the Travertine Terraces and on Obsidian Island. A very important factor in determining this aspect of the reoccupation of the bared areas is to be attributed to the saline content of the soils.

\section{REOCCUPATION OF STRANDS OF 1910.}

The lowering of the level of the lake during 1910 amounted to over 59 inches, and the dissolved salts amounted to about 0.6 per cent on June 1 of that year. A visit to the Imperial Junction beacl in May was made and Heliotropium, Leplochloa, Scirpus, Atriplex (two species), and many young plants of Spirostachys were found near the margin of the water.

Travertine Terraces were not inspected until September, but at that time a rank of Salix and Populus was found at the upper margin of the strand, while Distichlis and Heliotropium were scattered over the shelf. In October 1911 a heavy rank of Salix had formed at the upper margin, in which were seen a few Populus, while Distichlis, Scirpus olneyi, Pluchea sericea, P. camphorala, Juncus, Prosopis, and Hcliotropium were represented. At this time the flora of the strand of 1910 on the Imperial Junction beach was composed of Spirostachys, Suada, and Heliotropium.

The only note at Mecca in June 1912 was to the effect that Heliotropium in this emersion was going under, while in October only a few straggling specimens of Spirostachys and Suada were seen, although some of this might be due to agricultural operations. (Plate 22 A.)

A few Atriplex lentiformis and Populus may be assigned to this zone also. (Plate 23 A.)

The strand of 1910 at Travertine Terraces bore Pluchea sericea, P. camphorala, Heliotropium, Scirpus olneyi, S. paludosus, Salix, and Populus in June 1912. The last two named had by this time made a dense row of young trees with a height as great as 15 feet. In October the rank of trees (Salix and Populus) had made additional growth and included some Pluchea sericea, while Pluchea camphorata, Isocoma, Scirpus olneyi, Distichlis, Heliotropium, Prosopis pubescens, and Juncus cooperi were variously distributed.

The strand of 1910 bore only a straggling growth of Suxda and Spirostachys on Imperial Junction beach when examined in October 1912. At the same time a visit was made to Obsidian Island, which had not been seen since this beach was bared, and Pluchea sericea, Atriplex lentiformis, Baccharis glutinosa, Heliotropium, and Spiroslachys were found.

The advent and fate of the intruders on the areas laid bare in 1910 may be briefly summarized as follows: Six species germinated on the strand at Imperial Junction beach in May 1910, of which two survived when seen late in 1912. Four species had come into the bare area at Travertine Terraces in September 1910, and five additional ones were seen a year later. Seven species were seen in June 1912, but probably the missing two, Juncus and Prosopis, werc overlooked, since they were found in October. On this last date the full complement of 1911 was identificd, with the addition of a tenth in the form of Isocoma.

'The contrast of reduced numbers of the invaders on the alkaline gently sloping beach of Imperial Junction with the increase in the occupants of the steeper gravelly slopes of Travertine Terraces is again presented, the constituency of the flora of the strand of Obsidian Island lending support to the presumption that a similar movement must have taken place there also. 


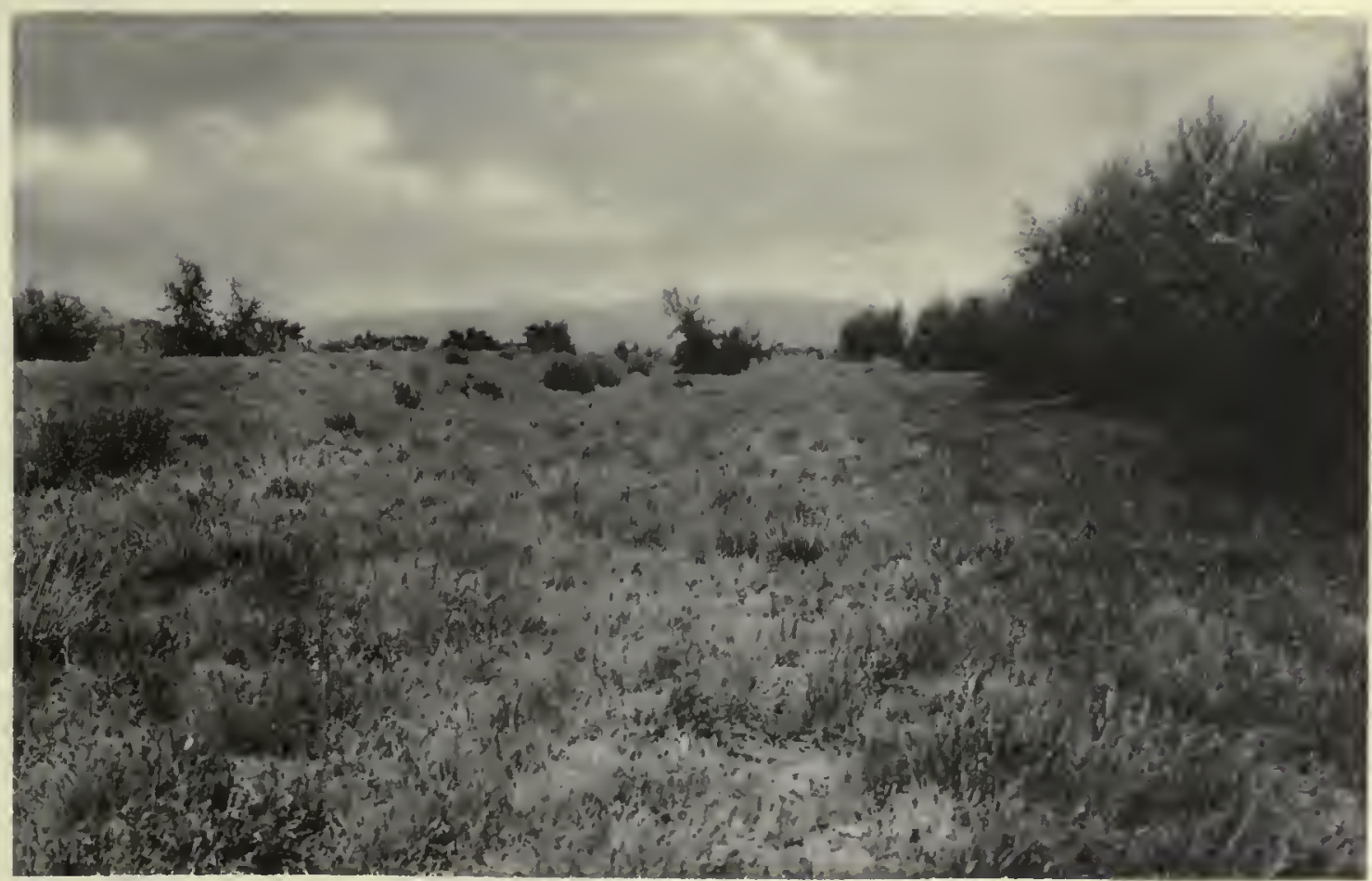

B

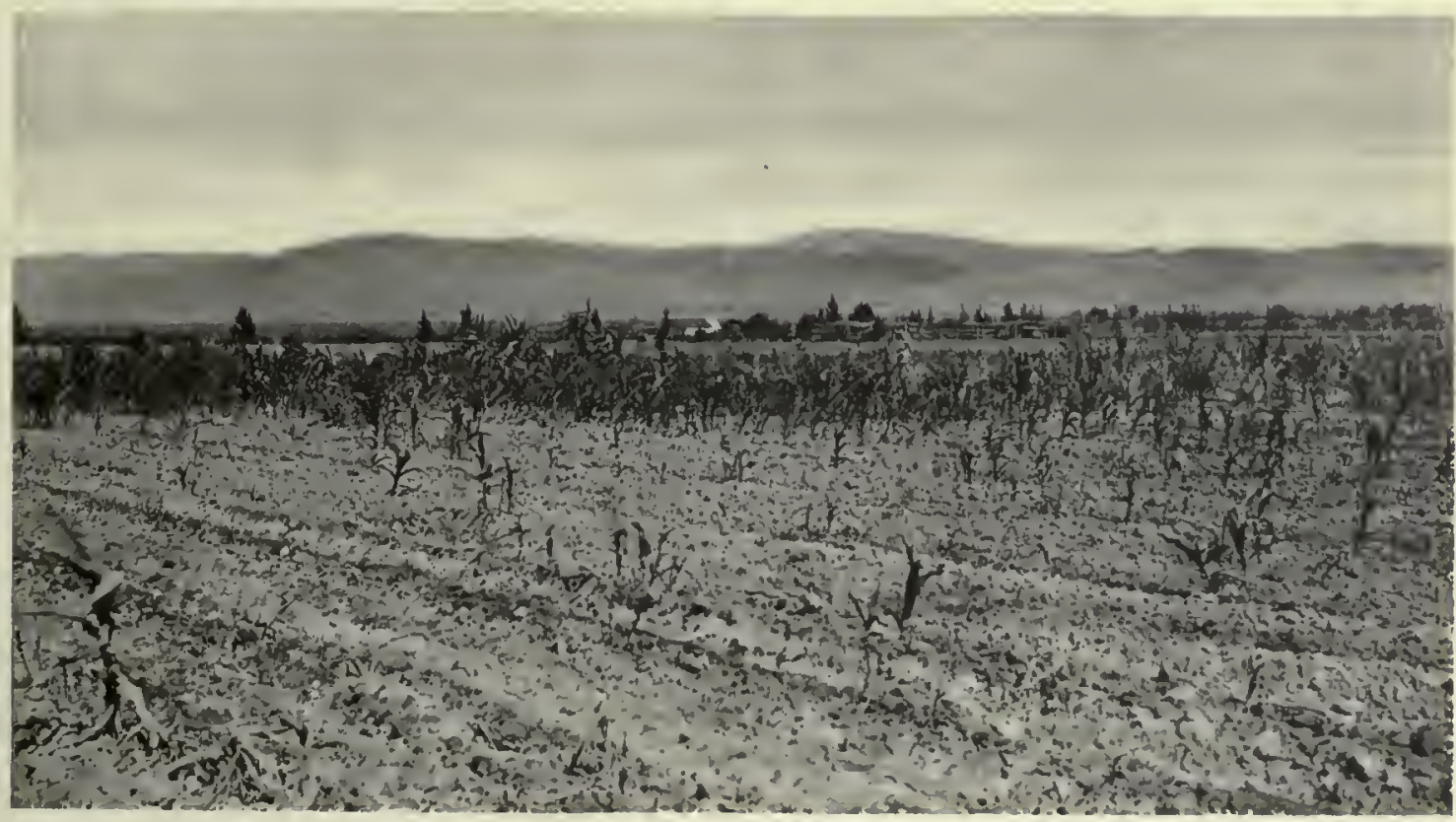

A. Strand of 1909. Travertine Terraces, October 1912. Dense formation of Distichlis with row of scattered individuals of Isocoma along middle of zone. Rank of Populus and Salix marking lower margin of strand. One Prosopis pubescens in middle of emersion; also several clumps of Juncus cooperi. Astragalus, Pluchea, and Heliotropium present, but not showing.

B. Establishment of a Ranch on Emersion of 1910, Mecca Beach, October 1912. Maize in foreground and recently planted cuttings of dates on left. Ranch house surrounded by trees of Populus and Salix. 



\section{REOCCUPATION OF THE STRANDS OF 1911.}

The total recession during this year was about 49.6 inches. The soluble salt-content of the water amounted to about 0.7 per cent at the beginning of the year.

A visit was made to the Imperial Junction beach in April 1911 by Mr. E. E. Free, who reported a band of vegetation, about 200 feet in width, extending up the slope from within 50 feet of the margin of the water. In following this for half a mile, Scirpus paludosus, Leptochloa imbricata, Heliotropium, Distichlis spicata, Scsuvium, Rumex, Spirostachys, and Sucda were seen. An examination of the zone in September of the same year brought to light only Spirostachys, Sucda, and Distichlis. It was notable that Atriplex had ceased to be a pioneer on this beach. (See Plate 24 13.)

The strand of 1911 at Mecca bore Typha, Scirpus, Atriplex lentiformis, and Spirostachys when examined in June 1912. Most of these appeared to be surviving when the place was visited in the following October.

The strand of 1911 at Travertine Terraces bore only Distichlis, Salix, and Populus in September of that year, which was also a notable departure from the history of previous strands. In June 1912 Distichlis, Heliotropium, and Spirostachys were seen on the shelf, while the remaining vegetation consisted of Salix, Populus, Typha, Pluchea sericea, P. camphorata, and Scirpus paludosus, largely collected in a dense rank at the upper margin. In October the rank at the upper margin of the strand included Salix, Populus, Prosopis pubescens, Typha, and Pluchea scricea, while Pluchea camphorata, Scirpus olncyi, Spirostachys, Sesuvium sessile, Hcliotropium, and Distichlis were now found on the floor of the terrace. (See Plate 24 A.)

The recently bared strand of Obsidian Island was vacant.

\section{REOCCUPATION OF THE STRANDS OF 1912.}

The water of Salton Lake had increased in concentration to such an extent that it contained nearly 0.9 per cent of dissolved material by June 1, 1912. The deposition of calcium as a carbonate had continued at such rate that emersed objects, such as twigs and branches of trees, were heavily coated with lime. The toxic action of the water would probably be greatly increased by this disturbance of the balance.

The strand of 1912 at Mecca was well dried out in places and offered much efflorescence when examined in October. Scattered over it and collected in favorable spots were Atriplex lentiformis, Pluchea sericea, P. camphorata, Spirostachys, Populus, Heliotropium, Typha, Salix, Distichlis, and Scirpus paludosus, an invasion which for numbers was foreshadowed by the plants seen on the emersion of 1911.

No plants were found on the ground laid bare by the recession of 1912 at Travertine Terraces in this year, in June, except Sesuvium. In October, however, the angle at the foot of the distinctly cut bank, which may be taken to mark the upper margin of this strand, included Salix 2 or 3 feet in height, Populus, Atriplcx lentiformis, Spirostachys, Hcliotropium, Prosopis, and Pluchea camphorata represented by active young plantlets, while Sesuvium was found both at the top and foot of the low bank. (Plate $25 \mathrm{B.}$.)

A visit on the following day showed that the strand of 1912 on Obsidian Island was still bare. Two days later the inspection of the Imperial Junction beach was made. The uppermost portion bared early in the year bore a dense zonc of Atriplex lentiformis, $A$. fasciculata, Sucda, Spirostachys, Scirpus paludosus, and Sesuvium. A second zone near the margin of the water, representing germinations of the midsummer, included Distichlis, Leplochloa, Scirpus paludosus, and Atriplex lentiformis.

It is to be seen from the above that the successful invasions of 1912 number far more than those of the preceding two or three years on most of the beaches. So far as the Imperial Beach is concerned more favorable conditions may well be aseribed to the silt thrown 
into the lake by the current of the Alamo River, which formed a deposit on the strands laid bare in this part of the lake, when visited in September 1911. In October 1912 Atriplex lentiformis, Pluchea scricea, Baccharis glutinosa, Heliotropium, and Spirostachys were present, the last-named in abundance.

The detail given again exemplifies the fact that depletion of the ranks of the original invaders follows quickly on the gentler alkaline slopes, while on the steep gravelly and sandy beaches the number of species soon increases. Thus the original census of the strand of 1911 at Travertine Terraces included only one species, presumably by reason of delayed germinations.

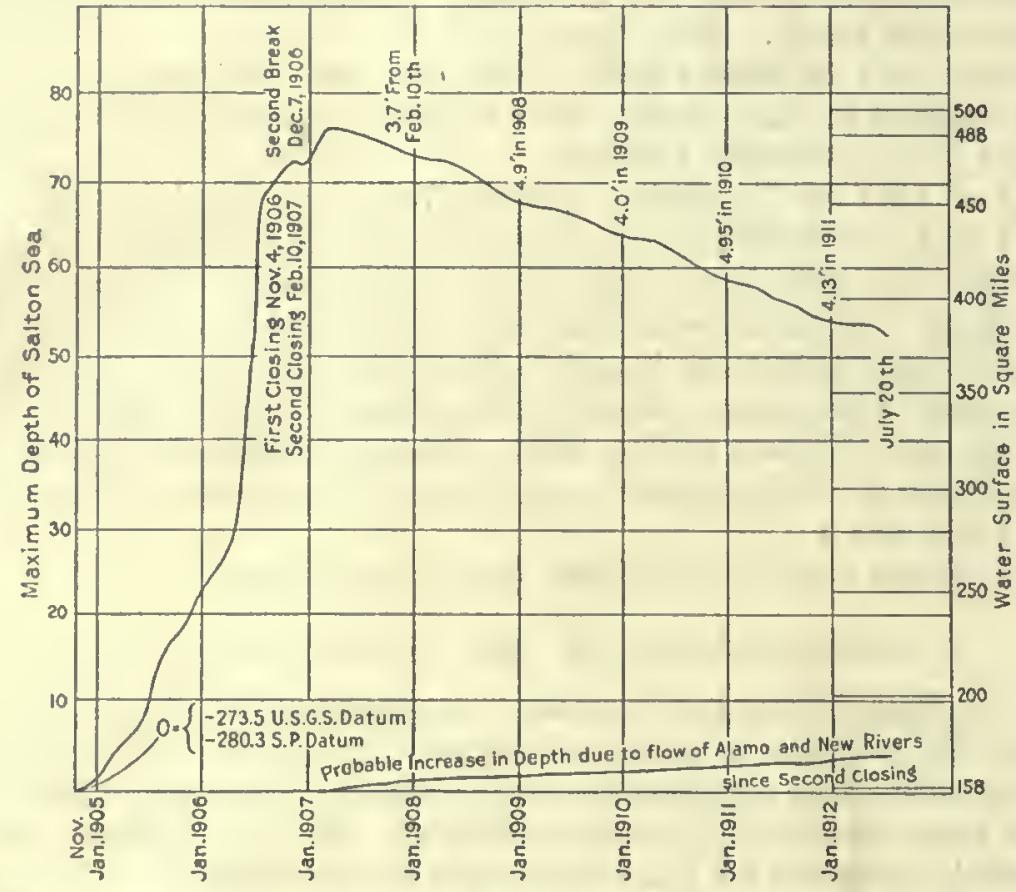

Fio, 3.-Curve showing obaogiog lovel of Saltoo Sea, 1905-1912, with estimated inflow of water through Alamo and New Rivers. (After II. T. Cory.)

\section{RECESSION OF 1913.}

The only examinations of the strands of 1913 which were made previous to the completion of the manuscript of this book were devoted to the emersions at Travertine Terraces. On February 8 the water was standing at the foot of a bank from 20 to 30 inches in height

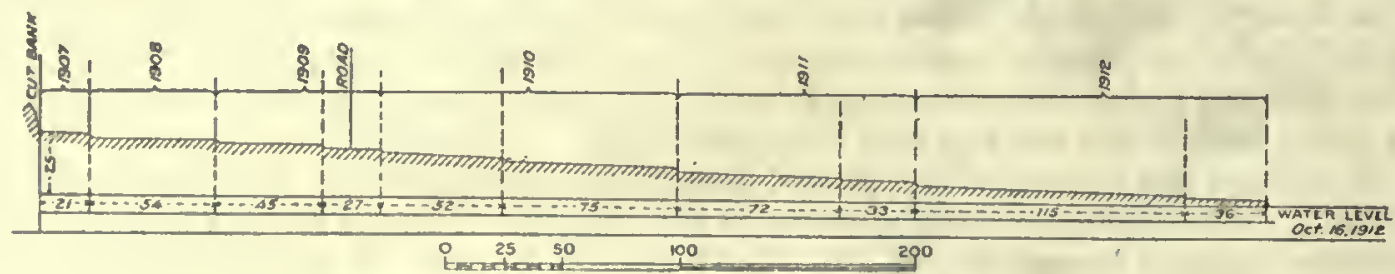

Fra. 4.-Diagram showing recession of water at Travertioe Terracos, 1907-1912.

(which was of the Inaximum steepness), masses being constantly undermined by wave action. Some of the flotsam accumulated at the base was taken for a test to ascertain what seeds might have already been deposited here. About a couple of pounds of this material was placed under cultural conditions and numbers of seedlings representing Atri- 

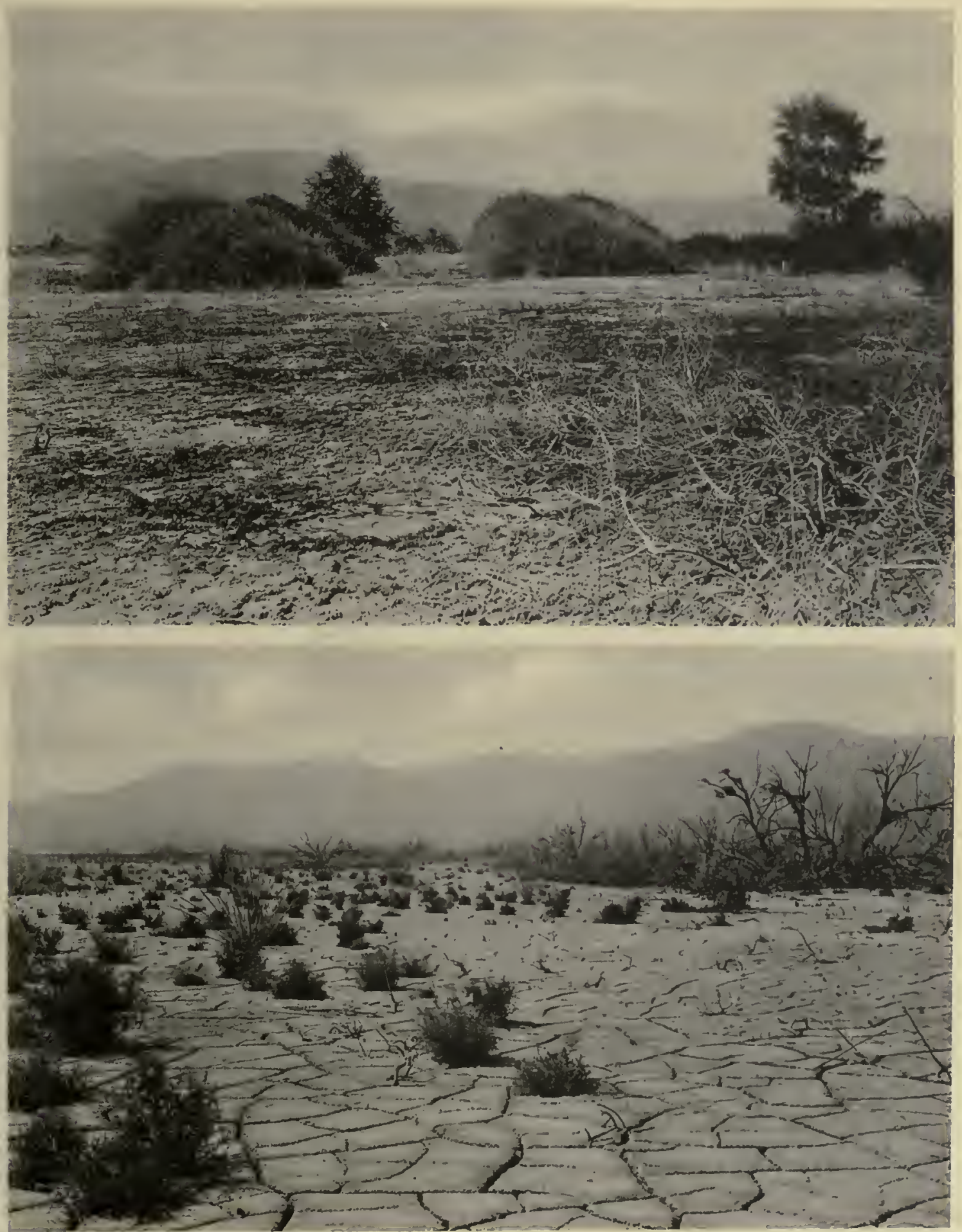

A. Emersion of 1910. Mecca Beach. Octooer 1912. Large hemispherical clumps of Atriplex lentiformis and trees of Populus macdougalii. Dead Prosopis in distance.

B. Emersion of 1911. Mecca Beach, showing conchoidal mud-fractures slightly weathered. Dead Prosopis with Nests of Water Birds used only while the Trees were surrounded by Water. Scattered plants include Atriplex lentiformis, Isocoma, Heliotropium. Spirostachys, and Pluchea camphorala. 


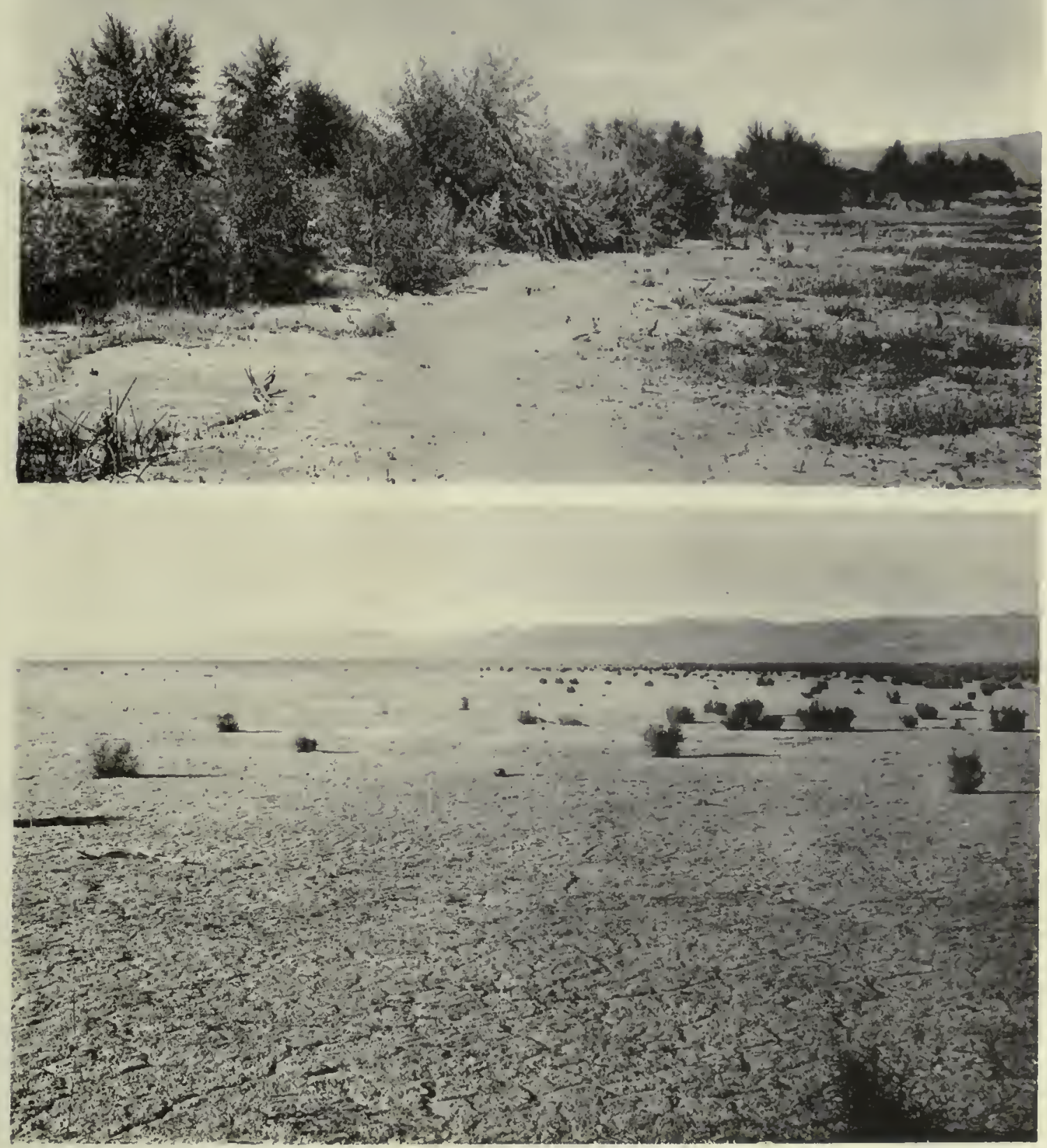

A. Uppermost portion of Strand of 1911. Travertine Terraces, October 15, 1912. Rank of Vegetation at margia includes Salix, Populus, Typha, and Pluchea serices, while Pluchea camphorata, Scirpus, Spirostachys, and HelioIropium are scaltered is the open.

B. Strand of 1911. Imperial Junction Beach, as it appeared on October 4, 1912 . Scaltering Plaols of Spirostachys, Surda, and Distichlis are present. 

plex, Heliotropium (?), Sesuvium, and a grass appeared. Measurements, of the level of the lake, besides those compiled into the curve shown in Fig. 4, were now received, from which it appeared that the surface had fallen 9.6 inches in August, 7.2 inches in September, 3.6 inches in Oetober, 2.4 inches in November, and 1.2 inches in December 1912. The next measurement (made on February 1, about the time of the first observation in 1913) showed that the level of the water had been raised 2.4 inches during January, clearly due to the lessened evaporation and the inereased inflow, and that the level had fallen an equal amount during February, so that the level on March 1 was the same as at the beginning of the year. A fall of 3.6 inches took place during March and 2.4 inelies during $\Lambda$ pril. The recession was probably at a slightly higher rate during May. On May 24 the rank of scedlings at the base of the bank included Atriplex, Cyperus, Ieliolropium, Prosopis pubescens, Salix, Populus, and a grass. The experiments described on page 162 would indieate that the Salix and Populus seedlings were from wind-borne fruits trapped by the bank, and that the Prosopis was from plantlets germinated in the water. The last-named, however, was found only among thick bunches of twigs and other buoyant débris, and it is possible that the pods or seeds did not float independently (see Plate 26).

\section{INFLUENCE OF THE LAKE UPON THE VEGETATION OF THE DRY SLOPES ABOVE ITS LEVEL.}

The flood waters of the Colorado River which flowed down the slopes of the Cahuilla Basin into the Salton Sink caused an enormous amount of crosion, as clescribed elsewhere in this volume. With the widening of the channels, bars and sand-spits were formed on which a vegetation characteristic of a river margin was established. The tops of the banks and the gentler slopes of the same were seen to support species of a halopliytic character, the presence of the stream having but little effect on the plants indigenous to the region.

More marked effects were to be seen on the bajadas or detrital slopes leading down from the mountains directly toward the lake. The waters of the lake were gently pushed up over these slopes and doubtless penetrated slowly to some depth. The infiltrating water would meet the slow underflow from the mountains with the result that the latter would be dammed and would be brought nearer the surface. A more luxuriant growth of halophytic and spinose forms on the steep slopes contiguous to the Travertine wash on the westward may be aseribed to this cause rather than to any increase in the relative humidity. Although every effort was made to find effects due simply to the influence of increased humidity nothing of the kind was seen, and all such appearances above the level of the strands were in places in which the structure was such as to present conditions for retarding the underflow. The amount of water evaporating from the lake was comparatively enormous, yet the vapor formed was carried away so rapidly that it would have but little effect in checking the transpiratory activities of land vegetation and thus increasing the physiological value of the scanty supply of soil moisture. The relative humidity with no wind may show an increase for a few hundred yards away from the shore of the lake, but such conditions prevail only during comparatively brief periods. Some observations on this matter were made near the western shore of the lake in February 1907, and the following extract is taken from my notebook.

"On February 11, the wet and dry bulbs at 40 feet from the shore read 73 and 62 at 2 h $25^{\mathrm{m}}$ p. m., indicating a relative humidity of 68 per cent and at $3^{\mathrm{h}} 34^{\mathrm{tm}}, 711 / 2$ and 67 , indicating a relative humidity of 87 per cent. In order to ascertain the extent of this humid zone the instruments were taken directly west, three-eighths of a mile from the shore, where a reading of 82 and 61 was obtained, indicating a relative humidity of 49 per cent at $3^{\mathrm{h}} 30^{\mathrm{m}} \mathrm{p} . \mathrm{m}$., and 15 minutes later a second reading showed 81 and $601 / 4$, indieating a relative humidity of about the same. It is thus to be seen that the zone of greater saturation is a comparatively narrow one, as on returning to one-fourth mile from the shore at $4 \mathrm{p}$. $\mathrm{m}$. the readings were 80 and $731 / 2$, indieating a relative humidity of 81 per cent. 
"On the evening of June 20, 1912, the relative humidity at a distance of 3 or 4 miles from the shore was 32 , which showed no increase at sunrise on the following morning. It had already been previously noted that contiguity to the Delta or bodies of water in an arid region docs not necessarily result in increased humidity, as evidenced by the fact that the amount of moisture in the air a few yards from the banks of the Colorado River was but little different from that of the drier parts of the desert widely separated from the Delta." I

\section{ENDURANCE AND SURVIVAL OF SEEDS AND PLANTS IN PLACE.}

The prineipal mechanical and chemical features of the Salton Sink now having been fairly presented, it will be pertinent to turn attention to the mechanical relations and life histories of the species which compose the aggressive hosts of plants which press upon the bared areas as invaders and possible occupants of the empty areas.

So far as the islands in Salton Lake are concerned, it may be assumed with fair certainty that their submersion in the saline water of the lake for a few weeks or a few months would result in the destruction of all of the living plants except such forms as Phragmites, Distichlis, Juncus, and Typha, species about which there is but little to discuss in the present connection, since they are not numbered among the pioneers on islands. Populus established in boggy locations near flowing wells endured submergence of its roots to the depth of a foot or two for a few weeks without material injury.

The mounds of organic matcrial surrounding saline springs 2 miles to the westward of the railroad station of Salton, which had been submerged by the waters of the lake a depth of a yard or more during the years 1907 and 1908, were found to show living rhizomes and stems of Phragmites, Typha, Juncus cooperi, and Distichlis spicata. The water which had covered them showed a total salt content of about 0.3 per cent at the beginning of this period, which had increased to 0.5 per cent a year later. The species noted generally grow in soils more or less highly charged with salts and their survival was in no wise unexpected. The changes resulting in dead stems of shrubs and trees have received extensive and detailed treatment by Professor Brannon in another section of this volume.

The tops of many of the larger plants, such as Atriplex, Suceda, and Spirostachys, with maturing seeds, the bases of the stems of which were surrounded by the waters of the lake, were held aloft in place and a portion of the crop was not dropped until after the ground around them was laid bare, with the result that a sowing was made without the aid of other distributional agencies in freshly bared strands. This effect was most marked at the extreme northwestern corner of the lake in 1908, and also to some extent on the northeastern shore, where the water covered a gentle alkaline slope.

On gently rising slopes, like those near the northwestern end of the lake near Mecea and on the castern shore near Imperial Junction, the water flowed about the bases of the shrubby vegetation, giving the spectacle of xerophytic forms growing under aquatic conditions. Efflorescences and other deposits and accumulations of salts on the surface were dissolved at once, so that samples of water like that taken near Travertine Point in May 1906 showed a total solid content $1,152.8$ parts in 100,000, or over 1 per cent, of which $\$ 84$ parts were common salt. This is about three times as much as in the main body of the lake. This fringe of highly saline water would exert a stronger toxic action on sceds lifted from the soil than the water of the body of the lake. The shallow layers of water near shore attained a much higher temperature in the midday with the thermometer over $100^{\circ} \mathrm{F}$. than that farther out in the lake. Both the higher concentration and the higher temperature would increase the sterilizing effects of the rising lake. (See p. 121.)

After both of these conditions have been allowed for, however, the supposition remains that the submergence of the arid soil of the isolated islands might not destroy all of the seeds present. The analysis of the manner in which a plant begins existence on a newly emersed island should take this fact into account, although the consideration is largely a

"MacDougal, The Delta of the Rio Colorado. Bull. Amer. Geog. Soc., vol. xxxvir, p. 4, 1906. 


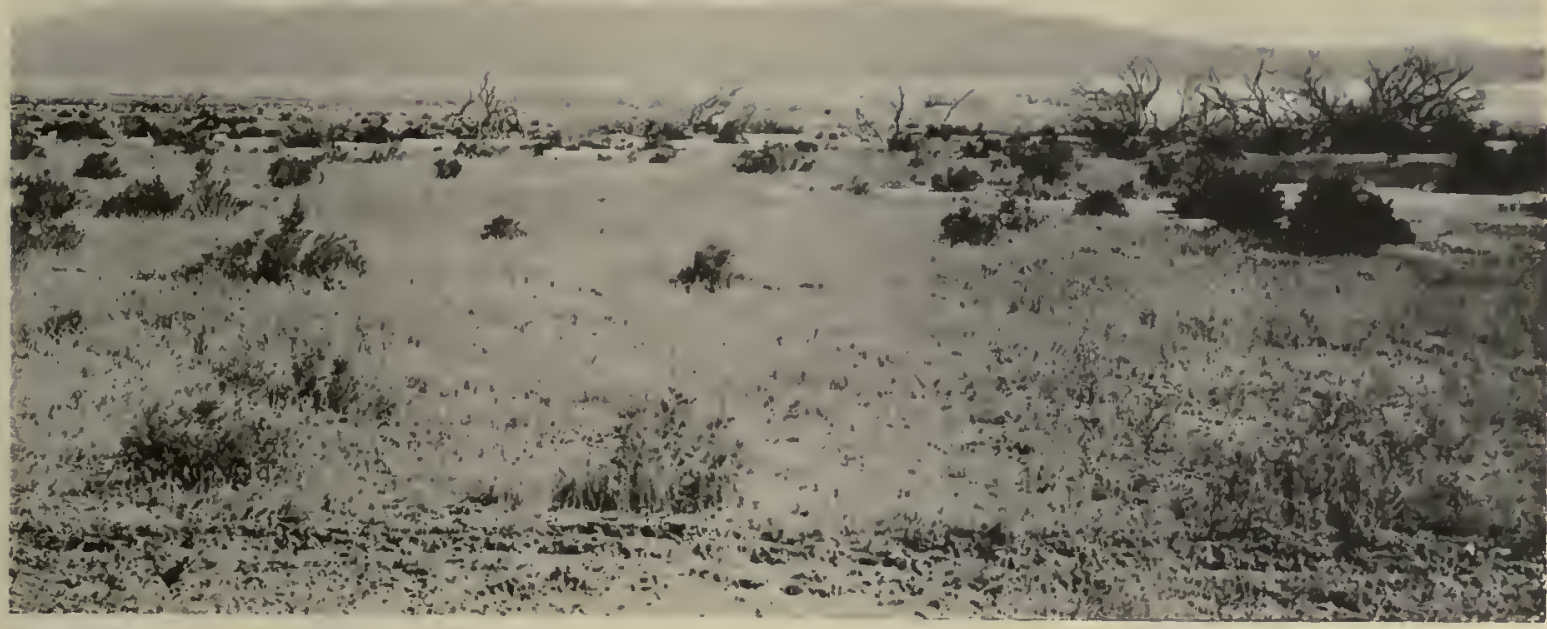

B

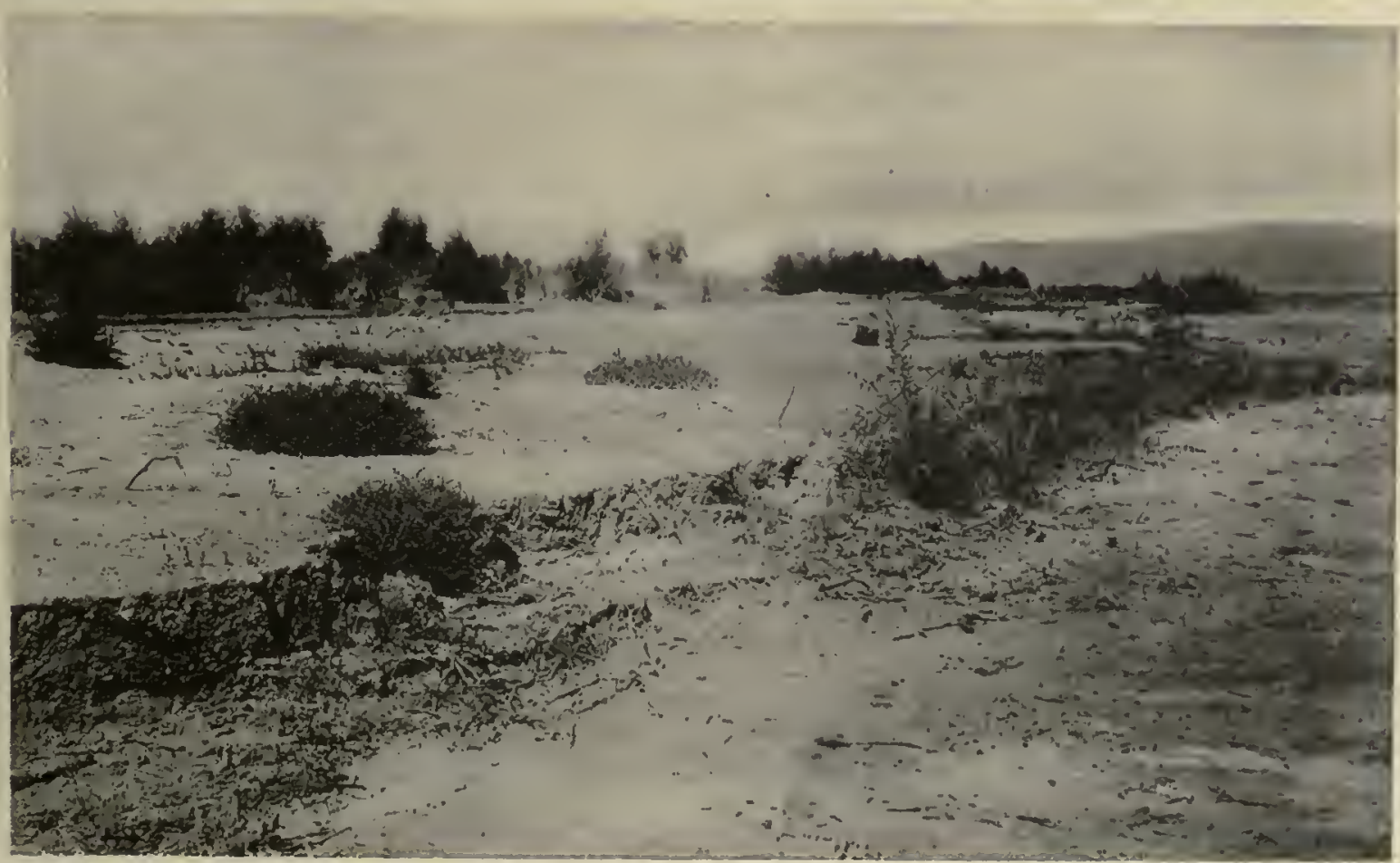

A. View down course of Travertine W'ash across Emersions of 1911 and 1912 . The steep banks of the shallow wash were obliterated during submergence. Dense formation of Distichlis, with scaltered plants of Spirostachys, Atriplex, and Heliotropium. Numbers of Prosopis pubescens killed by waler are seen in various stages of emersion. October 1912.

B. Cut Bank marking the mid-winter of 1911-12. Travertine Terraces. Salix, Populus, Atriplex lentiformis, Heliotropium. Pluchea camphorata, and Prosopis pubescens in rank at foot of bank on emersion of 1912. Sesuvium is also included and its rounded clumps are seen on the strand of 1911 above. 

theoretical rather than a practical one, since the upper layers of hills which became submerged and then arose as an island from the receding waters had invariably been so eroded and worn by the action of the waves that there remained but little question as to the presence of any plant by invasion rather than by endurance of the flood in place.

\section{POSSIBLE INVADERS OF THE STRANDS.}

Practically all of the species inhabiting the Cahuilla Basin, including those native to the alpine slopes of the San Jaeinto Mountains, are to be included among the forms the seeds of which might be carried by run-off streams, winds, or other agencies down to the unoceupied areas around the receding lake. The differences in climatic conditions and in the soil, however, would obviously constitute an effectual barrier to the greater number of the plants native to the rocky slopes of the mountains. Some of the barriers affecting the dispersal of species on mountain slopes are much too subtle to be detected by available methods of geographic survey. This is well illustrated by the cultures made at the Desert Laboratory, in which many species abundant on the higher slopes of the Santa Catalina Mountains in positions from which their seeds must have been carried to the lowlands in myriads for centuries are not found below a certain limit, although when the sceds are transported by man to the lower lands the plantlets survive and in some instances, such as that of Juglans, outstrip the lowland species in vegetative activity.

The species inhabiting the bajadas or detrital slopes of the basin, or of the lowermost part included in the Salton Sink, would be the most important elements in any invasion of surfaces left bare by the receding waters of the lake. The census of these forms is to be found in the section of this paper compiled by Mr. S. B. Parish.

A number of introduced species and weeds would constitute another element, and plants of this kind would be carried along the line of the Southern Pacific Railroad, which runs at varying distances from the shore of the lake for about three-fourths of its length. The water actually washed the ends of the ties for many miles of the line at the maximum level. It will be recalled also that a long stretch of the track previously ran below the maximum level and was moved up the slope to evade the rising waters.

The other element to be considered would be the species native to the valley of the Colorado River. The entrance from this region would be principally by flotation. The number of species included would be too large to be diseussed in detail. Only those with seeds which would be uninjured by long immersion would constitute potentialities in invasion from this source. The census of the invasions from 1907 to 1912 inclusive includes the following species:

\section{List of Species appearing on the Strands of Salton Sea.}

Amaranthus palmeri
Aster cxilis var. australis
spinosus
Astragalus limatus
Atriplex canescens
fasciculata
hymenelytra
lentiformis
linearis
polycarpa
Bacelaris glutinosa
Bouteloua arcnosa
Chamresyec polycarpa hirtella
Chenopodium murale
Coldenia plieata
Conyza coulteri
Cryptanthe barbigera
Cucurbita palmata
Cyperus speeiosus
Eelipta alba

Eleocharis sp.
Encelia criocephala
frutescens
Eriogonum plumatella
Franseria dumomassii
Heliotropium curassavicum
IHilaria rigida
Hymenochloa salsola
Isocoma vencta var. acradenia
Juncus cooperi
Lepidium lasiocarpum
Lippia nudiflora
Leptochloa imbricata
Oenotliera scapoides aurantiaca
Oligomeris glaucescens
Olneya tesota
Paroscla emoryi
spinosa
Phragmites communis

Pluchea camphorata sericea

Polypogon monspelicnsis

Populus maedougalii

Prosopis glandulosa pubescens

Psathyrotes ramosissima

Rumex berlandieri

Salix nigra

Scirpus amcricanus olncyi paludosus

Scsuvium sessile

Sonchus asper olcraceus

Sphreraleca orcuttii

Spirostachys oecidentalis

Suseda torreyana

Typha angustifolia

Wislizenia refracta 


\section{BIOLOGICAL AND PHYSICAL CONDITIONS OF DISSEMINATION AND REOCCUPATION.}

The sterilization of an area of land surface and its exposure to invasion of plants and animals start a series of distributional activities which may not come to a condition of stability or quiescence until after an extended series of adjustments and successions have been displayed. The initial rush of immigration to an unoccupied area would make visible to the observer the action and relative value of the disseminating agencies which are ordinarily hilden from view, demonstrate the selective action of habital complexes, and give scope to any of the possibilities usually associated with the rapid multiplication of the individuals in the successive generations of any lineal series. The inrush of forms into such an unoccupied area unbalanced by the competition and resistance of resident forms would permit species to exist under physical conditions near the limit of endurance and under the influence of environic complexes with which they do not usually come into contact. Some special inductive effects expressed in the architecture or in the qualities of the biotic elements might be expected under such circumstances.

The sterilization of the Salton Sink by the making of the lake and its gradual recession leaving a continuously widening strip of beach or strand around the decreasing body of water has given unexcelled opportunities for the determination of some of the more important phases of the reactions denoted above. In this instance the bared area lay in the midst of one of the most arid areas in the western hemisphere.

When the fresh waters of the Colorado River were poured into the Sink of the Salton, rapidly at first and then in a diminished stream which continues through the irrigating system to the present time, there is but little doubt that the seeds, rhizomes, and propagating bodies of many hundreds, perhaps thousands, of species were carried down into the lake. The vegetation which might thus contribute to the swarm of invaders comprised the various types of desert plants native to the arid regions in Arizona, California, Utah, Nevada, Colorado, and perhaps Wyoming, as well as the species native to the slopes of the Cahuilla Basin. The total list of invaders which survived and made some occupancy of the beaches includes less than 60 species, as detailed on page 141. These played most unequal parts in the pioneering. Some were represented by single individuals, others by two or three, while others formed dense ranks on the beaches which must have included hundreds or thousands of individuals annually.

The difference between the vegetation of the first emersion and that of succeeding seasons was far greater than that indicated by the difficulties of invasion or by the toxic action which might be ascribed to the simple and direct concentration of the lake water. In fact, a comparison of the data obtained by the chemist (see page 39) shows that a simple concentration of the lake water did not take place. Among other things the amount of potassium in the water showed no increase, although the amount present was probably adequate for the nutrition of all of the plants concerned. Next it was found that the magnesium lagged behind in the increase of the elements present in the water. The most striking feature of the chemical analyses, however, was illustrated by the calcium determination, this element soon beginuing to show a marked divergence from the main course of concentration. The possible significance of this deviation may be best understood when it is recalled that sodium in large proportions is toxic to plant protoplasm. This toxic action does not occur in the presence of calcium when the two elements sustain certain proportions to each other. Whether or not this masking or antagonizing effect is produced in the complex solution of Salton water is not known. ${ }^{1}$

It is not possible to predicate with any exactness the probable compounds of the ele-

${ }^{1}$ Osterhout, W. J. V. 'The permeability of protoplasm of ions and the theory of antagonism. Seience, vol. 1, xxxv, pp. 112-115, Jan. 1912. Siec also vol. xxxvi, pp. 575, 576, 1912. 
A
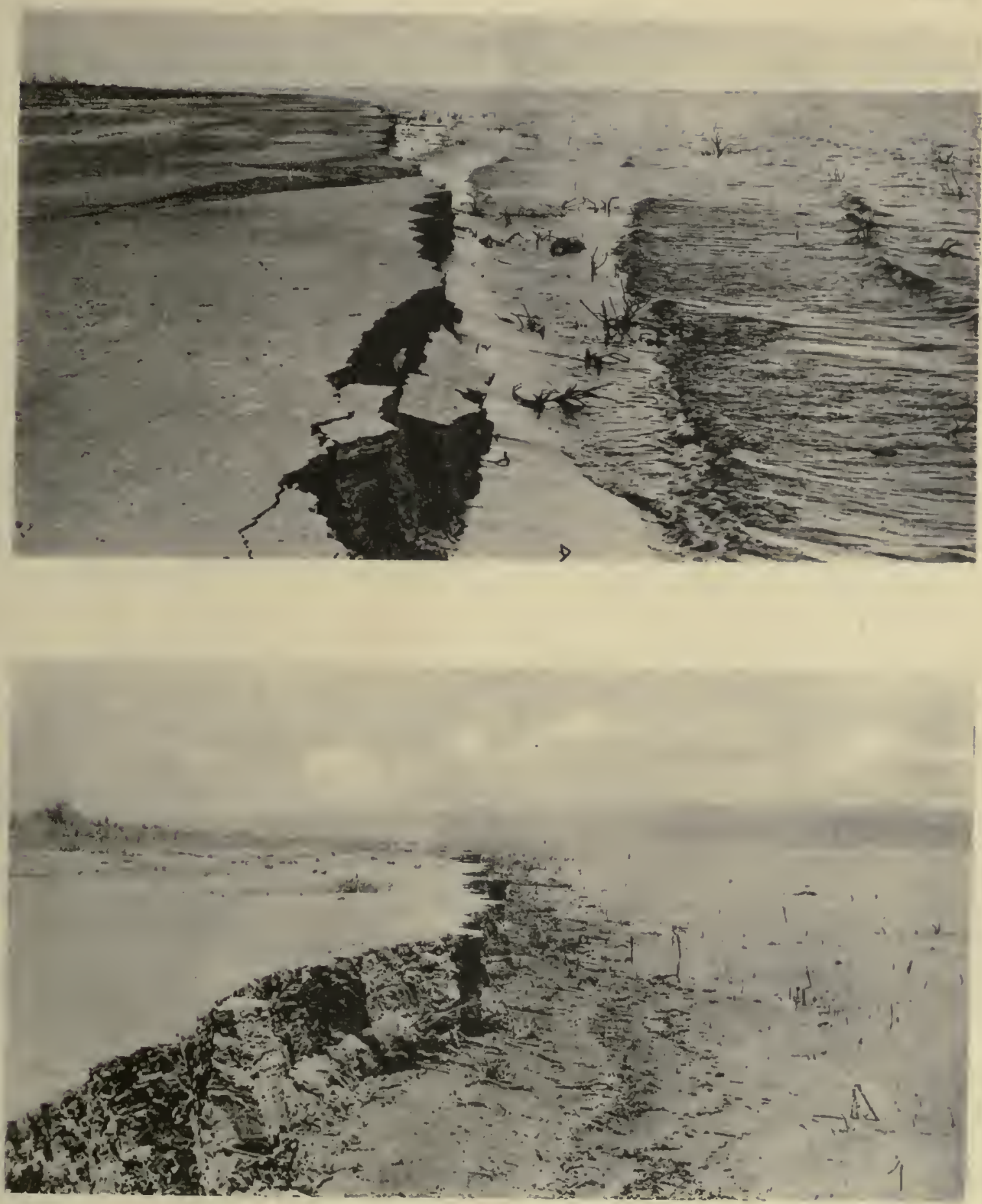

A. Cut Bank at upper limit of Strand of 1913. Travertine Terraces, as it appeared February 1913.

B. Bank at upper margin of Strand of 1912. Travertine Terraces, in May 1913, after a fall of aboul 8 inches in level of water. Seedlings of Heliotropium. Salix, Populus, Prosopis pubescens, Atriplex, Cyperus, and a Grass were established at fool of bank. 

ments found in the Salton Lake water and it does not seem profitable therefore to reduce the chemical results to terms of normal concentration. Sodium was present in the water of the lake to the extent of 112 parts in 100,000 in 1907, and calcium to less than 10 parts, the calcium therefore being but one-eleventh of the amount of the sodium. The ratio had changed but little by June 1908, but by June 1909 the sodium was as 13 parts to 1 of ealcium, and the period immediately preceding may be taken as being the time when the sulphur bacteria began to multiply and take on an inereased aggregate activity, resulting in the reduction of the sulphates and the deposition of calcium carbonate. Although the water coming into the lake from various sources was charged with calcium in small proportion, yet in 1910 the ratio of sodium to calcium had increased to 14 to 1 , in 1911 to 14.5 to 1 , in 1912 to 14.62 to 1 , and in $1913,16.4$ to 1 .

Many physical agencies would operate to carry seeds toward the sterilized beaches, and it will be profitable to consider some of the possibilities upon which only inferential evidence may be offered.

The Colorado River at the time that it poured the greatest volume of water into the lake was in a state of flood and had spread out over the lowlands along its course, lifting millions of seeds from their resting-place on the ground; these would be carried toward the lake. Some kinds, however, becnuse of their specific gravity, would sink, and these would have very little ehance of reaching the strands of the lake, as they would soon be covered with silt. Others which might float at first would soon become softened and by the imbibition of water would swell as if for germination, with the result that these also would be destroyed before they passed through the long overflow channel leading from the main channel into the Salton Sink, and some might actually proceed to germination, the plantlets being carried still further, as is suggested by the results on pages 144-153.

Some of the heavy seeds might adhere to trunks of trees and other floating objects and be carried with them to a final resting-place on the strands. In all cases, however, seeds of any kind would be subjected to the action of the saline water as soon as they were thrown into the waters of the lake. Seeds with indurated outer coats, such as some of the species examined in the flotation tests described on page 164, might be picked up by the water and carried the entire distance, or the seedlings might endure aquatic conditions for extended periods (sce page 150).

The heavy winds from the southeast, southwest, and northwest would lift and carry a large variety of seeds (such as those of Baccharis and Pluchea) long distances. Some might fall to the ground directly on the bared strand exactly at a time when the germination conditions were most favorable. Much greater numbers would tend to fall on the surface of the stream and of the lake itself. Once in the water, their further transportation would depend upon wave-action, which would be produced by the wind.

Traveling animals, especially birds, might bring seeds attached to their feathers or imbedded in mud clinging to their fect. In the present instances the principal birds were the pelican, cormorant, and various species of ducks. The first two feed upon fish and habitually alight either on rocks or branches of trees rising above the level of the water, or upon the arid rocky soil about their nests, as noted on the various islands. In one case the seeds would be dropped in the water and their origin would escape analysis, while in the second instance the soil would be too dry to induce germination, which if it did take place would end disastrously, since the surface about the nesting-grounds was trampled and worn so that green plants had but little chance of survival. Pelicans also alight and stand in ranks along muddy shores, and might in this manner deposit seeds in rows or lines.

The lake occupied the bottom of the bowl of the Cahuilla Basin and drainage channels from all of the converging slopes led toward it. In none of these, however, were there constant 
streams. The run-off or surface flow resulted from the precipitation accompanying the heavier storms, and when the streams were formed in this manner the water rushing down the steep slopes of the bajadas undoubtedly would pick up the accumulation of seeds lying in the shallow channels and carry them down into the lake, or perhaps cover some with sand and silt which with the included moisture would be very favorable to germination and survival. The invasions thus facilitated would result simply in the advance of species down the slopes crossing the strands at right angles, generally in places perhaps occupied previous to the making of the lake. Such action was of course noticeable on the uppermost beaches left bare during the first year's recession of the lake, and transportation by this method became less and less efficient as the distance from the maximum-level shoreline was left behind.

'The flotation by run-off streams becomes a more effective method for carrying plants onto the bared strands, especially from the fact that no prolonged subjecting to soaking would be endured. The subjection of the seeds to the brief action of the ephemeral stream and its subsequent contact with the moistened sand or soil would be of a character highly favorable to survival. It is evident that the soil conditions of the beaches during the first year of recession were different from those offered in any following year. Briefly stated, the surface layer had been leached to a slight depth by water containing the lowest proportion of salts. Another feature favorable to the development of the comparatively heavy vegetation of the emersion of the first year was the fact that the rapid rise of the lake would have lifted seeds from the ground and thus at the theoretical moment when the lake was at its maximum level the number of floating seeds which might be driven ashore by wind and wave action was greater than at any subsequent time in the history of the lake. The toxic activity of the water itself was least at the maximum level and began to increase at once. As was noted in the history of the earliest strand, the dead stems of some species remaining erect in place held aloft fruits which were not all cast off until after the waters had receded.

\section{FLOTATION AND GERMINATION.}

Since it appeared that the greater number of the species were finally carried to the emersed zones around the lake by water it was deemed important to make tests of the behavior of some of the forms when placed in water taken from the lake. The conditions were so specialized that it will not be profitable to review the literature of the general subject farther than to call attention to the chapter on dissemination of seeds in "Origin of Species" and also to Guppy's more recent observations."

These tests would have had their maximum value if they had been begun when the concentration of the water of the lake was lowest and the reactions of the seeds year by year correlated with the occurrences on the beaches. 'The overweening importance of flotation as a final means of dispersion was not evident, however, until the work was well under way. A supply of Salton water was taken from the lake in October 1912 and shipped to the Desert Laboratory at Tueson. The nearest analysis was that made in June 1912 (see page 47) and the concentration had in all probability slightly increased, so that the solid matter dissolved amounted to about 0.9 per cent.

A series of glass dishes was provided on a long table in a room with a north light. No artificial heat was supplied and the range of temperature, due to the fact that the room was kept closed during the first two months of experiments, was between $40^{\circ}$ and $60^{\circ} \mathrm{F}$. At the close of this period all of the preparations were removed to a glass house without artificial heat, where the temperature ran as low as $50^{\circ} \mathrm{F}$. at night and up to $88^{\circ} \mathrm{F}$. during the daytime. 'The range of temperature and the alterations thus provided would be so

' See Darwin, Means of Dispersal, etc., Origin of species, pp. 324-330. Reprint of sixth edition, New York, 1876. Guppy, Observations of a naturalist in the Pacific between 1896 and 1S99, vol. II, 1906, London. 
nearly similar to the conditions on the shores of the Salton as to make the results of direct value in a discussion of the action of the speeies treated on the shores of the lake.

Seeds of species which would represent the main features of the occupation of the beaches and also the principal anatomical types were procured, and these were thrown into dishes containing about 400 c.c. of Salton water, after which a loosely fitting cover was provided to prevent evaporation and consequent coneentration of the solution.

After standing for some time, the water would be poured off and a new filling would be made in order that the effeets of heightened concentrations might not introduce a variation into the results. The preparations were cxamined at intervals of a day or two during the first two months, and each time the beaker would be lifted from the table and shaken violently to simulate disturbances of the water due to wave-action. It was realized that this did not give the entire effect of disturbances of the lake where the wave-action might continue for a week witlout intermission. On the other hand, the shaking resulted in many instances in sending numbers of seeds to the bottom which liad been buoyed by adherent bubbles of gas attached to their coatings, and while some of the seeds probably floated a few days longer in the experimental vessels than they would have done in the lake, yet the prolongation was probably not more than one day in ten.

Amaranthus palmeri is a rapidly growing plant of short cycle and widely varying habit. It may reach maturity with a short unbranched stem a few inches in length, while on the other hand great branched stems may reach a height of 6 feet in the summer in the Delta lands of the Colorado. Here it is known as "quelite," and the green stems are eagerly eaten by grazing animals. The Cocopah Indians collect the seeds in late summer and preserve them to be used as food in the winter. The interrupted flower spikes terminate the stems and branches and the indehiscent utricles hold the seeds so that they are cast from the plant during an indefinite period. The shining dark lenticular seeds are not over $0.8 \mathrm{~mm}$. in diameter and less than half this in thickness, with an average weight of $0.3 \mathrm{mg}$. 100 seeds were thrown into a beaker of Salton water on November 16, 1912. The vessel was shaken daily at each examination and a few would go to the bottom, with the result that by January 10, 1913, all but one had sunk. The rising temperature started imbibition with the result that swollen seeds were brought to the surface, being buoyed by gas formed by the end of January (January 25). A week later tlıree seedlings were floating and two more were seen on February 17. The total number of germinations reached seven, and the seerllings had a combined length of root and hypocotyl of over $2 \mathrm{~cm}$. As these seemed to come to a standstill all were "stranded" on March 10.

A maranthus was found on the muddy shores of Obsidian Island and Imperial Junetion Beach in 1908 and 1909. Its failure to appear later can not be conneeted with anything except the inereasing salinity of the water. Although germinations ensued in Salton water of June 1912, yet the proportion was very small and the development definitely limited, while the stranded plants failed to survive. The flotation period of the seeds, 40 to 50 days, was one which would allow it to be carried long distances by water. Its small size and weight would likewise render it liable to be carried by birds or winds. 'The actual locations of the individuals in the filled washes and on the shores was highly suggestive of flotation.

Atriplex fasciculata is abundant in the Salton region, where it forms a small shrub, reaching a maximum height of 2 or 3 feet on various beaches. It is native to the ligher parts of Big Island and Obsidian Island as well as of the slopes about the lake, and was a prominent feature of the first group of species appearing on emersed beaches. The germination of seeds within a few feet of the margin of the water suggests that the fruits might have floated to the place or have been carried there by birds, although no actual tests could be made which would offer evidence on the subject. It is probable that the species, like $A$. cancscens, may survive progressive desiccation to the general condition 
of the slopes of the Sink, although the observations on this matter have not been made with the exactness with which the matter was treated with regard to $A$. canescens and Parosela emoryi.

A lot of seeds were cast into a vessel of Salton water on February 13, 1913, with the result that all floated for a few days, then began to sink, so that nearly all were on the bottom in three weeks. No germination ensued. The failure of the seeds to germinate may be ascribed to their age, and no opportunity was obtained for making a test with fresh seeds.

Atriplex lentiformis is a shrub which attains huge dimensions, the larger individuals making a dome-shaped mass which may be 15 to 25 feet high with a diameter nearly as great. The flattened utricles weigh 7 or $8 \mathrm{mg}$. and mature in the autumn. A supply was colleeted by Mr. S. B. Parish in October 1912 and 100 of these in an air-dried condition were thrown into a vessel of Salton water on November 16, 1912. These seeds showed a marked partial buoyancy. Nine sank on the second day after shaking, but the greater number remained afloat and germination ensued in both lots within a week. The radicles elongated so rapidly that a length of 1.5 to $2 \mathrm{~cm}$. was reached within a week, and the plantlets remained in indefinite positions in the water, some resting on the bottom at a depth of $10 \mathrm{~cm}$., others midway, others floating on the surface, all changing position to some extent with illumination and temperature variations (see Plate 27). The total number of germinations amounted to 85, and with warmer weather all of the plantlets rose to the surface, where they were noted on January 10, 1913. Lots of these were placed in the shallow water covering loam in a glass dish, but none of them struck root and survived the "stranding," although it is possible they might have done so if they had been tested as to this matter earlier; some attenuation and weakening had already been manifested when the trials were made.

This species is abundant in the Mecea region and the seeds might readily be carried down the beach slopes by run-off streams, birds, or other agencies. The introduction of the plant on the Travertine Terrace and on Obsidian Island, however, might have been due to birds or to the flotation of seedlings or to seeds, although the distance to be bridged renders the last-named method the least probable of the three. Among these introductions is the notable instance of a single individual on Cormorant Island, in 1912, its only known introduction to this place in five years. An occurrence of no less interest was that noted in October 1912, when some plants were seen on the emersed archipelago near Big Island. Flotation of scedlings or transportation of seeds by birds is suggested in the last-named instance (Plate $23 \mathrm{~A}$ ).

Baccharis glutinosa is a woody composite (reaching a height of 2 meters or more, with lanceolate glutinous leaves) which blooms all through the summer, and the compressed ribbed fruits, with a long silky pappus, become free from the receptacles in November and December and are supposedly carried about by the winter winds, many of course falling on the water. It proved difficult to free the fruits from chaff for weighing, and although they were seen to be not the lightest seeds tested, yet the surfaces offered by the pappus caused them to be carried long distances by air-currents; 100 of the fruits taken from an herbarium specimen collected in November 1908 were thrown into Salton water November 16, 1912, and floated without being wetted for some time. Shaking caused two to sink to a slight depth on the following day, and these had descended to the bottom on the 26th; five were down on December 9; eight were at the bottom on December 14, and no further changes were noted except that mould had formed on the floating fruits. This state of affairs prevailed as late as January 20, 1913. Shaking did not sink any more of the fruits, which were found to be nearly all imperfect; 35 which had sunk seemed to be sound. No germinations having ensued by March 9, or 115 days after the seeds had been put into the water, the preparation was discarded, as at this time the seeds had 


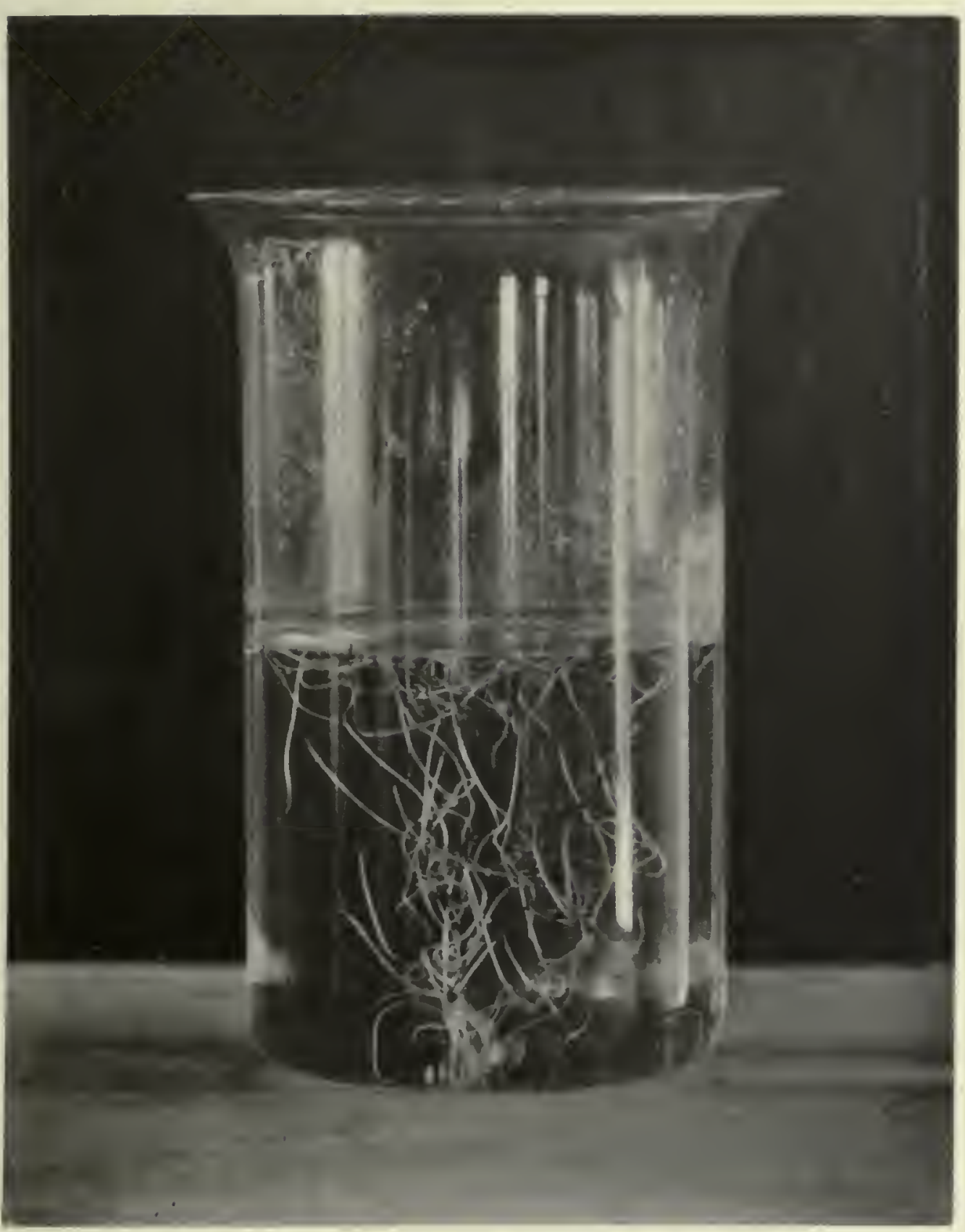

Flotation of Seedlings of Atriplex lentiformis in Salton Water, concentration of 1912. 
decayed. Baccharis appcared as a pioneer on the muddy Imperial Junction beaches in 1907 and 1908 and also on Obsidian Island, where it became strongly established. A single individual was one of the first two plants on Cormorant Island in 1908, but only a single individual was added to the place in the following four years. It also appeared on the archipelago near Big Island as found in 1912. All of the introductions werc in places suggestive of wind deposition, and in the southeastern part of the lake. The locations are those most liable to receive material by southeast winds from the Delta, in which the species is especially abundant. The original introduction on Obsidian Island was still flourishing in October 1912, and the single plant on Cormorant Island had survived until the same date.

Oligomeris glaucescens is the sole representative of the Resedacex in this region. It is a glaucous herb, branching at the base, with the branches ascending; its terminal flower spikes become mature around the Salton in April and May, while the ripe capsules containing seeds are found in place as late as the following February. The seeds are very rounded and slimy and their weight and dimensions appeared to be about the same as those of Sesuvium. Dried capsules from herbarium species collected in February 1908 were broken up and the mass of chaff and seeds was thrown into a vessel of Salton water November 25, 1912. No exact account was made of the number of seeds, but about threefourths sank within a day. No further change was noted until the preparation was placed in a sun-lighted glass house on January 20,1913, when all of the remainder of the seeds sank within a day. A single germination was noted 86 days after being wetted, and a dozen more were noted March 10. Preparations were made for "stranding" the lot, but all began to degenerate and were dead within a week. These reactions and the occurrences of the species only in 1907 and 1908, on the shores at Imperial Junetion Beach, Mecca, and Obsidian Island, suggest that the condition barring the species from later emersions consisted of the increased salinity of the water. The small size of the seed would make it liable to be carried about by birds, while the period of flotation indicated would cause it to be carried for distances between Obsidian Island and the shores to the southward. It is notable that it did not appear on the steeply sloping beaches of Travertine Terraces.

Isocoma veneta var. acradenia is a perennial composite especially abundant on the slopes and bajadas west of the lake, and generally found on very arid locations. The pappus bristles are stout and it does not appear liable to be carried long distances by the wind. Fruits taken from an old dried specimen were put into a dish of Salton water on November 25, 1912, and a few sank cvery day, so that all were on the bottom a month later. The proportion of perfect seeds is probably small and only two good embryos were found in the entire lot on January 25, 1913, at which time no indications of activity had been shown.

This plant was found on the emersions after they had been bare for some time, two years generally, and then only on the western shore, in positions into which they might. have been carried by the wind or run-off streams from the parent plants which were only a few hundred yards away.

Juncus cooperi is a rush of limited distribution in the deserts of the Colorado and Mohave, oceurring around saline springs. The reddish-brown cylindrical seeds weigh about $0.015 \mathrm{mg}$. and are furnished with an appendage which readily absorbs water. Despite this fact the seeds floated from November 16 until Deeember 4, at which time only 10 of the original 100 sank, and the remainder followed on the $23 \mathrm{~d}$, showing a flotation period of 37 days. Germination began soon after sinking, and by January 10, 1913, the hypocotyls were seen emerging from nearly all of the seeds on the bottom of the vessel. The seedlings became entangled by the extremely long trichomes which arise from the base of the hypocotyl, and rose to the surface in clumps with illumination and warner weather late in January. Some of these elumps were "stranded" on January 29 and had taken hold a week later. The schedule of the species is thus seen to include three weeks of flotation of some of the seeds, which is extended to nearly twice that time in others. Germina- 
tion begins about six weeks after contact with the water and seedlings which had floated three weeks were capable of taking root when stranded. All of these periods would probably be shortened in seeds liberated in late summer during warmer weather.

The observations of this plant show that it came on the beach only at the Travertine Terraces, where it appeared on the bared zones during the first year of emcrsion. Its appearance soon after the emersion of an old accretion mound of a saline spring in 1909 suggests that the stem-bases and perhaps the roots are capable of prolonged submergence. The restricted establishment of the plant, with its comparatively long flotation period of seeds and plantlets, is probably a matter of soil; both seeds and plantlets must have been carried to many shores both by water and by birds.

Leptochloa imbricata is an annual grass which appears to be abundant throughout the Delta of the Colorado, where fruits consisting of the minute grains inclosed in the glumes were collected by Mr. S. B. Parish in October 1912; 100 of these were placed in Salton water on November 16, 1912, with the result that one germinated within 10 days, while the remainder were still afloat and inactive until the end of January, when all of the sound embryos awoke with the rising temperatures and increased illumination. After allowing the plantlets to float for two weeks, the entire lot were "stranded," with the result that a fair proportion took hold and sent roots down into the moist saline soil.

The sole observations of this plant concerned its appearance on the emersed zones of Imperial Junction beach and on Obsidian Island in 1907, 1908, 1909, 1910, and 1911. Both places are directly affected by the inflowing current of the Alamo River from the Delta, and in both the recession of the water is followed by a desiccation of the soil which soon terminates the existence of the plant. It is notable that Leptochloa was not seen in any position in which it might not have been deposited by waves and that the radius of its dispersal does not extend more than 8 or 9 miles from the mouth of the fresh-water stream which might bring it into the lake. The small fruits might readily adhere to the fect of birds or to floating driftwood.

Pluchea camphorata is a stoutish annual with its clumps of stems reacling a height of about 2 feet in late summer. The achenes are furnished with capillary bristles and these would be cast loose from the plant in time for germination in the warm weather of autumn. Secds collected near Mecea in mid-October 1912 were placed on the water on February 11, 1913, and remained on the surface. The first germination was noted on March 1 and during the next 10 days it appeared that practically the proportion that might be expected had awakened. The fruits had not been scparated, as a result of which small tangled clumps of bristles and seedlings floated on the surface or were suspended at various depths in the water. A test was now arranged by which the water in which the plantlets were floating was poured into a glass dish filled half-full with packed soil. After this had been done the dish was tilted at such an angle as to give a miniature beach and a half dozen were "stranded" in the process.

Representatives of this species were found on the emersion of 1907 in May 1908 at Mecea, and it was seen to be distributed down the slope, following the recession of the lake at similar intervals as late as 1913; but seeding did not always follow the first occupation, and the plant was noted on the 1907 strand at Travertine Terraces, from which it afterward disappeared, but it was noted here, on the emersions of 1909 , on which it persisted until the preparation of this manuscript, and it came in on the emersion of 1910 at the same place (Travertine Terraces). The emersion of 1911 was also occupied by this plant at Travertine Terraces, and it was found on the islands which rose from the water near Big Island in 1909. It is plain, therefore, that fruits or plantlets of the species are transported across stretches of open water. The instances in which the occurrence of the plant could be best correlated with the phenomena of emersion were at the Travertine 'Terraces, and here the plant was not scen within a ycar's recession of the margin of the 
water. The only place in which the plant was found near the margin of the lake was on newly bared arcas in the archipelago of Big Island and the weight of probability lies with the conclusion that the fruits were carried to this place by winds. The fact that the fruits do not wet readily would operate against their being earried by adhesion to the legs or feathers of birds. The stranding test was arranged to bring the plantlets in contact with a substratum much like that of the shores of the lake and at a time when the seedlings had not been weakened by prolonged flotation.

Prosopis glandulosa is the "mesquite" of the Colorado desert. It is widely variant in liabit, being no more than a shrub on the upper parts of the bajadas or rocky slopes, while it becomes a tree of some sizc in the Delta, where it is the dominant woody plant. Its abundance in the alluvial lands and along streamways gives especial significance to its relations to water. The pods are compressed and indehiscent, 10 to $12 \mathrm{~cm}$. long, ripening in the autumn, and the sceds are surrounded by a mass of dry, spongy tissue which seems to contain a fermentable sugar. A large share of the pods are so completely bored by some insect that perlıaps not more than one or two perfect sceds may be found in each. Flotation tests were made by placing whole pods in Salton water and others were broken into fragments of various lengths.

The first trials werc begun in January 1913, with the species native to the Tueson region. Naked seeds sank like pebbles. Pods and fragments, however, sustained various positions in the water, some floating, some a short distance below the surface, and some on the bottom, according to the buoying eapacity of the gases resulting from the fermentation of material in the pods. No germinations were obtained in the first lot of seeds, probably by reason of the unfavorably low temperatures; some of the seeds became swollen, but the decay of the pods made it advisable to discard the preparation. Next, a lot of secds was put into Salton water on January 25. A month later some were removed to a vessel containing only one-fourth Salton water added to tap water. This seemed to make 110 difference in their activity, however, as both lots germinated in about equal numbers by March 10, at which time the temperatures were rising. The seedlings did not become fice from the sced-coats within a fortnight, but remained at the bottom until deterioration set in. Next, a lot of pods collected in the Salton region, early in March 1913, by Mr. S. B. Parish, was put into water. The fermentation of the material in the fleshy part of the pods made a strong odor, but no germinations ensued. These tests make it clear that the mesquite may not be disscminated by flotation of the secds or scedlings to any great distanec. The fleshy pods are attractive as food to many animals, perhaps to the larger birds, although the author knows nothing as to the extent to which they are so used.

The mesquite appeared on the bcaches of 1908 and 1909 at 'Travertine Terrace, but has not formed a member of the beach communities of later datc. The single specimen which was anong the pionecrs on Obsidian Island was transported to that place as a living branch, which was half buried in the sand of the beach and gave rise to the tree, the appearance of which has been described. (Plate $21 \mathrm{~A}$. )

Prosopis pubescens, or screwbean, has played the most prominent part of any trec on the beaches of the Salton. The indehiscent pods are rolled up into conpact eylinders, which mature in late summer, but remain attached to the tree indefinitely. The first tests with the seeds were made with material taken from herbarium specimens of the University of Arizona. These weighed about $6 \mathrm{mg}$., and sank to the bottom of a vessel of Salton water in which they were placed on January 19, 1913. Swelling began within a week, and one was germinating by the 31st; fifteen more, representing the entire number of perfect seeds, germinated within the next ten days. The cotyledons were released from the seed-coats somewhat slowly; and four rose to the surface of the water on February 15, two weeks after germination began. These carried on a slow but normal development for 
a month, and at the end of this time some generation of the radicles of two was noted, and the lot was "stranded" in soil saturated with Salton water of 1913. None survived, and it is probable that the time of actual flotation without injury is somewhat less than a month and that the conditions for establishment were unfavorable in any one of a dozen features. The fact that the seedlings float at all and come to the surface would make this plant more liable to be carried about than the mesquite, which, as described on page 149, does not free the seedling in the manner of this species. Pods taken from a tree in February 1913 sank to the bottom. Neither the seeds in these, nor in others freed from them, showed any action in a month; and no suggestion is to be made as to the agencies which might be cooperative with flotation in facilitating dissemination.

The screwbean was a marked feature on the steeper beaches laid bare on Obsidian Island and at the Travertine Terraces, where it has been found since 1907. Plantlets were seen late in the autumn on strands laid bare during the summer, presumably from seed of the preceding season. The greater number were immediately off the cut bank, marking the mid-winter stage of the water, and as the seeds are too large to be carried by the wind, and as they also sink, the presumption is in favor of the suggestion that seedlings are earried to the place by the waves. (Plate 29 A.)

Rumex berlandieri is a perennial which appears to reach maturity during the first season in the Salton region and plants may be found in bloom from May to October or November. The fruits, consisting of ovoid achenes inclosed in the sepals, may be held on the stems for several months, and their average weight is about $1.5 \mathrm{mg}$., of which the achene makes at least two-thirds; 100 of these fruits, from a dried specimen collected near the lake in February 1908, were thrown into a dish of Salton water on November 25, $1912 ; 5$ sank on the next day and a few more went down daily, until half were on the bottom of the dish a week after being wetted. Germination began a wcek later with those still remaining afloat and continued for over a month, at the end of which time the plantlets formed a tangled mass. Near the end of this time the seeds at the bottom began activity and the young plantlets rose to the surface, as a result of the formation of gas in the green tissues. The germination of the entire lot extended over a month. A lot of twenty achenes was separated from the calices and thrown into the water to ascertain whether or not flotation was duc to the seed or the adherent structures. All but one sank within three days and this one was probably defective. Nearly all had germinated within a week from the time they were wetted, although the temperature was now higher than when the original lot was tested. The plantlets rose to the surface as they attained some size, although three that were entangled with some débris on the bottom of the dish remained there without injury for a fortnight.

Two months after the first germinations had taken place a tangled mass of plantlets was "stranded" on loam saturated with Salton water and many survived and sent down roots into the soil. The soil, however, was moistened with Salton water taken from the lake in 1912 and the plants soon perished. The long flotation of the plant is a condition that would allow it to be carried great distances by wave-action or by currents, and doubtless introductions would result from the stranding of water-borne seedlings which might be grounded on soil the water of which was not too high in salts. Confirmation of these suggestions is afforded by the bchavior of the plant on the beaches. Up to 1908 it was met frequently in various localities, but after this time it did not appear until 1911, when the shore being laid bare at Imperial Junetion had been overlaid by silt from the Alamo River, in the Delta of which it was very abundant.

Scirpus paludosus did not appear on the shores of the lake until 1908, when it was seen on the Imperial Junction beach. The plant was apparently carried the full length of the lake during the year and came onto the beach at Mecca in 1909, while it did not figure among the pioncers on the Travertine Terraces until 1911, although Scirpus olneyi 
had been seen there in the two preceding years. Nothing is known as to the part played by propagative bodies in this dispersal. It is to be recalled that the species was not noted on the shores of any of the islands.

Scirpus paludosus is a bulrush first known from the upper waters of the Colorado River, and since it was not included in many collections along the lower courses of the river more than twenty years ago, it seems reasonable to assume that its flotation down stream and into the Delta (sce Parish, page 106, this volume) is a comparatively recent matter. Nothing may be said as to the causes which may have set up the distributional movement. No question remains, however, as to the fact that it is now much more widely disseminated than a few years ago. The threc-angled flattened achenes weigh $3 \mathrm{mg}$. and they come free and clean when mature. Mr. S. B. Parish collected a supply in the Sink in October 1912 and 100 of these were placed in Salton water November 16, 1912. All floated at first and none showed signs of wetting or of absorption of water until the 25th, when a few were seen adhering to the walls of the glass vessel. A day later some were water-logged and remained immediately beneath the surface. Shortly one sank to the bottom, and this process continued so that 14 were on the bottom on December 14, a month after being thrown into the water, while the total number on the bottom was but 24 on January 19, 1913; about 31 in all went to the bottom, where they remained for ten days, when some of these, as well as some on the surface, germinated and the number increased so that 17 seedlings were counted on March 17, and these were all on the surface. Some which had been floating a month were now "stranded" in a dish in which the water was that taken from the Salton in February 1913, and it was seen from the first that their survival was assured. Sound plantlets were seen on the water as late as April 4, six weeks after germination. A large number of sound seeds remained, some floating and some on the bottom. It is to be seen from this that the flotation properties of either the seeds or of the scedlings would be an important factor in the dissemination of the plant, and would easily account for its presence in the Delta or any place in the Sink. Some unusual characters of fruits were displayed by the plants of this species collected from the Salton beaches.

Sesuvium sessile is the prostrate sca-purslane of the beaches and saline areas of widely extended territory. It blooms during the entire warm season and seeds may be collected at almost any time in the Salton region. These are extremely small, weighing only $0.04 \mathrm{mg}$. A supply was procured in October 1912 and 100 placed in a dish of Salton water on November 16, 1913. All floated until December 9, at which time (23 days after being put into the water) 1 had germinated and 13 sank upon shaking. All sank by January 13, 1913, and the original seedling was still alive, no other germinations having taken place. With the coming of warm weather the outer coats were shiny with a thin layer of eollected gas and they began to rise to the surface, where all were floating on January 26. Germinations now began and apparently all of the sound seeds had sprouted by February 10 . A lot were "stranded" on February 15 and a large number sent roots down into the saline soil and were quickly established under terrestrial conditions.

It is evident that the behavior of the seeds is such that they might be carried in almost any manner about the lake, and the species appeared on emersed beaches soon after the soil was bared in the main observational areas; it is also included among the small number found on sterilized islands. Like nearly all succulent halophytes, it does not survive long in desiccated soils.

Spirostachys occidentalis is a succulent halophyte which occurs in saline areas in this region. The seeds are retained indefinitely after maturity, and hence it was possible to secure a supply of the crop of 1912 from plants near Mecca as late in the season as February 7,1913 . Some were thrown into a vessel of Salton water on February 14 and all had sunk within 24 hours. Germination began within the second day, and all of the perfect seeds had germinated within 100 hours after wetting. The seedlings soon began to rise to 
the surface and most of them floated there until March 17, when they were dredged out in clumps and placed in a tilted dish (containing soil and Salton water of 1913) in such manner that they were stranded. Two days later it was seen that some were beginning to creet the plumules and to show indications of survival, which was followed by complete establishment. The capacity of these seedlings for flotation is a matter of especial interest in connection with the fact that the seeds sink so readily.

Perhaps no other species has occurred so numerously upon the beaches as Spirostachys. It was notably abundant in the strip of beach at the uppermost level of the lake, where the soil containing a supply of the seeds was moistened for only a short time, and it also arose from seeds falling from stems which had maintained an ereet position in the mud. The ready germination of the seed suggests that the species may not be carried far by the flotation of these bodies, although germination might oceur soon after immersion at lower temperatures; yet the seeds sink readily. On account of the long period of possible flotation and survival, the plantlets may be carried great distances by currents, and the arrangement of plantlets on the beaches at Imperial Junetion and at Meeca suggests the stranding of scedlings which may have arisen by germinations almost anywhere about the margin of the lake.

Spirostachys was notably lacking on the emersion of 1910 at Travertine Terraces for a period after the beach was laid bare and it generally followed the recession of the lake at some distance at this place. Flotation would be excluded as a possible means of dispersal in all such cases, including its appearance on the higher level of Cormorant Island some years after the locations had been left behind by the water. Here and elsewhere the only reasonable supposition would be that seeds had been carried by strong winds or by birds.

Spirostachys appeared on 'Travertine 'Terraces in the emersion of 1912 by the middle of the summer of that year, and during the same season it also arose at other places, in a manner suggesting that the couditions for dispersal were highly favorable, although no reasonable conjecture may be made as to what these may be.

Plantlets have been found in the mud near the margin of the water, yet the plant survives progressive desiccation without serious changes in the shoot. It is still a member of the formation on the uppermost levels of the Imperial Junction, where it first appeared in 1907, and it has not been lost from any location in which it eame as a pioneer with the exception of 'Travertine Terraces, where seepages from an underflow were seen to furnish a supply of water which possibly contained too little salt.

Suada torreyana is an halophyte with soft subterete leaves, and the plant has a somewhat indefinite length of existence, maturing its fruits in late summer. With Spirostachys it is the most abundant species of the Sink, and it is especially abundant in places with saline soils. Seeds were collected near Mecca early in March 1913, and as they are retained indefinitely on the stems the supply of fruits lasts throughout the year and renders the species continuously subject to the action of dispersing agencies. Half of a lot placed in Salton water of February 1913 sank within three days and the remainder soon followed. Germination began within two days of the wetting. Free seedlings floated, though most were held at the bottom by portions of the utriele from which they had not become freed. A number were stranded in the usual manner on March 20, after they had been subjected to flotation for two weeks.

- 1 The seeds must have been present in the soil in immense numbers and those which were simply wetted but not moved near the upper limit reached by the lake in February 1907 doubtless constituted the majority seen on the ground laid bare by the recession of that year. IIt has also been noted that many of the stems remained erect although surrounded by water, and that the sceds which later fell around their bared bases constituted a part of the pioneer flora of the gently sloping beaches, such as that of Mecea. The species is to be included among those near Travertine Wash which were benefited by the hemmed 


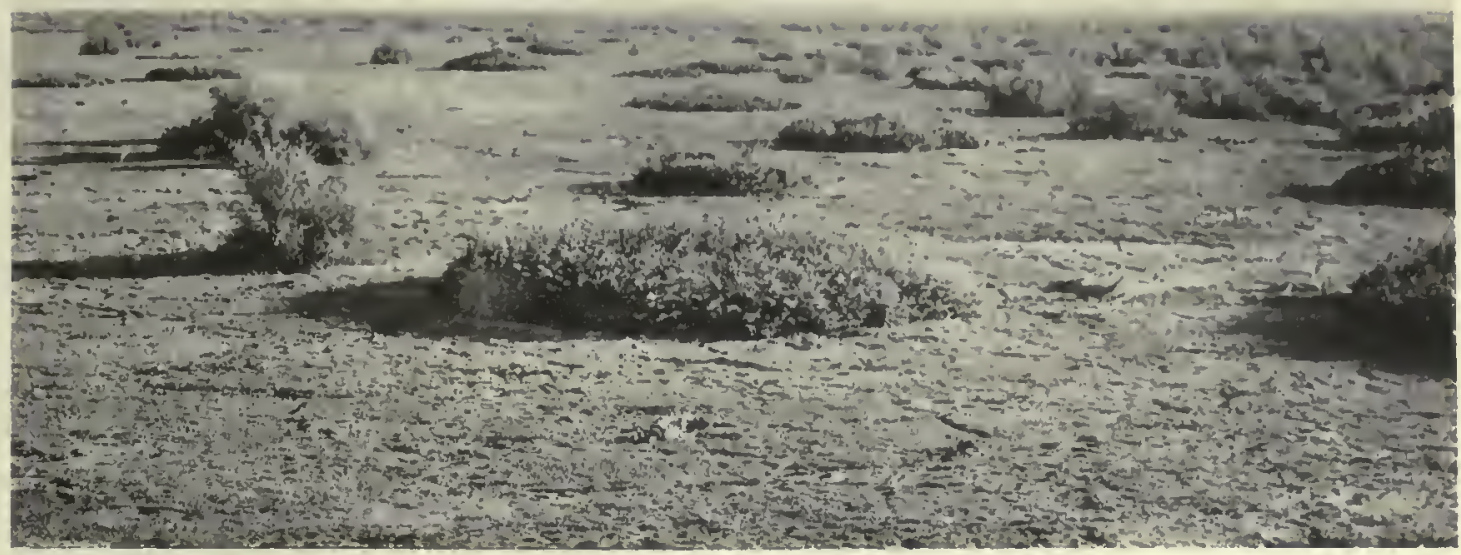

B

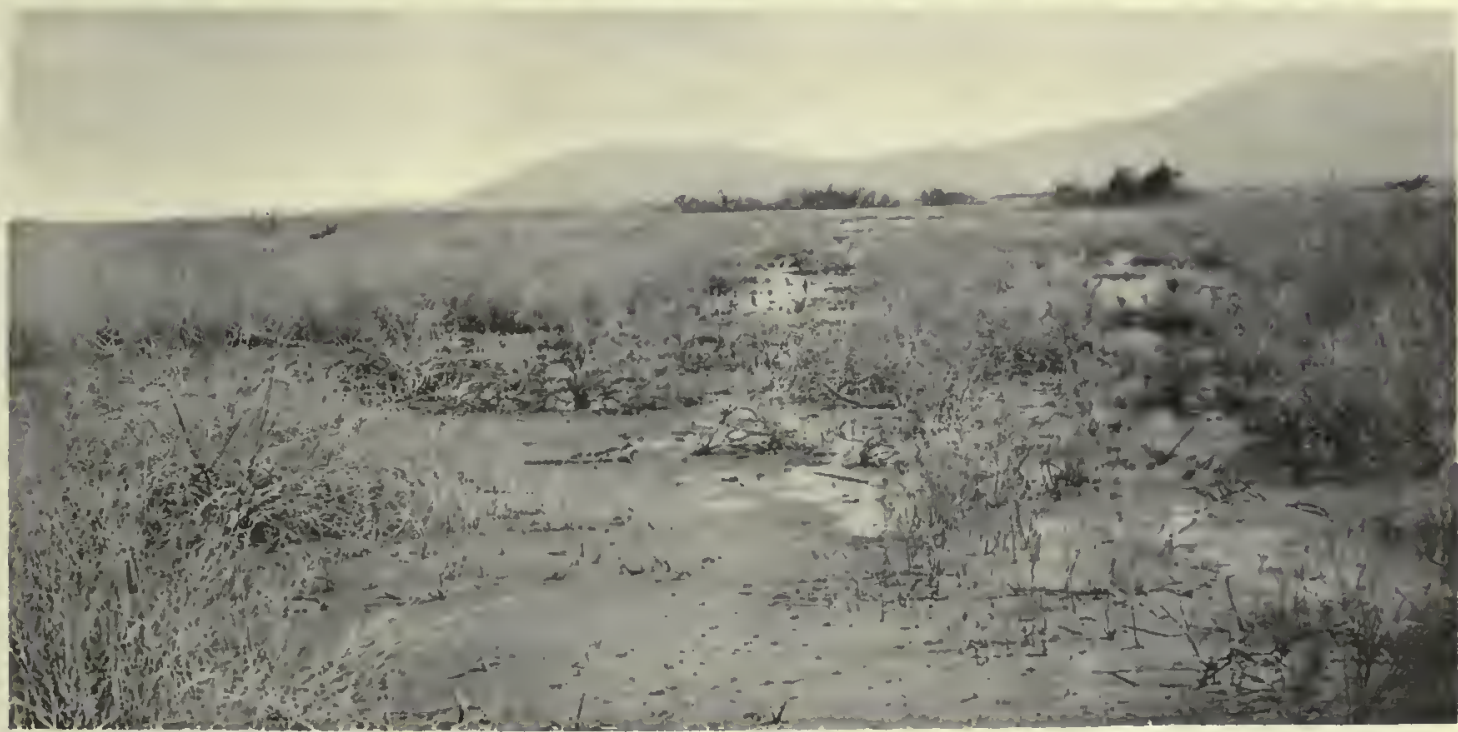

C

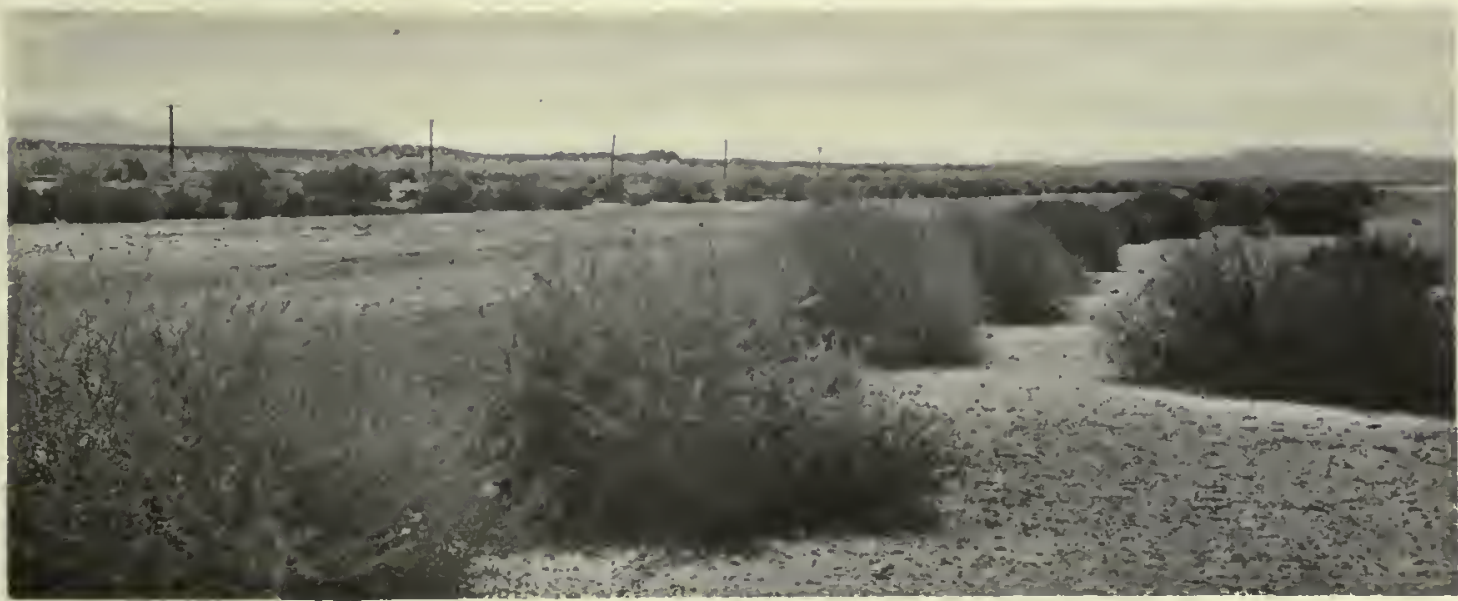

A. Rounded Clumps of Sesuvium, and single Plants of Spirostachys and Atriplex on the Mecca Beach, Strands of 1909 and 1910. Photographed October 1911.

B. Dead Stems of Sureda. Atriplex, and Spirostachys holding fruits from which the flooded ground of the Emersion of 1907 might be re-seeded. Mecea Beach, February 1908.

C. Rank of Suæda torreyana, upper margin of Strand of 1908, near Salion Station. Photographed June 1908. 
underflow, so that a more vigorous growth was made on the gromnd some little distance back from the recent high beach line. It is notable that although it was abundant here it did not at any time come onto the beaches of 'Travertine Terraces, which were less than a mile away, except in 1908, in which year it was also found on the shores of Obsidian Island; it did not survive in either place. It formed along the shore line near the Salton Slough in 1909, but has not maintained itself there.

Sucda was growing on the higher slopes of Big Island when the lake was formed and continued to survive there, yet it did not come onto the beaches of the outlying archipelago less than a half mile to the southward, which emerged from the water in 1909 and 1910 , although the northwest winds would be in a direction favorable for carrying them to this clistance.

It would be allowable to suppose that some seeds were carried by birds, yet the greater majority of the occurrences outside of the special eases noted above might be attributed to the action of run-off streanis which carried the seeds down the slopes to the beach, and those remaining at the margin or in the shallow water germinated in the zonal form displayed in Plate $28 \mathrm{c}$. Seedlings of such origin or from fruits carried to the water of the lake by any agency might endure sufficient flotation to cause them to be carried to some distance, although the failure of the plant to appear on two beaches near maturing crops of fruits does not support such an idea very strongly. It seems very probable that with the increasing coneentration of the water of the lake the specics may appear on other slopes not yet sufficiently saline to offer suitable habitat conditions.

\section{OCCURRENCE AND BEHAVIOR OF VARIOUS SPECIES ON THE BEACHES.}

Aster exilis was represented in the emersion of 1907 at Mecca by one plant which was seen in May 1908. It was next seen in the corresponding zone on Obsidian Island in late November 1908. It also appeared on the emersion of 1908 with $\boldsymbol{A}$. spinosus. It played no further part in the occupation of the beaches, although growing in abundance in the Delta and on flooded lands along the inflowing streams. Myriads of fruits must have been carried over the lake and lodged on the moist strands. The failure to germinate may only be attributed to the concentration of the soil salts, although this has not been tested.

Aster spinosus appeared on the shore of the southeast point of Obsidian Island in the emersion of 1907, as was observed for the first time in May 1908. The plants were in fruit when examined in November of that year. No further occurrence of the species in emersed zones was reported. Its transportation to the locality mentioned was probably due to birds.

Astragalus limatus is a native of the arid slopes and bajadas in the western part of the Sink and its appearance on the beaches was confined to those to which it might have been earried by run-off streams. It occurred on the Travertine Tcrraces on the emersions of $1907,1908,1909$, where it has maintained itself. The first appearance of the plant in any place was not on soil that had been bared less than a year. Several clumps of the plant on the Travertiue 'Terraces were observed in full bloom on February 8, 1913.

Atriplex canescens forms a small shrub about 3 feet in height and is very abundant in the Sink. It is therefore up the slope from almost all of the observational areas. Old plants fell down with the crumbling banks upon the highest beach of Travertine Terraces, although they did not survive; but seedlings arose here and upon terraces of the following years. The plant was also a constituent of the furst lot of plants on bared beaches at the other observational areas. It is to be noted that while it came onto the moist soil within a comparatively short distance of the water, it survived the progressive desiccation. In this behavior it is comparable with Parosela emoryi, which comes on recently bared gravelly and sandy beaches and persists throughout the changes resulting from progressive desiceation, although in soils with a much smaller salt-content. 
Atriplex hymenelytra is native to the upper slopes of Obsidian Island and it was seen to follow down the slopes on the steeply sloping beaches. It is not known whether the fruits could be transported by flotation or not. The suggestion lies near that its survival may be determined very largely by the composition of the soil.

Atriplex linearis was one of the four species of this genus which appeared among the earliest occupants of the alkaline strand at Imperial Junction beach; but if present after that year, it was represented by so few individuals as to escape observation.

Atriplex polycarpa, which ordinarily forms a shrub less than 3 feet in height, was observed but three times on the emersions, one on the beach of 1907 at Meeca and on the beaches of 1907 and 1908 at Travertine Terraces. It did not survive beyond the season and its general behavior here may be correlated with the fact that it ordinarily is found on rather dry soils, not very highly charged with salts.

Bouteloua arenosa appeared on the emersion of 1907 on the western side of the lake, and also upon the strand of 1908 at the Travertine Terraces, but it soon disappeared from both places.

Chamasyce polycarpa hirtella appeared on beaches on the western side of the lake in 1908 in places in which it might readily have been carried by run-off streams. The rapid widening of the beaches upon the gentle slopes, however, was not followed by its appearance a second time.

Chenopodium murale was found on the gentle slopes of the beach laid bare at Mecca, as seen in February 1908, but it could not be found there three months later. A second occurrence was noted on Imperial Junction Beach in Oetober 1909, but the plant did not become established in cither location. The seeds seem to be subject to the action of many carrying agencies, as it is to be seen in many widely separated parts of the world. Following these observations, it was next noted by the author along Khor Adit, leading down into the Red Sea, at an elevation of 1,500 feet, in northern Sudan.

Conyza coulteri was found in the emersion of 1907 at Mecca, during the visits of February and May 1908, but did not appear as a constituent of the beach flora on any subsequent occasion.

Coldenia plicata was found on the ground laid bare in 1907 on the western side of the lake, but no further participation in the oceupation of the beaches was noted. Mature plants fell with the masses of soil onto the beach of 1907 at Travertine Terraces, but apparently all died; although seeds of this plant must have been sown on other beaches here, none survived.

Cryptanthe barbigera was found on the southeast shore of Obsidian Island in such position with respect to the high level of the water as to give rise to the inference that it may have been carried there by birds. The burr-like fruits might readily become attached to feathers or carried on muddy feet. Although maturing fruits were seen, no reproduction occurred.

Cucurbita palmata inhabits the dry gravelly slopes of the Sink and has been seen on the bajadas west of the lake, maturing fruit in late summer or in mid-winter. The globular fruits have a hard outer shell and are very light, in consequence of which they may be rolled about by the wind, carried by small run-off streams, or floated by the lake.

This species was introduced more than once at Imperial Junction beach, but did not survive long there. Neither here nor on the gravelly beaches of Obsidian Island did it come ashore later than 1909. The defection might be partly due to two causes: the supply of fruits which would be brought onto the waters of the lake would decrease with the recession of the shore line, and the increasing salinity of the water would be injurious to the seeds; this last point was not tested. The plant survives in the emersion of 1909 on the gravelly beach of Obsidian Island, which furnishes the conditions of its usual habitat. The size and character of the fruit are such that it may be said with certainty that it has been transported only by flotation to the islands or to Imperial Junction Beach. (See Plate 29 A.) 


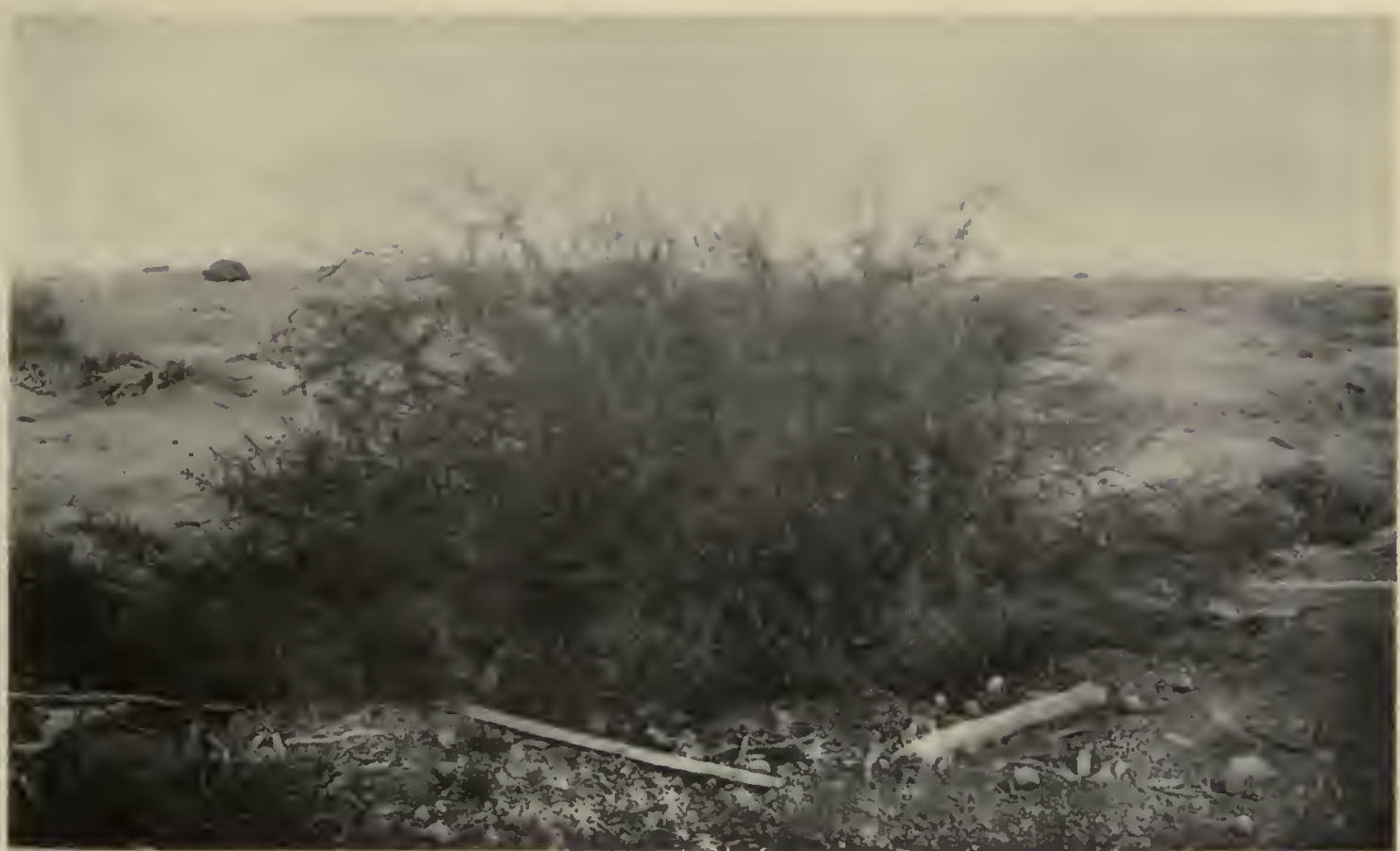

B

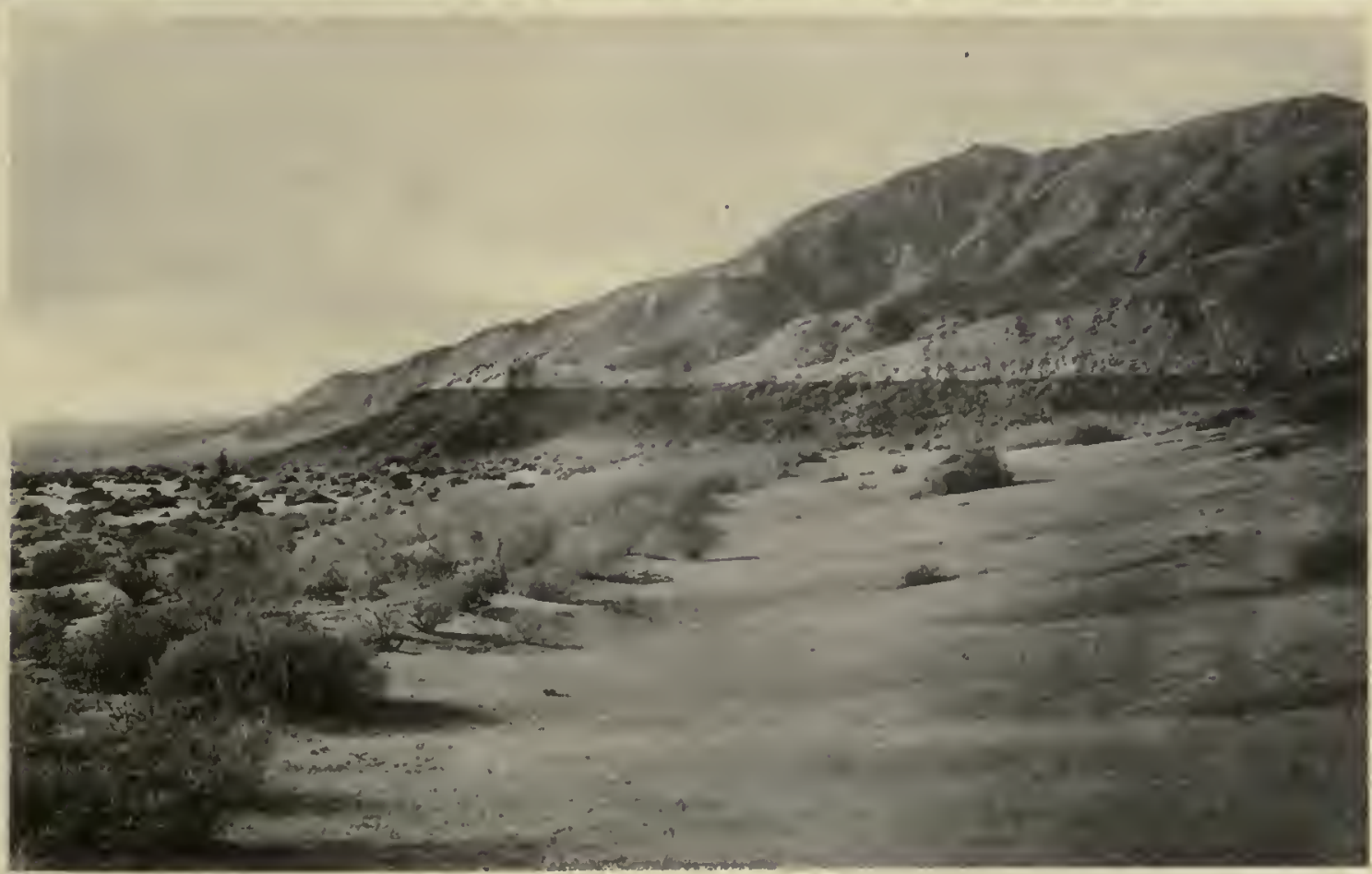

A. Prosopis pubescens at upper margin of Strand of 1907, west bay of Obsidian lsland. Fruits of Cucurbita palmata matured from introductions by fotation are also seen. November 1908.

B. Rank of Vegetation including Atriplex canescens, Coldenia palmeri, Franseria dumosa, Hymenochloa salsola, Parosela emoryi, and Petalonyx thurberi on ancient strands below sea-level near Travertine Rock. Line of Erosion of high beach level of Blake Sea on Rocks in distance. 

The introduction of this species by flotation and its subsequent survival on the beach is in contrast with the conclusions reached by Guppy with regard to the transport of gourds by ocean currents. Gourds are known to be carried by such means to points widely distant from their place of origin, but Guppy maintains that establishment takes place only by the aid of man. ${ }^{1}$ The constantly receding water in the Salton offers conditions different from those of sea-shores, and the gourd carried by its waters is a desert species which encounters accustomed conditions when stranded on a desiccating gravelly or sandy beach.

Cyperus speciosus is a sedge, the significant occurrence of which in this region is along high-water channels of the Colorado River. It was found in the Delta lands by Mr. Parish; also on the emersion of 1908 of Obsidian Island, which is direetly in the way of inflowing currents of the Alamo, which is in effect an effluent of the Colorado. It also grew upon the 1908 emersion at Travertine Terraces as well as those of 1909 and 1910. It may be probable that the later appearances are from seeds of the first introduction. No tests were made of the flotation of the fruits, but it is probable that their small size would render them liable to become attached to the feet of birds.

Distichlis spicata was one of the most abundant of the pioneers and it appeared on all of the beaches, although it soon perished under the stress of desiccation, especially in such places as the slopes at Imperial Junction beach. The dispersal by seeds is probably one of the most important means of dissemination, and in this both birds and waves inight play a part. Its appearance on a strand area was generally early in the year succeeding emersion, but in some instances it followed the water closely, as it did one year at Imperial Junction beach. The session of 1909 was characterized by heavy mid-summer precipitation, but this resulted in no increase in the number of pioneers of this species during that year. Beginning with 1910, however, it was seen that the beaches of 1909 everywhere about the lake bore a heavier mat of Distichlis than the ground laid bare in any other year. The disparity was evident as late as October 1912.

The vigorous growth of the rhizomes is such that the plant soon spreads from its original location to such an extent as to cross the boundaries of emersion zones. No experimental proof can be adduced, but the conditions suggest that detached rhizomes might readily be carried long distances by the water of the lake. It is possible that the immediate appearance of the species following hard on the recession may be due to the "stranding" of such living stems.

Eclipta alba was represented by one individual in the emersion of 1907 on Obsidian Island, when examined in November 1908, and a ycar later the species was represented in the emersions of 1908 in the same locality. Further observations of it in this place are lacking and it probably did not reproduce itself on the invaded area. A third occurrence was noted in 1909, on a newly emersed area near Big Island, which likewise had no result. The fruits of Eclipta are known to be capable of flotation for many months, and the manner of occurrence on the islands of the Salton suggests that the plant was carried to the beaches in this manner.

Encelia eriocephala made an appearance on the Travertine Terraces following the recession of 1908, where it failed to survive, and a single fruiting individual was found at the same time on the eastern shore of Obsidian Island. It failed to reproduce itself and, although fruiting specimens were seen up the slope from Imperial Junction beach, it found no further place on the bared areas.

Eriogonum thomasii was first seen at flood level and slightly above it on Obsidian Island in February 1908, as if the seeds had been carried to their places by birds or had been moved short distances by them after being washed ashore by the waves. These plants were seen three months later, and again in November 1908 on the southwestern

1 Guppy, H. B., Observations of a naturalist in the Pacific, vol. II, pp. 570, 571, 1906. 
side of the lake, but it disappeared within a year after this clate. It is to be noted that the species was found on the higher parts of islands not reached by the flood and that it inhabits localities of extreme aridity.

Franseria dumosa appeared in the emersion of 1907 on the western shores of the lake, to which place it was probably carried by run-off streams. The soil eonditions would favor its survival. This plant is a constituent of the final formation on old beaches.

Heliotropium curassavicum was one of the earliest pioneers on almost all of the beaches, being found in bloom on the 1907 emersion as carly as February 1908. It is notable, however, that with the progressive desiceation of the beaches it perished within two years, except in such places as the Mecea area, where the low, gently sloping beach had a high soil-moisture content, and on Obsidian Island, where the beaches were so steep that the actual distance from the margin of the water of the receding lake and the original strand was comparatively small.

It was consistently included among the pioneers in the suceessive emersions studied, and likewise appeared to be injured very quickly by any notable decrease of soil-moisture. Heliotropium came in on the islands of the archipelago south of Big Islaud in 1908, but Cormorant Island, the most isolated of all of the emersed areas, did not receive it until 1912, when two plants in bloom were found on its upper slopes. The transportation to this place may be attributed to birds, with a high degrec of probability, especially as the seeds are very small and sink within a short time. No opportunity was afforded for testing the flotation of the seedlings. The two plants found were on a spot that must have been above the water for at least two years and they had germinated and come to bloom within the year, after the manner of freshly deposited seeds.

II ilaria rigida was noted but once, and then on the zone laid bare by the recession of 1907 on the western side of the lake. The species is native of the higher slopes to the westward and the seeds might have been carried down the slopes by run-off streams. Nothing is known as to the survival of early introductions, but the species might be expected ultimately on such slopes.

Lepidium lasiocarpum appeared in the silt-filled chamels of the washes on Imperial Junction beach following the recession of 1907, but apparently did not survive long or withstand the progressive desiccation, the effeets of which were very marked in this locality.

Lippia nudiflora came onto the beach of Obsidian Island at the same time as Psathrotes and Sphoralcea and formed distinct mats on the southeastern shore, which persisted during all of 1908, but had perished when the place was visited in October 1909 . The weight of inference would suggest flotation to the place, either in the form of seeds or living stems.

Oenothera scapoidea aurantiaca came down onto the strand of 1907 with Franseria and Wislizenia and also appeared on Obsidian Island, to which place it may have been carried either by waves or by birds. It is surmised that its seeds would not endure long inmersion in salty water. It disappeared from the ranks of invaders on the shore of the island within a year, but probably follows down the gravelly slopes on the western side of the lake by irregular seeding and establishment.

Olneya tesota occurs with some frequeney up the slopes of the Sink in all directions from the lake, but its seedlings were seen but once on the emersed zones. This was in the emersion of 1907 and the observation was made in November 1908. It seems probable that the beans were washed down the slopes by run-off streams.

Parosela emoryi was in many respects one of the most important species which appeared on the beaches. It came on the emersion of 1907 on Obsidian Island, which it must have reached by flotation, and was seen there in 1908. A second invasion in the same year was noted on the southwestern side of the lake. The original location on Obsidian Island was still held in October 1912. Occurrences in the emersion of 1908 were also noted on the southwestern side of the lake and on Obsidian Island below the introduction of 1907. A 
third introduction took place in the zone of 1909 at the same place on the west bay of Obsidian Island, which was in such position as to receive objects from the west or northwest driven down the lake by northwestern winds. An oceurrence was also noted on the lands emerging from the water south of Big Island. The occupations seem permanent. $\Lambda$ s has been shown elsewhere, this plant is a prominent constituent of the formations on ancient beaches near Travertine Point, 200 feet above the recent high level of the lake. The spectacle is therefore presented of a species coming onto the moist strand and becoining established in the moist saline soil in such manner that the intense and progressive desiccation does not injure it. The only other plant which appeared in the present work with a similar capacity of endurance was Franseria dumosa. (Plate 29 в.)

Parosela spinosa attains the dimensions of a small tree along numerous washes in the Sink and is especially abunclant near the Travertine Terraces, but its single appearance on the beaches was upon the gently sloping shores to the southward, in the cmersion of 1908. Nothing is known as to its reactions to saline solutions and no tests were made of the secds.

Phragmites communis is found at numerous places all through this region where springs and seepages afford sufficient soil-moisture, and many thousands of rhizomes must have been earried into the lake by the inflowing current. The first occurrence of these was noted at the Travertine 'Terraces in 1908, where two were on the shelf laid bare in 1907, and it also appeared on the emersion of the following year. Since that time Phragmites has not appeared among the species occupying the beaches, although no cause for this absence may be assigned, unless it be the increasing toxicity of the lake water. No doubt exists as to its endurance of the lake water during 1907 and 1908; for an accretion mound of a spring near Salton station, which had been submerged during 1907 and 1908, bore rhizomes of this plant which had survived the immersion. It is possible, however, that the toxic limit of concentration accentuated by the loss of calcium was reached in 1909 and that living plants were not carried by the lake after 1908. All of the known introductions were from rhizomes floating in the water. (Plate 18 A.)

Pluchea sericea, or arrow-wood, is a shrub which reaches a lieight of 3 to 7 feet in the Delta of the Colorado. The fruits bear copious pappus, on account of which it is readily borne aloft by the winds. Maturing fruits were seen in May and consequently this plant found a foothold on the strip which had been laid bare at this time and was still moist. It appeared on all of the beaches except that it was more sparsely represented during 1909 and 1910 than at other times. Introduction appeared to be followed by establishment in nearly every case. No well-attested records are at hand as to its extermination on any beach, although it was recorded as missing in certain instances, perhaps by being overlooked. The heavy stand on this plant on the strip laid bare on Imperial Junction beach in 1907 was still represented by a great number of individuals in October 1912, although it was seen that nany were slowly dying, presumably from the lack of moisture in the soil. The actual margin of the lake had by this time receded over a mile from where they stood.

Pluchea was also one of the first plants carried to the sterilized surfaces of the islands, and its extreme buoyancy in the air renders it liable to be sown thickly everywhere. Millions of the fruits, like those of all of the compositaceous plants of the region, would undoubtedly fall into the water, but it can not be said whether or not these would germinate there or in the moist mud at the margin when they became stranded.

Polypogon monspeliensis was seen but once, in May 1908, when mature plants with maturing seeds were found on ground recently laid bare by Imperial Junction beach. The single introduction may have been by birds or by wave action.

Populus macdougalii is found in moist locations at various places in the Cahuilla Basin and some trees were below the maximum level of the water near Mecea. The water, which at the time of the high level eontained only about 0.25 or 0.33 per cent of salt, covered the 
ground around the bases of the trunks, but no measure of the penetration could be made. Solne of these trees survived. The fruits are probably capable of enduring even a higher proportion of salts, since a rank of plantlets was found at the upper margin of the shelf laid bare at Travertine Terraces in 1908, also at the upper margin of the emersions of 1910 , 1911, and 1912. The low rate of recession during the winter, coupled with the violent waveaction, is responsible for the small cut bank which separates the emersion of one year from that of the next. It was just under this bank that the dense row of this tree was established, which is indicative either of a dispersal of fruits before mid-winter and their germination early in the year, or of early maturation of fruits in the spring and their immediate lodgment in the angle at the foot of the upright bank. The flying fruits fill the air at the time of their ripening and many might fall directly on the ground, or upon the water a few feet or a few hundred yards away and be washed ashore. (Plates $24 \mathrm{~A}$ and $26 \mathrm{B.}$

Psathyrotes ramosissima appeared on the beach laid bare in 1907 on Obsidian Island. It was seen first in February 1908 and was fruiting in May of the same year. Despite this production of seeds, it did not reproduce itself and was not seen again here or elsewhere in the emersed zones. The only assignable cause of its defection would be the toxicity of the soil salts increasing with desiccation.

Salix nigra like Populus survives the submergence of its roots in water slightly saline, as was shown by the behavior of many trees on the Mecca beach. The seeds likewise appear to germinate in the presence of some concentration of salts. The occupation of the beaches by seedlings was confined to the western shore of the lake. Some were secn at the foot of the long bajadas southeast of the Travertine Terraces and this plant formed the most prominent feature of the dense rank of perennial plants which was formed at the upper margins of the emersions of each year. It appears on the records for 1907 and 1908, but disappeared from both within a year. But one Salix was present on the 1909 emersion when it was examined in 1912. The invasion began to be heavier after this and a crowded row of Salix as well as of Populus was found at the upper margin of the emersion of 1910, in September of that year, which had persisted and by June 1912 had made a rank of trees 10 to 15 feet in height which have continued to grow since that time. Another heavy rank was formed at the upper margin of the emersion of 1912 and plantlets were seen as early as June of that year. The species did not appear so early in 1912 and no plantlets were found at the upper margin of the emersion in June 1912, but in mid-October young trees 2 or 3 feet in height were present. (Plates 24 A and 25 B.)

The dispersal of the seeds must be under much the same conditions as those of Populus. The species was found only on the beaches of the western shores of the lake and no instance was found of its transportation across the open lake to the emerging islands. Trees are present at springs near 'Travertine Terraces and fruits may have lodged directly on the moist strands or have fallen in the water and been washed ashore. Germination took place in soil high in salt-content.

Spharalcea orcuttii was seen but once and then only in a single plant on the shore of Obsidian Island in the path of the direct inflow current of the Alamo River, under the same circumstances as Psathyrotes, but failed to reproduce itself. Both of these plants probably floated to the place.

Typha angustata was found in great abundance in the Delta and around many springs in the Salton Sink. Its fruits must be carried widely by air-currents, yet its appearances as a pioneer on the emersed strips were very few. It was first seen in the moist filled channels of the old washes on Imperial Junction beach emersed in 1907, but these plants succumbed to the increasing aridity within a year. Next it was a pioneer in the emersion of 1908 on the Travertine Terraces, but these individuals perished with the desiccation following recession. A single plant coming from a rhizome washed ashore was found on the Imperial Junction beach in 1909 and much material of this plant was found at various 
places around the lake, although it is not known how many plants arose in this way. It is certain, however, that the duration of such individuals would be brief unless they were near a spring or seepage. Typha has appeared in the emersions of 1911 and 1912 near Mecca, but hore the ground is high in moisture and numerous scepages and overflow channels from wells make conditions widely different from those at the lower end of a desert bajada. Numerous colonies of mature plants fruiting abundantly are also present up the slopes from the Mecca location, so that its dissemination here may be considered simply as a spreading down a slope already occupied by it. The seeds are known to sink within a very short time after they fall upon the water and almost all cases of their dispersal must be attributed to air-currents.

Wistizenia refracta was seen but once and then on the emersion of 1907 on the western side of the lake, along with Franseria, Hilaria, and other species of arid habitats. It played no further known part in the initial occupation of the beaches.

\section{THE MOVEMENTS OF PLANTS INTO STERILIZED AREAS.}

The main thesis of this paper has been that of the manner in which seed-plants were carried into moist zones or strands around a receding lake which had been completely sterilized by immersion in the salt water. The submerged area of nearly 500 square miles was part of an extremely arid region, the native flora of which is fairly represented by the census of the Sink above the present water-level. The number of species is small and includes 8 trees, 23 shrubs, 10 semi-shrubs, 30 perennial herbs, and 51 annual herbs. These plants being present on the slopes of the Sink, their seeds would be most liable of all plants to be carried down to the beaches. The agricultural operations on the slopes to the southward of the body of the lake brought into this region 31 additional species, which were also especially liable to be carried to the bared areas. Besides those included in the preceding number, every species within a long radius to the southward and eastward might be considered as being liable to be carried to the strands of the receding lake. The high mountain wall to the westward would form a fairly effectual barrier in that quarter.

The culture ground or emersed strips to which attention was directed were not in a static condition, however. The ground was arid and the soil variously charged with salts varying in composition and concentration. The observations of Mr. E. E. Free, recorded in this paper, show that the soluble content of the soils was not materially modified to any great depth in places which have been laid bare by the receding waters during the first six years' recession of the lake. The moment that the waves failed permanently to lave any part of the strand, therefore, it began to pass from a saturated condition back to the desiccated state induced by the arid climate of the region. The surface layer, a few inches in depth, would at first contain a soil-solution approximately equivalent to the water in the lake, but evaporation rapidly concentrated this, and the plant which might have found a foothold in the comparatively fresh soil would be subjected to the action of solutions of increasing concentration. The salts dissolved in the water of the lake increased from 0.25 to ncarly 1 per cent during the period of the observation, so that even the initial conditions of emergence of the soil changed progressively.

Sixty species were found on the beaches examined during the six years in which the obscrvational areas were examined closely. These beaches amounted to about 5 square miles only, but since they were chosen to include diverse soils and slopes they probably represent more than a majority of the species introduced. Five trecs, 17 shrubby species, and 38 herbaccous forms were included among those which appeared upon the beaches during the period mentioned. Two of the trees inhabit moist areas, while the other three are of xcrophytic habit; 9 of the shrubs are halophytes and survive in soils varying in salt content, this habit being most pronounced in Suocda and Spirostachys and least perhaps in Baccharis or Pluchea. Eight of the herbaceous pioneers are halophytic, while the 
remaining 30 are usually found in places in which the concentration of the salts in the soil-water is very low, and some of these are of xerophytic habit while others inhabit moist areas. It is evident that the species which may be expected to appear in greatest number on the beaches laid bare in the further recession of the lake will be drawn from the 17 pronounced halophytes; the presence of seepages and springs will afford small areas in which others may appear. The secondary occupations or the species which might be expected on the older and uppermost strands would be of the xerophytic trees, shrubs, and herbaccous xerophytes.

It is interesting to note that included among the carlier forms on the beaches was Sonchus oleraceus, which was also one of the first plants to be found on the lava flows of Mauna Loa, Hawaii, as observed by Forbes. ' The seeds of this widely disseminated weed are undoubtedly carried long distances, and as they are produced in great profusion may be expected almost anywhere in the tropies or temperate zones.

\section{HISTORICAL.}

The strand flora of Krakatau included but 67 species in 1906, as reported by Ernst, ${ }^{2}$ although the strand flora of the Inclo-Malayan region comprises about 320 species. It is thus to be seen that not one-fourth of the plants, tle habits of which were suitable for such conditions, had been carried to the shores of this island sterilized by volcanic action in a quarter of a century. The total flora in 1906 included but 92 seed-plants and 22 ferns and mosses. Ernst estimates that 39 to 72 per cent of these may have been brought to the island by sea-currents, 10 to 19 per cent by birds, and 16 to 30 per cent by air-currents. This author attributes the transportation of the 16 ferns to this last agency, also all of the compositaceous species.

Britton, in a recently published discussion of the derivation of the flora of Bermuda, ${ }^{3}$ points out that 80 per cent of the higher plants are identical with forms native to the West Indies and to the mainland of North America. 'The analysis of the liabits and occurrence of these species leads to the conclusion that 41 (or over 18 per cent, including all of the halophytes) have becn carried to Bermuda by flotation and 38 per cent by air-currents. The grasses and compositx, as well as ferns and mosses, are supposed to have arrived in this manner.

The presence of nearly 44 per cent is attributed to birds. It is to be noted that the island of Krakatau is separated from other land by only a few miles of open water, whilc Bermuda lies far out in the Atlantic and nearly 600 miles of ocean separate its surface from Cape Hatteras, the nearest land. It is also important to consider that the revegetation of Krakatau has been in progress but a few years, while the carrying of seeds and spores to I3ermuda has gone on without interruption for an extremely long period. These differences may well account for the much greater importance attached to birds as carricrs in the case of Bermuda and the lessened effectiveness of flotation. It is notable that these authors estimate the part played by winds as practically the same.

\section{THE PHYSICAL CONDITIONS OF THE SALTON SINK.}

'The general setting of the biological stage around and on the Salton is much different from the complexes furnished by Bermuda or Krakatau. The islands in the Salton Lake were submerged in salty water and emerged to pass by rapid desiccation to an arid condition. Their surfaces are scparated from the mainland by distances nearly as great as those of Krakatau, however. Fresh-water inlets constantly pour currents laden with silt

\footnotetext{
1 Preliminary observations concerning the plant invasion on some of the lava flows of Manna Loa, Hawaii. Occasionnl papers of the Bernice l'auahi Bishop Museum of Polynesian Ethnology and Natural Ilistory, vol. v, No. 1, p. 19, 1912 .

2 The new flora of the voleanie island of Krakatau, p. 57. Translated by A. C. Seward, 1912.

"Botanieal cxplorations in Bermuda. Jour. N. Y. Bot. Garden, vol. xIII, p. 189, 1912.
} 
and seeds into the saline lake which is increasing in salinity and toxicity as against the constancy of composition of sea-water. The initial vegetation on beaches laid bare by the recession of the lake appears on strands down-slope from localities bearing a halophytic and xeropliytic vegetation. These desert slopes reccive but little rainfall and have nothing but ephemeral streams, run-off currents (which rush down the shallow channels for a few minutes or a few hours) being made by the precipitation of vagrant storms. Such run-off currents furnish a special method of flotation of seeds and propagulæ which would not be encountered in any place except in arid regions.

\section{NATURE OF THE EVIDENCE.}

It is obvious that most of the conclusions with regard to the dissemination or dispersal of plants in cases like those under discussion must rest largely upon circumstantial evidence and that the reasoning employed is largely inferential. To emphasize this point it need only be said that no one has actually followed an individual plant in its movement over a wide distance with identification at all stages of the journey. The only part of the matter which is amenable to direct observation and controlled experimentation is that which may be brought into tests of the length of flotation and germination of seeds, fruits, and propagative bodies. The importance of results bearing upon this subject is attested by the number of workers who have devoted attention to the matter. The positive evidence at hand as to the relation of the size of seeds, form and structure of fruits, shape of appendages, etc., is also of some value, while the presence of seeds in mud on the feet of birds, or attached to their plumage, is highly suggestive of possibilities and allows the observer to account for the presence of plants in localities otherwise unexplainable.

The seeds of one-fourth of the species which were found on the newly emersed beaches were treated experimentally in flotation and germination tests, and these represented fairly well the size, structure, and general anatomical features of the entire lot, although the untested remainder might well be expected to present some novel reactions.

\section{GERMINATION, FLOTATION, AND SURVIVAL.}

The first and main series of tests were made in equalized temperatures slightly lower than a similar treatment would have secured in the Salton region itself, but it is doubtful whether much difference might be found in the minima encountered in the two cases. Furthermore, the march of the seasons in the two instances was parallel, since the seeds were put in Salton water in the middle or latter part of November at about the same time as if they had been cast from the plant in the Salton area. The plantlets derived by the germinations would have corresponded fairly well with others allowed to germinate on the beaches where the seeds might have been deposited by the waves or carried by the winds or birds. The seeds which might be expected to fall into the water in a free condition weighed from 0.013 to $6 \mathrm{mg}$. The fruits inclosing the seeds of Atriplex lentiformis weigh 7 or $8 \mathrm{mg}$. Other fruits not tested, such as the large globular melons of Cucurbita palmata, may weigh as much as 30 to 50 grams, even when dried, but by reason of their comparatively great size are very buoyant on water.

It seems to be generally conceded that structures or appendages are of small consequence in dispersal of seeds over any great distance, and it is worthy of note that fully 80 per cent of the species occupying the beaches are liable to be moved by the wind.

The initial plants on the bared strips were generally arranged in well-defined zones or bands, which might give the observer the impression that they could have been deposited in this strict order only by waves, but the recession of the water is followed by a concomitant desiccation which leaves a moist strip which varies in width according to the slope and texture of the soil in the separate localities and affords the only suitable conditions 
for germination of deposited seeds. Next it is to be recognized that the crop of seeds, such as those of Populus, Salix, or Pluchea, may mature and be freed from the plant all within a comparatively brief period, during which time the number carried about by the wind would be distinctly noticeable. Thus the few days in which the fruits of Populus are in the air serve to distribute them in such number that they may become an annoyance by clogging wire mosquito screens, or by passing into houses through open doors or windows. It is evident that strands would be thickly strewn during the fortnight in which these seeds are so thick in the air and that this plant might be entirely absent from the remainder of the emersion of the year unless seeds or fruits falling on the water were capable of surviving the effects of such flotation and saline action.

Still another phase of wind-deposition of seeds was presented by the Travertine Terraces, which are characterized by a strict rank of vegetation arising at the foot of the higher well-defined cut bank formed in mid-winter as well as the base of the more indefinite ledge which may be made in mid-summer. The vertical surface of the cut bank, being composed of moist earth and of the flotsam collected at the base on a slope that drops away slightly (making an angle greater than a right angle), a mechanical trap is formed causing eddies and other effects and resulting in deposition of wind-borne bodies including seeds. (Plates $25 \mathrm{~B}$ and 26.)

A visit was made to this place on February 8,1913, when an unusually high-cut bank was observed which might have been formed by wave-action of more than average violence or to a greater recession of the lake level. The face of the vertical wall of soil which was caving and falling down ranged from a few inches near the margins of the observational area to a height of 26 or 28 inches at the crest of the slope which they cut across. The water was comparatively quiet, but the wavelets were still lapping against the base of the mud wall, and here was massed flotsam consisting of feathers, shells, and fragments of wood of more than one kind and other fine material, among which some seeds might be expected.

About two pounds of this material were taken up from a line extending about a yard along the bank, put into a waterproof covering, and carried to Tucson. Some glass jars were filled with a commercial quartz sand and this was saturated with Salton water taken from the lake in October 1912. The débris was now spread on the surface and enough water added to float it. The preparations were placed in a glass house at a temperature of about $50^{\circ}$ to $80^{\circ} \mathrm{F}$. The first germination appeared 11 days after the preparations were made, and the first plantlet developed was an Atriplex; a grass started into activity a week later and a second grass was included in the final list of germinations. By March 20, a month after the first seedlings had appeared, 20 germinations had taken place. The rising temperature made it necessary to water the preparations and in this process the fragments of wood on the surface were moved about by the water in such manner as to destroy six of the seedlings; a second watering resulted in the death of two more. The sand in which the plantlets were growing would have been moistened by water from underneath on the beach, and the fatalities noted would have probably been less at this stage of their development than in the experiments. It is quite probable that the greater number of the seedlings which were killed before identification were Sesuvium or Heliotropium. A visit to the place late in May showed a large number of seedlings of Salix and Populus besides a few of Heliotropium, Cyperus, Atriplex, Prosopis, and a grass.

The results of these tests suggest that the willows and poplars which come into the rank at the base of such vertical walls made by the waves must be wind-borne. While about 50 of the 60 species appearing on the Salton beaches might owe their presence to the action of winds, nevertheless other agencies display great effectiveness; a rough evaluation of the balance of forces will show a number in which the seeds might be carried by the wind only, and in such a list there would be included $A$ ster spinosus, $A$. exilis var. australis, Baccharis glutinosa, Encelia eriocephala, Isocoma veneta var. acradenia, Pluchea 
camphorata, P. sericea, Populus sp., Salix nigra, Sonchus asper, S. oleraceus, and Typha angustifolia, a total of 12 species, or about 20 per cent of the total number. Three-fourths of this number were carried to the sterilized islands, but not Populus, Salix, and Isocoma, or rather it should be said that suecessful germinations of these were not seen. Thic beaches on the islands offered conditions not at all suitable for any of these species and they were lacking from the Imperial Junction beach perhaps for similar reasons.

Positive evidence of the action of birds in carrying seeds is extremely difficult to secure. The seeds of a large number of the species coming onto the bcaches are very small, and nearly all of those tested for flotation and germination would adherc to a rod of wood or glass or to the finger when thrust into the water in which they were floating and then withdrawn. Such adhesions would be greatly facilitated by even the smallest particle or layer of mud and it seems reasonable to assume that many thousands of seeds must have been carried about in this manner. Cryptanthe barbigera occurred on Obsidian Island in such manner in 1908 as to suggest that the burr-like fruits may have been earried to the shore by birds, while Spirostachys was found near nests of pelicans and cormorants in positions in which seeds may have been detached from the legs or feathers of a bird. In addition to the species the seeds of which appear to be borne about by the wind only, Astragalus, Chamoesyce, Coldenia, Eleocharis, Encelia, Franseria, Hilaria, Hymenochloa, Oenothera, Olneya, Parosela emoryi, Prosopis glandulosa, and P. pubescens would not be liable to be carried by the birds. The 34 remaining species offer many probabilities of introduction by birds, although profitable surmise may not be made as to the actual importance of the plants carried about in this way. (Plates $31 \mathrm{~B}$ and $32 \mathrm{в.)}$

Attention is to be called again to the fact that the zonal arrangement of the initial individuals on a beach would not be incompatible with the idea of seeds carried by birds, since it was observed that flocks of alighting birds ranged themselves in long lines at or ncar the water's edge in positions fairly correspondent with those later occupied by ranks of vegetation; but nothing more definite may be said, in concluding the discussion of this phase of the subject, than that one species was found where it must have been carried by birds, another near nests in positions which it might have reached by wind or flotation, and that 32 others had seeds liable to be carried about by adhesion to the limbs or plumage, or in the crops.

In the transportation of seeds and plants which finally lodged on the sterilized areas flotation played a part much more important in the Salton region than in any other region that has yet been studied, paradoxical as this may seem in a desert region. Furthermore, the number of instances in which seeds and plants could have been introduced by water only are fairly large. Among these are to be included the deposition of rootstocks of Typha, of rhizomes of Phragmites, of a living branch of Prosopis glandulosa, of stems of Distichlis, and of fruits of Cucurbita on various beaches, while the tubers of Scirpus paludosus are readily moved in this manner.

The species tested in the Laboratory may be taken as offering the general conditions of the entire lot of plants with which this paper is concerned. Reference to previous pages will confirm the statement that Atriplex lentiformis does not sink, but the floating seeds germinate within a few days on the surface. Juncus floats 37 days, then germinates quickly after sinking. Leptochloa germinates 78 days after being wetted and while still afloat. Sesuvium remains afloat 23 to 50 days, then sinks and germinates. Rumex seeds float only 3 days when stripped, but supported by the calices or other parts of the inflorescence may remain afloat until germination ensues. Isocoma remains afloat less than a month. Oligomeris remains afloat about 60 days and germination ensues, both at surfacc and among the sunken ones to some extent. Amaranthus floats 30 days, then the seeds sink and a few germinate within the next fortnight. Baccharis floats less than a month and Pluchea about the same length of time. Spirostachys sinks within a day and begins germi- 
nation at once. Prosopis pubescens and $P$. glandulosa sink at once, and the seeds of the first begin to germinate within a few days. Scirpus paludosus had a large number of seeds afloat after 120 days, although more than half had sunk while a few had germinated. Seeds of Suceda behave much like those of Scirpus, except that a greater proportion sink within a day or two and germination ensues more quickly among these at the bottom, beginning within two or three days. It is thus seen that 9 of the 15 species tested remain afloat for a length of time which would permit them to be driven by the action of the waves a distance equal to the long axis of the Salton Lake. It is evident, however, that a consideration of the flotation of the seed alone affords evidence of but little conclusive value in the study of the revegetation of a sterilized area such as that under discussion. The fate of the seed at the end of its flotation period or of the seedling is quite an important consideration.

The results of floating seedlings has probably not hitherto had adequate evaluation as a bio-gcographical factor in dissemination and dispersal. The evidence of the flotation tests makes it plain that in 10 of the $\mathbf{1 5}$ species tested the flotation period of the seed, which in the different species may be from a day or two to four months or more, may be followed by the survival of the plantlet for periods of such length as to render them liable to be carried about by many agencies.

Buoyant plantlets may remain on the surface or in the surface layers of the water for a period as great or in some cases much greater than that of the seed, and their survival would depend upon the nature of the beaches on which they might become stranded. The successful tests with Sesuvium, Leptochloa, Pluchea, Spirostachys, Prosopis, and others showed that plantlets which had floated for two or three weeks were sound and healthy and sent roots down into the substratum when "stranded," in imitation of their probable action in the lake. Plantlets of Rumex remained sound and made a slow growth after a flotation period of two months, but their stranding test was made with soil saturated with the Salton water of 1912 , in which they have not survived around the lake. The latest introductions of the species on the beaches was upon soils saturated with water of the concentration of 1908 , which had but little more than one-third of the salt-content of that of 1912, but it came on the Imperial Junction beach again in 1911, when the alkaline soil was being overlaid with silt from the Alamo inflow. There is but little in this behavior to suggest special adaptation or peculiar fitness, since the seedlings of almost any land plant will float, especially in the sunlight with the copious liberation of free gases.

Writers on plant-dispersal have been disposed to regard ready germination as prejudicial to wide dissemination, although it is admitted by Guppy that the species included in the mangrove formations are widely distributed by the action of currents. ${ }^{1}$ Some of the species encountered about the Salton present the condition of the radius of possible dissemination being greatly lengthened by flotation of seedlings.

Another phase of the movement of seeds and propagative bodies into the sterilized areas of the beaches peripheral to the lake is that by which the ephemeral run-off streams following rainstorms carry material down the slopes, effecting a radial penetration and arrangement of the introduced species. Some slight action of this kind was observed on Obsidian Island, where one or two species were carried down from the summits which rose above the water even at its recent highest level, but it was most marked on the western shore of the lake, where long bajadas come down to the lake from the mountains several miles distant, and similar action was also indicated by some of the movements of vegetation at Mecca.

The actual weight or size of the seed or body would have but little influence, since the force of these streams which may run in any given "dry" channel but a few hours in a year is such that the finest sand and rocks weighing several pounds are tumbled along

"Guppy. Observations of a naturalist in the Pacific, vol. Ir, pp. 76-87, 1906. See Chapter IX, "Abortive germination in warm seas." 
and deposited on the margins or in bars, and the seeds which survive the attrition they receive during such movement would, some of them, come to rest in layers of moist sand, in which germination might speedily ensue. Spccies with a long resting period might lie dormant until a favorable condition of moisture or temperature were encountered. Among the species observed which may be definitely assigned to the class moved by run-off are Astragalus, Bouteloua, Chamoesyce, Coldenia, Conyza, Encelia frutescens, Hilaria, Hymenochloa, Oenothera, Olneya, Parosela emoryi, and Wislizenia. The distances traversed were not in any instance over a mile or two and it is evident that, when the movement of a plant this distance down a gentle slope is considered, many forces (including winds and animals) might play a part, although perhaps a minor one. Obviously the action of the run-off streams would contribute to give the recession of the first year from the maximum level of the lake a flora far richer in number of forms than that of any succeeding year.

\section{SPECIES APPEARING EARLIEST ON THE BEACHES.}

A profitable comparison of the initial species on newly emersed beaches may be made by a review of the observations of the plants on Imperial Junction Beach with a slope of 1 to 300 and an alkaline adobe soil, and on the Travertine Terraces with a slope of about 1 in 20 , upon which the water cut terraces and shelves.

Amaranthus, Atriplex canescens, A. fasciculata, A. linearis, A. polycarpa, Cucurbita, Baccharis, Heliotropium, Lepidium, Leptochloa, Oligomeris, Pluchea sericea, Rumex, Sesuvium, Spirostachys, Sucda, and Typha appeared on the emersion of 1907 at Imperial Junction Beach, as noted in the early part of 1908 , while only Atriplex canescens and Phragmites were included in the first plants on the beach of 1907 at Travertine Terraces.

Atriplex fasciculata, A. polycarpa, Leptochloa, Scirpus paludosus, Spirostachys, Typha, Suceda, and Polypogon were found on the emersion of 1908 at Imperial Junction Beach and Typha, Heliotropium, Distichlis, Pluchea sericea, Phragmites, Bouteloua, Salix, and Populus on the beach of the same year at Travertine Terraces.

Leptochloa, Scirpus, Typha, Heliotropium, Pluchea sericea, Sesuvium, Suceda, Spirostachys, Atriplex fasciculata, and A. canescens came on the emersion of 1909 at Imperial Junction Beach. Distichlis, Heliotropium, and Pluchea camphorata comprised the entire census of the Travertine emersion of 1909 when visited in 1910.

Heliotropium, Leptochloa, Scirpus, Atriplex fasciculata, Spirostachys, and Suceda were the first species to come on the emersion of 1910 at Imperial Junction Beach; Distichlis, Heliotropium, Populus, and Salix made up the entire pioneer flora of the beach of 1910 at Travertine Terraces.

Scirpus, Leptochloa, Heliotropium, Distichlis, Sesuvium, Rumex, Suceda, and Spirostachys came first on the emersion of 1911 at Imperial Junction Beach, while the emersion of 1911 at Travertine Terraces (when the census was taken as in previous years, late in the autumn) showed only Distichlis, Salix, and Populus.

Atriplex fasciculata, A. lentiformis, Sucda, Spirostachys, Scirpus, Sesuvium, Distichlis, and Leptochloa came into the emersion of 1912 during that year at Imperial Junction Beach, while Sesuvium, Salix, Populus, Atriplex lentiformis, Spirostachys, Heliotropium, Prosopis pubescens, and Pluchea camphorata appeared on the shelf of 1912 at Travertine Terraces.

Numerically as to species, the pioneer flora of the alkaline beaches in the series of six years ran $15,8,10,6,8$, and 8 , while that of the steeper sandy and gravelly benches of the Travertine Terraces formed a series of $2,8,4,3$, and 8 . The average number of species appearing on Imperial Junction Beach was nearly twice as great as that on the Travertine Terraces, the low gradient of the slope of the beach being favorable to the introduction and establishment of plants, while the alkaline soil appeared to afford conditions for halophytic forms superior to those of the Travertine Terraces. The range of 
variation in the number of species introduced year by year is seen to be large, a fact which suggests that the lack of a wind in a certain direction during the fortnight in which seeds are falling from the parent plant might materially restrict their dispersal, while an opportune storm would carry light or appendaged seeds to a much greater distance. The number of events which might influence any agency in moving seeds are almost countless. Thus the feeding habits of the fish which are preyed upon by pelicans and cormorants might result in variations in the part played by these birds. Rainstorms moistening the surface layers might not only furnish favorable conditions for germination, but also carry a large supply of sceds of various species down the slopes, etc. Mention has already been made of the possible effects of rapid and slow evaporation by which stranded seeds would be left behind on soil from which evaporation was very great.

The analyses of the annual census shows that Atriplex linearis, Lepidium, and Cucurbita did not find a place on the beaches after the first recession in 1907, and that Atriplex polycarpa and Phragmites dropped out of the pioneer class after 1908; Pluchea sericea, while coming on many of the beaches later, did not figure as an innovator after 1909, and Atriplex canescens and Typha stopped in 1910; Pluchea camphorata began appearing among the pioneers on Travertine Terraces in 1910, although it was one of the first plants to be seen on one of the sterilized islands. Six and probably seven species, therefore, which originally came with the first occupants of the two special areas noted above, had dropped out within the first four years of the recession of the lake. Such defection suggests at once a restricting factor in the concentration of the water of the lake saturating the soils of the beaches, together with the proportions of certain constituents. The only features which might have a bearing on this matter are shown in table 34 .

TABLE 34.-Concentration and proportion of cerlain constituents of Salton water (per cent).

\begin{tabular}{|c|c|c|c|c|c|c|}
\hline & 1907. & 1808. & 1909. & 1910. & 1911. & 1912. \\
\hline 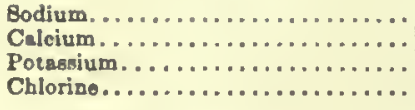 & $\begin{array}{r}111 \\
10 \\
2.3 \\
170\end{array}$ & $\begin{array}{c}134 \\
12 \\
2.8 \\
204\end{array}$ & $\begin{array}{c}160 \\
13 \\
3.2 \\
241\end{array}$ & $\begin{array}{c}189 \\
14 \\
3.8 \\
281\end{array}$ & $\begin{array}{r}228 \\
15.6 \\
3.8 \\
339\end{array}$ & $\begin{array}{c}271 \\
17 \\
3.8 \\
395\end{array}$ \\
\hline Total of coluble solid. . . . . . . & 364 & 437 & 618 & 604 & 718 & 847 \\
\hline
\end{tabular}

The differentiation of the action of the elements in such a complex mixture as that presented by Salton water is not easily made. While the increasing disproportion between sodium and calcium might offer itself as a feature accounting for toxicity, yet it is to be seen that even as late as 1912 the amount of the latter present would suffice to balance the sodium. The great amount of chlorine suggests that it is to this substance that the increasing toxicity might be ascribed.1

\section{SUCCESSIONS AND ELIMINATIONS.}

The successions or transitions in the vegetation of arid shores of bodies of either salt or fresh water are very abrupt, as has been found by the examination of great stretches of the coast of the Gulf of California. The tidal zone may bear such plants as Laguncularia and other tide-marsh plants, but immediately above the action of the waves the vegetation of the desert finds place.

The ephemeral character of Salton Lake with its rapidly sinking level called into action a set of conditions entirely different from those to be met on the shores of a body of water

1 Niklewski Bronislaw. Ueber den Austritt von Caleium- und Magnesiumionen aus der Pflanzenzelle. Ber. d. Deut. Bot. Gesell., vol. xxvII, p. 224, 1909. 
fluctuating about a fixed level. In the Salton the water receded at such rate that during the time of maximum evaporation in May or June a strip more than a yard in width would be bared permanently, and seeds of all kinds in motion at that time might fall on it and germinate. All other physical conditions now were minor to the fact that the soil began to desiccate toward a soil-moisture content equivalent to that of the surrounding desert. Occasionally small flat places or shallow depressions in the soil would be occupied by a growth of Spirulina, which with the drying of the soil would, with the surface layer of the soil a few millimetres in thickness, break into innumerable concave fragments, but this was not followed by any definite procedure.

The main facts of interest on the shores centered about the survival of the initial sowings on the beaches, the later introductions being for the most part only of minor importance. The chief features of the endurance of the initial forms and of the appearance of additional species on the beaches after the first year may be best illustrated by a recapitulation of the observations on the two beaches taken for the discussion of initial occupation, the Imperial Junction Beach and the Travertine Terraces.

The emersion of 1907 at Imperial Beach bore Atriplex canescens, A. fasciculata, A. linearis, A. polycarpa, Amaranthus, Baccharis, Cucurbita, Distichlis, Lepidium, Leptochloa, Heliatropium, Oligomeris, Pluchea sericea, Sesuvium, Spirostachys, and Sucda early in 1908. Late in 1908 Amaranthus, Baccharis, Distichlis, Heliotropium, Oligomeris, Rumex, Sesuvium, and Typha had disappeared. Late in 1909 Atriplex canescens, A. fasciculatus, Sucda, Pluchea sericea, Spirostachys, and Cucurbita still survived, while a secondary introduction of Baccharis and of Chenopodium had taken place, both being represented by only a few individuals, and these did not maintain themselves.

Atriplex canescens, A. fasciculata, and Spirostachys had multiplied and thrived in 1910, while Suceda seemed to have not multiplied; Pluchea was losing a large share of its individuals as a result of the desiccation. The census in 1911 was practically that of 1910 with the added losses of Pluchea, and no change in the balance was visible late in 1912 . The original sowing of this place included 17 species, 8 of which had disappeared within a year; one of the remaining 8 was lost in the following year, and two of the original pioneers were reintroduced only to disappear quickly. The census showed only 5 species in 1910 , all of which were still in evidence in 1912, but with Pluchea sericea losing ground. The full return of the area to the conditions prevailing up the slope might bring in Franseria or an occasional Larrea or Olneya, while the number of individuals of the other species would be reduced on account of the diminished soil-moisture supply. It is to be noted that the changes here are wholly and directly connected with the water supply, and that the survivors are halophytes, one of which was undergoing deterioration by reason of the inadequate supply.

The original introductions on the emersions of 1907 of the Travertine Terraces comprised two species, Atriplex canescens (from seeds which had fallen down a caving bank) and Phragmites (which had washed ashore as a rhizome). The cut bank may have figured as a mechanical trap for grounding wind-borne seeds, or some other condition may have come in, for now Atriplex polycarpa, A. canescens (re-introduced), Bouteloua, Astragalus, Distichlis, Heliotropium, Juncus, Pluchea camphorata, Prosopis pubescens, Phragmites, Sesuvium, Spirostachys, and Suceda (13 in all) were present. The place was not seen again until October 1910, when only Distichlis, Prasopis pubescens, Phragmites, and Astragalus remained.

Late in 1911 Astragalus was not found, although as an annual its seeds were probably present, while Pluchea sericea and Salix nigra had come in, making 5 species with another probably present. Late in 1912 all of the above elements had come in except Salix and Isocoma, while a single small plant of Prosopis glandulosa was recognized, which had probably been confused with $P$. pubescens, up to that time. The surface was fully occupied, and of the six species present it seemed likely that Phragmites, Distichlis, and Pluchea would 
soonest perish on account of the increasing aridity. The final condition of this beach would probably be one in which I socoma would endure, although no estimate of the behavior of the other species can be made except to point out that they are not on the slope just above the high level of the lake, which is of the extreme desert type of this region.

The two beaches which have thus been analyzed display different types of behavior. The gently sloping alkaline Imperial Junction beach received a sowing of 17 species during the first year of emersion and no secondary introductions. The stress of increasing aridity has depleted the number of the pioneers until but 5 species remain, of which one, Pluchea, will soon fail for lack of sufficient soil-moisture. The final flora of the slope will probably consist of species now occupying it, but with greatly reduced number. An occasional individual of one or two other species may come in.

The Travertine Terrace of 1907 was probably subject to wave action during the greater part of that year and its original occupants may be taken to include 13 coming on in 1908; these were quickly reduced to 4 species two years later, when secondary introductions began, of which Pluchea sericea and Isocoma have played an important part. The last named may be regarded as a plant which would be suitable for endurance of the final conditions of the desiccated slopes of this locality.

\section{ANCIENT STRANDS.}

The strands of the Travertine Terraces were on the crest of an arched slope or bajada, which would ultimately be subjected to the maximum action of the wind; which is the more important meteoric feature in this region. In consequence of its action it was not possible to find the ancient beach ridges or the edges of terraces which would correspond in position to the vertical banks which marked the mid-winter level of the Salton during the recent period of the lake. But a number of well-marked strands were to be recognized, lying at various levels within 100 feet of the level of the ancient high beach-line. These beaches owe their preservation to the fact that they were formed on the concave part of the slope and in places sheltered from the prevailing wind and with no run-off. These were well marked to the southward of Travertine Rock and also to the westward. The character of these strands is such that they may not be safely taken for seasonally formed strands, but each one might be considered as marking the maximum level of the lake at some previous filling. This assumption is supported by the fact that such well-marked beach ridges were not found anywhere near the present level of the lake (see Plate $29 \mathrm{~B}$ ).

Ancient strands of well-marked structure are to be seen on the steep slopes westward of Salton Slough, where a hill rises to such a height that its summit was covered at the highest level of Blake Sea; 83 well-marked beach ridges were seen on the slopes of this hill in 1910.

An examination of a strand south of Travertine Rock was made in October 1912, and a photograph was taken (see Plate $30 \mathrm{~A}$ ). The plants marking its position was a comparatively dense desert formation inclusive of Atriplex canescens, Coldenia palmeria, Franseria dumosa, Hymenochloa salsola, Parosela emoryi, and Petalonyx thurberi, all of which were restricted to a band or zone which varied from 12 to 18 feet in width. A second examination of another strand in February 1913 included the above except Atriplex canescens.

It is notable that Parosela and Atriplex, which are members of this formation, which dates the beginning of its development back for at least a century or two, also appear on similar strands on Obsidian Island and elsewhere shortly after emersion.

\section{THE REOCCUPATION OF STERILIZED ISLANDS.}

The slopes of the Sink were interrupted at various places by small elevations consisting of rock in place, the most notable elevation being in the southeastern part of the submerged area. Three of these hills rose above the highest recent level of the water, and detailed 


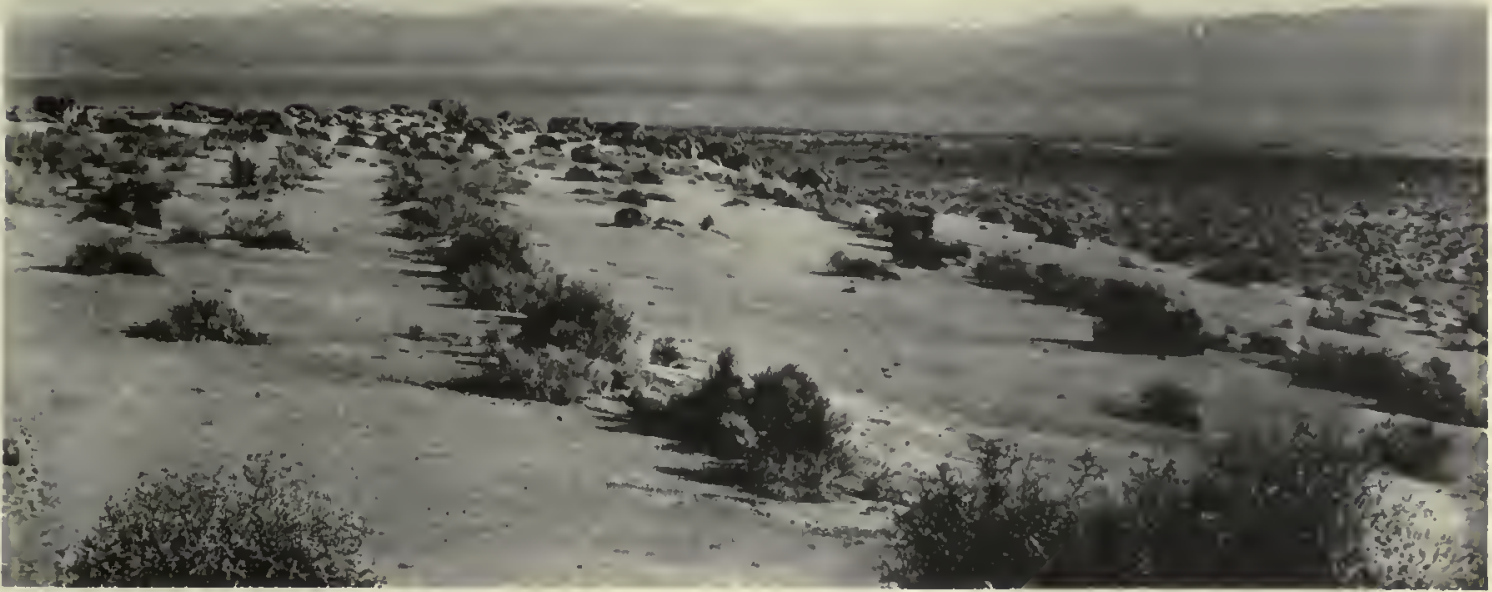

B

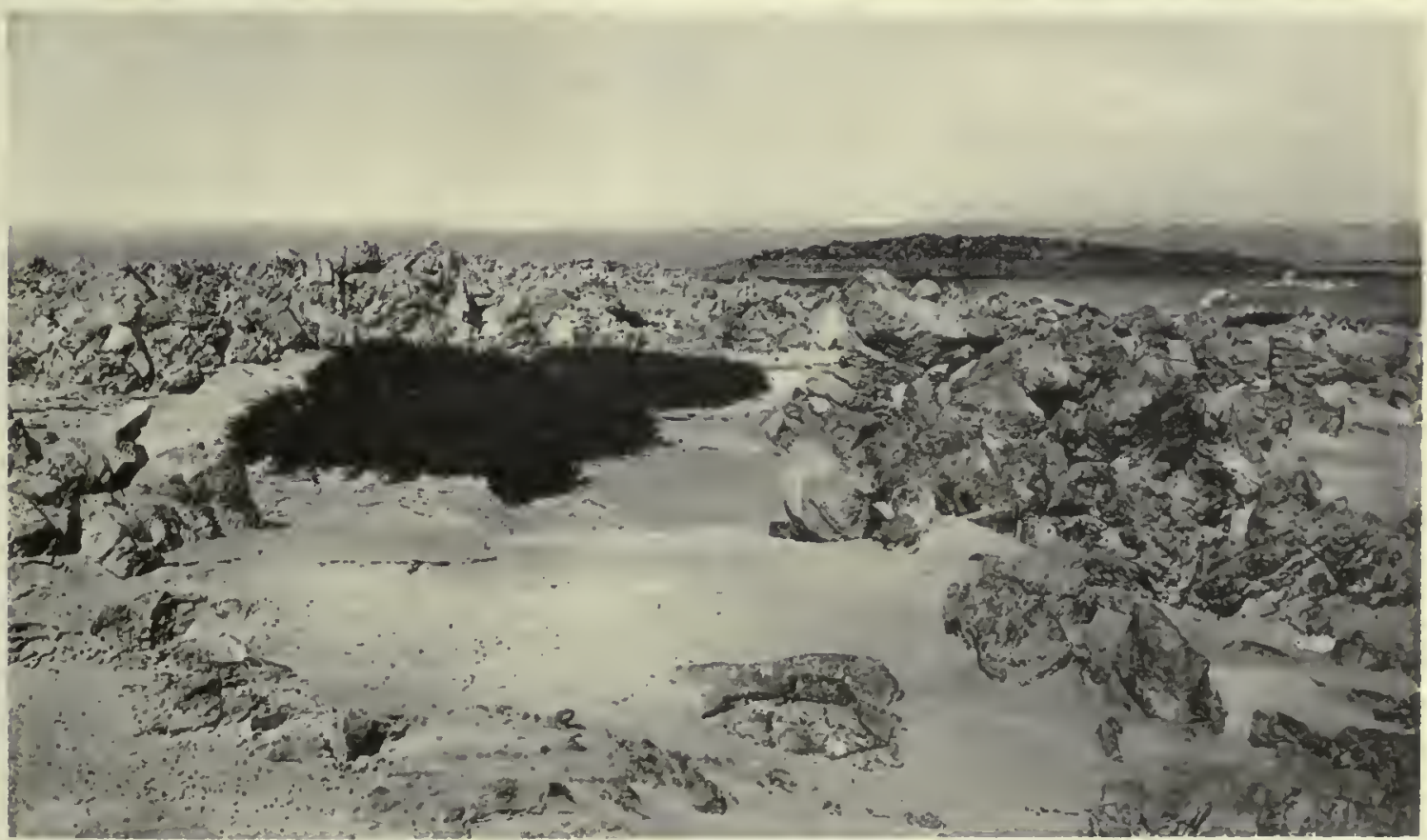

A. Ranks of Vegetation on Strands formed by water of Blake Sea probably three or four centuries ago. View to northward near Travertine Rock with Salion Sea on right.

B. Dense mat of Sesuvium as first occupant of sterilized area on outlying portion of Big lsland. October 1909. 

observations on the beaches and shores of one of these, Obsidian Island, have already been described. All but two or three of the numerous species which appeared on the emersed strips were, in all reasonable probability, carried here from places outside of the lake, and reference will be made to their action in the following pages; but some of the hills were completely covered by the water at rest, or by wave-action, and these deserve special attention, since as experimental settings they constitute much stricter tests of the theories of seed-dispersal than others in which the summits remained above the water (see Plate $31 \mathrm{~B}$ ).

The greater mass of the hills consisted of rock with surface layers and pockets of windblown soil before the inundation. The action of the water resulted in washing much of this soil from the hills and the saturated salt-solutions which steadily increased in concentration may be taken to have killed or set in action all seeds present. If germination ensued the seedlings would of course be floated away.

Some of the species of seed plants which thrive in the vicinity of salt springs have already been noted as surviving after a year of submergence, and a small shrubby species, among the Carrizo dunes, showed similar endurance, yet none of these species was seen on the islands, which appeared to be completely sterilized, except perhaps as to minute organisms such as bacteria, and it seems probable that those present in the dry soil were extirpated and those found after emersion are to be regarded as introductions.

The first example of colonization of a sterilized island was met in October 1908, when a visit was made to Cormorant Island, 2 miles to the northward of Obsidian Island, near the location of some salses or mud volcanoes now deep under water. This island was separated from the mainland by about 6 or 7 miles of water, which reached a depth of about 34 feet at the maximum, and a greater depth between it and the nearest island. (See Plate 31 в.) The top of the island showed a rocky surface of whitened rhyolitic obsidian in November 1908. No exposure of fine soil was visible and it was evident that the waves had been driven across its summit repeatedly during a large part of 1907. A great number of nests of aquatic birds were placed among the rocks and the surface all about them showed signs of having been trampled by both young and old birds.

Pluchea sericea and Baccharis glutinosa were each represented by one plant. As both of these species are compositaceous and the fruits are carried long distances by the wind, the probabilities are largely in favor of their deposition here by the action of air-currents. Both species grow in abundance on the mainland 12 or 15 miles to the southward, and the summer winds may have brought them here late in 1907. The seeds of both appear to germinate in the presence of some proportion of salt.

Cormorant Island lay away from the main routes of travel about the lake and its rocky shores could not be gained in any kind of rough weather. The second visit to the place was made in October 1912. The original individuals of Pluchea and Baccharis had survived. An additional individual of each was also present. That of Pluchca was some yards from the original plant, and may have arisen from one of its seeds or from a newly introduced one. The second individual of Baccharis was near the original, so near that it might have come from offshoots or seeds, but probably did not represent a second introduction. That the total increase of the two species was limited to a single individual each in four years was a very astonishing fact, as both of the original plants had fruited probably three times and the annual crop must have included a large number of seeds, while the later emersions down the slopes of the island showed many clay exposures in which germination might have taken place. The island was dome-shaped, being about 1,200 feet in its long axis with half that width, and rising about 30 feet above the water. The entire surface was now carefully scanned, with the result that two individuals of Sesurium and one of Atriplex lentiformis were found in a place probably emersed in 1908, and one Atriplex was lower down in the emersion of 1909 and one in that of 1910 and one in 1911. Heliotropium curassavicum was represented by two individuals, both of which were in bloom, 
while between 15 and 20 examples of Spirostachys were scattered over various emersions, their age suggesting germinations during 1912 or late in 1911. Six species were thus seen to be present, with a total representation of about 30 individuals, and plants of 3 of the species were mature and either were fruiting or had done so; 2 of the 6 were compositaceous with fruits abundantly furnished with pappus. It would seem probable that these two spceies were carried here by the wind. The seeds of Atriplex lentiformis germinate very quickly after being wetted, but the plantlets are capable of floating for periods of several weeks. The occurrence of the four individuals seen here might well be attributed to such action. The fruits as noted (see page 146) are fairly large and are not so readily carried by either birds or the wind as some of the others. The minute seeds of Sesuvium float for two or three weeks after falling in the water, and the seedlings rise to the surface and are capable of flotation for extended periods. Seeds of this size are also very liable to be carried about by violent winds, while they readily adhere to any object thrust in the water in which they are floating and might well be earried to the island by any one of the methods mentioned. The seeds of Heliotropium might likewise be carried about by several agencies, although it is to be noted that despite the enormous number of seeds and the abundance of the opportunities only two individuals of Sesuvium and of Heliotropium grew on the island in six years. This, however, would be a very brief period in the conditions of transportation of a species to new lands in practical geographical work. Spirostachys is also subject to the conjunction of many conditions which might bring it to the island, but the appearance of young plants far above the present level of the water suggests that the seeds were carried to the place either by winds or birds. The indefinite retention of the seeds on the parent plant, making a erop which falls to the ground over a long period, furnishes material which might be acted on by either of the agencies mentioned. The positions of the young plants render of comparatively little importance the fact that the seedlings are capable of flotation for an extended period. All of the species mentioned were also present on the beaches of Obsidian Island, 2 miles to the southward, and also on the smaller islands to the southwestward, described below.

Immediately after the examination of Cormorant Island in November 1908, a visit was made to a small island which had risen above the surface or rather had been laid bare at some time late in 1907 or early in 1908; a sand bar, barely above the level of the water, now ran from it to the larger land mass, but had not been bare long enough to figure in the history of the pioneer species which must have reached the place several months earlier. Many square yards of sandy and gravelly soil furnished suitable conditions for germination, while the higher part of the emergence consisted of a lot of blocks of Obsidian, some a meter in diameter, which would have served very effectually in causing the deposition of wind-borne seeds. A single plant of Sesuvium in bloom, Heliotropium also in bloom, Pluchea camphorata, Spirostachys, Parosela emoryi, Atriplex lentiformis (?), and single plants of two unrecognizable species were present. A second small island to the westward and south of Big Island showed a surface consisting of extremely rough and broken rock masses with small level pockets of moist soil, bearing a few plants of Pluchea sericea, Sonchus asper, Heliotropium, Atriplex lentiformis (?), and Eclipta alba. These islands were much frequented by pelicans and cormorants nesting among the rocks. The considerations noted above apply to the presence of the same species here. Eclipta probably floated to the place, and Sonchus might have been carried by the wind; the position of Parosela on Obsidian Island (as described previously) suggests flotation, but nothing in its location here could be taken as evidence of the manner in which it had been carried to the spot. This would apply also to the unknown species.

These islands were visited again a year later (October 1909) and showed only Pluchea camphorata, Spirostachys, Sesuvium, Heliotropium, Atriplex, Scirpus paludosus, and Pluchea sericea; from which it is to be seen that Sonchus, Eclipta, and the two unknown species 
A

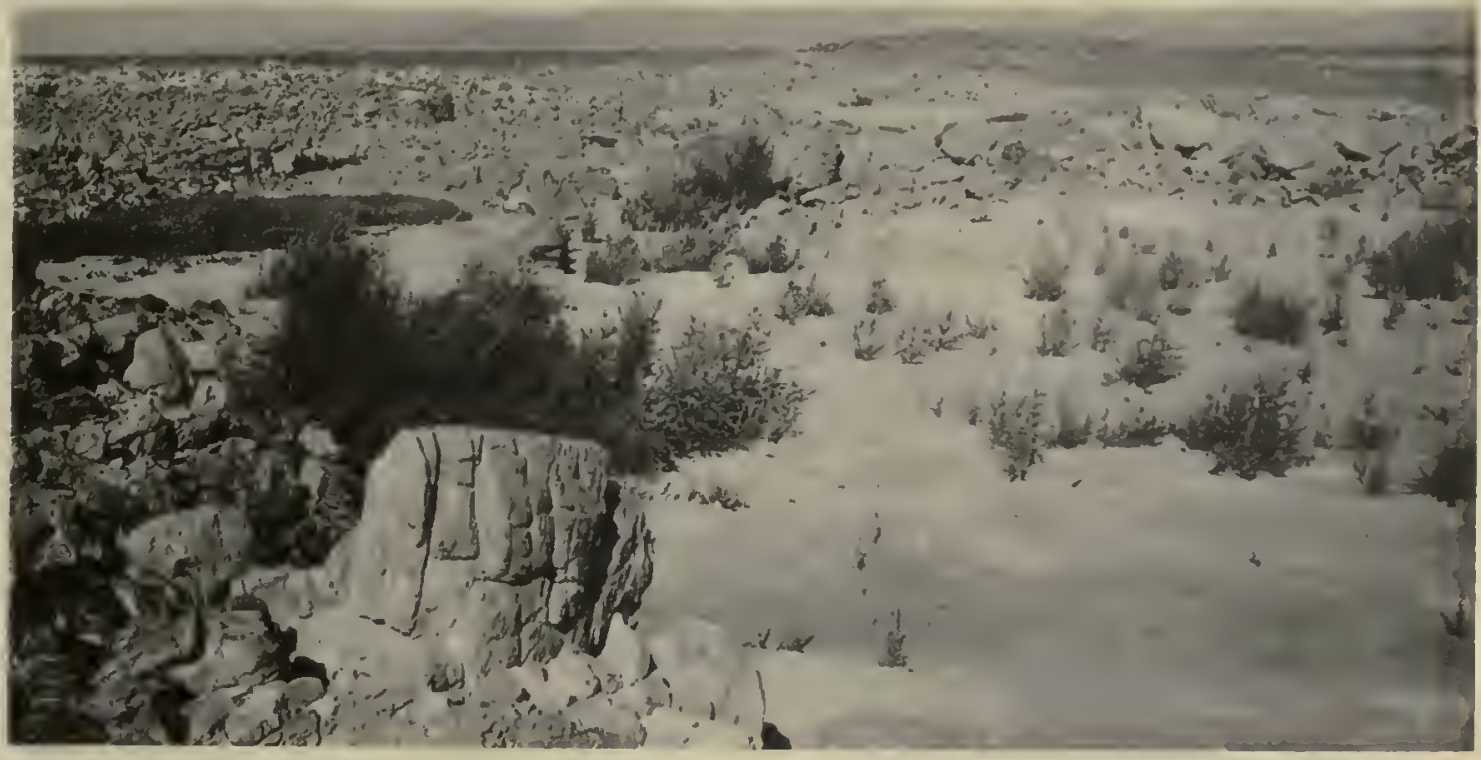

B

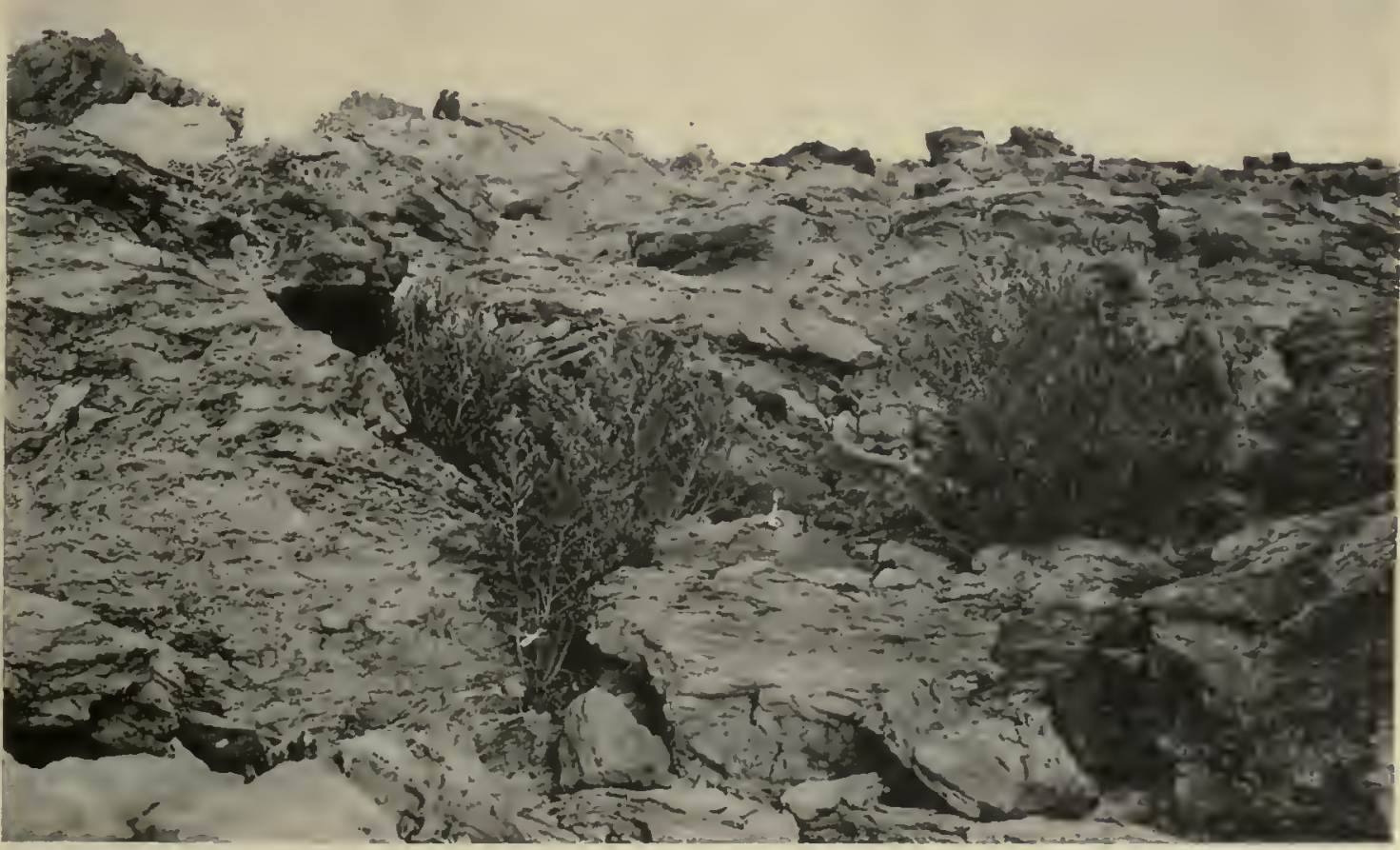

A. Pluchea sericea and Spirostachys occidentalis as first occupants of a sterilized area on Big Island, October 1908.

B. Baccharis glutinosa, one of the first occupants of Cormorant Island, October 1912. 


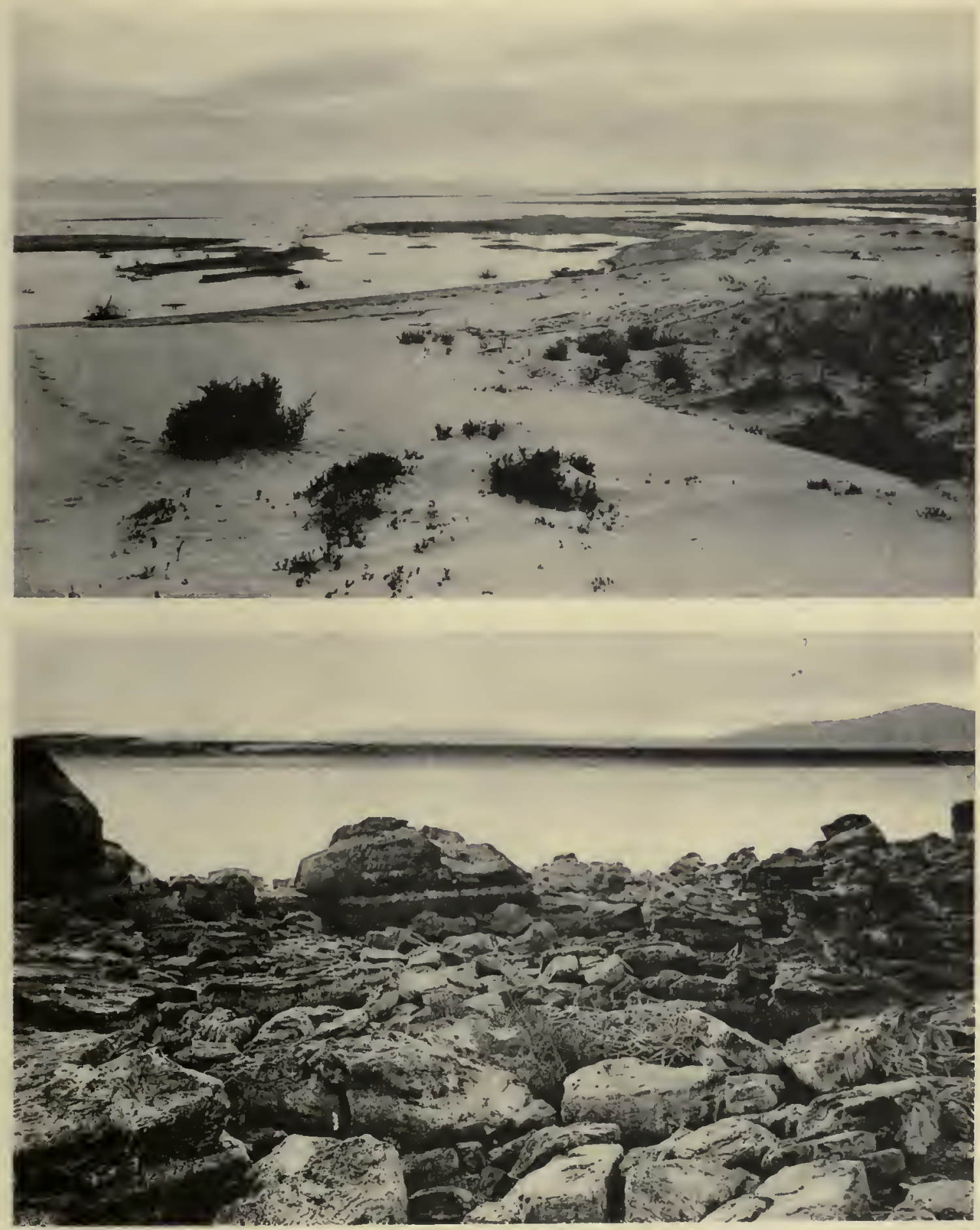

A. Islands and Clay Bars emerging on southwestern Shore of Salton Lake, October 1912. The sterilized areas are being first occupied by Spirostachys, Suocda, and Sesuvium. Larger islands out in the lake to left.

B. Spirostachys occidentalis established near a Cormorant's Nest on small island near western shore of Salton Lake. Photographed October 1912. 

had disappeared, while Scirpus, with a seed especially liable to be carried by the currents, had come in. An additional island had been laid bare a short distance north of Big Island some time during 1909, and in October of that year the restricted bit of gravel and sand which might offer conditions for plants bore a few individuals of Pluchea camphorala and Sesuvium, both of which might have been wind-borne, though Sesuvium may have come by any of the methods mentioned above. Although the lake abounded in fish and these were used as food by the birds, no direct evidence was obtained that they were effective, directly or indirectly, in the transportation of seeds.

The next inspection of the surface of these islands was made in October 1912, at which time all had become connected with the main part of Big Island. The slopes of this bore only Atriplex fasciculata, Suoda, and Eriogonum deserticola, not identical with the pioneers on the beaches of the lower lands. The northernmost islet now bore Spirostachys and Heliotropium on a clayey flat, while Atriplex lentiformis, Pluchea sericea, and Baccharis glutinosa were on the higher rockier ridge. The original introductions had thus disappeared and the later flora was like the pioneers in not being derived from the slopes of Big Island, but was composed of species which were probably wind-borne, or had come from sceds or plantlets deposited by the waves, while birds may have been responsible for some; all had crossed a water barrier at least 10 miles in width.

The lower areas in this archipelago were much frequented by aquatic birds, while on all of the visits tracks of a number of small quadrupeds were seen. On the final visit in October 1912, the tracks of a raccoon were seen; burrows of rodents were numerous; the round foot-prints of some member of the cat family were in evidence, and small lizards abounded. No estimate could be made of the numbers of any of these animals. Two rabbits were seen, however; these and the rodents feed upon plants and seeds and their activity may have had a very direct connection with the disappearance of the species noted above. This island has been continuously isolated since some time in 1904 or 1905 , a matter of some importance in the heredity of these short-lived species.

In October 1912 a small rocky island, separated from the western shore of the lake by a stretch of open water 500 feet in width, was encountered near the Carrizo District. Some clayey silt was found among the rocks. Spirostachys was represented by several young plants and two individuals of Heliotropium in bloom were seen. The rocks and clay near the margin of the water were coated with a blue-green alga. Some of the Spirostachys grew up beside a cormorant's nest and may well have been brought there by these birds, although this species is such a ubiquitous invader that its movements can not be ascribed entirely to any one agency. (Plate 32 в.) A shoal with a clayey and sandy surface, lying a few yards off the shore at the extreme southwestern corner of the lake, was inspected on the following day and bore only Spirostachys and Suoda. (Plate 32 A.) 



\section{GENERAL DISCUSSION.}

By D. T. MacDouont.

The Cahuilla Basin is a structural trough lying immediately to the eastward of an abruptly rising mountain range which separates it from the Pacific. The depression is shaped much like the bowl of a spoon, the tip of which comes to within a short distance of the Gulf of California. An ancient beach-line, lying a few feet above present sea-level, incloses an area of about 2,200 square miles; and this lowermost portion of the basin has been designated the Salton Sink in the present paper.

The original depression was of unknown depth; and it has been filled to within 284 feet below the mean tide-level by the alluvial outwash from the slopes of the mountains which bound it on three sides. Borings to a depth of 1,700 feet show a series of interbedded sands and clays, such as might be encountered in any one of the similar troughs in central Arizona, which had been filled by material worn down by wind and water from the mountain slopes. The bottom of the basin obviously lies far below the present level of the gulf; yet it is clear that "Blake Sea," the ancient body of water which filled the basin to the level of the highest beach, was composed of fresh water, at least during a part of its existence-as evidenced by the heavy layer of travertine formed on the rocks bencath its surface at the highest level, by the presence of fresh-water shells, and by the composition of the saline layer on the bottom of the Sink, evidently derived by condensation of fresh water rather than from evaporation of sea water. (See discussion of this point by Free, pages 22 to 34 .)

Essential differences of great importance to the naturalist are to be recognized between the history of the undrained basins of California and Nevada and that of the Cahuilla. At times the former contained bodies of water, the formation, fluctuation, and disappearances of which were directly connected with climatic variations in the region in which they lic.

The Cahuilla Basin, on the other hand, has probably been the scene of incursions from the ocean in earlier times; and the formation and existence of Blake Sea may not be directly connected with the climate of the immediate region. Likewise, the modern gatlering of the waters in the Sink is not to be attributed to climatic effects. The earliest existence of the Salton Sea within historic times is that shown on Rocque's map (1762, see Plate 5). Collated reports give the presence of flood-water in some volume in the Sink in 1828, $1840,1849,1852,1859,1862,1867$, and 1891 . These occurrences do not seem to be correlated with any climatic measurements, and are perhaps directly connected with the oscillations of a silt-laden stream in alluvium. This view is strengthened by the fact that the fillings of the Pattie Basin have not been synchronous witl those of the Cahuilla.

The study of the behavior of the soils of the emerged strands and uncovered beaches has yielded some points of interest and value in the interpretation of lacustrine action, especially with respect to the evaporation from saturated soils, and the surprisingly small leaching effect resulting from prolonged submergence in water, the dissolved content of which is lower than that of the soil solutions.

It has been customary with geologists and geograpliers to assume that the waters of ephemeral and fluctuating lakes are reduced and their salts dropped out as in a test tube. The action of iron and sulphur bacteria has been well known for some time, but no good opportunity had hitherto occurred for controlled observations of their possible influence 
on the composition of disappearing lake waters and on the deposition of calcium and other substances from these waters. The reduction of sulphates in the lake water by Spirillum and other forms resulted in the formation of hydrogen sulphide as one product, some of which would escape into the air, while a portion would be oxidized by Beggiatoa, with the separation of free sulphur and the liberation of sulphuric acid. Oxides of iron might also be formed and all of the above recombinations might take place in stages of concentration in which no such action would occur in biologically sterile solutions. The intervention of algal and bacterial organisms in the formation of a type of travertine characteristic of the higher levels of Blake Sea has also been demonstrated beyond reasonable doubt. These processes seem to be carried on much more vigorously in the presence of organic matter, and the results of such activities are particularly in evidence in the vicinity of decaying stems and woody structures of all kinds. Furthermore, the hydrolyzing action of organisms of the Amylobacter group upon the cortical tissues of the plants submerged by the waters of the lake is a matter of some interest in the study of the formation of coal deposits and in the making and preservation of fossils.

The Cahuilla Basin is subject to a mixed type of climate. It lies far enough inland so that overheating should result in a continental type of climate, particularly with respect to the rainfall. Its great bowl, however, lies immediately in the lee of a great mountain range which rises abruptly from its southwestern side, with the result that fringes of mountain storms reach out over part of its area at times, while the topographical conditions favor the development of the intense and localized precipitation known as cloudbursts. The general features of the precipitation are shown in table 35, furnished by the U. S. Weather Bureau.

TaвLE 35.-Rainfall record, in inches, of Indio, California (elevation, 20 feet).

\begin{tabular}{|c|c|c|c|c|c|c|c|c|c|c|c|c|c|c|c|}
\hline Besson. & $\frac{\Delta}{3}$ & 总 & 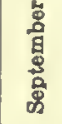 & 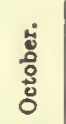 & 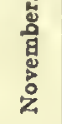 & 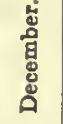 & 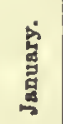 & 总 & 造 & 당 & 总 & $\stackrel{g}{g}$ & $\begin{array}{l}\text { 品 } \\
\text { 号 } \\
\text { \% }\end{array}$ & 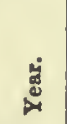 & द्. \\
\hline $1877-78$. & .... & $\ldots$ & .... & . & 0 & 1.98 & 0.10 & 0 & 0 & 0 & 0 & 0 & & 1878 & 1.10 \\
\hline 1878-79. & 0 & 0 & 0 & 0 & 0 & 1.00 & 0.60 & 0.30 & 0 & 0 & 0 & 0 & 1.90 & 1879 & 1.30 \\
\hline $1879-80$ & 0 & 0 & 0 & 0 & 0.40 & 0 & D & 0 & 0 & 0 & 0 & 0 & 0.40 & 1880 & 0.70 \\
\hline $1880-81$ & 0 & 0 & 0 & 0 & 0 & 0.70 & 3.45 & 0 & 0.50 & 0 & 0 & 0 & 4.65 & 1881 & 3.95 \\
\hline 1881-82. & 0 & 0 & 0 & 0 & 0 & 0 & 1.50 & 0 & 0 & 0 & 0 & 0 & 1.50 & 1882 & 2.50 \\
\hline 1882-83. & 0 & 0 & 0 & 0 & 1.00 & 0 & 0.80 & 1.13 & 0.11 & 0 & 0 & 0 & 3.04 & 1883 & 2.96 \\
\hline $1883-84$ & 0 & 0 & 0 & 0.06 & 0 & 0.86 & 0 & 3.16 & 0.62 & 0.46 & 0.46 & 0 & 5.60 & 1884 & 6.38 \\
\hline $1884-85$ & 0 & 0 & 0 & 0 & 0 & 0.70 & 0 & 0 & 0 & 0.10 & 0 & 0 & 0.80 & 1885 & 1.00 \\
\hline 1885-86. & 0 & 0 & 0 & 0 & 0.90 & 0 & 0 & 0 & 0 & 0 & 0 & 0 & 0.90 & 1886 & 0.12 \\
\hline $1886-87$. & D & 0 & D & 0 & 0.12 & 0 & 0 & 0.93 & 0 & 0.30 & 0 & 0 & 1.35 & 1887 & 1.43 \\
\hline $1887-88$ & 0 & $\mathbf{T}$ & 0.05 & 0.15 & 0 & 0 & 0.75 & 0 & 0 & 0 & 0 & 0 & 0.95 & 1888 & 2.96 \\
\hline $1888-89$ & 0 & 0 & 0 & 0 & 1.10 & 1.11 & 0.57 & 0 & 1.05 & 0 & 0 & 0 & 3.83 & 1889 & 6.47 \\
\hline $1889-90$ & 0 & 0.95 & 0 & 0.60 & 0.01 & 3.29 & 0.65 & 0.06 & 0 & 0 & 0 & 0 & 5.56 & 1890 & 1.23 \\
\hline $1890-91$. & 0 & 0.10 & 0.20 & 0 & 0 & 0.22 & 0 & 1.90 & 0 & 0 & 0 & 0 & 2.42 & 1891 & 3.31 \\
\hline 1891-92. & 0 & 1.16 & 0 & 0 & 0 & 0.25 & 2.00 & 0.43 & 0.22 & 0.04 & 0.14 & 0 & 4.24 & 1892 & 2.83 \\
\hline 1892-93. & 0 & 0 & 0 & 0 & 0 & 0 & 0.03 & 0 & 1.60 & 0 & 0 & o & 1.63 & 1893 & 2.64 \\
\hline $1893-94$. & 0.05 & 0.75 & 0.07 & 0 & 0.14 & $\mathbf{T}$ & 0 & 0 & 0 & 0 & 0 & 0 & 1.01 & 1894 & $T$ \\
\hline $1804-85$ & $T$ & 0 & 0 & 0 & o & 0 & 6.01 & 0 & 0 & 0 & 0 & $\mathbf{T}$ & 6.01 & 1895 & 6.01 \\
\hline $1895-96$ & 0 & 0 & 0 & 0 & 0 & 0 & 0.92 & 0 & 0 & 0 & 0 & 0 & 0.92 & 1896 & 0.92 \\
\hline 1896-97. & 0 & 0 & 0 & 0 & 0 & 0 & 1.10 & 0.19 & 0 & 0 & 0 & 0 & 1.29 & 1897 & 3.39 \\
\hline $1897-98$ & 0 & 0 & 2.10 & 0 & 0 & 0 & 0.10 & 0 & 0.30 & 0 & 0 & 0 & 2.50 & 1898 & 1.70 \\
\hline 1898-99. & 0 & 0.30 & 0 & 0 & 0 & 1.00 & 0.40 & 0 & 0 & 0 & 0 & 0 & 1.70 & 1899 & 1.30 \\
\hline $1899-1900$ & 0 & 0 & 0.10 & 0 & 0.60 & 0.20 & 1.00 & 0 & 0.30 & 0.15 & $\mathbf{T}$ & 0 & 2.35 & 1900 & 2.74 \\
\hline $1900-01$. & 0 & 0 & 0.08 & 1.04 & 0.17 & 0 & 0.29 & 1.46 & 0 & 0 & 0 & 0 & 3.04 & 1901 & 1.75 \\
\hline 1901-02. & 0 & 0 & 0 & 0 & 0 & 0 & 0.40 & 0.20 & 0 & 0 & 0 & 0 & 0.60 & 1902 & 2.00 \\
\hline $1902-03$ & 0.10 & 0 & 0 & 0 & 0.50 & 0.80 & 0 & 0 & 0.20 & 0.75 & 0 & 0 & 2.35 & 1903 & 1.58 \\
\hline $1903-04$. & 0 & 0.10 & 0.12 & 0 & 0 & 0.41 & 0.87 & 0.38 & 0.20 & 0 & $\mathbf{T}$ & 0 & 2.05 & 1904 & 2.43 \\
\hline $1904-05$ & $\mathbf{T}$ & 0.33 & 0 & 0.08 & 0.19 & 0.41 & 0.87 & 2.00 & 1.30 & 0 & $\bar{T}$ & 0 & 5.18 & 2905 & 5.37 \\
\hline $1905-06$ & 0 & 0 & $\mathrm{~T}$ & $\mathbf{T}$ & 1.06 & 0.14 & $\mathbf{T}$ & 0.97 & 2.06 & 0.47 & 0 & 0 & 4.70 & 1906 & 7.10 \\
\hline $1906-07$. & $T$ & 1.07 & 0.04 & $\mathbf{T}$ & 0.60 & 1.89 & 0.59 & 063 & 0.96 & 0 & 0.05 & 0 & 5.83 & 1907 & 3.88 \\
\hline $1907-08$ & 0 & 0 & 0 & 1.60 & 0.05 & $\mathbf{T}$ & 0.95 & 0.57 & 0.01 & 0 & 0 & 0 & 3.18 & 1908 & 3.64 \\
\hline $1008-09$ & $T$ & 0.45 & 1.60 & 0 & 0 & 0.60 & 0.28 & 0.29 & 0.45 & 0 & 0 & 0 & 3.13 & 1909 & 4.07 \\
\hline $1900-10$ & 0.00 & 0.87 & 1.12 & 0.00 & 0.20 & 0.86 & 0.47 & 0.00 & 0.08 & 0.00 & 0.00 & 0.00 & 3.60 & 1910 & 1.05 \\
\hline $1910-11$ & $\mathbf{T}$ & 0.08 & 0.00 & 0.12 & 0.30 & 0.00 & 0.66 & 1.06 & 0.22 & $\mathbf{T}$ & 0.00 & 0.00 & 2.44 & 1911 & 2.53 \\
\hline 1911-12 & 0.25 & 0.00 & 0.34 & 0.00 & 0.00 & 0.00 & 0.00 & 0.00 & 1.66 & 0.35 & 0.63 & 0.02 & 3.15 & 1912 & 4.60 \\
\hline $1912-13$ & 0.04 & 0.00 & 0.00 & 1.90 & 0.00 & $\mathbf{T}$ & 0.12 & 0.93 & 0.02 & & & & & & \\
\hline
\end{tabular}


The annual average from data covering 36 years is seen to be 2.74 inches and the character of the precipitation phenomena suggests a high degree of aridity. The maximum amount received in one year was 7.10 inches (1906) and the lowest, a "trace" (less than 0.01 inch) in 1904, giving a variation as 1 to 1000, a proportion occurring in deserts of a pronounced degree of aridity only. In addition to this expression, the ratio of possible evaporation from a free-water surface to the annual amount of precipitation has been useful in characterizing deserts. About 116 inches of water would evaporate from the surface of a small vessel on the ground in the open in the Cahuilla during a year; this is 15 times the amount which has fallen in any one year, 43 times the average, and many thousands of times the minimum. (These estimates are to supersede the figures given in a statement made before the Royal Geographical Society of London in December 1911, and published in the Geographical Journal, vol. 40, p. 105, 1912.) The possible cvaporation in northern Africa at Algiers is about 60 inches annually, but in the interior of the Sahara it is much greater. The figures in table 36 , compiled by Dr. W. A. Cannon, give data from four points, of which Laghouat is far inland and Ghardaia the most arid. The measurements were made in millimetcrs with a Piche evaporimeter and should be multiplied by 0.74 to obtain the evaporation from a free-water surface.

TABLE 36 .

\begin{tabular}{|c|c|c|c|c|c|c|c|c|c|c|c|c|c|}
\hline & Jad. & Fob. & Mar. & Apr. & May & June & July & Aus. & Sept. & Oct. & Nov. & Dec. & Yeas \\
\hline $\begin{array}{l}\text { Laghouat......... } \\
\text { Ghardaia........ } \\
\text { Touggourt....... }\end{array}$ & $\begin{array}{r}889 \\
172.4\end{array}$ & $\begin{array}{l}1023 \\
233.4 \\
163.9\end{array}$ & $\begin{array}{l}2434 \\
340.7 \\
240.5\end{array}$ & $\begin{array}{l}2031 \\
528.7 \\
274.3\end{array}$ & $\begin{array}{l}2892 \\
611.7 \\
385.2\end{array}$ & $\begin{array}{l}373.9 \\
699.1 \\
459.4\end{array}$ & $\begin{array}{l}421.2 \\
749.2 \\
565.8\end{array}$ & $\begin{array}{l}379.6 \\
693.0 \\
487.3\end{array}$ & $\begin{array}{l}264.8 \\
468.8 \\
329.4\end{array}$ & $\begin{array}{l}173.9 \\
329.4 \\
222.6\end{array}$ & $\begin{array}{l}153.8 \\
257.7 \\
166.1\end{array}$ & $\begin{array}{l}159.2 \\
225.5 \\
142.3\end{array}$ & $\begin{array}{l}2753 \\
5309\end{array}$ \\
\hline Algiers...... & 84.2 & 96.8 & 90.6 & 118.3 & 261.8 & 158.6 & 275.0 & 205.0 & 265.5 & 129.0 & 136.1 & 143.2 & 1654 \\
\hline
\end{tabular}

The possible evaporation for a year at Ghardaia is about 160 inches, and as the average precipitation is 0.5 inch the ratio would be as 1 to 330 as compared with 1 to 43 in the Cahuilla. While this basin is by no means so arid as the Sahara, the desiccation results in the reduction of the soil moisture to a minimum during the warmer season, and organisms would not only be subjected to intense aridity, but also to the action of soil solutions of a high concentration. This effect is highly accentuated in places where the evaporation results in the deposition of soil salts, given a charged substratum in which only halophytes can survive. Seepages and flowing wells afford a supply of ground water in places which furnish conditions for vegetation not essentially different from those in any warm climate, although the species which inhabit them are subjected to a high rate of water-loss. The occasional rains call into action a few plants of short cycle, which likewise may be of more or less mesophytic habit. The number of such "annuals," however, is very small, as it is in the Libyan desert in Northern Africa. ${ }^{1}$

Outside of these types the specialized conditions of soil moisture, soil salts, evaporating capacity of the air, and aspect of the precipitation offered by the more arid portions of the basin and of deserts in general might be expected to be accompanied by the presence of specialized types of vegetation, especially since it is reasonably certain that the desert of the Colorado, in which the Cahuilla lies, has been arid since Tertiary times. It seems highly probable that the entire number of characteristic desert plants have undergone their evolution within the period during which this region has been arid. No fossil material has been recovered which suggests reduced spinose shoots, such as those of Zizyphus, Condalia, or Parkinsonia, on the one hand, or the succulent stems of the Cactacex, Euphorbiaceæ, Asclepiaceæ, or Crassulaceæ on the other, although some of the ancient Bennettiales and Cycadales suggest that they were suitable for endurance in regions in which the water-

\footnotetext{
${ }^{1}$ See MacDougal, The Deserts of Western Egypt. Plant World, vol. 16, p. 291. 1913.
} 
loss would be great. Similar structures, however, are offered by the swamp xerophytes of the present time, and the ancient species with a habit and structure of sclerophylly were characterized by reproductive mechanisms which made a supply of moisture a necessity.

If other desert plants were included in the earlier floras their remains have not yet been found. It is to be conceded, of course, that the conditions in deserts are not favorable to the making or preservation of fossils. The comparative fewness of the individuals, the destructive effects of organisms in brackish water, the fierce grinding action of the torrential stream flow, and the looseness of the material laid down, would all act to destroy plant remains and give a sparse record. The wind-blown material deposited as loess would be equally unfavorable for the preservation of plants. Probably the best set of conditions would be those in which a desert stream-way originating in the highlands would carry material from its middle dry course and bury it in the alluvium, as must be taking place in the Colorado Delta at present, yet nothing of the kind has been examined which would justify the assignment of any great age to the xerophytic habit among plants.

Not a little interest attaches to the conifers in this connection, as the members of this group probably represent the earliest structures which might be suitable for existence in arid climates. The group as a whole is widely distributed with regard to climate and geological history. Some of the species live in cold, others in warm humid climates, while others not widely dissimilar in structure are found in regions of great aridity. Survival under such circumstances has been attributed by Groom to architectural features. ${ }^{1}$ The size, outer membranes, and longevity of the leaves may show a wide range of variation with consequent modification of use and loss of water. It seems highly probable that the trees of this group were the first plants of size to inhabit arid areas, although the xerophytic habit has not been carried so far as to allow them to endure the conditions of the intensity offered by the Sahara or the Cahuilla. Furthermore, it can not be said that the structural features of the coniferæ are the ones which have been developed or modified to meet the conditions of greater aridity by other plants. In other words, the most marked and the most pronounced xerophytic developments have taken place by other methods than those which find expression in the conifers.

It may make toward a better understanding of this matter if it is recalled that the major movement in phylogeny and habit in plants has been away from types with separated gametophytes in which the sporophyte and the gametophyte have an independent existence, toward forms in which the sporophyte vastly outranks the gametophyte in size and carries the bisexual generation within its tissues, living under more or less aquatic conditions, toward preponderantly sporophytic forms, capable of effecting reproduction and of carrying on the reproductive functions under progressively arid conditions. The logical development of such an evolutionary tendency would of course produce the xerophytic types last of all, and while it is not easy to fix upon a time when these appeared, yet the weight of inference lies in favor of the assumption that desert vegetation is composed chiefly of modern vegetative types.

A large proportion of the species which might be included in the flora of a desert region may be distinctly of a mesophytic habit requiring a large supply of moisture for their development. These forms are either localized around the sources of ground water, or they may be annuals or of short cycle coming to maturity rapidly within seasons of periodic rainfall. As has been pointed out elsewhere, the number of types of this kind is very small in the Salton Sink and in the Libyan Desert where the rainfall is highly uncertain as to its amount and time of occurrence. The features of such plants which seem to have a direct connection with their habitat are those of rapid development and the ability of the ripened seeds to endure long desiccation at high temperatures.

' Remarks on the ecology of the conifers. Annals of Botany, vol, Xxiv, p. 241. 1910. 
Thrce main types of plants, however, are distinguishable as being characteristic of arid areas and of the included localitics in which the soils are highly charged with salts: the spinose xerophytes, which are generally woody shrubs, with reduced branches and small and indurated leaves, although some herbaceous forms are to be included; the succulents, in which roots, stems, and leaves have been variously modified by the exaggeration of parenchymatous tracts, so that they may hold a large amount of surplus water; and the halophytes or species inhabiting saline areas, many of which also carry a large balance of water.

The spinose xerophytes are perhaps the most widely prevalent of all of the plants characteristic of arid regions. Alhagi, Parlinsonia, Holocantha, Condalia, Zizyphus, ctc., are examples of the group and these plants show many morphological and physiological qualities having the force of adaptations or accommodations to the environment, though a too direct causal connection is not to be taken for granted. Plants of this type are found in all regions in which arid climates of any type prevail-in the Cahuilla, in the Sahara where the rainfall is low and uncertain, as well as in regions like that around the Desert Laboratory, in which well-defined periods of precipitation come with a certain regularity. Examples of this type are also found in localized dry habitats in regions with a comparatively moist climate. It is notable that spinose types make up the few species which are to be found in the most arid regions in which the supply of moisture all comes from underneatl and the evaporating capacity of the air is highest. The roots are in constant absorbing contact with the soil at all times, and although the actual amount, or rate of acquisition of water may be low, it is true that once absorbent contact with the soil is broken it is not easily restored; hence these forms are not easily transplantable. The sap of the stems and leaves of some of the spinose xerophytes has been found to show a concentration of over 100 atmospheres, which is far higher than that of ordinary mesophytic plants, and the suggestion lies near that this condition in the shoot might be a means of damage to the absorbing organs of uprooted plants and that the transpiration stream once broken is not to be restored readily under such extreme conditions, which do not extend to include the roots under ordinary circumstances.

The succulents are inost abundant in regions in which the precipitation comes within well-defined seasons with fair regularity, and hence are not to be expected in the Cahuilla or in such climates as those of the Sahara. They are, however, a very important element of the flora of the region about the Desert Laboratory, parts of South America, and eastern and southern Africa. Cacti, several genera of the Asclepiadaccx, Euphorbiaccx, tlic Yuccas, Amaryllidacex, etc., furnish examples in which tracts of parenchyma in various members become greatly exaggerated, and in which a great balance of water accumulates. The root-systems of such plants, so far as they are known, appear to have an absorbent contact with the soil only during the rainy season, when the moisture content is high, and the concentration of the soil solution is lowest. 'The inequality between the collcentration of the sap of the shoot and the roots, which was noted in the spinose plants, is not present, as the juice of the cacti does not usually show an osmotic pressure of more than 10 or 12 atmospheres. In contrast with the continuous absorbent action of the roots of the spiny types, many of the succulents actually undergo a decortication of the root-system during the dry seasons, so that the taking in of water in any quantity is impossible until new rootlets have been formed. This usually takes place very quickly with the coming of the rains.

It is to be taken for granted that the succulents are subject to the same high evaporative action of the air as the spinose forms of the regions which they inhabit. It is therefore to be expected that their external structure and morphology would include some of the features characteristic of the spinose forms. As a matter of fact many of these are exhibited in more pronounced or highly developed stages. Induration, thickening, or heavy coatings 123 
of $w a x$ and resinous material on the epidermis, retardation and restriction of the development of branches and shoots, are among the more striking of these features. Spinosity in general results from the atrophy of branches, but this failure to develop has become so complete in such cacti as the Echinocactus that the entire shoot is cut down to a single cylindrical or globose stem, bearing only spines.

The halophytes, many of which are cosmopolitan, inhabiting sea-shores in moist climates, comprise both the spinose and succulent types. The latter are represented by Spirostachys and Suada, and the former by Distichlis, Atriplex, and Pluchea. The concentration of the sap of the halophytes is midway between that of the spinose forms and of the cacti. A distinction is to be made between the cosmopolitan succulent types and those of the salterns and bitterns of the desert. The species from the shore wilt quickly when placed under high evaporative conditions and are therefore much different from the types named above. It is probable that the type as a whole originated in charged soils in arid regions. It does not seem to be going too far to assume also that these conditions are identical with or fairly similar to those now prevalent in the Salton Sink and elsewhere. The xerophytes and halophytes of the Salton Sink are therefore to be seen living under the conditions coincident or causal to their evolutionary development. It will not be profitable to venture an analysis of the environmental complex in an effort to detect possible causality. The only hypothesis hitherto put forward in explanation of this matter is to the effect that succulents, particularly the halophytes, owe their qualities to the inductive action of the chlorides generally present in the substratum, both in saline areas and along seashores. The chief argument seems to have been one of coincidence, and no note was taken of the fact that succulent halophytes also belong in the bitterns in which the salts are carbonates and sulphates.

One condition of the environment is universal in deserts, the high evaporating capacity of the air, the effects of which are to be seen even in many plants with an abundant supply of soil-moisture and whose shoots are exposed to desert wind-action. This state of affairs, conducive to a high rate of water-loss, is generally manifested or accompanied by the restriction of leaves, the induration of surfaces, and the atrophy of shoots exhibited by spinose and succulent xerophytes and halophytes. A general parallel is offered by the behavior of a dish of hydrated gelatine which may be exposed to the air under high evaporative conditions. If the conditions of desiccation were of the intensity of the desert, the outer surface would soon become coagulated and the hardened surface would thus effectually check the loss of water from the layers beneath. This in its final analysis is what takes place in the body of the plant. The expanding shoot is a structure of plasmatic colloids and the loss of water or other features which would tend to coagulation of expanding cells would check their growth and be followed by atrophies of various degrees. The actual form of the shoot of the plants so affected would of course be modified in the most serious manner according to the special morphological features presented, and it is to be understood that the stele and the general morphogeny of the type were determined previous to their encounter with the conditions of aridity; yet with the widest diversity of actual surface, shape and size of organs, stomatal variations, and seasonal habit, results may be seen suggestive of the hardening or coagulatory effects of high evaporatory rates, and the coincidences are so sweeping and universal as to suggest that a causal connection is present.

If it be assumed that the modification of the extent of development of the shoot may be connected with physical agencies directly external to this member and acting directly upon it, there remains the question of succulence to be accounted for.

Succulence in general entails the exaggeration of parenchymatous tissue, cortical or medullary, and the accumulation in the resulting enlarged tracts of a surplus or balance of water, which physiologically forms a pocket or reservoir with respect to the transpiration stream. Such tracts may be developed in roots, stems, or branches-or even in leaves, 
as in the agaves and crassulas. The plasmatic units or cells are increased in botl number and size, growth liaving been stimulated in both the phases of extension and multiplication. The concentration of the sap in such cells as noted above is generally not very high and in a large number of instances mucilages and gums are present, making the cells practically masses of indefinitely expanding water-absorbing colloids.

The obvious direction in which to turn, therefore, in the search for agencies which might cause or accompany succulcncy would be one in which hydratation agencies which would cause the swelling of the colloidal cells would be taken into account. Not until recently would such an inquiry have met with evidence that would be valuable in the discussion of the subject. This evidence is now at hand, however, in the form of the recent writings of Borowikow, as to influence of certain substances upon growth expansions. ${ }^{1}$

The experimentation of Borowikow seems to show that the acids (hydrochloric, sulphuric, nitric, acetic, and boric) within certain limits of concentration cause an increased growth of seedlings in a manner corresponding fairly with the swelling of gelatinous colloids treated with the same reagents in equal concentrations. The effect is not due simply to the hydrogen, but is the summed result of both ions. The alkaline metals exert a similar hydrating effect upon gelatine and upon growth. Increase of the concentration beyond certain limits would be followed by coagulatory effects in gelatine and by diminished growtl in the plant. Coagulatory effects and retardation of growth are produced by the action of salts of metals, of mercury, copper, strontium, calcium, barium, magnesium, lithium, potassium, and ammonia, which show a diminishing effect upon proteinaceous colloids in the order named. These results suggest a possible means of analysis of the conditions of succulency. The lyydratation of the mucilaginous contents of the bodies of certain cacti tested at the Desert Laboratory does not take place in the manner of the growth-effects described by Borowikow, however, and it is evident that the problem is a complicated one.

The disturbances in the Salton Sink following the making and the gradual desiccation of the lake were of course attended by the exposure of many species to unusual intensities of concentration of some of the substances active in coagulation and in hydratation. But little attention could be given to such environic reactions, yet (as described in a previous section of this paper) noticeable deviations in leaf and stem characters were found in Aster exilis, Prosopis glandulosa, and Atriplex canescens, in addition to variations in the fruits of Scirpus paludosus. The thicker stems and heavier shoots of the first-named species are strikingly suggestive of effects such as those ascribed to hydratation action of acids and alkalies.

The whole possible range of hydratation and coagulatory effects seem to be included in the seasonal changes in the brines described by Professor Peirce in the present volume. Dilute solutions with sodium chloride and calcium salts present seem to be accompanied by hydratation and growth, which are checked with a concentration supposedly increased beyond the optimum. The crystallization out of the sodium and of the calcium and the subjection of the algæ to the influence of the magnesium and potassium appear to be followed by encysting, which may be taken as being due to the neutralizing effect of these substances upon the proteinaceous colloids of the cells.

The fact that 4 out of a total of 60 species which found place on the strands exhibited modifications of structure not observed elsewhere led directly to a consideration of the endemic species of the Sink. Atriplex saltonensis Parish, Sphoralcea orcutti Vasey and Rose, Cryptanthe costata Brandegee, Calandrina ambigua Howell, Astragalus limatus Sheldon, A. aridus A. Gray, and Chamoesyce saltonensis Millspaugh are to be included in this category. It is true that Calandrina is found a short distance beyond the limits of the Sink, but the remaining 6 species are not known to occur beyond and above the high

${ }_{1}^{1}$ Borowikow, G. A. Ueber die Urøachen des Wachstums der Pflanzen, Biochem. Zeitschr., vol, xurv, p. 230.1913. 
beach line marking the level of Blake Sea which filled the basin to this shore line within comparatively recent time. The situation suggests that these species originated in the Sink since it was last filled and the inference is strongly in favor of such a conclusion. According to Mr. Parish Astragalus limatus is so closely related to A. preussii A. Gray of the Mohave desert to the northward that it has been considered a variety of it, but the other endemic species noted have no near relatives in the immediate region. If the possibility of the origination of these forms within the Sink be allowed it is also suggested that other species might have originated in like unanner but become disseminated over a wide area in such manner that their nativity is undiscoverable.

The origination of a species within the limits of the Sink or in any basin such as the Cahuilla would probably be followed by its dissemination over surrounding arid regions. The recent formation of the lake, in which about 7 cubic miles of water were poured into the Sink, covering an area of 450 square miles, constituted the beginning of an experiment in which exact studies could be made as to the movements of plants on such sterilized areas. Submergence, of course, resulted in the extermination of the vegetation; then the slow recession of the waters due to evaporation exposed a peripheral strip from a few feet to a half mile wide every year. The total area thus laid bare every year was 8 to 10 square miles, and this afforded the means by which the action of various disseminational agencies might be tested and compared; furthermore, the test areas showed a slight but measurable progressive modification year by year. The concentration and composition of the water with which each area was moistened was characteristic, and the constitution of the vegetation on the strip nearest above newly bared strips differed every year from that nearest the new beaches of the preceding year.

The disseminational agencies which were to be taken into account included those which might be active in the dry phase of the basin and others which might have been called into action by the formation of the lake itself. Winds carried seeds about the region in a manner probably but little changed. The run-off streams coming down the slopes continued their characteristic action in the incidental transportation of fruits, seeds, and propagative bodies, much as in the dry periods of the Sink, but the flood streams of the Colorado would constitute an unusual feature, while the wave and current actions of the lake would be features directly connected with the existence of the lake. The activities of birds in distributing seeds has been the subject of a voluminous literature, although their actual efficiency in carrying seeds to new areas has not been adequately tested. Their possible intervention in this region, however, was enormously increased in importance, since vast numbers of cormorants, pelicans, and ducks were attracted by the possibilities of food in the form of fish offered by the lake.

It is obvious, therefore, that the phenomena connected with the making and desiccation of the lake did not include simply the extermination of the species on an area and the simple re-entrance of these and other species into the bared area. The things which exterminated the vegetation brought many new conditions, including new disseminational agencies and a whole series of soil conditions different from those prevailing in the area previous to flooding.

The progress of a seed from its place of origin on the slopes of the Cahuilla toward the bared beaches might be imagined as across or over a number of barriers, which would be of such character as to stop a large number and thus form the sieves of natural selection. Thus, for example, a free seed being carried down the shallow channel of a run-off stream during the few minutes or hours in which water would run down its shallow channel at intervals of a year or two, would be liable to be buried under débris, crushed by rolling rocks, or deposited where it might be eaten by rodents-or, being wetted, would be killed by the high temperature. It is as if the moving seeds were thrown against a series of sieves, the meshes of which offered openings differing not only in area but in form. The screening 
action of the environic sieves was such that out of the hundreds of species which must have been thrown against the barriers only 60 reached the beaches and germinated. 'The last of the series of screens would be the conditions of the beaches themselves, which varied from year to year. To complete the figure it would be necessary to imagine the last of the series of sieves in the great selecting machine as being constantly changed in pattern and size of mesh.

Furthermore, the selective action does not cease with the germination of the seed which has been carried to the beach. Here a new series of sieves was to be encountercd, consisting chiefly of the phenomena of progressive desiccation, which would soon bring many species to the limits of endurance and to death. Others surviving under extreme tension would offer suggestive possibilities as to responses of possible importance in their evolutionary development, such as have been suggested by the behavior of Prosopis, Aster, Scirpus, and Atriplex.

It became obvious during the course of the work that the origination of qualities or structures upon which dissemination would depend might, in many instances at least, have no possible connection in a causal way with the agencies themselves. Thus, for example, the desert gourd which was carried about the lake and deposited on various beaches owes this dissemination to structures which could hardly be attributed to any excitation action on the part of water or to any previous selecting action. The same mechanical qualities of flotation and dissemination are displayed by the fragments of pumice which were carricd about at the same time.

The communal life and successions on the beaches showed some interesting diversities. The manner of the occupation of the zones laid bare by the receding waters was chiefly determined by the water, and hence the first communities of plants were of the nature of strand-steppes. The history of such formations showed two distinct phases, both also determined chiefly by edaphic conditions. The strands of the more gently sloping alkaline beaches were at first occupied by a greater number of species than the bared strips on the steeper gravelly shores, and the pioneers gained a foot-hold earlier. This difference may be attributed in greater part to the fact that the narrower, more steeply sloping beaches were subject to the action of storm waves for a longer period than the broader zones on the gentler slopes, and also to the fact that the latter actually presented a greater area of soil for the reception of seeds.

The arrangement of the pioneers on any beach would be characterized as open, and on the gentler alkaline slopes the tendency in general was toward a decrease, both in the number of species and individuals, with few or no secondary introductions, thus making a direct change toward the true open or desert formations. The gently sloping beach at Mecca, however, receiving some seepage water, did not exhibit such simple results. Steeply sloping beaches, as represented by the Travertine Terraces and the shores of Obsidian Island, showed two phases of succession, differing chiefly in degree. The open formations on the shores of Obsidian Island showed some tendency to become closer or denser in irregular areas, which soon began to thin in the final change toward the open descrt formation. The benches of Travertine Terrace were characterized by the development of dense ranks comprising a half dozen species or less at the upper margins of the annually bared strands, which were soon thinned in accordance with the general tendency toward desert formations, but at the same time the greater part of the surface of the terrace was knit together in a close formation by a mat of Distichlis. This closed formation, however, soon began to show the effects of desiccation, and the progression toward the desert formation with the introduction of xerophytes would be seen within three or four years after the zone had been laid bare by the lake. The transition is so rapid, or so abrupt, that species appearing on strands two years old are also included in ancient beach ranks marking the positions of strands 300 to 400 years old. The revegetation of the area submerged by the 
waters of the lake in Salton Sink is therefore seen to be chiefly influenced by soil-water or other edaphic conditions during the first year or two after emersion, after which the formations become increasingly open in the progression toward the extreme desert type. The evaporating capacity of the air may be taken as being an agency of increasing importance with the age of the formation.

Submergence and consequent extermination of the flora of portions of the Salton Sink have occurred many times in the last few centuries, and the reoccupation of the bared strands has taken place with the complex interplay of biological and mechanical agencies partly suggested and partly described in the preceding pages. 




$\begin{array}{ll}\text { QK } & \text { VacDougal, Danjel Trembly } \\ 938 & \text { The Salton Sea } \\ \text { D/A13 } & \end{array}$

BioMed

PLEASE DO NOT REMOVE CARDS OR SLIPS FROM THIS POCKET

UNIVERSITY OF TORONTO LIBRARY 
